Fall 1985

\title{
1985 Miracle Yearbook
}

Cedarville College

Follow this and additional works at: https://digitalcommons.cedarville.edu/yearbooks

Part of the Higher Education Commons, Organizational Communication Commons, and the Public Relations and Advertising Commons

\section{Recommended Citation}

Cedarville College, "1985 Miracle Yearbook" (1985). Yearbooks. 57.

https://digitalcommons.cedarville.edu/yearbooks/57

This Book is brought to you for free and open access by DigitalCommons@Cedarville, a service of the Centennial Library. It has been accepted for inclusion in Yearbooks by an authorized administrator of DigitalCommons@Cedarville. For more information, please contact digitalcommons@cedarville.edu. 


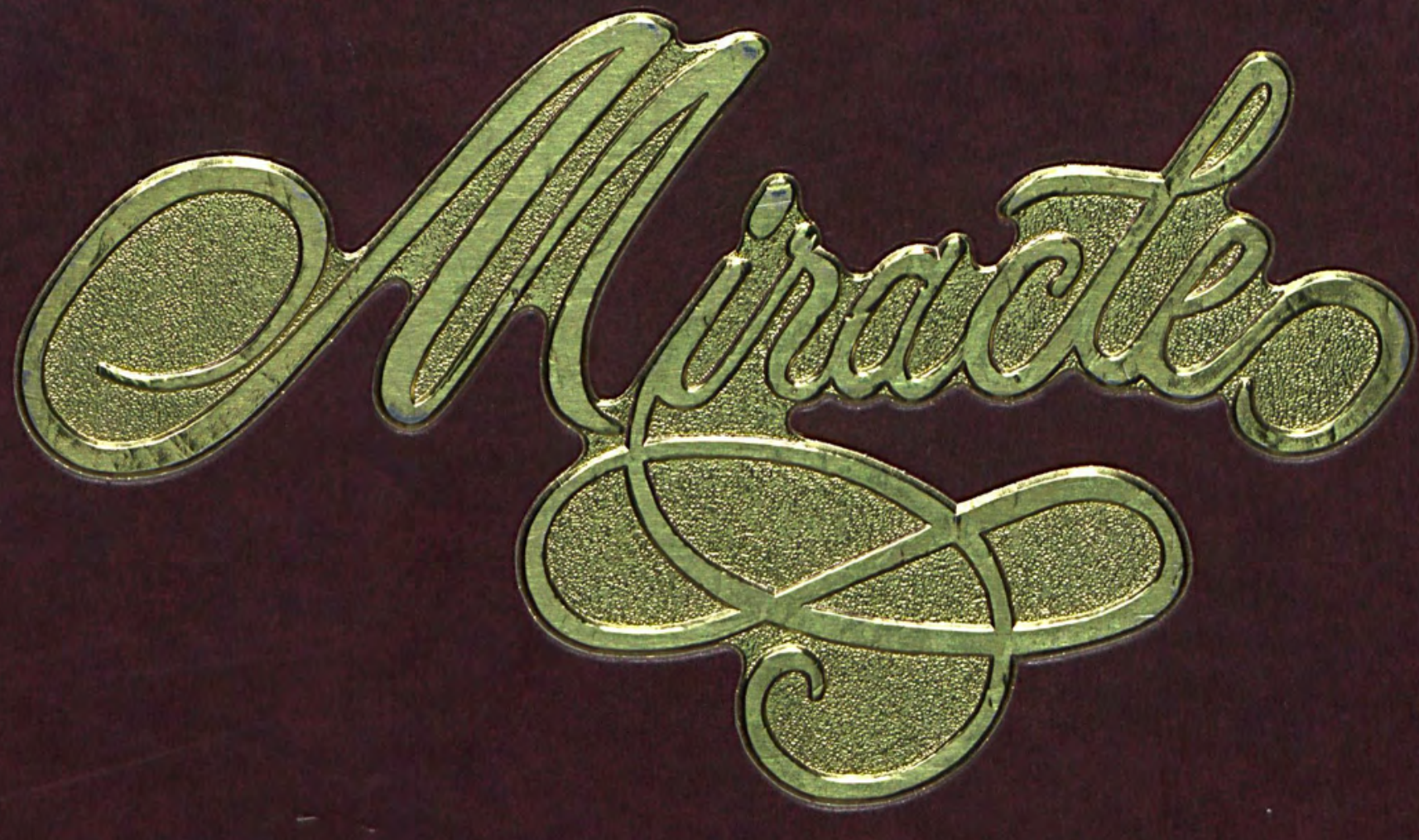




\section{For Reference}

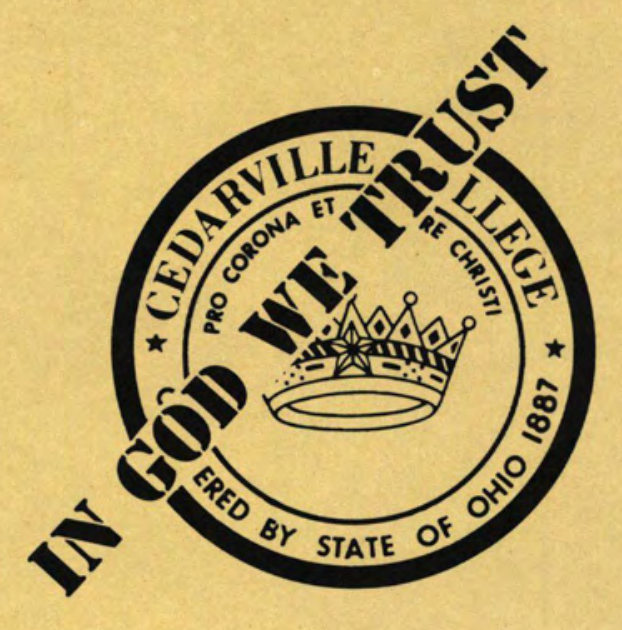

Not to be taken from this room 


$$
\begin{gathered}
A \\
378.7714 \\
C 389 \\
V .32 \\
1985
\end{gathered}
$$




\section{CONTENTS}

2 Dedication

4 Administration

8 Opening

22 Student Life

56 Christian Service Groups

84 Sports

120 Current Events

128 Personnel

144 Seniors

178 Senior Highlights

194 Undergraduates

233 In Memory Of ...

236 Campus Organizations

254 Editor's Page

256 Index 


\section{Dedication:}

\section{Bringing Praise And Glory To God}

$\mathbf{T}$ hose of us who have come to know Dr. Dwayne Frank (especially China enthusiasts) have come to know him affectionately as Comrade Frank. "Comrade" became the proper form of address of China after Mao Tse Tung's "liberarion" of China in 1949. The literal translarion of "Comrade" is "one working for the same aim." As we consider the suitable criteria for a dedicant and the appropriare words to express our appreciarion to that person, should not the shared "aim" that we have as brorhers and sisters in Christ be that which dominares our deliberarions? For wherher we consider the aim of efforts in China, the aim of Cedarville College, the aim of the 1985 Mirade, or the aim of each of us as individuals, we are to be as "one working for the same aim": the aim of bringing praise and glory to God. ". . . He chose us in Him before the foundation of the world, that we should be holy and blameless before $\mathrm{Him} . .$. to the praise of the glory of His grace ..." (Ephesians 1:4 and ba NASB).

Dr. Frank has been exemplary as one seeking to be holy and blameless in all areas of his life. In his humble dedication to our Lord, in his role as a husband and farher, and in his positions as reacher, colleague, friend, cirizen, church member and team leader, Dr. Frank has consistently demonstrared the means (being holy and blameless) to our aim (the praise and glory of God).

Dr. Frank, it is to you this 1984 Miracle is dedicared. We thank you for your contribution to our school and our lives. As we review your achievements, may we all join in giving praise and glory to God: for you have repearedly reminded us that we are nor "adequate in ourselves, but our adequacy is from God ... for we do nor preach ourselves bur Christ Jesus as Lord, and ourselves as your bond-servants for Jesus' salke" (II Corinthians $3: 5$ \& 4:5 NASB).

Sara Beartie Myron Youngman 

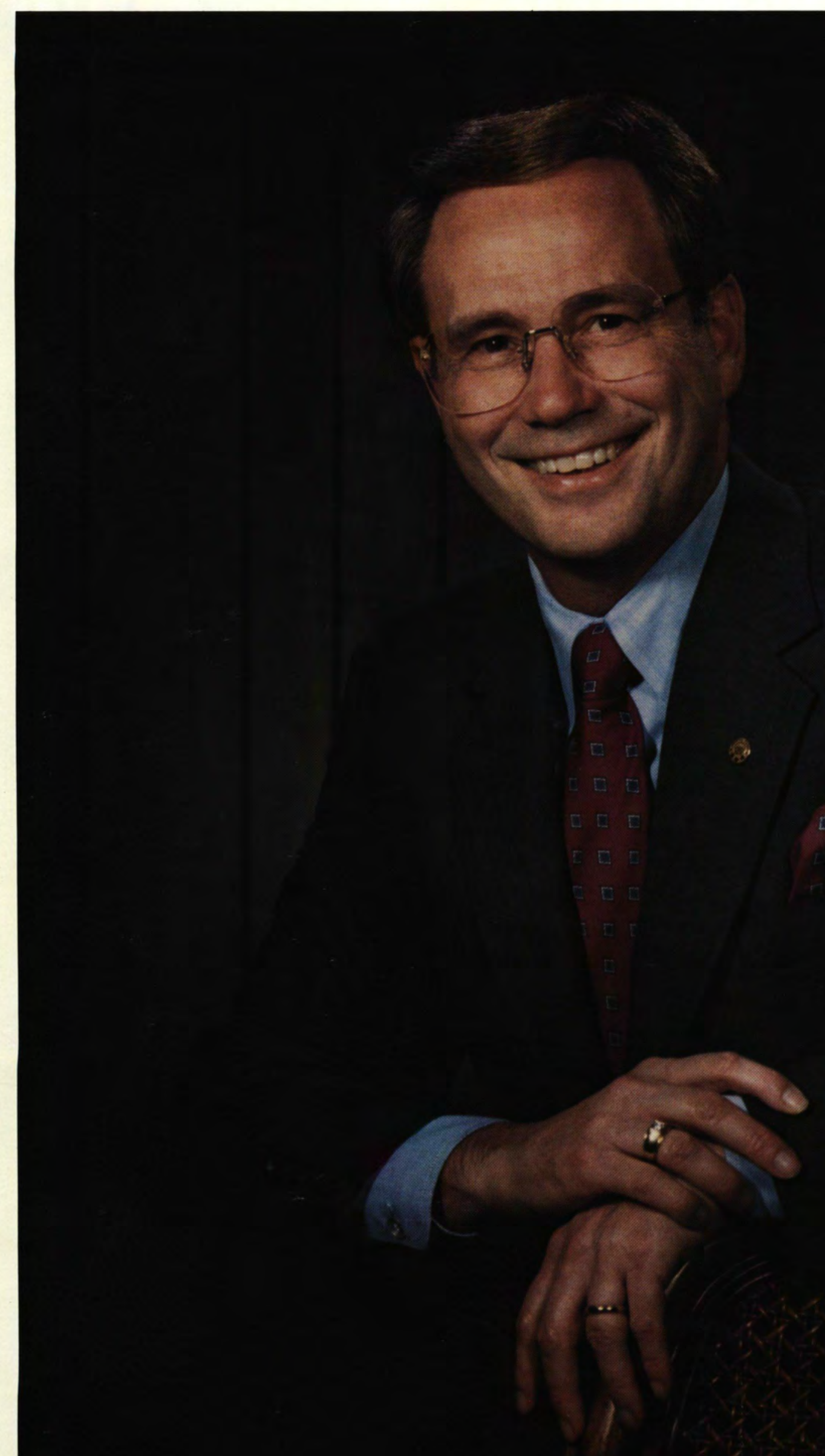

Paul H. Dixon, D.D., President 


\section{Trustees}

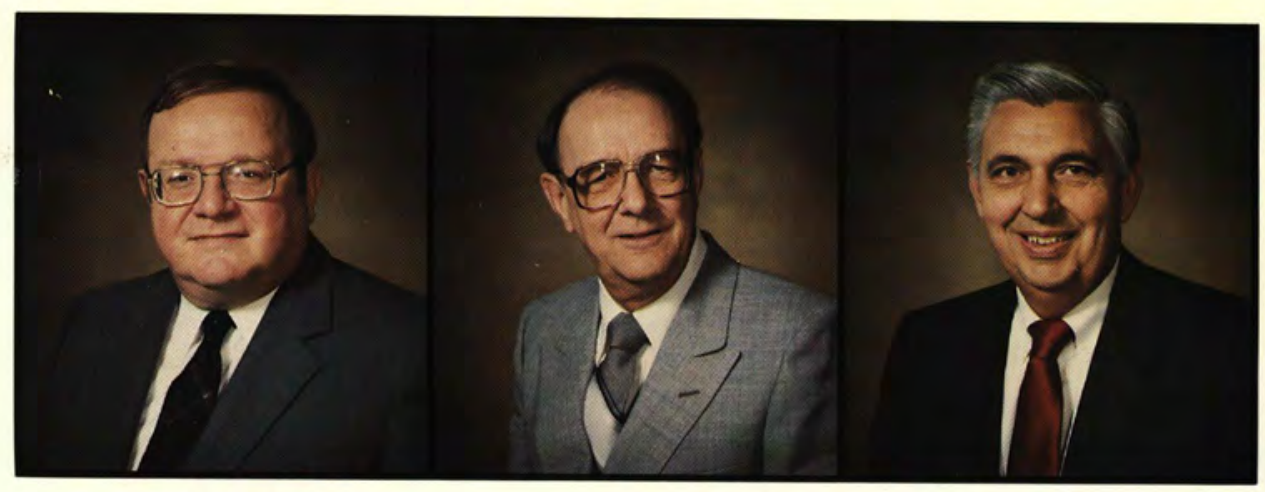

CHANCELLOR

Dr. James $T$. Jeremiah Emeritus
Dr. Eugene Apple, Secy.
Dr. William Brock

Mr. Gilbert Brueckner

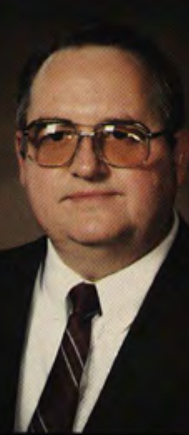

Mr. James B. Carraher

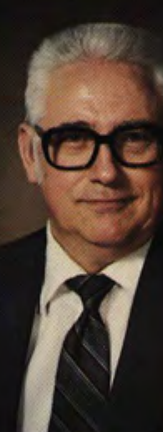

Dr. Jack Cline

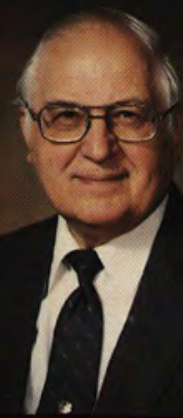

Mr. John Draxler

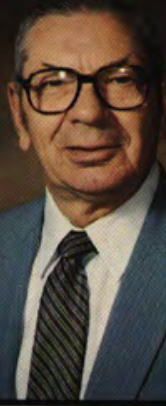

Mr. George Englemann, Vice Chm.

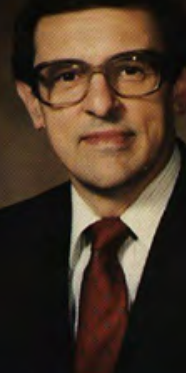

Rev. Larry Fetzer
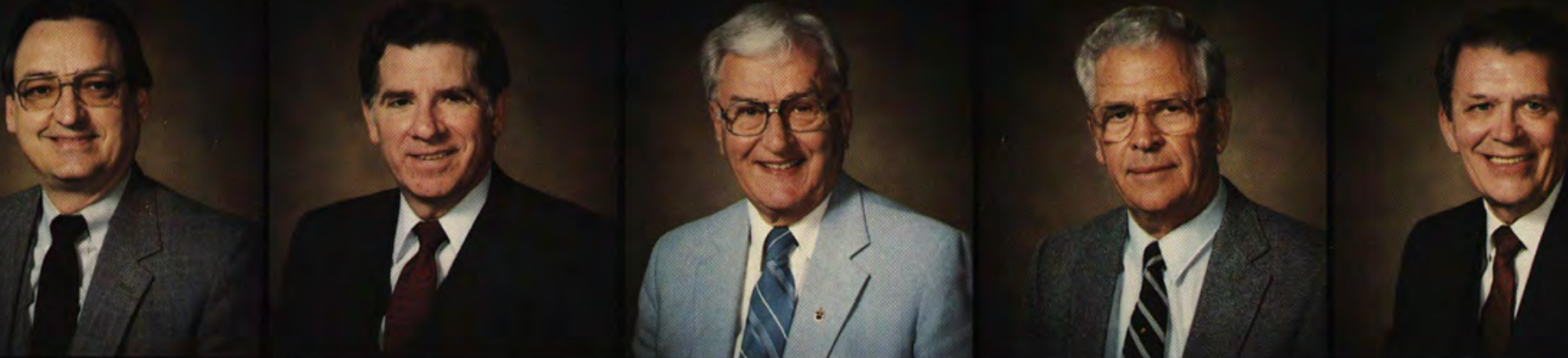

\section{Mr. Roy Guenin}

Dr. Jack W. Jacobs

Mr. J. Dale Murphy, Treas.

Mr. George O'Bryon

Rev. Irwin Olson
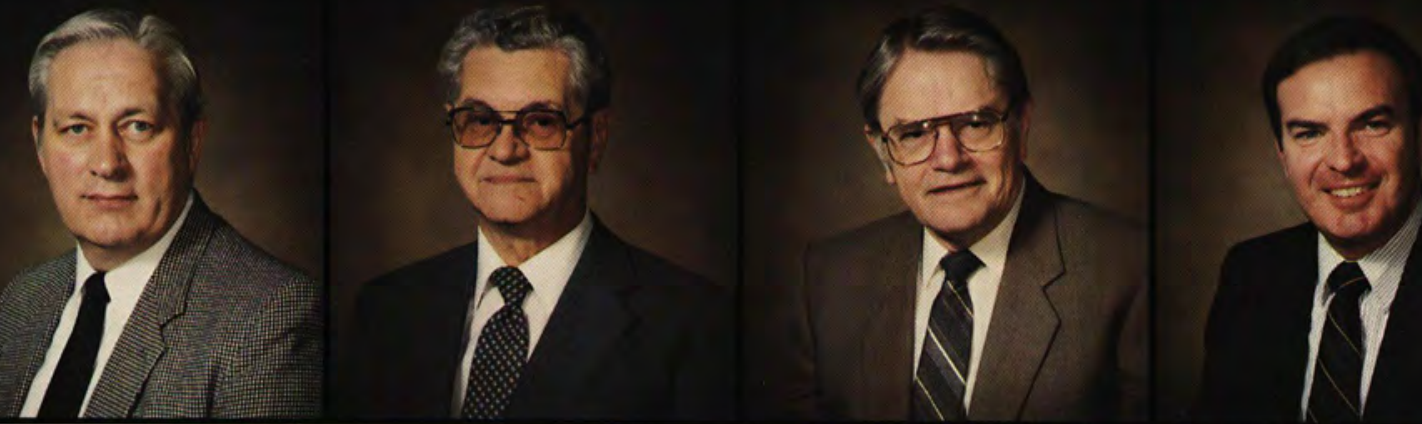

Rev. Lynn Rogers

Dr. Gerald Smelser

Dr. Robert L. Sumner

Dr. Paul Tassell

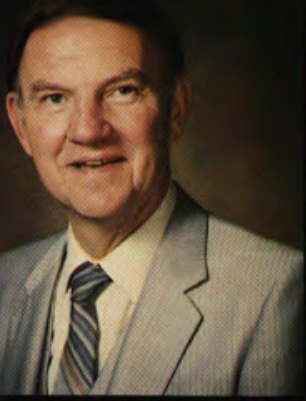

Dr. Donald Tyler, Chm.

\section{Not Pictured:}

Mr. Francis Bresson

Dr. J. Don Jennings

Mr. C.E. Gene Miller

Mr. Charles A. Barth - Emeritus

Mr. Arthur Dyke - Emeritus

Mr. William Patterson - Emeritus

Rev. Earl Willetts - Emeritus 


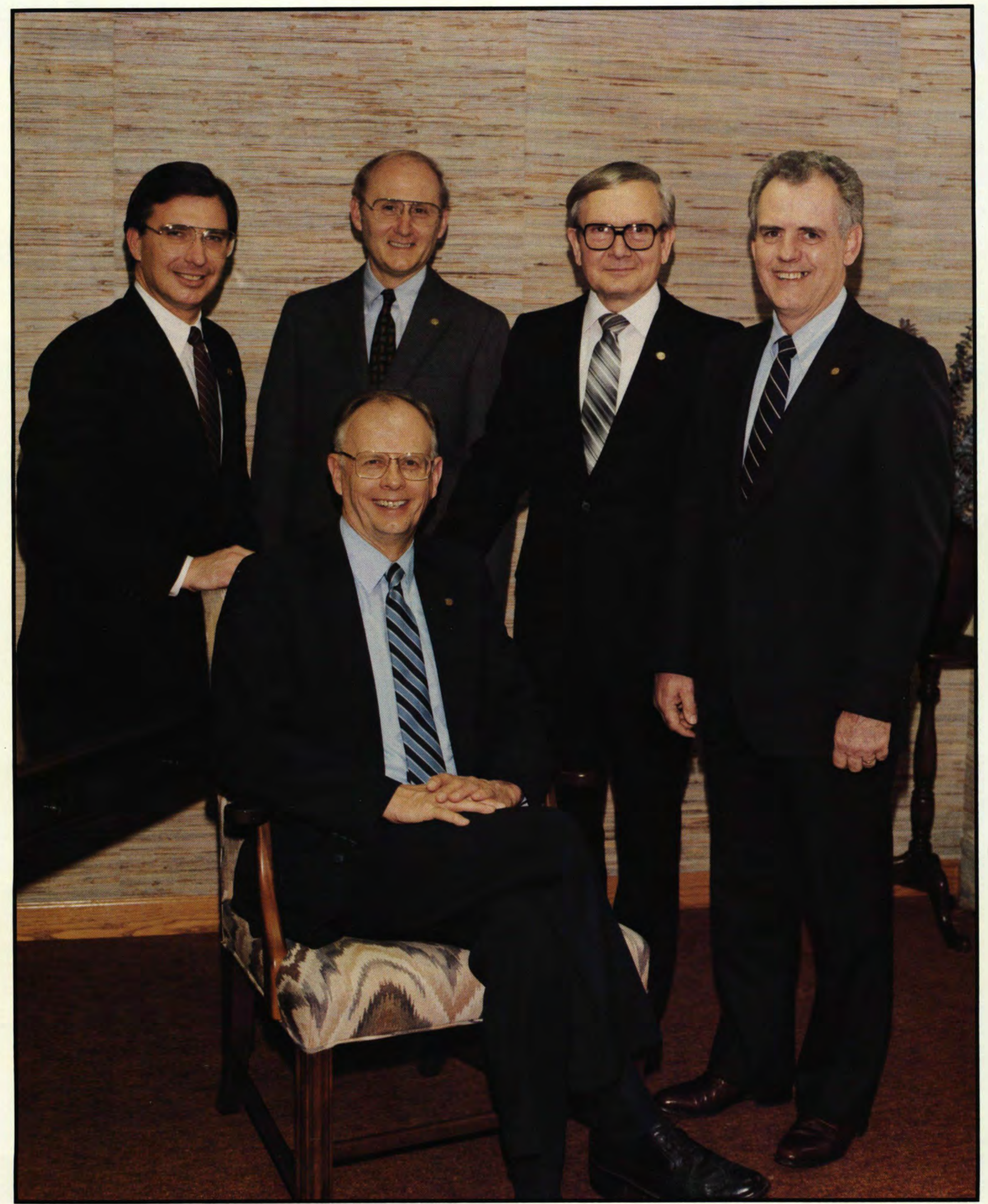

\section{Martin Clark Donald Rickard Kenneth St. Clair Vice President for Development \\ Vice President for \\ Student Services \\ Harold Green \\ Vice President for \\ Campus Ministries}

\section{Clifford Johnson}

Academic Vice President 


\section{ACADEMIC CHAIRPERSONS}

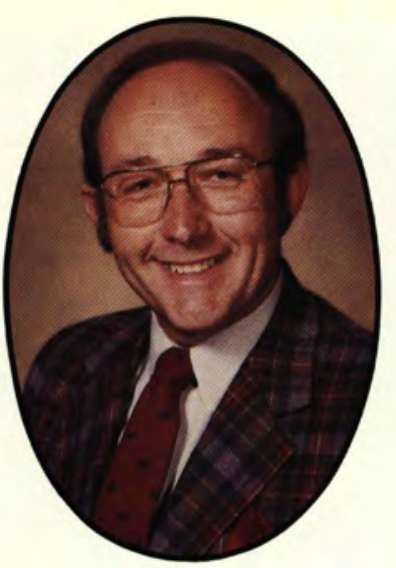

J. Murray Murdoch, Ph.D.

Social Science and History

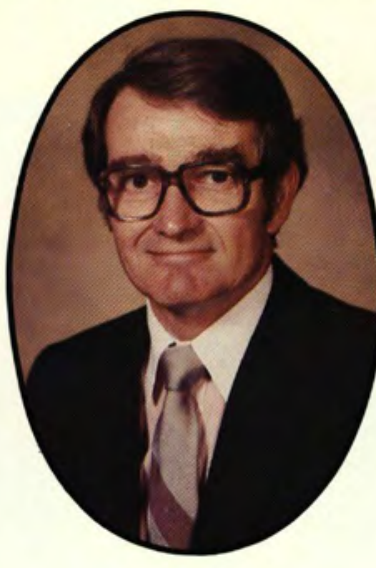

Robert G. Gromacki, Th.D.

Biblical Education

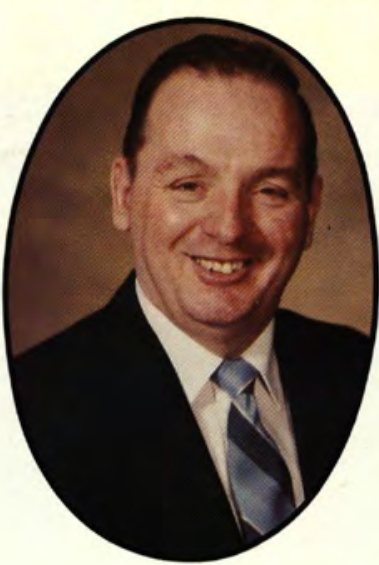

Clifford W. Fawcett, D.B.A.

Business Administration

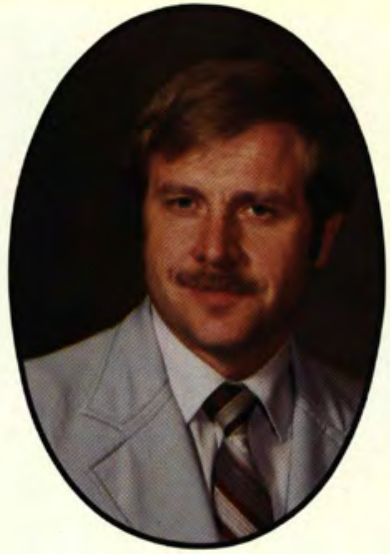

James R. Phipps, Ph.D. Communication Arts

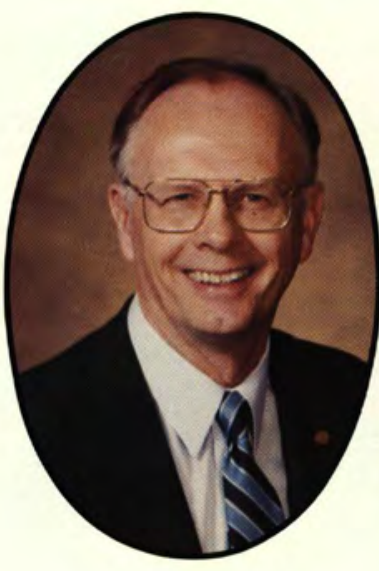

Clifford W. Johnson, D.Ed.

Vice President for Academics

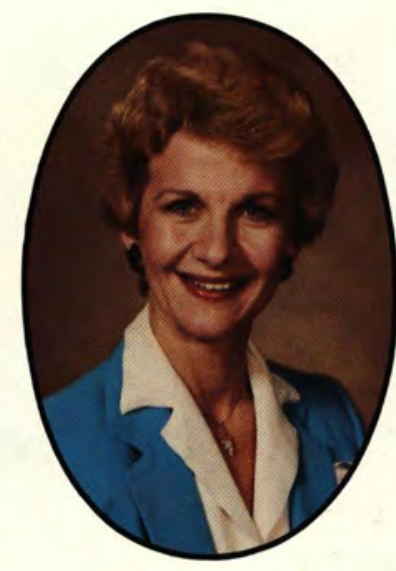

Sharon S. Biddle, Ph.D. Associate Academic Vice President

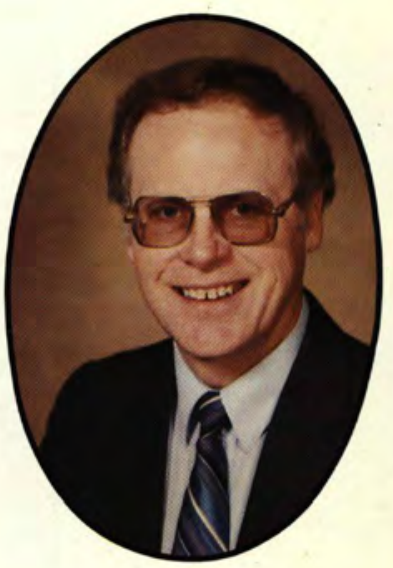

Dwayne I. Frank, D.Ed. Education

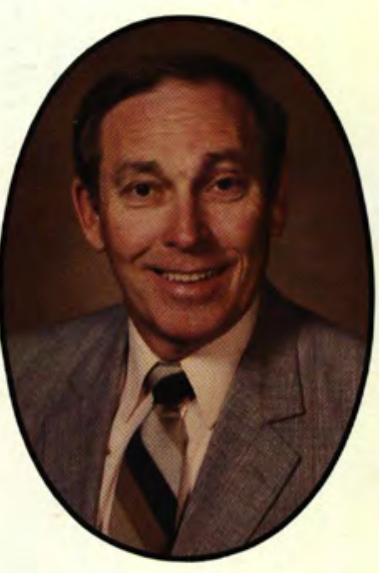

Donald Callan, Ph.D. Health and Physical Education
Ph.D.

Psychology

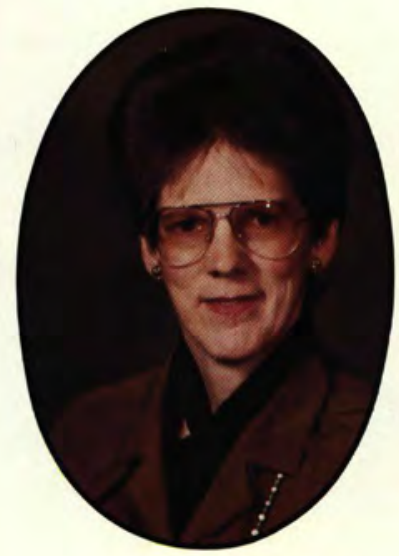

Irene B. Alyn, R.N., Ph.D. Nursing

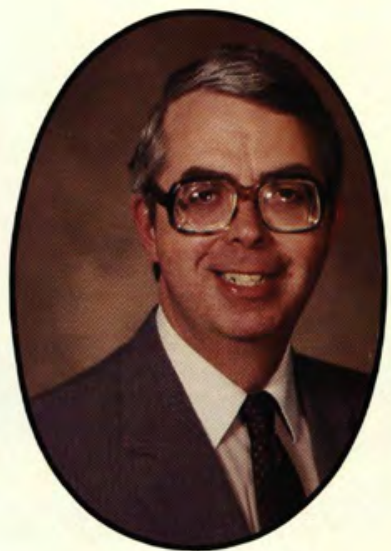

David L. Matson, Ph.D. Music

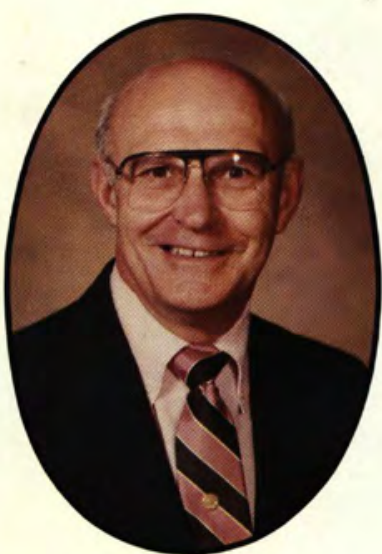

Edward E. Spencer, M.A.

Language and Literature 


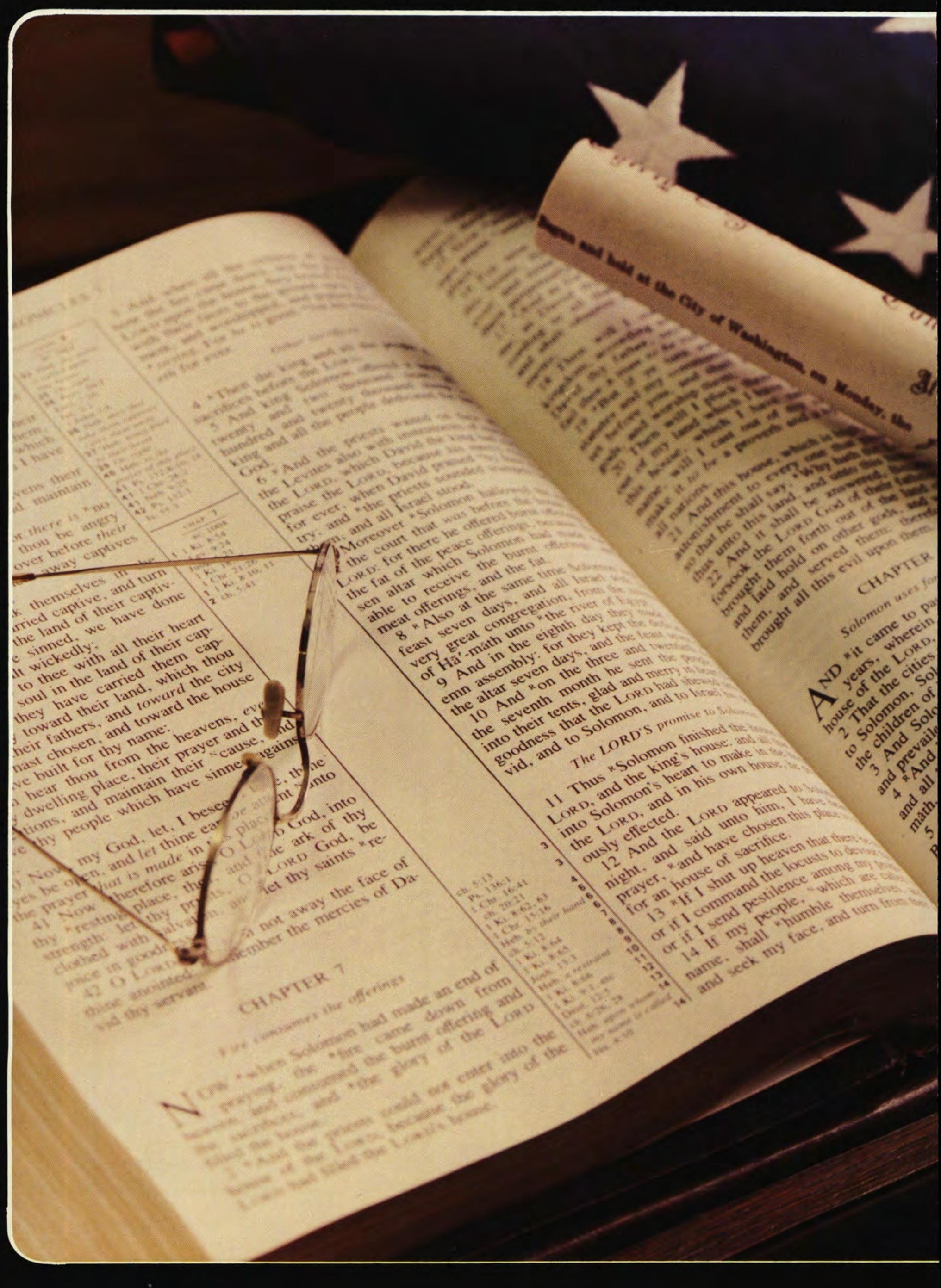




\section{"We IUfill Irust In Thee ...}

If my people, who are called by my name,

shall humble themselves, and pray, and

seek my face, and turn from their

wicked ways,

then will $J$ hear from heaven, and will forgive their sin, and will heal their land.

JJ Chronicles 7:14

And they that know thy name will put their trust in thee; for thou, Lord, hast not forsaken them that seek thee.

Psalm 9:10

Blessed is that man that maketh the Lord his trust.

psalm 40:4

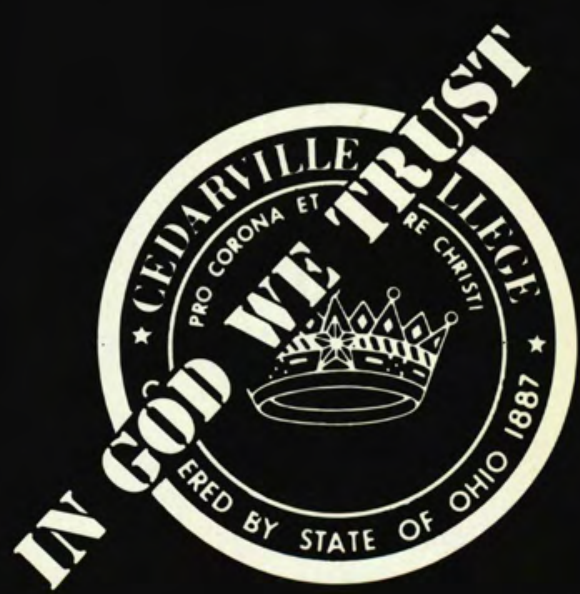

Opening 9 


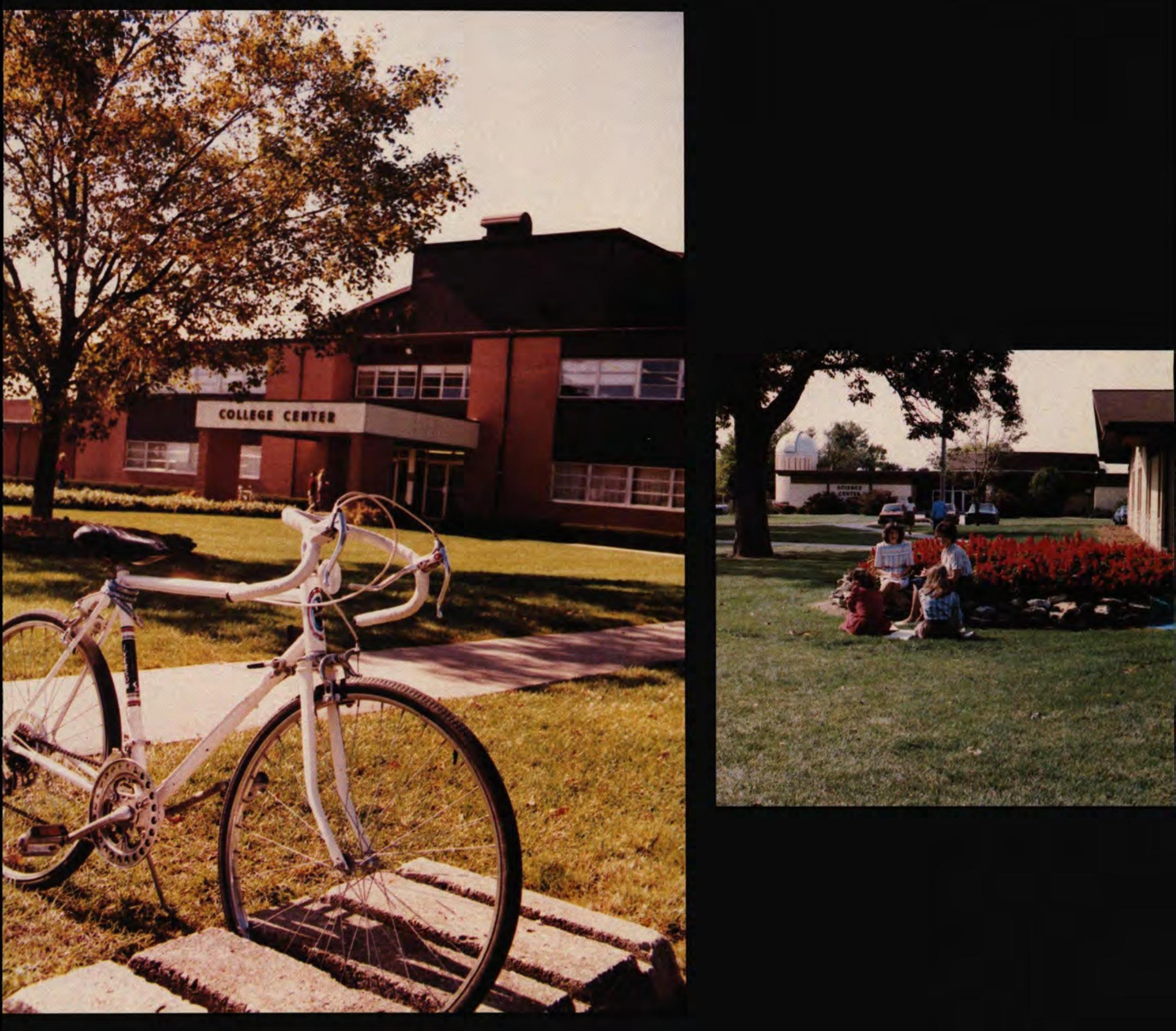




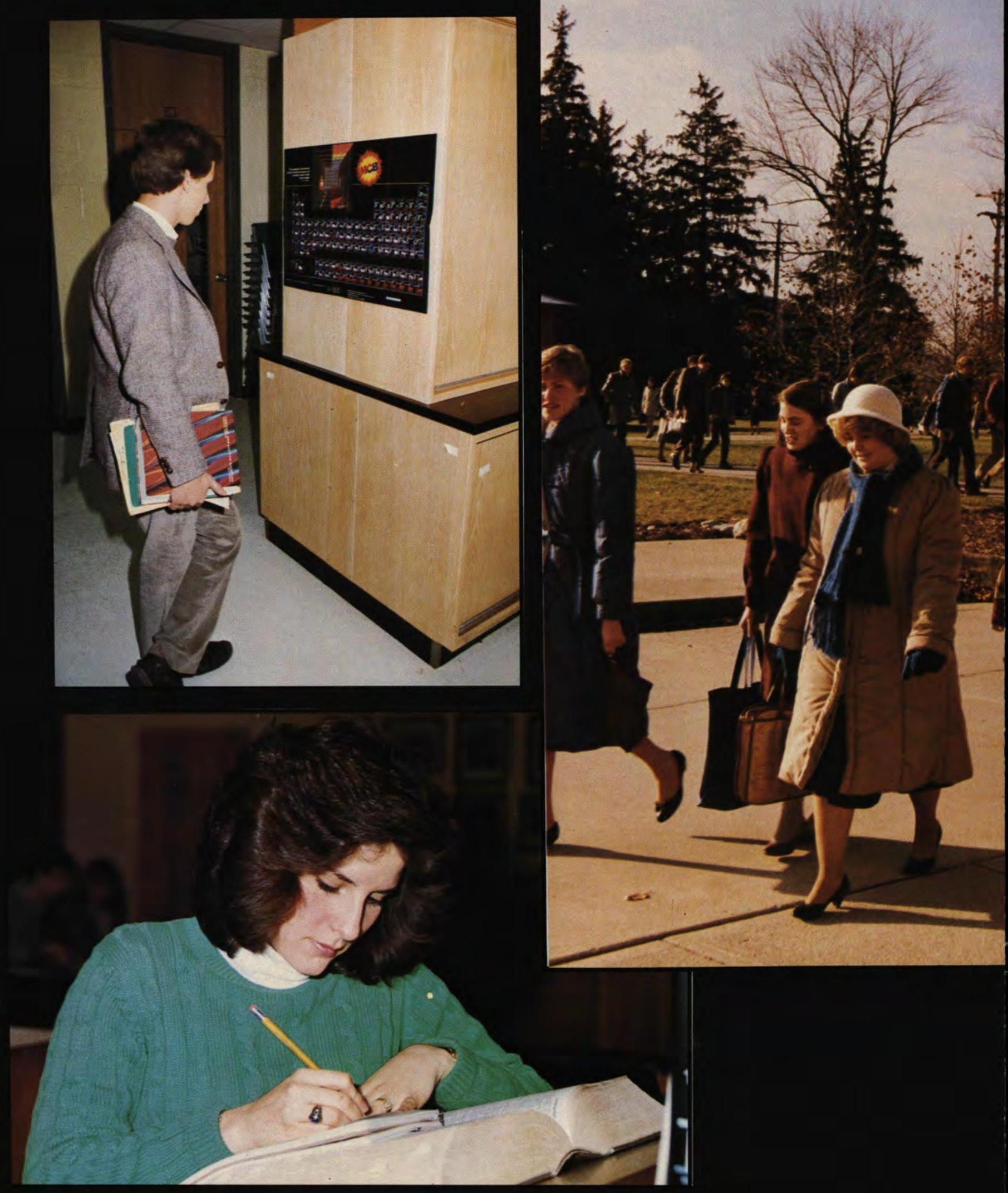




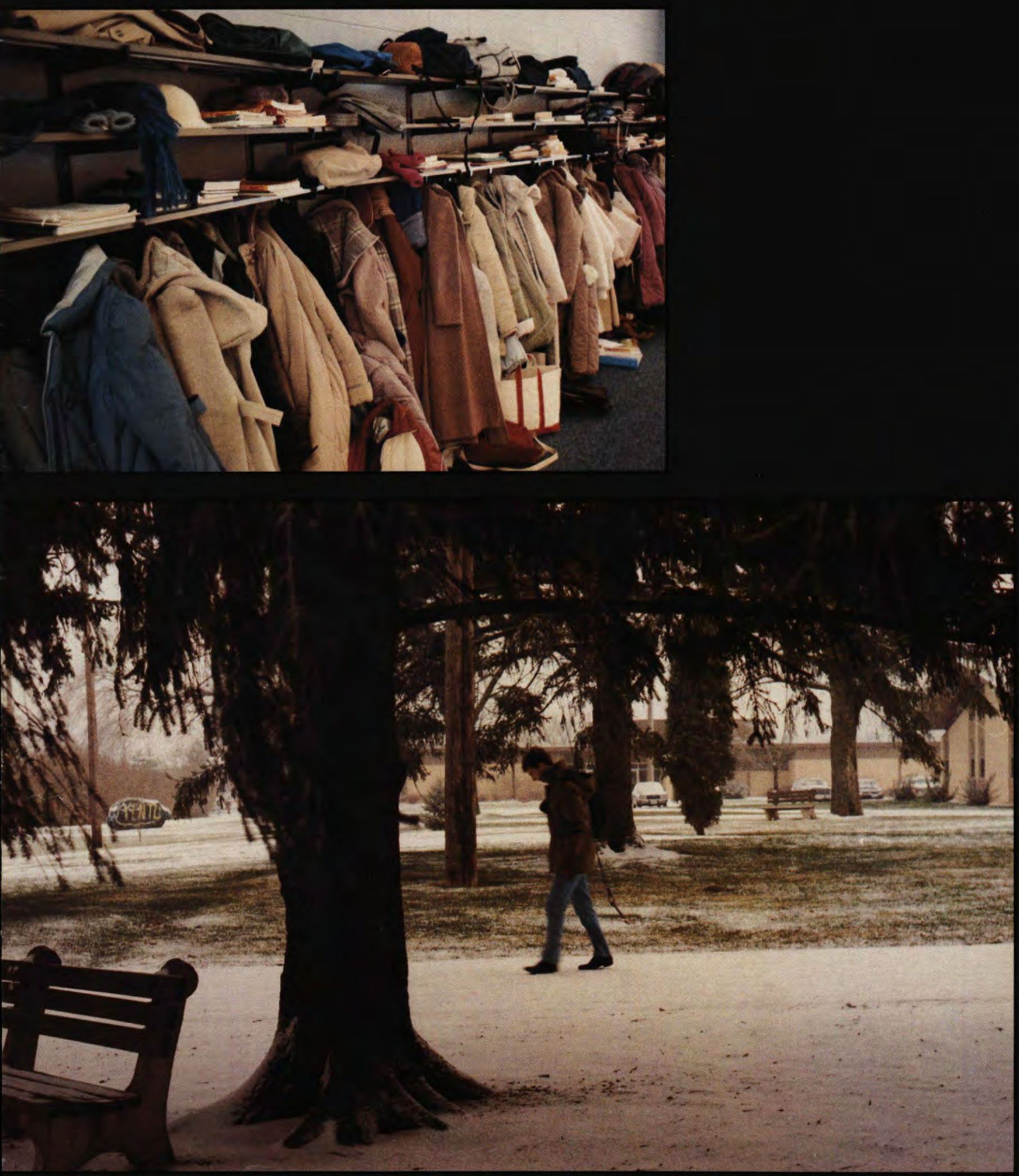



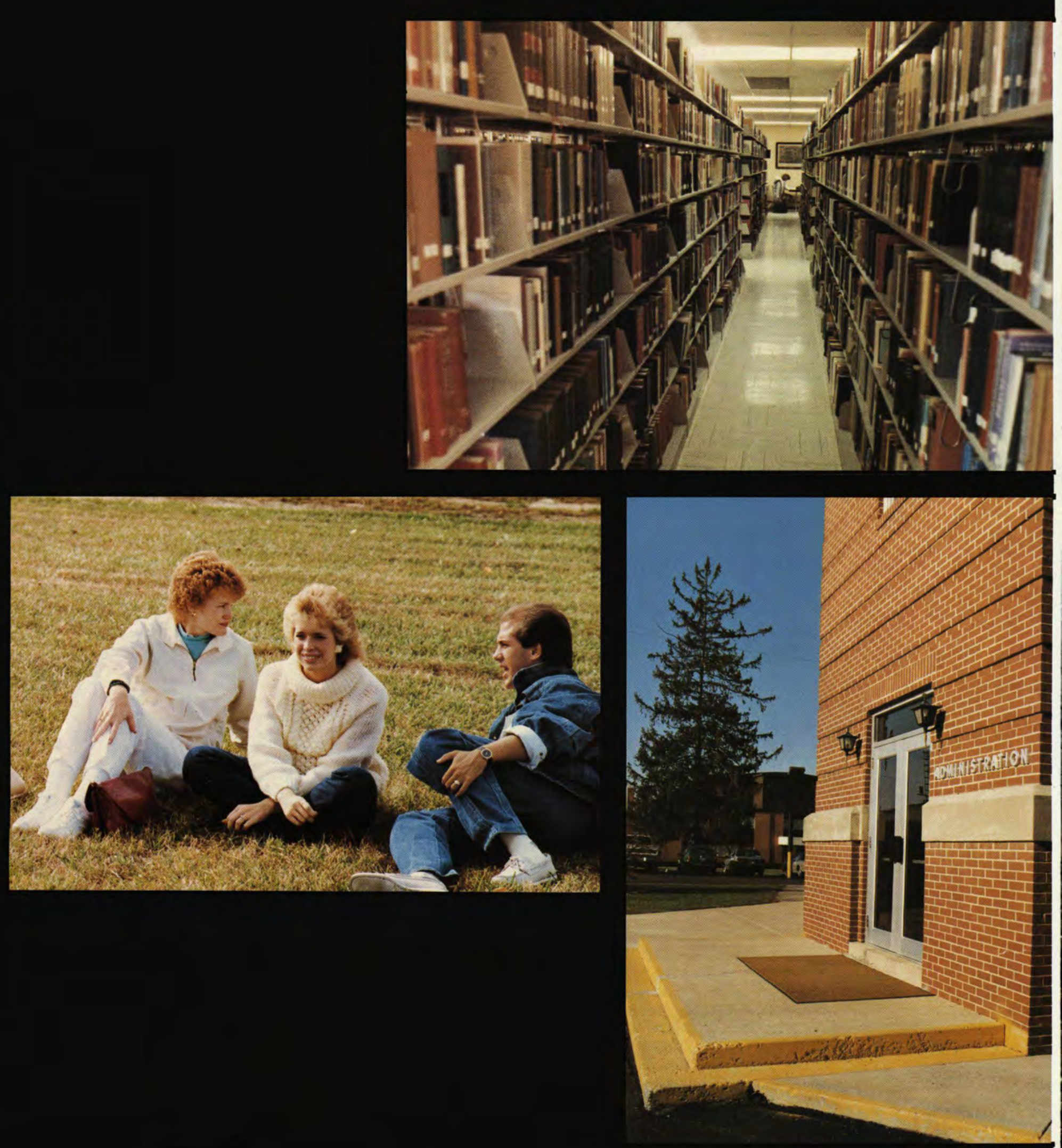


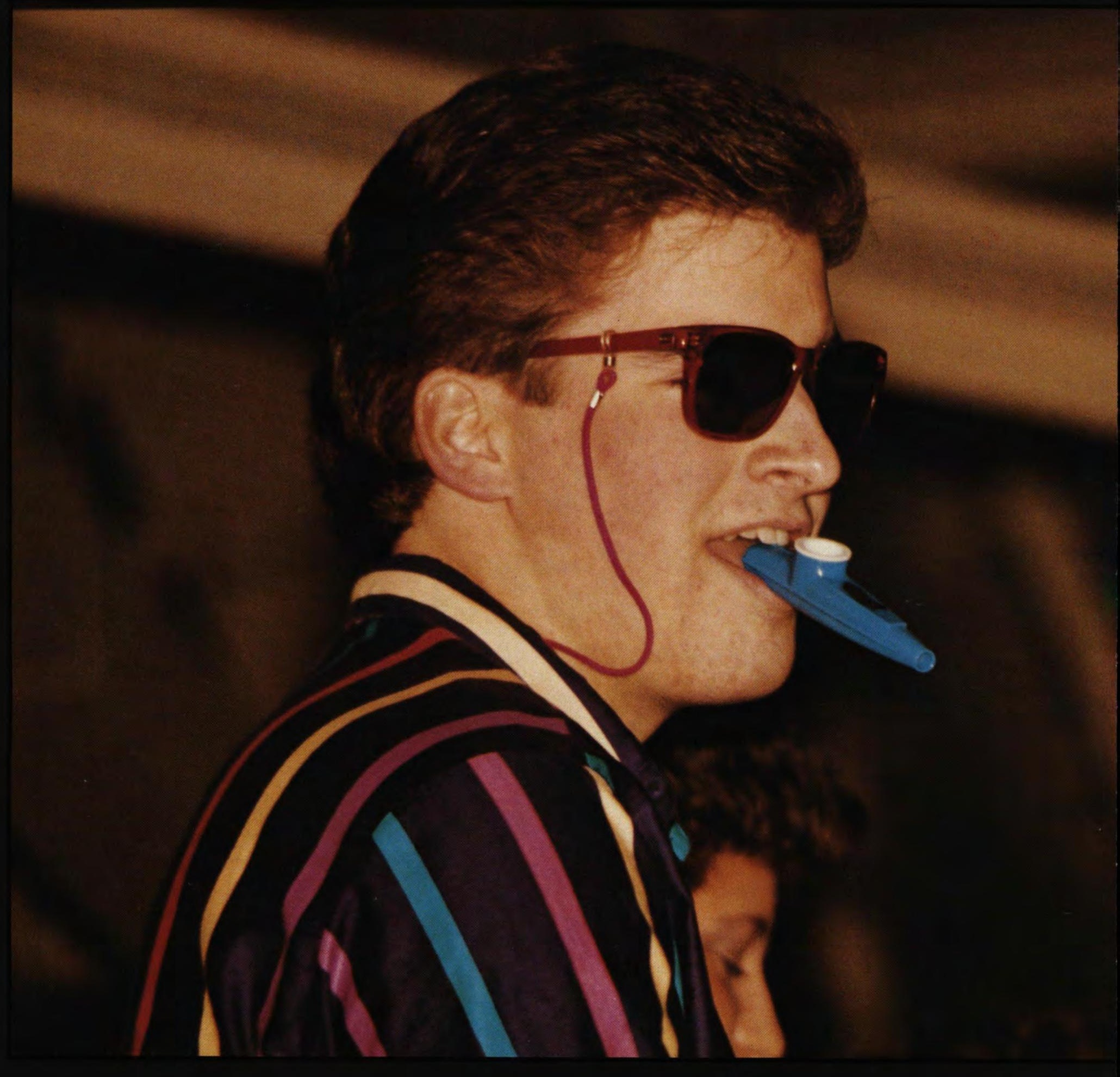

18 

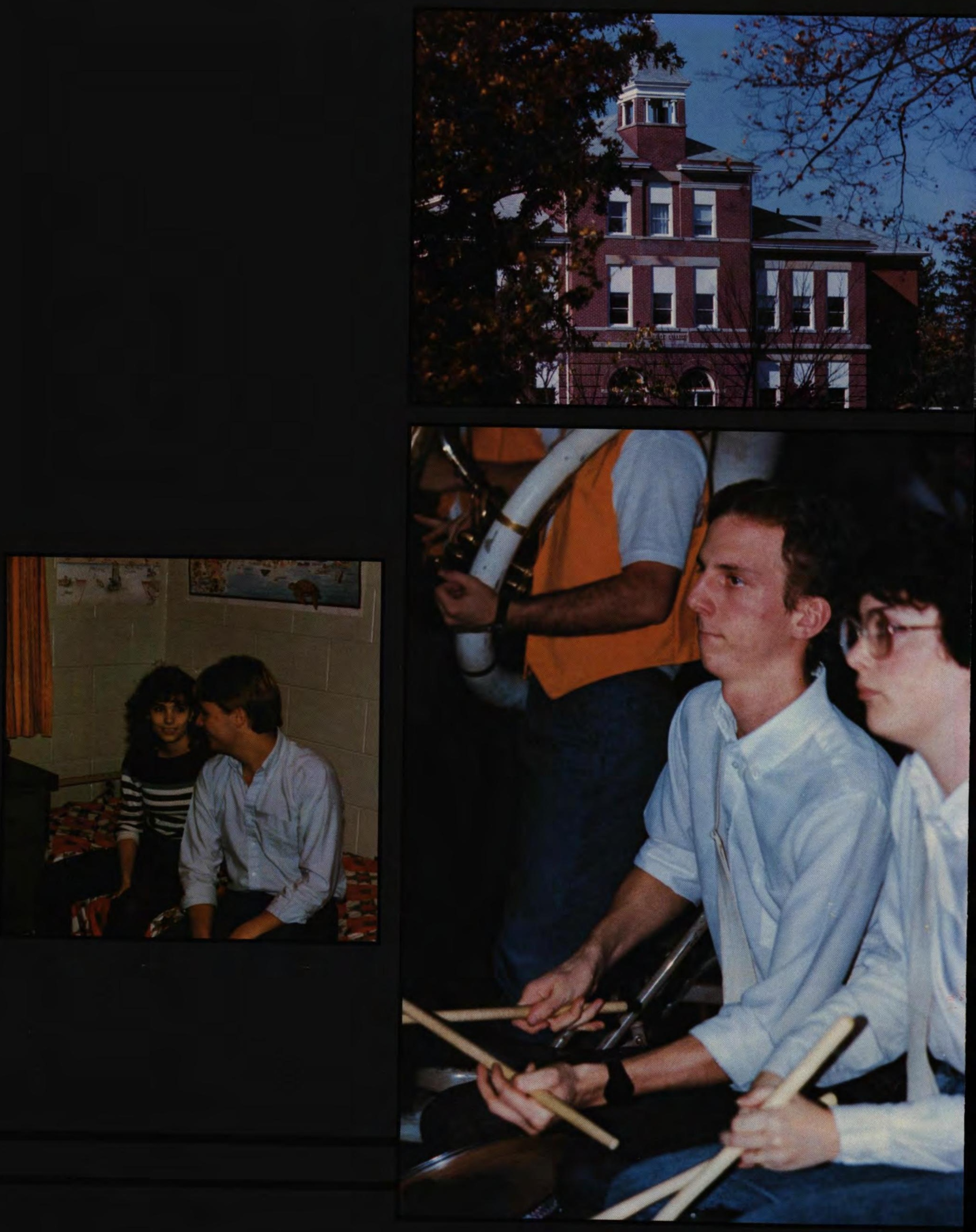


\title{
"Student Life Is Togetherness
}

\author{
99
}

The sum of the rwo words "student" and "life" intense, compacred, academic rraining Contrary to im ages of diligent students cramming ar every opportunity, discussing ideologies in the Post Office, or hermitizing in their study carrels, student life brings to mind those images of everything but the time spent in individual srudy. Srudent life is rogetherness in the dorm room and in walking down the "runway" with a friend. How much more fun is earning aerobics points when this privare rorrure is endured with a fellow $M \&$ M's earer? Sharing complaints and grimaces of horror somehow makes receiving the new quarter's syllabus bearable We squeal "bravo" inwardly as we proudly warch pals perform on the Alford stage During open houses, while ratring at the gym, or driving to group shopping exper iences, our bodies bump and collide and our spirits unite On the next few pages, the Miracle has tried to copture the events, activities, and times that have inspired us to reach our and rouch one anorher's lives through the common bond of our Savior

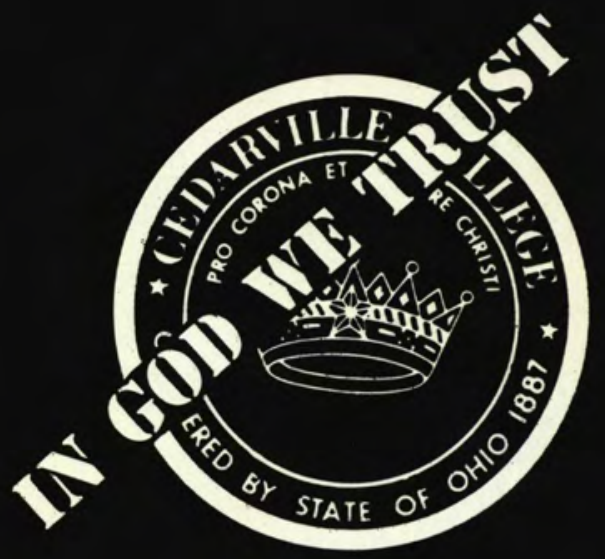




\section{Homecoming 1984}

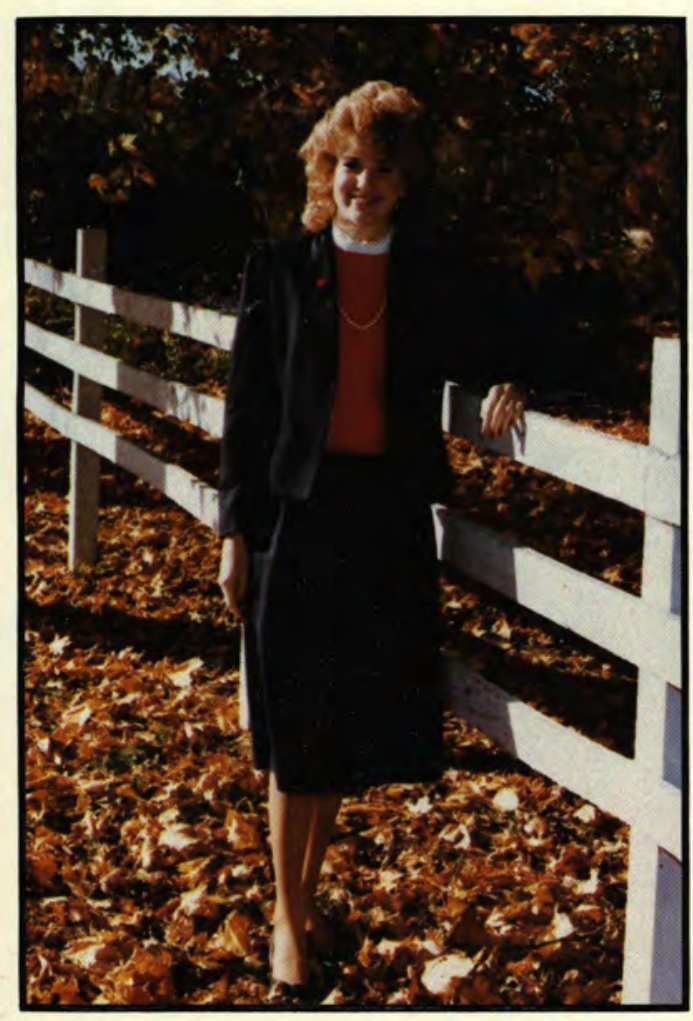

Mary Ann Rose Sophomore Attendant

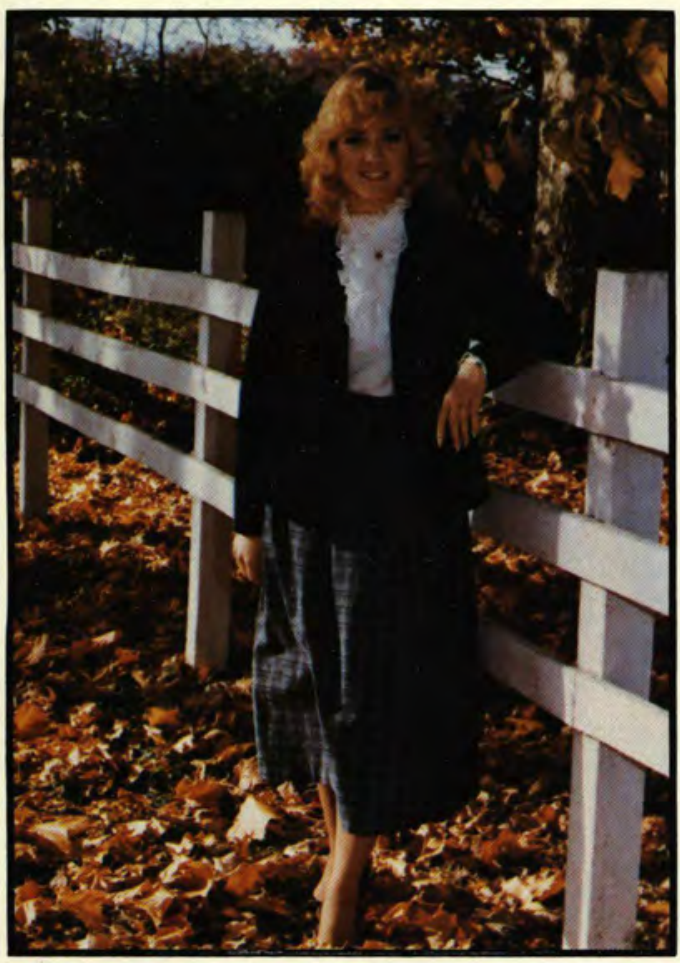

Becky Peters

24

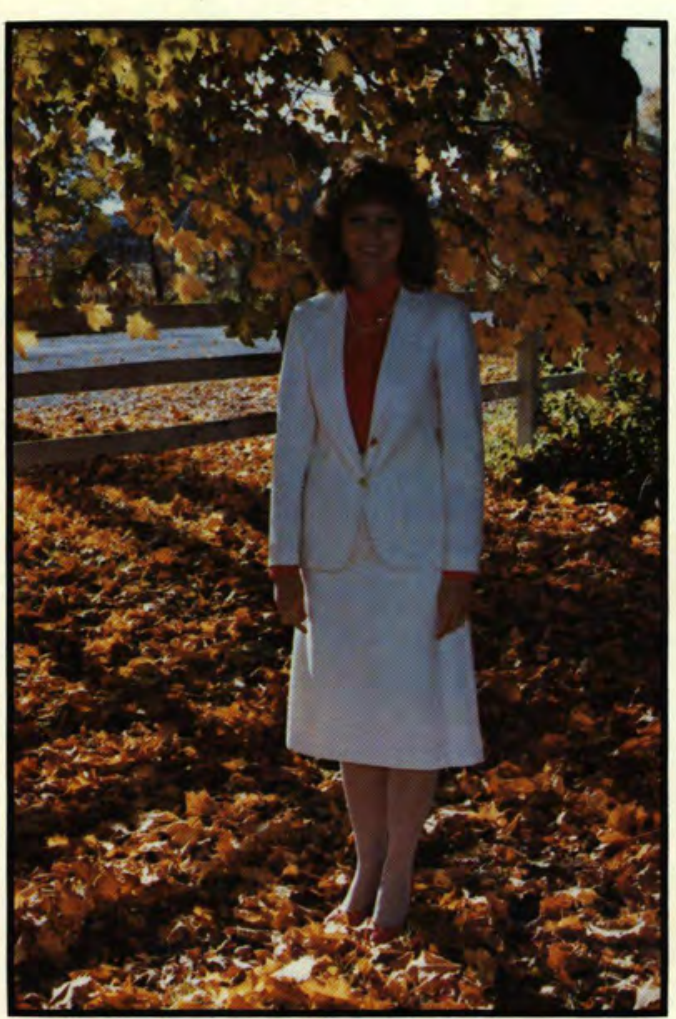

Linda Hess

Senior Attendant

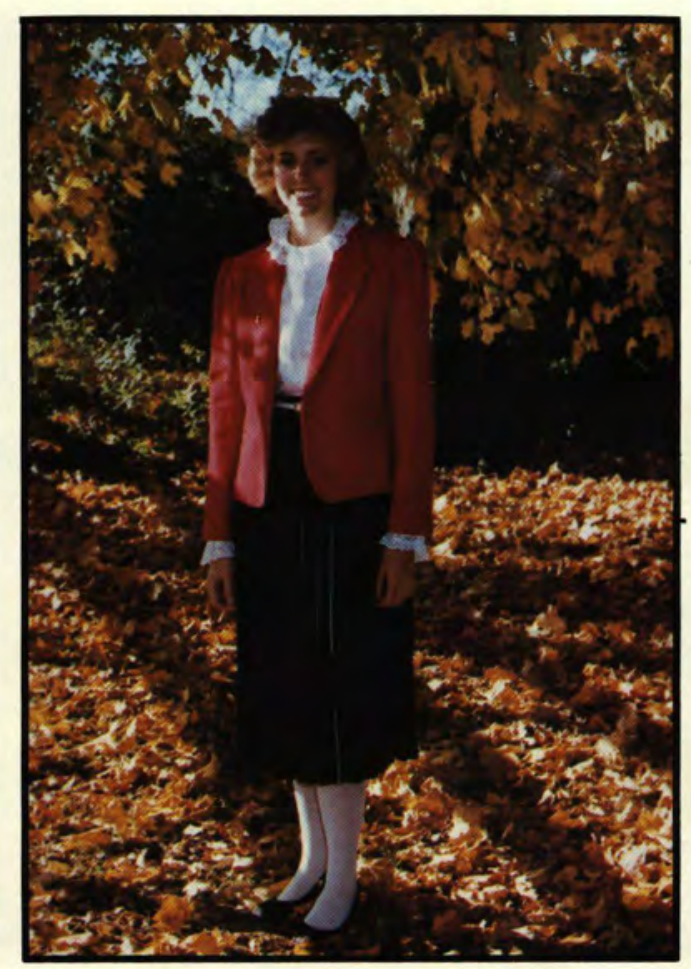

Christine Dell Senior Attendant

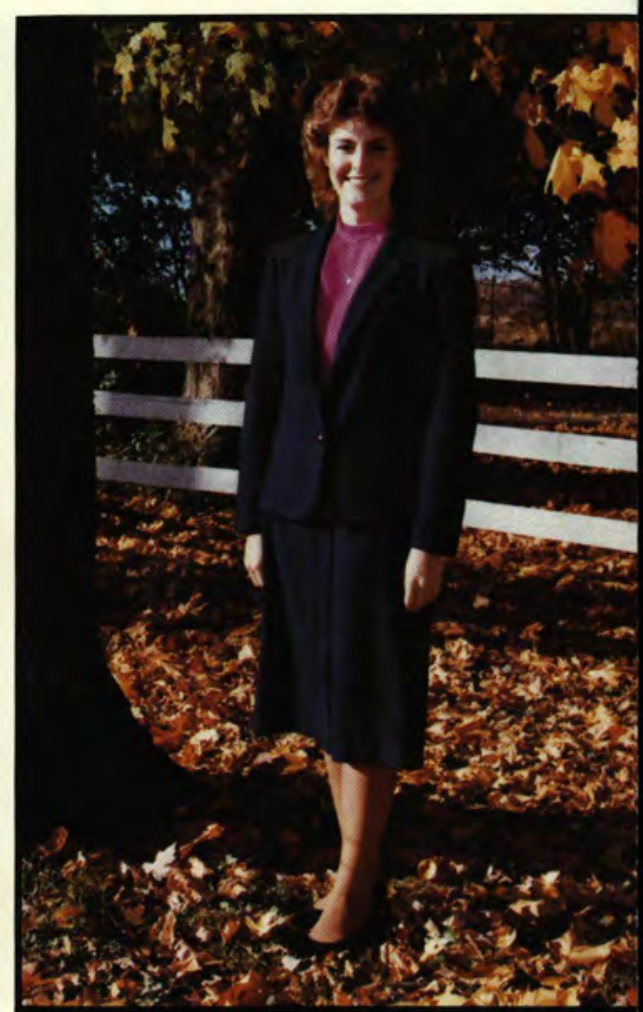

Laura Dimacchia Junior Attendant

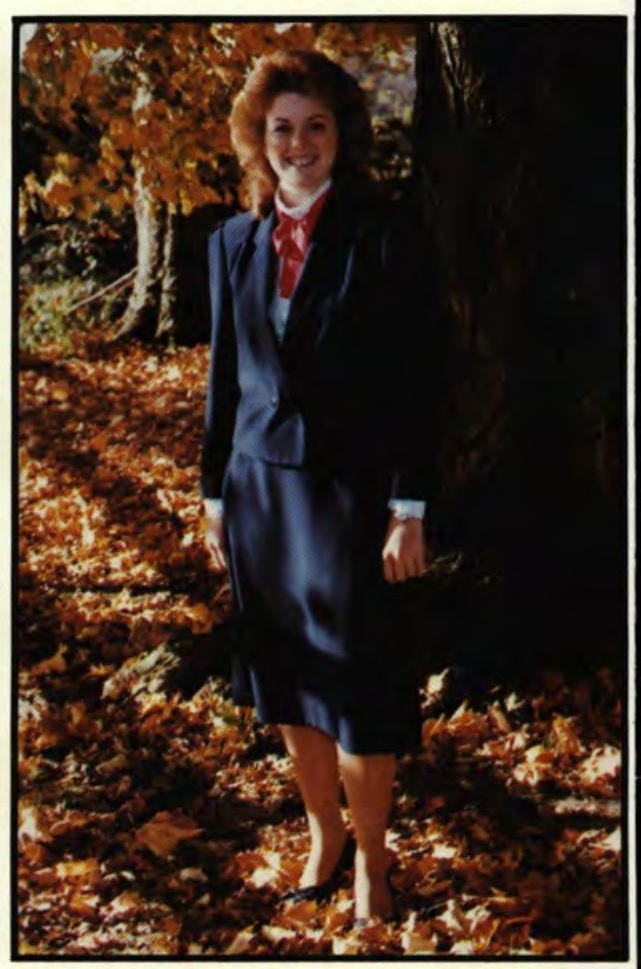

Esther Bucklew Senior Attendant 


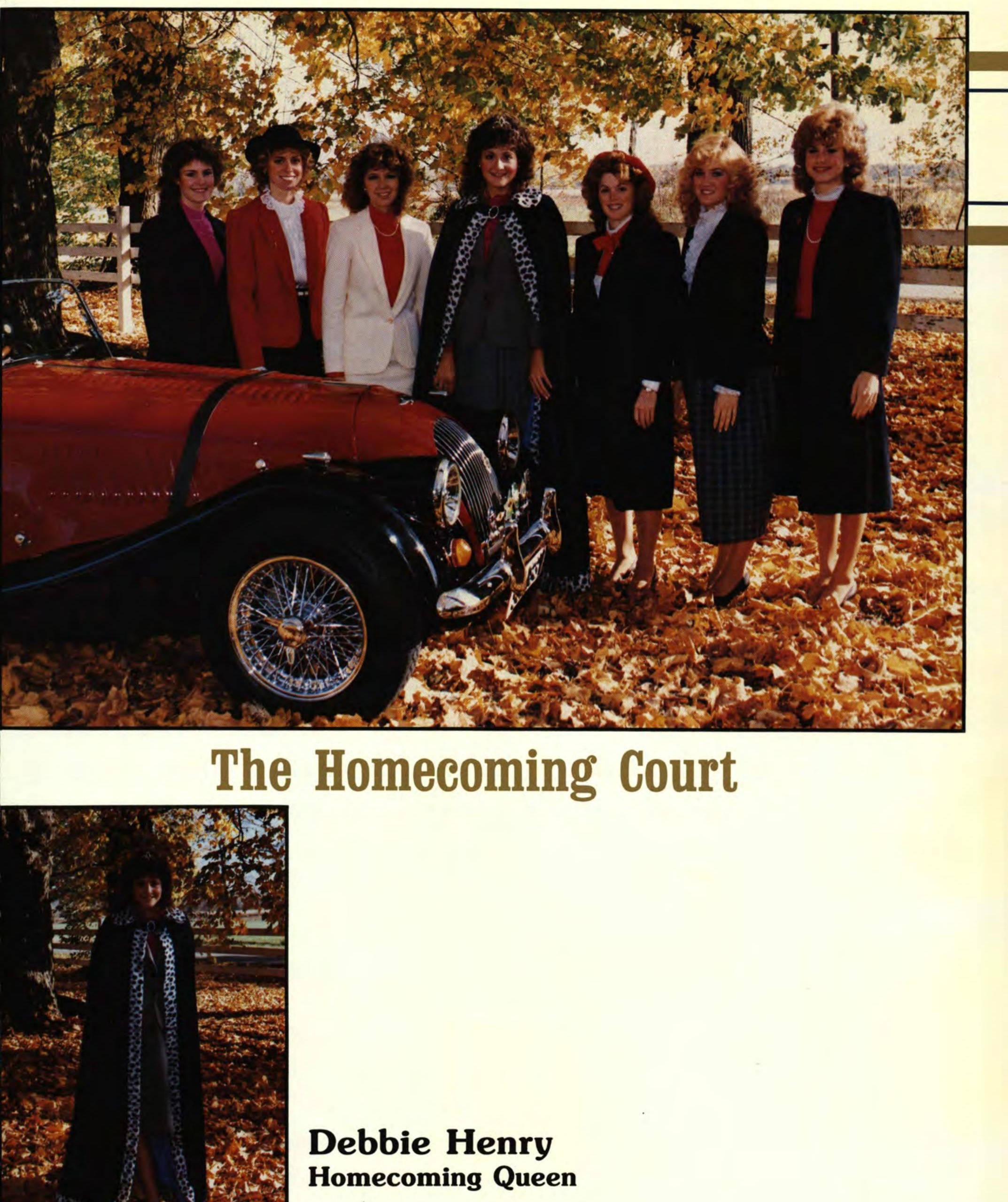

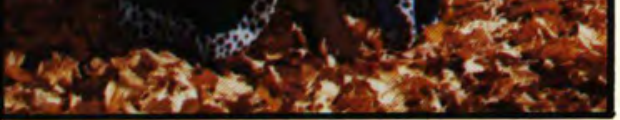




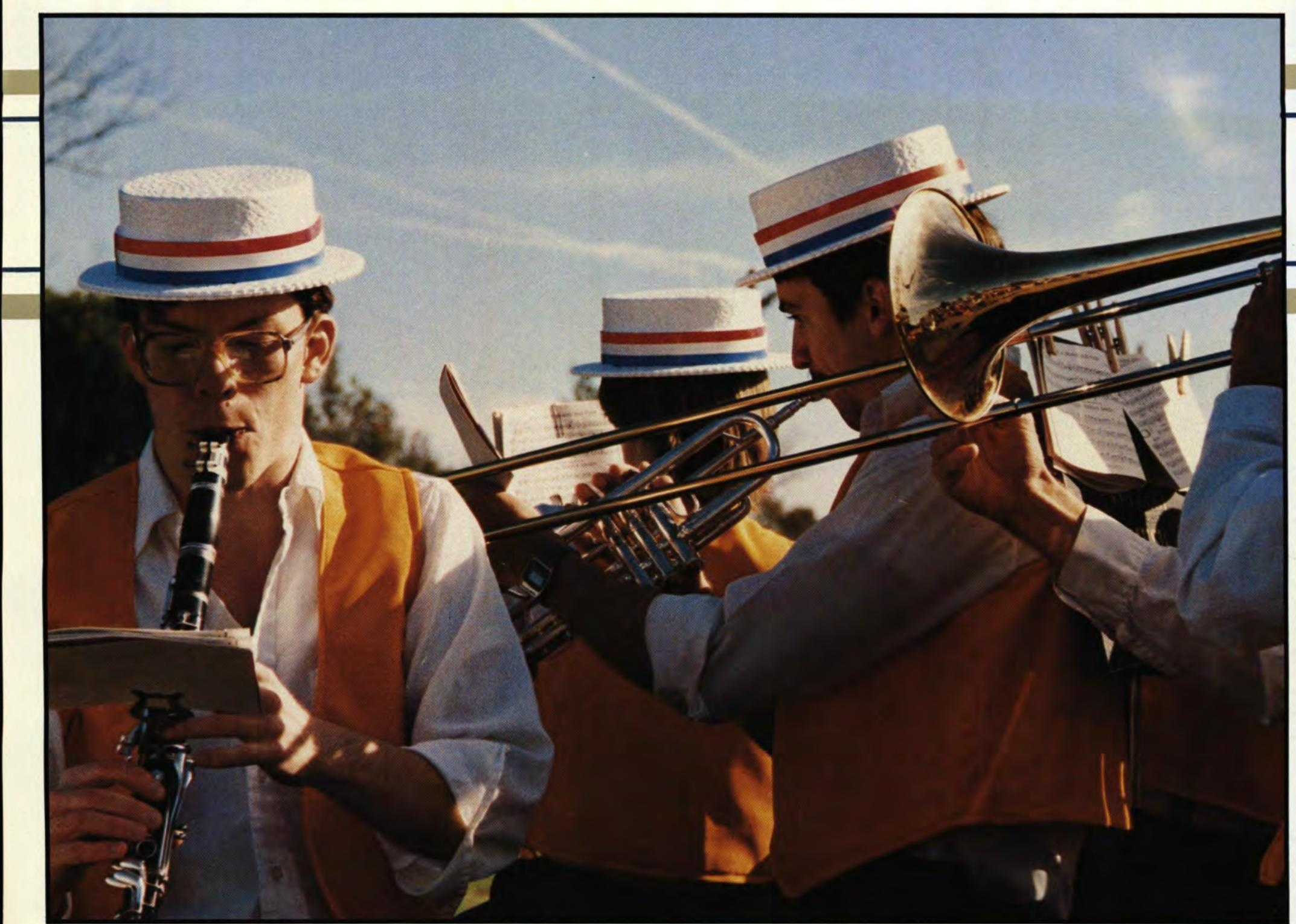

This yearbook is devored to capruring eager students, revered professors, victorious reams, live-wire organizarions, friendships and traditions and loyalties. From time to time you will remember some of these "caprured" experiences; bur many orher moments, our personal and intimate, come alive when you rerurn to alma marer for Homecoming.

For students returning from summer vacation, the campus armosphere revolves around the planning and building of floats, the selecting of the queen and her court, and the anticipation of a soccer team victory. In controst, the alumni's view of Homecoming is more than class reunions, participaring in the Road Run, being a spectaror at the parade, artending the award luncheon, or cheering ar the annual soccer game. For former students, Homecoming is that time when they once again experience that special feeling of remembrance as they sit in a favorite seat in a familiar classroom, gaze our a particular window and recall the seasons' colors, lean against a stairwell wall, or sir on a park bench under a tree recalling a moment of laughter or tears with a special friend.

Homecoming is a warm handshake or the embrace of a friend not seen in years. It's being here. Ir's coming home. It's reliving those special memories of one of the best experiences of life. As someone said, "Time nor distance can never challenge the memories of what has been."

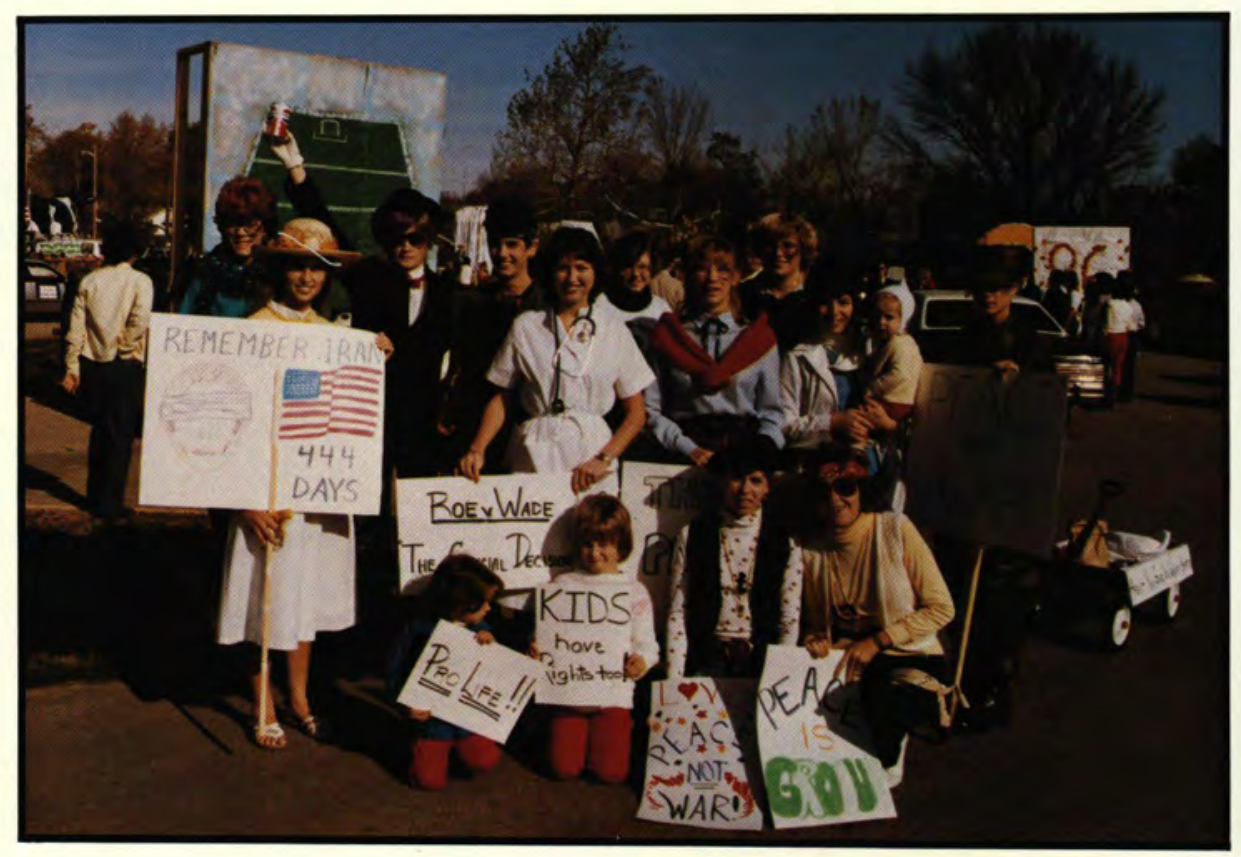

by Gary Kuhn Alumni Relarions Director 


\section{Memories Of A Lifetime}
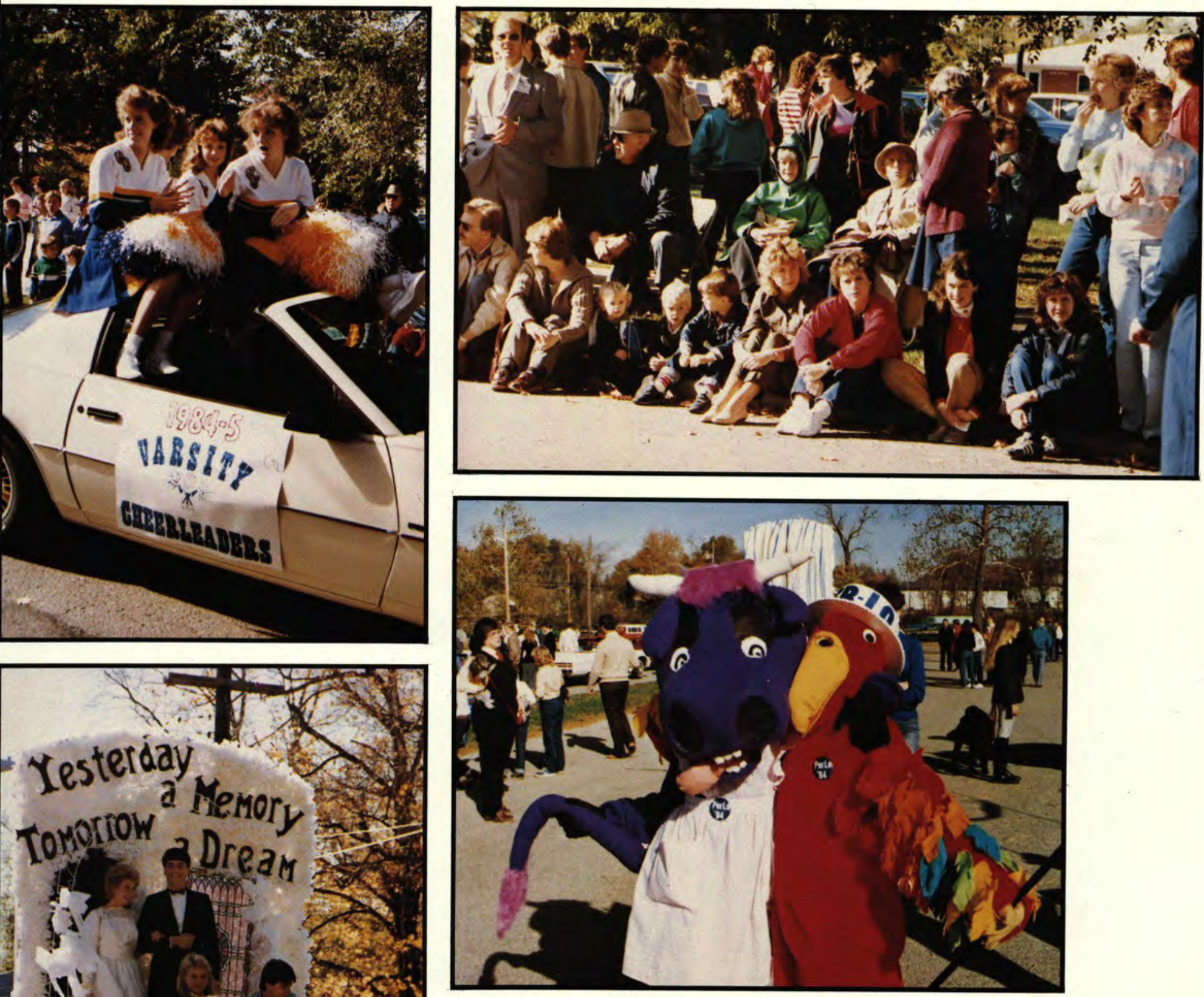

Yesteriay ax o >

- Yesterday a Memory Tonoriow a Dream in
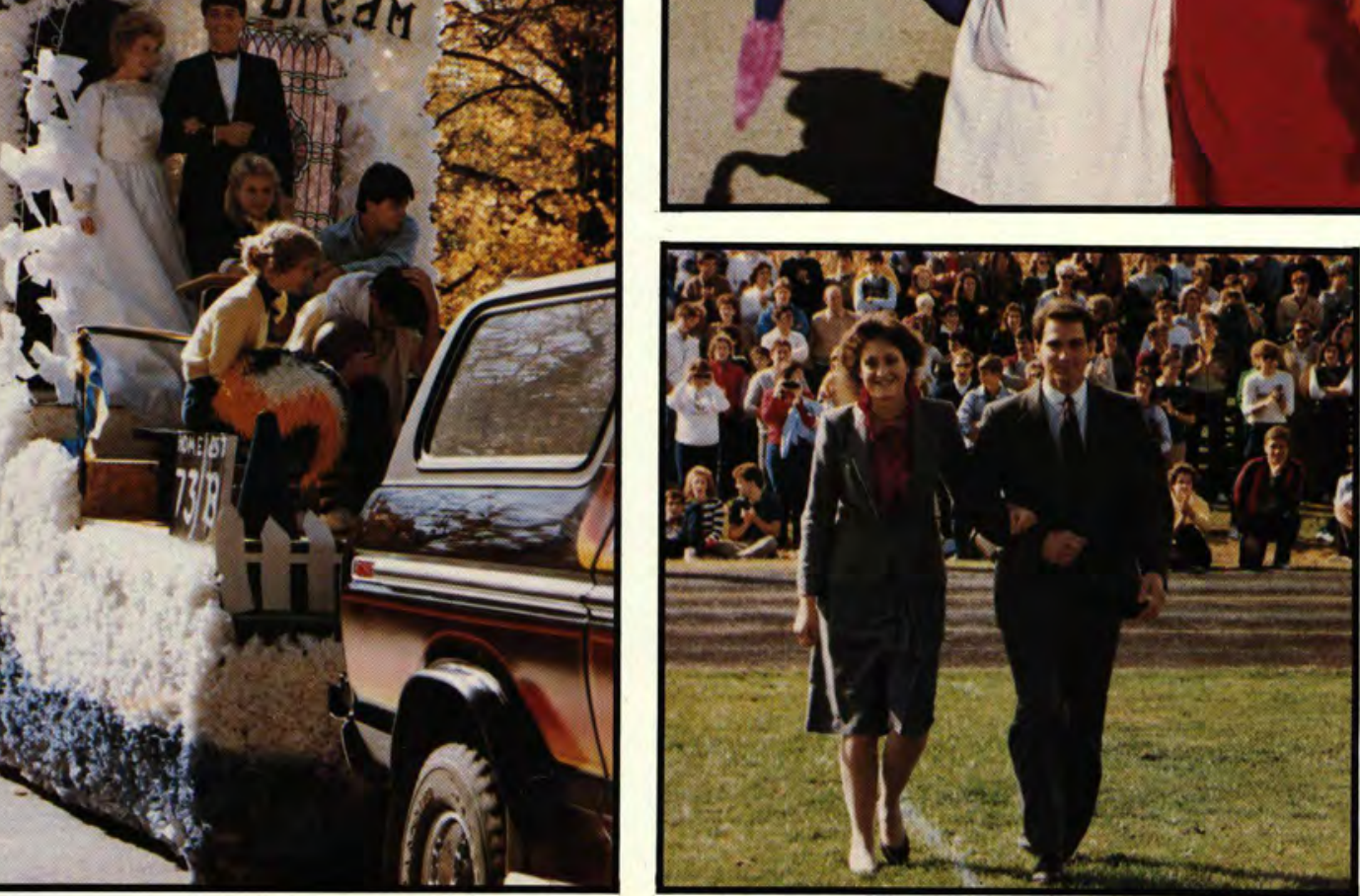


\section{Cedar What?}
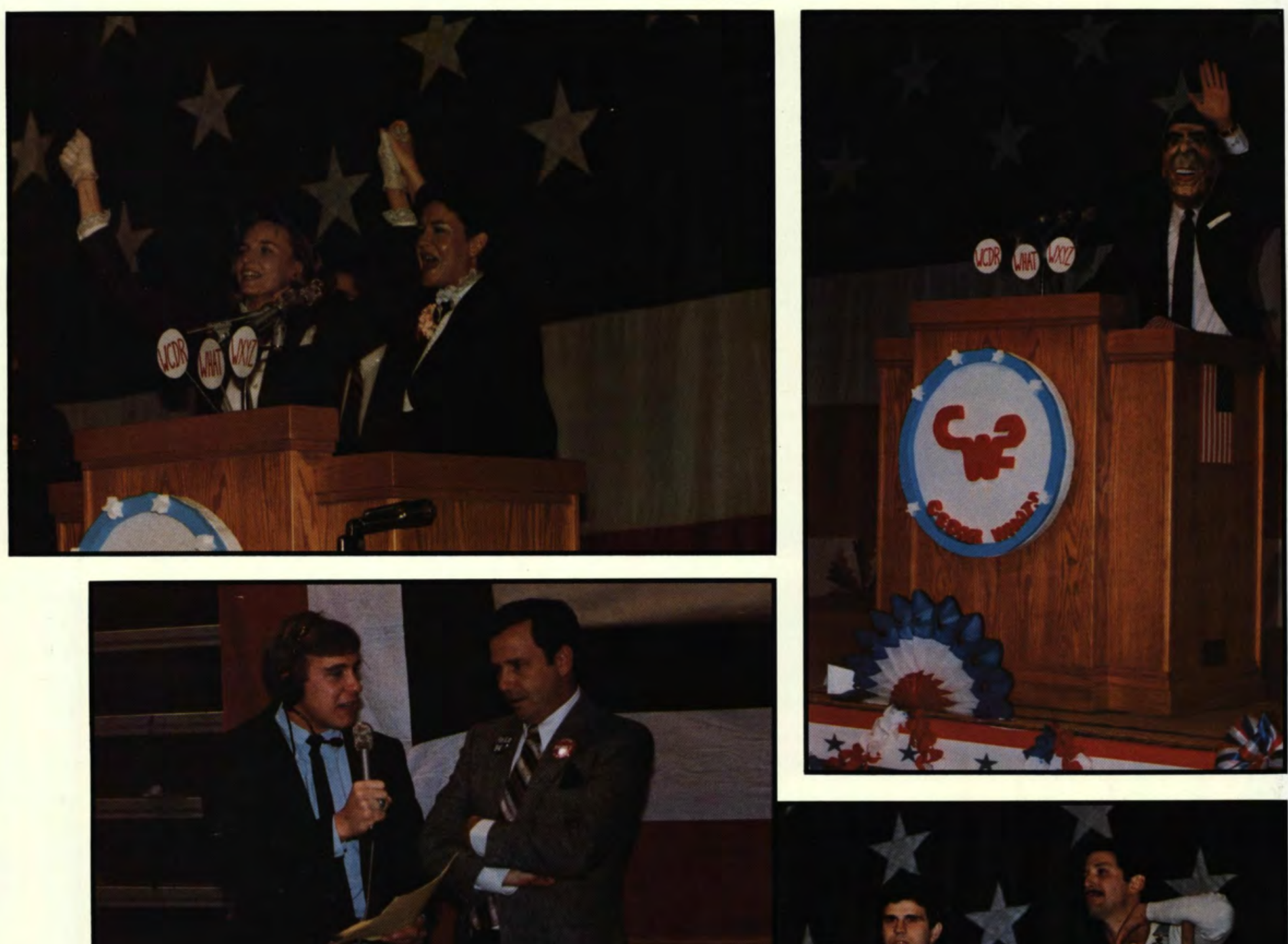

$000^{4}$

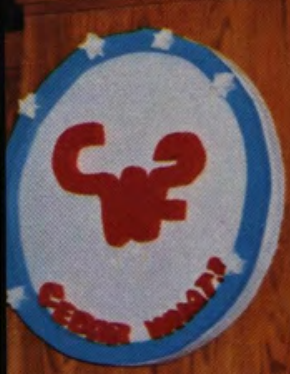



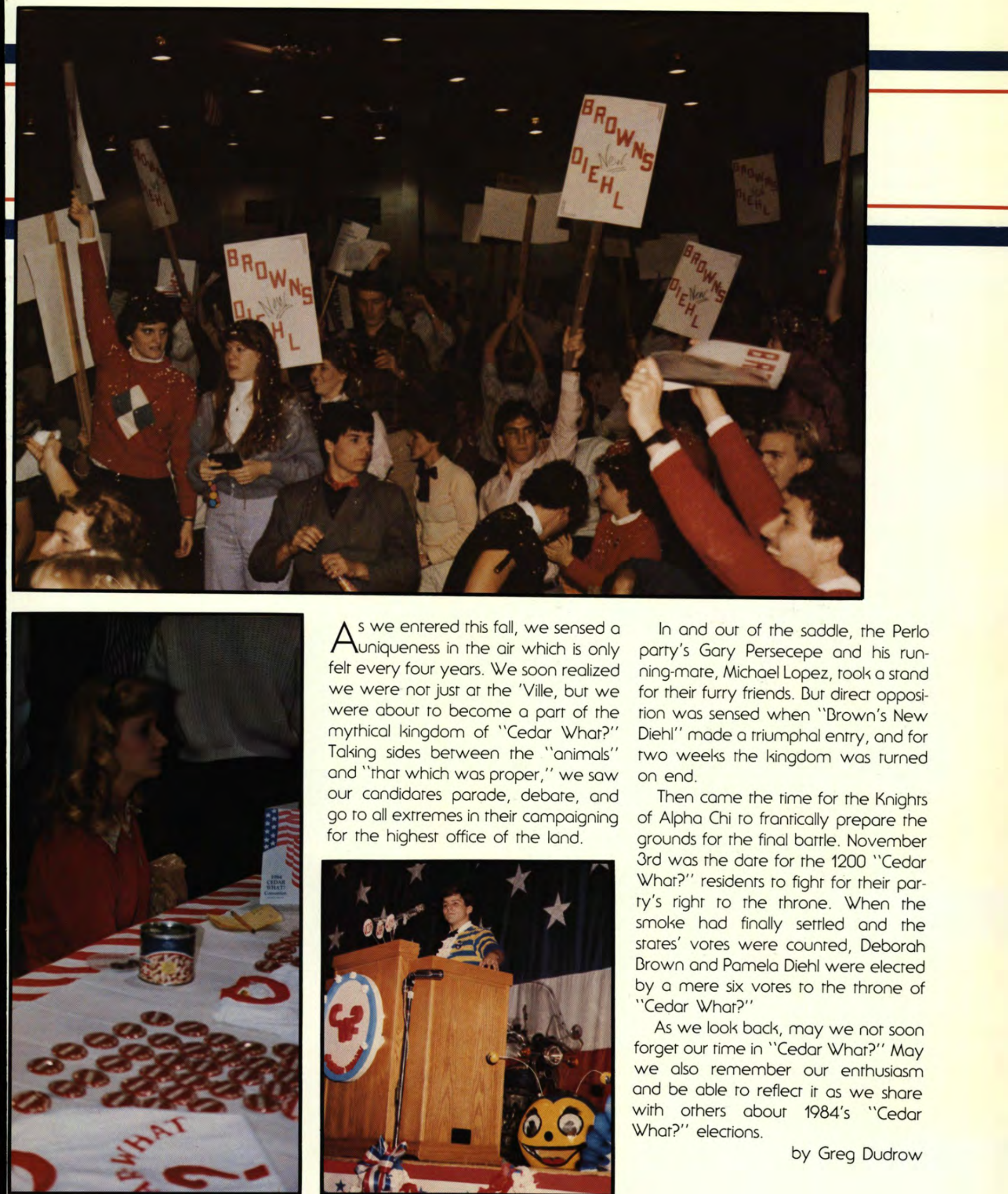

$\triangle \mathrm{s}$ we entered this fall, we sensed a

In and out of the saddle, the Perlo parry's Gary Persecepe and his runfelt every four years. We soon realized we were not just at the 'Ville, but we were about to become a part of the mythical kingdom of "Cedar What?" Taking sides between the "animals" and "thar which was proper," we saw our candidates parade, debare, and go to all extremes in their campaigning for the highest office of the land.

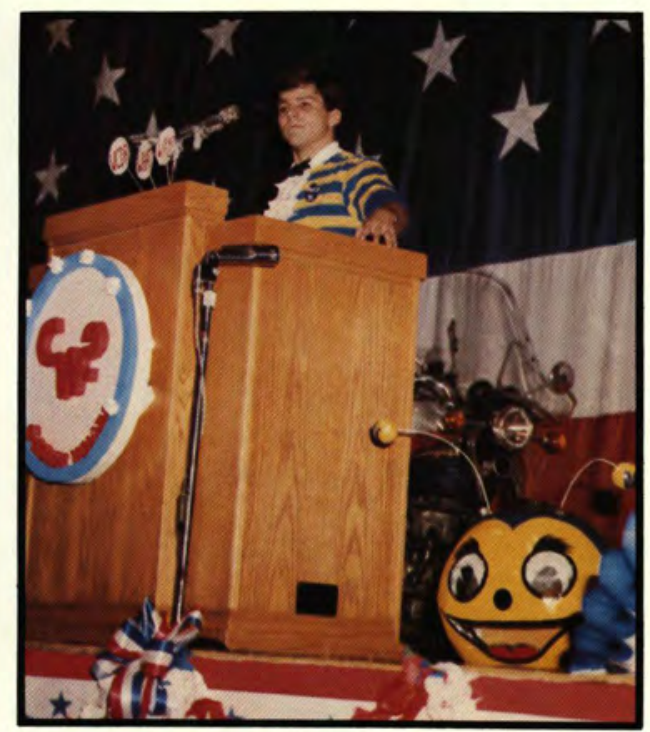
ning-mate, Michael Lopez, took a stand for their furry friends. But direct opposirion was sensed when "Brown's New Diehl" made a triumphal entry, and for two weeks the kingdom was rurned on end.

Then came the time for the Knights of Alpha Chi to frantically prepare the grounds for the final battle. November 3rd was the dare for the 1200 "Cedar What?" residents to fight for their party's right to the throne. When the smoke had finally settled and the states' vores were counted, Deborah Brown and Pamela Diehl were elected by a mere six vores to the throne of "Cedar What?"

As we look back, may we not soon forget our time in "Cedar What?" May we also remember our enthusiasm and be able to reflect it as we share with orhers about 1984's "Cedar What?" elections.

by Greg Dudrow 
$\triangle$ nxious waiting.

A mad scramble,

In the room across the hall,

To finish cleaning.

7:50 pm

Shut the currains,

Door opened,

"Is my hair O.K.?"

"Quick, put that box somewhere else!"

7:55 pm

"Close the bathroom door!"

"I did."

"Did someone pur the cookies our?"

Santa adjusts his beard,

Warm and itchy already

One final "Ho , $\mathrm{Ho}^{\prime}$ " in the mirror.

Good.

8:00 pm

OPENHOUSE!!!!

Once a year,

Mad scramble,

Putring best foot forward,

The rest in the closet.

Unit one.

"Wow!"

Foil covers everyrhing,

Lights twinkle.

In the hall,

Santa - lap empry,

"Ho, ho, ho."

Candy and a plare of cookies,

On the rable beside him,

He smiles

A young Santa,

Only 19.

Herds trample,

Lawlor shakes.

Peals of laughrer,

Looking in windows from the balcony walk,

Tour de Force,

"Where now?"

Cookies in hand,

Aimlessly wandering,

Unit 11.

Rating rooms,

Floor clean,

Under the bed,

Dust.

Sneaking a peek into closers,

Under beds and in desk drawers,

In the shower,

Avalanche!

Dirty dishes,

Dirty clothes,

Food,

An ironing board,

And two typewriters.

Clammy palms,

In the hall another herd posses by,

Looking in cautiously.

Peeking around the corner of the door,

Looking for a friendly face,

Embarrassed to find none.

$\mathrm{COOL}$, sunglasses though it's dark, Jacket collars turned up,

Walking with a swagger to impress,

Open House
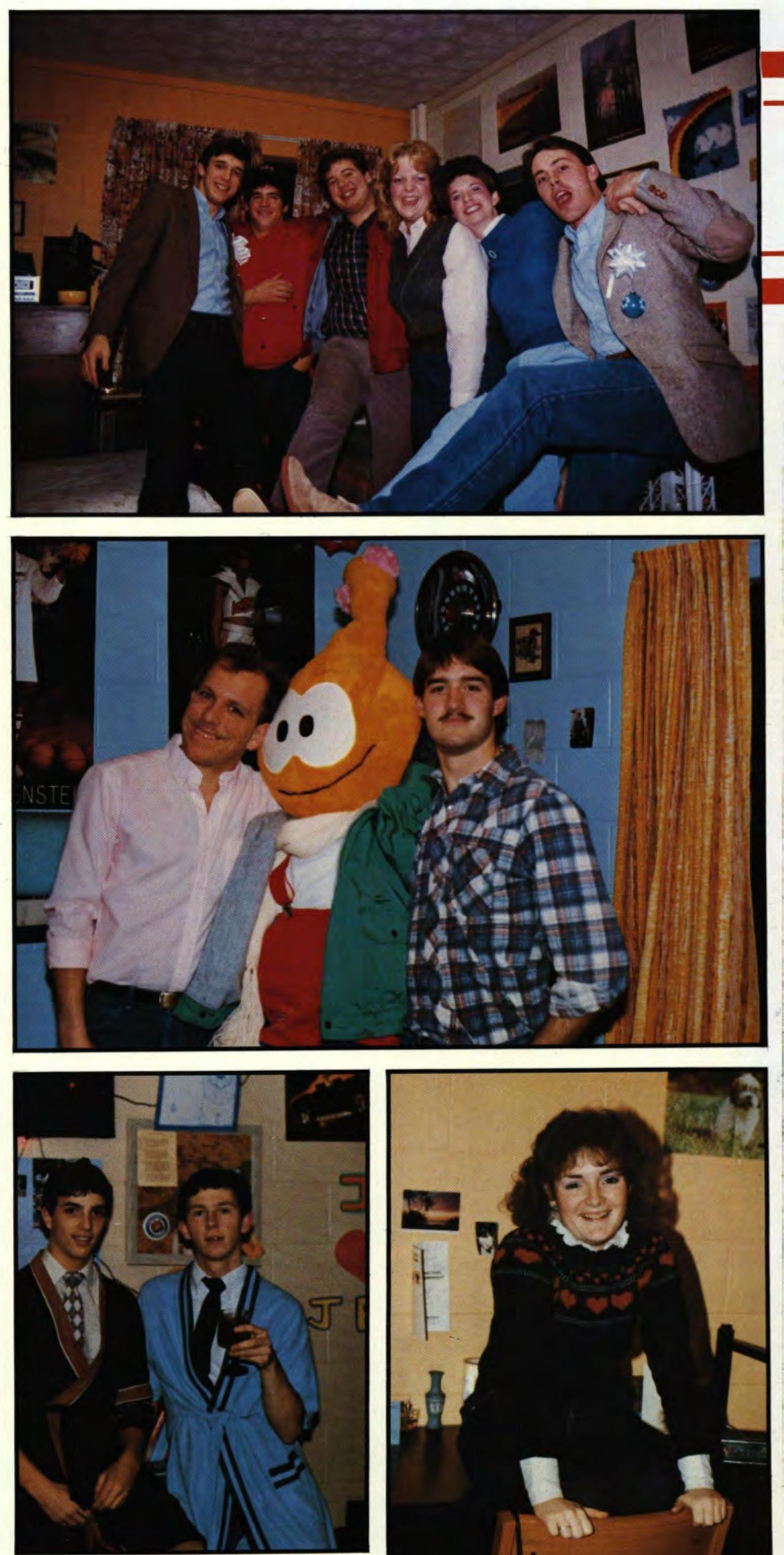

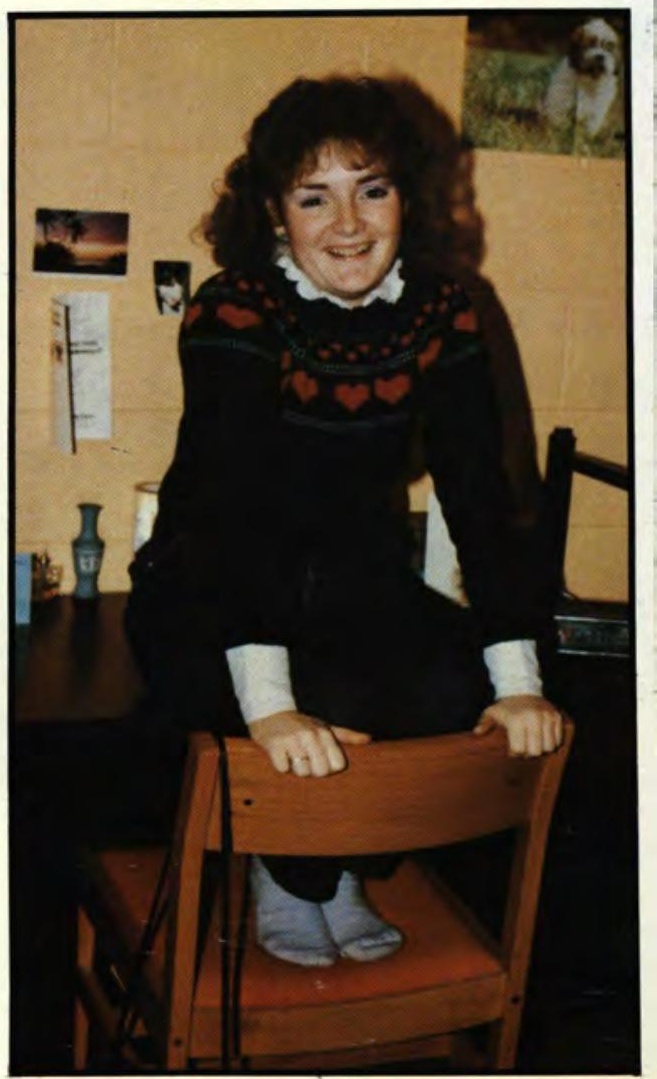




\section{'Mockingbird Moves Audience}

Hey Kim, what are you doing tonight?" । asked

"Oh, I've gor to go to play rehearsal. Tonight we're doing the court scene," yelled Kim Fry.

To Kill a Mockingbird was a moving play presented during the fall and directed by Mrs. Rebecca Baker. As I sar in the background warching students tryour, practice, and finally perform, I saw written words come alive. Mrs Baker saw how important the message of this play was and, therefore, fear accompanied her excitement in direcring the play.

In a small town in Alabama during the de pression-ridden years, there lived a family named Finch. They believed in trurh and honesty; unfortunarely, they seemed to be a rarity amongst the others in their area. The many losses Articus Finch suffered, however, were blighred by one staggering vicrory: he was able to go to sleep ar night knowing he had dealr trurhfully. His neighbor said it simply, "We trust him to do right.

Ler Carla Rirchie, who played the lead character of Scout, explain the play in her words: "Hey! Don'r you remember me? I'm Jean Lou ise Finch, but most everyone calls me Scout.

"This will only rake a minure. I gorra rell you abour what happened to me! Come sit over here on the porch

"Me, an' Arricus, an' Jem, an' nearly everyone in Maycomb gor to pay a visit to Cedarville College so we could rell them a story 'bour us! Got any gum?

"Well, anyway, the story was abour some- thing that really happened to Jem, an' Articus, an' me this summer. Jem an' me gor to meer Dill, an' he wanred to make Boo Radley come our!

Tom Robinson gor in some real bad rrouble and Arricus - whar? Oh, he's my farher had to defend him ar a real trial and everyrhing

"Some people made a lor of fun of me and Jem cause our farher was defendin' a Negro, bur we jus' held our heads high and acted like gentlemen.

'Boo Radley started leavin' things in the knorhole. We didn'r know who it was ar first, but when we were arracked by that rerrible Mr. Ewell, it was Boo who saved us!

"And we sure learned some pretry important things. Atricus turned out to be the best forher ever. He shor ol' Tim just when we were beginning to think he was too old to do anything. He raught us how to step in orher people's shoes, too. Jem stepped in Mrs. Dubose's; I srepped in Boo Rodley's; Arricus? I think he was rryin' to step in every shoe in Maycomb!

"Hey. Whar's the marter? Hey! Are you listening to me? Yeah, I guess it's gerting prerty lare and Cal will be wantin' me ro ger washed for supper.

"I sure hope we ger to see the people of Cedarville again somerime. You know ... they were real nice.

By Carl Rirchie Brenda James
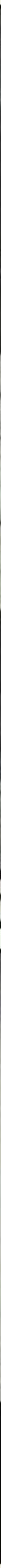
Police officers Mike Mikeshell and Todd Bishop check out the Hendrix apartment.

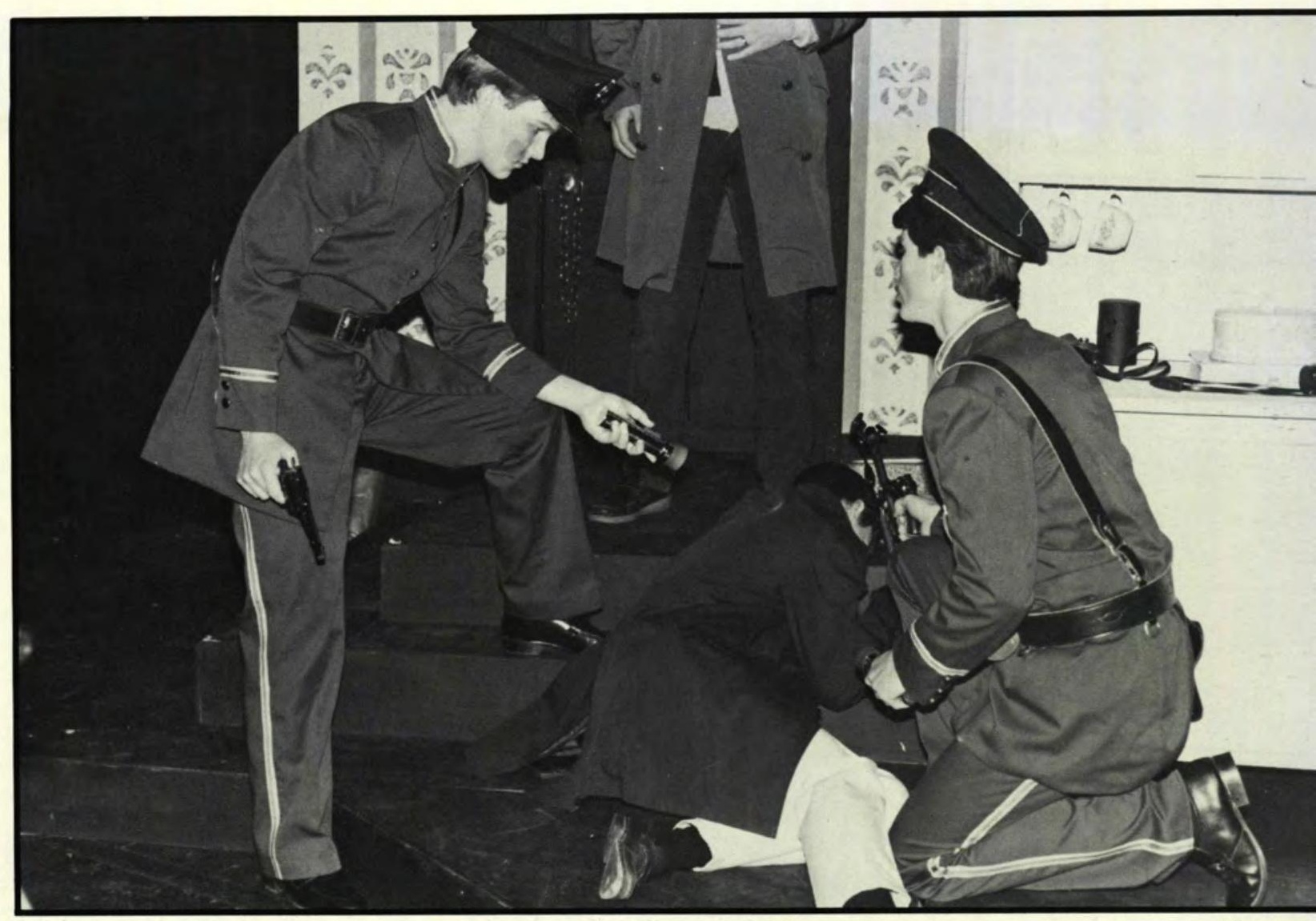

\section{The Cast}

Elena Michael

Gary Barker

Gary Cooke

Jeff Beste

Jim Unger

Sherry Rotramel

Mike Mikeshell

Todd Bishop

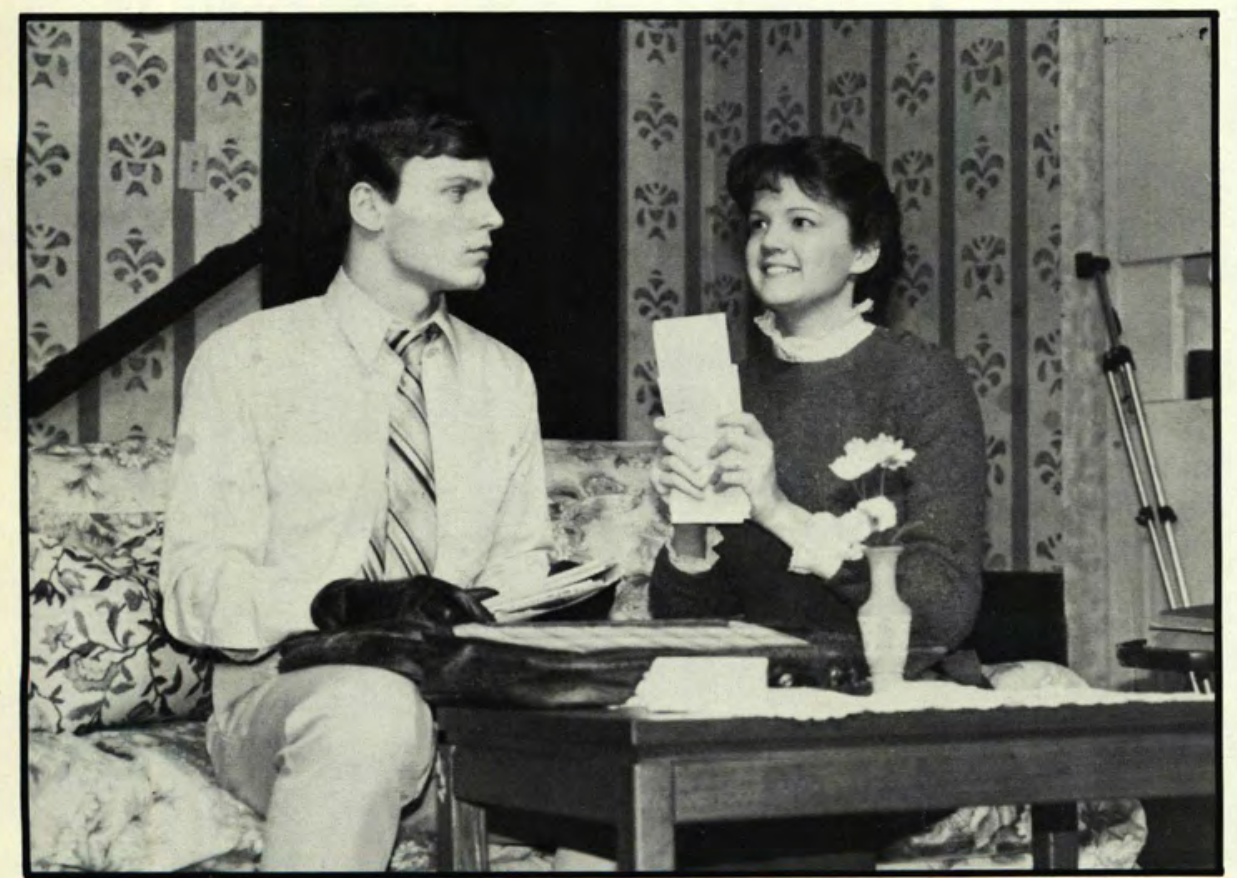

The blinded and unsuspecting Suzy converses with Mike Talman (Gary Cooke). Sam Hendrix (Jeff Beste) comforts his wife Suzy (Elana Michael).

Suzy Hendrix

....Mr. Roat

Mike Talman

Sam Hendrix

Sgr. Carlino

Policeman

Policeman 


\section{HAIR-RAISING AC'IION}

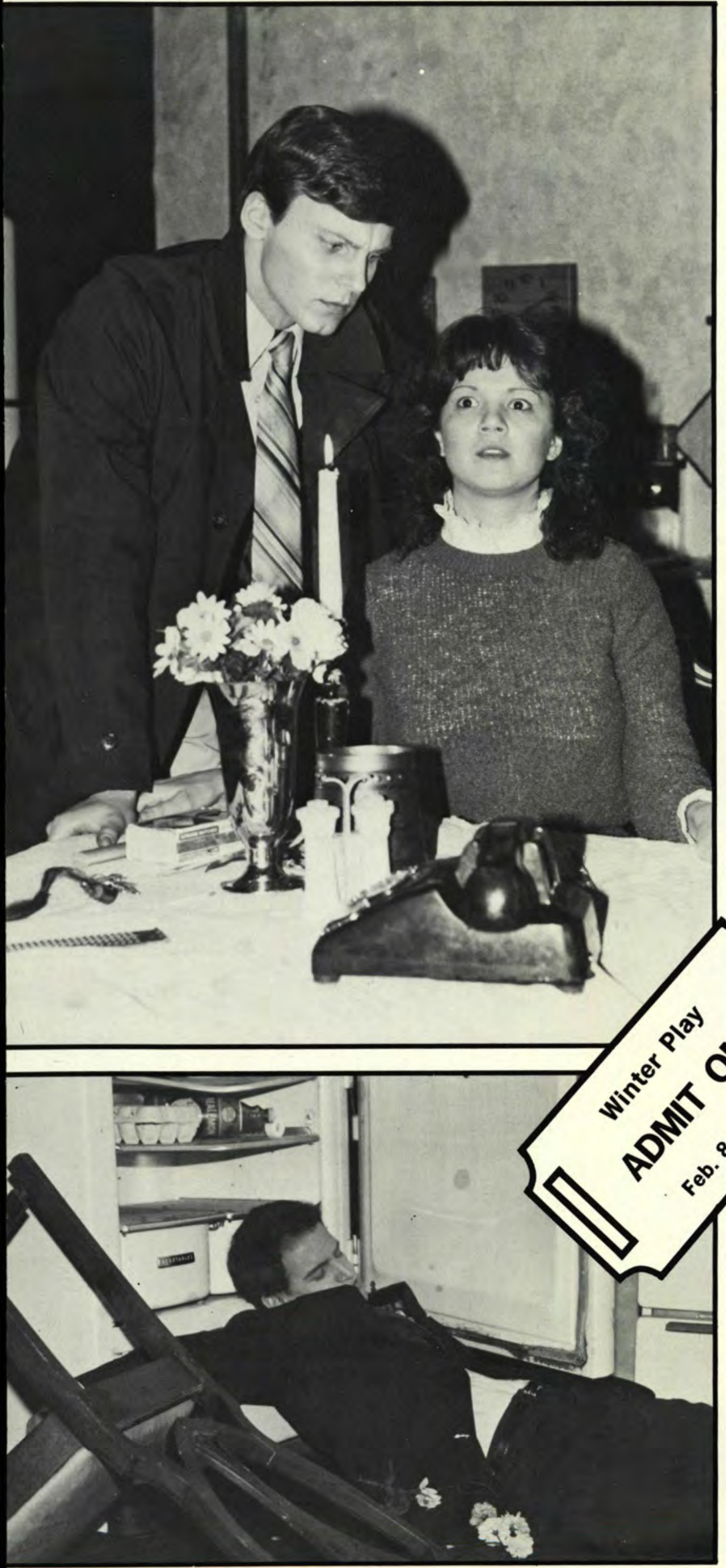

$A$ quick glance down the Alford aisles reveals only the benign interior of the well-used auditorium. For the winter play, Wait until Dark by Frederick Knotr, however, hair-raising action transformed Alford into a pit of terror for audiences. The rwo act mystery drama pitted the blind Suzy Hendrix (Elena Michael) against the sinister Mr. Roat (Gary Barker) as they vied for the possession of an extraordinary doll within the confines of Suzy's apartment.

Drawing capacity crowds, the play's climactic confrontation between Suzy and Roat brought hearts into mourhs of every audience member; some even screamed aloud. According to play director David Robey, the success of the play was in part due to the "strong audience participarion in the frighrening conclusion of the play."

The first mystery play tackled in several years was presented four times to a full house each time. Don Jones, the rechnical director for the Village Players, designed and built the masterful ser which grearly added to the suspense of the drama. Members of the audience filed our hurriedly from the interior of Jones' transformed Alford; no one wanted to be left after dark.

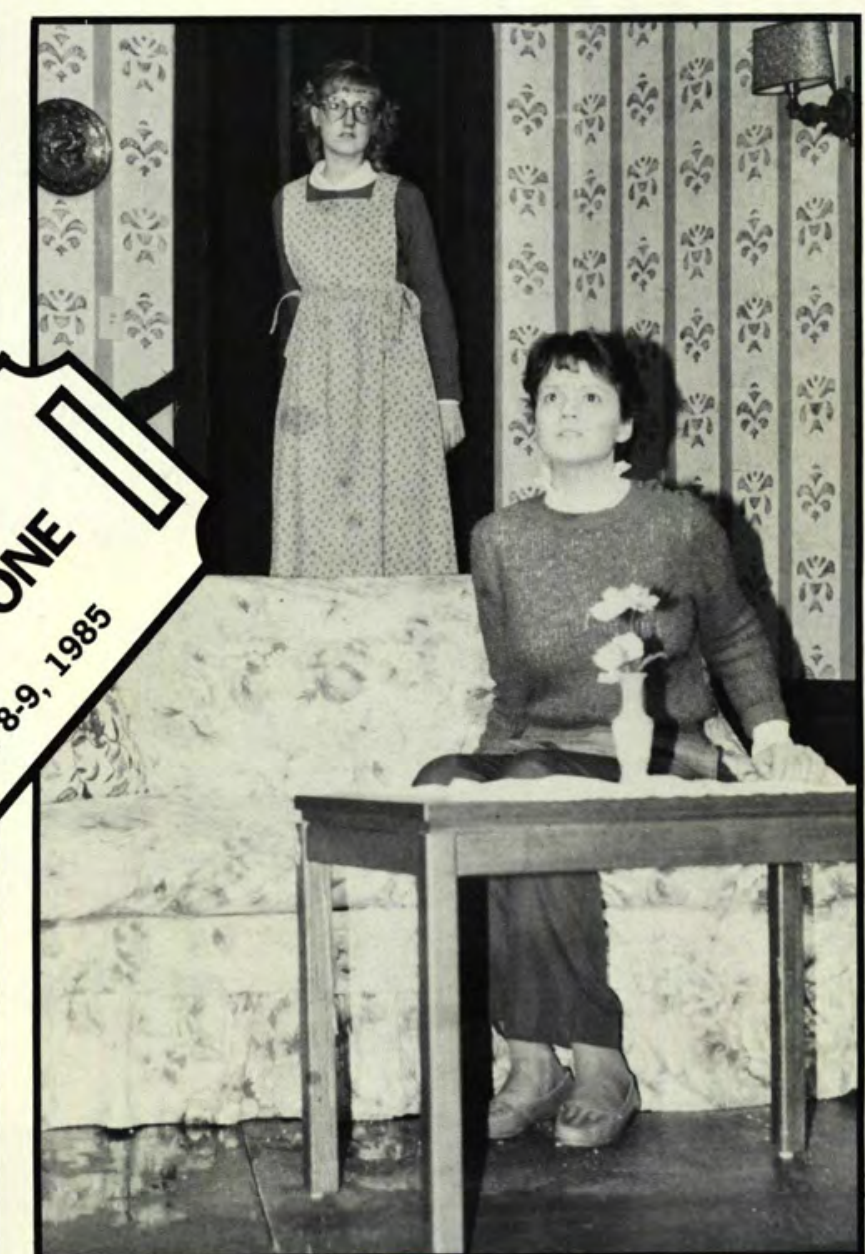

Above, Left: Confronted by Talman, Suzy becomes alarmed. 


\section{TAMING THE SHREW

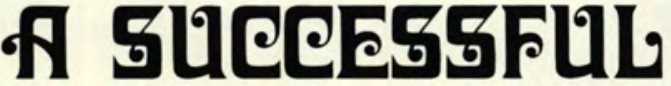 5How}

"Ir is better to dwell in the corner of the housetop, than with a brawling woman and in a wide house."

Proverbs 25:24

Men have attempted to subdue the irascible vixens of their time since the fall of man; for the last four hundred years, Shakespeare's portrayal of this effort has entertained audiences by making light of the challenges of living with a "shrewish" woman. On the first rwo weekends in May, the Village Players presented Shakespeare's Taming of the Shrew as directed by David Robey.

The cast of twenty students and faculty was led by Rebecca White and Gary Cooke in the roles of Kate and Perruchio. Shown on Parent's Weekend, many visitors had an opportunity to view what Professor Robey termed "a successful show."

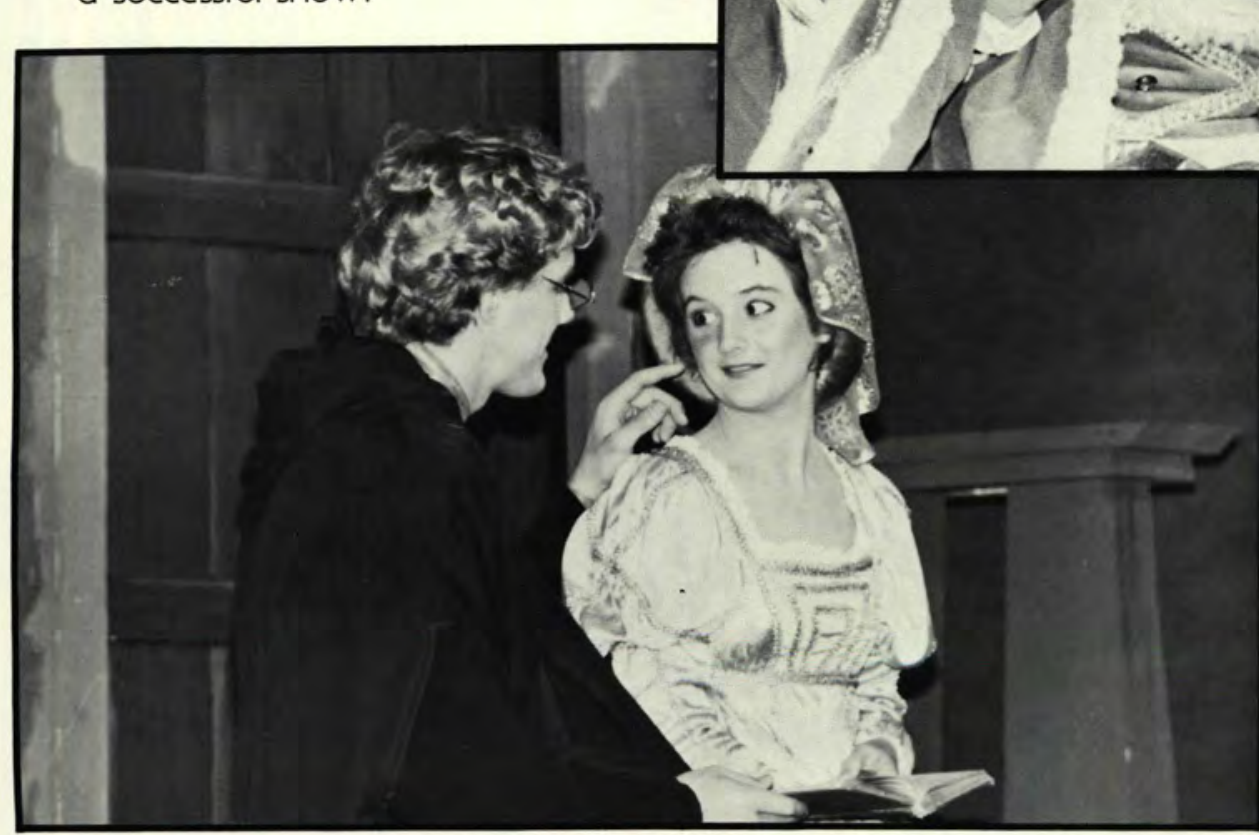



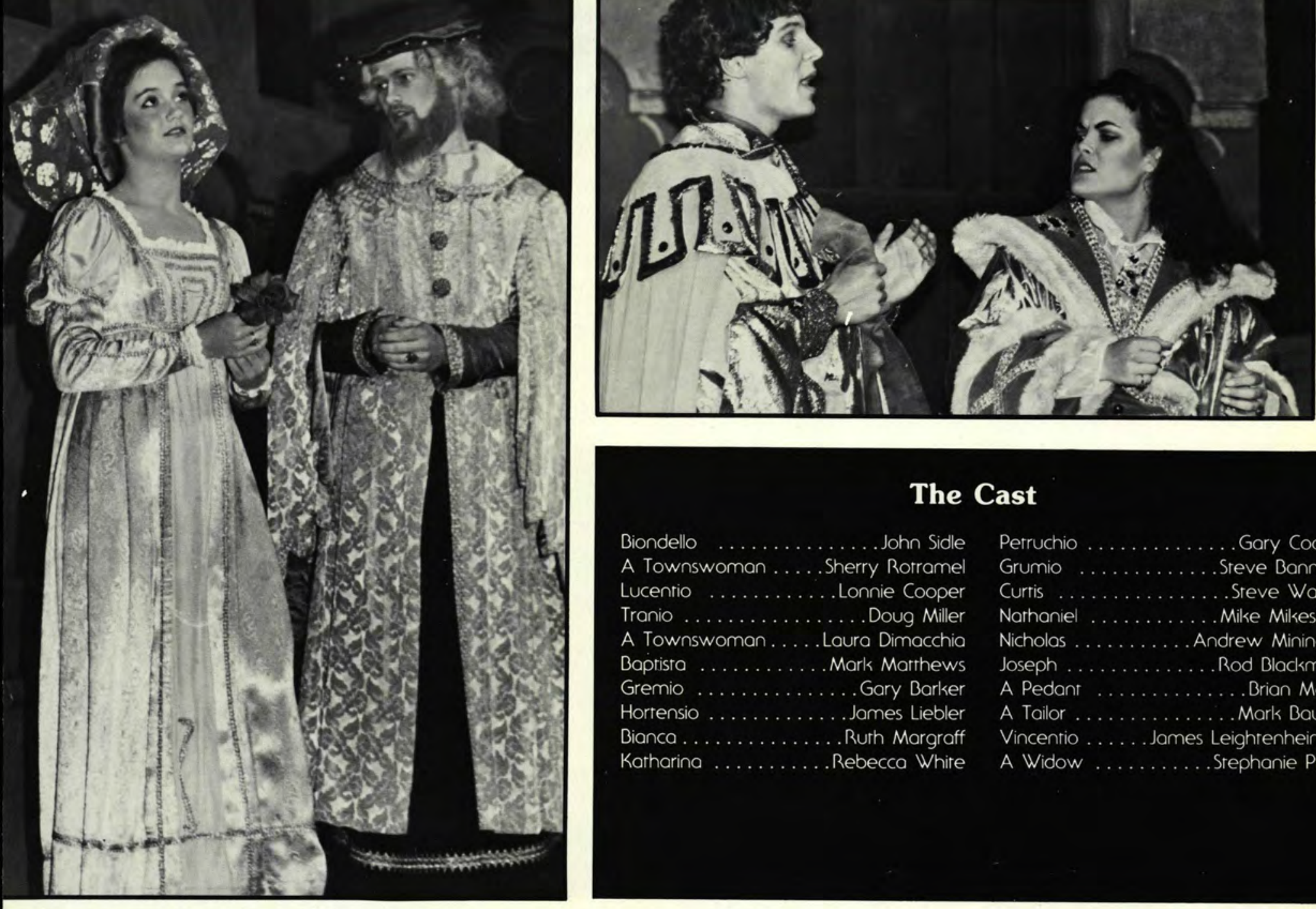

\section{The Cast}

Biondello ............... John Sidle Perruchio

A Townswoman .... . Sherry Rorramel Grumio

Lucenrio .............Lonnie Cooper Curris .

Tranio ............... Doug Miller Narhaniel

A Townswoman.... L Laura Dimacchia Nicholas.

Baptista ... . . . . . . Mark Marthews Joseph .

Gremio . . . . . . . . . . . . Gary Barker A Pedant

Hortensio ... . . . . . . . James Liebler A Tailor .

Bianca ... . . . . . . . . . Ruth Margraff Vincentio

Karharina .............. Rebecca Whire A Widow ........... Srephanie Pratr

Gary Cooke

Sreve Banning

.Steve Walrer

Mike Mikeshell

Andrew Mininger

Rod Blackman

. Brian Maas

Mark Baugh

.Srephanie Pratr 


\section{Dorm Life: Home Sweet Home?}

Many adjustments have to take place when major adjustment is moving from the comforts of home to the problems and inconveniences of dorm life. Mom is no longer there to do your laundry, clean your room, or make your bed.

You always wonder why in the world you brought so much stuff and how in the world you're going to fit it into a tiny room that's barely big enough for rwo beds! But somehow you manage to find a place for everything and soon it becomes home. After a few room fines you get into the habit of making your bed, and after ruining an entire load of laundry you finally break down and ask your mom how to do it.

College life would be quite dull withour the excitement of living in the dorm. The late-night "study" parties, sunbarhing in Maddox courtyard in the spring, the crazy Lawlor parties heard all over campus, and deep theological discussions at $2: 00$ in the morning. Living with seven other unitmates develops a closeness that builds life-long friendships. These friends are there during the bac times and the good rimes, and during the sad rimes and happy times.

Living in the dorm may at first seem like an unbearable situarion, bur 'in the end it will turn our to be one of the grearest aspects of college life.
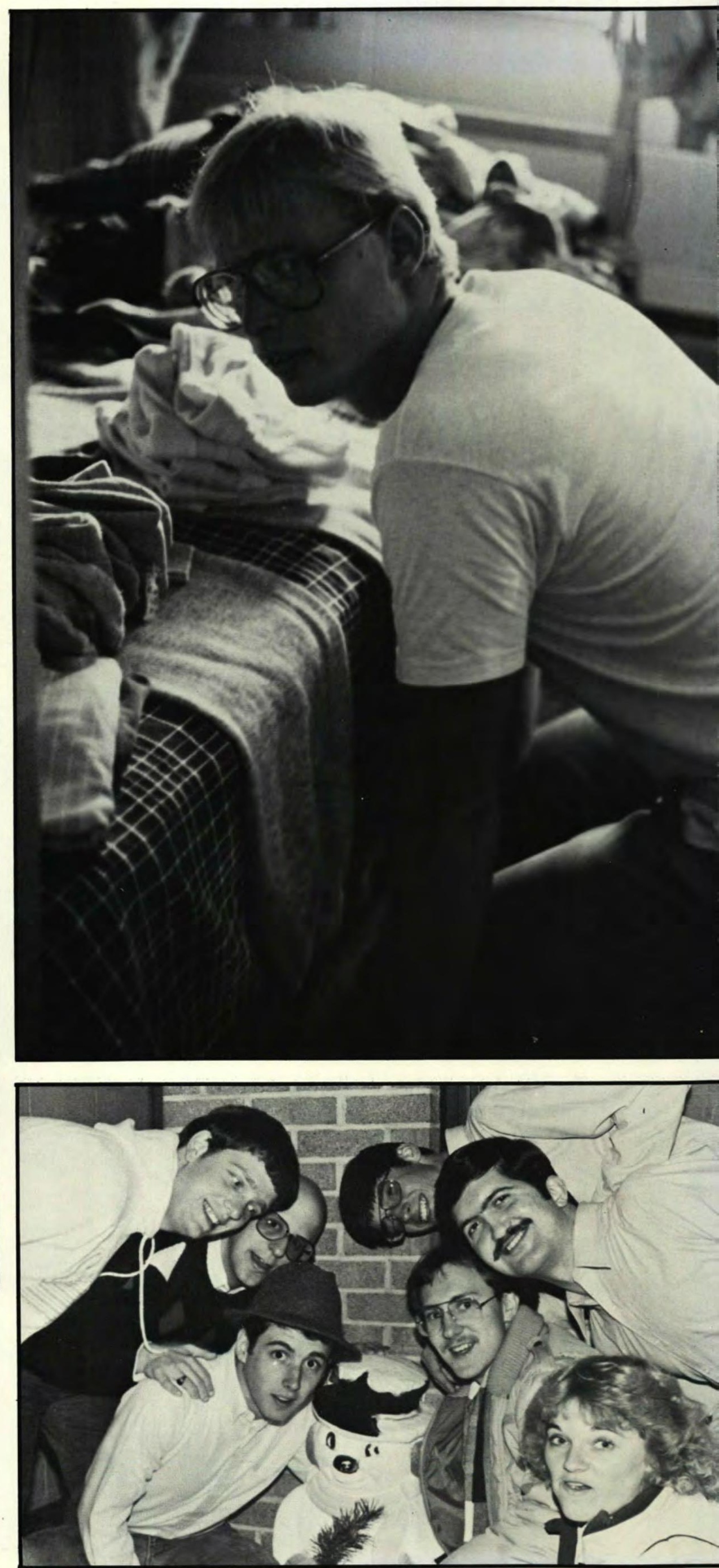

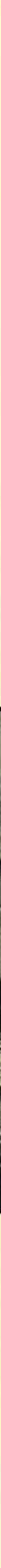


\section{NOVICE STUDENTS NOT NEW TO TALENT}

randing on stage in a bathrobe and ani-
mal slippers with rollers in my hair and singing "Mr. Mailman" to the tune of "Mr. Sandman" was about the last thing I expected to be doing my first three weeks at Cedarville. How I went through with it l'll never know, but I am so glad I did. The 1984 New Srudent Talent Night was performed on Ocrober 19. In order to perform in the talent show there were auditions the previous week. After few practices it was finally bright lights, (no camera), and HOT action! The evening's entertainment ranged from five girls singing barbershop style to a classical flute solo. It definitely was a "dog eat dog night" with our MC's Percesepe and Lopez playing the act literally. Well, I may never live down the bathrobe and curlers image, but the entire evening was well worth it. Its purpose was fulfilled by aquainting the new students with the student body.

by Jennifer Haufler
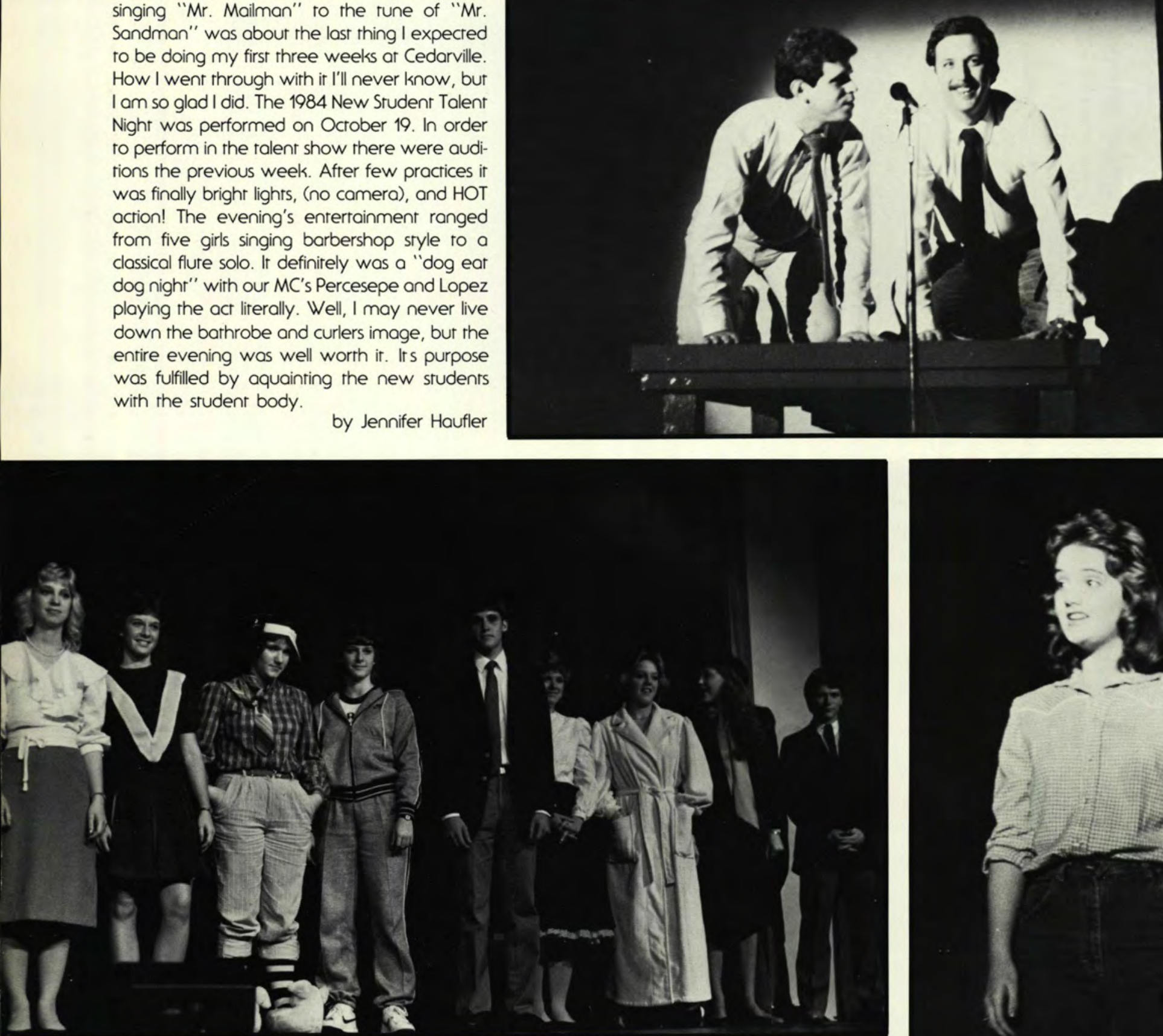

Top: Encees Percesepe and Lopez promore their Cedar What? campaign while entertaining the audience

Upper Left: Participants line up on Alford stage to take their bows.

Far Right: Ruth Margraff shows her dramaric ability.

Right: Performing a song she composed herself, Tanya Williamson displays her talent to the audience.
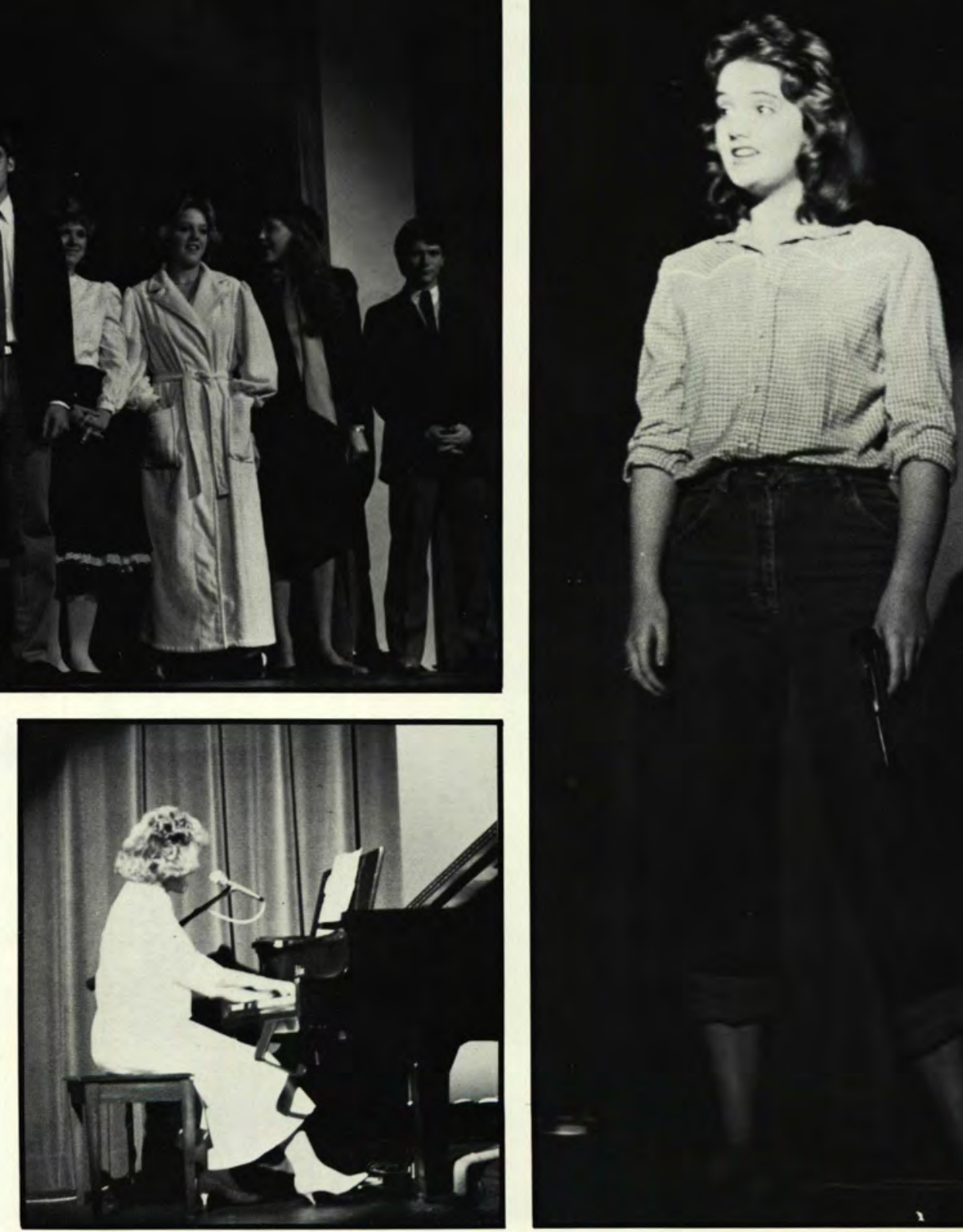


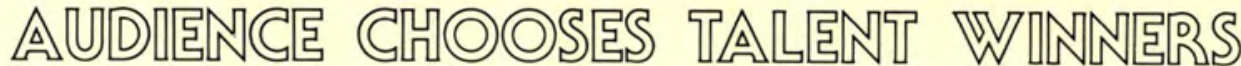

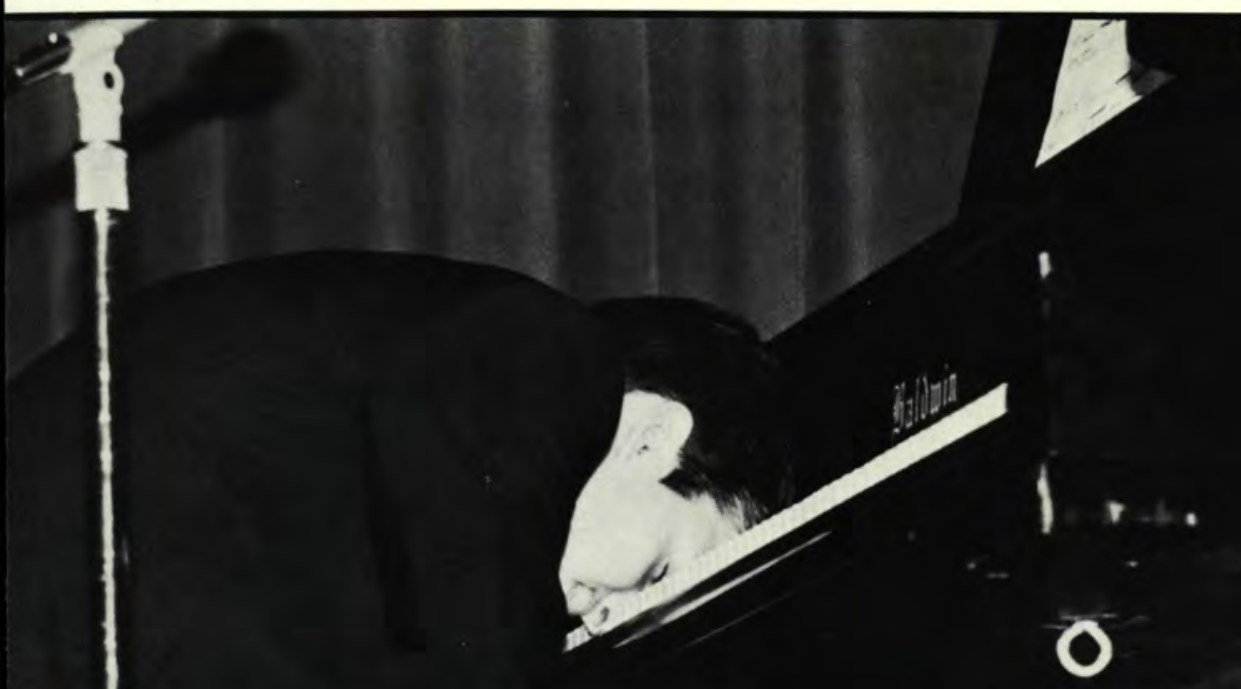

T his year the men of Alpha Chi designed their annual Alpha Chi Talent Night ro involve the whole student body. For the first rime, members of the audience did somerhing orher than enjoy themselves: this year the Talent Show became Cedarville College's version of the "People's Choice Awards" as the audience chose the winners of the comperition. Prior to this year, a panel of judges selected the winners from the ranks of the many ralented performers.

Opened to anyone, this talent show had somerhing for everyone, ranging from originally sacred to outright farcical. Eric Helmuth, with his rendition of "P.D.Q. Bach," Brian Maddox's "The Race," and the "Sentimental Journey" taken by the Nostalgics garnered first, second, and third prizes respectively.

Instrumental selections constitured a large portion of the production including a saxophone quinter, a flute solo by Al Lopez, and "Heaven Came Down" performed on trombone by Lynell Smith. While singers with humorous or otherwise ralented intents enterrained the audience with "Bertha's Song," Jim Unger performed his original song, "The Sovereign Way"; Chris Tupps and Donna Thomas borrowed from Fiddler on the Roof to present "Do You Love Me?" Alice Boyd presented a version of the rime-worn Cinderella story in a rarher backwards foshion entitled "Rindercella." In an original endeavor, Kim Murphy's improvisarional comedy number demonstrared that talent as presented by Alpha Chi was definitely unique
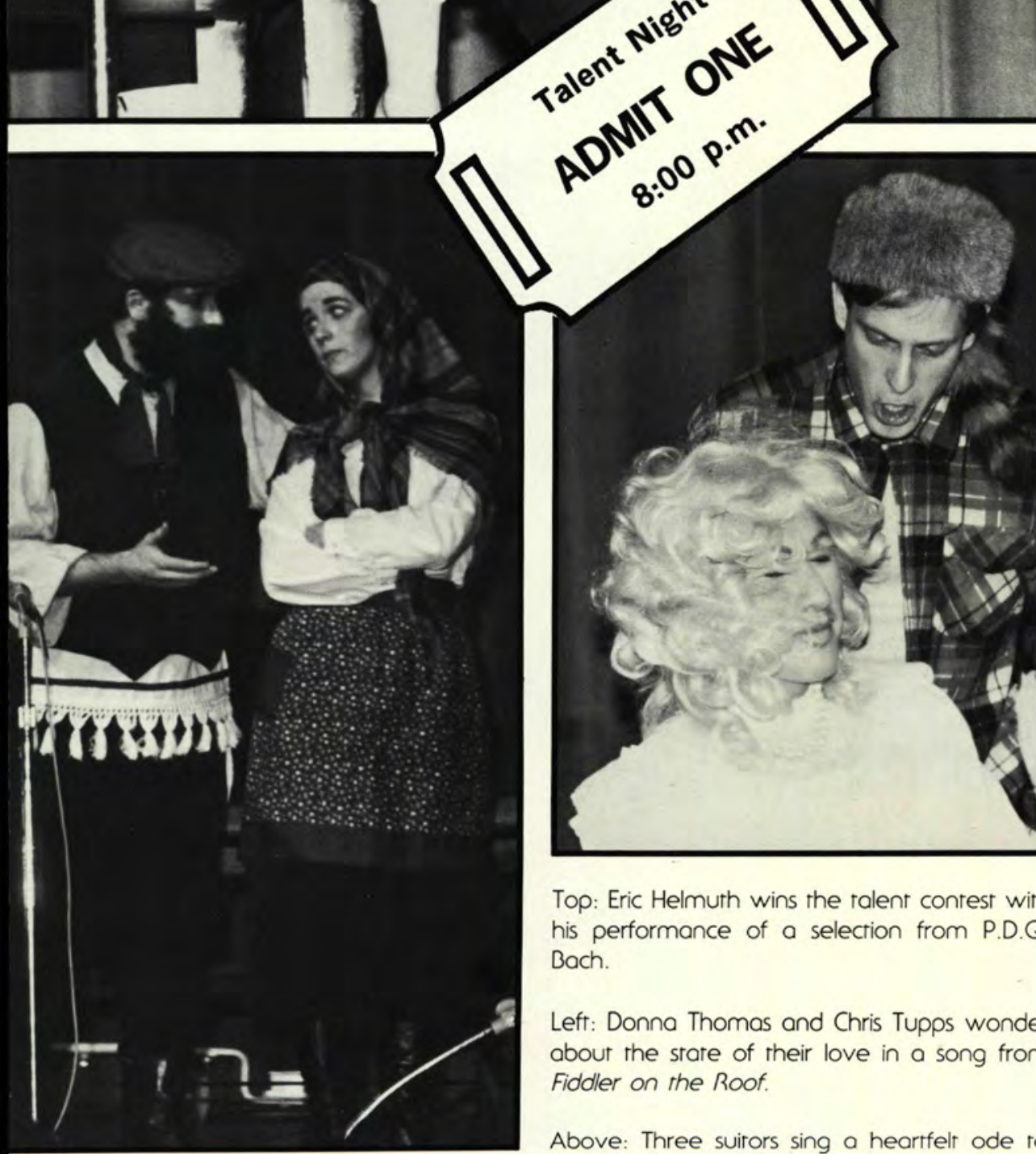


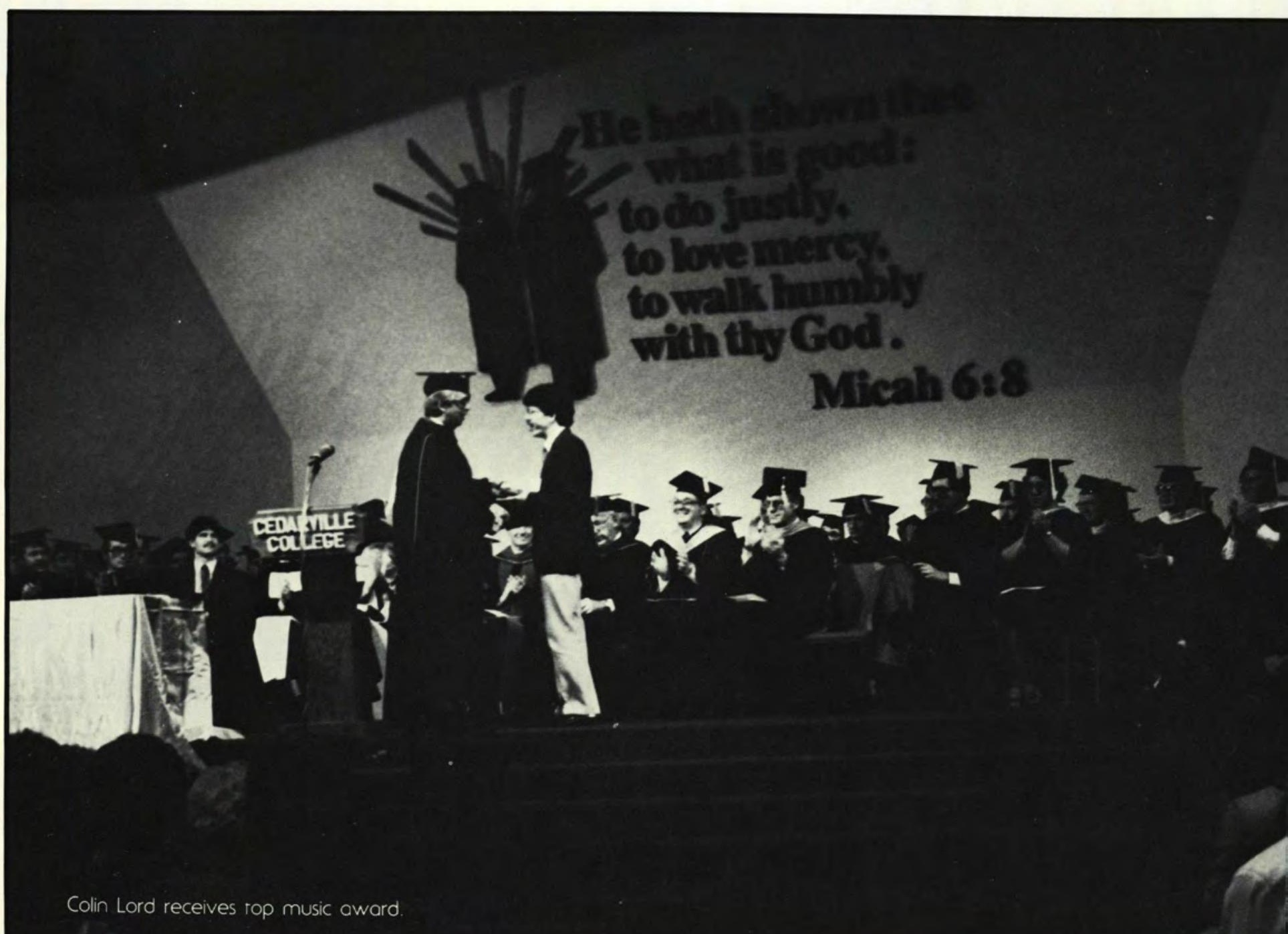

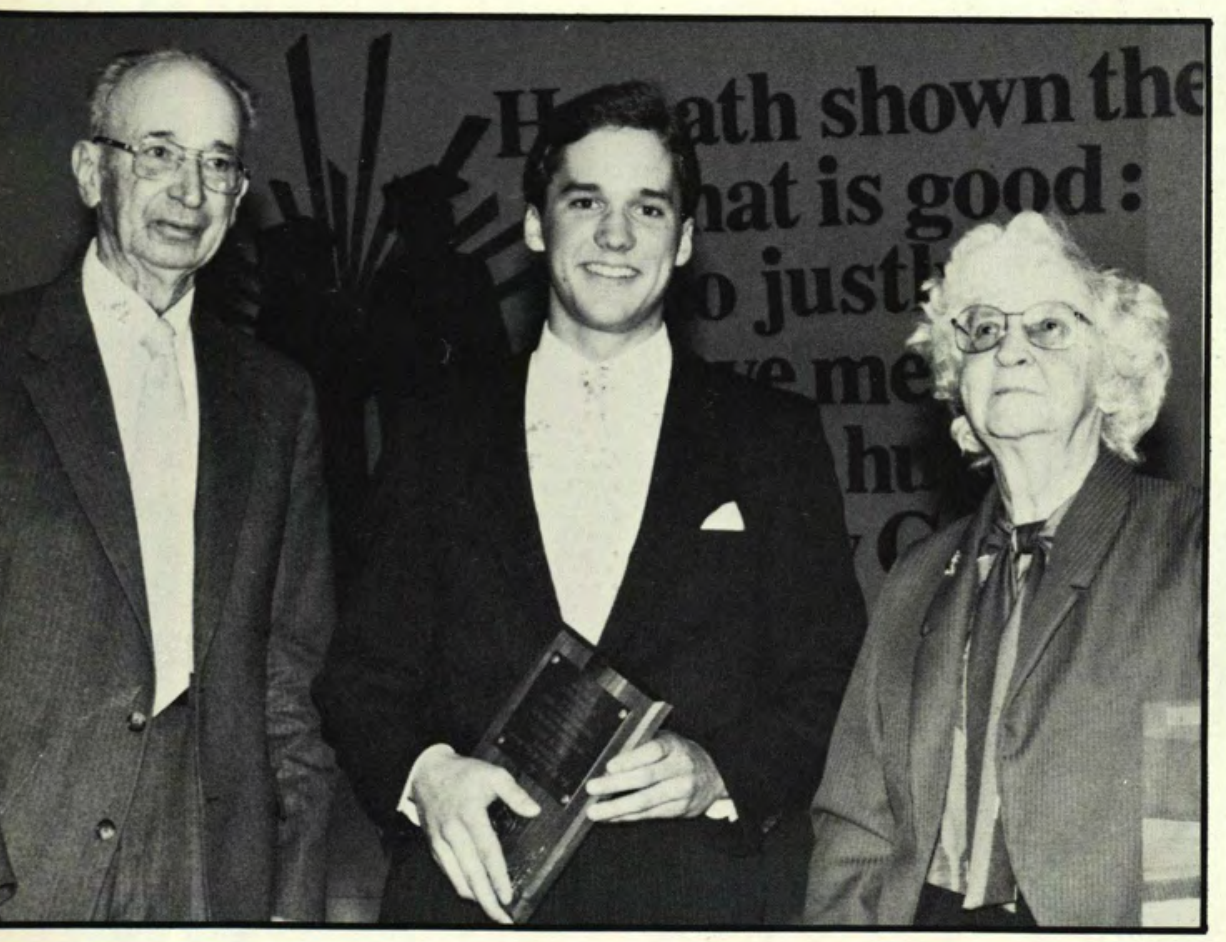

James Reirer, recipient of John W. Bicketr Heritage Scholarship.

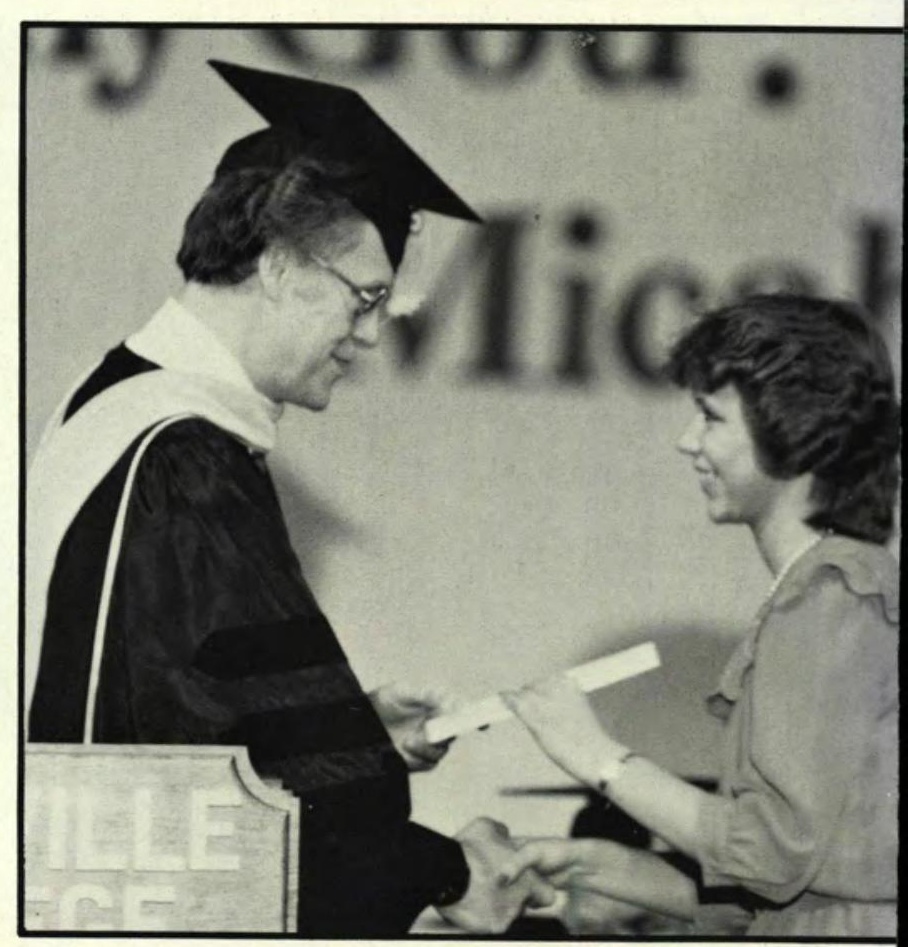

Lori Hess receives the Irma M. Dodson Award. 


\section{Students Enjoy Sophisticated Entertainment}

I chapel the usual introductions and announcements concerning upcoming Artist Series events almost always ended with the exhortation "... and we encourage you to attend." To the inexperienced or uninformed student, this verbal inviration to cultural exposure might sound akin to the proverbial coaxing a mother gives when administering castor oil. The Artist Series, however, proved not only to be healthy for the student's cultural diet but also extremely palatable to his senses.

Under the organizational hand of director Dick Walker, Campus Activities Office provided the college with five major events. These events were sources of dares, suits and ties, fancy dresses and high heels, and polished countenances; students had an opportunity to accustom themselves to the decorum and dress befitting the sophisticated entertainment they enjoyed.

Most of the events emphasized the musical talents of a variety of artists. In January the Dayton Philharmonic Orchestra presented a concert under the direction of renowned conductor Charles Wendelken-Wilson. April brought in two musical events, Nielson and Young, a piano duo, and Adrian Van Manen, a tenor soloist. Nielson and Young appeared with the Concert Chorale.

The Gregg Smith Singers, fearuring soprano soloist Rosalind Rees, presented a multifaceted program of music from four centuries. The focal point of the presentation was their unique spatial presentation which fearured members of their group literally spaced throughout the aduitorium enveloping their listeners in sound. Another unique evening produced John F. Schurman in Eccentric Preacher, a one-man stage performance of Charles Haddon Spurgeon's twenty year seminary reunion.

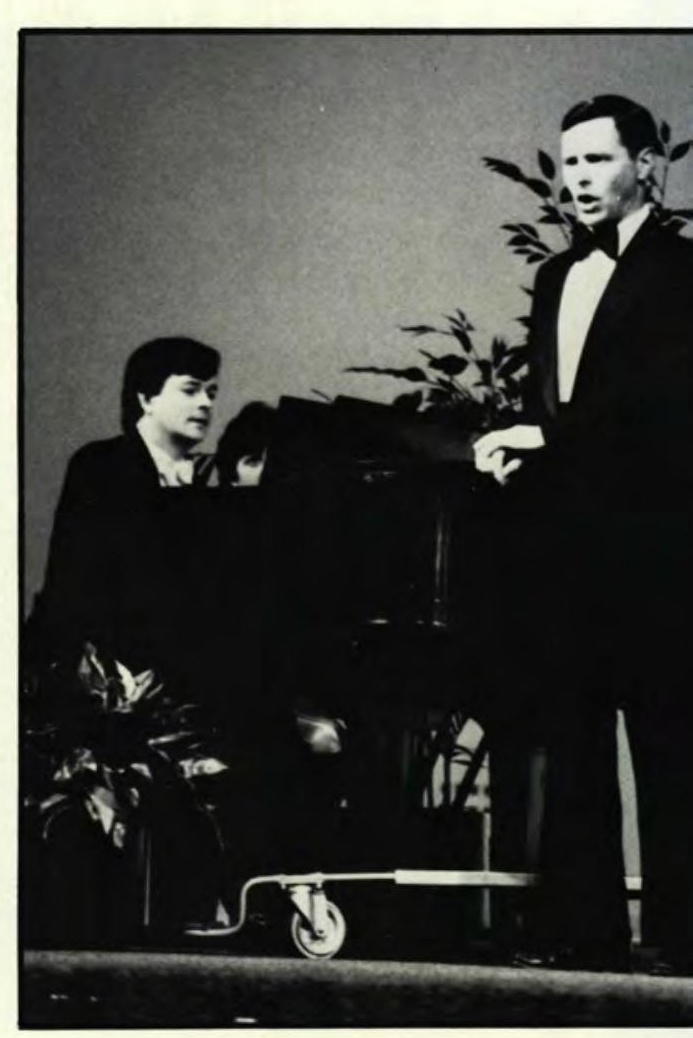

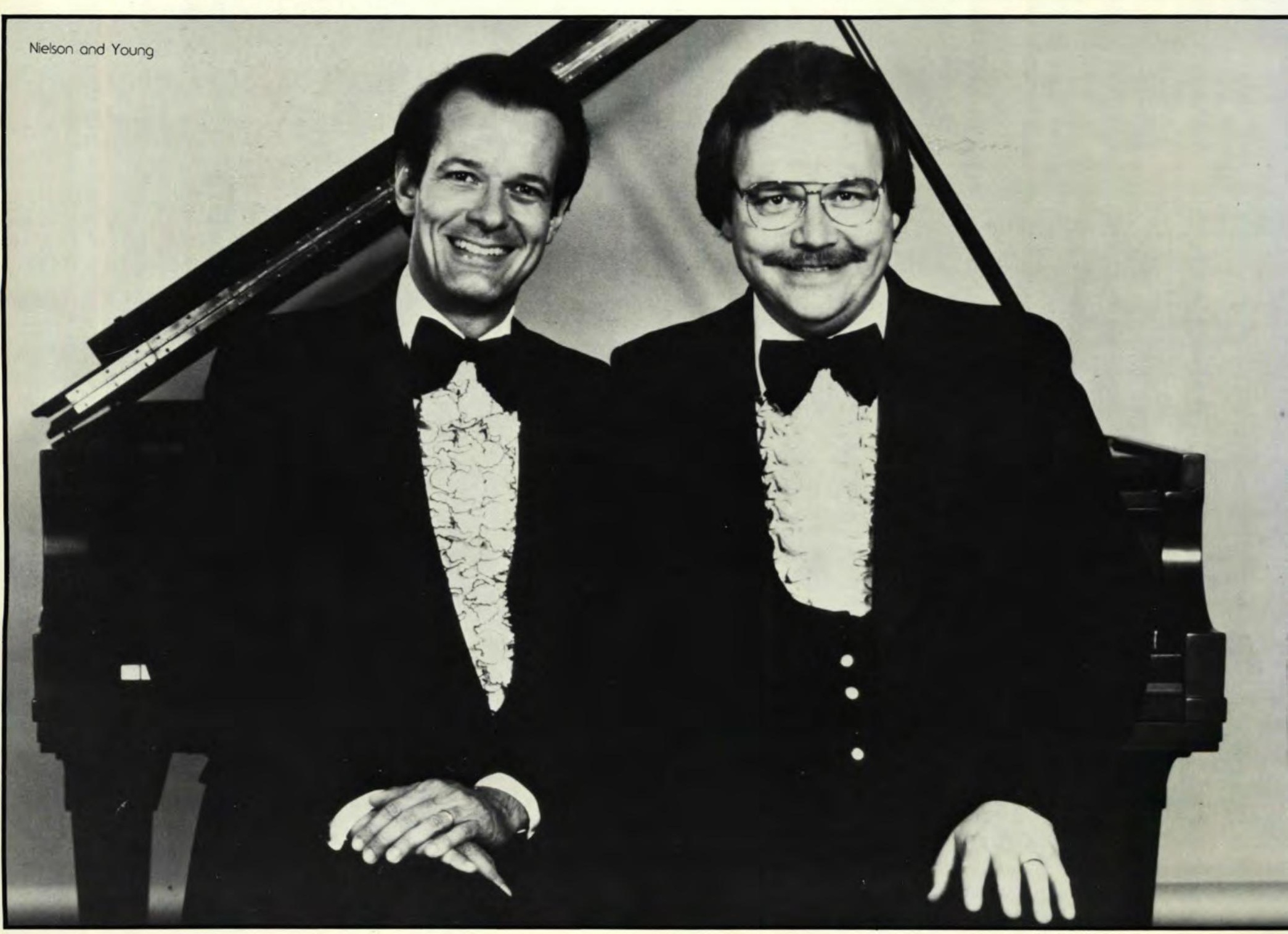




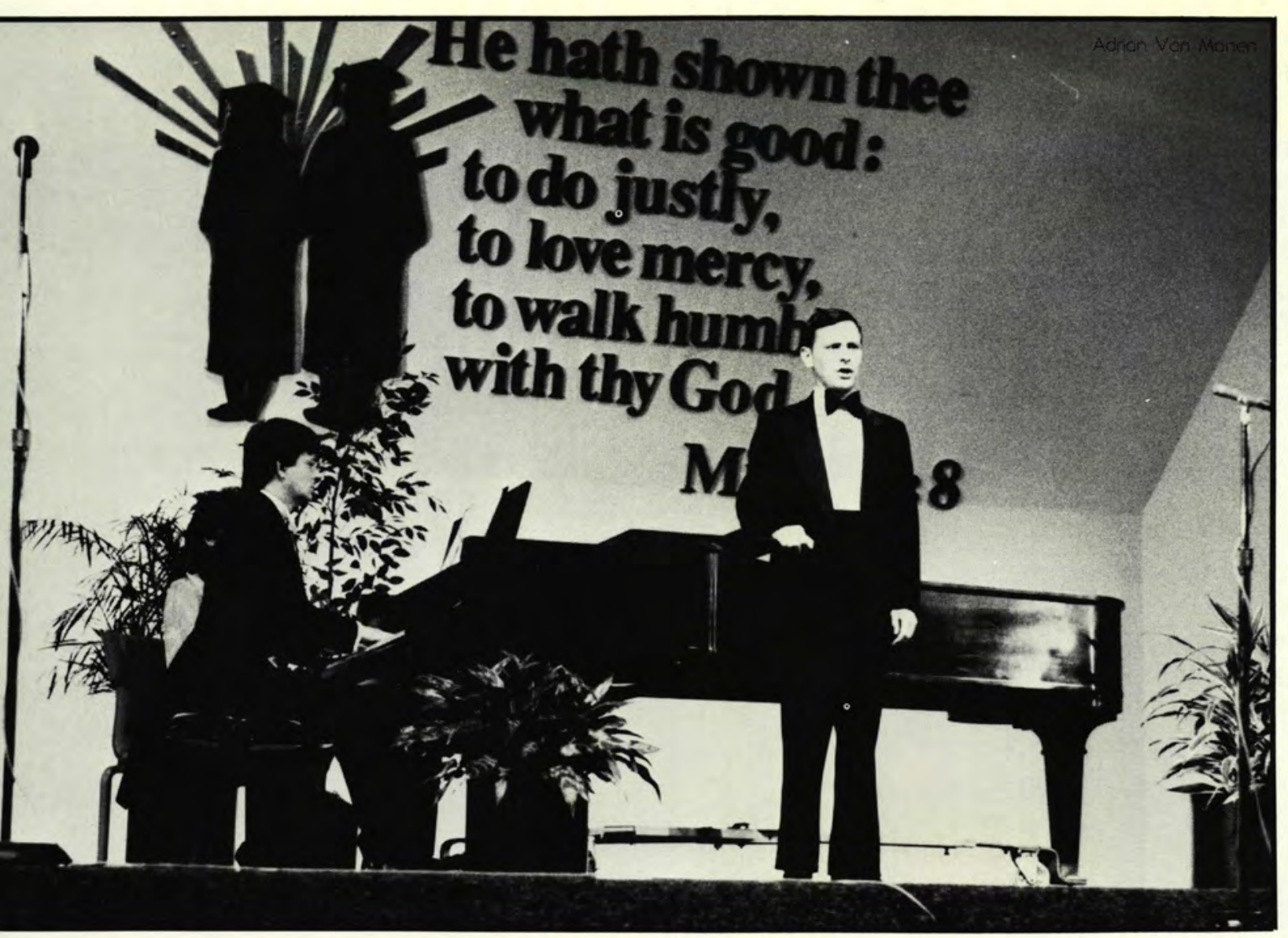

(ced.ınille (iollege presents

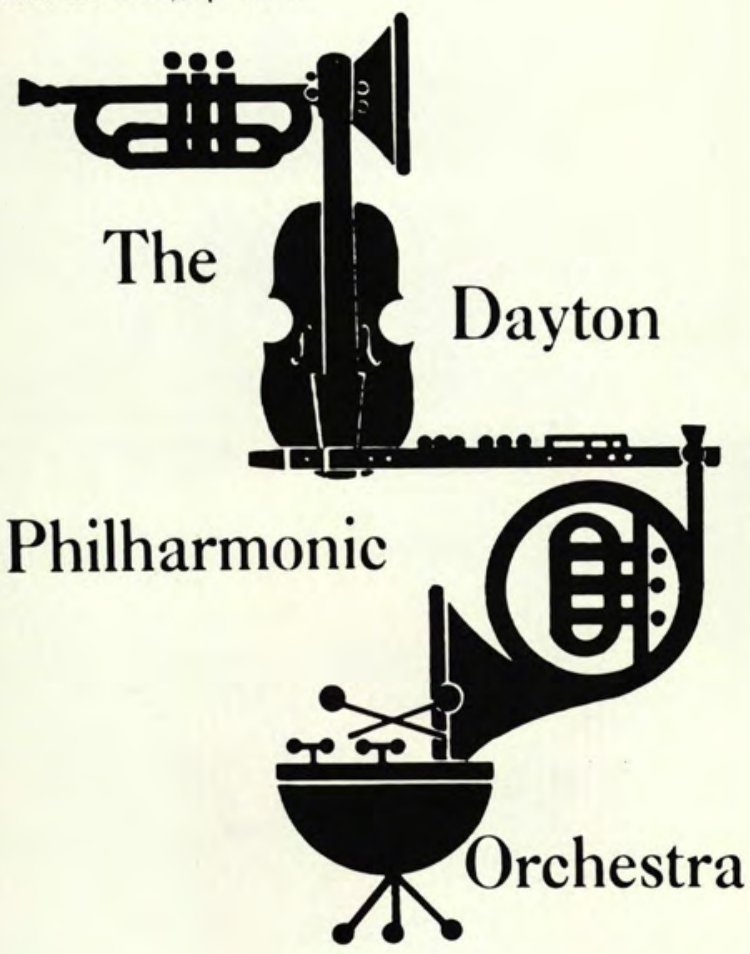

Charles Wendelken-IVilson, Conductor

January 25,1985 $\mathrm{xp} . \mathrm{m}$.

James T'. Jeremiah (hapel
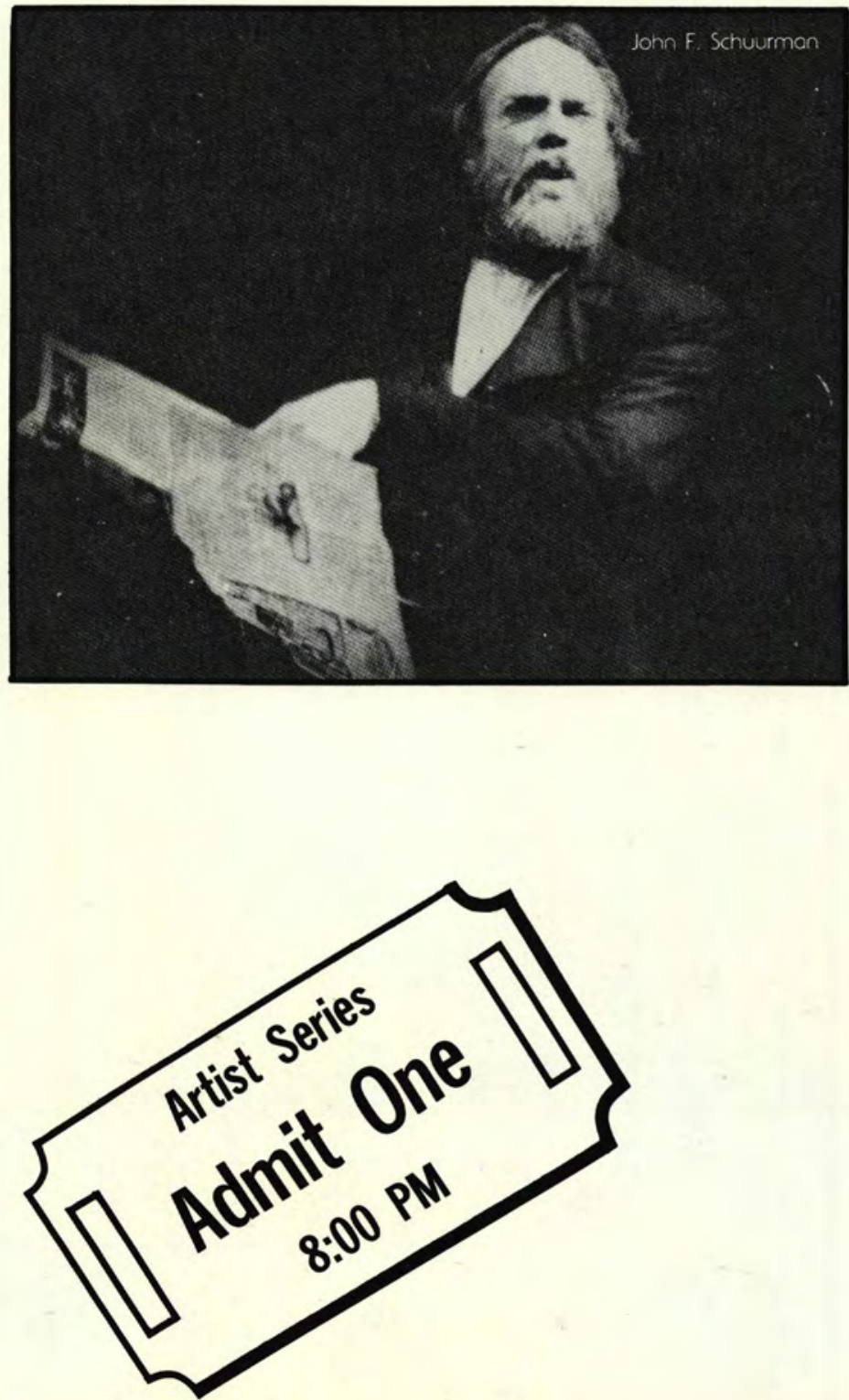


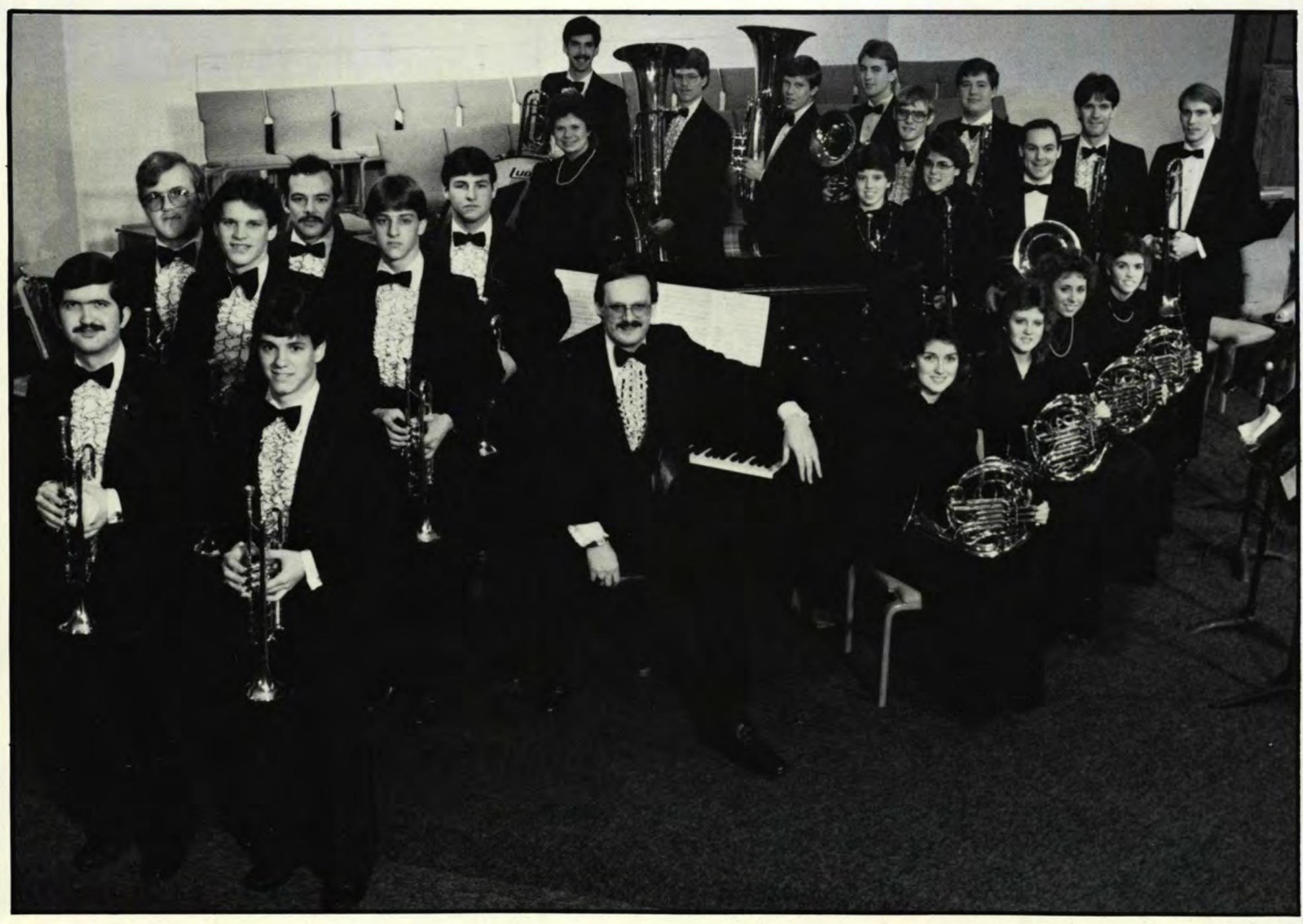

First Row: Bill Bany, Gerry Walloce, Sherrie Warson, Jill Sandy, Karen Bearrie, Janice Warren, Second Row: Rich Carey, Ed Supplee, Tom Goehring, John Srephens, Joel Harbough, Direcror - Mr. Dicuirci, Third Row: Janice Dudley, Dave Hartsough, Mart Creamer, Temple Knowles, Jeff Marrin, Debbie Berdy, Bryan Crump, Lynell Smirh, Sreve Wood, Jim Caro, Tim Smirh, Scort Brooker

T

he Brass Choir experienced a major change this year when Mr Charles Pagnard rook a leave of absence to advance his educarion. Mr. Mike DiCuirci stepped in and rook over the position as director and proved to be a great asser to the great year the Brass Choir experienced.

The Brass Choir started off their year ar the annual Prism concert where they performed one number. Their first major concert in November was with the Band. They also had their own concert on February 15. The theme of the concert was "Celebration of Love' and was developed around the theme of Christ's love for us and our love for one-anorher. Mr. and Mrs. David Warren acted as narrators. They, along with a slide presentation and two vocal numbers, made the concert a very different and special one.

This was the first year that the Brass Choir didn't go on a major tour. The group did go on a rwo day outing, however, where they presented their "Celebrarion of Love" concert in Ohio and Michigan.

The Brass Choir ended their year with Honor's Day chapel and the Pop's concert. Mr. DiCuirci commented that the 25 member group had a good spirit this year. Weekly devorions, cooperation, and caring for one another contribured to this good spirit, along with special individuals such as chaplain Tim Smith, social chairman Janice Warren, and assistant director Jim Caro.
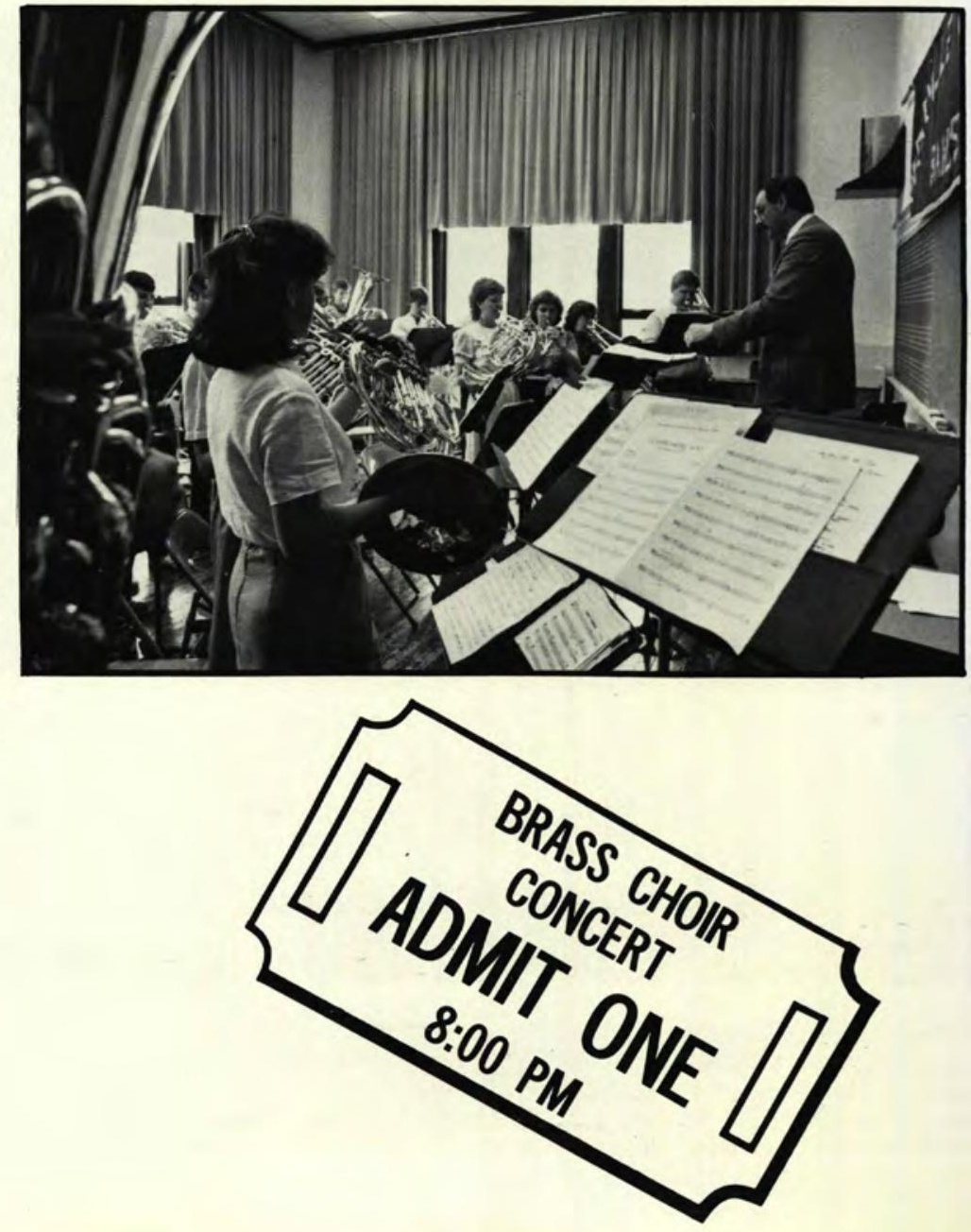


\section{Good Spirit Marks Year For Band And Brass Choir}

The 75 member Symphonic Band had a very busy year this year having six major performances plus a thre day tour. Their year began with the Prism Concert, Home Choir, and ended with the Pop's concert, Memorial Day chapel and ourdoor concert.

Highlights for the Band throughout the year included the Christion Band Conference, which was the largest in its history. It consisted of ren bands, 400 visitors, and a mass band with 500 performers. The guest conductor ar the band conference was Dr. George Wilson from Nariona Music Comp. The orher highlighr wos the band's three day rour which rook them to Kokomo, Indiana and Akron, Ohio

The year wos marked by enrhusiosm, excellent porticiparion, and challenging music
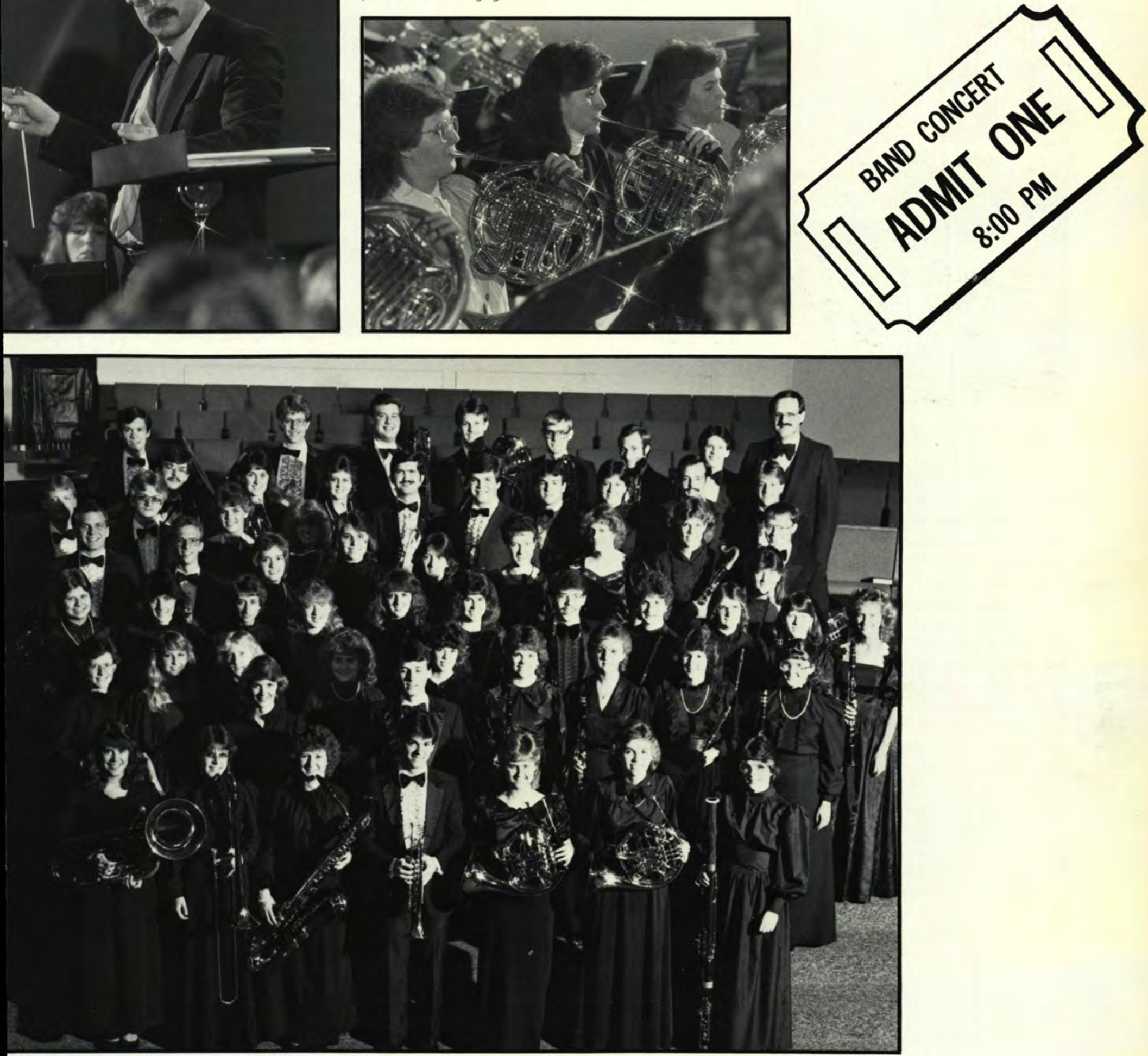

st Row: L. Spiegel, L. Smirh, H. Haist, G. Wallace, G. Price, J. Warren, T. Mackenzie, Second Row: B. Fisher, C. Holland, D. Heirzman, C. Weidman, B. Snyder, McBrayer, L. Bowlen, G. Ruggles, D. Phillips, J. Thompson, A. Alexander, Third Row: J. Dudley, R. Dorr, J. Garmarter, D. Borleis, J. Burr, S. Sralrer, C. Lord, E. esen, J. Cobb, L. Norton, K. Herrick, Fourth Row: D. Eller, T. Phillips, D. Dysert, L. Hoberli, D. Noggle, C. Vontrease, J. Oakes, S. Nichols, D. Wolrer, Fifth Row: D. rson, C. Most, A. Joslin, S. Holbrook, Sixrh Row: D. Horne, S. Warson, J. Sandy, B. Bany, T. Hummel, J. Harbaugh, M. Cook, T. Goering, J. Srephens, Sevenrh w. D. Frey, M. Creomer, S. Wood, R. Smirh, B. Crump, R. Hoywood, E. Supplee, Direcror - Mr. Dicuirci. 


\section{Interested Students Present "Messiah" Once Again}

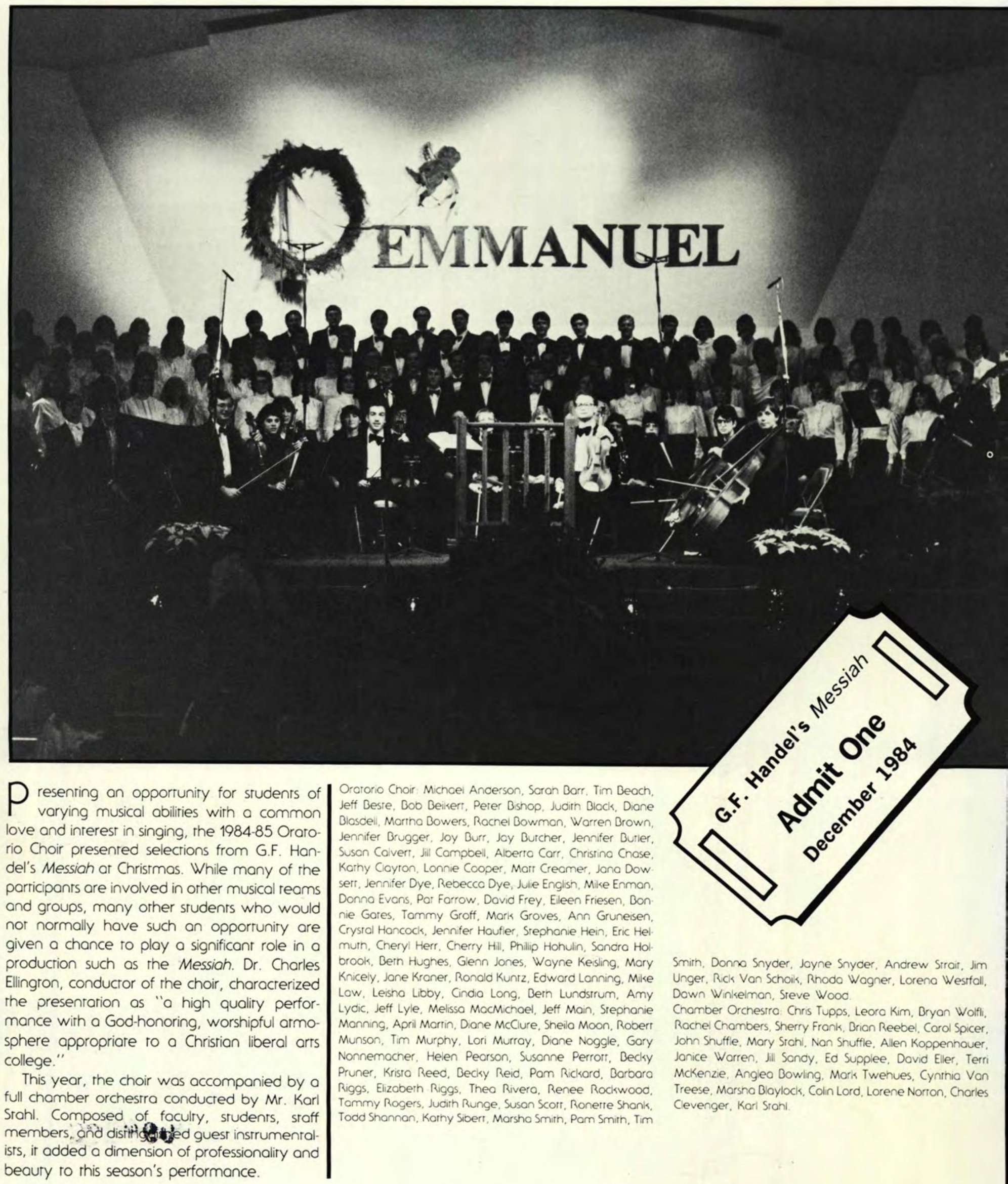




\section{Monday Chapel: Family Devotions}

"M eet me by 'James T.' "'

"Save about five seats, O.K.?"

Eventually lights dim and voices hush to a low hum and raise once again to fill the chapel with a ringing rendition of "A Mighty Fortress is Our God." Stragglers sneak into back rows, stepping on stray toes, purses, and books. No one seems to mind, though, because it is Monday morning, the first and only time for the entire college family to garher for the week.

Anticipating the message, students

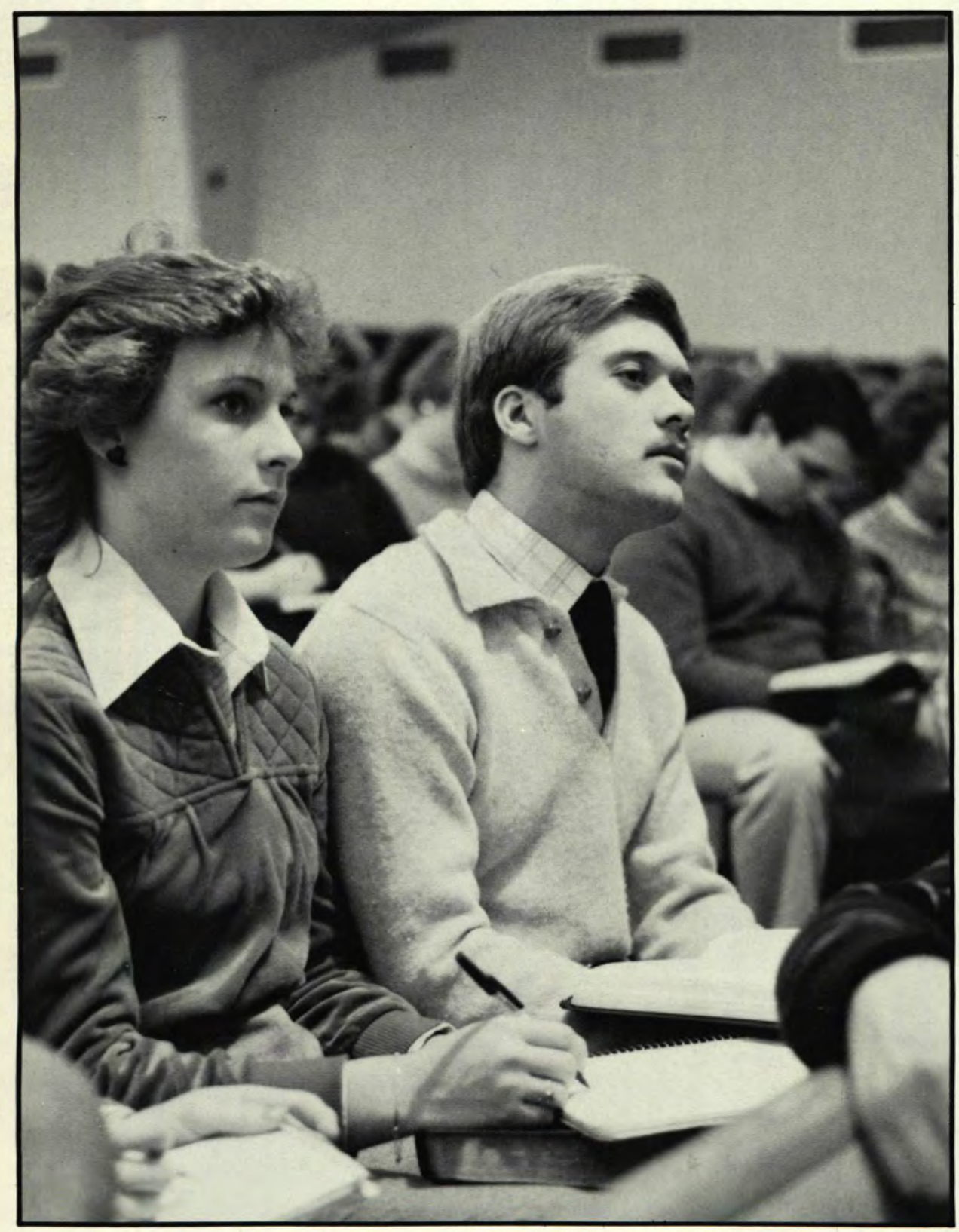

sit comfortably amidst the staff and faculty that serve them so diligently during the week. Preceeding his pertinent year-long series of messages on daring, marriage, and family, Dr. Dixon greets the body assembled before him, peppering it with anecdores and announcements concerning the state of the college. Scurrying for notebooks, our college family is unired under the leadership of our president and bonded together by the fellowship of a regular, familiar Monday chapel. We are family.

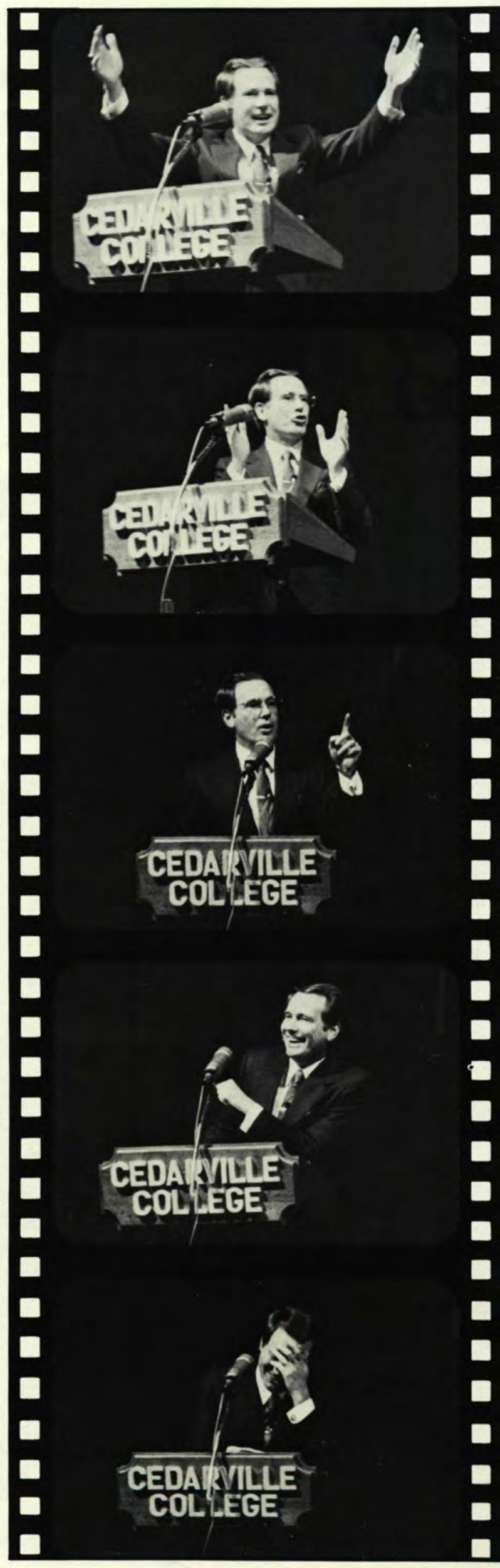



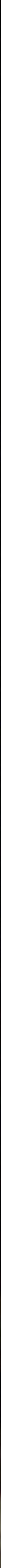


\section{Analyzing The True Vine}

When the students of Cedarville College reflect upon the seas of memories pertaining to this particular fall quarter, many thoughts will come flooding back. For the majority of students, it was a time to renew friendships, a time to encourage academic and spiritual growth, and possibly a time to look toward graduation. For freshman it was a time to meet new friends, a time to grow away from Mom and Dad, and a time to marure.

Many important experiences will also contribute to those fall memories. For example, many students will never forget the Foll Bible Conference's impact on their lives or the speaking of Dr. David Jeremiah. Dr. Jeremiah centered his messages on the John 15:1, 2 passages: "I am the true vine, and my Farher is the husbandman. Every branch in me that beareth not fruit he taketh away: and every branch in me that beareth fruit, he purgeth it, that it may bring forth more fruit." Dr. Jeremiah also used the parable of the sower and the seed found in Marthew 13:4-8; 19-23.

These passages were implanted into the hearts and minds of many by Dr. Jermiah's skillful exegesis and genuine concern for young people. We all witnessed the Holy Spirit moving in the lives of many people during the week of Seprember 24-28. I will nor forger the reaching of Dr. Jeremiah; for on September 25, 1984, I recommitted my life to Christ and all of my doubts were wiped away.

Steven M. Campbell
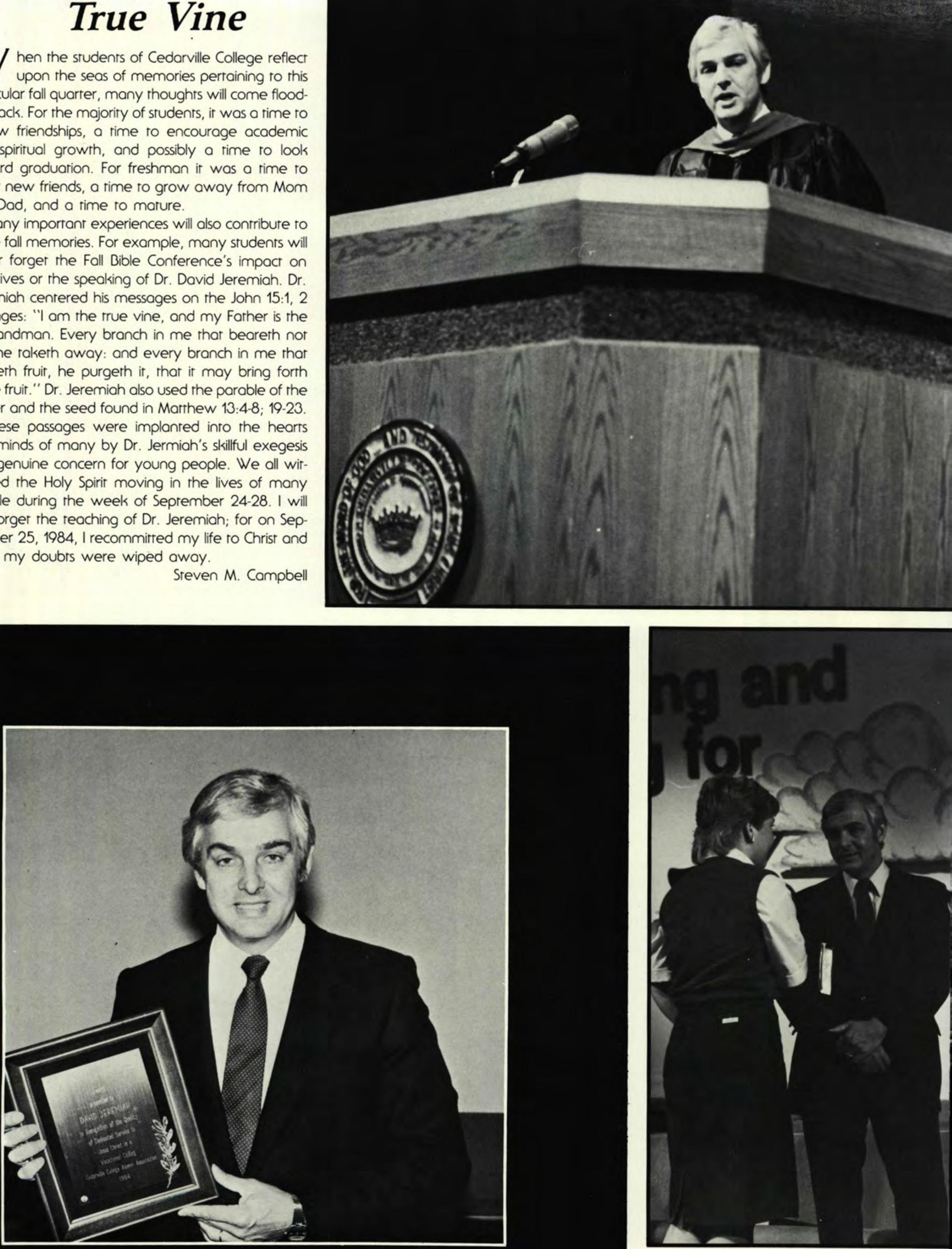

\section{David Jeremiah}



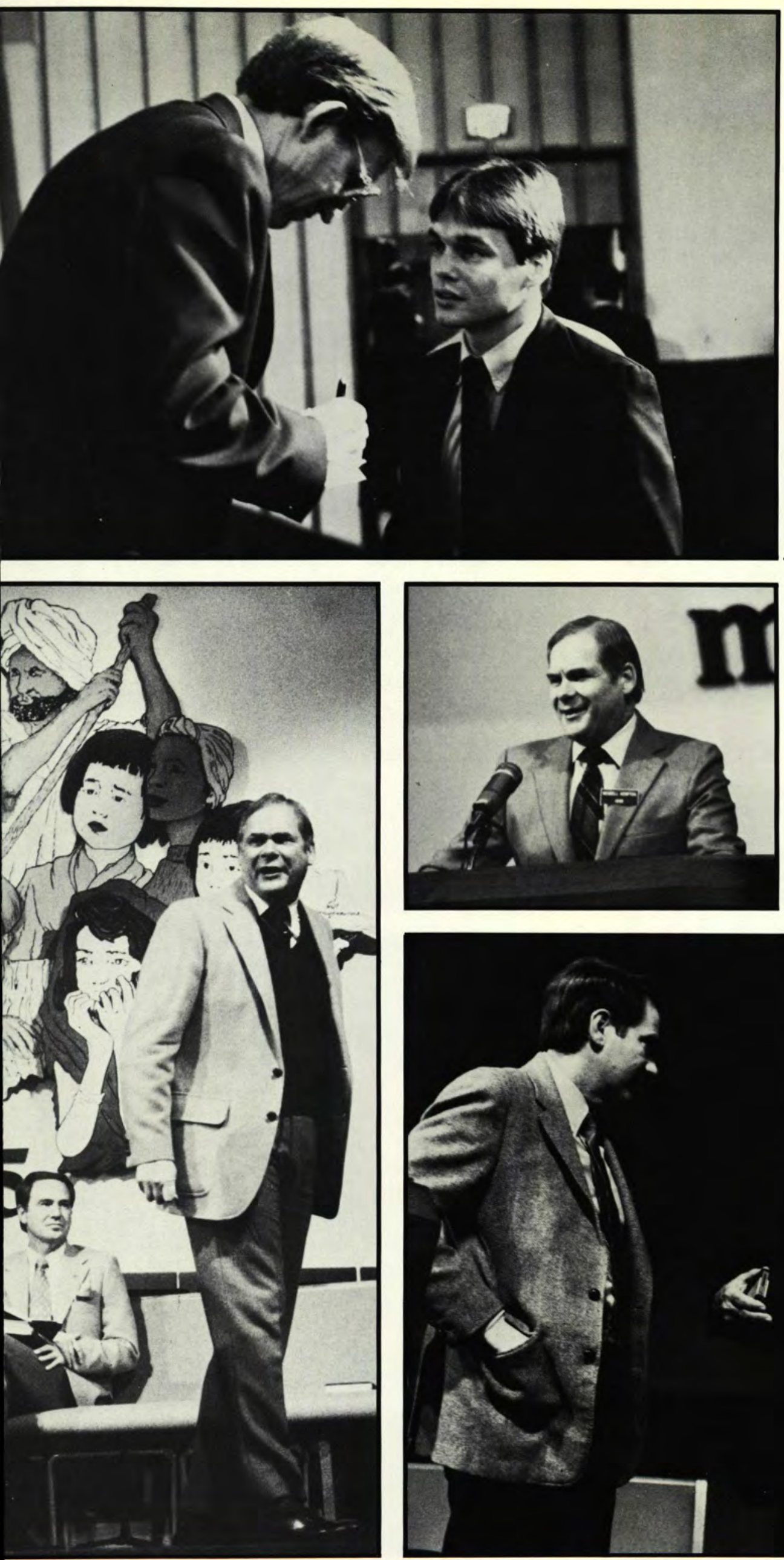

\section{"Special Hearts For God ... ."}

$\triangle$ frican hurs, bloared children begging for A money, poor slide presentations, unable speakers: these are just a few things that come to mind when thinking of a missionary conference. But Cedarville's winter quarter Missionary Conference was much different than this stereoryped view.

As we sat throughour the week in the various chapel meerings, we learned what it meant to "love God" by Wendall Kempton and to have a burning desire to minister no matrer where we are. We heard of the desperare need to witness on our college campuses by Hal Miller, and we heard the rouching stories of the children from Hawaii by Paul Verslus.

Many of the missionaries had boorhs with various information about their personal ministry. Ir was a privilege to meer them, talk wirh them, and even share a meal in the cafereria with them.

Missionaries were no longer far away people in our minds but real people with rea needs and with very special hearts for God. May we too develop hearts for wirnessing as theirs no marter where we are.

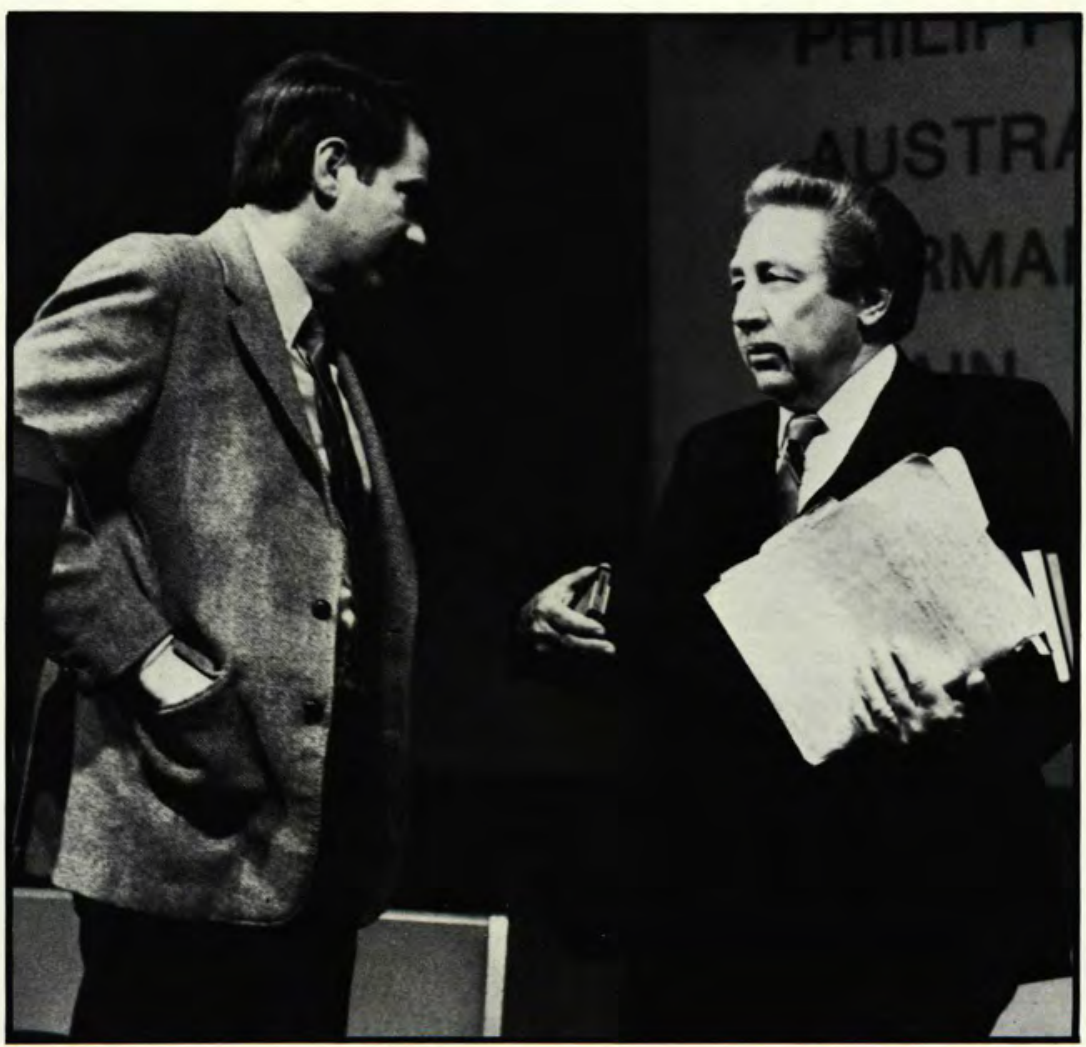




\section{How's Your Prayer Life?}

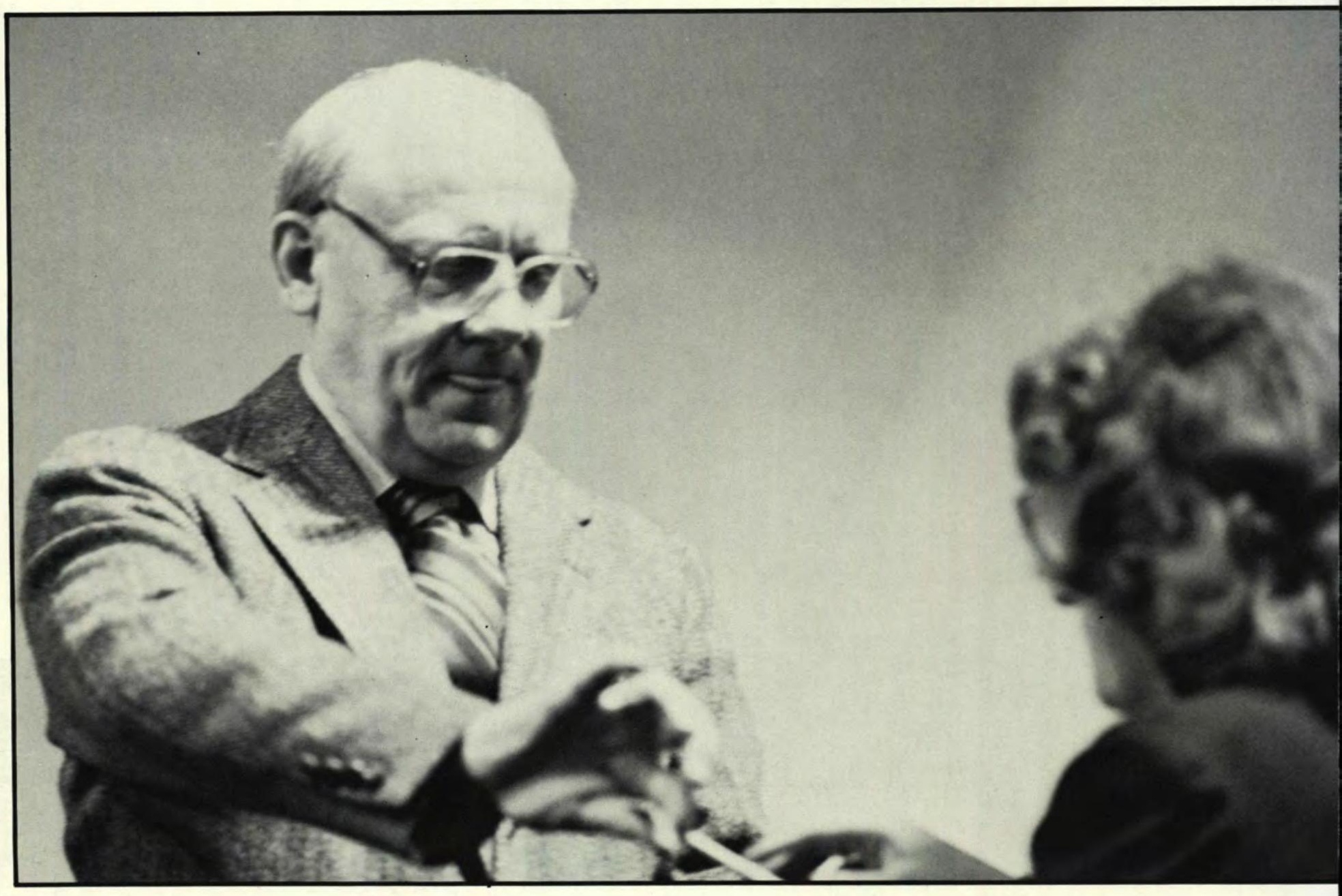

B y the rime Spring Enrichment Conference rolls around each year, most students' ears have been so inundared with names, speaker styles, and messages that distinguishing among them is a difficult rask. This spring, however, students woke up, sat up, pricked their ears, and took our notebooks to record the messages of a special man of God. Dr. Warren Wiersbe had come to Cedarville College.

Instead of giving the College a continuous set of messages on one subject, Dr. Wiersbe elected to serve up a buffer of topics pertinent to the College Family. His first message dealt with purting a life back together using the principle of submission as found in the book of Rurh. To emphasize this, he stared that the purpose of life is not to find freedom but to find the Moster: only in the Master is freedom. His unique blend of dry humor and humility appealed to the wide range of individuals who came varying distances to hear him speak.

Throughour the morning and evening messages, Dr. Wiersbe wove the thread of one particular aspect of the believer's life, that of prayer. He gave a series of admonitions for receiving answered prayer: the first of which was for the believer to be "washed" or cleansed of the sin in his life. Encouraging a prayer inventory, his second point, contained four different levels or depths of a prayer life. Most importantly, Dr. Wiersbe drove home the importance of each believer's being a part of the answer to prayer: a role that he himself played in the conference this spring.
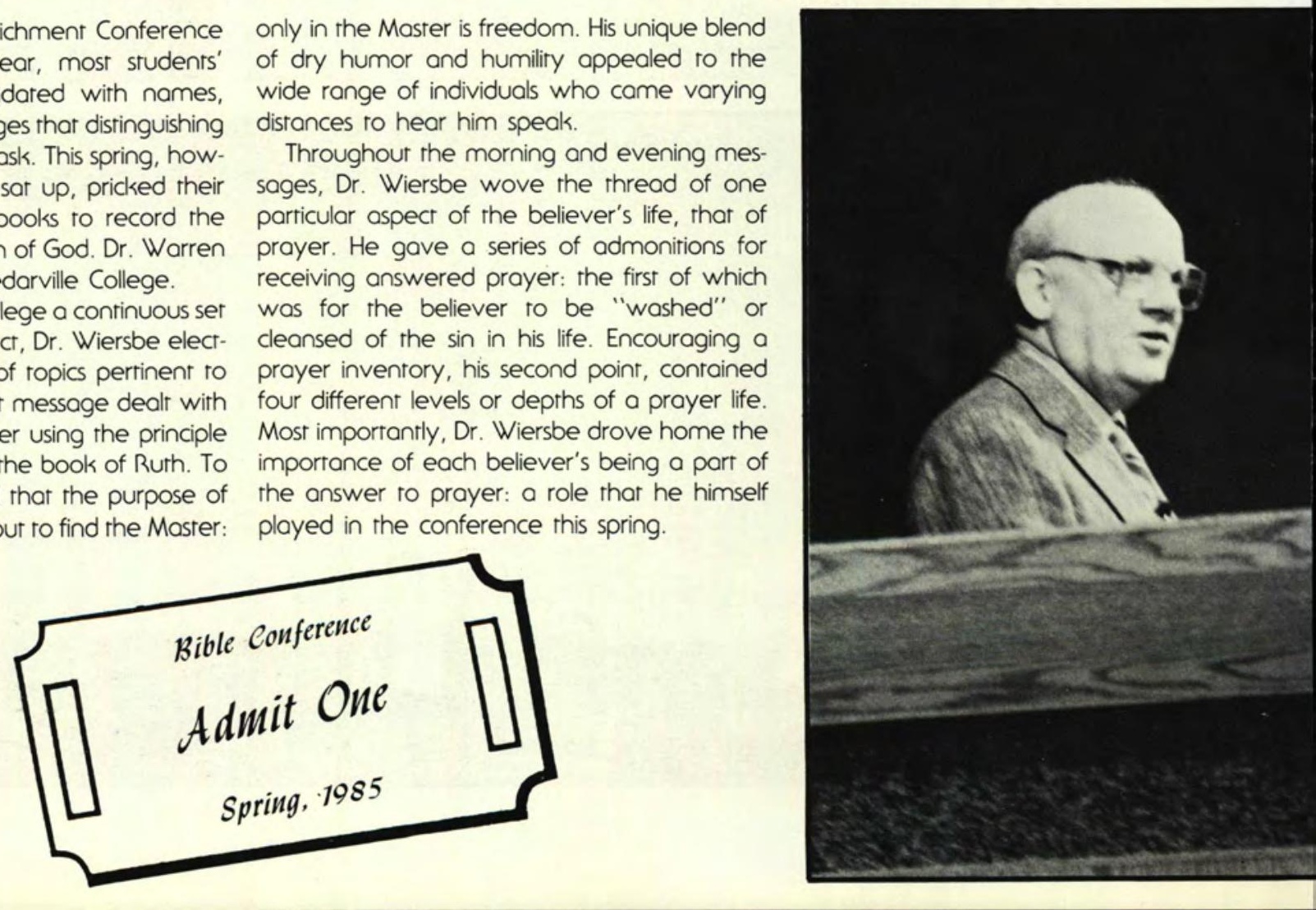

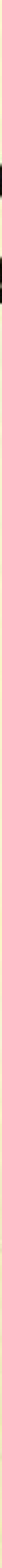

This year's Inforum brought renowned lep-

rosy doctor Paul Brand to the college dur-

ing the spring quarter. An advocare of the value of human life, Dr. Brand spoke on the timely ropics of abortion, rerminal illness, and euthanasia. Piquing students' interest with his wry humor and interesting ancedores, Dr. Brand approached his topics stressing the dignity and worth that God has artributed to each human life wherher it be a ferus or a rerminally ill cancer victim.

On the final day of the mini-conference, a panel composed of Dr. Brand, Dr. Helmick, professors Gary Percesepe and Dan Estes, and Student Body President De Smith answered questions posed and compiled by students. The thought provoking discussion that ensued gave students the opportunity to contemplate the existence of man in the presence of his God.

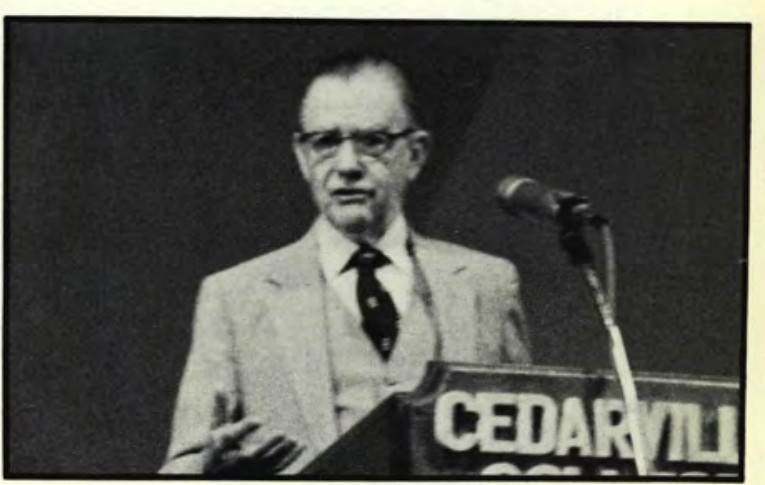

\section{Micah 6:8}

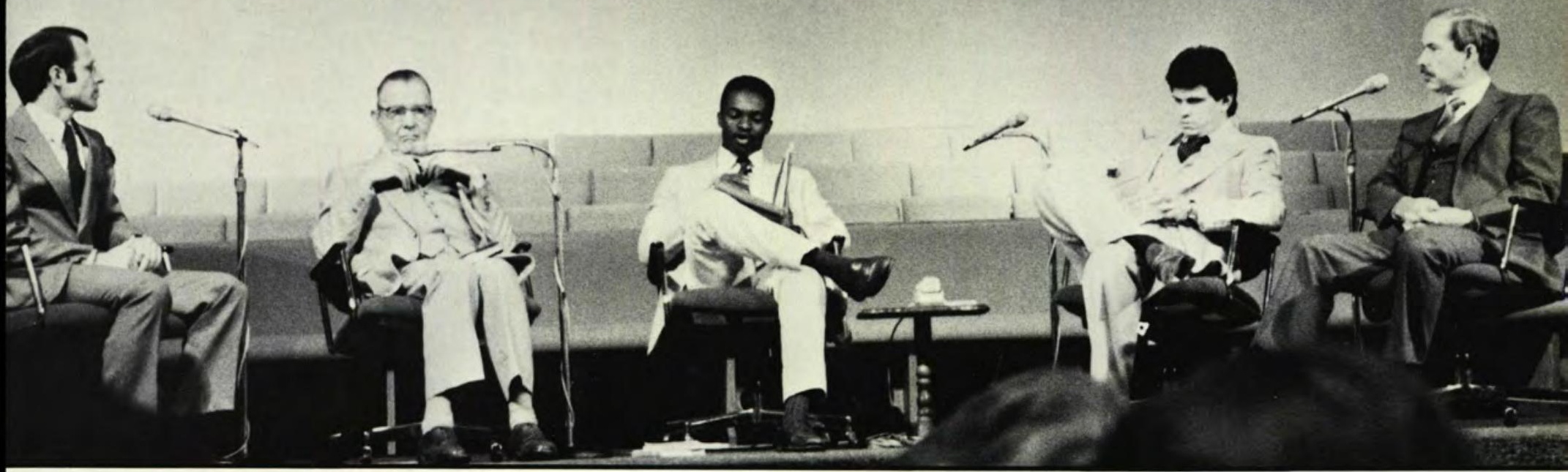




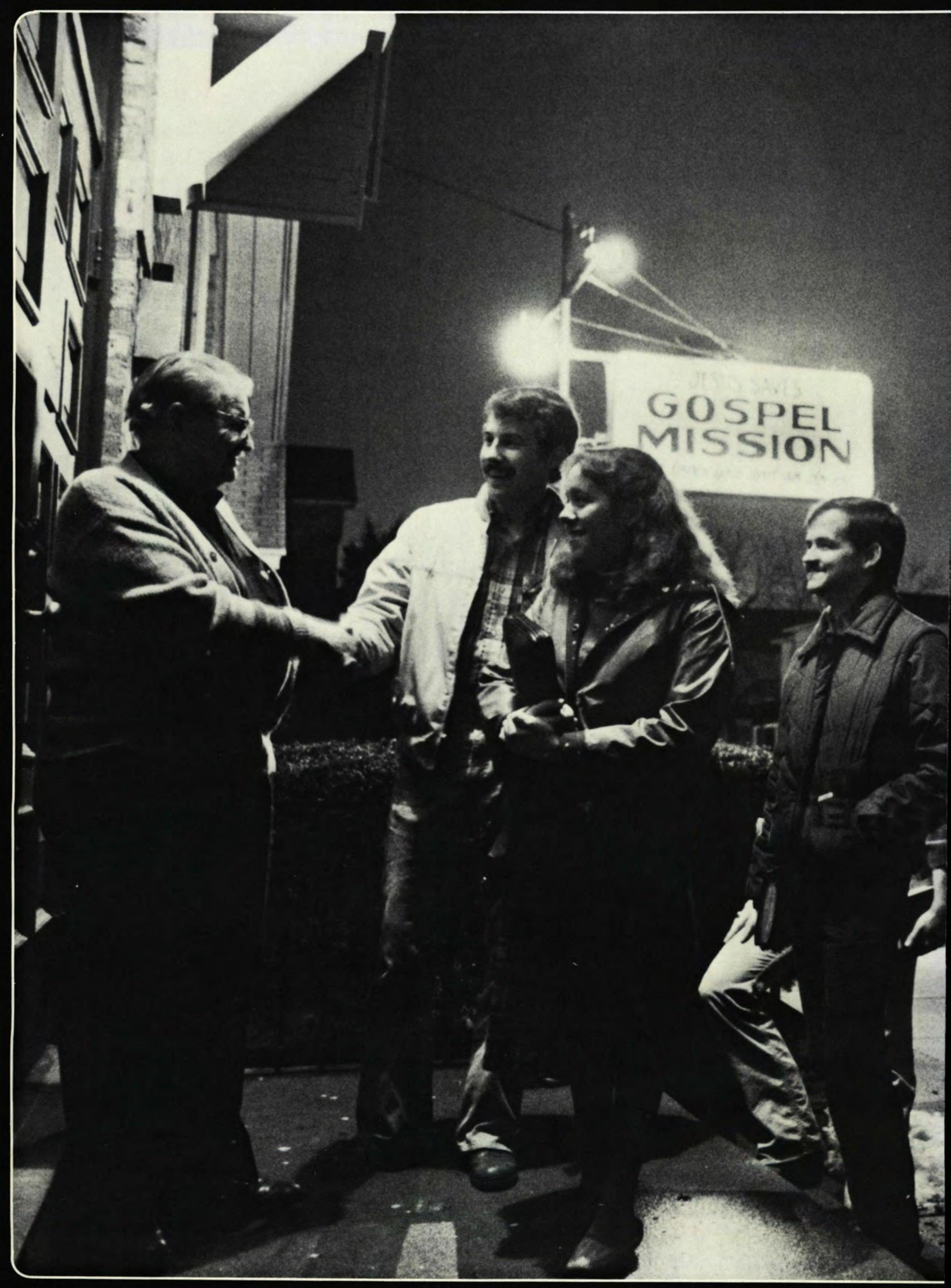




\section{Christian Service: Sowing The Seed ... Reaping The Harvest}

S erving the community through ChrisStian Service activities, the students of Cedarville have opportunities to minister to those in need. Most of the Christian Services shown in the following section meet daily or weekly, serving as listeners, companions, helpers, counselors, but they ulimately serve as sharers of the trust they have placed in their God. As they give of themselves, these students in rurn trust in God to reap a bountiful harvest from what He has allowed them to sow.

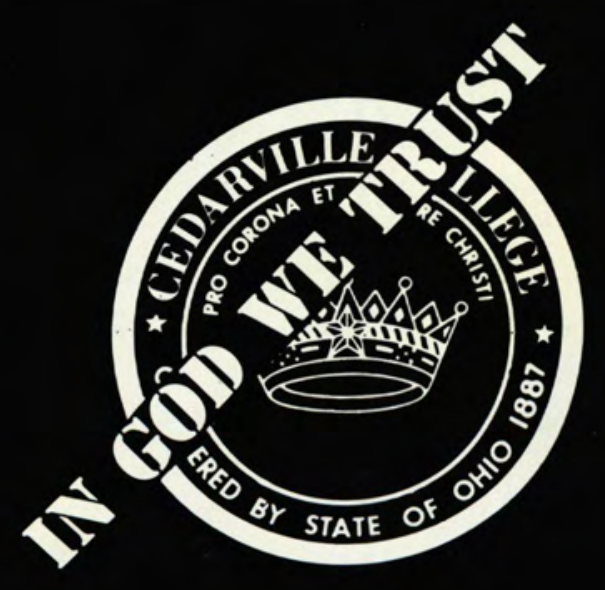




\section{Abundant Lif}

"The Lord is my strengrh and my shield, my heart trusted in him, and I am helped: therefore my heart grearly rejoicerh; and with my song will I proise him."

Psolm 28:7

Seared: Dan George, Jill Winkleman, Kristino Whirtaker, Dave Belford, Dawn Winkleman.

Sranding: Dove Eller (Leoder) Kevin Hoskins, Liso Tyson, Tim Beoch, Christina Chose

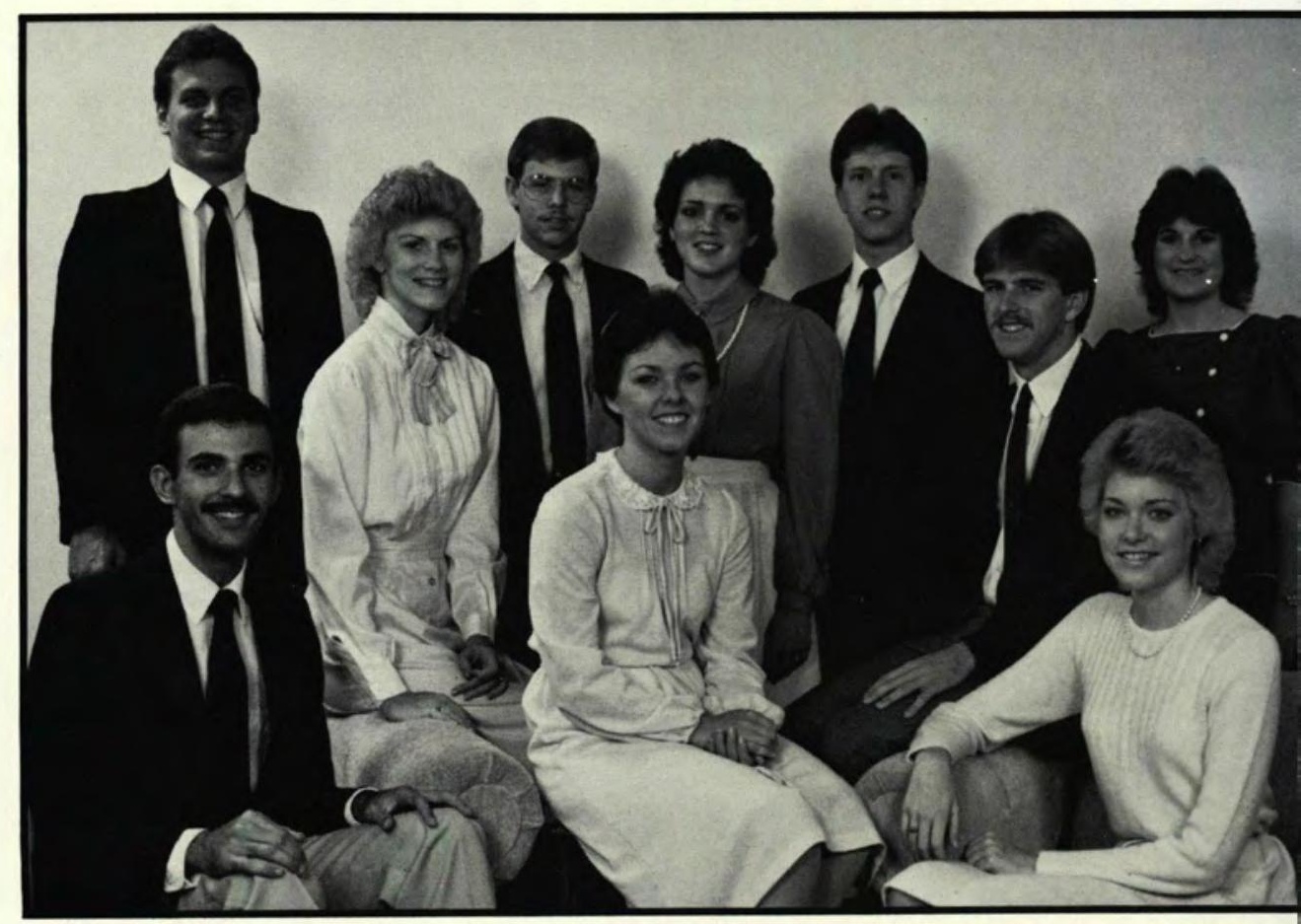

"That the communication of thy faith may become effectual by the acknowledging of every good thing which is in you in Christ Jesus."

Philemon 1:6

Ruth Brown, Paul Collins, Ann Hoskowich, Fran Hoskowich, Keirh Hammer, Dan Hunt, Darryl Litrle (Lead er), Tonya MCBee, Tracy McCoy, Deb bie Roddliff, Finny Rojchel, Sylvie Ringernechr, Chuck Scort, Jone Sparling, Keirh Soules, Jack Srumm, Kristina Whitraker, Debbie Mowrey, Judy Oakes.

\section{Central State Campus Evangelist}

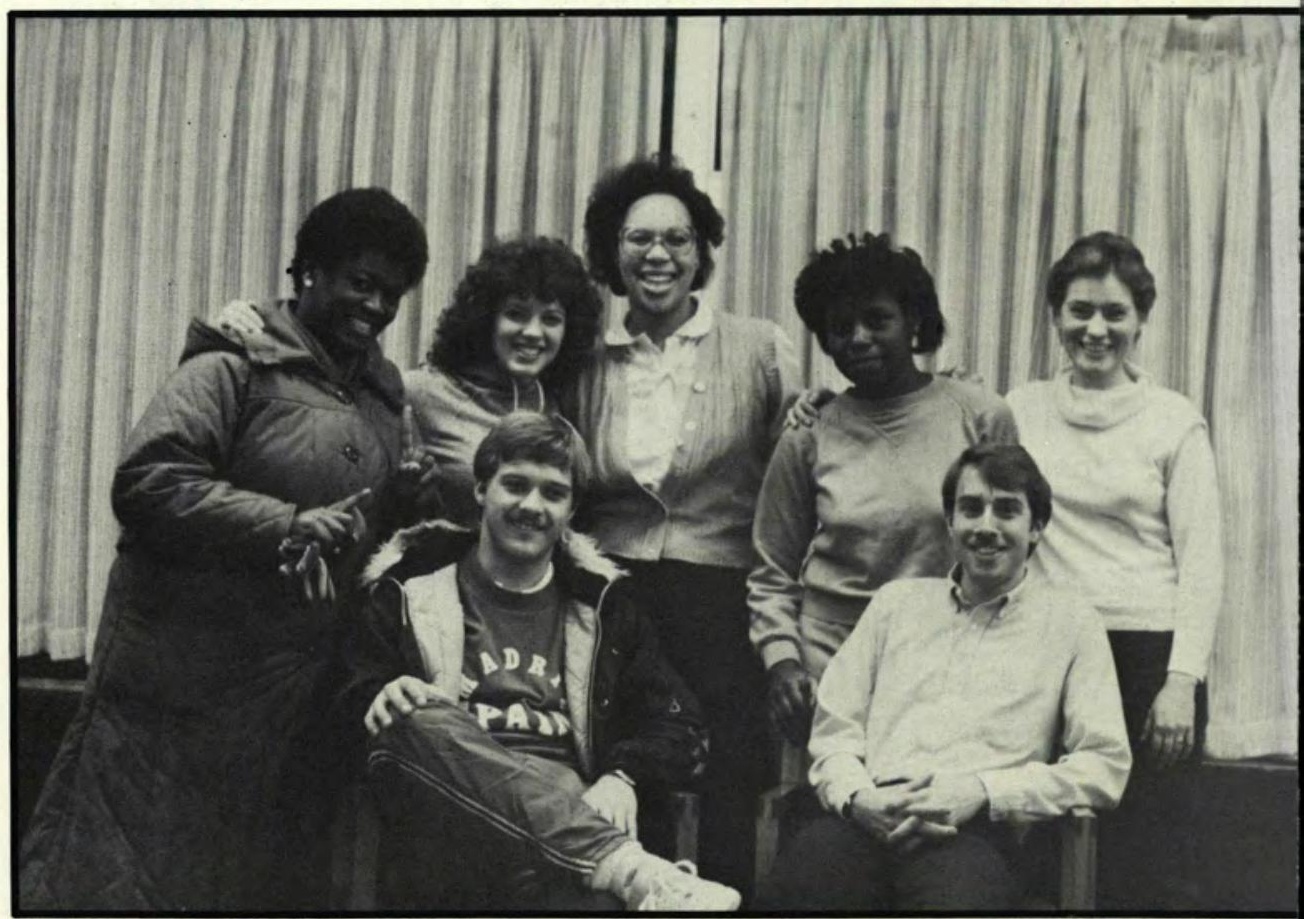




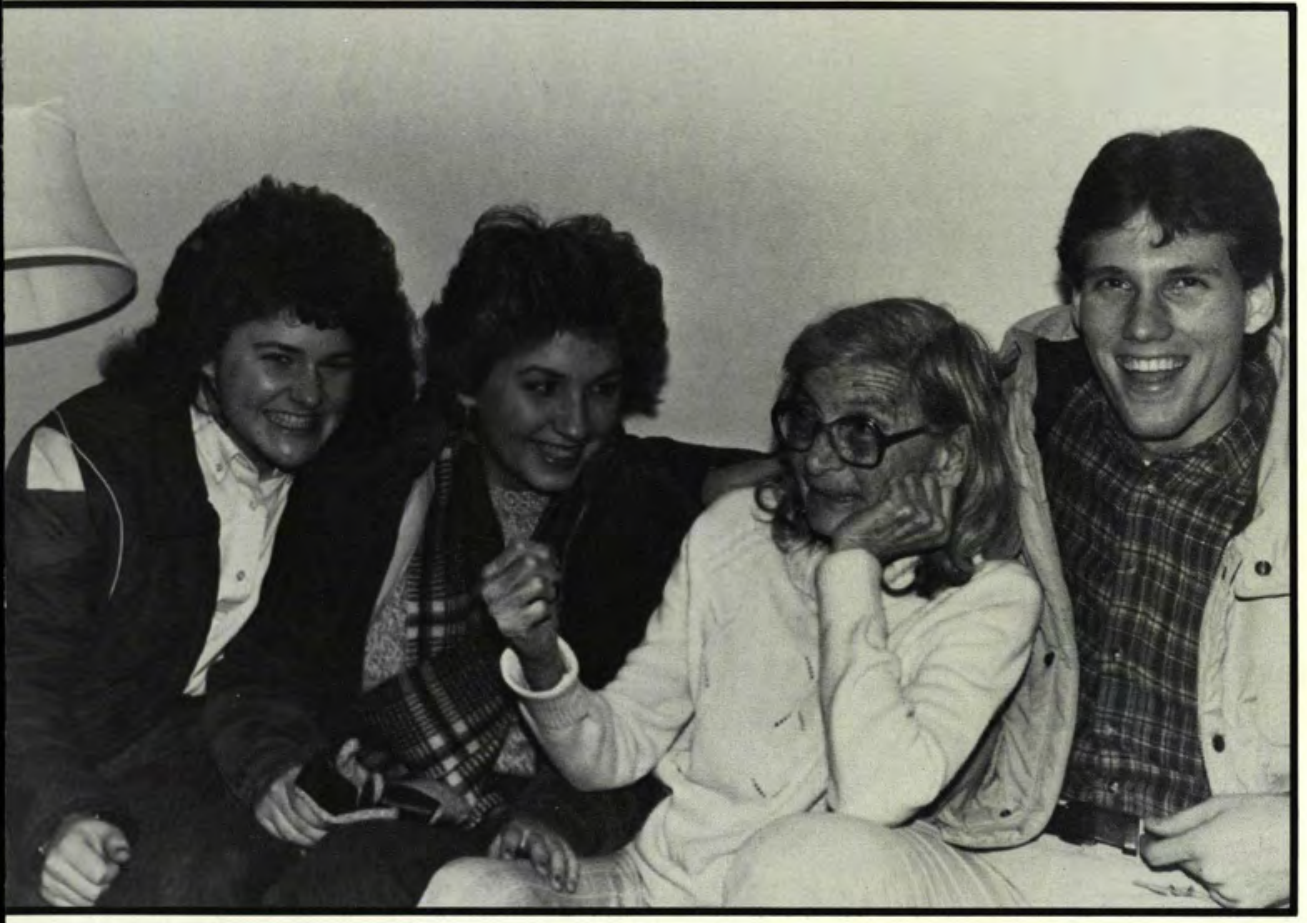

"For even the Son of man come not to be ministered unto, but to minister, and to give his life a ransom for many."

Mark 10:45

Lynne Borrlert, Prudy Benevides, Don Byrum, Marc Chirwood, Mart Corry, Noel Hock (Leader), Karhy Harris, Liso Hamilron, Joonie Hull, Jocelyn Johnson, Beth King, Galyn Nook, Lorena Shaff, Berh Snyder, Mike Warfield.

\section{Payton Detention Home}

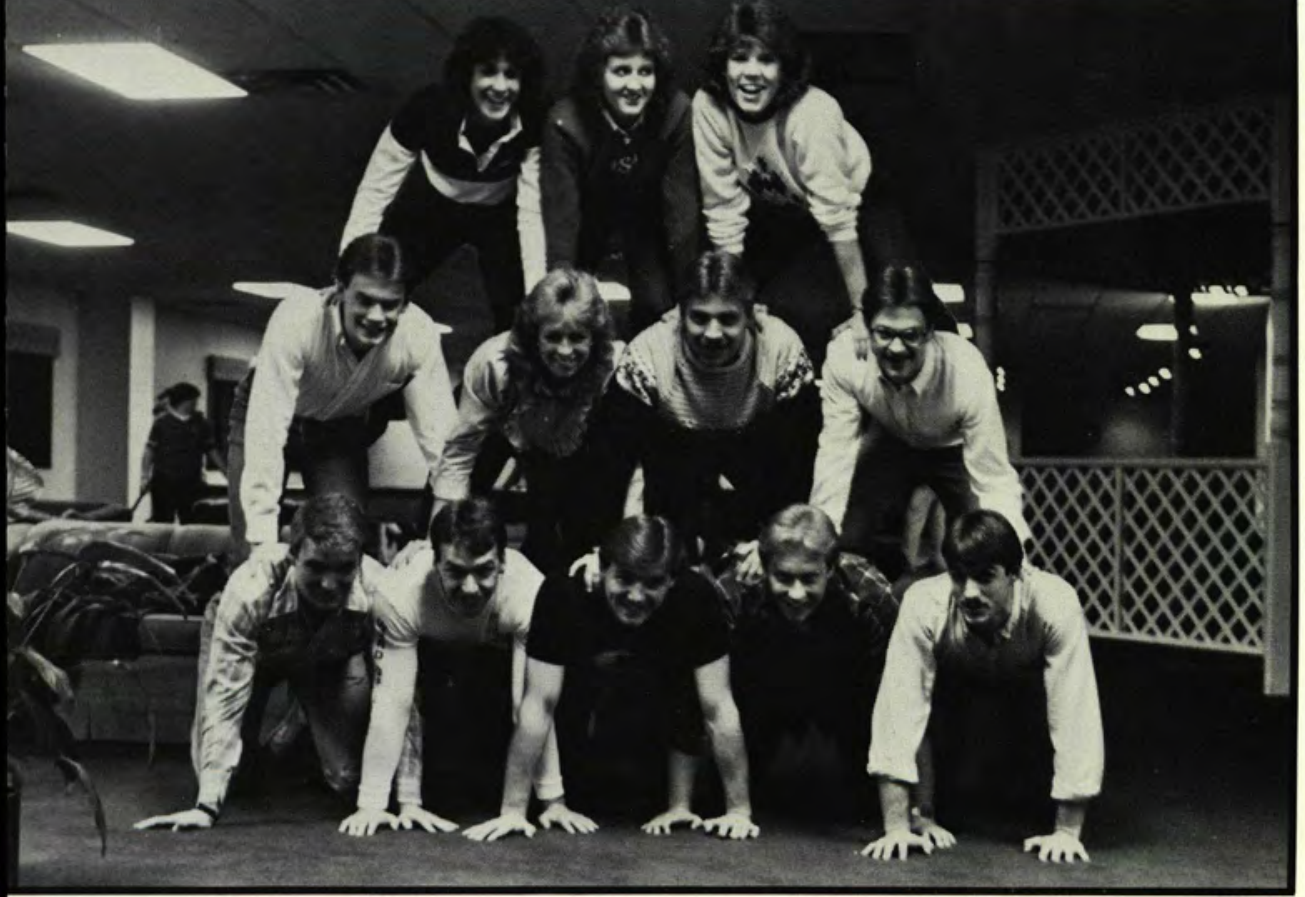

"Preach the Word; be instant is season, out of season, reprove, rebuke, exhort, with all longsuffering and doctrine. II Timothy 4:2

Top Row: Jill Sandy, Sonya Nichols Mid dle Row: Scort Morgan, Laura Wuestner (Leader), Todd Coston, Mart Dickenson, Borrom Row: Dave Wuestner, Jone Schaedel, Lamar Eifert, Glen Brown, Sreve Emmons. 


\section{Schulze Nursing Hom}

"For God harh not appointed us to wrath, but to obtain salvarion by your Lerd Jesus Christ, who died for us, that, wherher we wake or sleep, we should live rogerther with him. Wherefore comfort yourselves rogerher and edify one anorher even as ye also do."

I Thessalonians 5:11

Rurh Brown, Donna Hallman, Cheryl Herr, David Mossman, Dave Nerzky, Jack Srumme, Donna Windish.

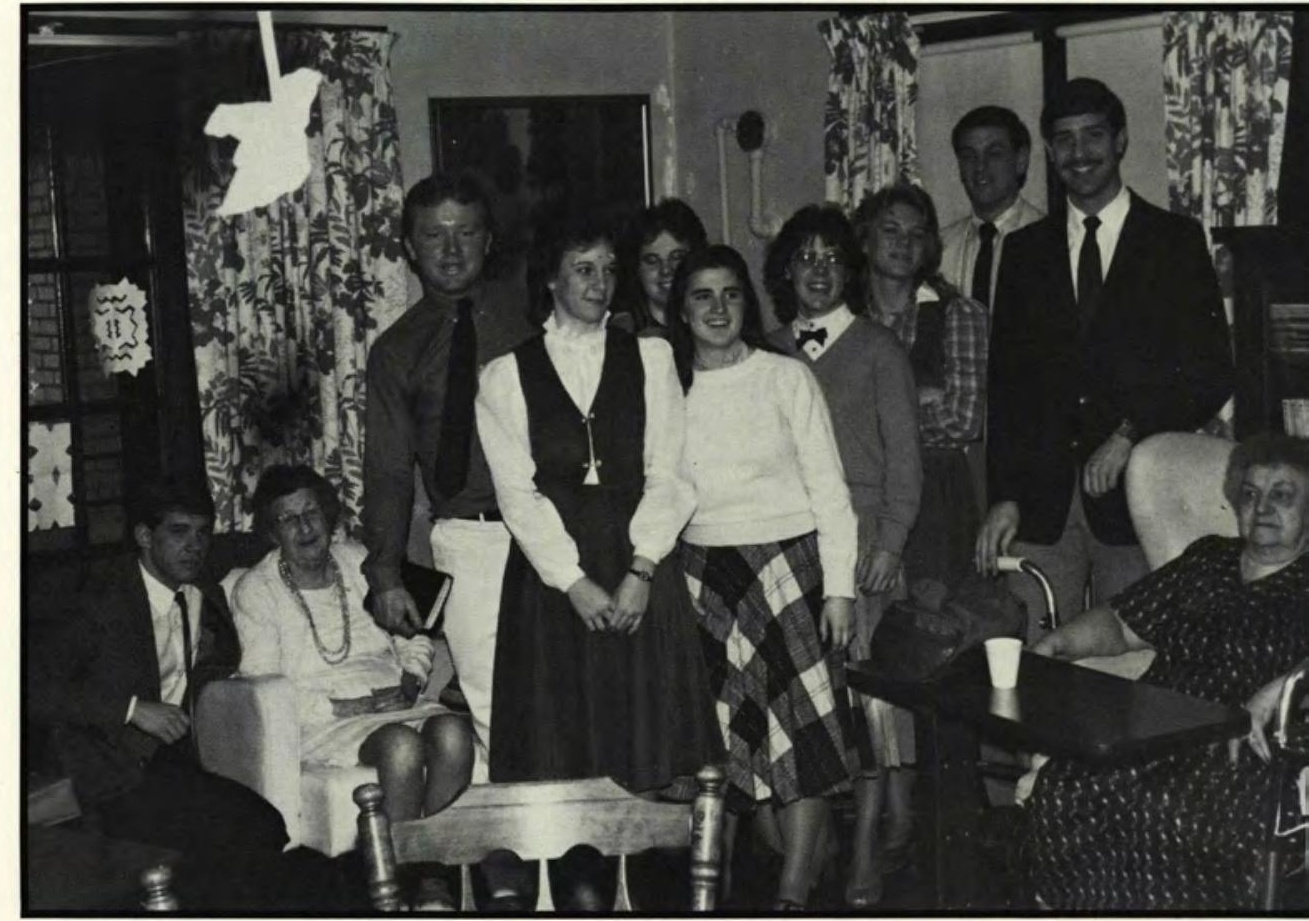

"And be ye kind one to another, renderhearted, forgiving one another, even as God for Christ's sake hath forgiven you."

Ephesians 4:32

Seared: Shari Leach, Ruth Kirtland Sranding: Brian Toylor (Leoder), Karo Ray, Andrea Snyder, Grant Williams.

\section{Master's Puppets I}

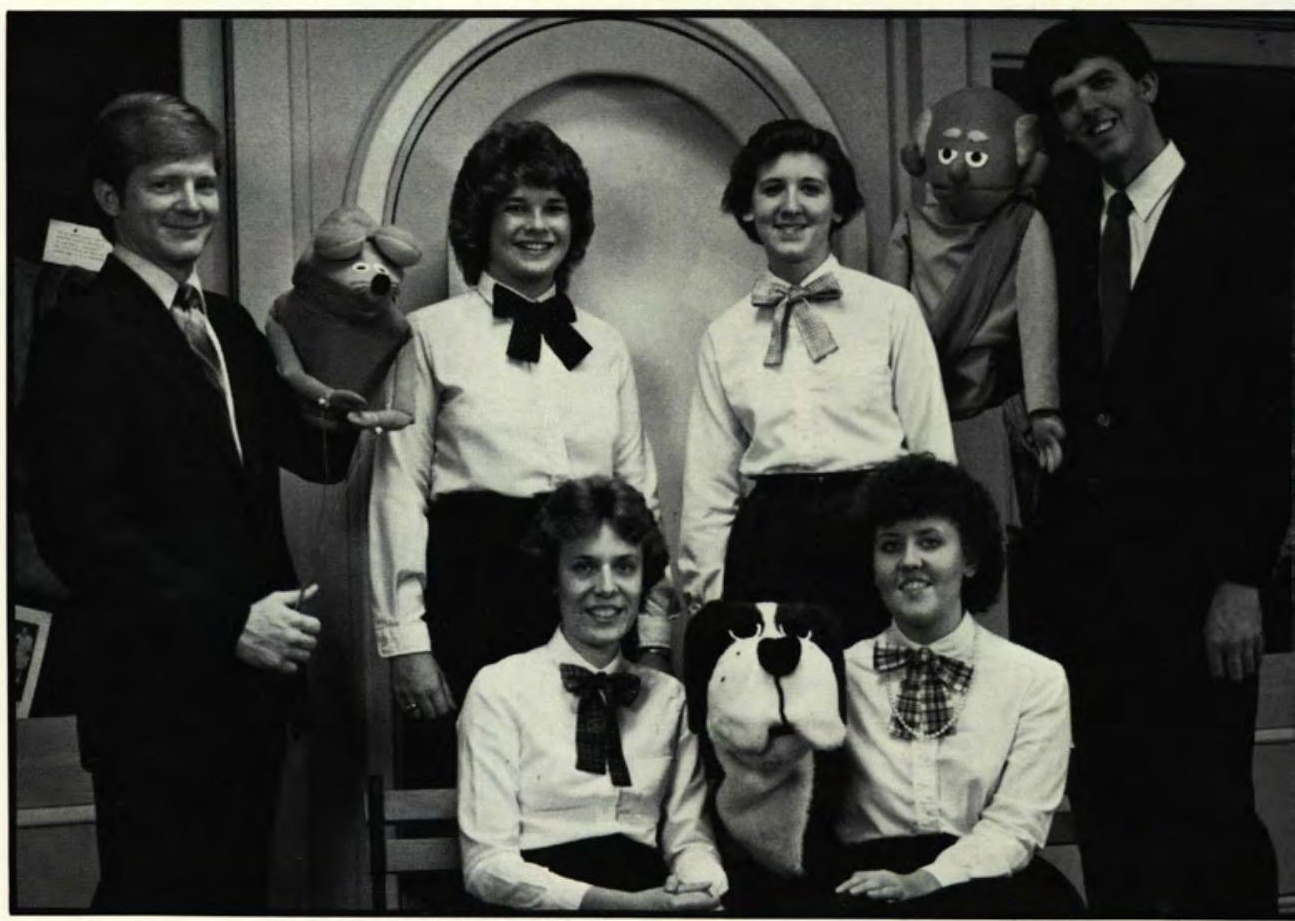




\section{wordbearers I}

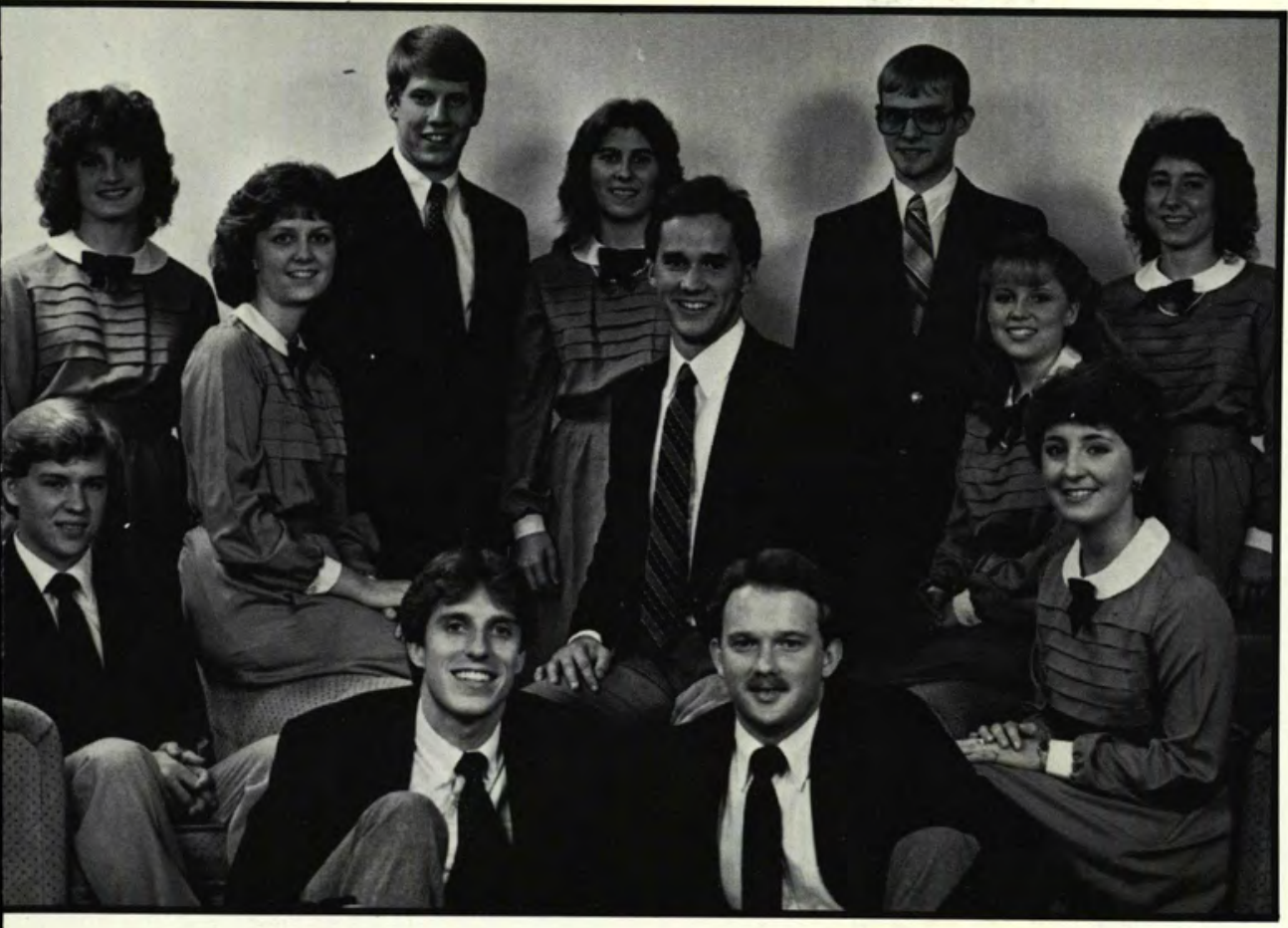

\section{Mercy Hostpital}

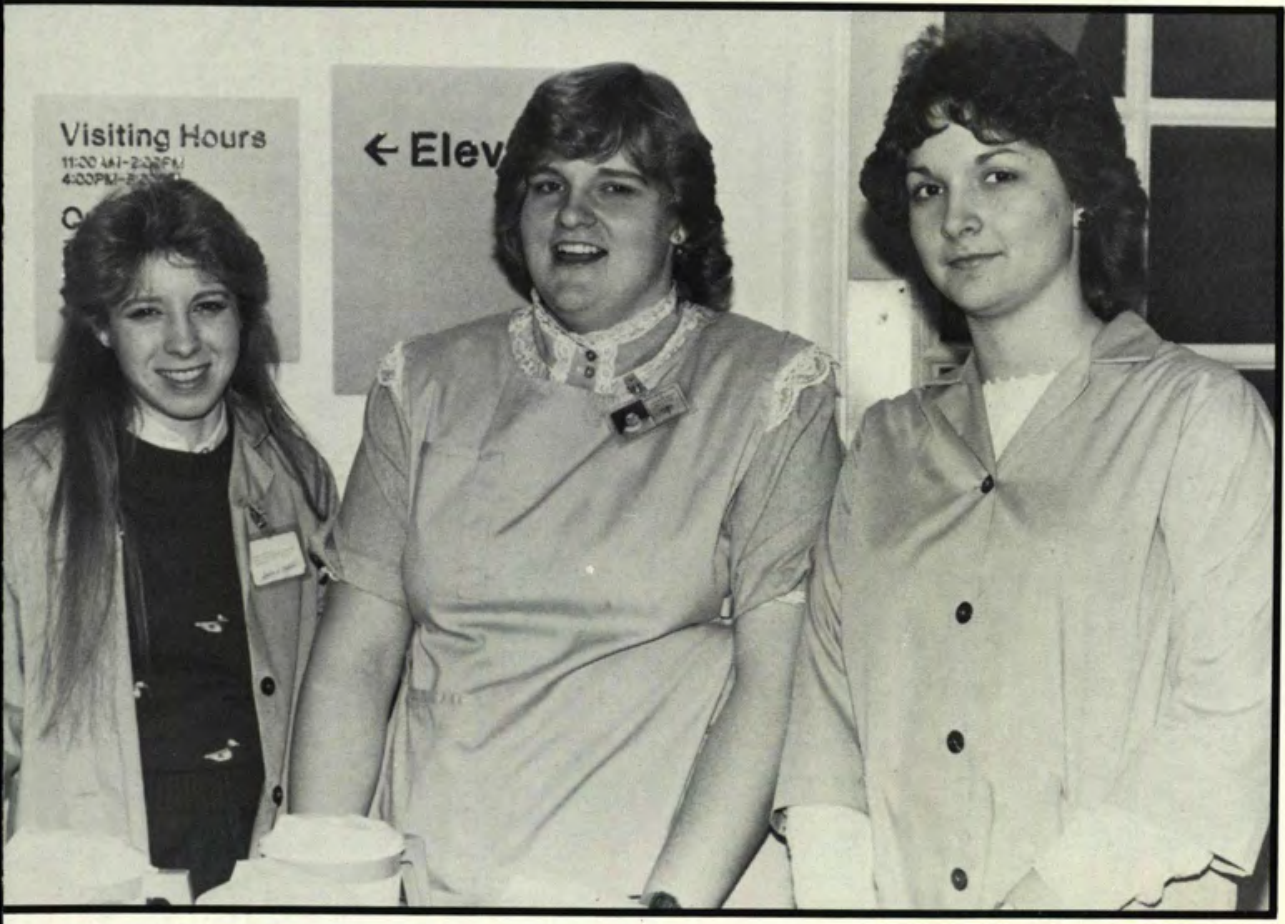

"O come, let us sing unto the Lord: let us make a joyful noise to the rock of our salva tion. Let us come before his presence with thonksgiving, and make a joyful noise unto him with psalms. For the Lord is a grear God, and a grear king above all gods."

Psalm 95:13

Seared, Front Row: Randy Johnson, Dave Robinerte. Seared, Second Row: Ron Mackey, Anne Edwards, Jim Reirer (Leoder), Shari McAllester Jody Perers. Sranding: Kim Bragg. Temple Knowles, Melisso MacMichael, Bryan Crump, Shelly Polsdorfer
"Let your light so shine before men, that they may see your good works, and glorify your Farher which is in heaven."

Marthew 5:16

Laurie Benedict, Sue Ellen Black, Teeno Coronaro, Cindy Guido, Berh Hoeke, Tommy Jones, Susan Lafferty, Tonya McBee, Berh Nester, Sue Rasmusson, Terri Youngless. 


\section{Greenwood Manor Nursing Hom}

"And He said unro me, My grace is sufficent for thee: for my strengrh is made perfect in weakness. Most gladly therefore will I rarher glory in my infirminties, that the power of Christ may rest upon me."

II Corinthians 12:9

April Augustus, Lee Ausrin, Judy Block, Diane Blasdell, Bill Bianco, Bruce Bowman, Perry Chiarelli, Sally Cochran, Janis Comforr, David Douglos, Laura Dykstra, Dave Eller, Brian Ensminger, Julie Gayer, Mark Groves, Linda Hess, Lori Hess, Ann Hunrer, John Irving, Me lanie Irving, Bruce Keisling, Roge Losh, Tracy Laurance, Kristi Mossie, Rurh Moson, Cliff Mast, Bruce McNobb (Leader), Sandi Porter, Kim Robinson, Jane Sporling.

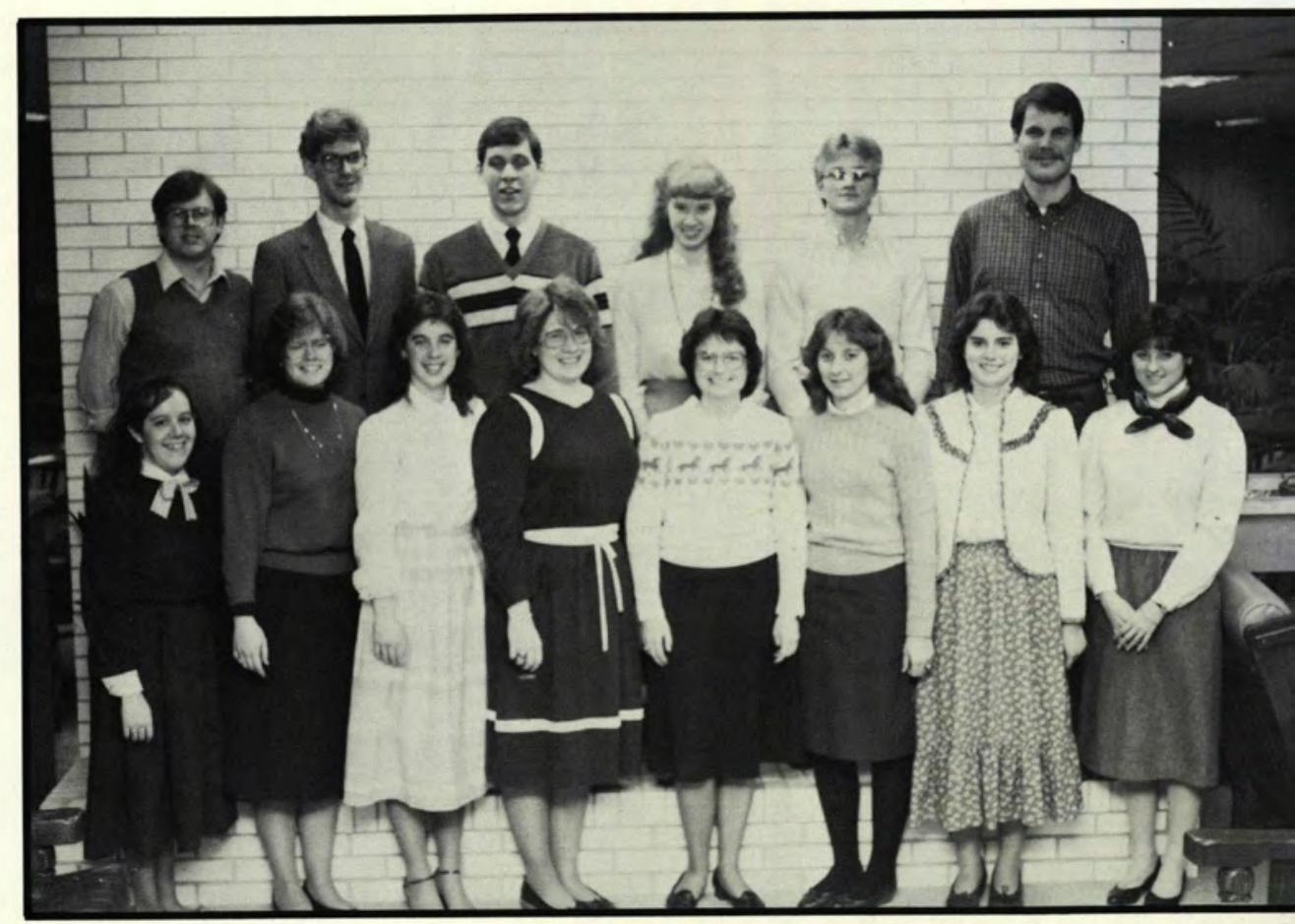

\section{Australia M.I.S. Teat}

"And he hath put a new song in my mourh, even praise unto our God: many shall see it, and fear, and shall trust in the Lord. Blessed is that man that makerh the Lord his trust and respecterh nor the proud, nor such as rurn aside to lies."

Psalm 40:3-4

Seared: Jim Unger, Debbie Henry, Chuck Scorr. Middle Row: Ellen Spencer, Elena Michoel, Jennifer Dye. Bock Row: Mike Low, Bob Beikert, Jeff Beste.

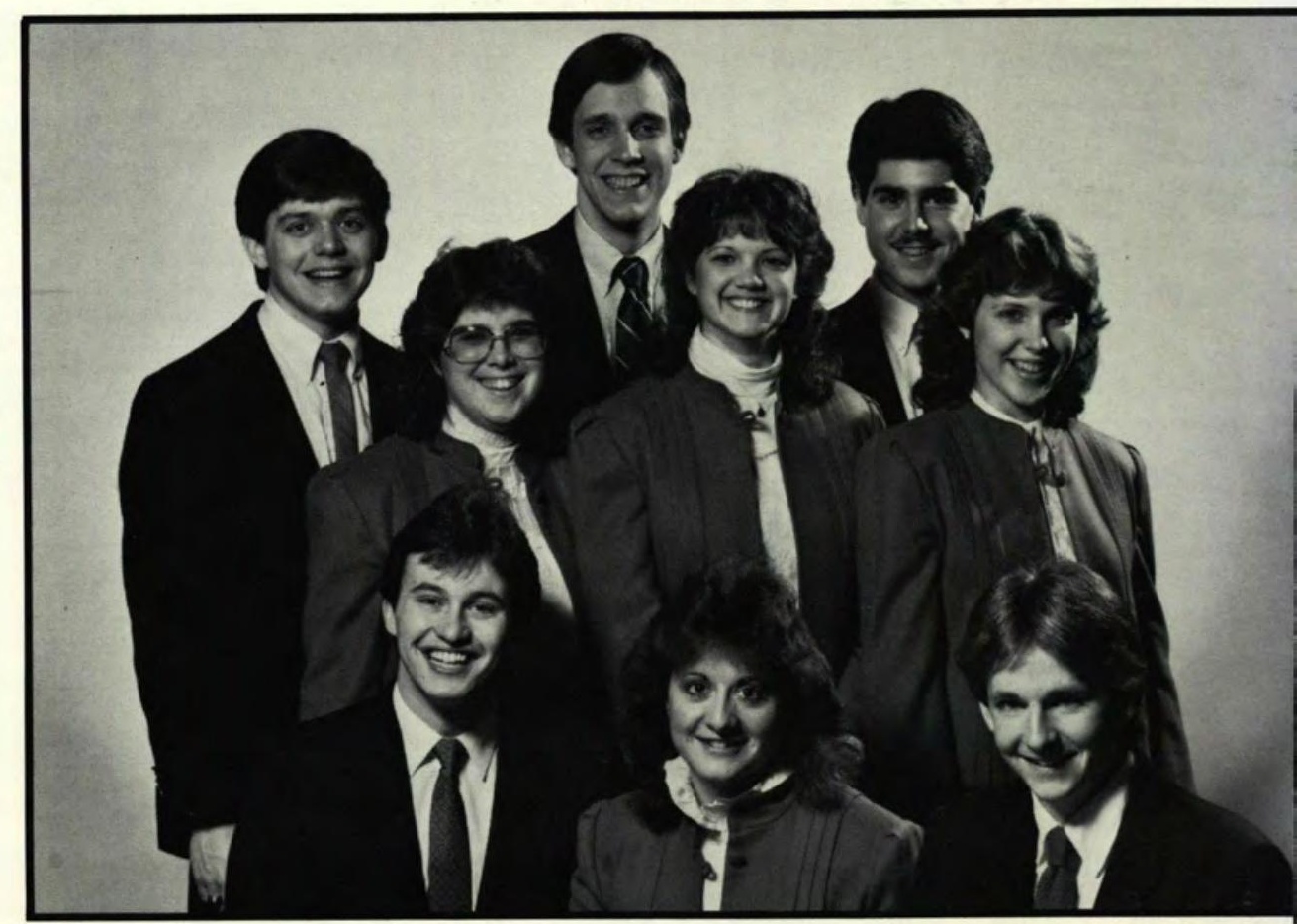


ounds Of Joy

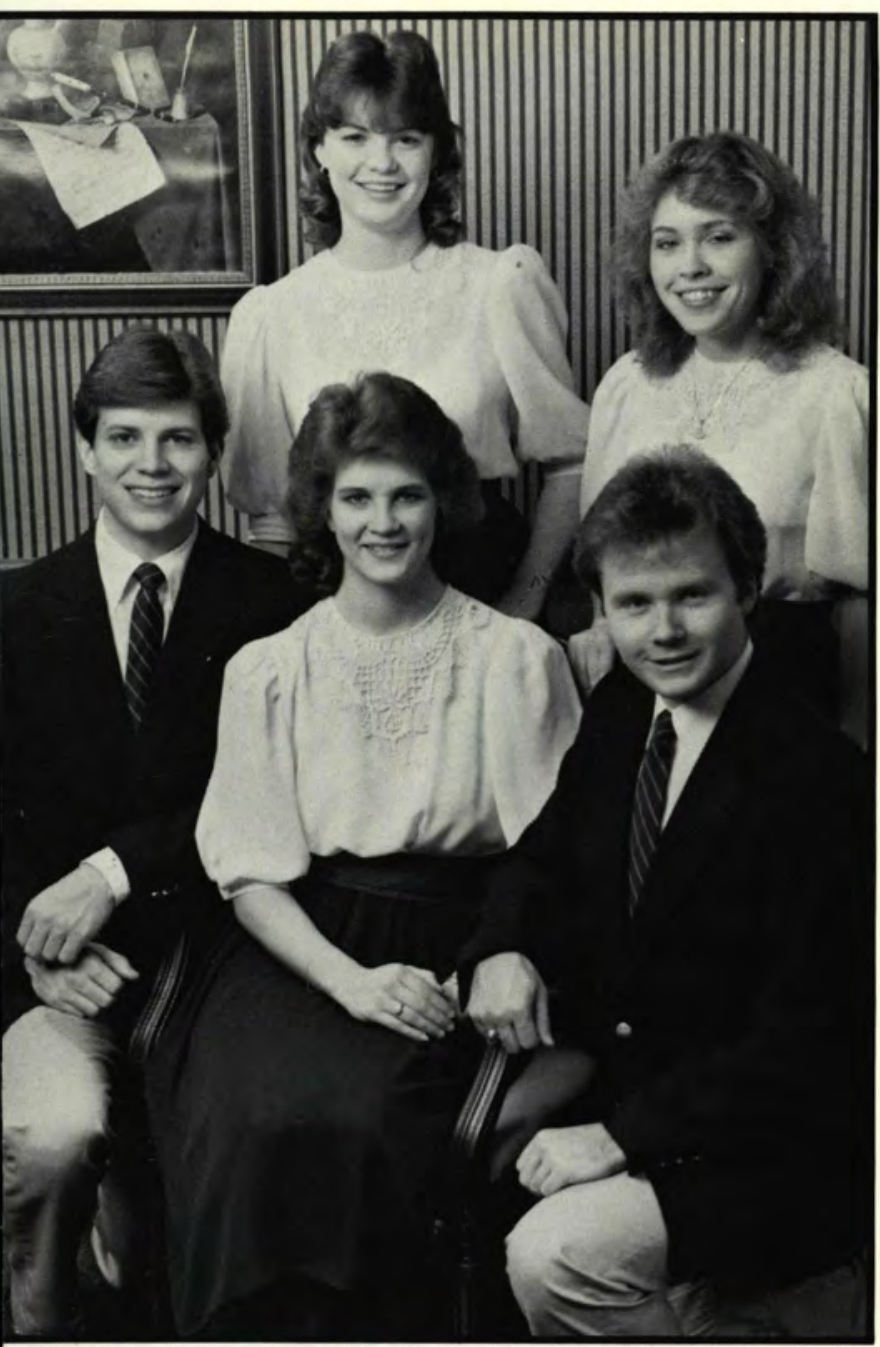

"O magnify the Lord with me, and ler us exalt his name rogerher."

Psolm 34:3

Front Row: Will Marling, Volerie Blay lock, Jerry Cornich; Bock Row: Liso Proll, Borb Riggs.

\section{ethesda Rehabilitation Center}

'And ler us nor be weary in well doing for in due seoson we shall reap, if we faint nor. As we have therefore opportuniry, let us do good unto all men, especially unio them who are of the household fairh."

Galarians 6:9-10

Jon Bresson, Rob Broline, Donna Doug. as, Jona Dowsert, Kirk Foirhurst (Leader), Berh Goldsmirh, Sue Greerham, Shown Hinkson, Jan Johnson, John Litrle. Dione McClure, Cheryl McHenry, Andy Minninger, Diane Noggle, Lori Orraway, Carolyn Parrick, Lisa Richards, Rick Seidel, Connie Thibo. 


\section{Antioch Campus Evangelist}

"O keep my soul, and deliver me: ler me nor be ashamed, for I put my trust in thee.

Psalm 25:20

Anne Angell, Mark Baker, Dino Bor chelder, David Berghen, Debi Bell, Karhleen Clayron, Cynrhio Cronrarh, Cary Danielson, Dave Edwards, Jeff Ericson, Linda Lons, Amy Jo Guest, Mary Jones, Jim Koerber, Holly Marshall, Cicero Mukes, Rurh Morgraff, Liso Henry, Jim Murdock, Judy Oakes, Mark Prevost, Michelle Livingston, Gwen Price, Todd Rhoades, David Robinson, Tracy Roy, Todd Shannon, Jane Sparling, Lori Splegel, Wendy Srith, Amy Thomas, Donald Tung, Rob Thompson, Chris Tupps, J. Williams, S. Zerpirer.

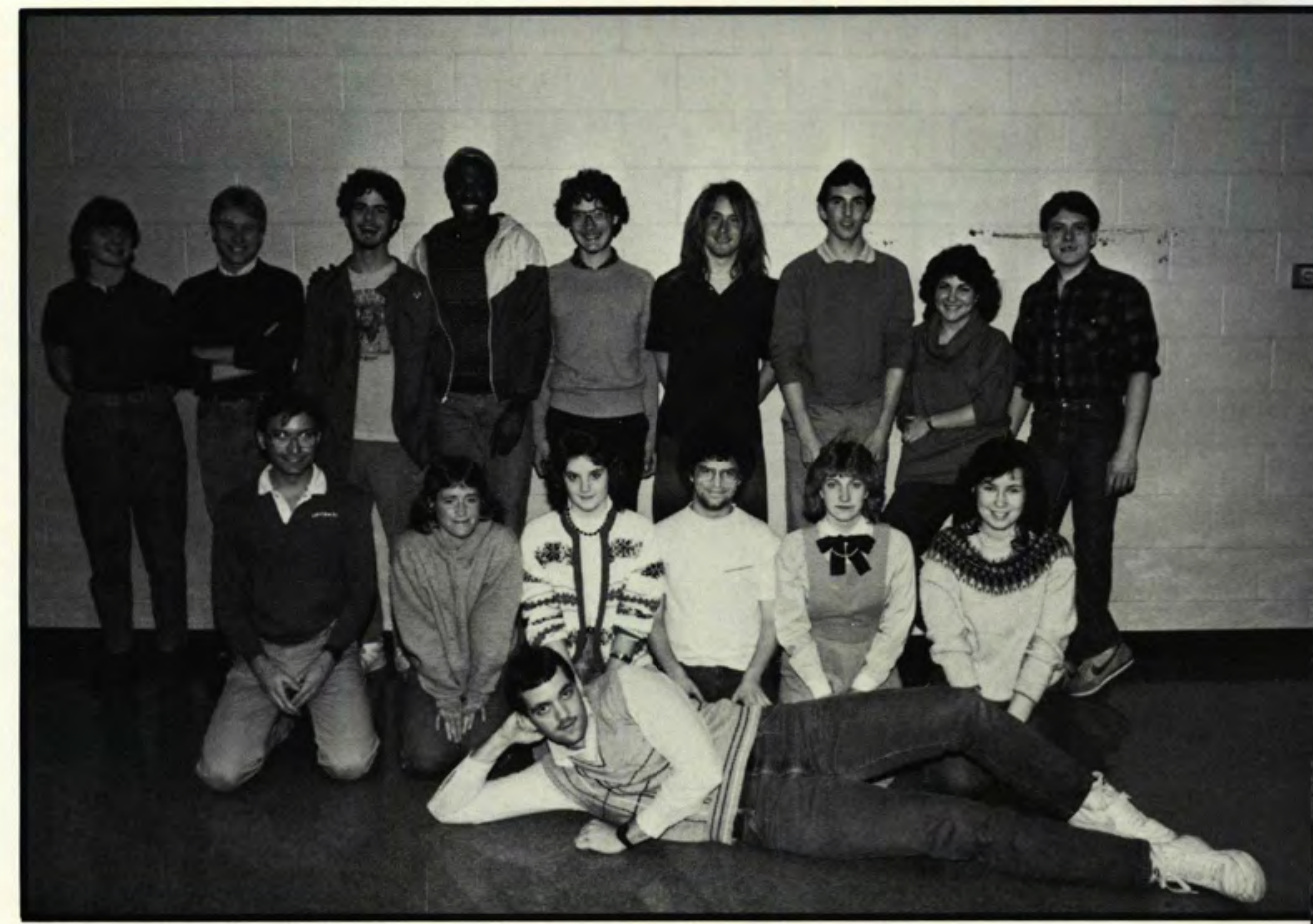

\section{Summer Master's Puppet}

"Nor with eyeservice, as menpleasers; but as the servants of Christ, doing the will of God from the heart; with good will doing service, as to the Lord, and not to men."

Ephesians 6:6-7

Front Row: Robin Young, Middle Row Laura Harrsough, Alon Gipson, David Williams (Leader), Standing: Scort Moyer.

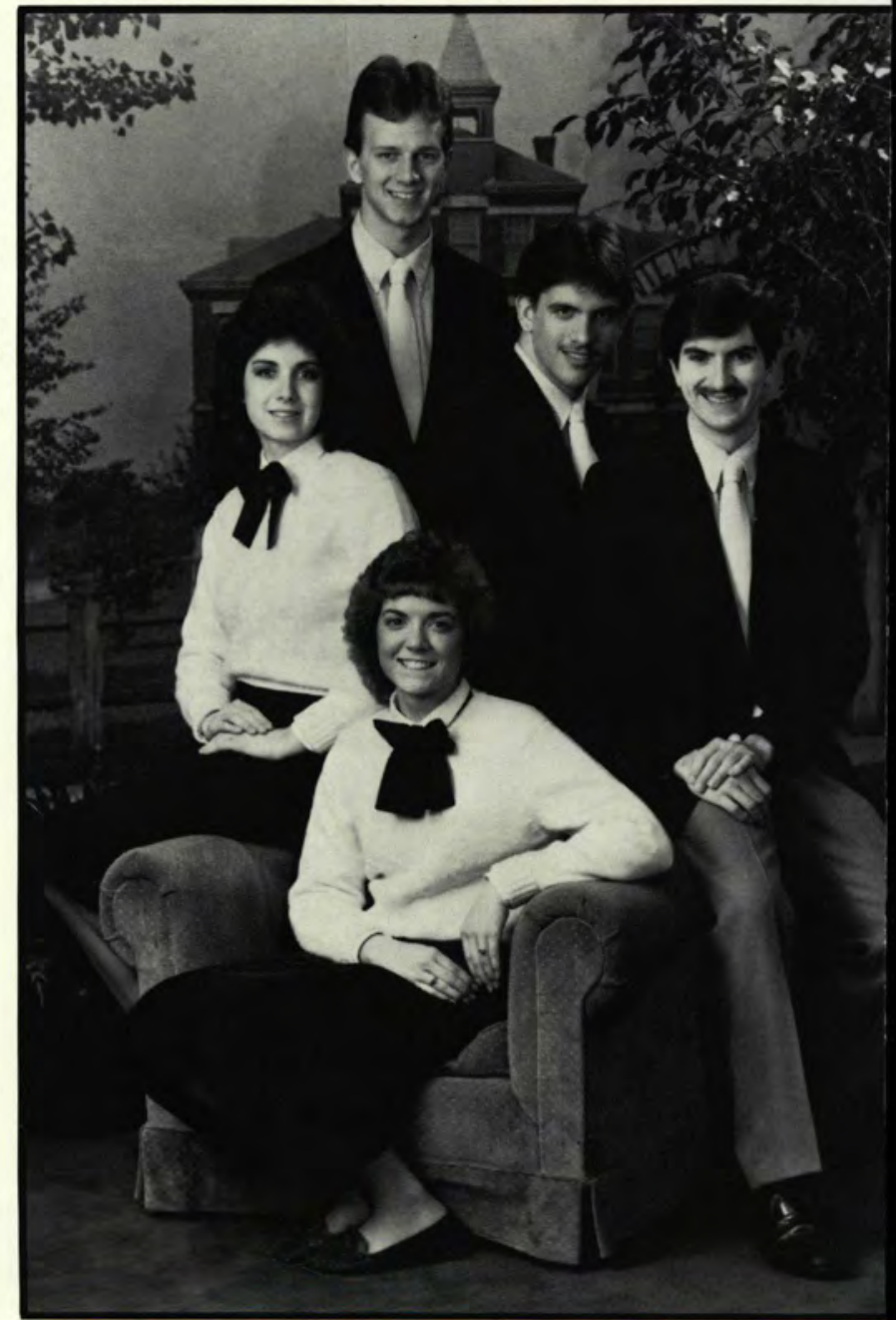




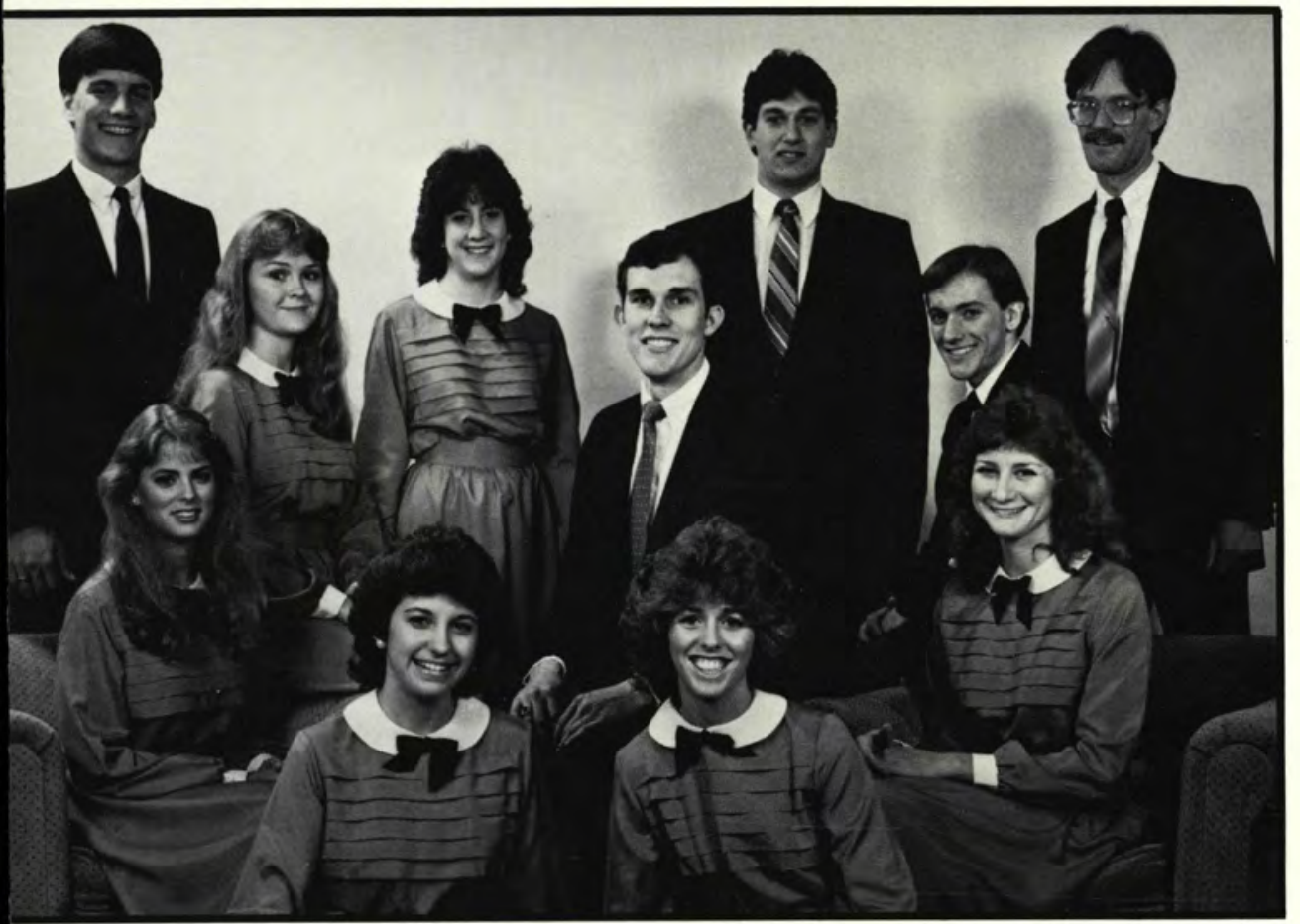

\section{dd Fellows Rest Home}

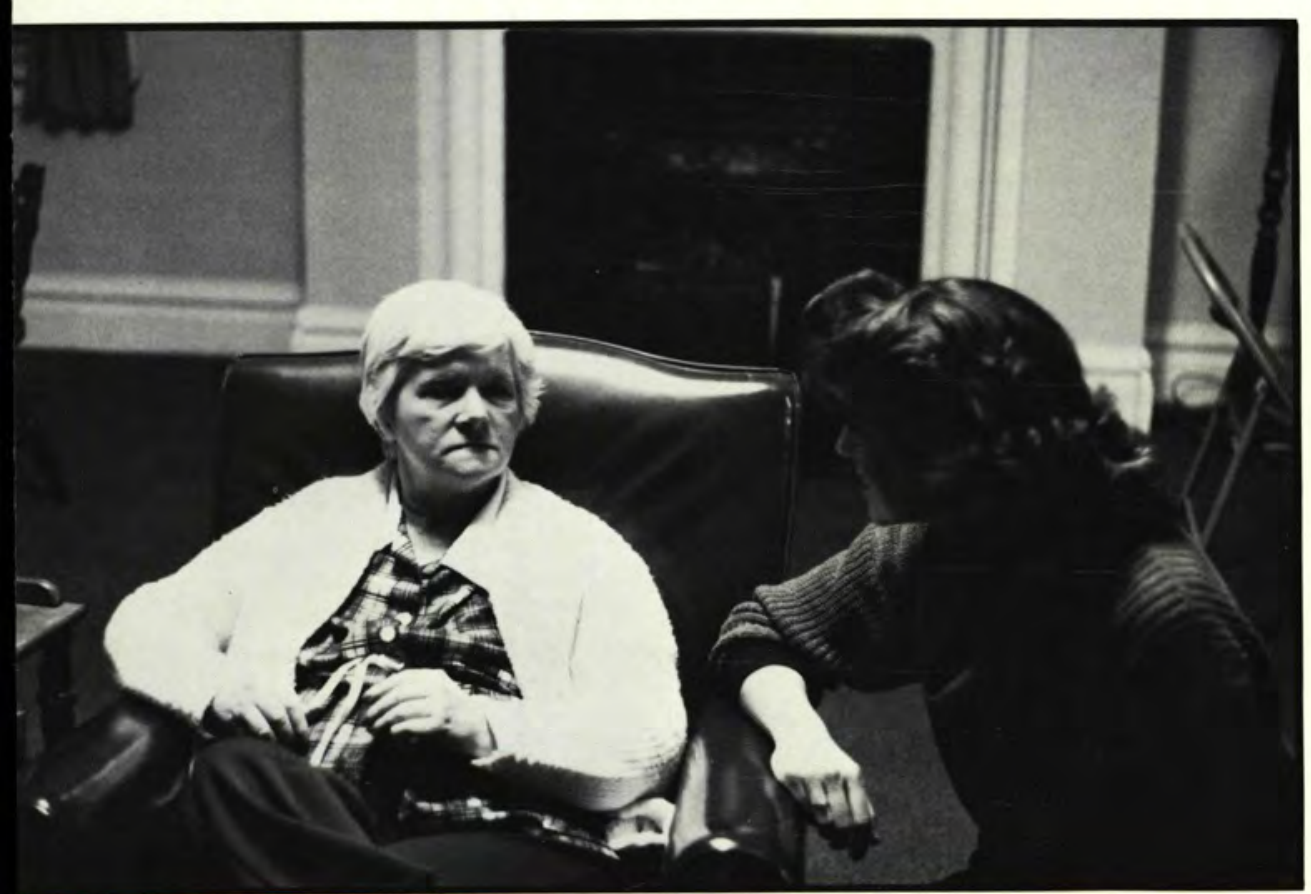

"Do not fear, for I am with you; Do not anxiously look about, you, for I am your God. I will strengthen you, surely I will help you, surely I will uphold you with My righteous right hand."

Isaiah 41:10 (NAS)

Seared, First Row: Karla Himes, Jennifer Burler. Seared, Second Row: Erin Coffman, Gina Long, Alan McCain (Lead er), Brian Hedges, Teena Shupert Sranding: Dave Kercham, Janer Wirte kind, Mike Anderson, Tim Smirh.
'Let us therefore come boldly unto the throne of grace, that we may obrain mercy, and find grace to help in time of need."

Hebrews 4:16

Kennerh "Dave" Bone (Leader), Dan iel L. Bayes, Becky Bennert, Dave Bennert, Annerte Bloxham, Sreve Cre meon, Judy Denning, Judy Eogleston. Jeff Ellior. Cheryl Holland, Dove Konz, Carhy Lombord, Randy Monroe, Rurh Murroff, Mary Rose, Linda Shaffer, Korla Simpson, Bill Toft, Mark Van Keeck, Shari Woshburn, Aaron Whirocre. 


\section{Master's Puppets}

"But thanks be to God who always leads us in His strength in Christ, and manifests through us the sweet aroma of the knowledge of Him in every place."

II Corinthians 2:14 (NAS)

Seared: Laura Hartsough, Marla Fuller Sranding: Judy Wirtaker, Brandon Wolrz, Daniel Leirch, Phyliss Trivert.

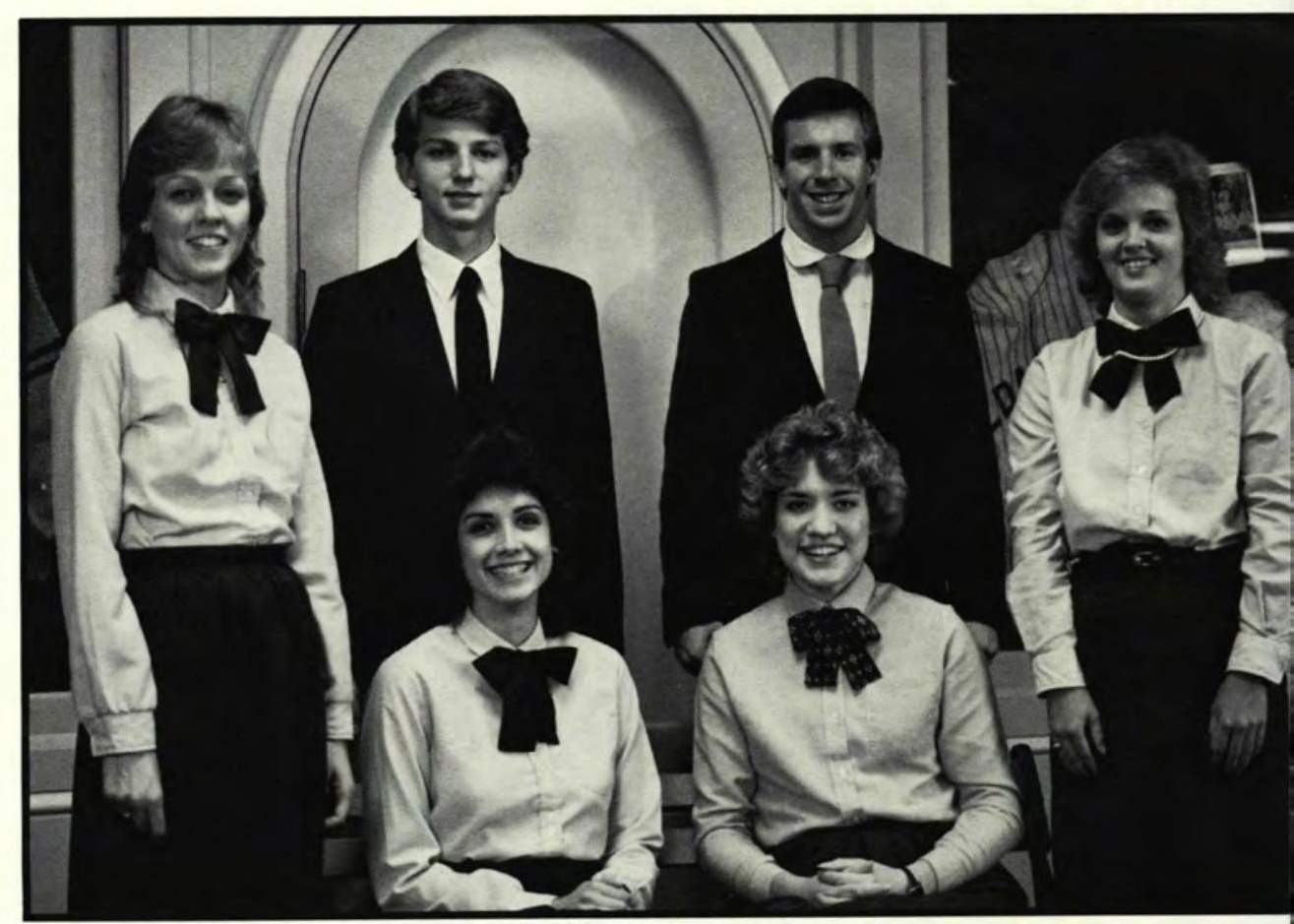

\section{Mueller Residential Cente}

"And this is the confidence that we have in Him, thar, if we ask anything according to his will, he hearerth us: and if we know that he hears us, whatsoever we ask, we know that we have the peritions that we desired of him."

I John 5:14-15

Anne Angell, April Avey, Bretr Bornard, Lynn Bartlert, Mike Basler, Jomie Beight, Rebecca Bellerson, Down Deachmen, Becky Bliss, Lisa Bowler, Kit Brodman, Jeannie Burzlaff, Rhondo Culberr, Mark Clark, Sherri Cruver, Kris Cline, Goil Doiker, Tim Day (Leoder), Perry Defelice, Shawno Denney, Dar rell Conlin, Janer Derstein, Dave Ed. wards, Janice Estes, Tonyo Evans, Jen nifer Everoge, Dan Everrert, John Exley, Alice Fenstamaker, Laura Fish, Debi Furman, Sarah Gerx, Dand Galland, Donno Horman, Kelly Herbert, Nancy Howkins, Jim Homes.

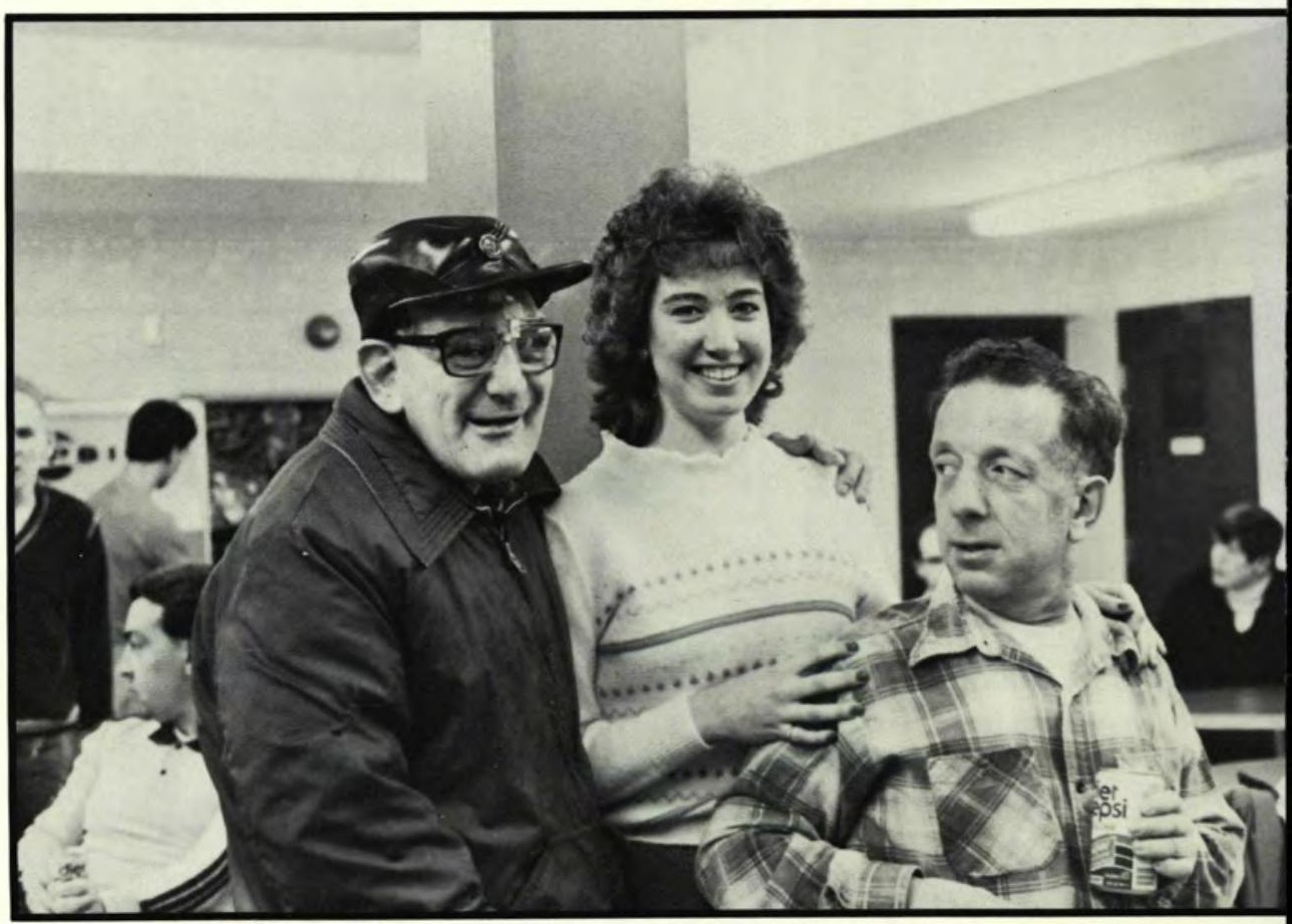




\section{Hospitality Home East}

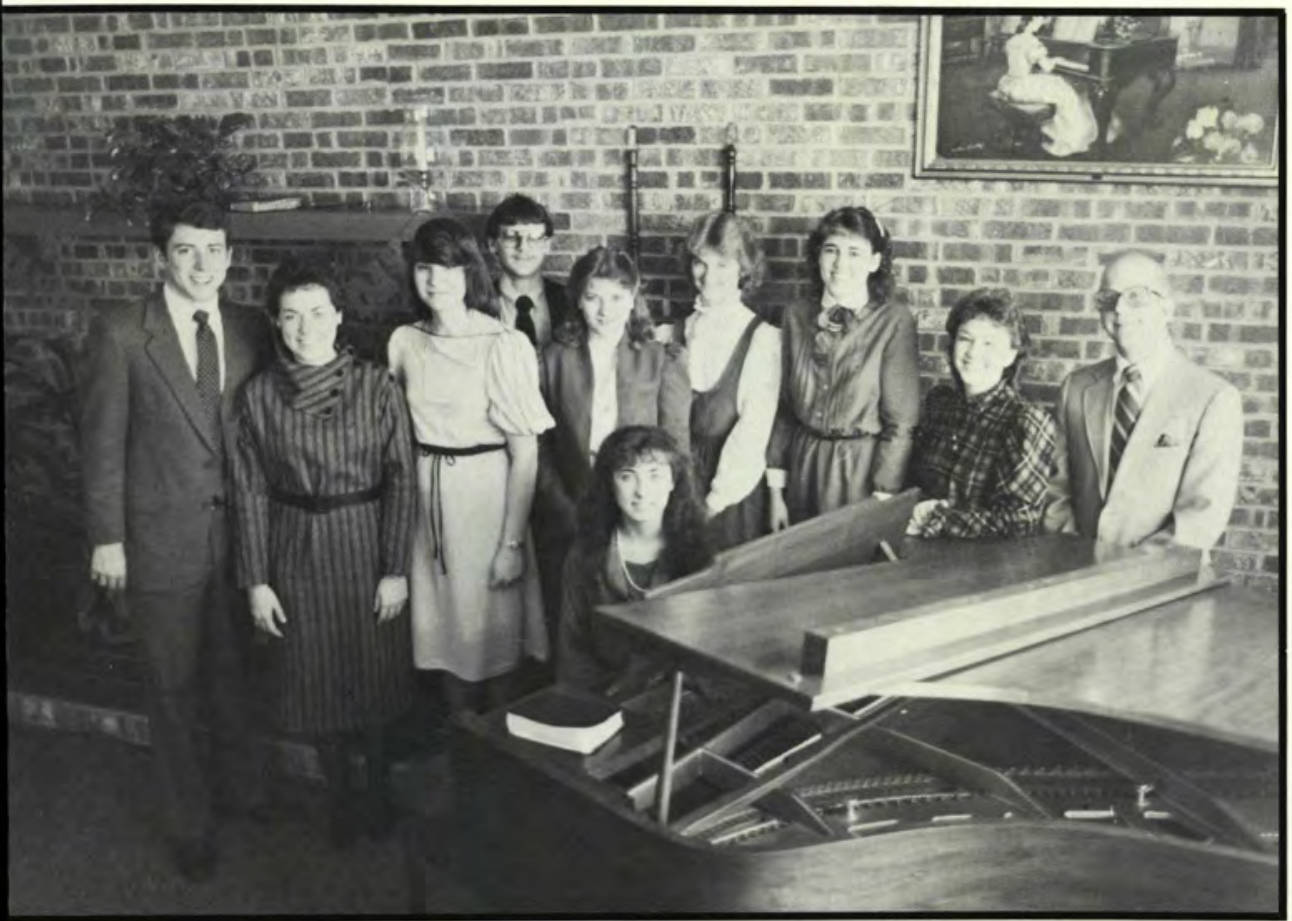

\section{ummer Swordbearers}

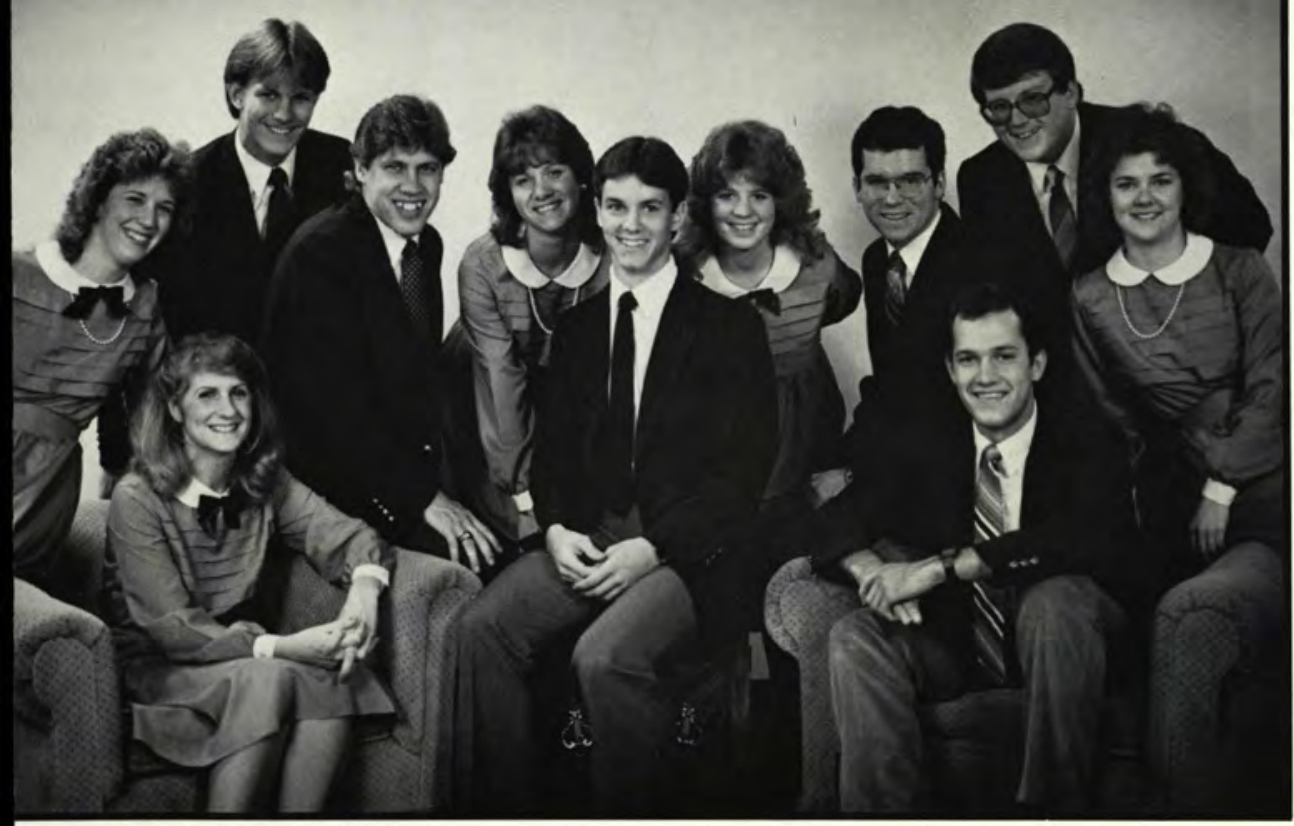

"And the peace of God, which passerth all understanding, shall keep your hearts and minds through christ Jesus.

Philippians 4:7

Bill Bany, Debbie Bell, Lauri Benedict, Terri Banning, Martha Buck, Richard Chasse, Perry Chiarelli, Gail Daiker, Sherri Davis, Jana Dowsert, Julie Erdmann, Holly Flenner, Tomara Hershberger, Phil Hohulin, Bob Hood (Leader), Dove Kommeyer, Mary Jones, Jim Murdoch, Melanie Knouff, Danielle Kizee, Lori Lindsey, Denise Lowe, Lorry Miller, Michelle Leloh, Diane Ortoway, Teresa Polmer, Dove Sallee, Jeff Porrick, Don Thacker, Sherri Tice, Amy Thomas, Brian Worfle, Rick Van Shoick, Judy Weston, Parti Webb, Sheri Whitcomb, Pete Wright, Gwen Price, Theresa Youngless.

'But grow in grace, and in the knowledge of our Lord and Saviour Jesus Christ. To Him be glory borh now and forever. Amen."

II Perer 3:18

Donna Thomas, Melissa Marshall, Ron Smirh, Alvin Tucker, Sue Scort, Gerry Wolloce, Pam Rickard, Ed Lonning. Tom Carr (Leader), Par O'Donnell, Karhy Sragg. 


\section{Knights Of Pythia}

"For, Brethren, ye have been called unto liberty; only use not liberty for an occasion to the flesh, but by love serve one anorher.'

Galarians 5:13

Front Row: Hearher Macfarlane, Pomela Woods, Bock Row: Diane, Blosdell, Wayne Keisling.

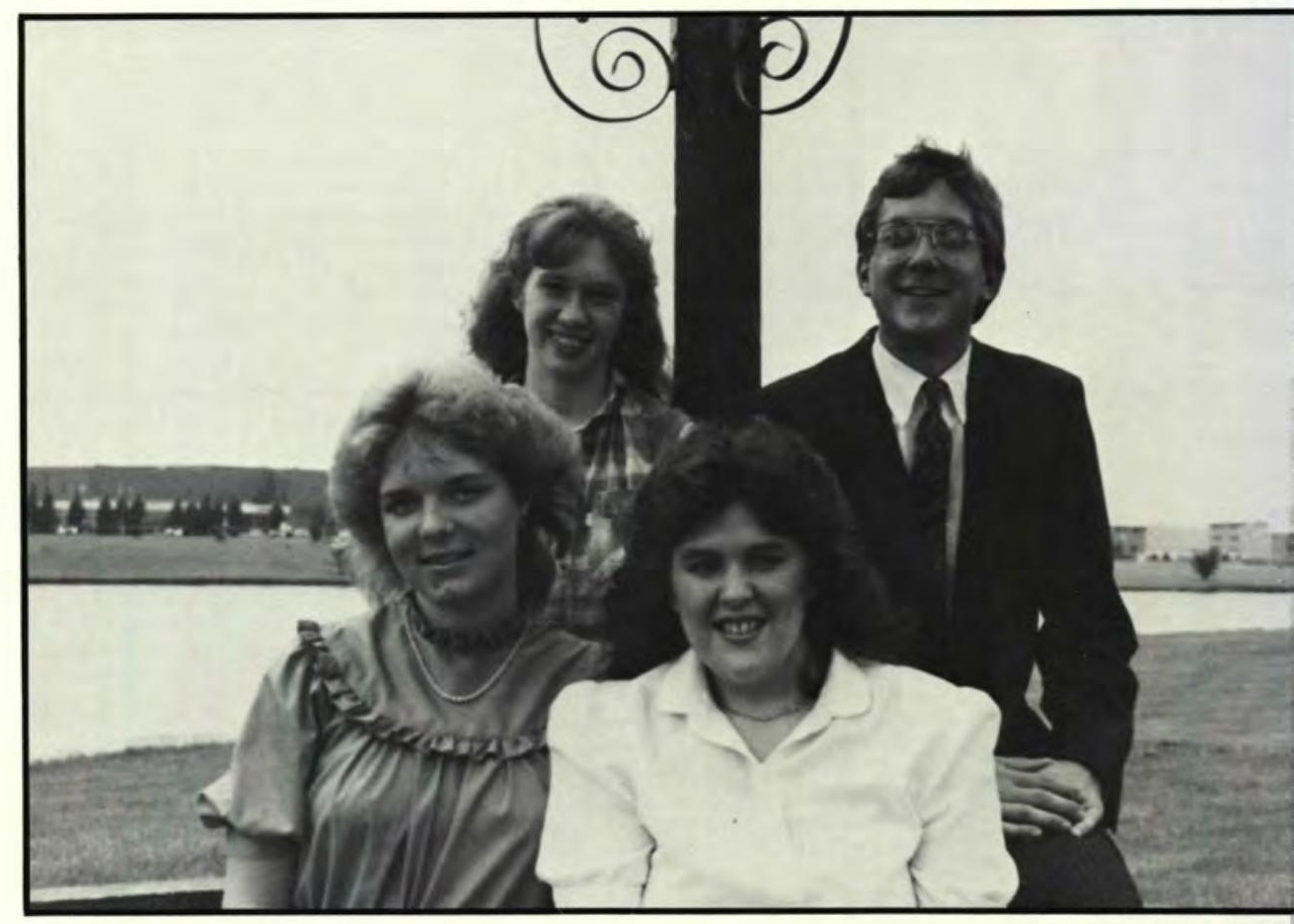

\section{Wright State Campus Evangelist}

"Bur ye are a chosen generation, a royal priesthood, a holy nation, a peculiar people; that ye should show forth the praises of him who harh called you our of dorkness into his marvelous light."

1 Perer 2:9

Suzanne Herr, Krisanne Bartholomew, Eric Shrum, Amy Phillips, Shelly Broughron.

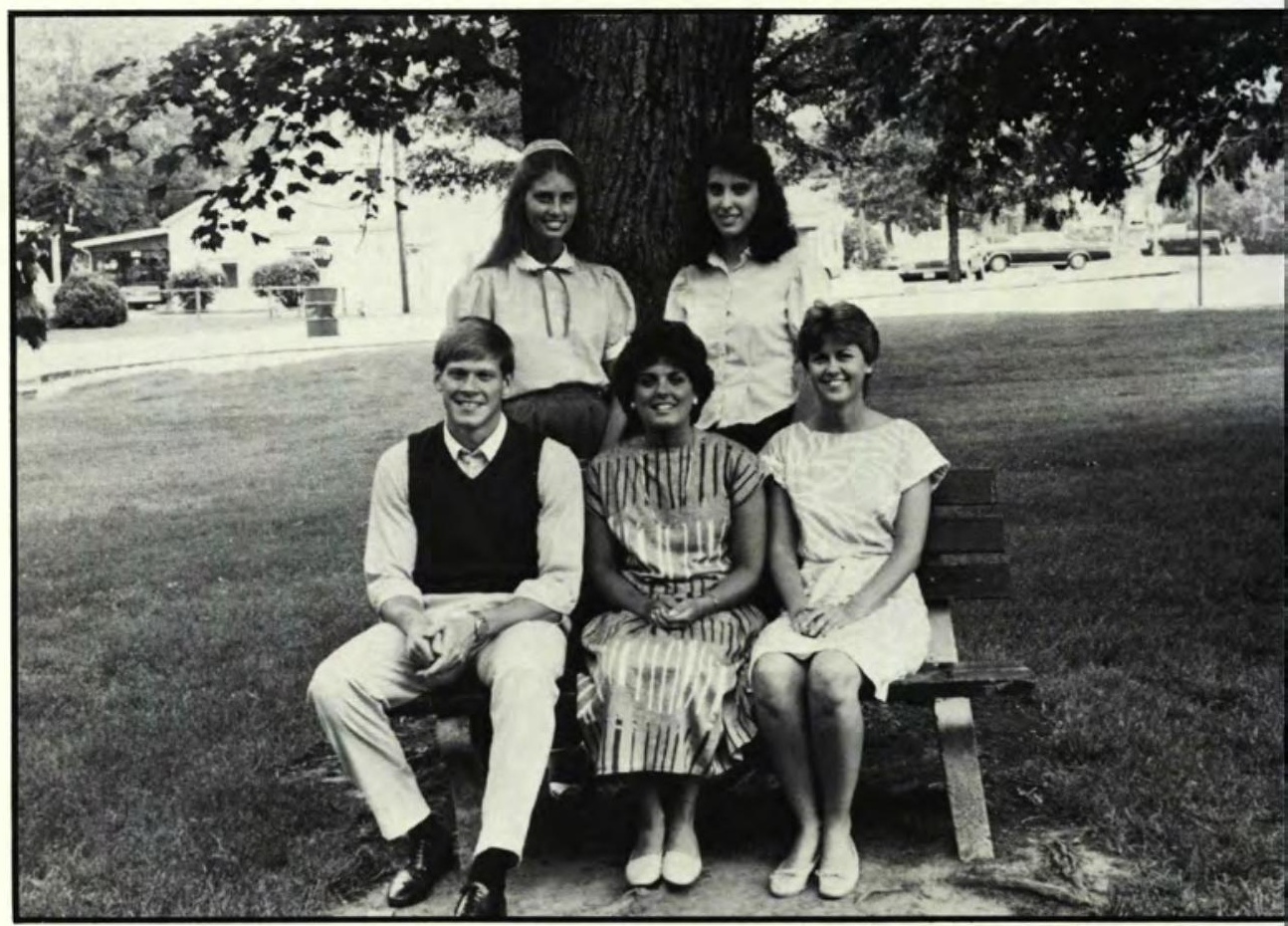




\section{China M.I.S. Team}

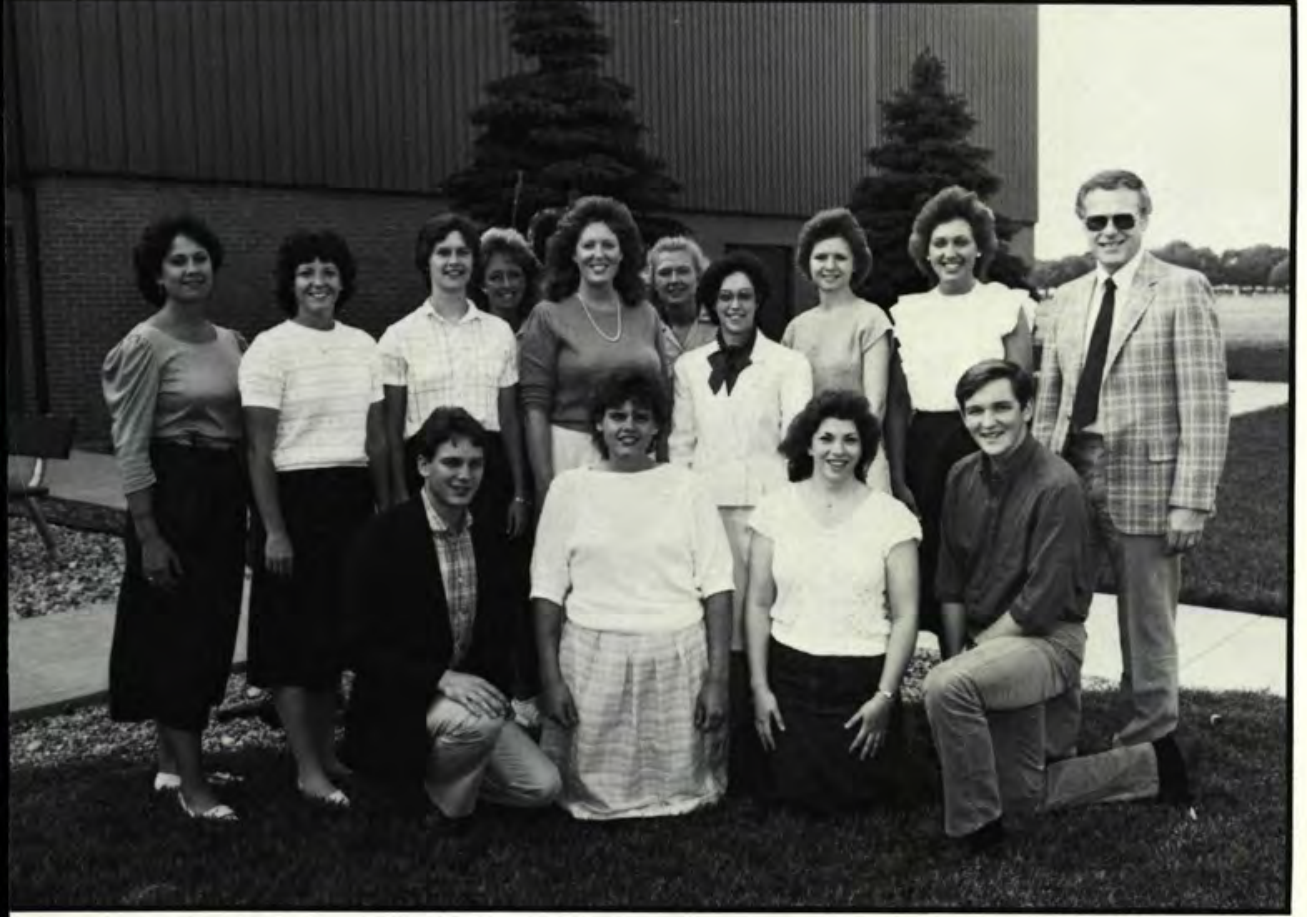

\section{lorida Spring Break Team}

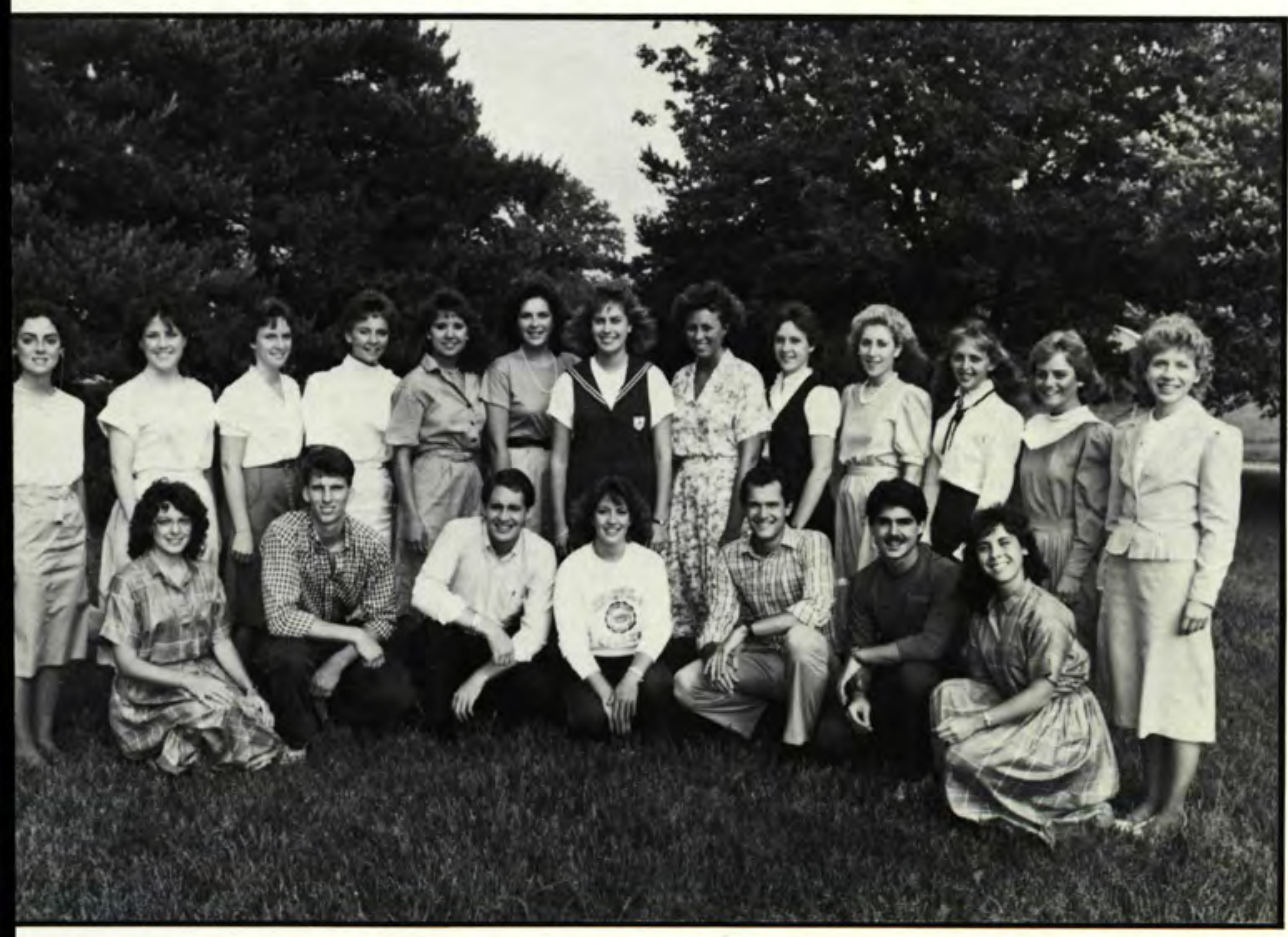

"Not that we are sufficient of ourselves to think any thing as of ourselves; but our sufficiency is of God."

2 Corinthians 3:5

Front Row: Keith Holt, Sracy McGoskill, Mary Welch, Errin Mulberry, Bock Row: Sarah Anderson, Jewel Schroder, Dione Lichrensteiger, Loura Wuestner, Shelly Frank, Kathy Worren, Sharon Rawson, Lynn Cadamus, Tonya Bumpus, Dwayne Frank.
"For God hath nor given us the spirit of fear; bur of power, and of love, and of a sound mind."

2 Timothy 1:6

Front Row: Alice Boyd, Rob Thomson, Jeff Lyle, Donno Douglas, Tom Corr, Jeff Beste, Debi Bell, Back Row: Foy Schonfeld, Donna Ford, Toni Lynn VanBeveren, Diana Phillips, Parti Parker, Lindo Lons, Nancy Ozinga, Karen Beartie, Terri Lynn Vanbevren, Deb schonfeld, Corole Roland, Amy Thomos. Liso Fisher. 


\section{Quebec M.I.S. Teat} him follow me; and where I am, there shall also my servant be: if any man serve me, him will my Farher honor."

John 12:26

Dr. Rex Rogers, Tommy Rogers, David Beverly, Stephonie Hein, Jim Murdoch, Dione Weover, Tim Smirh.
"If any man serve me, ler

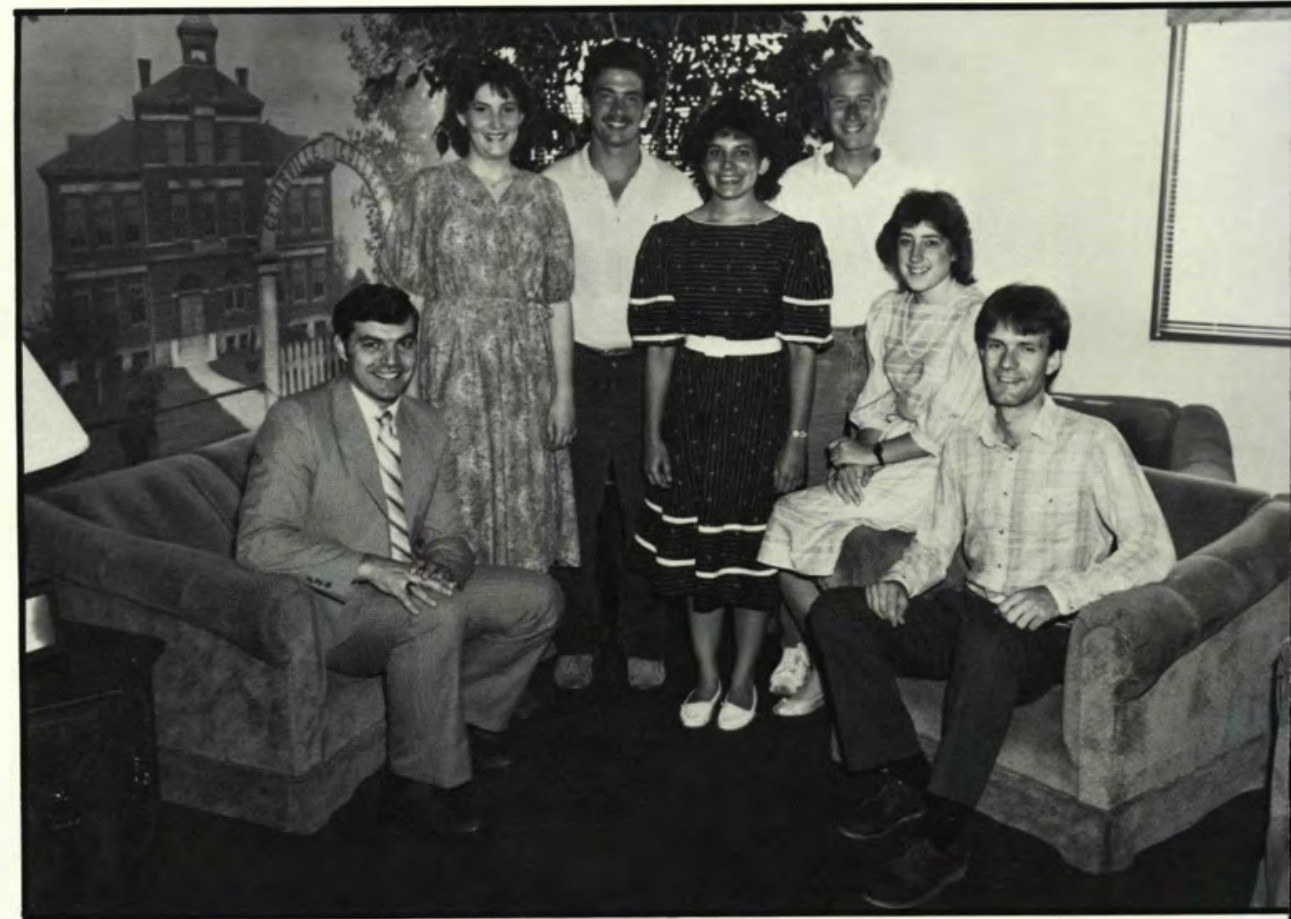

England M.I.S. Tea

"O come, let uș sing unto the Lord: Let us make a joyful noise to the rock of our salvation.

Ler us come before his presence with thanksgiving, 'and make a joyful noise unto Him with psalms.

For the Lord is a great God, and a grear King above all gods."

Psalm 95:1-3

Temple Knowles, Anne Edwords, Jim Reirer, Dave Robinerte, Gina Long. Joellyn Perers, Kim Brogg, Brian Crump, Randy Johnson, Sharon McAllester, Me lissa MocMichael, Jeff Lyle.

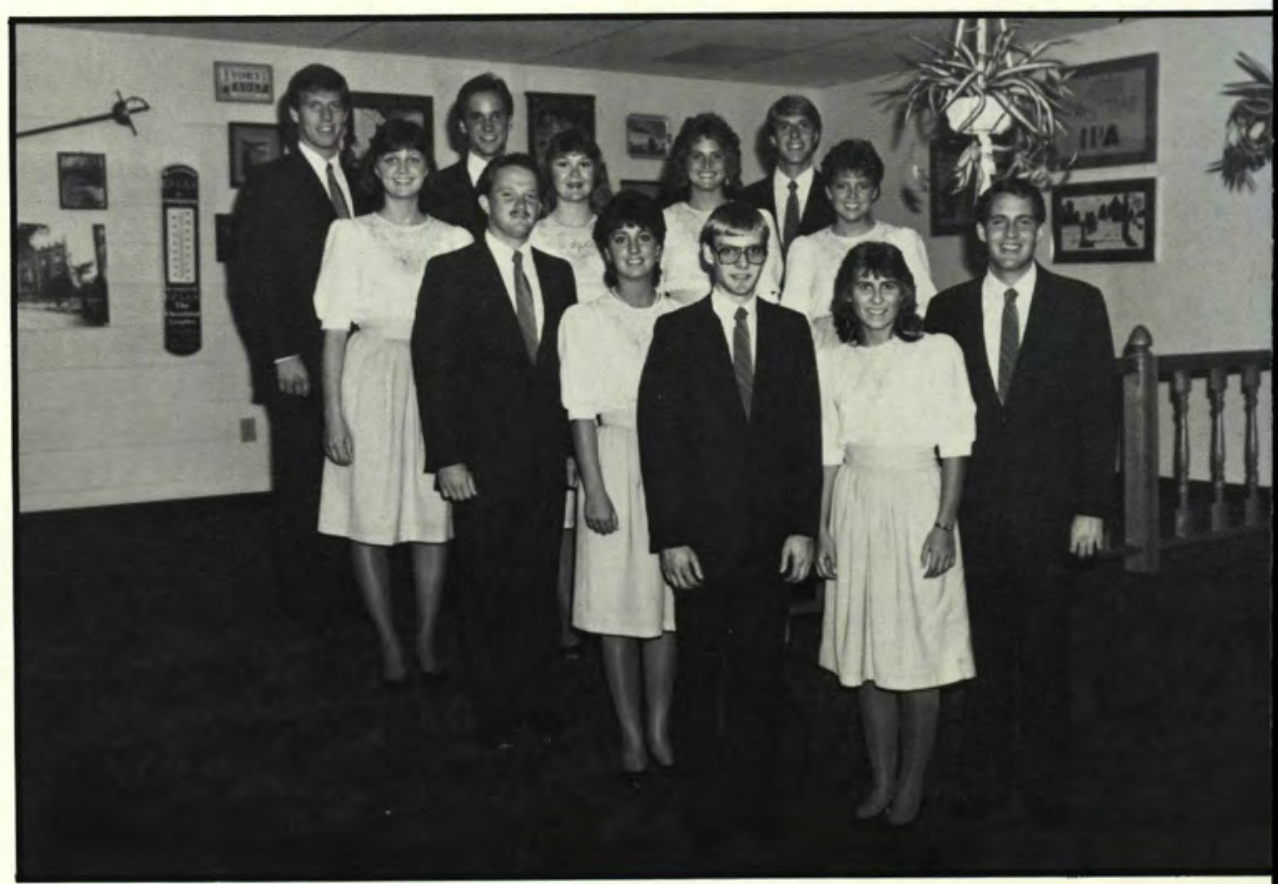




\section{Spain M.I.S. Team}

'According to my earnest expectarion and my hope, that in norhing I shall be ashamed, but that with all boldness, as always, so now also Christ shall be magnified in my body, wherher it be my life or by dearh."

Philippians 2:20

Ronaldo Ponce, Debi Bell, Alice Boyd, Cami McGrow, April Martin, Tami Eimers, Dennis Papp.

"For God is not unrighreous to forget your work and labor of love, which ye have showed roward his name, in that ye have ministered to the saints, and do minister."

Hebrews 6:10

First Row: Amy Guest, Jill Michonski, Thereso Wilson, Colleen Rockey, David Shepherd, Dan Shepherd, Scor Schieferstein, Jon Beight, Second Row: Gayl Colkins, Pamela Sranfill, Donalda Edwards, Thomas Goehring Marcio Jones, Cindy Guido, Volerie Hite, David Shallmon, Barry Kirchen, Ben Smirh, Karen Troyer, Lyle Compbell, James Beight, Sreve Coores, Third Row: Lori Tyree, Denise Ross, Laura Rowland, April Banks, Joy Harden, Jennifer Cranick, Debbie Van Dorf, Laurly Anderson, Sorah Barr. Marilyn Beon, Donno Birtsch, Dave Beal, Chris Dail, Joy Burr, Julie Gersema, Cheryl Paxson, Greg Lombert, Kim Ports, Errin Mulberry, Jennifer Houfler, Chris Freidkin.

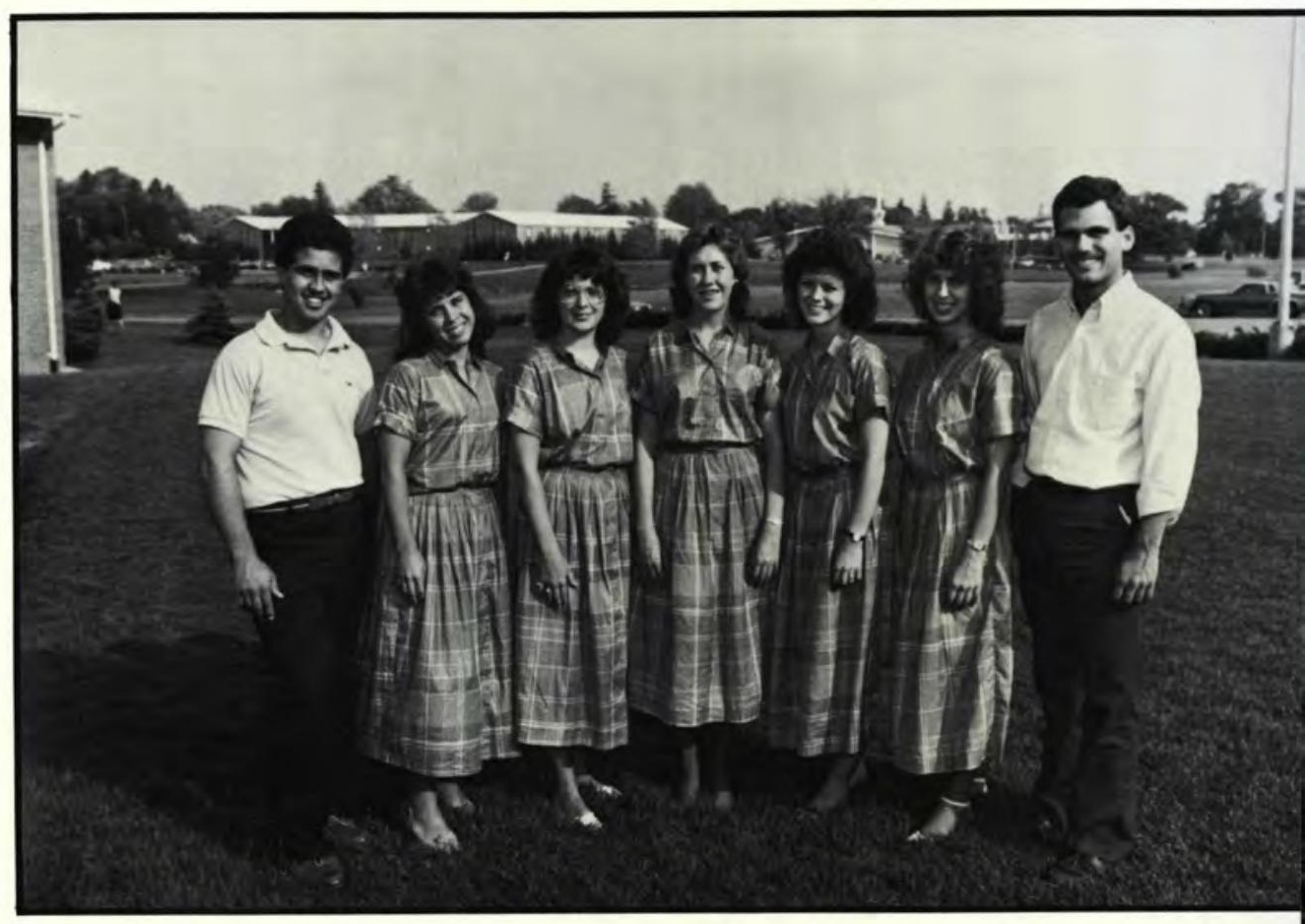

\section{Swordbearers Extention Tean}

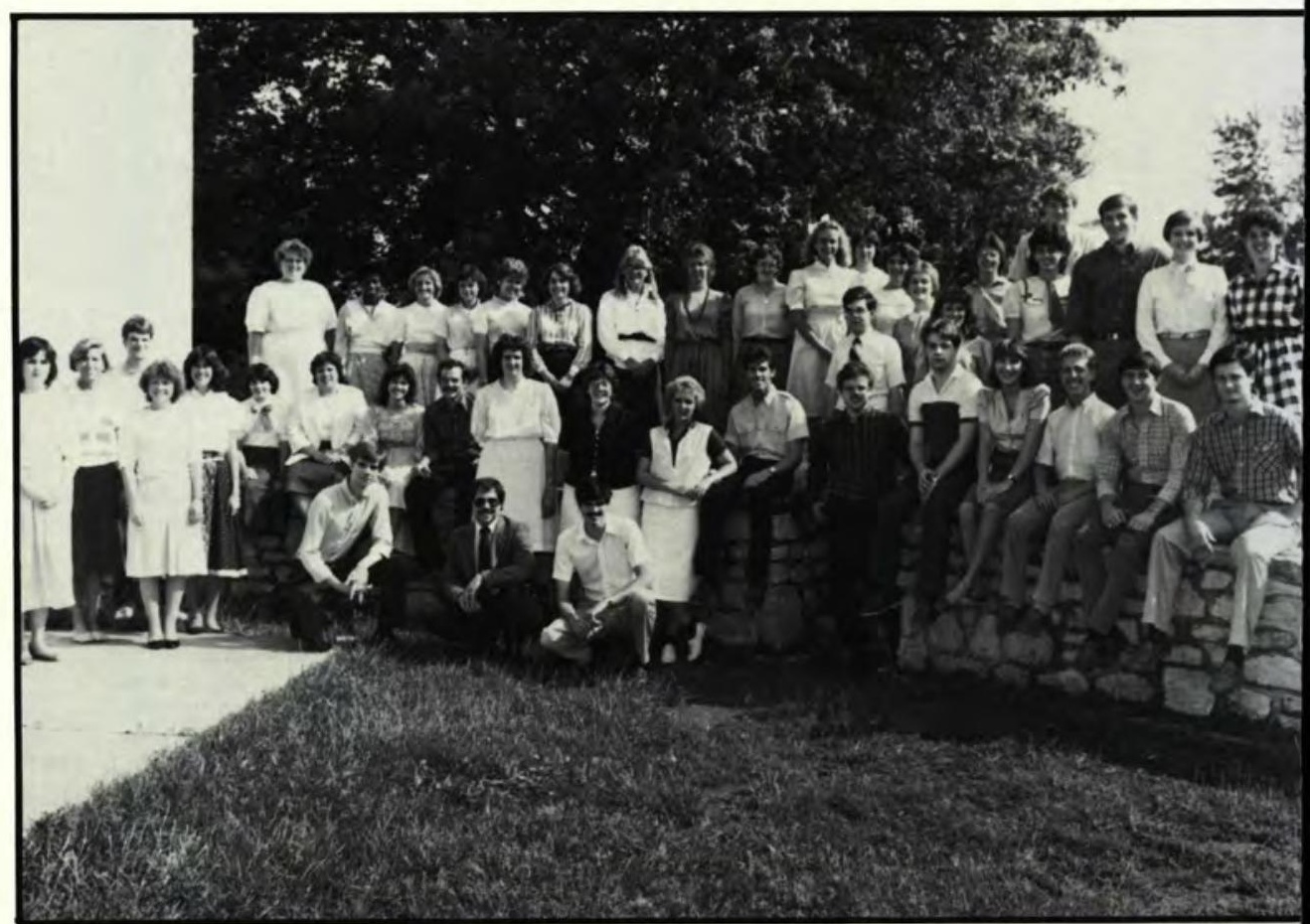




\section{Jah Team}

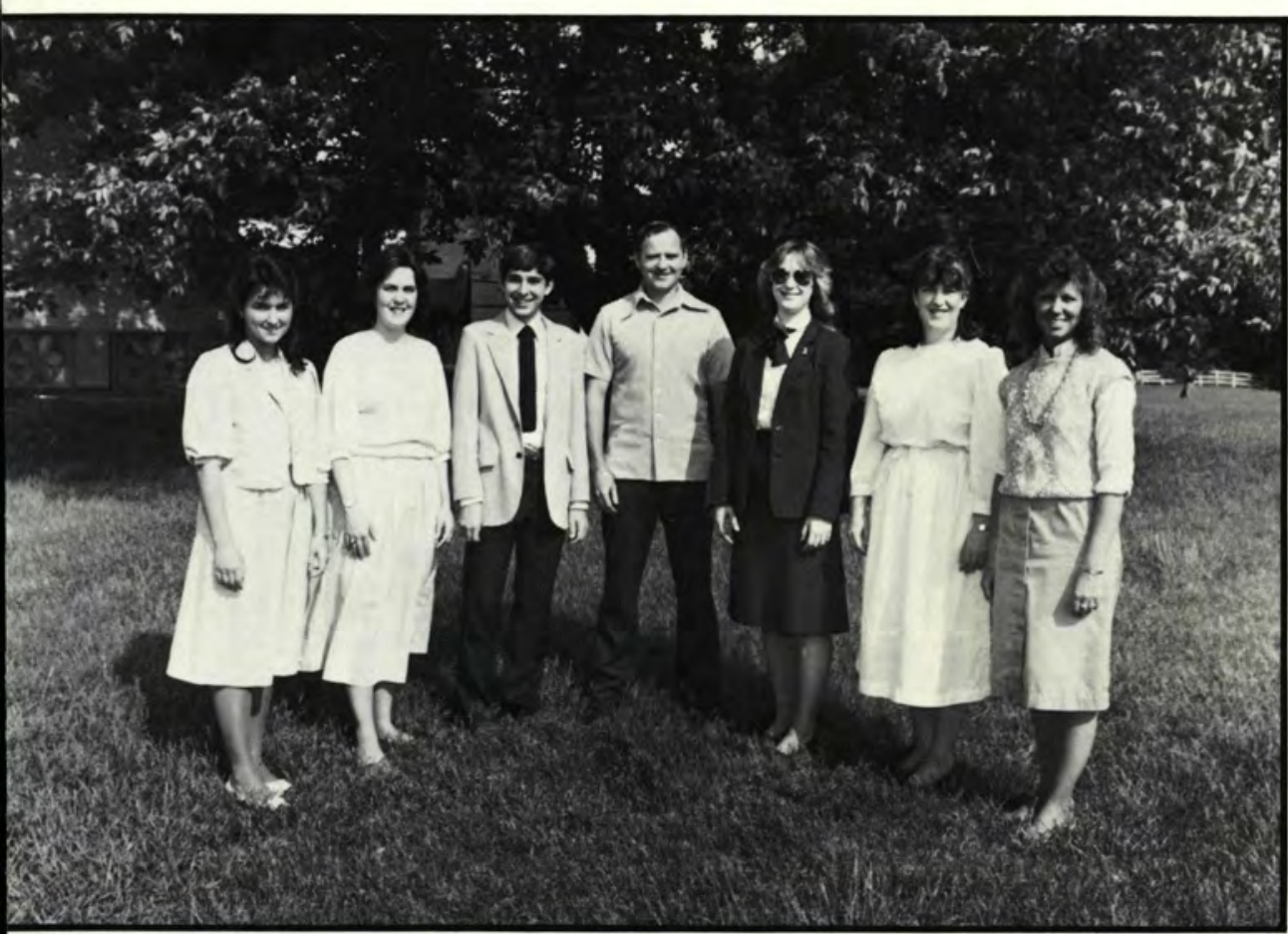

\section{$V C H$ A.M.}

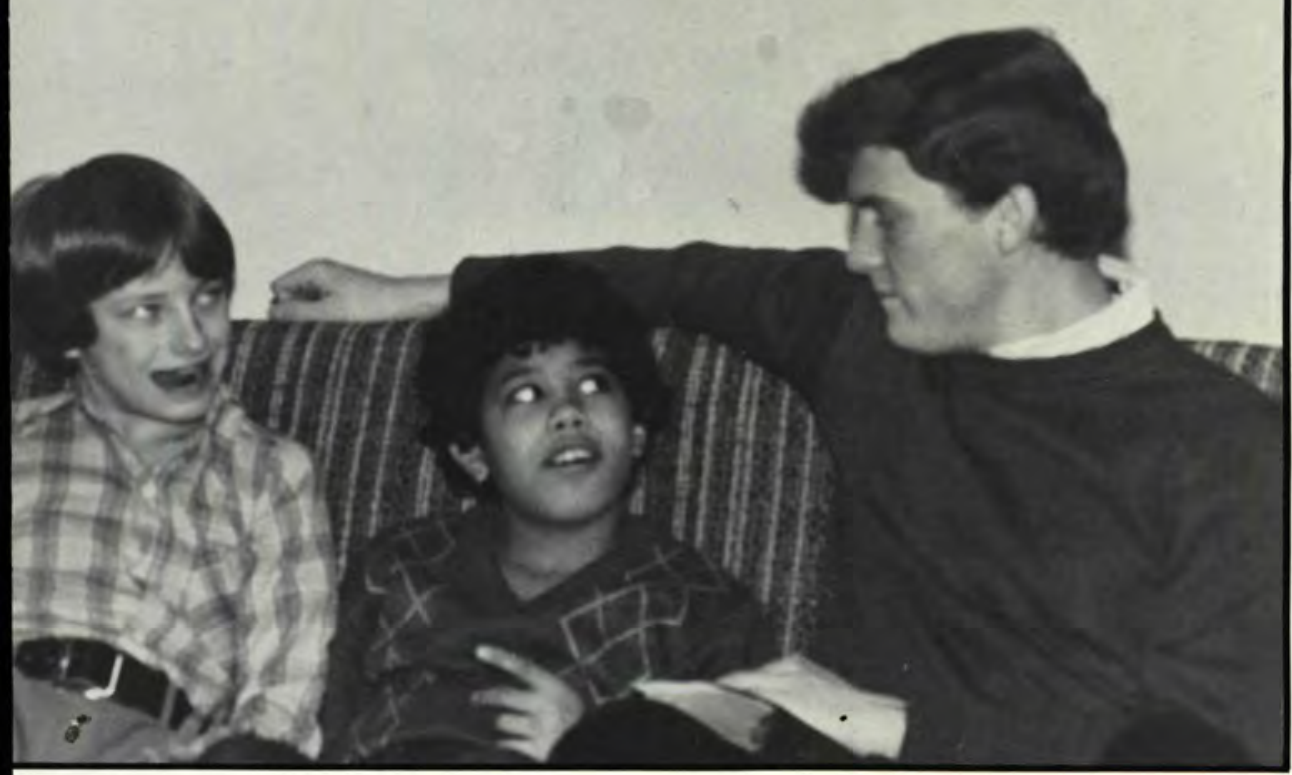

'For the word of God is quick, and powerful, and sharper than any twoedged sword, piercing even to the dividing asunder of soul and spirit, and of the joints and marrow, and is a discerner of the thoughts and intents of the heart."

Hebrews 4:12

Debbie Ramaker, Amy Jo Guest, Brendo Budd, Robert Young, Kendra Doc tor, Debbie Clem.
'To the weak become I os weak, that I might gain the weak: I am made all things to all men, that I might by all means save some."

1 Corinthians 9:22

April Ames, Marc Anthony, Dina Bat chelder, Hearher Byrnes, Tony Demerri, Liso Fisher, Robin Hilsmeier, Debbie Holmes, Debbie Johnson, David Kalin, Dan Karz, Michelle Longo, Party Marihugh, Kim Murphy, Ken Nichols, Cheryl Rendle, Melody Schulrz, Morlene Siefert, Janae Smart, Jayne Snyder, Larry Srarkey, Alan Tirus, Jenny Tirus, Scort VanMerer, Ron Wolrer, Bob Ward, Kristen Weber, Brent Ziegler. 


\section{Heathergreen}

"Mine eyes shall be upon the faithful of the land, that they may dwell with me: he that walkerh in a perfect way, he shall serve me."

Psolm 101:6

Front Row: Kristen Srogg, Sherry Frank, Karen Srogg, Middle Row. Mory Coons, Brad Bresson, Chad Bresson, Shannon Sounders, Kendro King, Bock Row: Lynne Sickau, Jeff Martin, Sreve Moyer Mark Mirchell, Kendra Doctor.

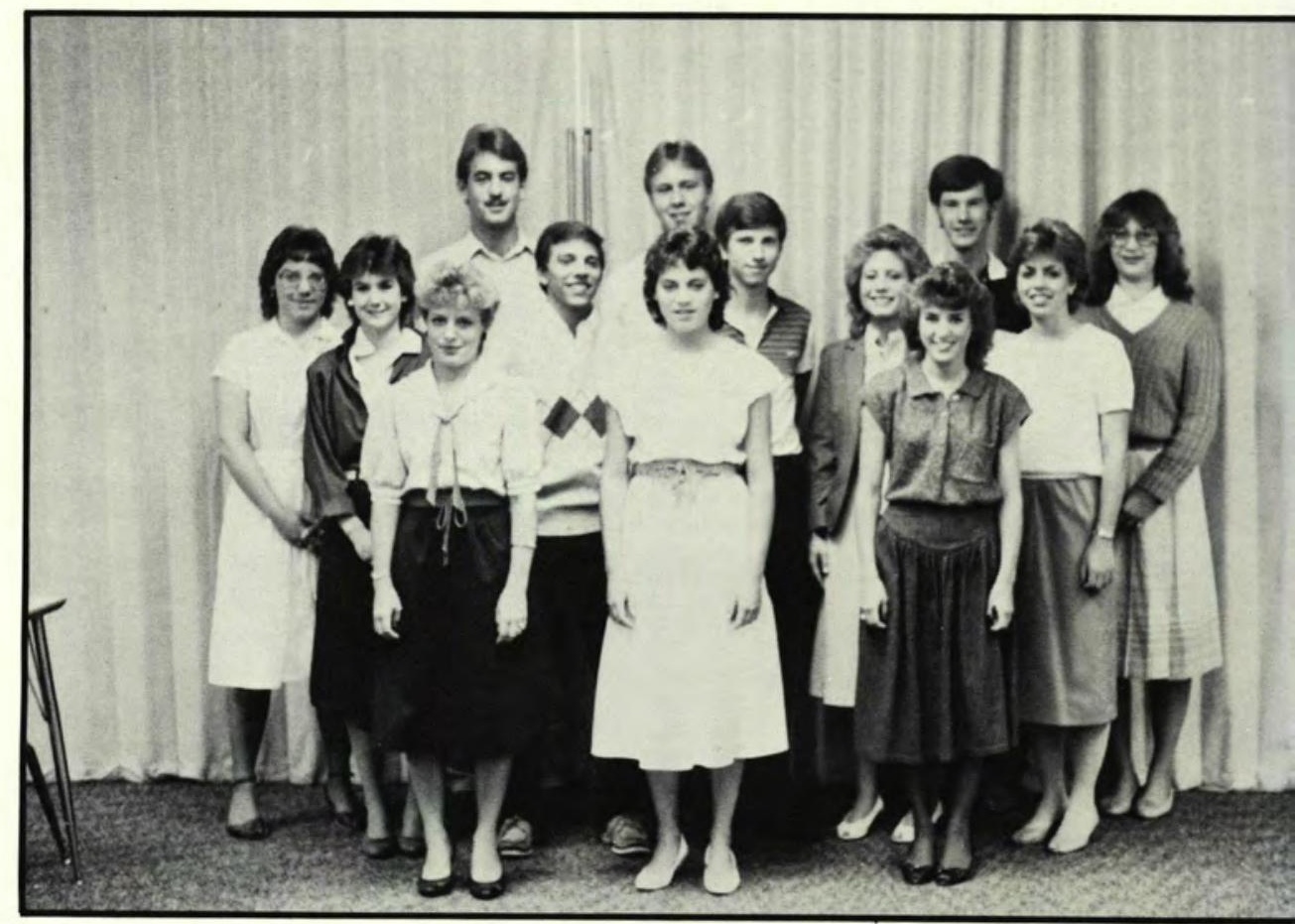

"Yer I will rejoice in the Lord, I will joy in the God of my salvation.

The Lord God is my strength, and he will make my feer like hinds' feet, and he will make me to walk upon mine high places."

Habakkuk 3:18, 19

Steve Meyer, Tracy McCoy, Kristo Nickoson, Chris Schroder, Michelle Longo, Kirk Foirhurst, Wendy Bell, Jane Sporling, Clancy Cruise, Jack Srumme.

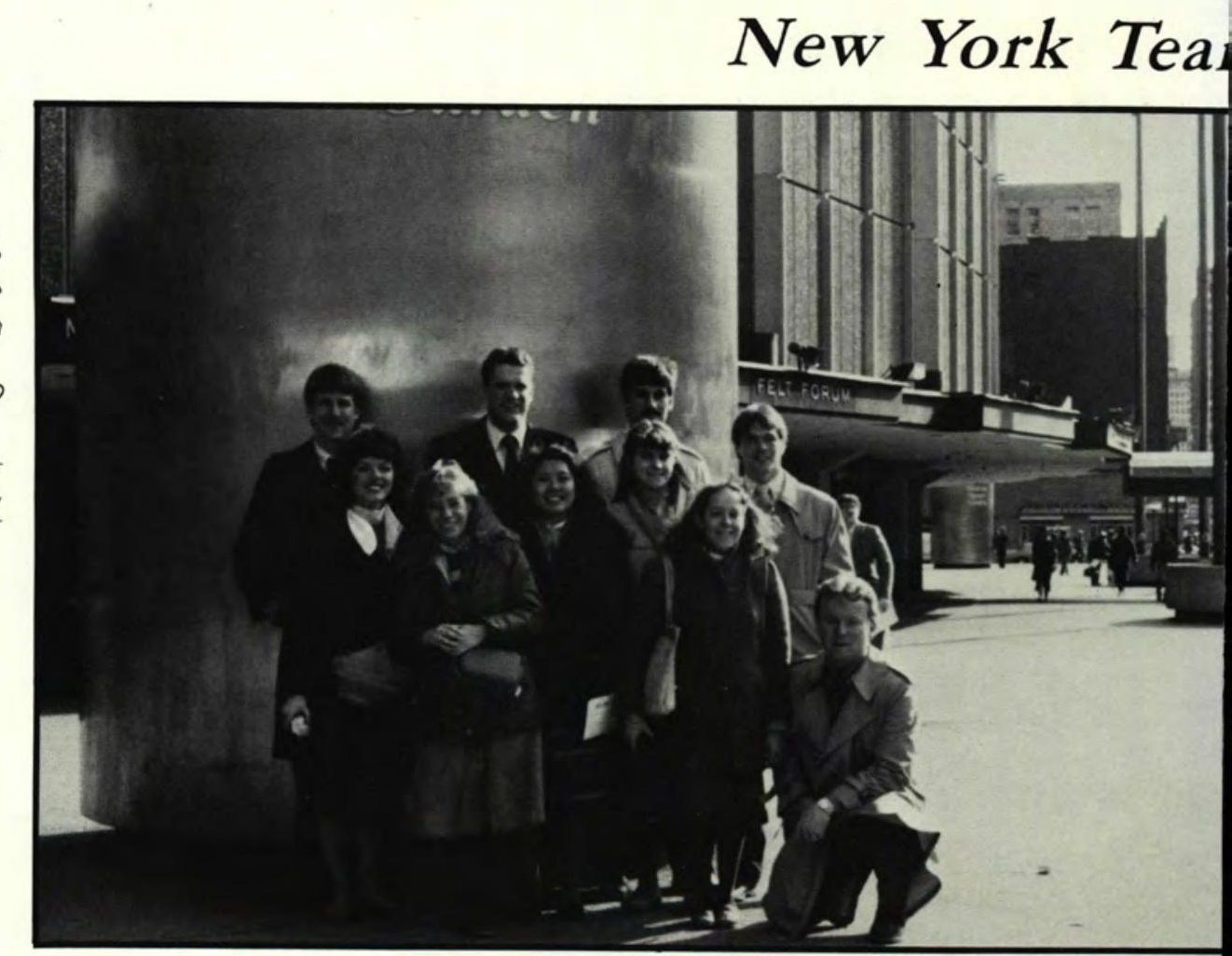




\section{Cincinnati Rescue Missior}

"A new commandment I give unto you, that ye love one anorher; as I have loved you, that ye also love one anorher.

By this shall all men know that ye are my disciples, if ye have love one to another.

John 13: 34.35

Mark Foirhurst, Diane Blosdell, Bob Bei kerr, Sandra Kennedy.

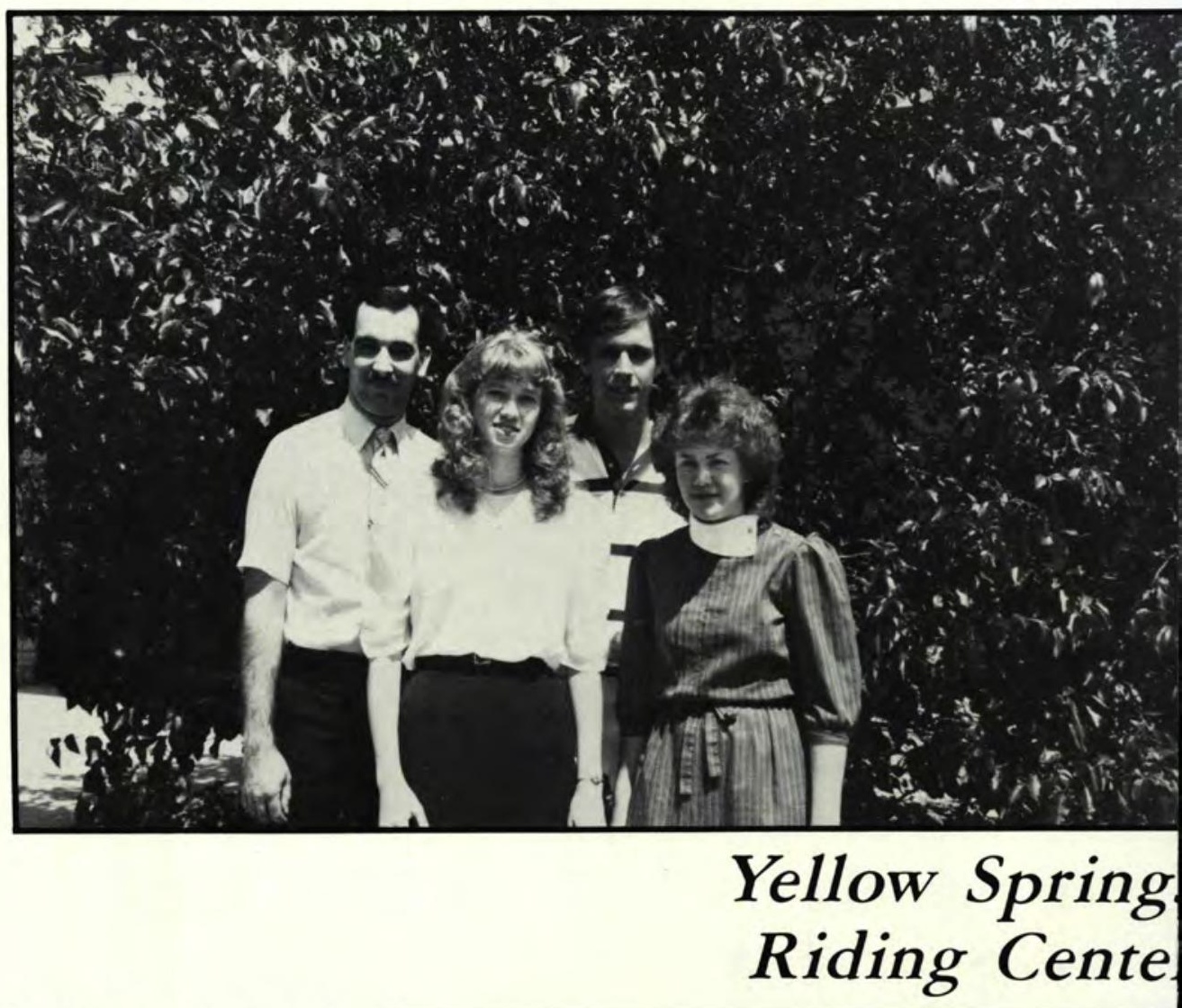

"Herein is our love made perfect, that we may have boldness in the day of judgement: because as he is, so are we in this world."

1 John 4:17

Denise Boss, Martho Bowers, Chris Cheek, Poul Chilson, Tami Eimers, Dovid Frey, Darci Garbig, Tammy Groff, Fran Haskowich, Dan Howk, Hope Hibbard Hearher MocForlane, Jeff Martin, Rurh Moson, Rob Meoak, Errin Mulberry, Berh Nester, Lynda Peart, Krista Reed, Debra Perers Linda Shaffer, John Ruhly, Vicki Slane, Lila Seest, Loura Wolker, Brenda Surliff, Carhy Worson, Valerie Teed.

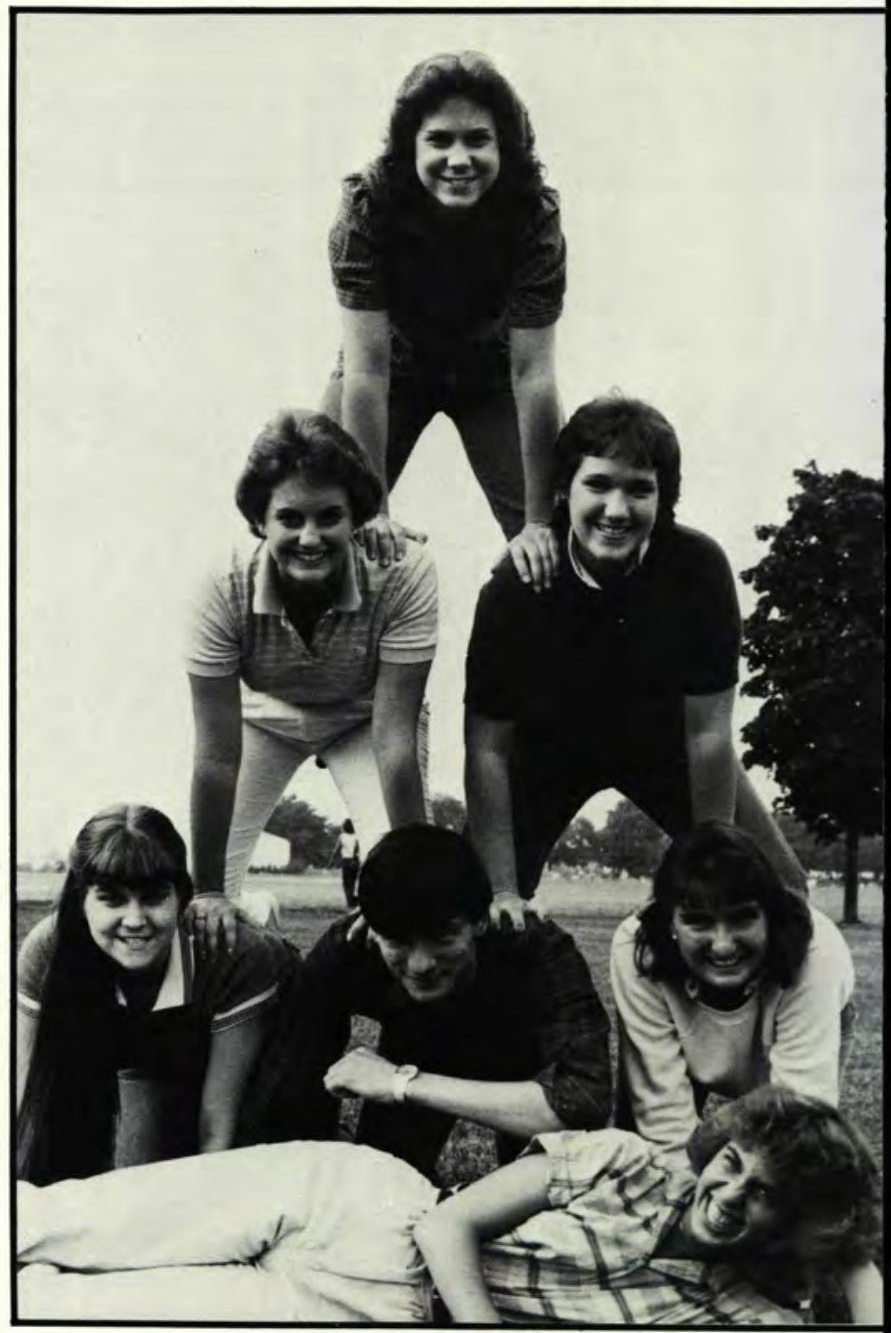


OVCH P.M

"And the things that thou hast heard of me among many wirnesses, the same commit thou to faithful men, who shall be able to reach orh ers also."

\section{Timorhy 2:2}

Debi Bell, Linda Browning, Diane Coo per, Sue Dean, Yvonne Facey, Berhe Hornbeck, Vicki Jackson, Krissi Mossie Foith McGnee, Lori Reed Corole Ro. land, Sherry Rorramel, Deena Shriver. Tonya Smirh, Lila Srause, Cynrhia Wog. ner. Gory Borker, John Bercou, Sreve Freemon, Jeff Giberr, Doug Iverson, Tip Link, Poul Muchley, Bob Munson, Mark Reed, Don Simerly, Sreve Toir, Rodney Smirh, Dovid Woodord.

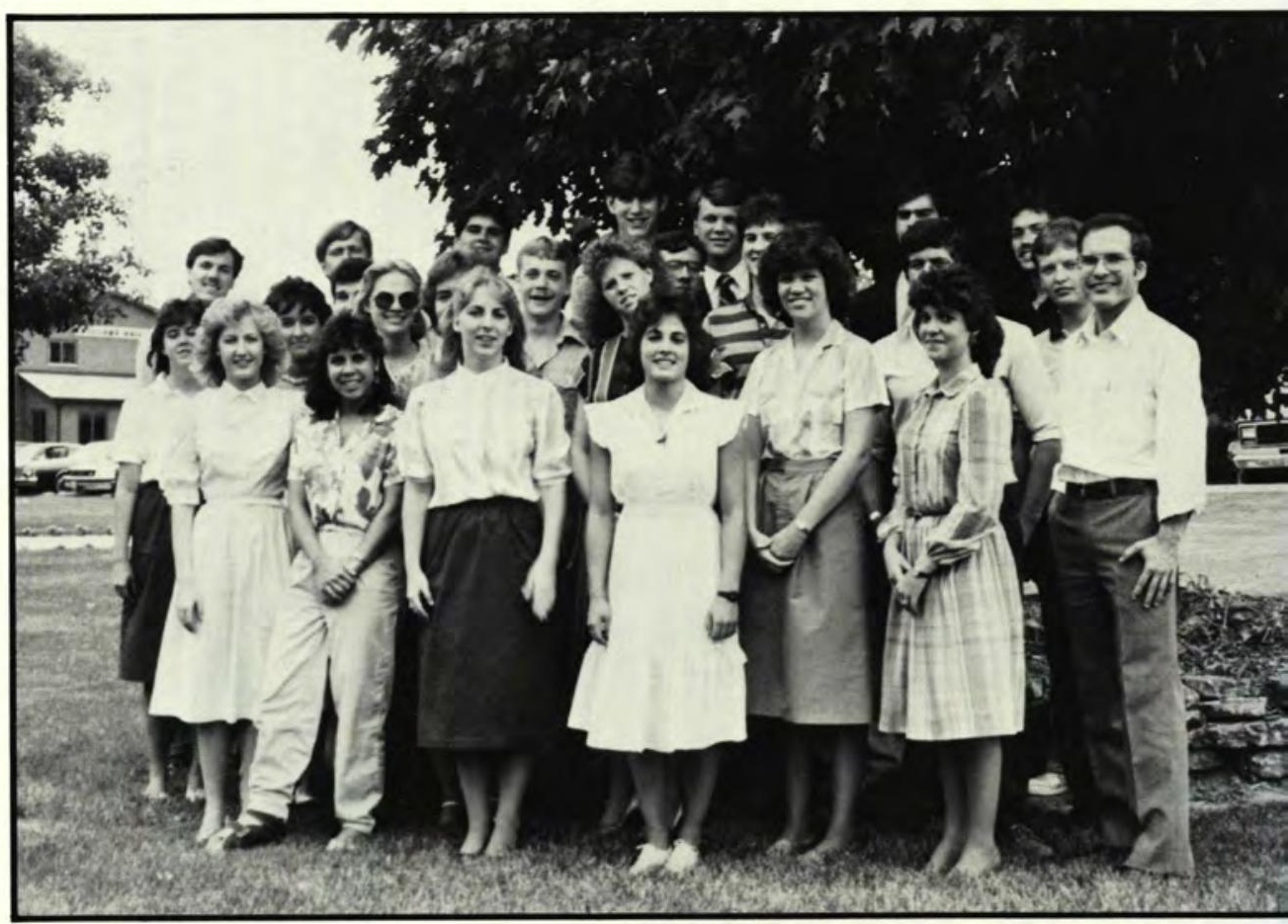

\section{Heathergreen}

"Be kindly affecrioned one to anorher with brorherly love; in honor preferring one anorher."

Romans 12:10

Alberr Borrert, Shelly Broughron, Dove Barkeson, Nancy Columbo, Kristi Culp. Dovid Douglas, Stacy Gunther, Lahay Heron, Dove Holl, Ann Hoskowich, Ann Hinrer, Dave Johnson, MaryLou Kincaid, Dione Johnson, Sandra Kennedy. Jeff Marble, Karhy Sibert, Phyllis Trivert. Kim Robinson, Rhondo Smirh.

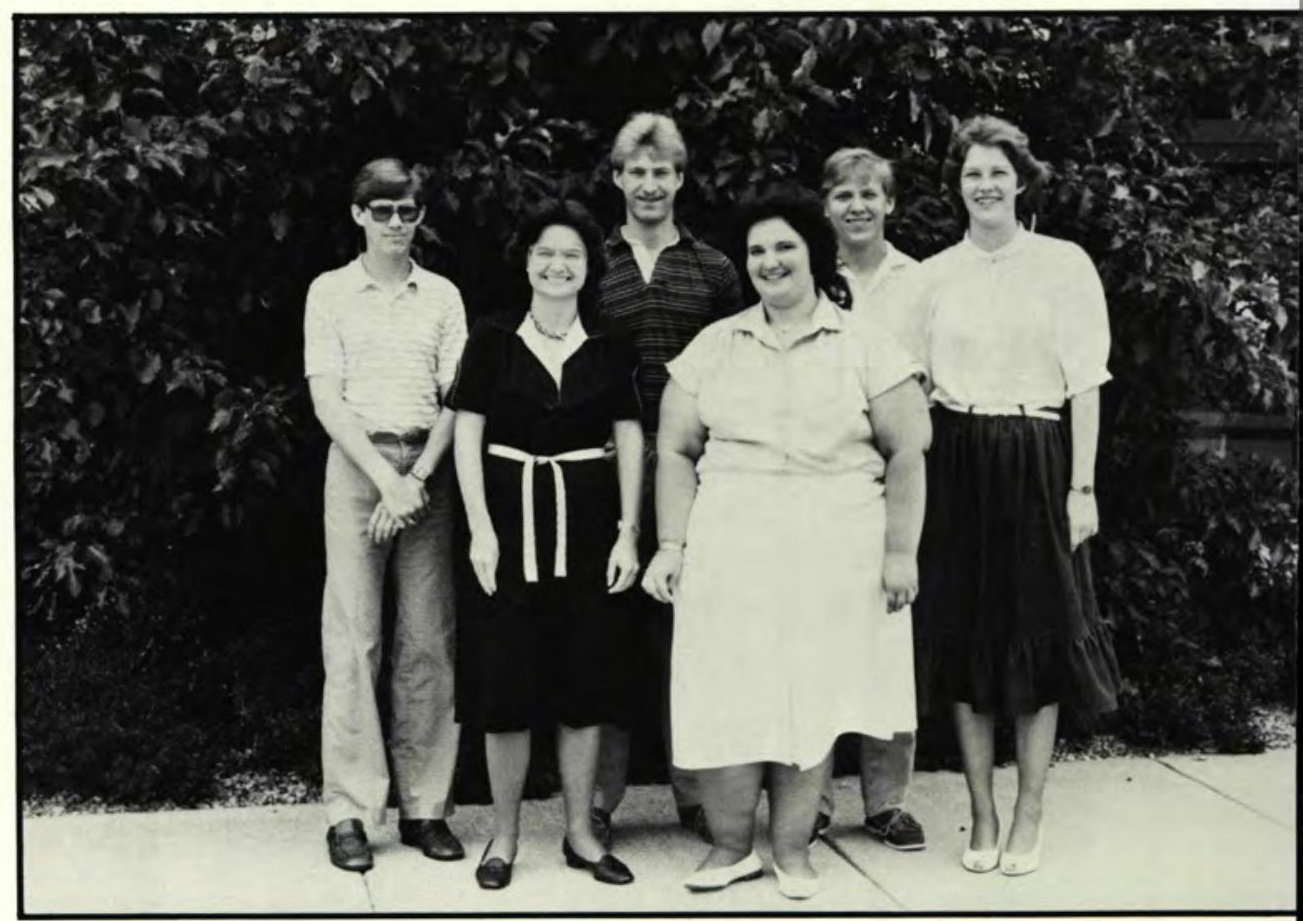




\section{Parent Datrons}

Joyce Alexander

Flushing, MI

Delmar and Luora Augustus

South Charleston, $\mathrm{OH}$

Mr. and Mrs. David L. Ames

Florence, $\mathrm{NJ}$

James L. Atkinson

East Alton, IL

George and Barbara Baldwin

Lakeland, FL

Mr. and Mrs. Ray Baker

Quincy, IL

William W. and Linda K. Bany Sr. Montpelier, $\mathrm{OH}$

Mr. and Mrs. Robert R. Banzhof Muncy, $P A$

Mr. and Mrs. James W. Barker Sheffield Lake, $\mathrm{OH}$

Roy and Marian Barker

Rochester, NY

John and Marilyn Bartus

Toledo, $\mathrm{OH}$

Mr. and Mrs. Robert F. Bauer

Beavercreek, $\mathrm{OH}$

Lee and Betty Jane Beach

Elizabethtown, PA

Rev. and Mrs. Alan Beal

Fayette, $\mathrm{OH}$

Bob and Ellen Beattie

Runnells, IA

Mr. and Mrs. Dale R. Bennett Lakewood, $\mathrm{OH}$

Earl and Sandy Bennett

Zanesville, $\mathrm{OH}$

Mr. and Mrs. Robert J. Bercaw Troy, $\mathrm{OH}$

Mr. and Mrs. John A. Berdy Tallmadge, $\mathrm{OH}$

Mr. and Mrs. Jennings Birtch Hallstead, $P A$

Rev. and Mrs. Bob Blaylock Chattanooga, TN

Mr. and Mrs. Merlin B. Bliss Belding, MI
Mr. and Mrs. John Boer

Croydon, Victoria, Australia

Mr. and Mrs. Larry D. Bowlen Smithfield, $P A$

Mr. and Mrs. Howard C. Bowman Elida, $\mathrm{OH}$

Judith and Douglas Bradman

DeWitt, MI

Richard Bresson

Xenia, $\mathrm{OH}$

Mr. and Mrs. Robert Britton

Kingston, MI

Mr. and Mrs. John E. Brooks

Alexandria, $\mathrm{OH}$

Doris A. Browne

Washington, D.C.

Mr. and Mrs. Fred Budd

Arcola, IL

Mr. and Mrs. Claude W. Burghen Audubon, $\mathrm{NJ}$

Marshall and Liz Butcher Othello, WA

Gilbert and Evelyn Butzlaff

Humacao, $P R$

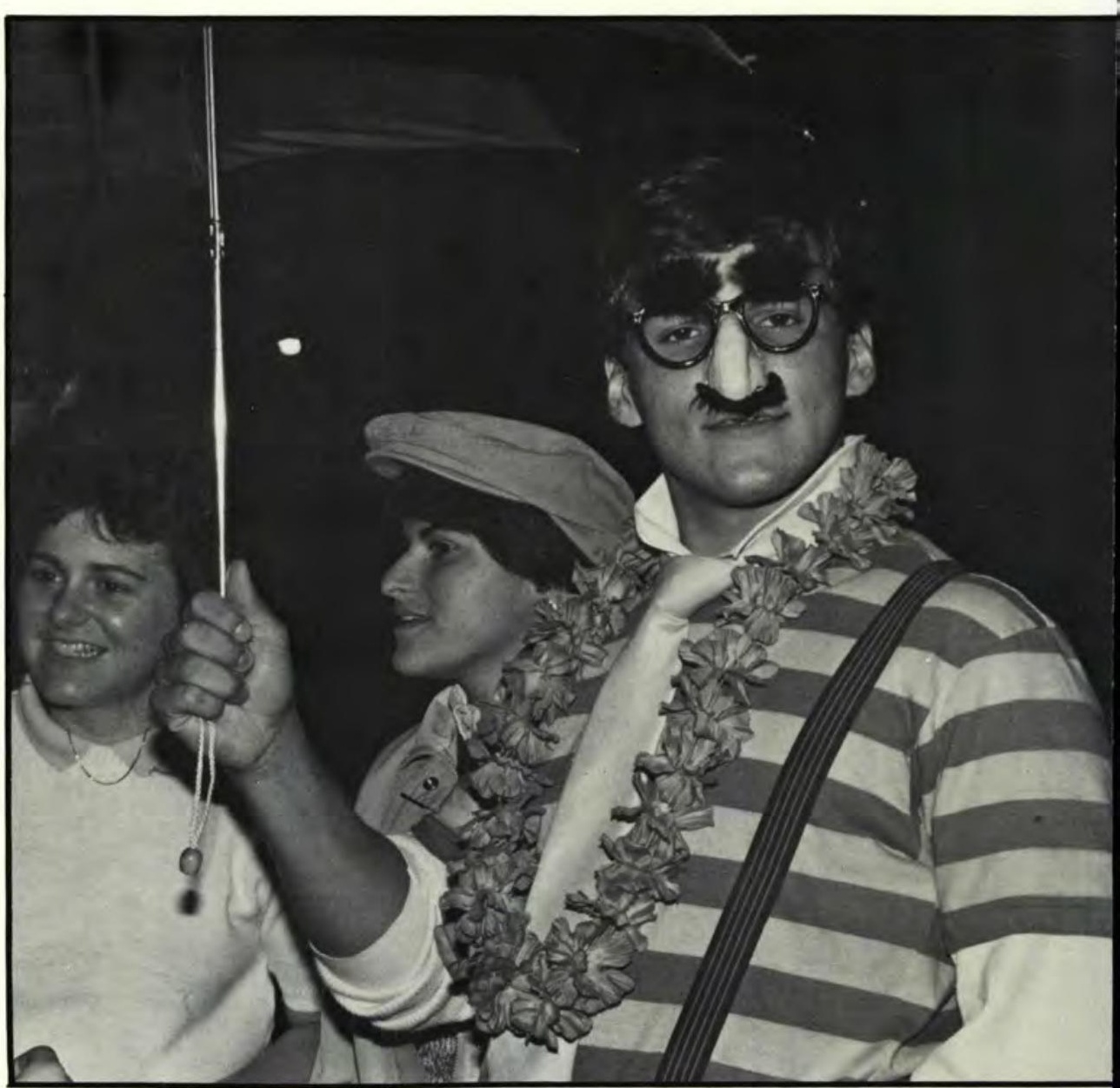

Mr. and Mrs. B.R. Cadle

Ravenswood, WV Cedarville, $\mathrm{OH}$

Mr. and Mrs. Larry Campbell Ypsilanti, MI

Jim and Jean Carr

Grand Blanc, MI

Mr. and Mrs. James B. Carraher

Mr. and Mrs. Preston Chandler Hadley, NY

Dr. and Mrs. W.E. Cherry Sterling, IL

Mr. and Mrs. Donald Chilson Reed City, MI

Mr. and Mrs. Robert Chitwood West Chester, $\mathrm{OH}$

Mr. and Mrs. Larry G. Clark Bethesda, $\mathrm{OH}$

Mr. and Mrs. Larry C. Clemens Limerick, $P A$

Mr. and Mrs. Jud Clements Loudonville, $\mathrm{OH}$
Dr. and Mrs. Donald Callan Toledo, $\mathrm{OH}$ 


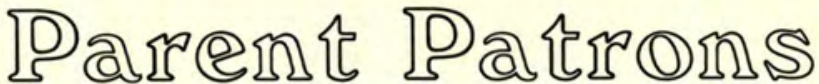

\section{Mona Coiro}

Amston, $\mathrm{CN}$

Mr. and Mrs. Kenneth Cook Howard City, MI

Gary and Betty Cooke

Indianapolis, IN

\section{Linda Cornelius}

Long Valley, NJ

Mr. and Mrs. Robert R. Cotton Cherry Hill, NJ

Mr. and Mrs. Ron Cox

Margate, $F L$

Mr. and Mrs. Robert L. Crump Pontiac, MI

Mr. and Mrs. James Curtis

Veedersburg, IN

\section{James and Lois Day}

Belle Center, $\mathrm{OH}$

Dr. Joe and Joyce DeCook Holland, MI

Mr. and Mrs. Clyde Derstine Schuylkill Haven, PA

Mr. and Mrs. W. Dimacchia Lorain, $\mathrm{OH}$
Mr. and Mrs. Kenneth R. Dobbel Schroon Lake, NY

Jack and Nancy Dowden

Austin, MN

Mr. and Mrs. Thomas J. Driscoll East Windsor, $\mathrm{NJ}$

Mr. and Mrs. William Drummer

Fairview Village, $P A$

Mr. and Mrs. R.M. Dykes

Des Moines, IA

\section{H. Edelin}

Washington, D.C.

Mr. and Mrs. Homer Edwards Kipton, $\mathrm{OH}$

Robert T. Edwards

Mishawaka, IN

Mr. and Mrs. James P. Eller Barberton, $\mathrm{OH}$

\section{Bob and Helen Erdmann}

Southfield, MI

Mr. and Mrs. Terry N. Evans

Chattanooga, TN

Mr. and Mrs. Doy Everage

Eminence, IN
Mr. and Mrs. Fred D. Everett Fairfield, IA

Ronald and Doris Everitt

Columbus Grove, $\mathrm{OH}$

Mr. and Mrs. Will Fairhurst Wooster, $\mathrm{OH}$

Bernard and June Ferguson

Cincinnati, $\mathrm{OH}$

The David Fish family

Newbury, $\mathrm{OH}$

\section{Wayne and Janice Fite}

Milford, $\mathrm{OH}$

Mr. and Mrs. Larry Fornell

Barron, WI

Mr. and Mrs. Robert Fread Loveland, $\mathrm{OH}$

Mr. and Mrs. Charles Freeburger Southampton, $P A$

Mr. and Mrs. John Frey

Davison, $M I$

Mr. and Mrs. Marlin D. Fuller South Bend, IN

Tom and Maxine Geese

Fresno, $\mathrm{OH}$

\section{Donald and Dorothy George} Hillsdale, MI

Dr. and Mrs. Dean Gifford Urbana, IN

\section{Allen and Joyce Gipson} Springfield, IL

Richard and Nancy Goocey Russell, $K Y$

Mr. and Mrs. Fred Greetham Wellington, $\mathrm{OH}$

Mr. and Mrs. Jeffrey Grumbeck Burlington, $\mathrm{OH}$

Mr. and Mrs. Bruce Grunelsen Mansfield, $\mathrm{OH}$

Mr. and Mrs. Noel F. Hack La Grange, $\mathrm{OH}$

Mr. and Mrs. David S. Hallman Pottstown, PA

Lois Van Dorf Halvorsen

Milwaukee, WI 


\section{Parent Pa他OnS}

Robert and Marilyn Hannay Westerlo, NY

\section{Roger and Dianne Hansen}

Rockford, MI

Rev. and Mrs. Elvin Harden Hart, MI

\section{George and Pat Hardman}

Stevens Point, WI

\section{Dick and Helen Harper \\ Rochester, NY}

Mr. and Mrs. Glen Harrington Akron, MI

Mr. and Mrs. Dallas Hart

Terre Haute, IN

Mr. and Mrs. Royce Hartsough South Bend, IN

Richard and Martha Haskowick Pequannock, NJ

Mr. and Mrs. F.H. Haufler Reading, $P A$

Mr. and Mrs. Wayne Heal Bunker Hill, IL

Mr. and Mrs. Esty E. Helmick West Milton, $\mathrm{OH}$

Mr. and Mrs. Daryl Henderson Springfield, $\mathrm{OH}$

Rev. Larry and Hazel Hess Akron, $\mathrm{OH}$

Mr. and Mrs. Berton Hibbard Woodhull, $N Y$

Rev. and Mrs. John Hippard Shelbyville, IL

Mr. and Mrs. Kenneth P.

Hoddelmann

Brentwood, NY

Mr. and Mrs. Dave Hoecke Berea, $\mathrm{OH}$

Mr. and Mrs. Floyd Hofer Milwaukee, WI

Rev. and Mrs. R.D. Holliday Huntsville, Ontario, Canada

Mr. and Mrs. John Holman Freeport, IL

Patricia Hornbeck

Perry, MI
A. Hoskins

Philadelphia, PA

Bob and Esther Howder

Kagoshima City, Japan

Mr. and Mrs. W.J. Howdyshell Pickerington, $\mathrm{OH}$

Mr. and Mrs. David Huebscher Maple Hts., $\mathrm{OH}$

Mr. and Mrs. Albert A. Hultz

Pottstown, PA

Mr. and Mrs. Paul Hunn

New Lebanon, $\mathrm{OH}$

Rev. Roy and Joanne Hunter

DuBois, $P A$

Clifford H. Imhoff

Riverview, MI

Dr. and Mrs. Lloyd C. Jackson Bloomfield, IN

Mr. and Mrs. Eugene W. Jacobs Loveland, $\mathrm{OH}$

Mr. and Mrs. George Jacobson Dayton, $\mathrm{OH}$

Mr. and Mrs. Dennis James Columbus, IN

Lynn and Mary Ann Jefson Decatur, IL
Don and Christal Jillson

Hackensack, NJ

Mr. and Mrs. Karl Johnson Sao Paulo, Brazil

Mr. and Mrs. John W. Jones Martinsburg, WV

Mrs. Mary Jones

Ohlman, IL

Mr. and Mrs. Robert E. Jones Wellman, IA

Mr. and Mrs. Francis T. Joslin Wisconsin Rapids, WI

Guenter and Ingrid Kass Centerville, $\mathrm{OH}$

Rev. and Mrs. Wayne Keisling Prattsburg, NY

Paul and Joyce Kemp Alexandria, VA

Mr. and Mrs. Hugh Kennedy Cambridge, Ontario, Canada

Mr. and Mrs. Harold Kenyon Salt Point, NY

Mr. and Mrs. James Kettel Grafton, $\mathrm{OH}$

Mr. and Mrs. Blaine Keyes Great Valley, NY

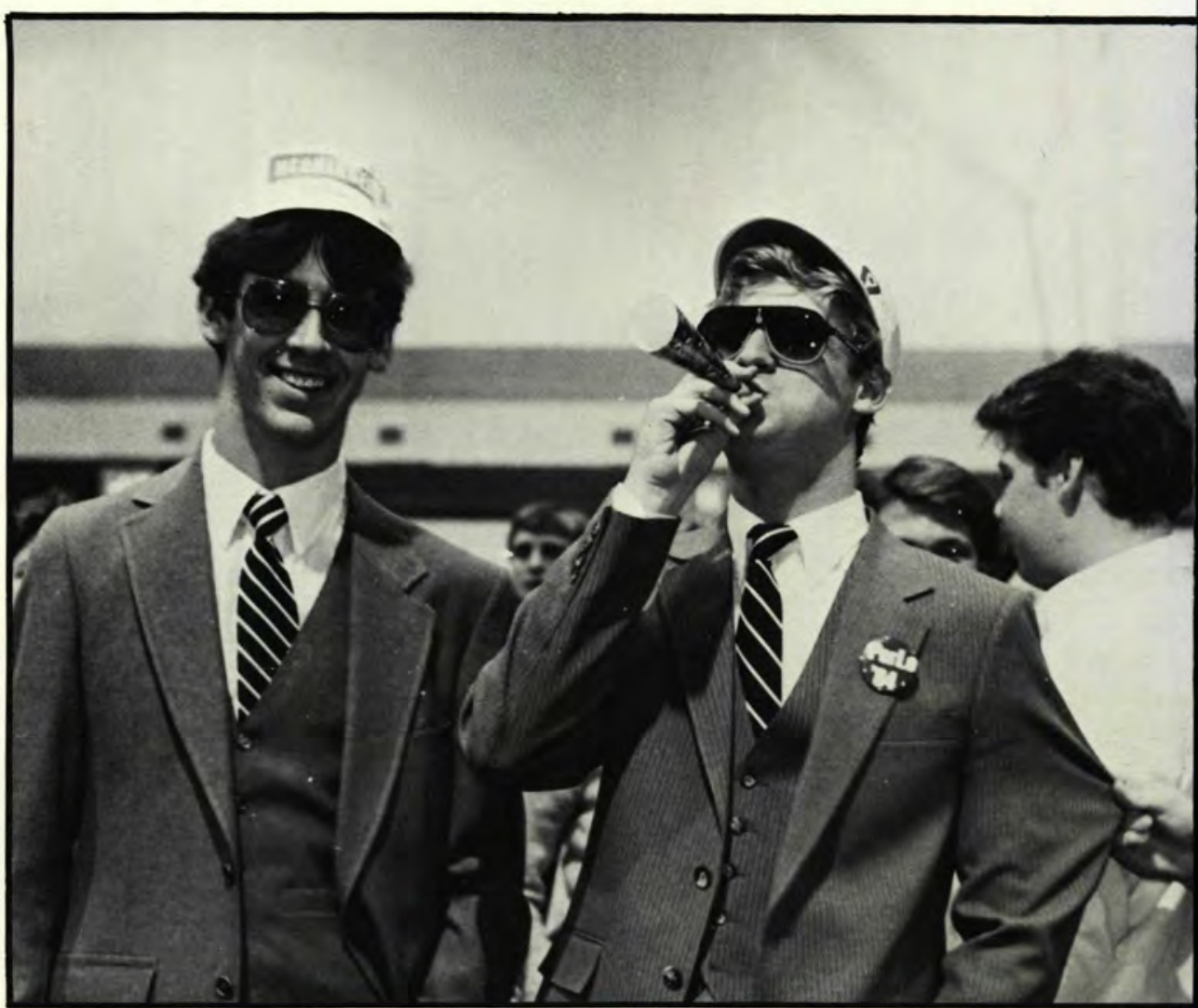




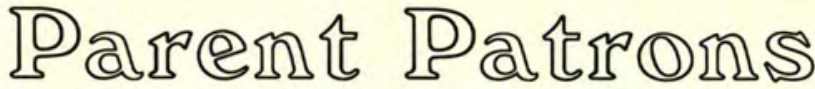

Mr. and Mrs. Charles Kincaid

Elyria, $\mathrm{OH}$

Mr. and Mrs. William F. Kinney

Reading, PA

Stanley and Colleen Kirby

Prospect, $\mathrm{OH}$

Mr. and Mrs. Sherman G. Kitchen Mahaffey, $P A$

Ralph and Joyce Knowles

Brunswick, ME

Mr. and Mrs. Robert J. Koerber

Colchester, $\mathrm{CN}$

Norma and Jim Kolinski

Toledo, $\mathrm{OH}$

Tom and Joy Draner

Cheyenne, WY

Delbert and Doris Dreuscher

Union Grove, WI

Mr. and Mrs. Ralph P. Kuivinen (parents of Tom Mach)

Fairview Park, $\mathrm{OH}$

Mr. and Mrs. Robert Laird

Vincentown, $N J$

Larry and Charlotte Laird

Ankeny, IA

John and Charlotte Lambert

City, VA

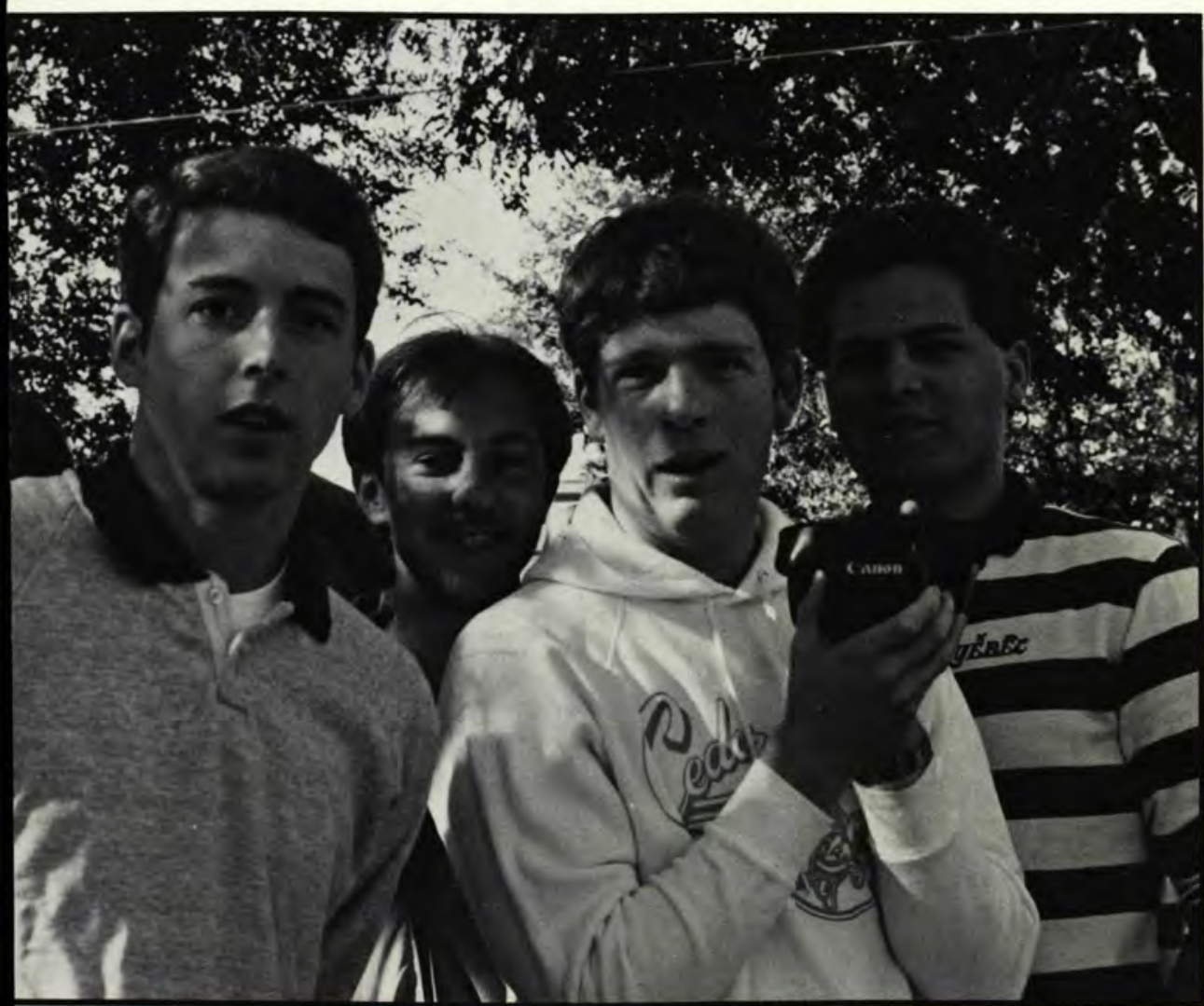

Greenville, SC
Mr. and Mrs. James Markison Brookfield, IL

Mrs. Roberta J. Marriott

Cincinnati, $\mathrm{OH}$

Mr. and Mrs. Franklin Marshall Phoenixville, $P A$

Mr. and Mrs. John Marshall Blackwood, NJ

\section{Al and Jan Martin}

Grass Lake, MI

Omer and Charlene Mastin Independence, $K Y$

Rev. and Mrs. Clyde L. Mathewson Batavia, $N Y$

Mr. and Mrs. B.C. McCain Dallas, TX

\section{Janet and Bob McCaskill}

North Jackson, $\mathrm{OH}$

Mr. and Mrs. Allen McIntyre Sallsbury, $M D$

Mr. and Mrs. Donald J. McKibben Continental, $\mathrm{OH}$

Anna Merriwether Alton, $\mathrm{NH}$

\section{David Malcolm}

Mr. and Mrs. Francis R. Michonski Simsbury, $C T$

Mr. and Mrs. Salvatore Mignogna (parents of Lynn Calisti)

Greensburg, PA

Howard and Caroline Mills Sandy Creek, NY

Mr. and Mrs. Larry E. Miller Gallipolis, $\mathrm{OH}$

Mr. and Mrs. Sanford Mills Vermilion, $\mathrm{OH}$

Mr. and Mrs. Charles S. Monroe Springfield, $\mathrm{OH}$

Mr. and Mrs. Theodore S. Montross Centermoreland, $P A$

The William D. Moon Family Erie, $P A$

Mr. and Mrs. Kenneth Moore Marysville, $\mathrm{OH}$

W. Eugene and Shirley Morris Marietta, $\mathrm{OH}$ 


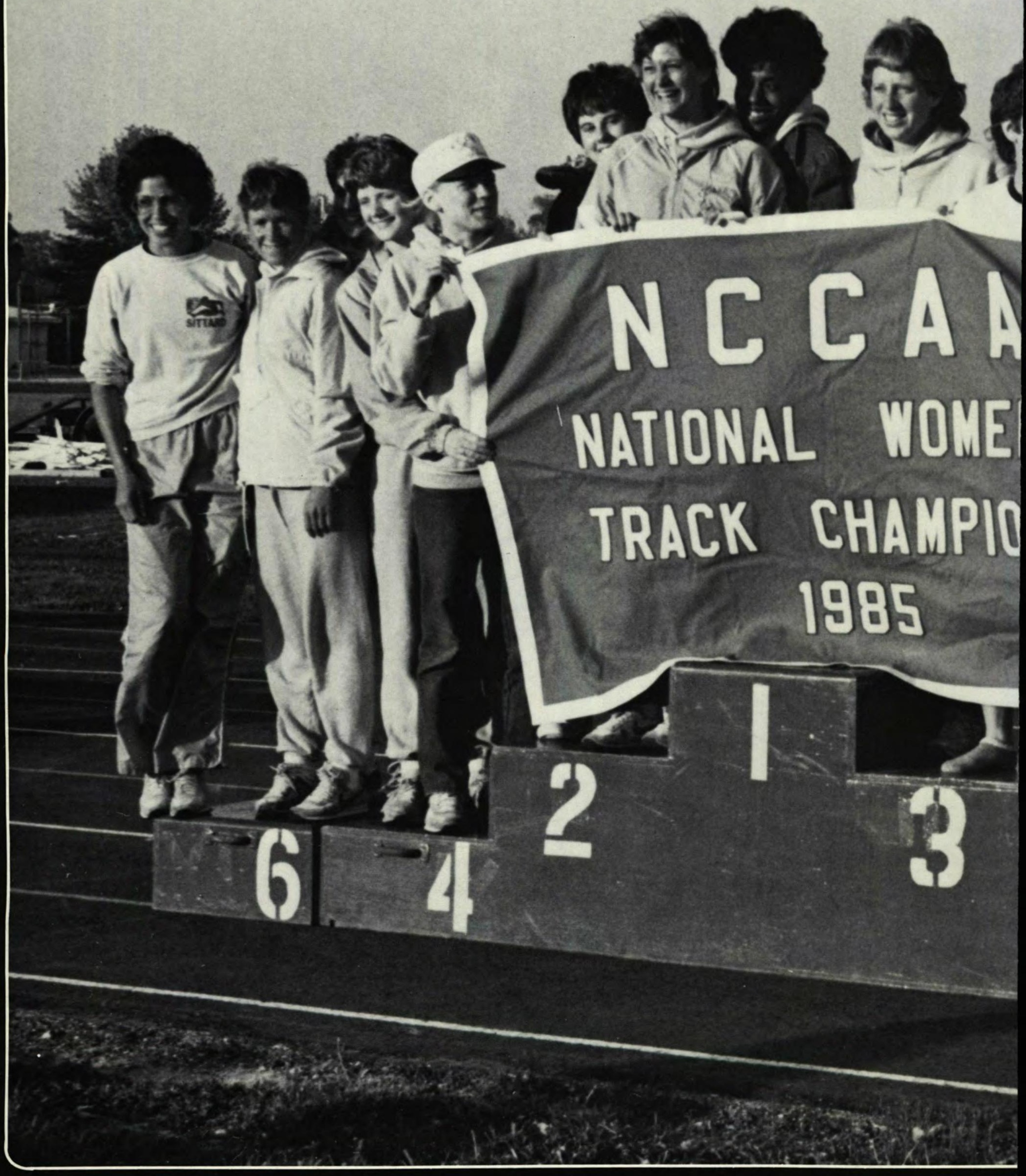




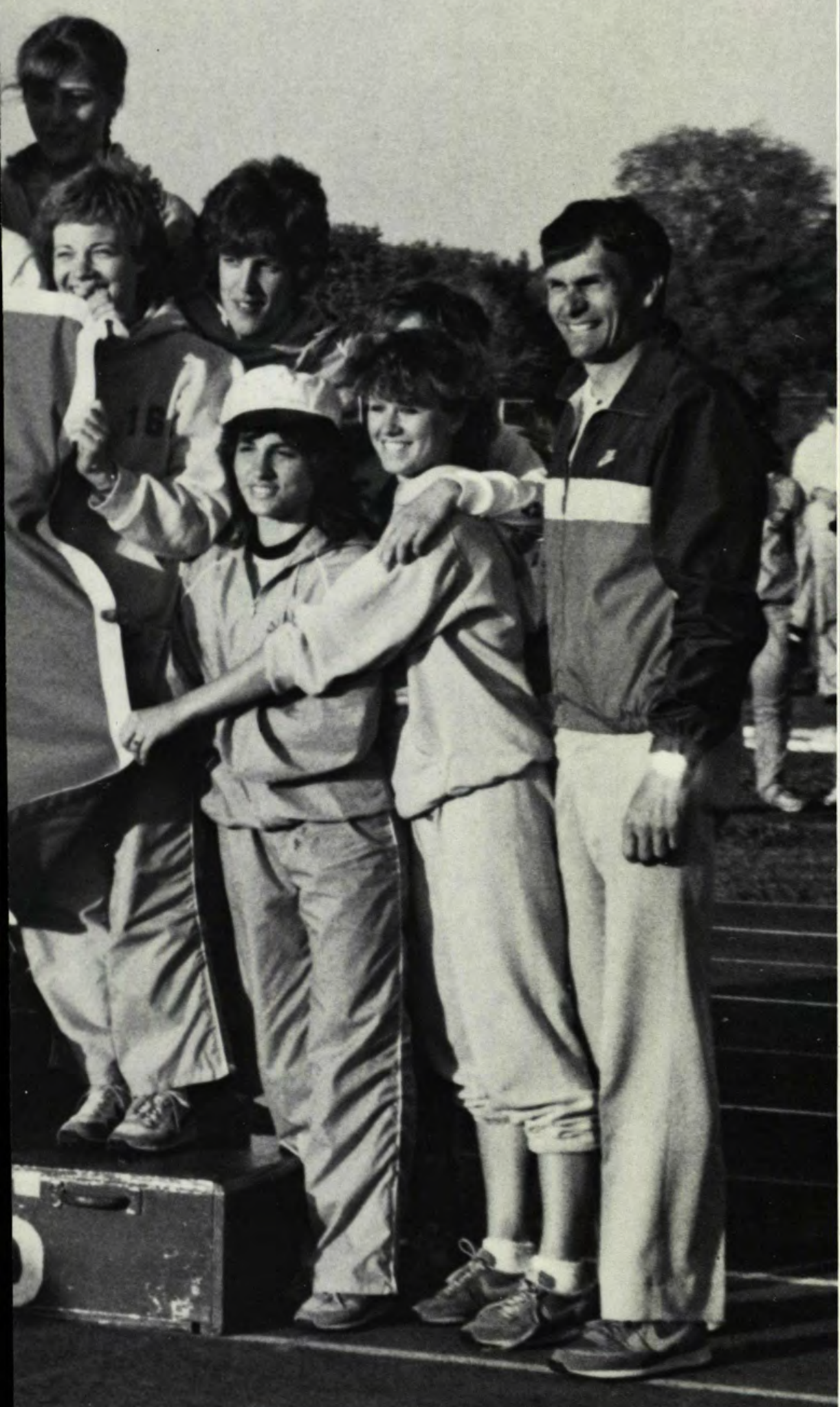

\section{Sports: Providing An Outlet}

hysical activity is an important as-
pect of life, just as important as the spiritual, academic and social aspects; recreation and sports provide a healthy balance for each Cedarville student

Competition is highlighted by the seven men's and six women's intercollegiate arhletic teams presented in the following section. The recreational program includes a variety of intramural sports for individuals or teams. All of these physical activities provide outlers for the frayed nerves and boundless energies of the students pictured on the following pages.

David Sallee

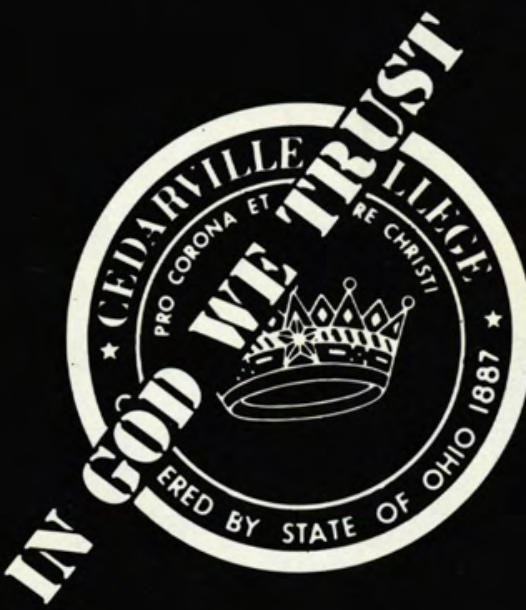




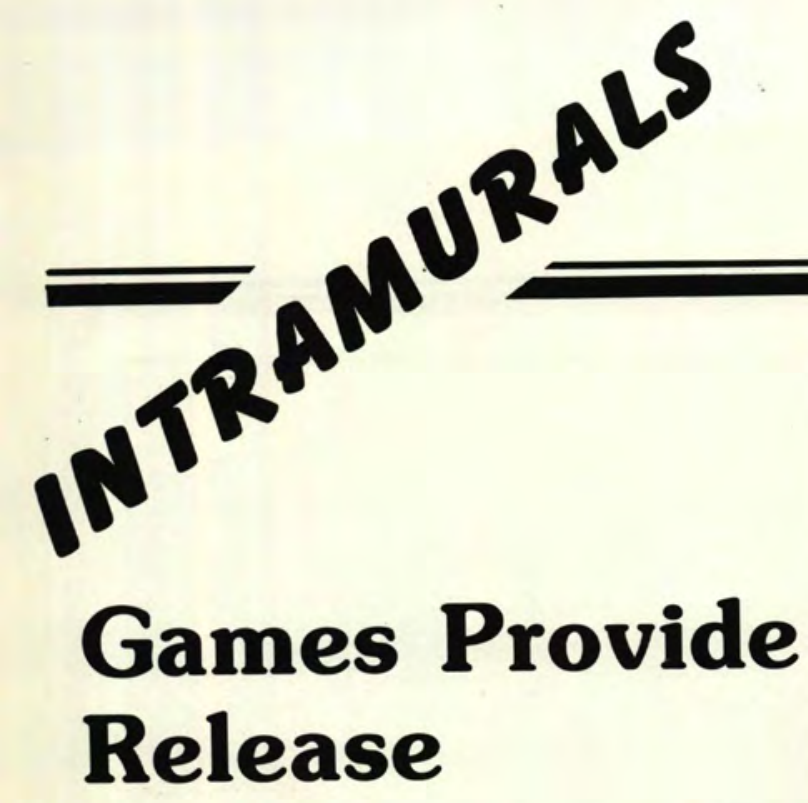

Y ou've got three midterms, a ten page tomorrow. It's 7:00 PM. You haven't started any of it and are contemplating borh suicide and prof-a-cide. At this point, you are quite confident that you are as close to a mental collapse and delirium tremens as you'll ever be. Instead of slipping on that white jacker with the comfortable wrap-around arms, however, you slip into your Nikes and head for the A.C. After all, the three-man baskerball finals are tonight; you've got priorities!

Intramurals provide the outlet needed to mend frazzled nerves and curb energetic, athletic apperites. Unlike intercollegiare sports which require exceptional talent, intramural spors require only interest; anyone can play regardless of ralent, because it's all in fun until the finals, anyway!
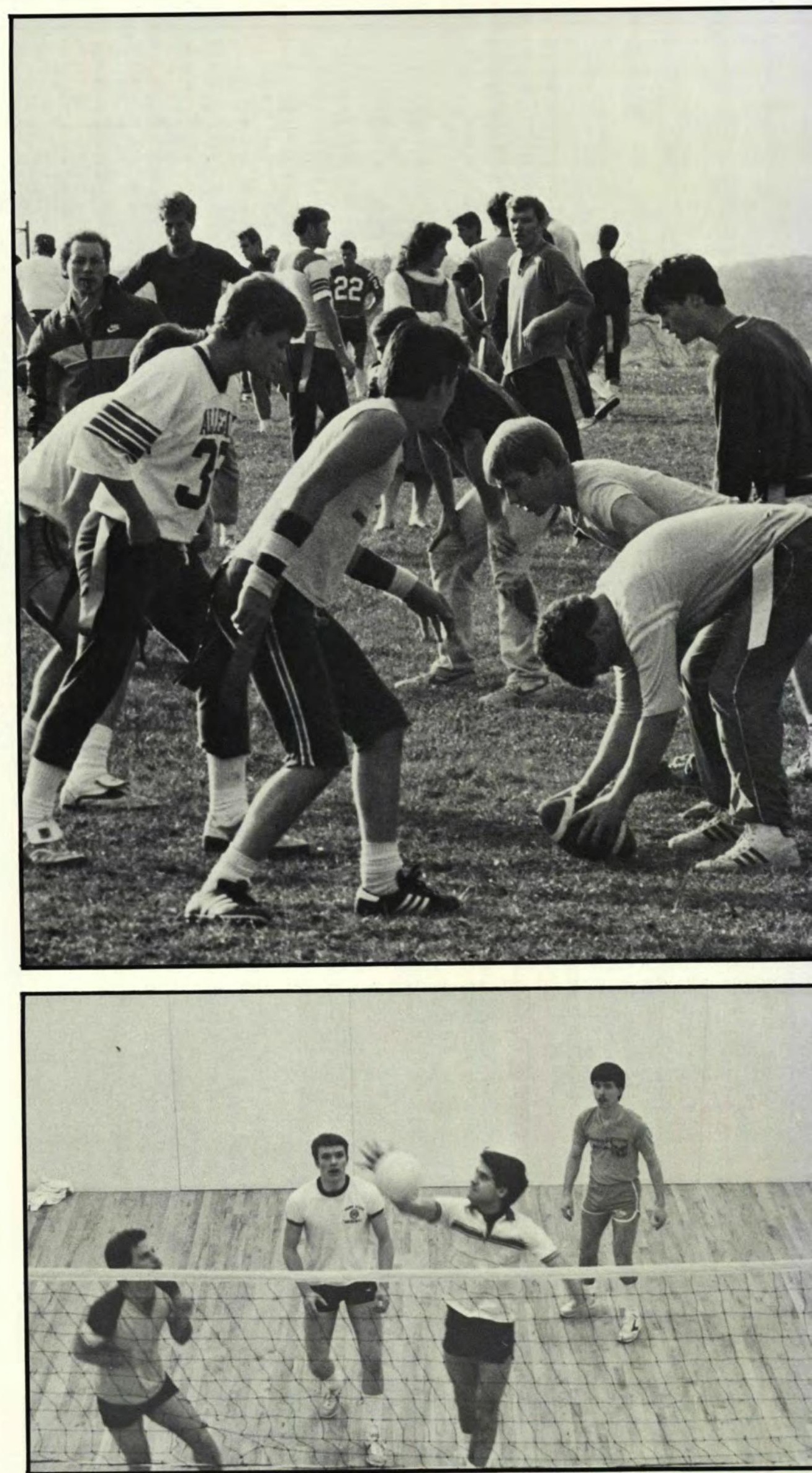


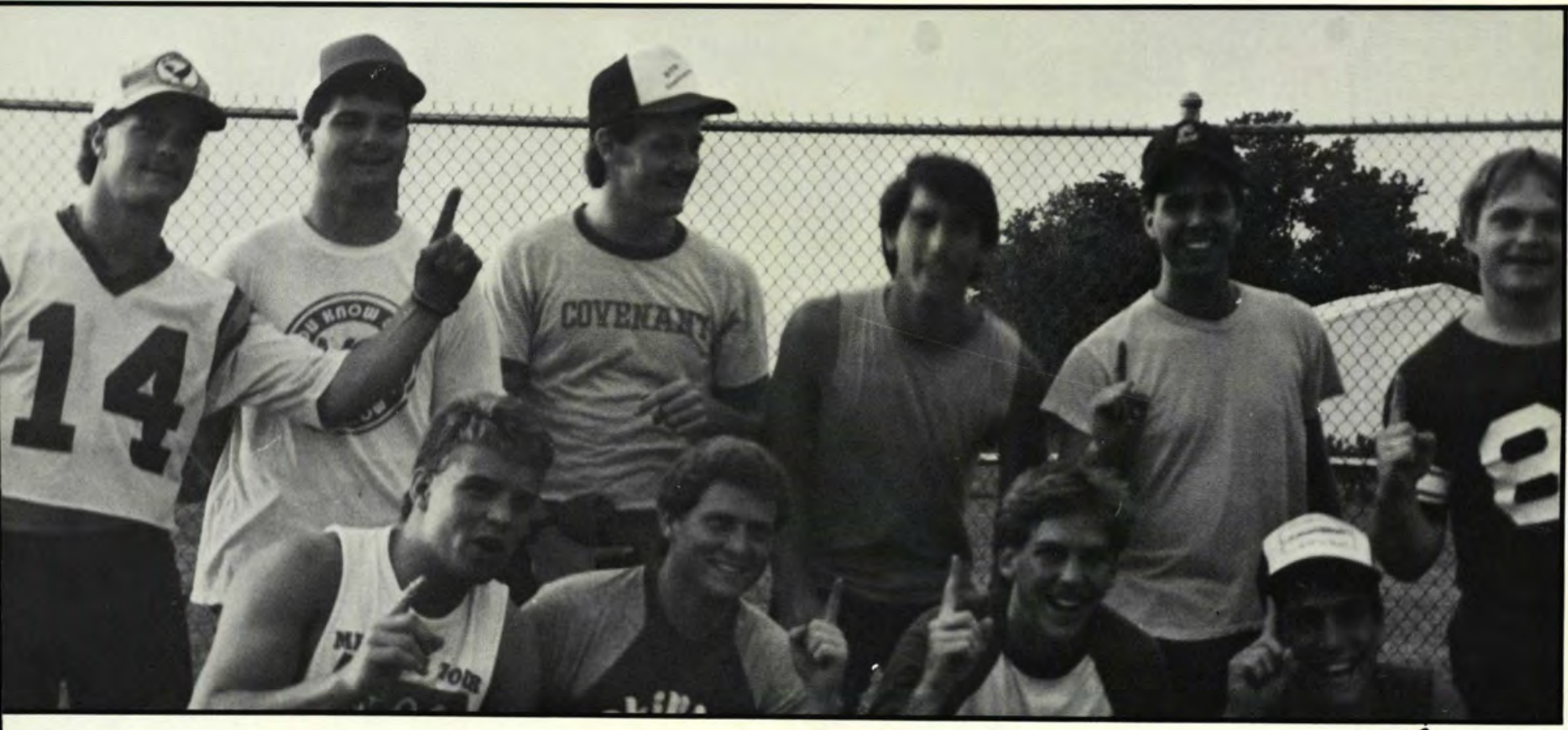

\section{8 .}

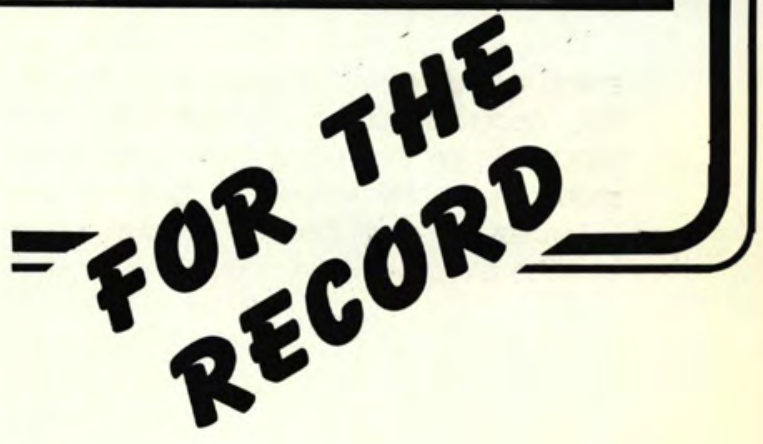

Flog Foorball

Powderpuff Foorball

Co-Rec. Volleyball

Soccer

Women's Volleybol

3-Man Boskerball

ABA League

NBA Leogue

NBA-B Leogue

Women's Boskerball

Men's Boskerball

A Leoogue

$B$ Leogue

Indoor Soccer

Walleyball - Men

Wolleyball - Co-Rec

Indoor Softball

Men's Volleyball

Women's Softball

Men's Softball

Super Dorms

Class Closh

Bowling League 39ers

Crushers

P.A.W.'s

Kickers

Clossics

Cruise ॥

Bears

Almocs

Vorsity Clossics

Mules

Banshees

Ball Busters

WHODINI

Wally Wonders

Boys of Rr. 303

Foculry/Sraff

Angelic Ones

Splinrered Lumber

Berhel/Willerts 100-124

Sophomores

Compbell's Crew 

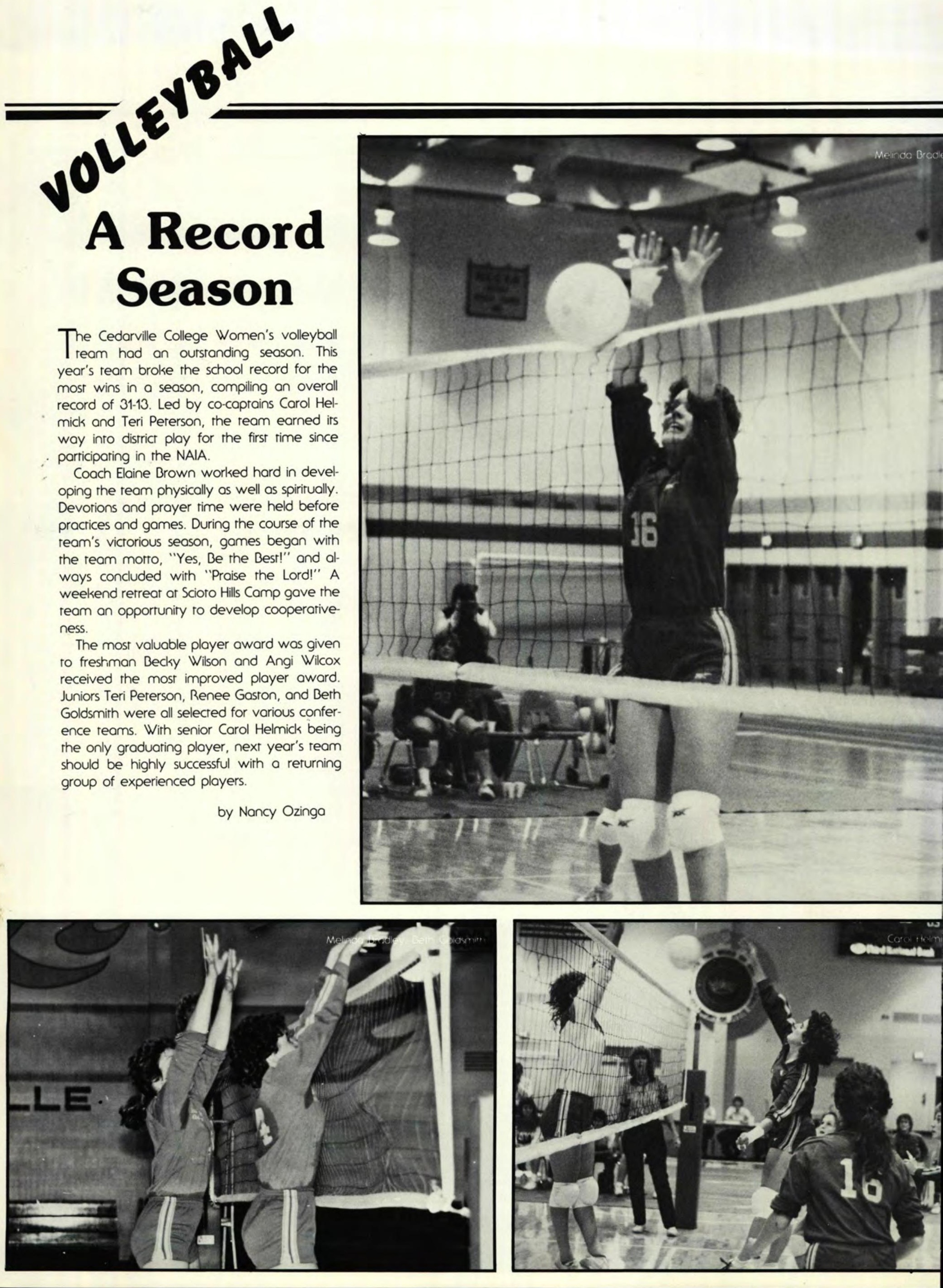


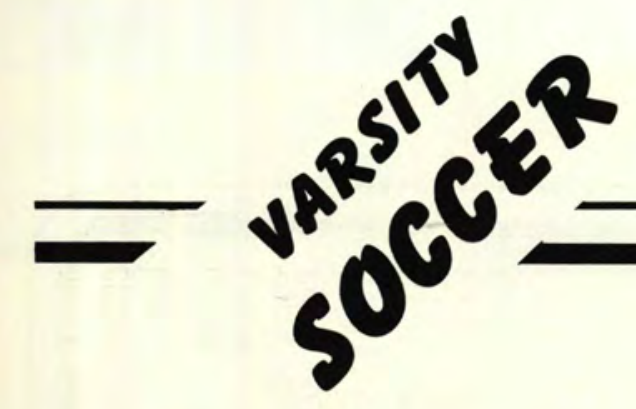

\section{Dream}

\section{Becomes} Reality

To make it to a national tournament during the season begins, reams anxiously awair a shot at the title. Texas and the NCCAA nationals seem to be an unrealistic goal to many players, but the 1984 Jackers thought otherwise.

As summer rapidly drew to a close, the soccer ream was hard at work in preparation for the opening game against Denison University. The returning letrermen entered pre-season camp with high expectations for the season. The talent and the ability were there for a great year. Those high expectations were quickly dampened as the team lost its opening game to Denison 2-0. For the next 9 games the team suffered frustration as those high expecrations became a sub .500 record of 4-5-1. At this point some changes needed to be made and Coach McGillivray altered the line up in an atrempt to turn things around.

The second half of the season speaks for itself as the team rallied to win 8 out of its last 10 games. Those high expectations returned and the dream suddenly became reality when the ream defeared Marion College $10-3$ and Grace College 2-1 to earn the right to travel to Longview, Texas, and compere in the NCCAA National Soccer Tournament.

The 1984 soccer season has been labeled a success. This success comes not only from an 11 8-1 record,placing second in the NAIA District 22, capruring the NCCAA District 3 title, and from placing fifth in the NCCAA national tournament, but also from the many values and principles that Coach McGillivray strove to instill within each one of the players. Each person had his ups and downs as every team does; but as the season drew to a close, the team could say that every individual player played for the honor and restimony of the Lord Jesus Christ.

by Noel Hack
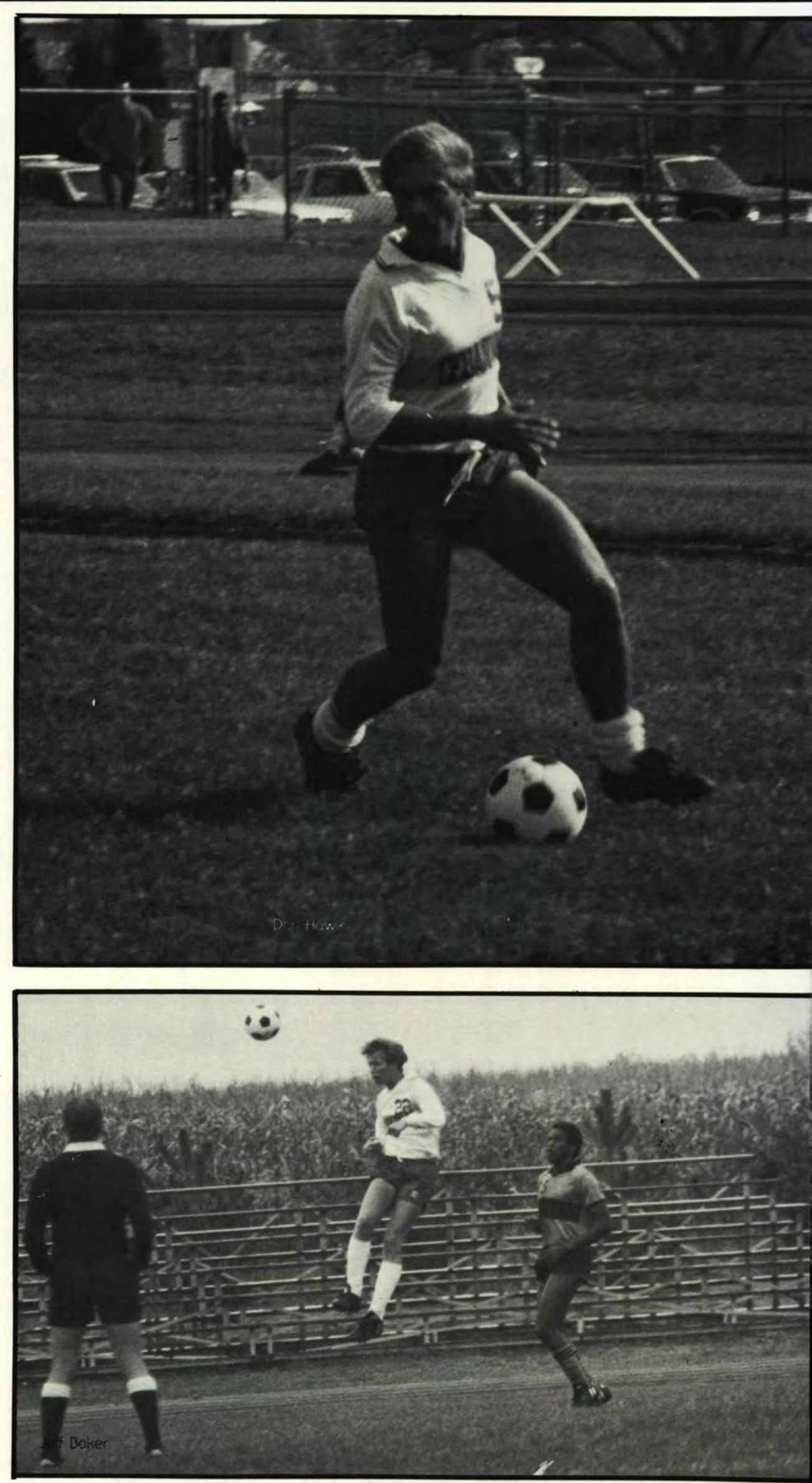


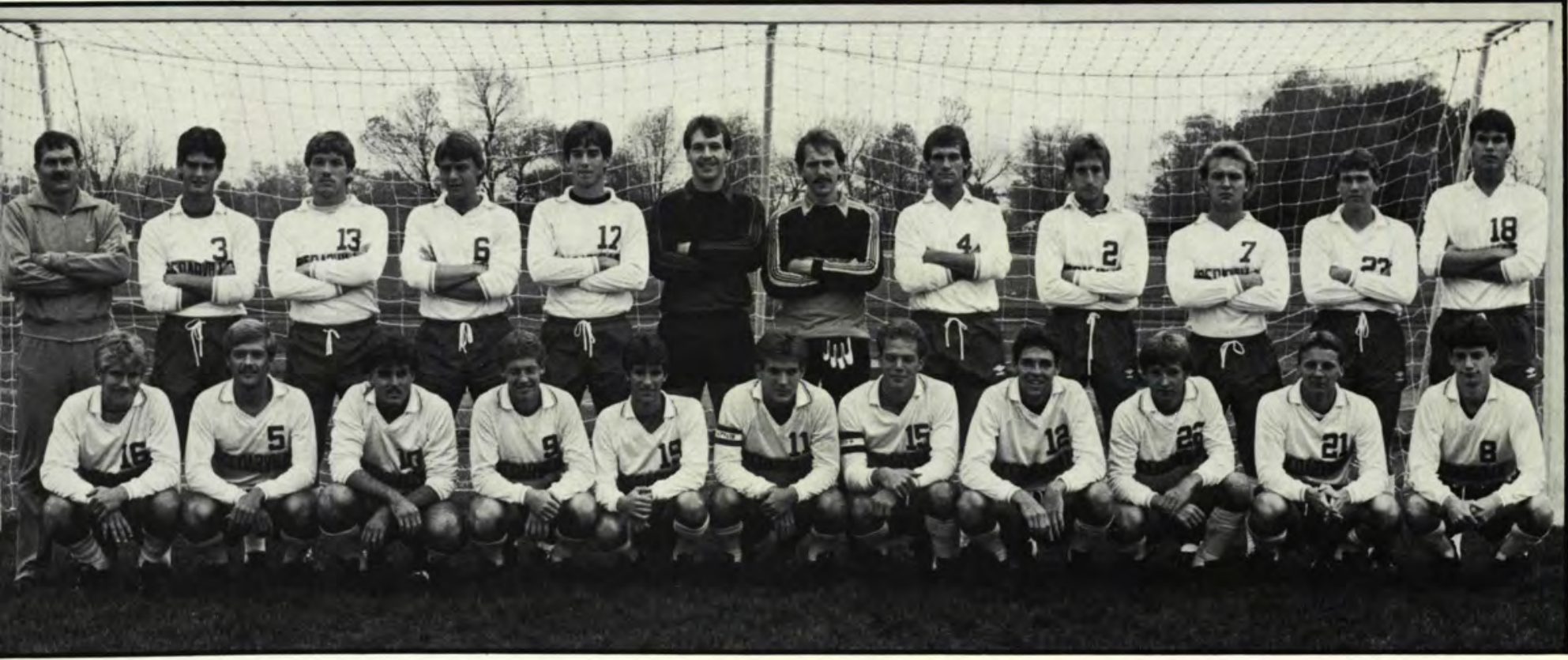

First row: Greg Norden, Dan Hawk, Troy Custudio, Phil Fogle, Andy Mininger, Tom Fite, Noel Hack, Brent Ziegler, Jeff Baker, Tim Davis, Brian Hultz; Second row: Coach John McGillivray, Rick Seidel, Mark Fleerwood, Jon Reid, Dave Moody, Jan Schaedel, Dan Byrum, Chuck Abel, Wayne Anderson, Curt Critcher, Tom Pererson, Dan Crotts.
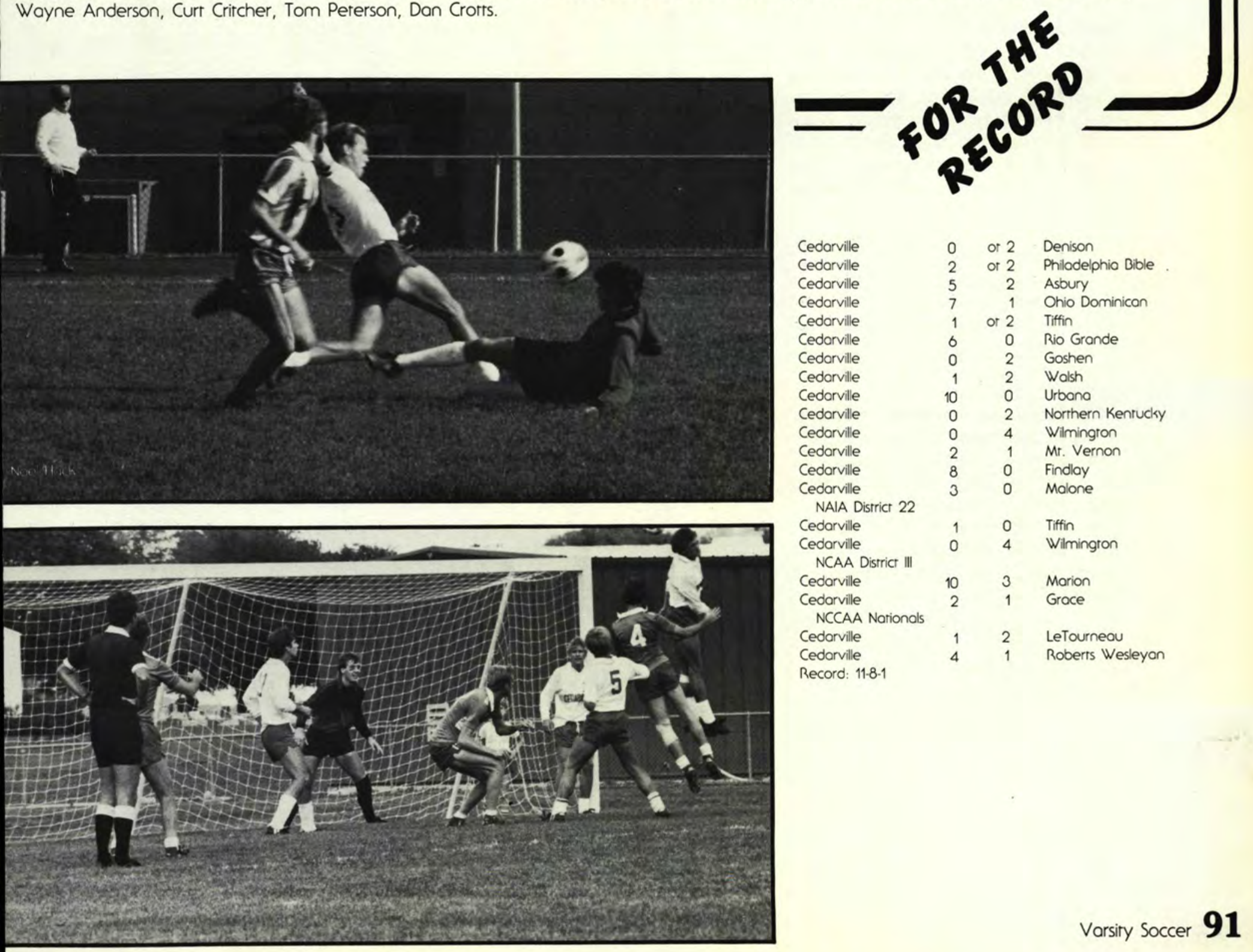

\begin{tabular}{|c|c|c|c|}
\hline Cedarville & 0 & or 2 & Denison \\
\hline Cedarville & 2 & or 2 & Philodelphio Bible \\
\hline Cedorville & 5 & 2 & Asbury \\
\hline Cedarville & 7 & 1 & Ohio Dominican \\
\hline Cedarville & 1 & or 2 & Tilffin \\
\hline Cedorville & 6 & 0 & Rio Grande \\
\hline Cedorville & 0 & 2 & Goshen \\
\hline Cedorville & 1 & 2 & Wolsh \\
\hline Cedorville & 10 & 0 & Urbana \\
\hline Cedorville & 0 & 2 & Northern Kenrucky \\
\hline Cedorville & 0 & 4 & Wilmingron \\
\hline Cedarville & 2 & 1 & Mr. Vernon \\
\hline Cedarville & 8 & 0 & Findlay \\
\hline $\begin{array}{l}\text { Cedarville } \\
\text { NAIA District } 22\end{array}$ & 3 & 0 & Malone \\
\hline Cedarville & 1 & 0 & Tiffin \\
\hline $\begin{array}{l}\text { Cedarvile } \\
\text { NCAA Districr III }\end{array}$ & 0 & 4 & Wilmingron \\
\hline Cedarville & 10 & 3 & Marion \\
\hline $\begin{array}{l}\text { Cedarville } \\
\text { NCCAA Narionals }\end{array}$ & 2 & 1 & Groce \\
\hline Cedarville & 1 & 2 & LeTourneou \\
\hline Cedorville & 4 & 1 & Roberts Wesleyon \\
\hline
\end{tabular}



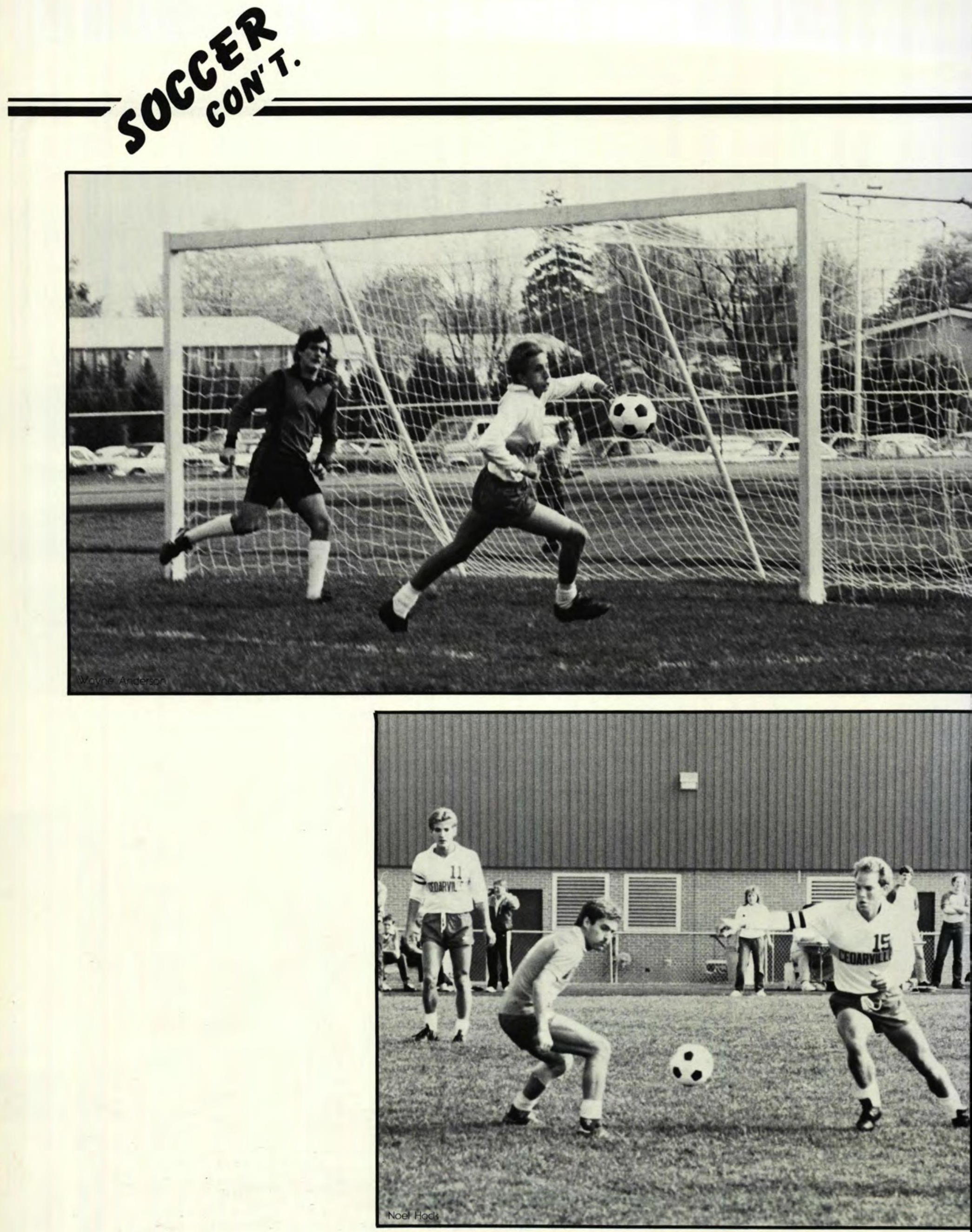


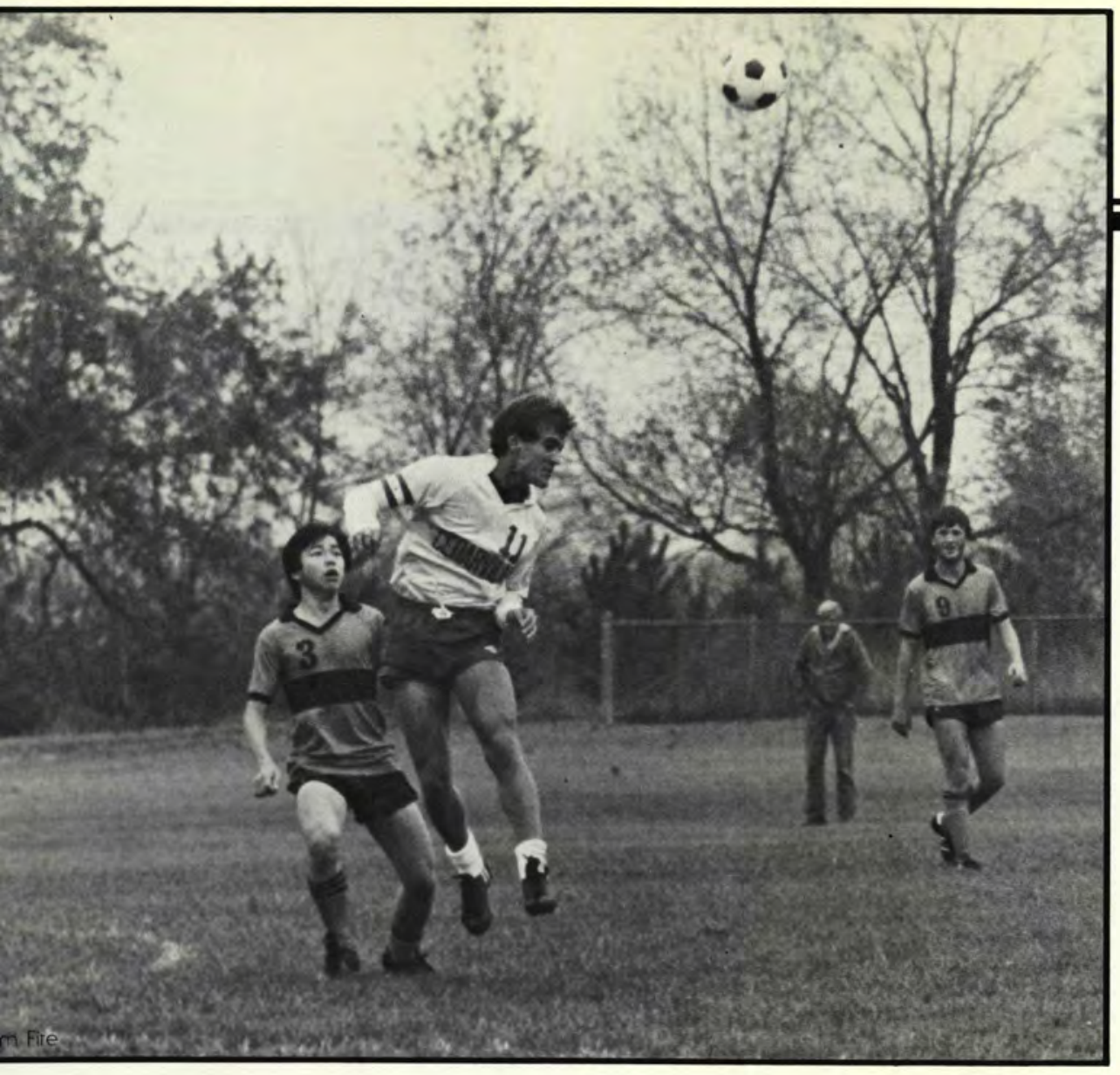

\section{J.V. Soccer Team}

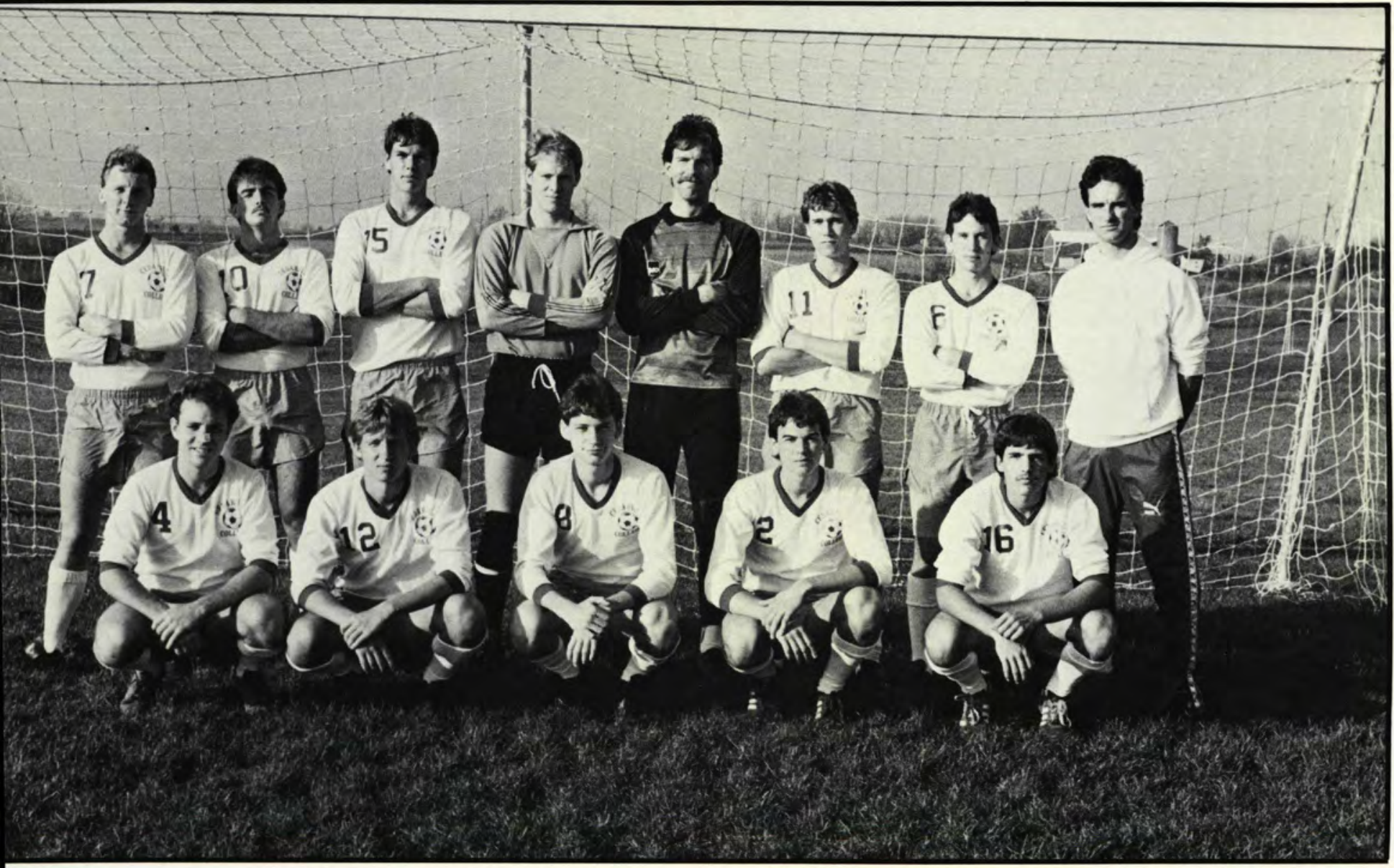




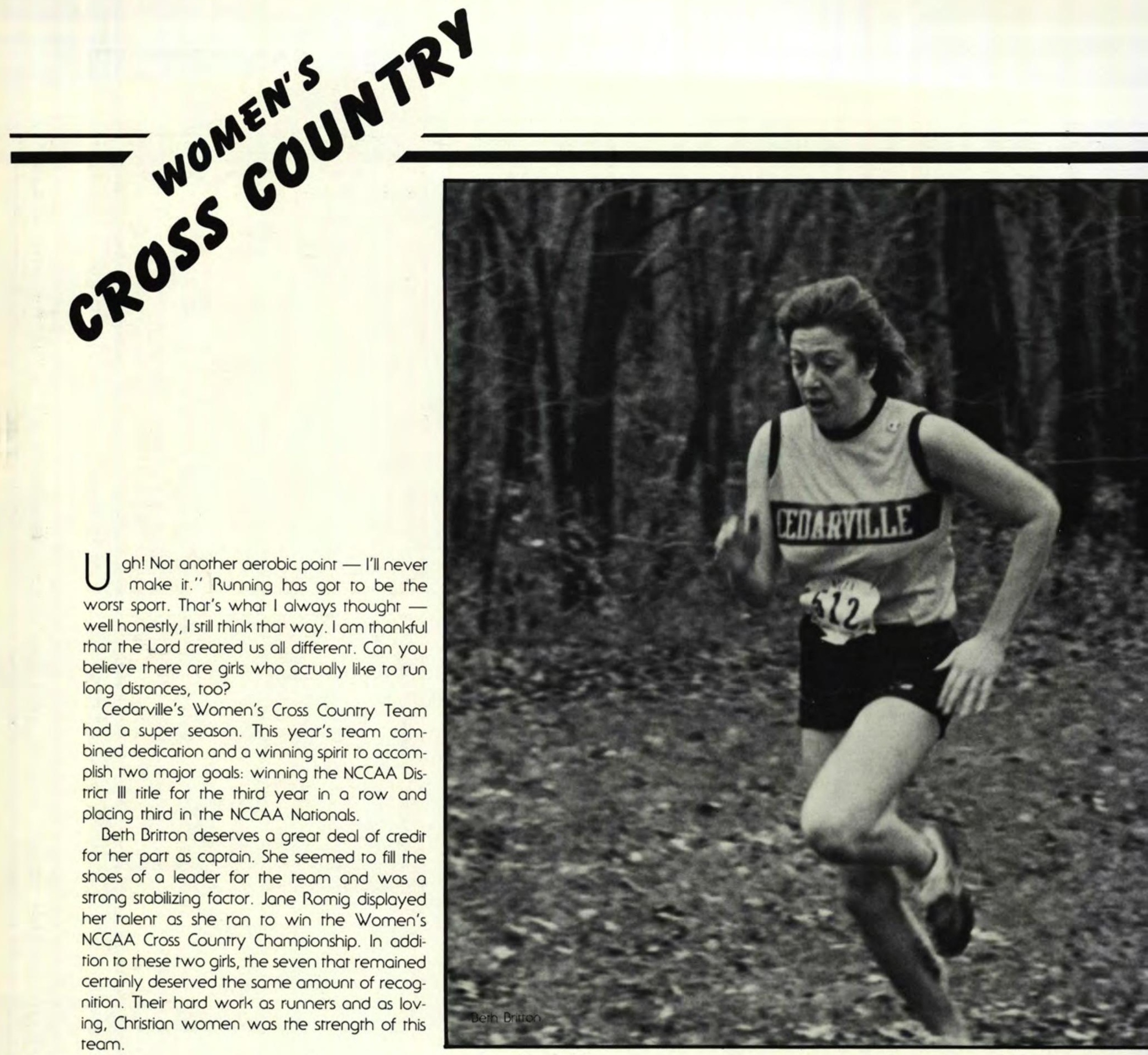
ream.

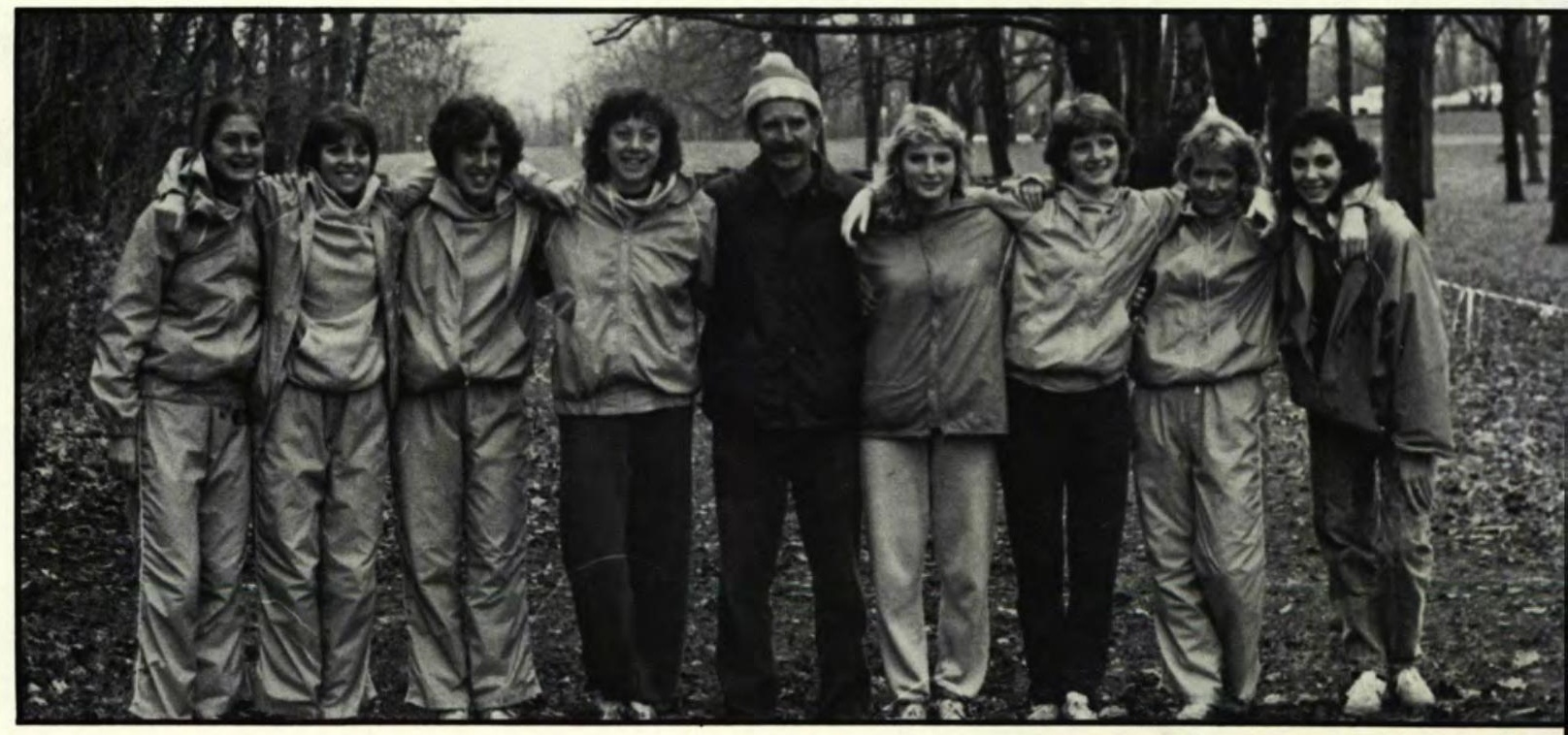

First row: Berh McGillivray, Jane Romig, Cheryl Rendle, Berh Britron, Coach Elvin King, Debbie Pare, Becky Averill, S Vaughan, Ann Blessing. 

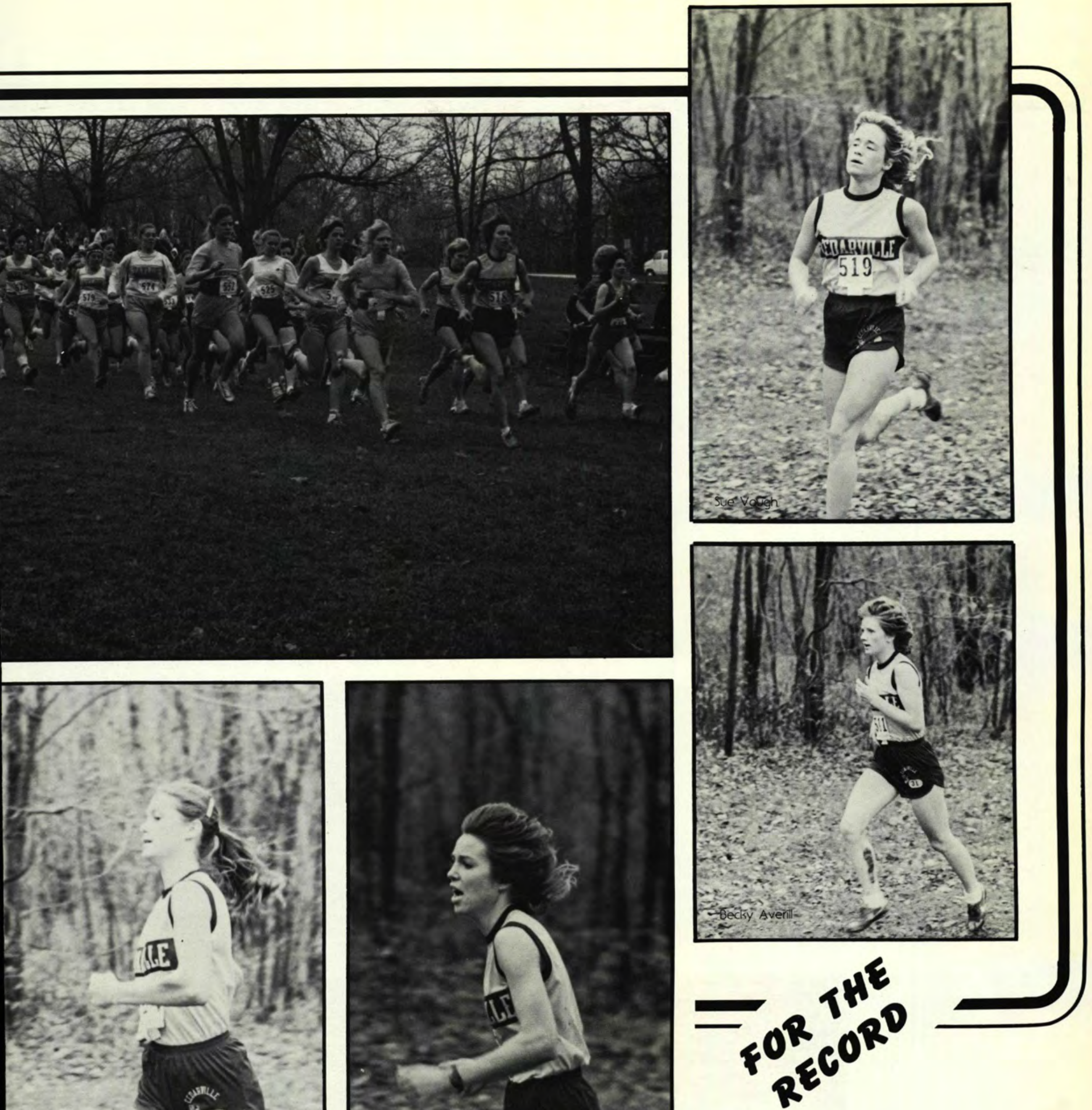

Grace Invirarional

Earlham Invitarional

Anderson Invitariono

NCCAA District III

NAIA District 22

NCCAA Narionals
4 th our of 4

1st out of 5

4 rih our of 8

1st out of 3

3 rd out of 4

3rd our of 8 

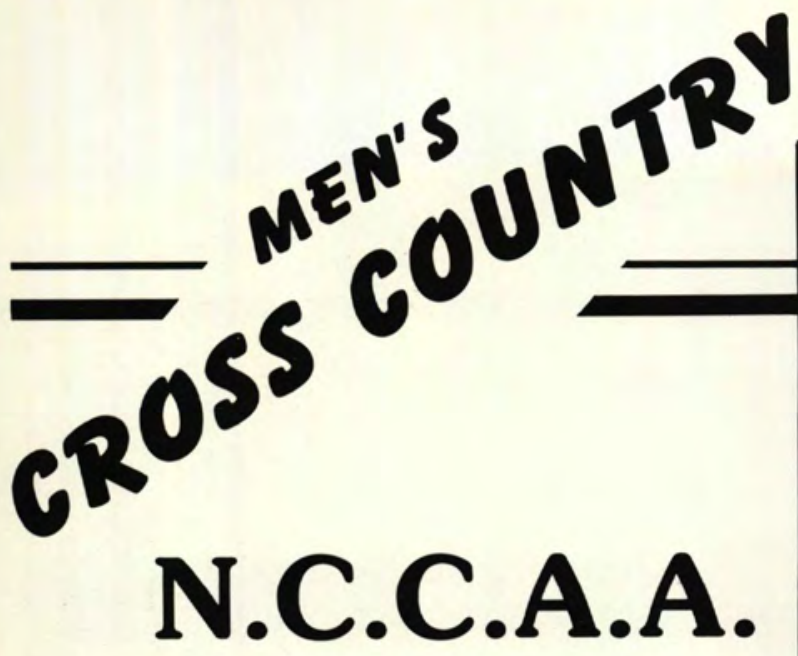
Runners-up

- ifreen-year coach Elvin King assembled an- orher strong Yellow Jacket cross country squad in '84 as the harriers ran in two narional meers for the second straight year. Cedarville was the NCCAA runner-up again to five-rime champion Anderson College. The Jackers finished 24th our of the 37-ream NAIA field.

Ar the NCCAA, sophomore Rusty King placed the Jackers in tenth place to make the All-America ream. Junior Tom Hill was 11 th as one of three Coaches' All-Americans. Orher Cedarville scorers were sophomores Gary Anderson, Dave Schumaker, Dave Cherry and junior Scorr Brooker. They won the NCCAA District III ritle for the renth rime in the last eleven years.

Besides the second-place NCCAA showing, the Yellow Jackers qualified for the NAIA Narionals by virtue of their runner-up District 22 finish. Their orher second-place ourcome was ar the Hanover Invirarional where there the Universiry of Louisville nipped Cedarville by only rwo points.

The individual who was the ralls of the 1984 season was Rob Moore, a narive of West Olive, Michigan. He won four meers, finished third in rwo orhers, was eighth in NAIA District 22,15 th in the NCCAA, and 31st ar the NAIA Narionals. "Rob has just a remarkable year," said King about his prize performer. "He is continually learning abour how to control a race. I look for him to improve even more the next rwo seasons."

Junior Sreve Cox was Cedarville's "Most Im. proved" runner. He, along with Cherry and Schumaker, saw a lor of varsity acrion. "We have to be pleased with our season," declared King as he summed up the campaign. "Our last three teams have been some of the best that Cedarville has ever had. We feel like our program is on the rise and we believe that we can ger even berter."

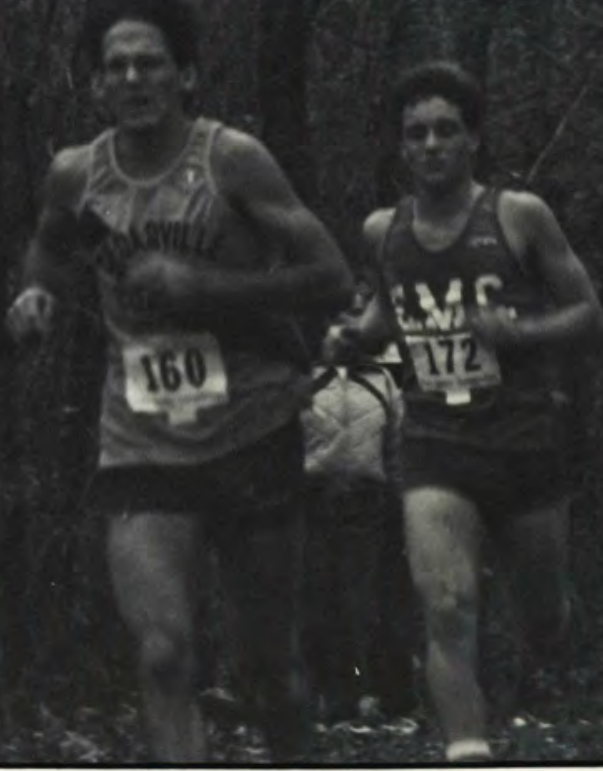




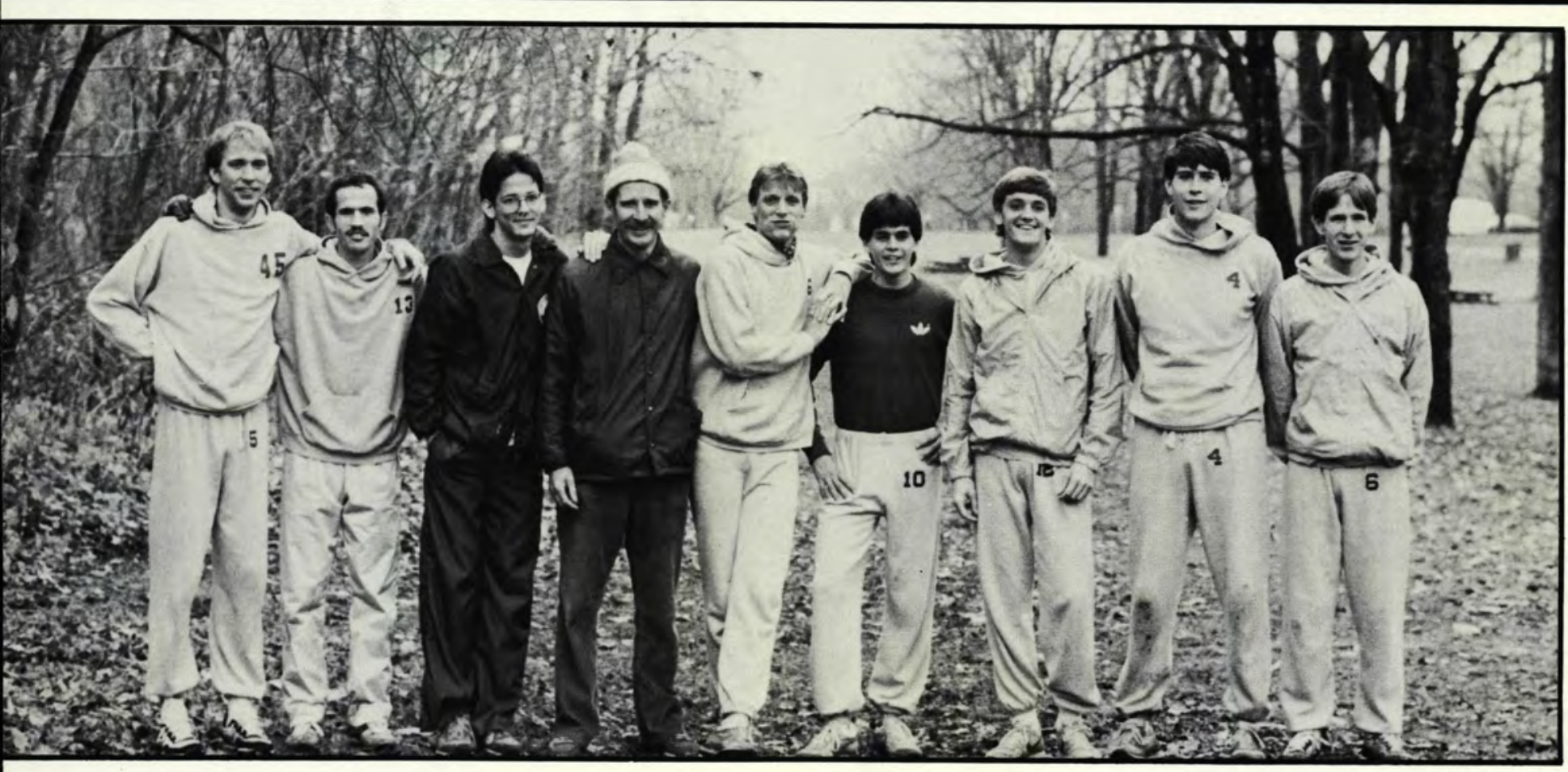

First row: Scort Brooker, Steve Cox, Dave Schumaker, Coach Elvin King, Gary Anderson, Tom Hill, Rob Moore, Doug Cheery, Rusty King.
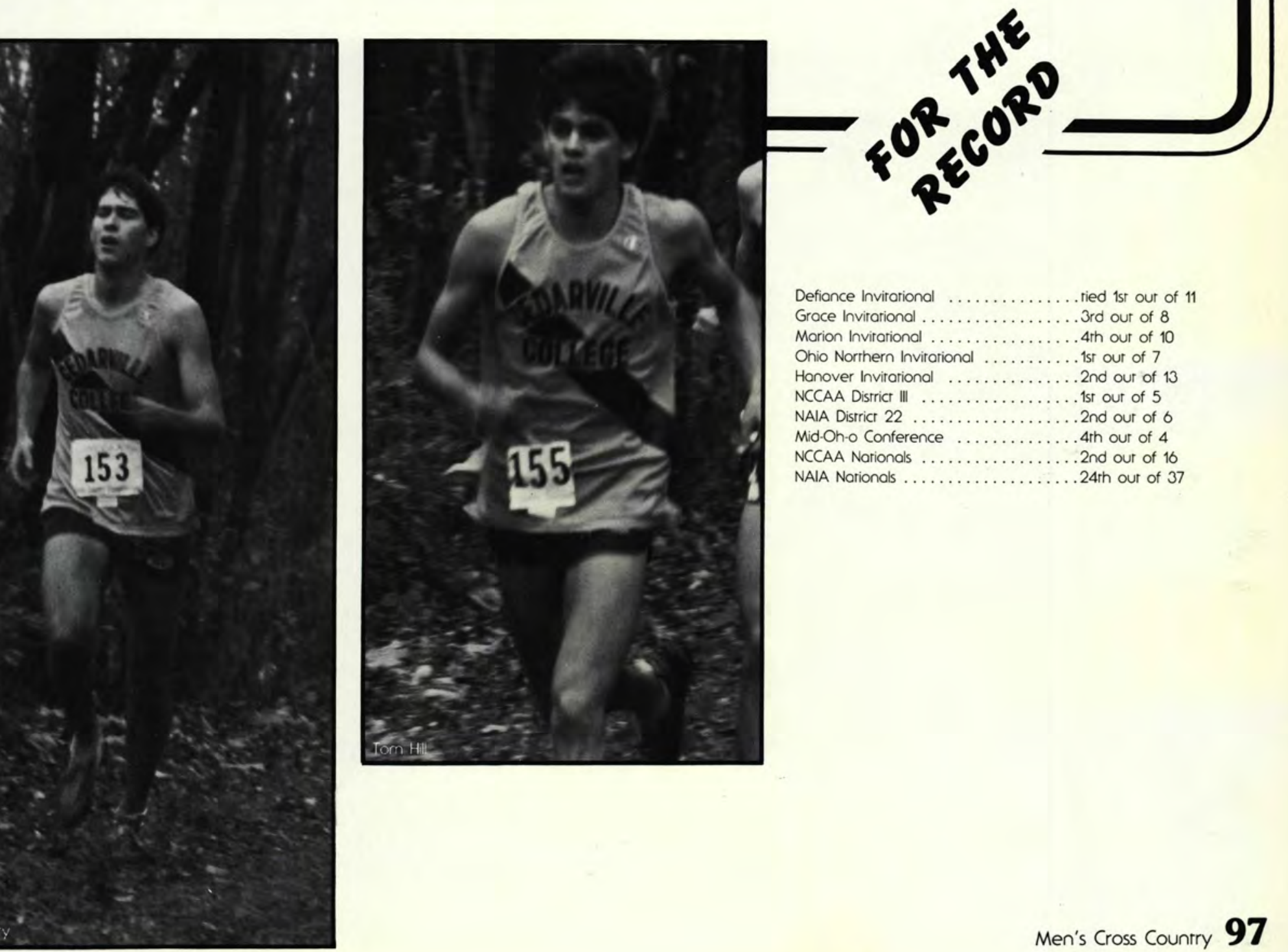


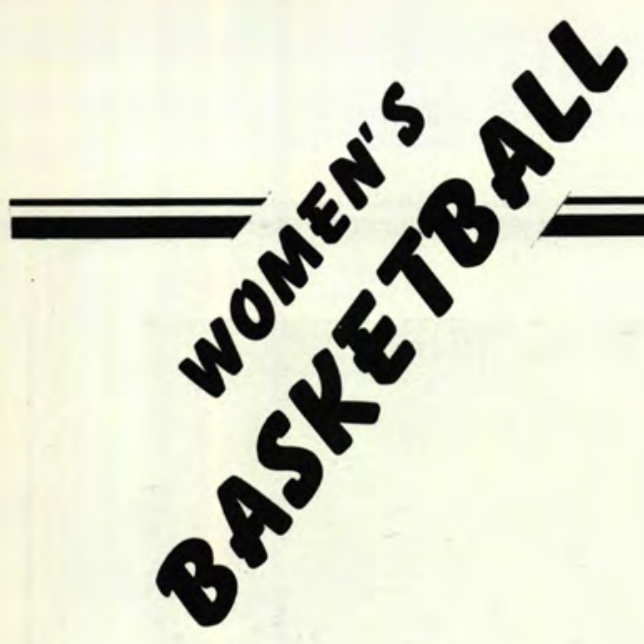

\section{Murphy} Leads

\section{Lady Jackets}

A pparently, the women's baskerball ream I had an enigmaric player named Murphy whose name did nor appear on this year's roster. According to Dr. Karol Hunt, team coach, the team "had a Murphy's Law season: if anything could go wrong, it did." Although the women closed the season with a disappointing 6-21 record, they showed dedication and persistence in making the year a rime of growth and restructuring.

To highlight the season, the women hosted the NCCAA Narional Boskerball Tournament with Dr. Hunt acting as the director. On the evening following a disappointing game in which they scored the least number of points in a narional tournament, the women came back to score the most number of points in a national tournament game.

Plagued by injuries and with only one rerurning starter, the team was forced to rely on the young talent found in freshmen Tonya Bumpus, Stacy McCaskill, Parti Parker, and Crystal Parrick, who ried with Sherri Norrick for assist leader honors. Senior caprain Jewel Schroder lead the ream in scoring while junior Berh Goldsmith who had the highest free throw percentage also earned honors as the ream's leading rebounder. The women can look forward to a strong ream next year with many rerurning players except one - Murphy.
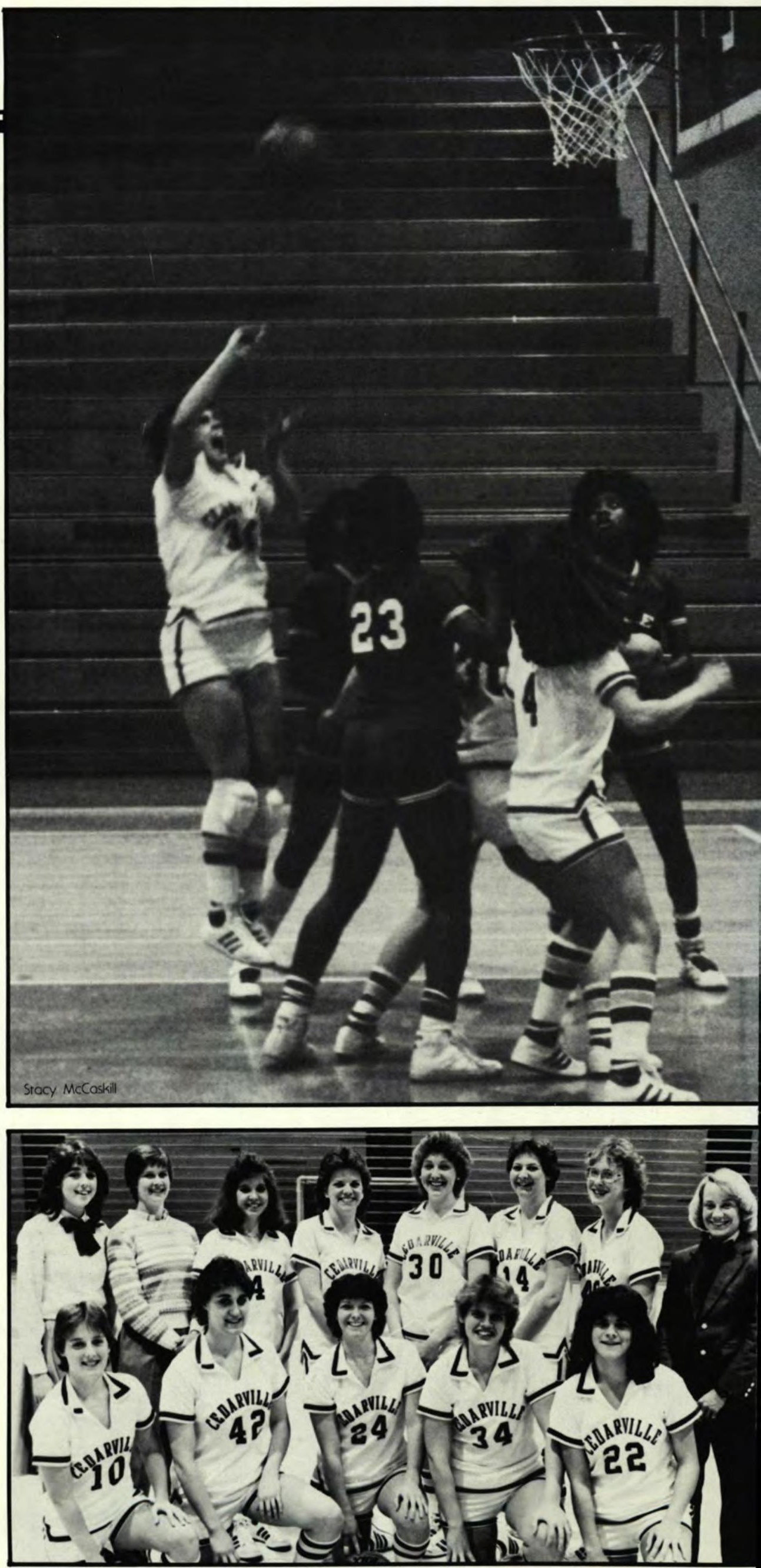

First Row: Crystal Parrick, Berh Goldsmirh, Jewel Schroder, Sracy McCoskill, Sherri Norrick; Second Row: Manager Burron, Assistant Coach Diane Lichrensteiger, Parti Parker, Rurh Eissens, Tonya Bumpus, Karen Headdings, Julie Bu Coach Dr. Karol Hunt. 

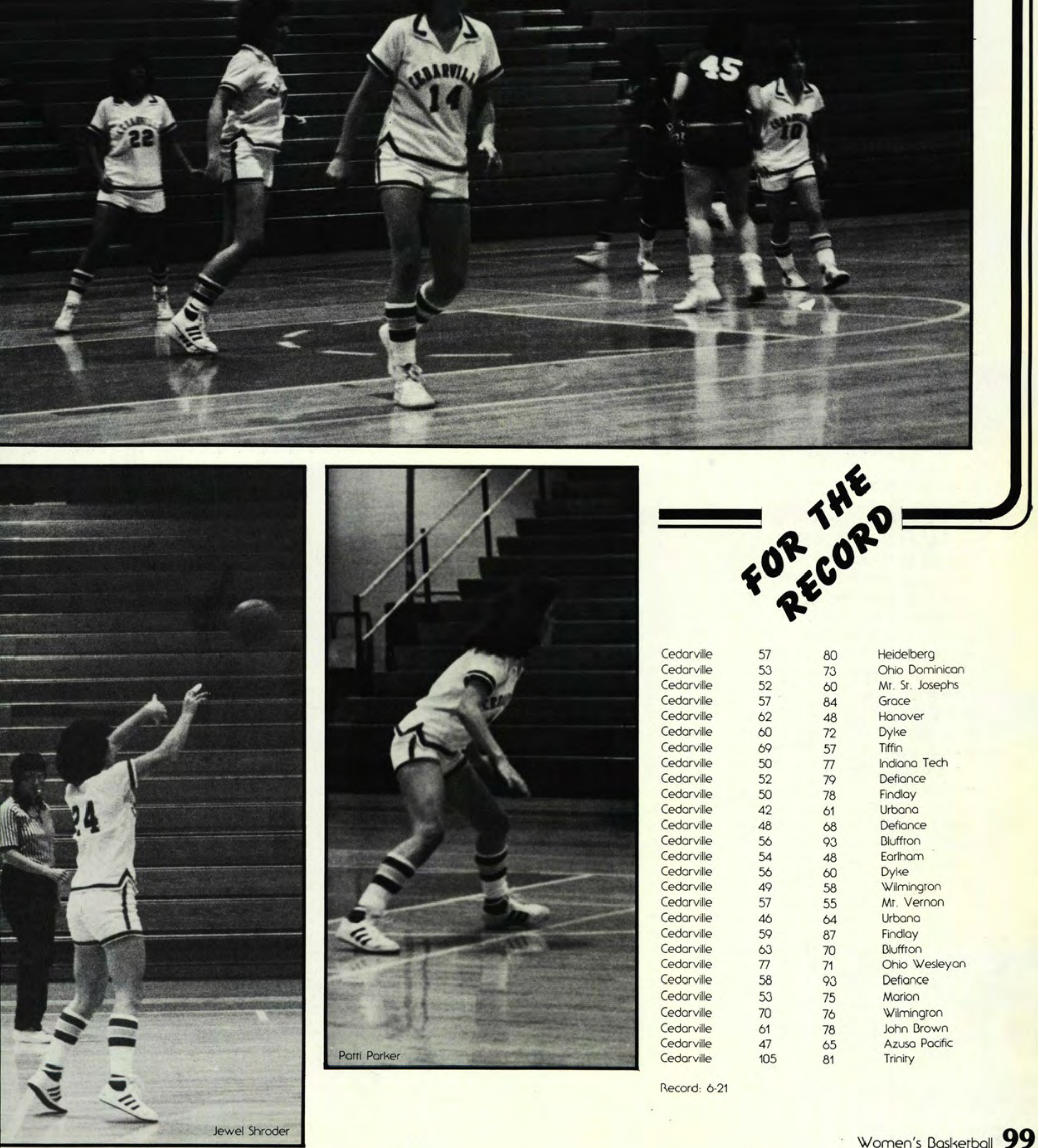

$\begin{array}{llll}\text { Cedarville } & 57 & 80 & \text { Heidelberg } \\ \text { Cedarville } & 53 & 73 & \text { Ohio Dominican } \\ \text { Cedarville } & 52 & 60 & \text { Mr. Sr. Josephs } \\ \text { Cedarville } & 57 & 84 & \text { Grace } \\ \text { Cedarville } & 62 & 48 & \text { Hanover } \\ \text { Cedarville } & 60 & 72 & \text { Dyke } \\ \text { Cedarville } & 69 & 57 & \text { Tiffin } \\ \text { Cedarville } & 50 & 77 & \text { Indiana Tech } \\ \text { Cedarville } & 52 & 79 & \text { Defiance } \\ \text { Cedarville } & 50 & 78 & \text { Findlay } \\ \text { Cedarville } & 42 & 61 & \text { Urbana } \\ \text { Cedarville } & 48 & 68 & \text { Defiance } \\ \text { Cedarville } & 56 & 93 & \text { Bluffton } \\ \text { Cedarville } & 54 & 48 & \text { Earlham } \\ \text { Cedorville } & 56 & 60 & \text { Dyke } \\ \text { Cedarville } & 49 & 58 & \text { Wilmingron } \\ \text { Cedarville } & 57 & 55 & \text { Mr. Vernon } \\ \text { Cedarville } & 46 & 64 & \text { Urbana } \\ \text { Cedarville } & 59 & 87 & \text { Findlay } \\ \text { Cedarville } & 03 & 70 & \text { Bluffron } \\ \text { Cedarville } & 77 & 71 & \text { Ohio Wesleyan } \\ \text { Cedarville } & 58 & 93 & \text { Defiance } \\ \text { Cedarville } & 53 & 75 & \text { Marion } \\ \text { Cedarville } & 70 & 76 & \text { Wilmingron } \\ \text { Cedarville } & 61 & 78 & \text { John Brown } \\ \text { Cedarville } & 47 & 65 & \text { Azusa Pocific } \\ \text { Cedarville } & 105 & 81 & \text { Triniry } \\ & & & \end{array}$




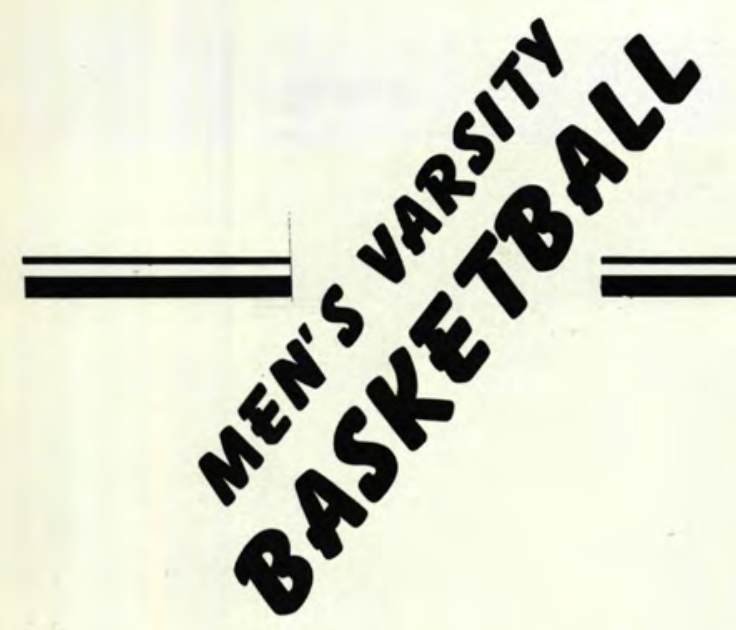

\section{Freshmen}

\section{Excel In}

\section{Rebuilding}

\section{Year}

L est feelings of symparhy arise for the L men's baskerball ream's ever-so-close but nonetheless losing record of 14-15, let it be known that the team actually gained more than it lost. Due to an exrensive recruiting campaign, the team had an abundance of freshmen, three of whom joined the starting line-up for a good portion of the season. Freshmen Chris Reese, Tony Ewing, and Mike Freeman led the ream in scoring respectively, gaining priceless experience whose value will be realized in furure seasons.

Upper classmen like seniors Tom Greve and John Srnis provided the leadership for the young Jackets so that, according to Mark Womack, "the rookies could adequarely learn the college game." MVP Greve graduares as Cedarville's all rime assist leader and a member of the honored 1000 point club despite a nagging thigh injury. Several other players including David Yeager, Kirk Fairhurst, and Mike Campbell also received a fair share of playing time to round out the scoring effort.

In conference play the Jackers faced formidable opposition in almost every team they played. The combined efforts of the novice and experienced players enabled the ream to defear five of their foes in what head coach Dr. Don Callan labeled "a balanced league." Highlighring the season, Dr. Callan also reached his 350th career win. With the experience gained along the way, the Jackers hope to convert a restructuring year into furure winning seasons.

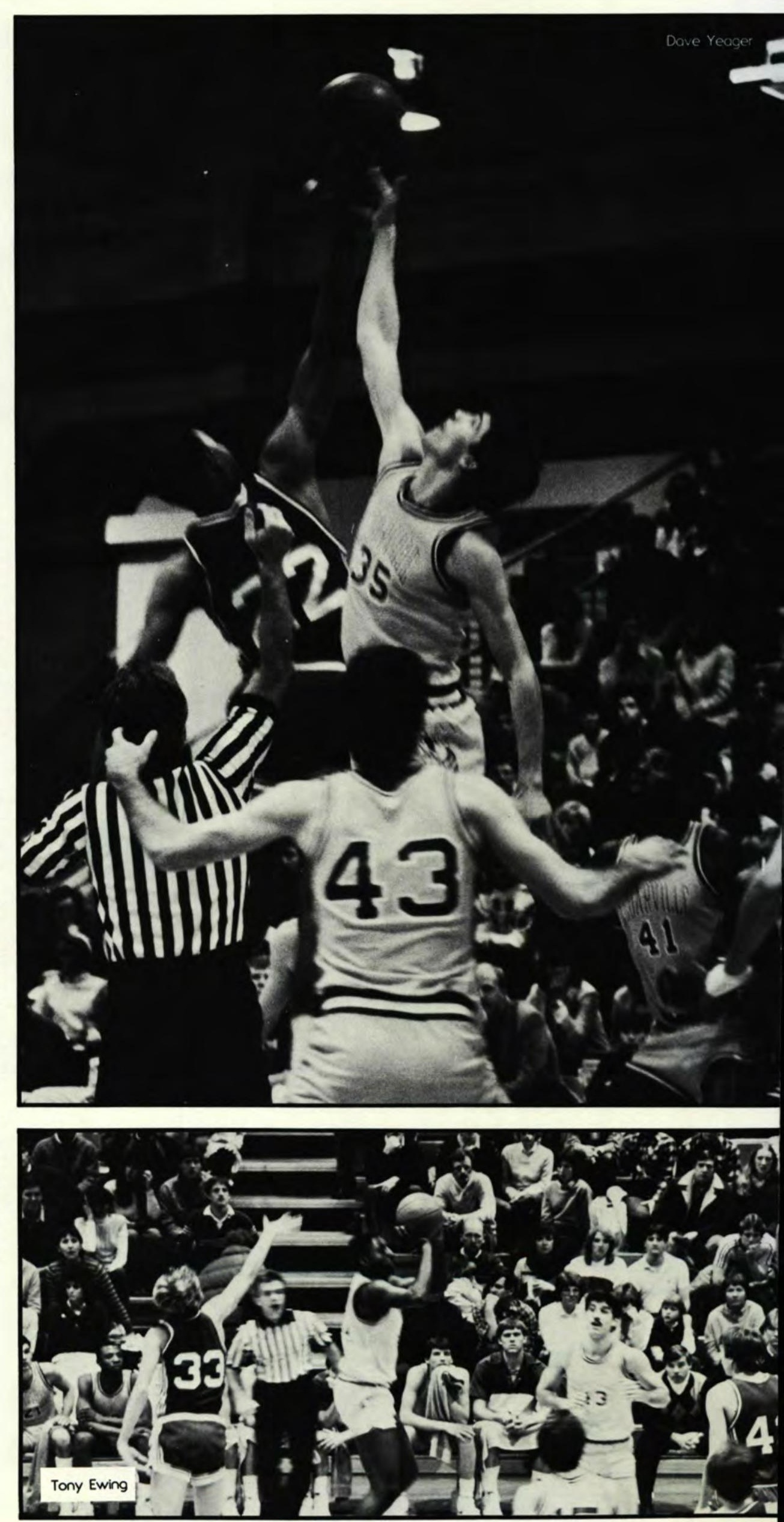




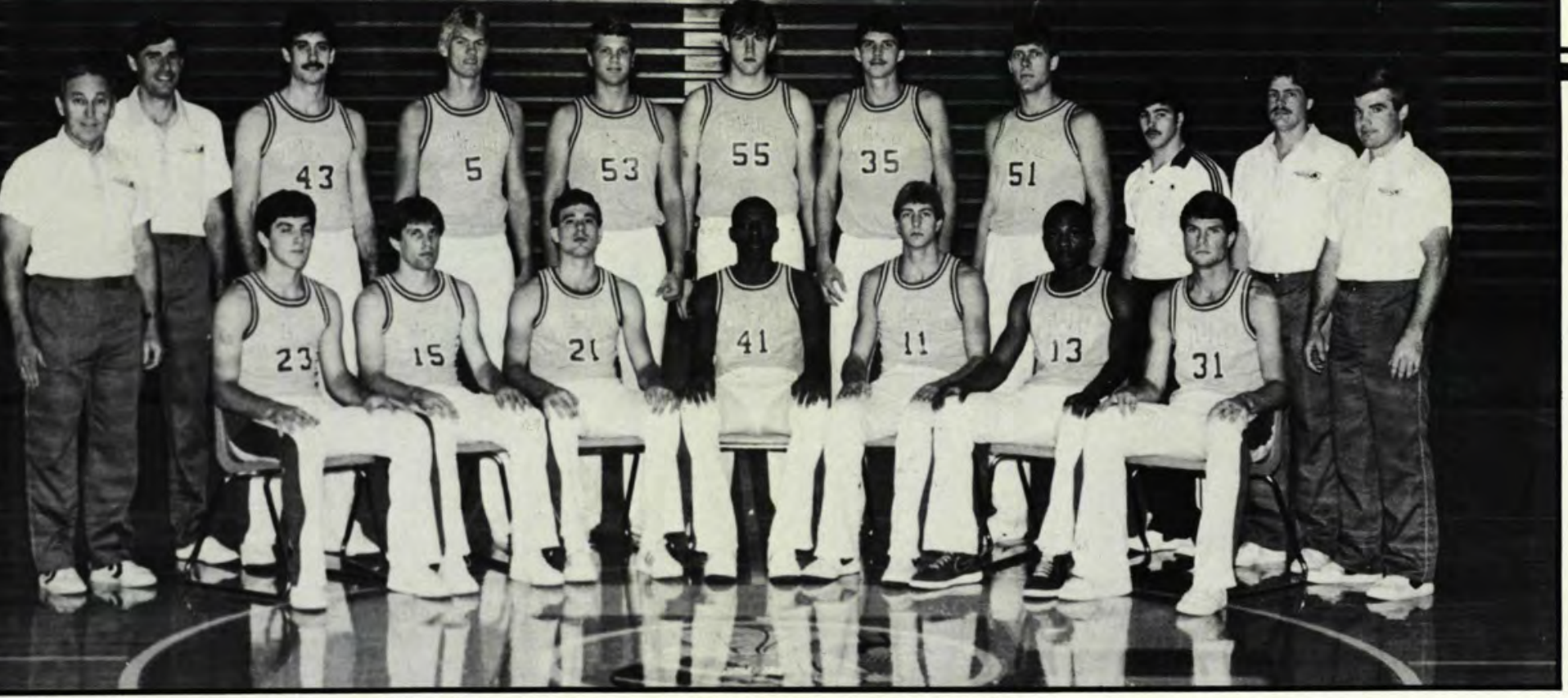

First Row: Danny Olinger, John Srnis, Tom Greve, Tony Ewing, Mike Campbell, Mike Freeman, Chris Reese; Second Row: Head Coach, Dr. Don Callan, Assistant Coach, Steve Young, Kirk Fairhurst, Mike Modderman, Chris Walter, Don Simerly, Dave Yeager, Steve Terpstra, manager, Mike Enman, Coach, Mark Kempron, Coach, Bob Fires

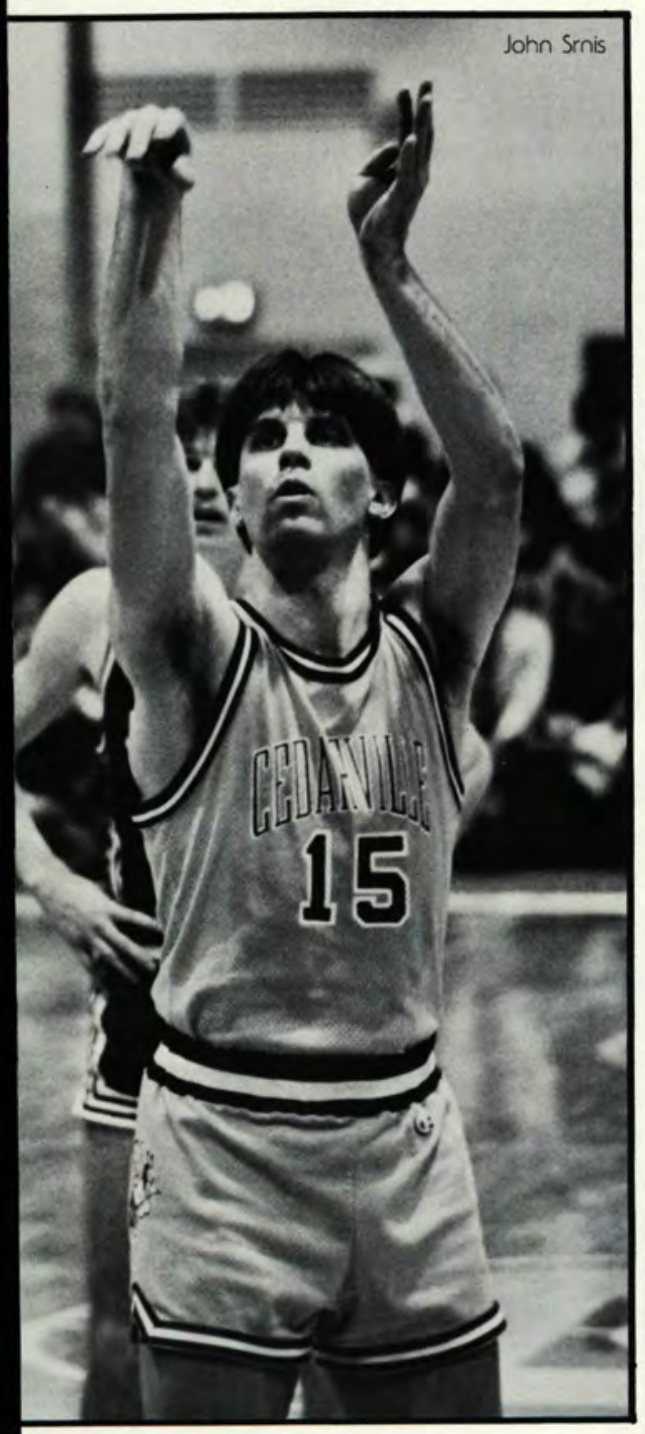

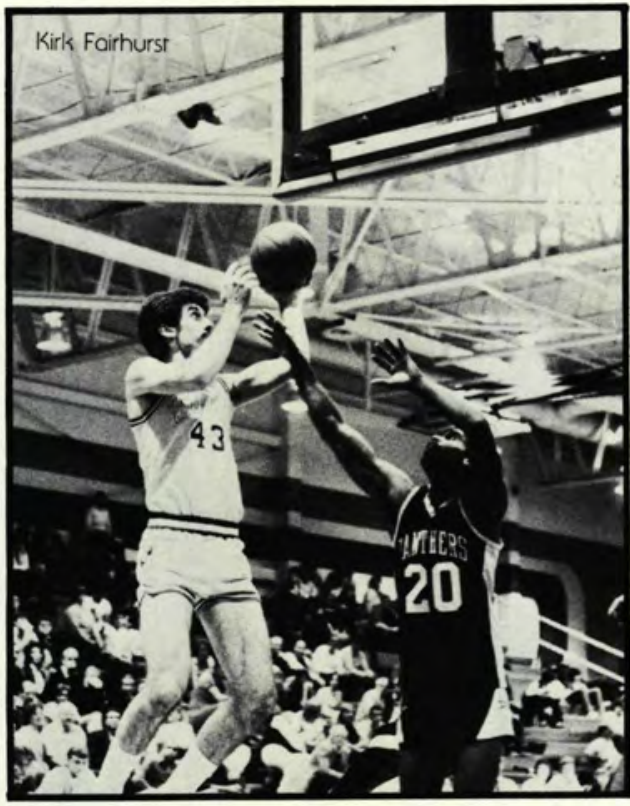

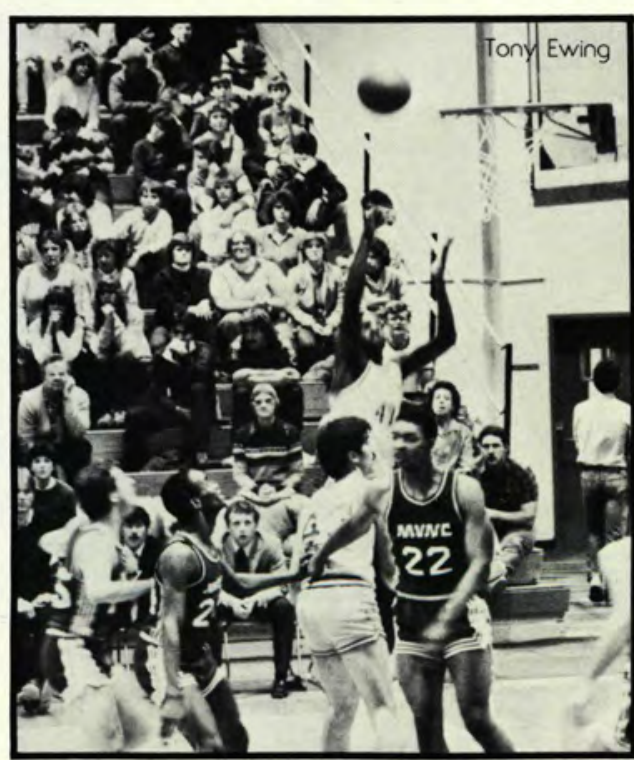

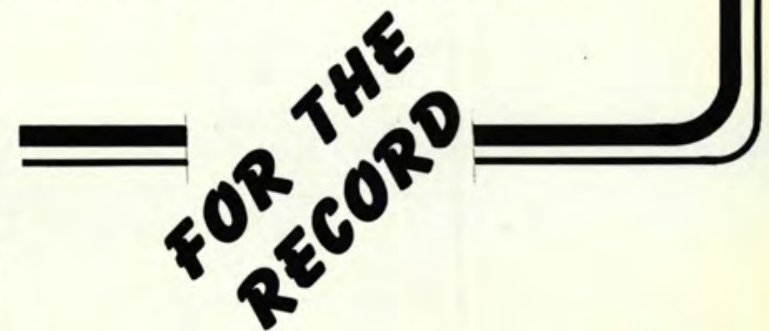

$\begin{array}{lrrl}\text { Cedarville } & 64 & 56 & \text { Goshen } \\ \text { Cedarville } & 65 & 66 & \text { Groce } \\ \text { Cedarville } & 68 & 55 & \text { Ohio Dominican } \\ \text { Cedarville } & 88 & 99 & \text { Rio Grande } \\ \text { Cedarville } & 83 & 73 & \text { Indiana Tech } \\ \text { Cedarville } & 113 & 82 & \text { Franklin } \\ \text { Cedarville } & 71 & 76 & \text { Wirtenberg } \\ \text { Cedorville } & 75 & 70 & \text { Ohio Wesleyan } \\ \text { Cedarville } & 87 & 81 & \text { Franklin } \\ \text { Cedarville } & 87 & 99 & \text { Denison } \\ \text { Cedorville } & 73 & 60 & \text { Wilmingron } \\ \text { Cedarville } & 84 & 97 & \text { Bluffron } \\ \text { Cedarville } & 94 & 69 & \text { Quebec-Three Rivers } \\ \text { Cedarville } & 97 & 89 & \text { Western Onrario } \\ \text { Cedarville } & 66 & 64 & \text { Tiffin } \\ \text { Cedarville } & 76 & 80 & \text { Urbano } \\ \text { Cedarville } & 54 & 70 & \text { Malone } \\ \text { Cedarville } & 81 & 80 & \text { Mr. Vernon } \\ \text { Cedarville } & 101 & 107 & \text { Ohio Dominican } \\ \text { Cedarville } & 69 & 92 & \text { Rio Grande } \\ \text { Cedarville } & 61 & 81 & \text { Wolsh } \\ \text { Cedarville } & 83 & 85 & \text { Tiffin } \\ \text { Cedarville } & 91 & 74 & \text { Urbana } \\ \text { Cedarville } & 61 & 76 & \text { Malone } \\ \text { Cedarville } & 85 & 60 & \text { Ohio Dominican } \\ \text { Cedarville } & 81 & 98 & \text { Rio Grande } \\ \text { Cedarville } & 100 & 96 & \text { Mr. Vernon } \\ \text { Cedarville } & 81 & 108 & \text { Wolsh } \\ \text { Cedorville } & 69 & 81 & \text { Taylor } \\ & & & \end{array}$

Record: 14.15 


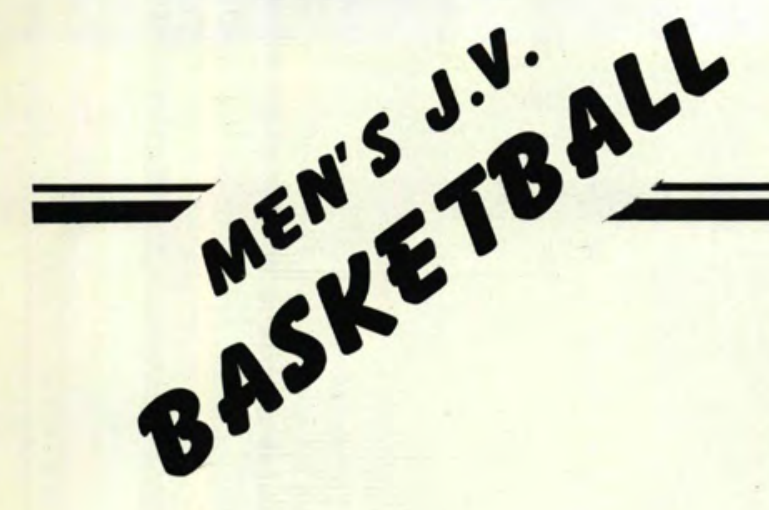

\section{The}

Beginning Of The

\section{Future}

$W$ hile a goal of the men's Junior Varsity Waskerball ream is certainly to establish a foundarion for furure varsity seasons, this year's ream nor only gained a grear deal of valuable experience, but also they exhibited an impressive scorecard. The men combined efforts to bring about the second most successful JV ream in Cedarville College history, posting a record of 13-4. Resident college sports expert, Mark Womack, characterized this ream as "unselfish and developed," which is an explanarion for the extent of its success.

Players such os junior Steve Terpstra, sophomore Doug Pugh, and freshman MVP Mike Warfield contributed significantly to lead the team on to larer victories over teams which had bearen the Jackets earlier in the season. The result of this unity, exemplified on court, sarisfied players and spectarors; baskerball fans can certainly look forward to the events of next season.
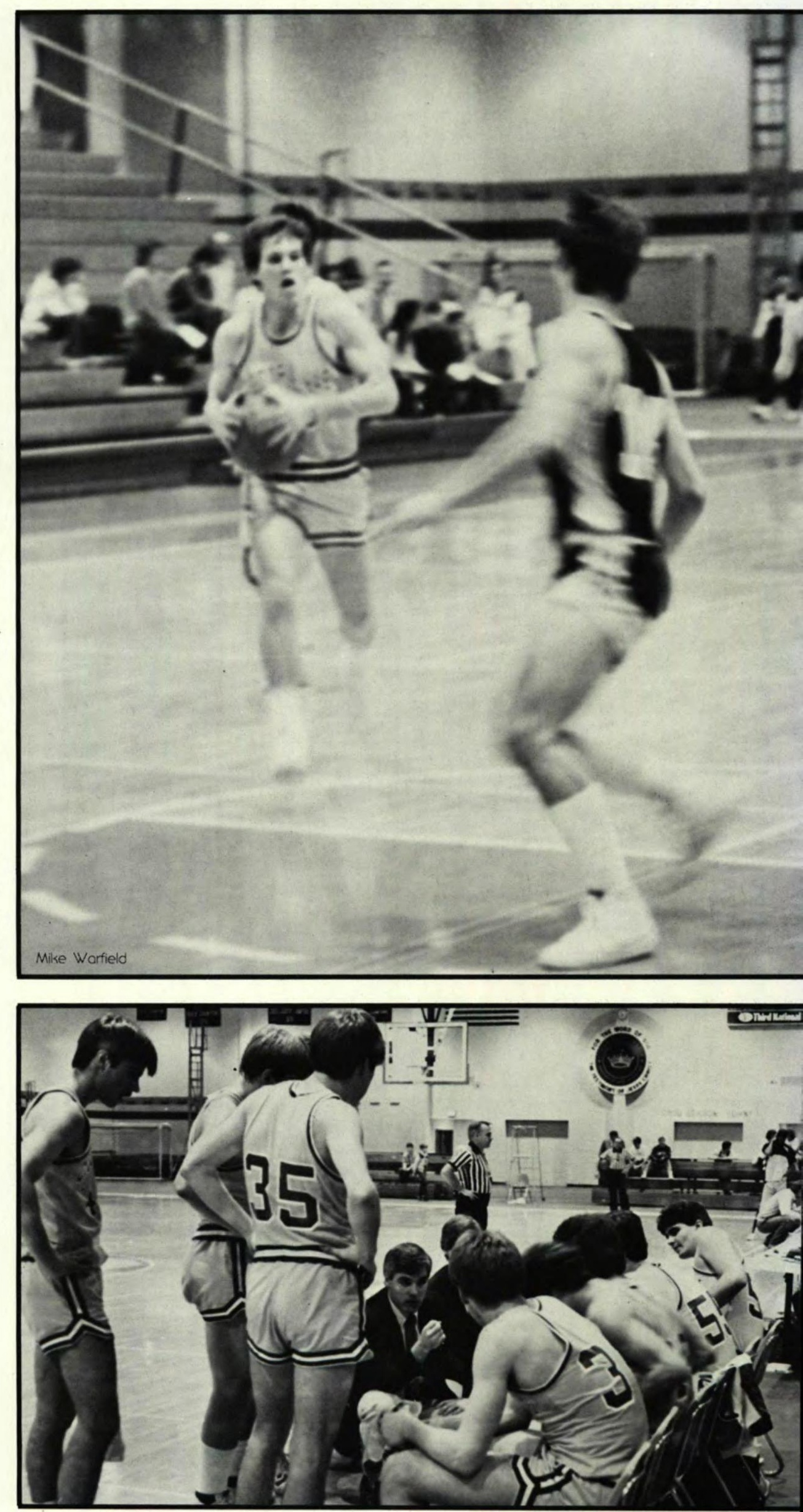


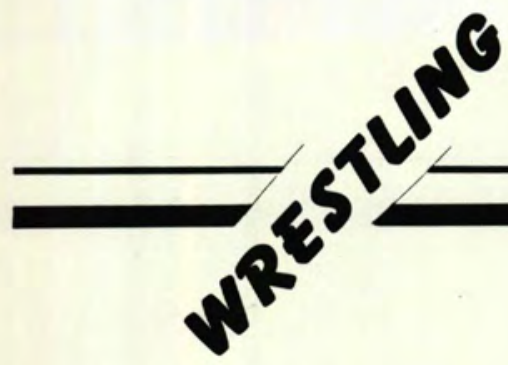

Starting From

\section{Scratch}

T he most unusual fact or statistic about the 1984-85 men's wrestling ream is that no ream existed or was planned when school opened. Coach Ron Comfort and several wrestlers, however, determined to keep the program alive, and wrestling was reinstared.

Composed entirely of freshmen and sophomores, the team had to face opposition from formidable Division II and III schools in order to compete. While the season record of $2-10$ betrays the ream's inexperience, the strong third pace finish at the NCCAA National meet indicares the growth that took place throughout the season.

Praising the perseverence of his men, Coach Comfort stared, "No single individual can be pointed our; each and every wrestler contributed his share to the program." Those wrestlers returning to grapple in the 1986 season can assuredly look forward to one thing: there will be a ream next year.
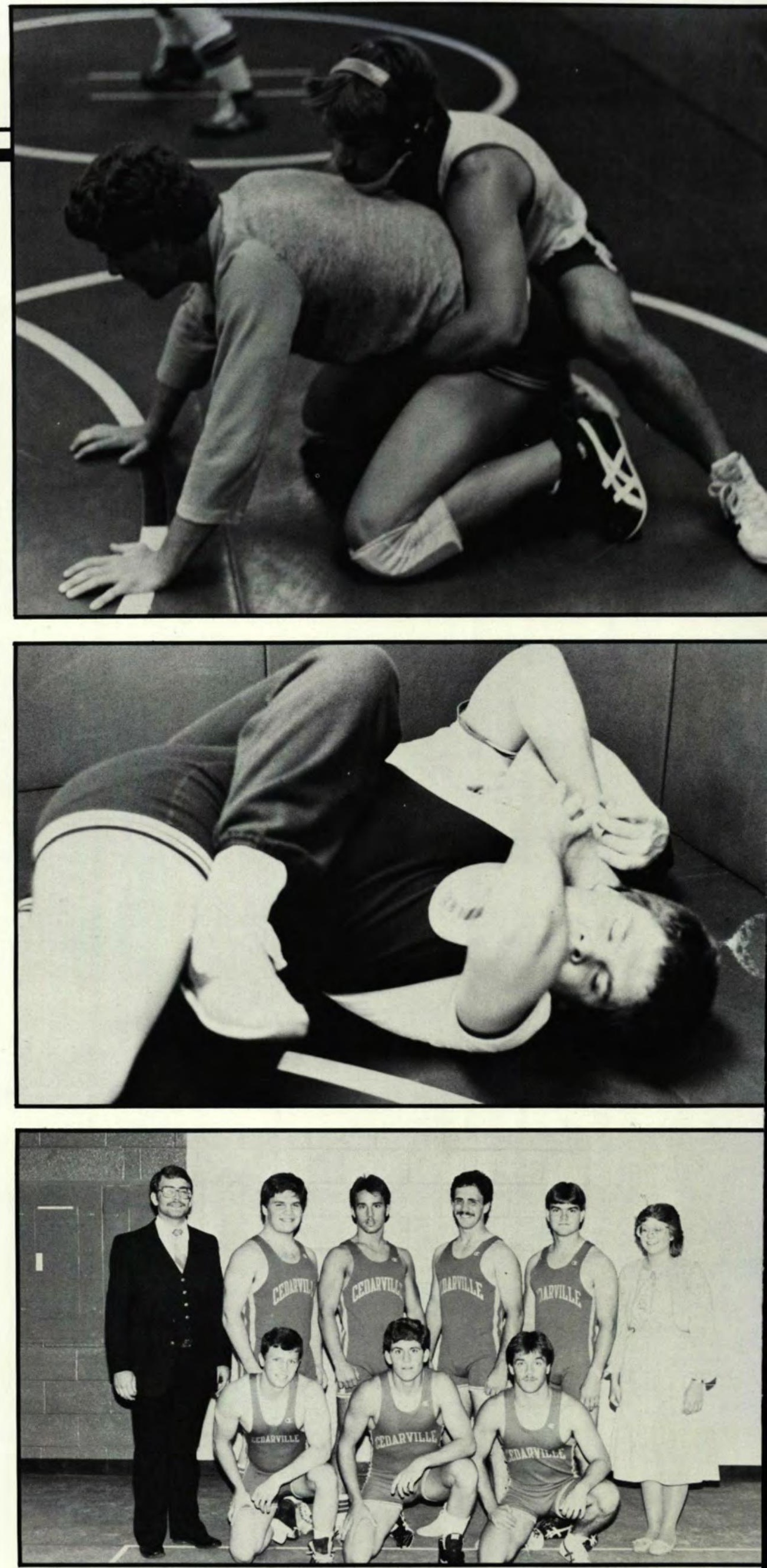

First Row: Todd Dowden; Kelly Moore, Chris Link; Second Row: Cooch Ron Comfort, Todd Hummel, Rob English, English, Galyn Nook, Sraristician, Janis Comfort 


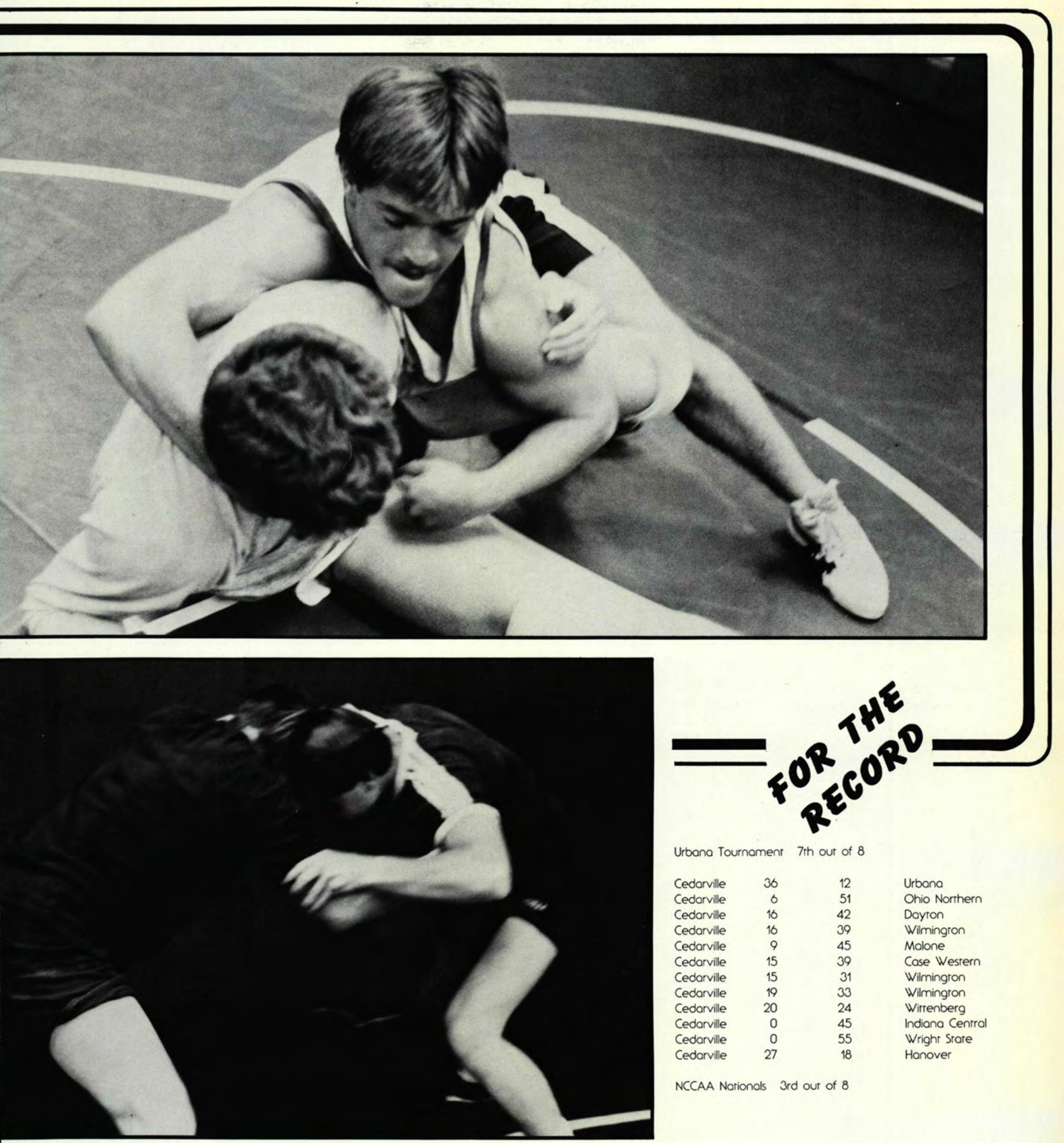



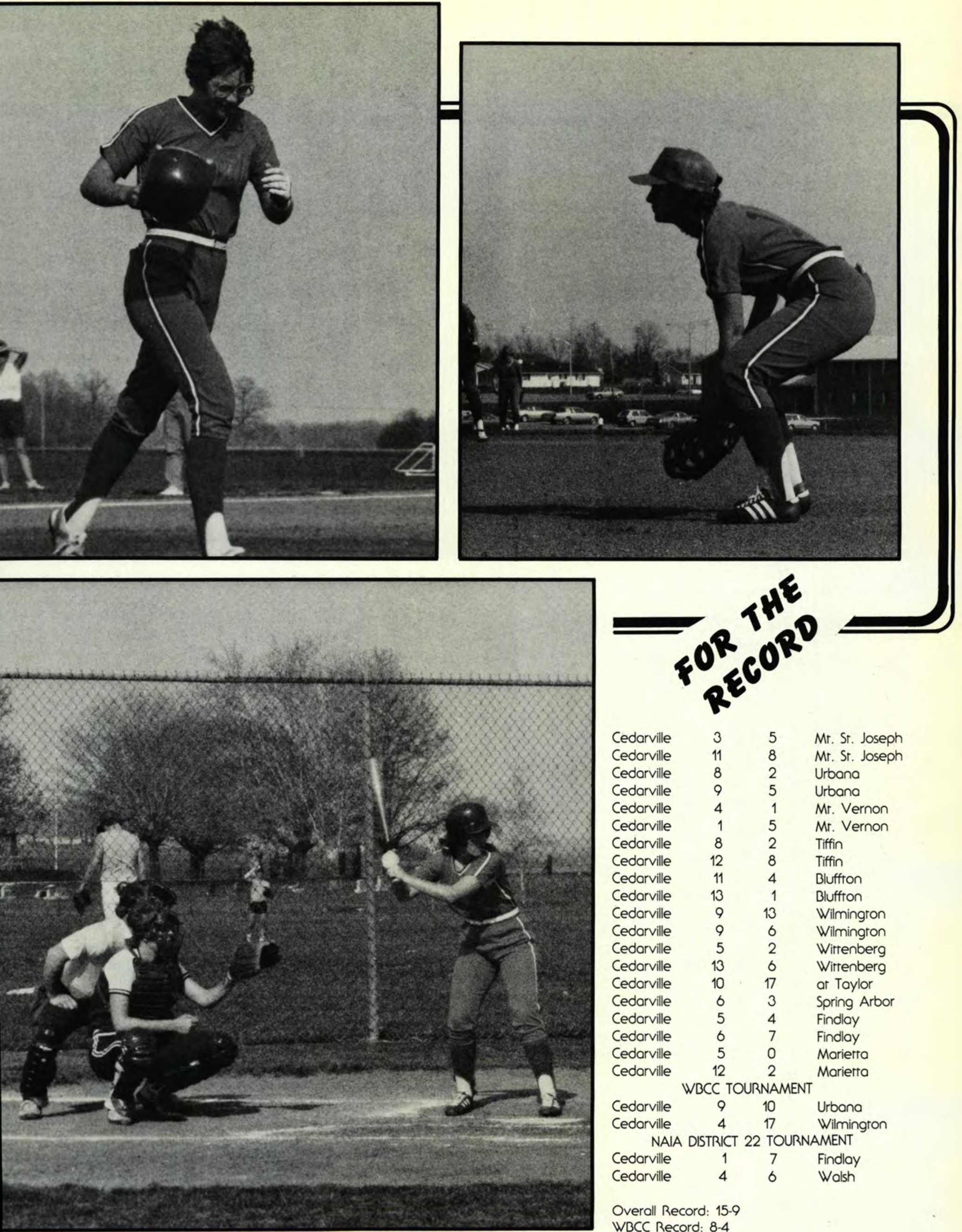

Cedarville

Cedarville

Cedarville

Cedarville

Cedarville

Cedarville

Cedarville

Cedarville

Cedarville

Cedarville

Cedarville

Cedorville

Cedarville

Cedarville

Cedarville

Cedarville

Cedarville

Cedarville

Cedarville

Cedarville

Cedarville

Cedarville

Cedarville

Cedarville

$\begin{array}{ccl}3 & 5 & \text { Mr. Sr. Joseph } \\ 11 & 8 & \text { Mr. Sr. Joseph } \\ 8 & 2 & \text { Urbana } \\ 9 & 5 & \text { Urbana } \\ 4 & 1 & \text { Mr. Vernon } \\ 1 & 5 & \text { Mr. Vernon } \\ 8 & 2 & \text { Tiffin } \\ 12 & 8 & \text { Tiffin } \\ 11 & 4 & \text { Bluffton } \\ 13 & 1 & \text { Bluffton } \\ 9 & 13 & \text { Wilmingron } \\ 9 & 6 & \text { Wilmingron } \\ 5 & 2 & \text { Wirtenberg } \\ 13 & 6 & \text { Wirtenberg } \\ 10 & 17 & \text { ar Taylor } \\ 6 & 3 & \text { Spring Arbor } \\ 5 & 4 & \text { Findlay } \\ 6 & 7 & \text { Findlay } \\ 5 & 0 & \text { Marierta } \\ 12 & 2 & \text { Marierta } \\ \text { BCC TOURNAMENT } & \end{array}$

TOURNAMENT

$\begin{array}{lll}9 & 10 & \text { Urbana } \\ 4 & 17 & \text { Wilmingron }\end{array}$

IA DISTRICT 22 TOURNAMENT

46 Walsh

Overall Record: $15-9$

WBCC Record: 8-4 


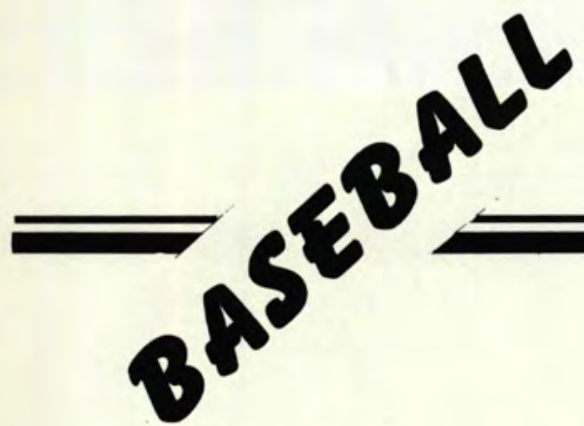
parked by the leadership of first-year
baseball coach Dan Coomes, the men's baseball ream rebounded from a disappointing 1984 season to post a 1985 record of 18 wins and 11 losses. These wins included victories over the formidable opposing reams of University of Dayton, Central State, and Mr. Vernon Nazarene College.

Sophomore Danny Olinger and senior, "Best Defensive Player" Gary Mills also led the ream in its successful campaign in the roles of cocaprains. Sophomore Tom Pratr was named to the NAIA District 22 team, while Finney Rajchel was named "Most Valuable Player" by his reammares. These individuals combined with other team members to advance to the finals of the NAIA District 22 finals where they were defeared by Ohio Dominican.
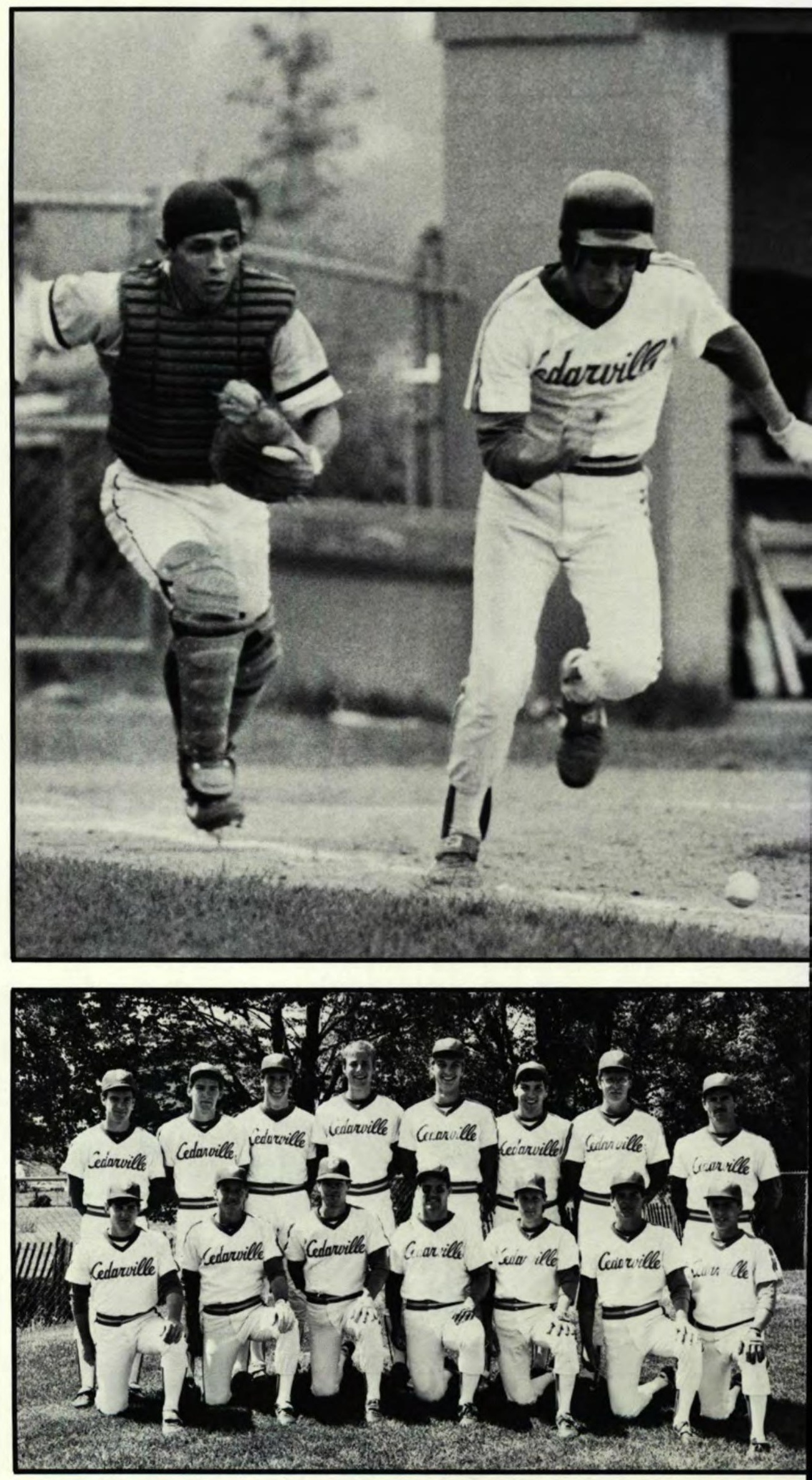

Kneeling: Chris Walrer, Norm Cox, Roger Lutrrel, Gary Mills, Steve Cremean, Nare Hunrer, So Springer. Standing: Ken Horton, Bryan Montross, Tom Pratr, Finney Rajchel, Dan Erlandson, Dan Olinger, Steve Sagraves, Coach Dan Coomes. 


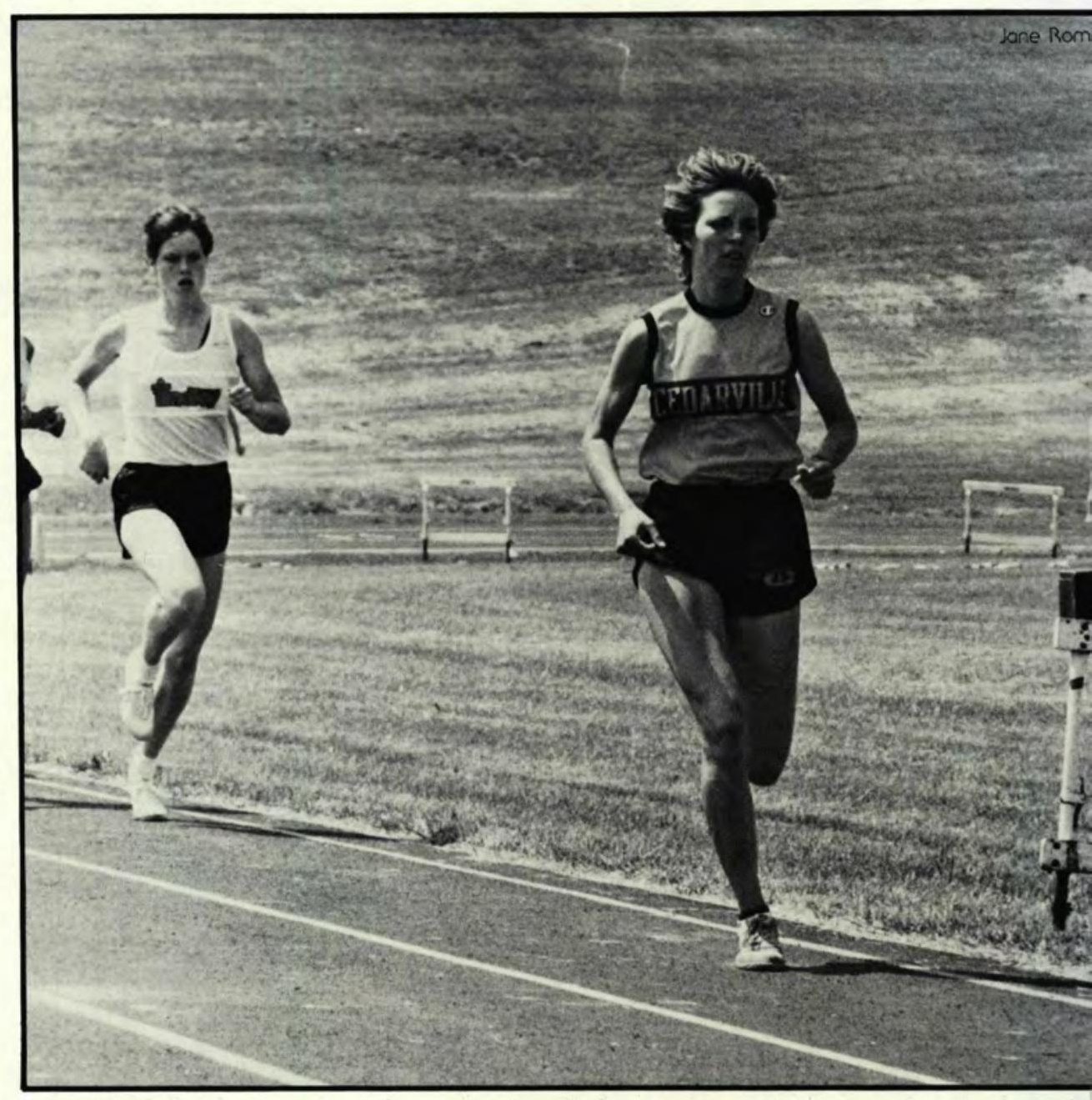

They've come a long way! In only rheir fourth year of intercollegiare comperition, the women's rrack ream had a seoson thar Coach John McGillivray lobeled their "strongest and most successful." The women rurned in ourstanding performances rhroughour the season in every evenr; school records were broken in all bur rwo events. Ar the top of the heap of accolodes amossed by the women was a first place ream finish ar the NCCAA Narional Track Championships. Contriburing ro her ream's impressive win, Jone Romig ser meer records in the 800 and 1500 merers.

Romig wos also named Ourstonding Female Performer of the meer and wos the recipient of the Wheeler Award given to the ourstanding NCCAA track and field arhlere of the yeor

In oddirion Esther Mohr and Berh McGilivroy were No rional Champions in the 400 merers and high jump. Cooch McGilivray, appropriarely owarded for his contribution to the ream's success, shared in the laurels by receiving Coach of the Yeor honors.
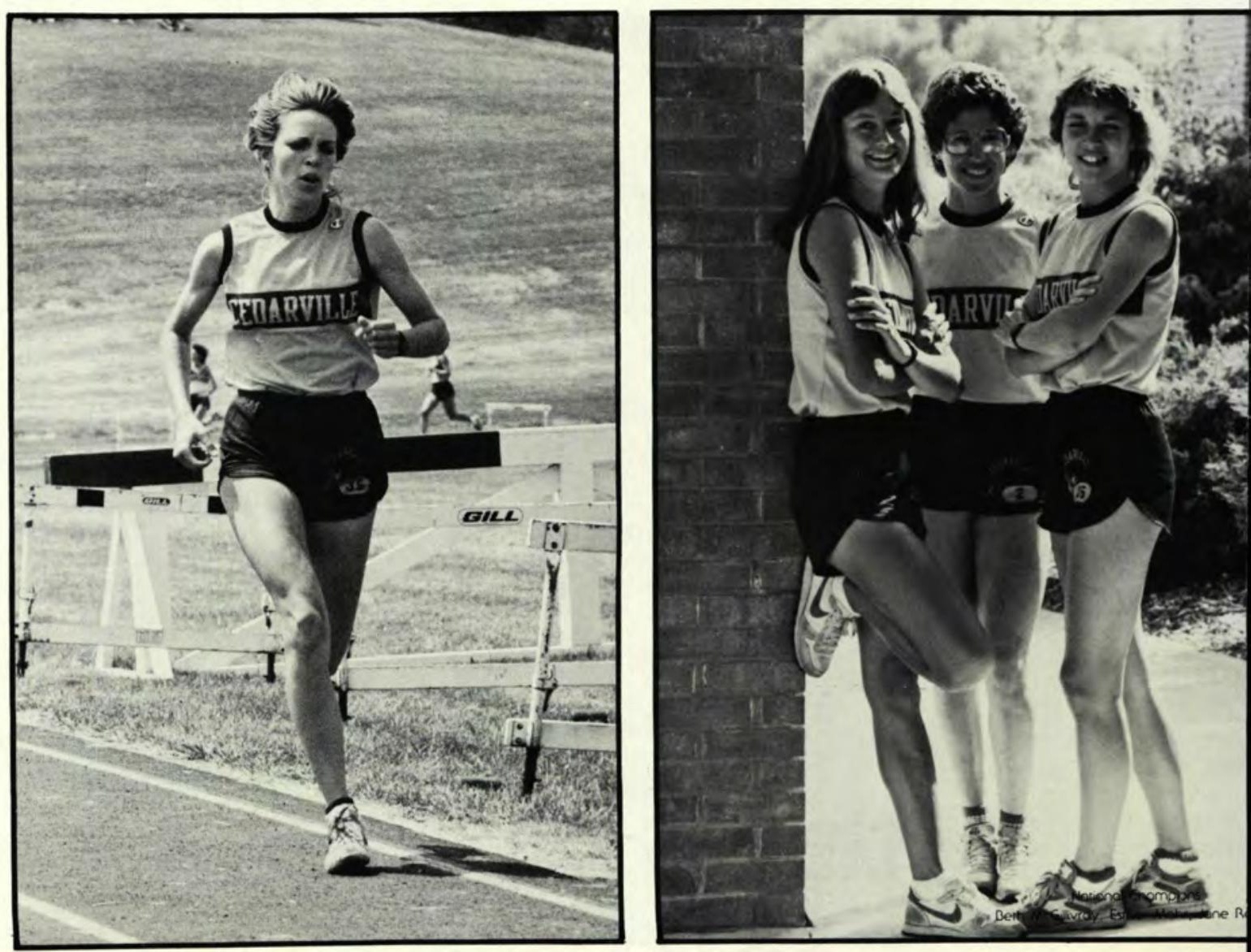


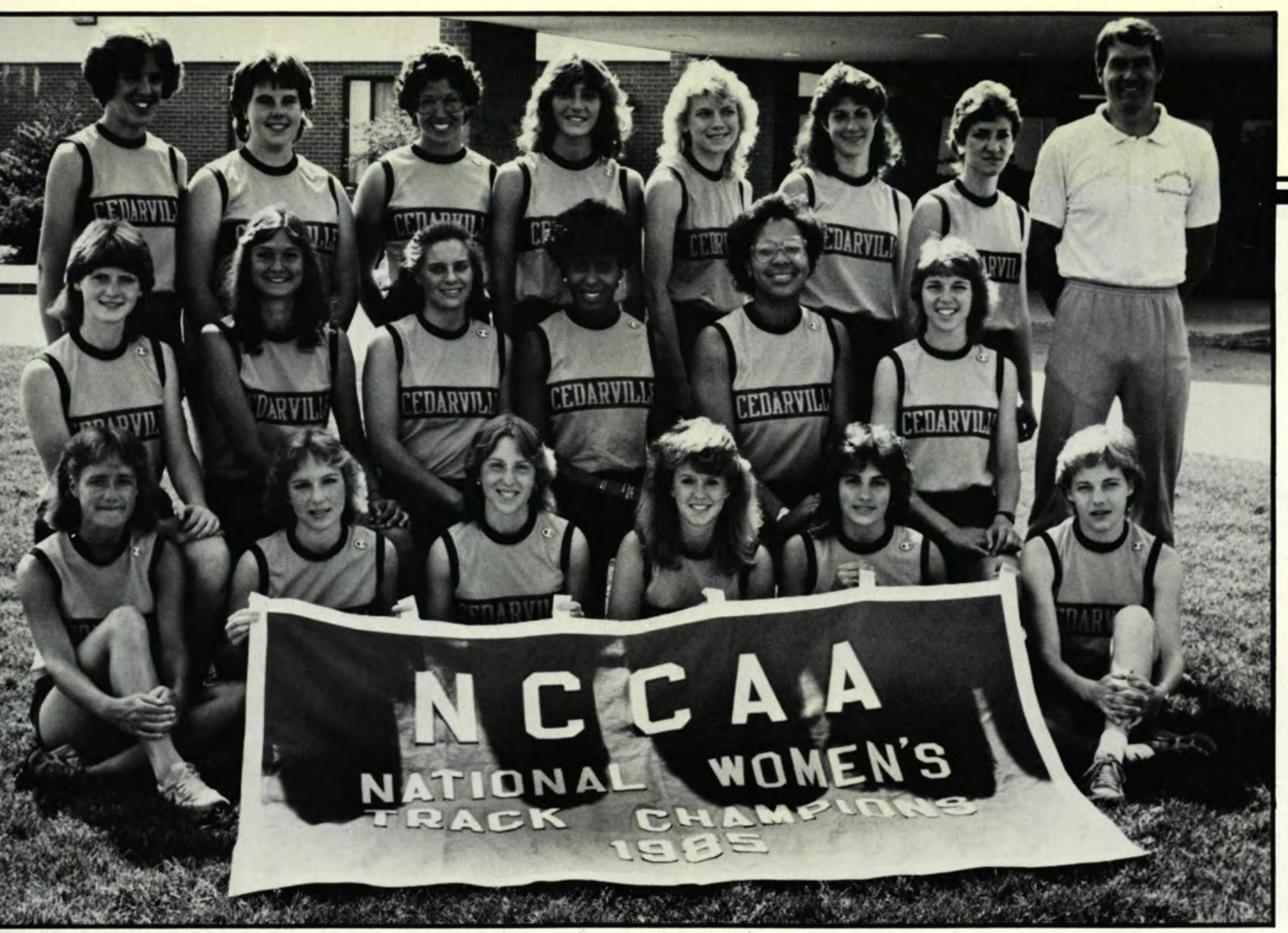

ar Row: Sue Voughn, Ann Haskowich, Fran Hoskowich, Wendy Grady, Cindy Collier, Kris Parman, Middle Row: Becky Averil, Berh McGillivray, Karhy Reynolds, Tanya Jee, Ebbie Raddiff, Jone Romig, Back Row: Cheryl Rindle, Loura Huggarr, Esther Mohr, Grerchen Mounrz, Jody Eckert, Michelle Snyder, Karhy Worson, Cooch McGillivary.
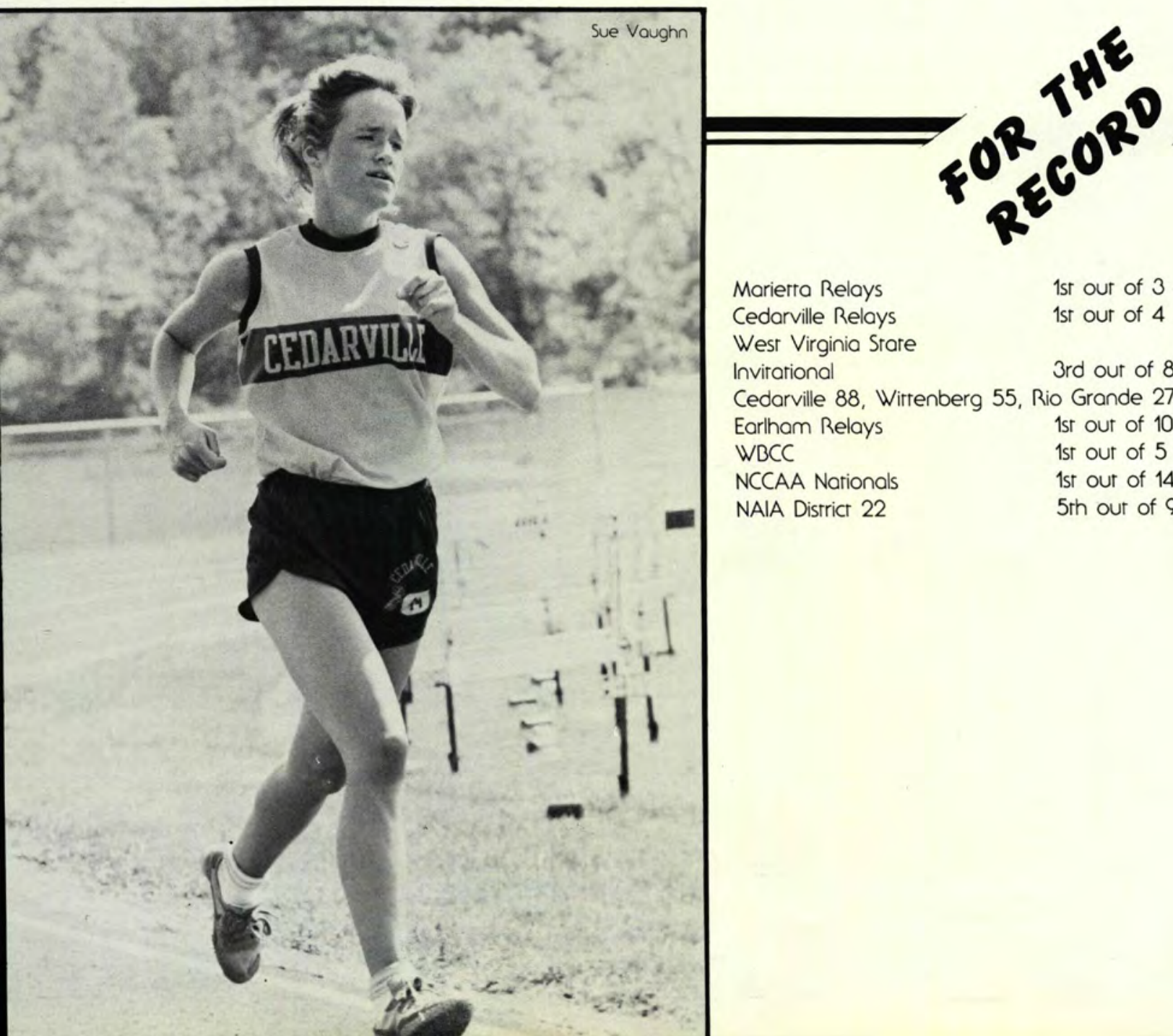

Marierta Relays

Cedarville Relays

West Virginia Stare

Invirarional

Cedarville 88 , Wittenberg 55 , Rio Grande 27

Earlham Relays

WBCC

NCCAA Nationals

NAIA District 22 1st out of 3

1st out of 4

3rd our of 8

1st out of 10

1st out of 5

1st out of 14

5 th out of 9 


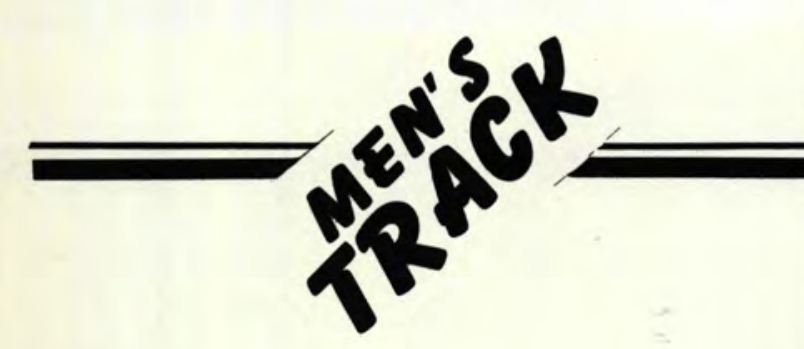

\section{Diversity Leads}

\section{Team}

The diversity of talent displayed by the I men's track ream led the ream to several championships and a variery of impressive victories. Culrivaring the talent of team members early in the winter months, Coach Elvin King saw the beginnings of a ream thar would rake second place ar the NCCAA Narional meer and win several invirationals including those ar West Virginia Stare, Findlay College, and the Marierra Relays.

While Rob Moore copped ream MVP honors because of his strong finishes throughout the season, many orher ream members contribured significantly to the season's success. The ream members ser school records in five different events, further demonstraring the deprh and diversity of the ream's talents. Leading the distance runners, NAIA All-American Moore ser a record in the 1500 merers. Sprinters De Smith and Tim Walrers ser records in the 100 merers and 110 merer hurdles and were also named to the NCCAA All-American ream. Setring records in the javelin and hammer were Scort Hannay, onorher All-American.

Always striving for excellence, the ream in the form of its many members once again reached longer distances, foster times and new heights.
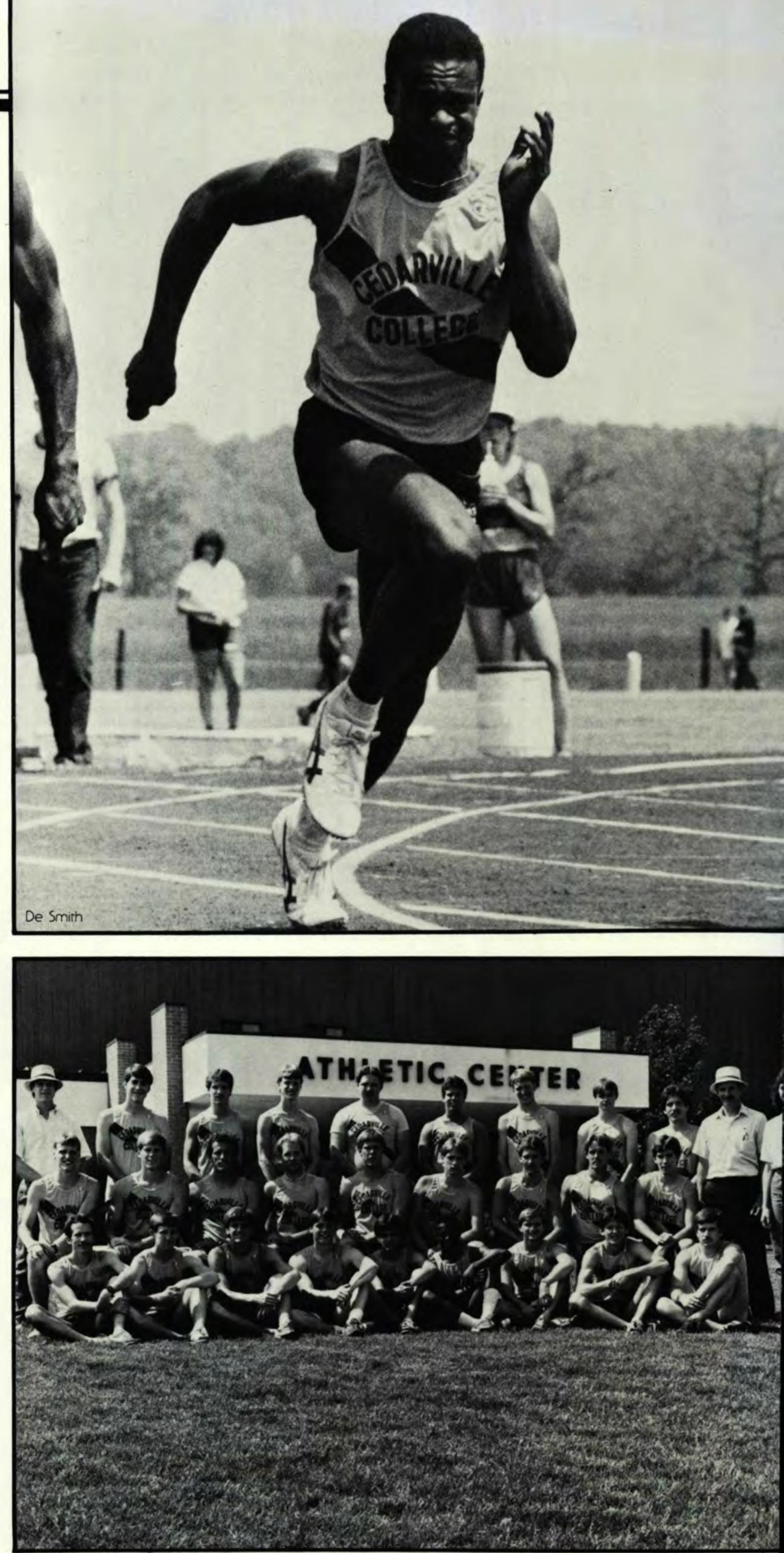

Front Row: Steve Cox, Rusty King, Rob Moore, Clancy Cruise, Tom Hill, De Smith, Dave Christm Dave Schumaker, Ric James, Middle Row: Gary Anderson, Eric Shrum, Tim Walrers, Jan Brewin, Sreve Terpstra, Joel Hayden, Clarence Eddy, Scort Hannay, Dave Moody, Back Rd Manager, Doug Cherry, Dean Price, Kevin Wallace, Philip Hulbert, Marc Herrmann, Scorr BroolJim Parvis, Ron Kuntz, Coach Elvin King, Manager - Ann Blessing. 

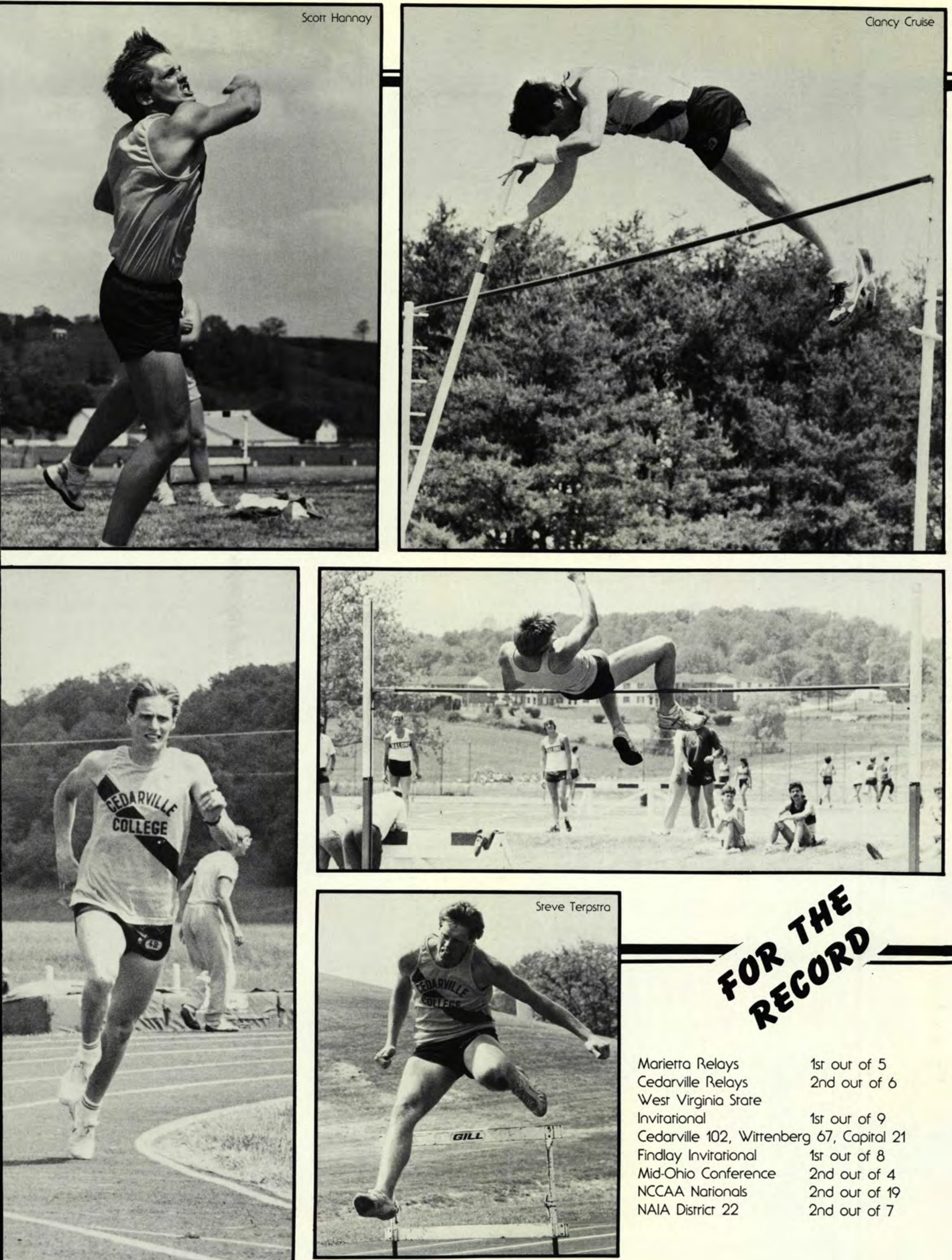

Marierta Relays

Cedarville Relays

West Virginia Srate

Invitarional

Cedorville 102, Wittenberg 67, Copira

Findlay Invirational 1st our of 8 Mid-Ohio Conference

NCCAA Narionals

NAIA District 22 1st out of 5

2nd out of 6

1st our of 9

2nd our of 4

2nd out of 19

2nd our of 7

$$
\text { 更 }
$$




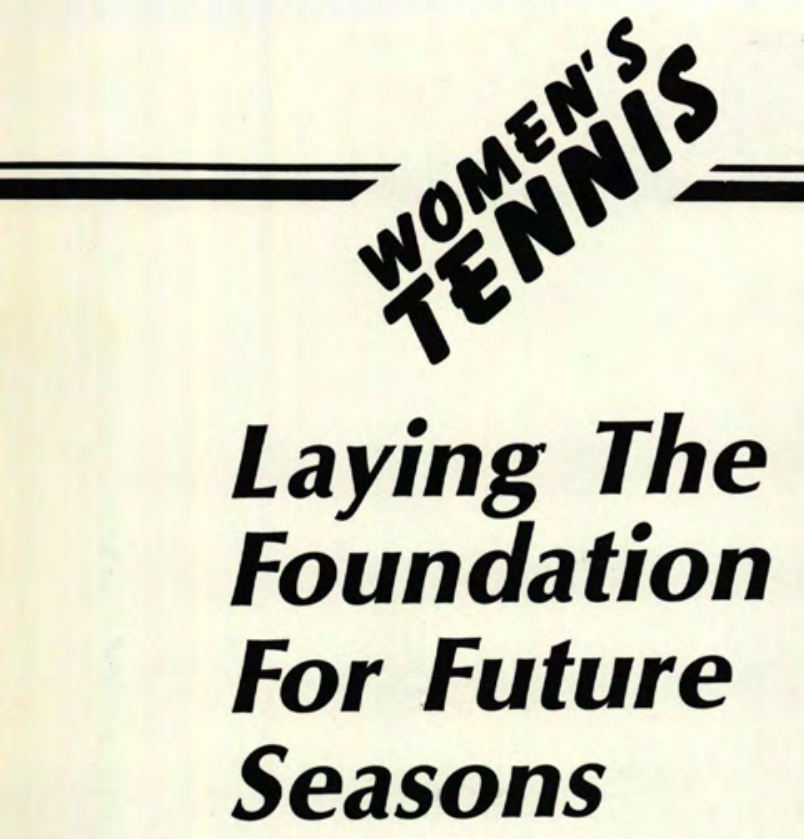

E xperience: It is the sought-after

E foundation upon which winning teams are built. For the women's tennis ream, 1985 was a season of laying foundations for furure seasons.

The ladies finished a somewhat disappointing third place in the NAIA District 22 home match, failing to defend their title. Posting an adequate but losing record of 4-6, the 1984 women met the challenges presented by opposing reams. Their record belies the effort and talent displayed by the ladies as many of the meets were lost by only one point.

Lee Austin and Roge Lash gained some valuable experience in their novice year; Austin posted the best record of the season at her number six position, and Lash was recognized as the best rookie. The doubles team of Laura Wuestner and Dawn Reehl won AllDistrict honors. Tracy Turner and Melanie Marhewson earned team awards as most-improved and coach's award respectively.

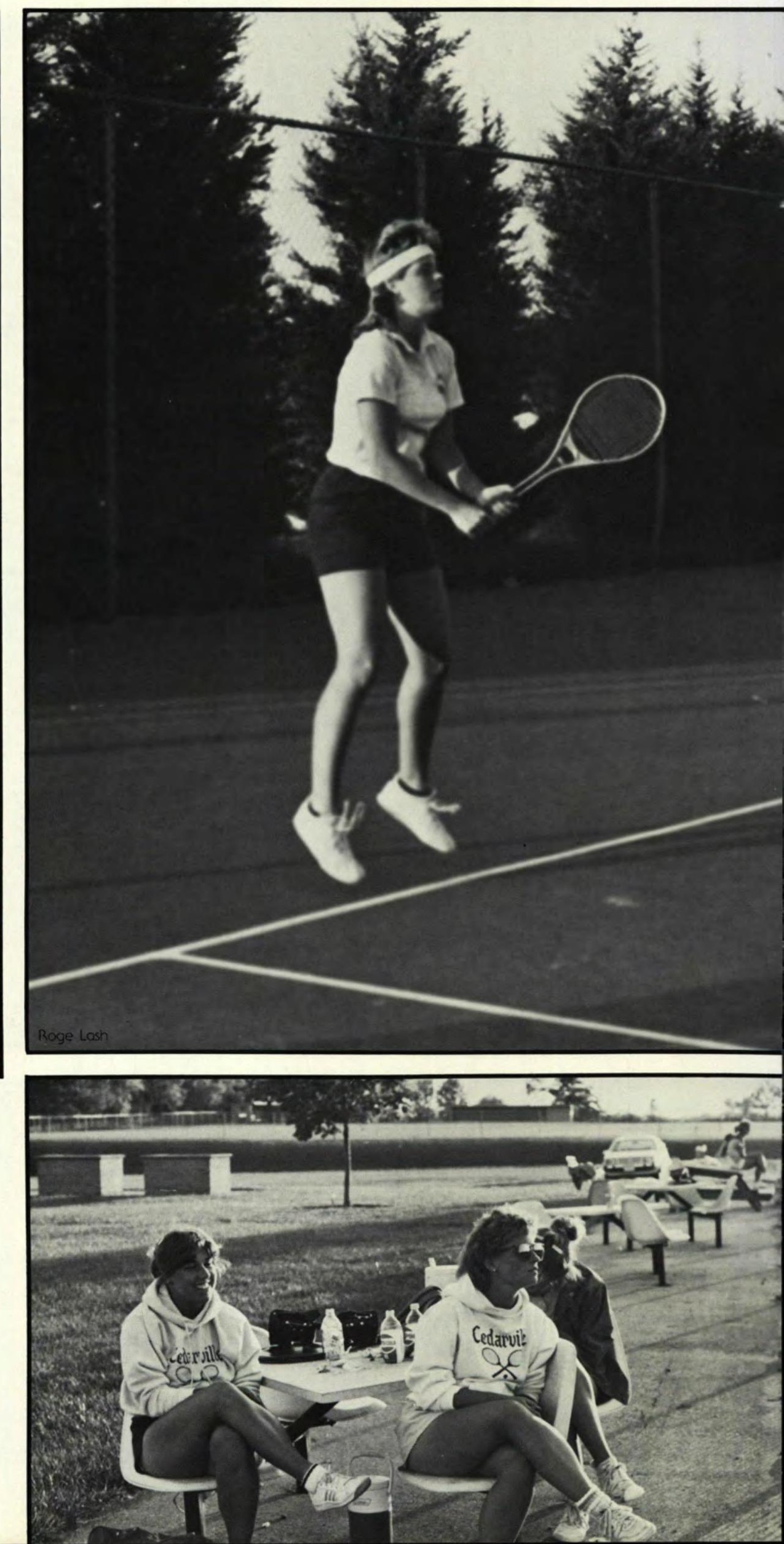




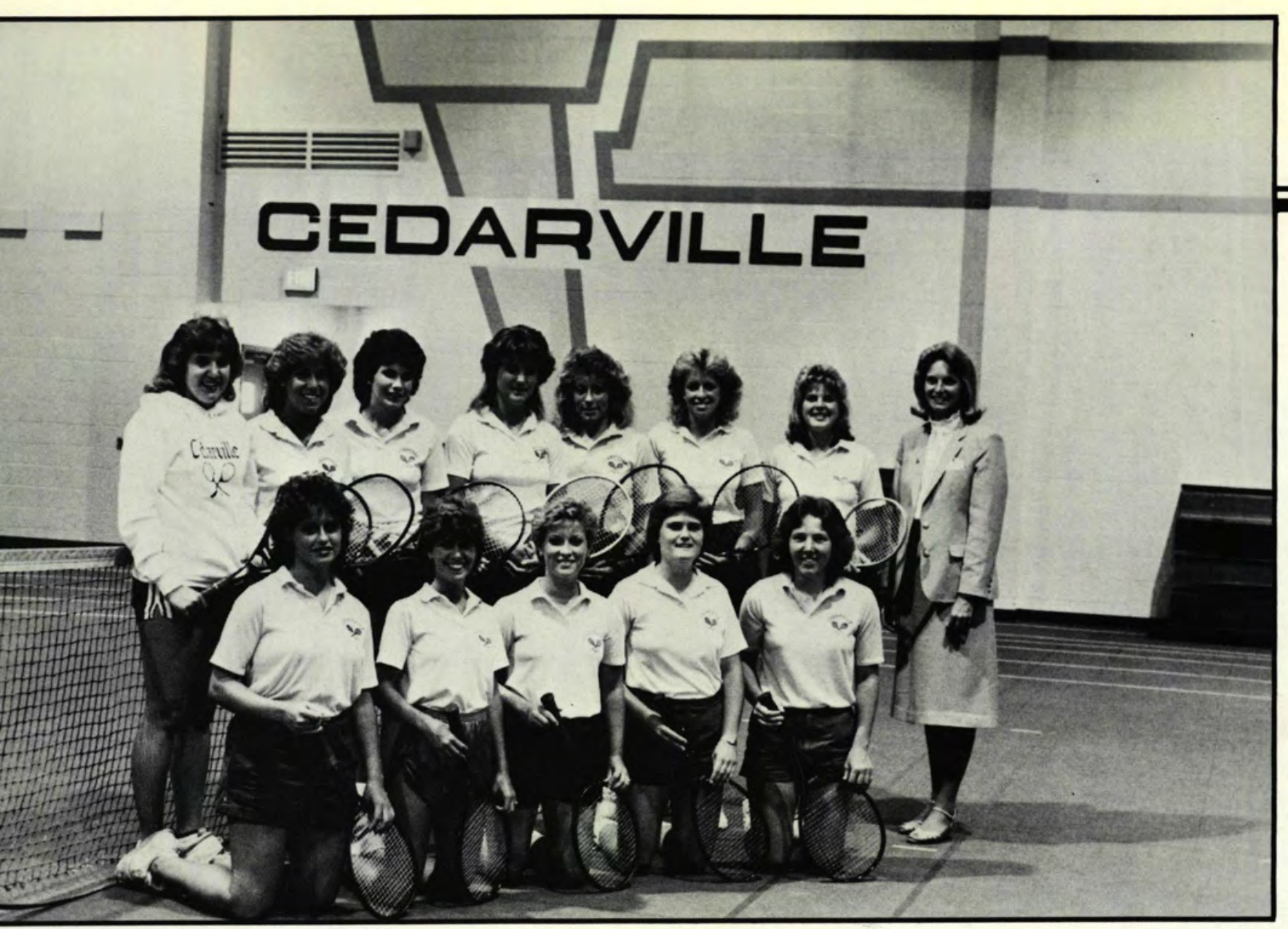

r Row: Lee Austin, Cindy Stolzfus, Judy Happe, Melanie Marthewson, Tracy Turner, Back Row: Berh Nester, Dawn Reehl, Parti Webb, y Corton, Deborah Yacynych, Laura Wuestner, Roge Lash, Coach Dr. Diehl.
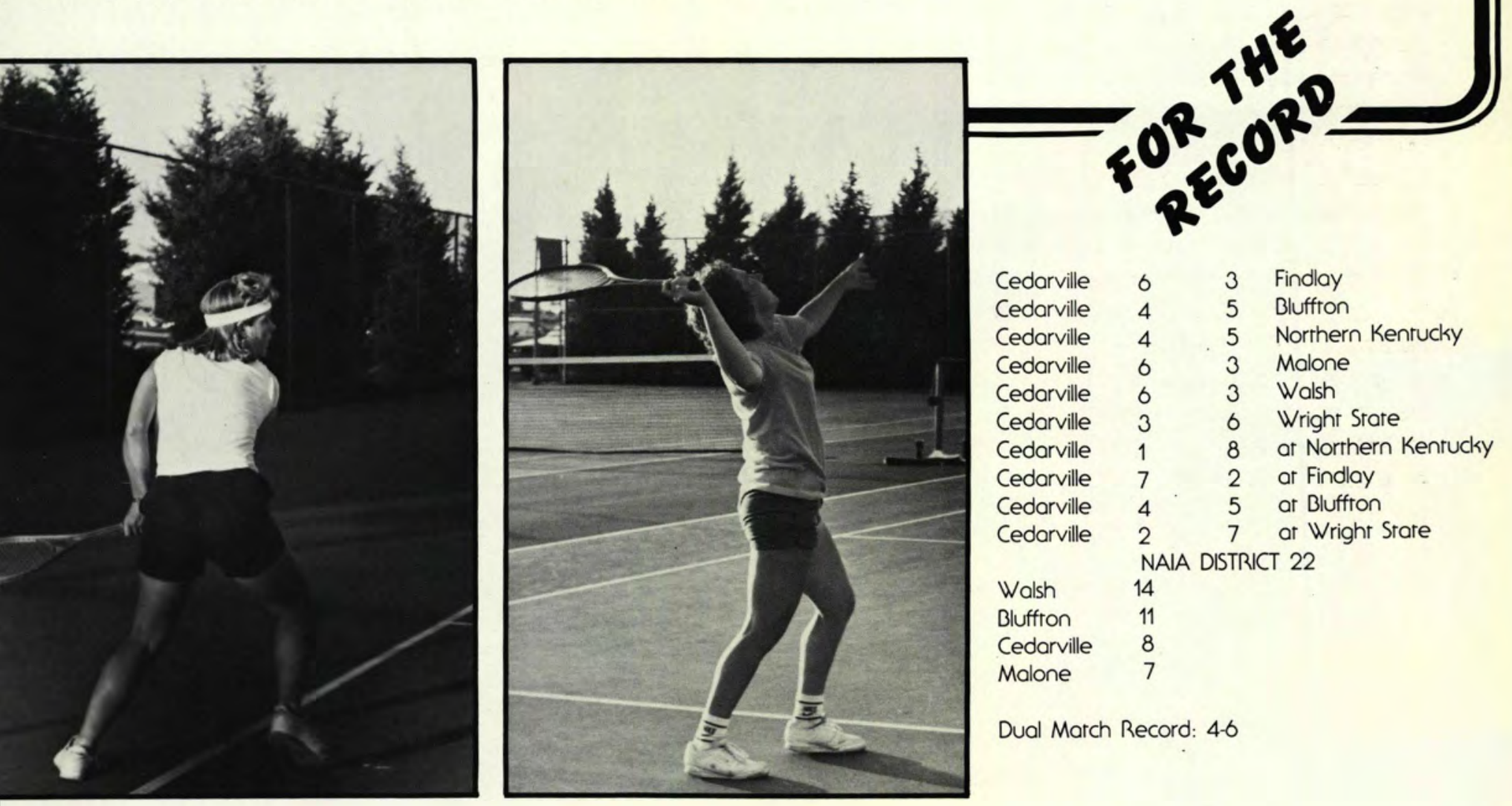

Cedarville $6 \quad 3$ Findlay

Cedarville $4 \quad 5$ Bluffton

Cedarville $\quad 4 \quad 5$ Northern Kenrucky

Cedarville 6 3 Malone

Cedarville $6 \quad 3$ Walsh

Cedarville $3 \quad 6 \quad$ Wright State

$\begin{array}{llll}\text { Cedarville } & 1 & 8 & \text { at Northern Kentucky }\end{array}$

Cedarville $7 \quad 2$ ar Findlay

Cedarville 4.5 ar Bluffron

Cedarville $2 \quad 7$ ar Wright Stare

NAIA DISTRICT 22

Walsh $\quad 14$

Bluffton 11

Cedarville 8

Malone 7

Dual March Record: 4-6 


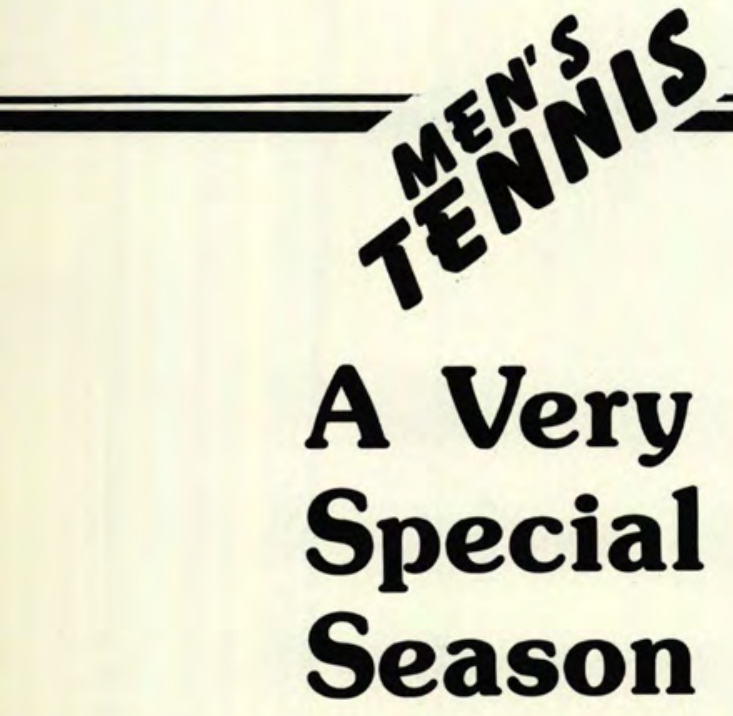

"They did what no one in the district thought they could do. A lor of years we had been favored to win hands down; this year we were nor favored and won the district anyhow. That made this season very, very special."

Summing up his twentierh year of coaching men's tennis at Cedarville, Dr. Murray Murdoch praised his ream's determination in a year "When norhing came rerribly easy." Wirh only two players rerurning from the varsity line-up, former junior varsity from the varsity line-up, and doubles players filled the empry positions capably. As a result, the ream compiled an impressive season's record of 15 wins and 3 losses which included winning an exciting 5-4 march over Walsh, The Mid-Ohio Conference ritle, and their fourteenth consecurive district crown

Guiding his reams with his skilled coaching hand, Coach Murdoch has amassed a phenominal record of 336 wins and 45 losses over the last twenty years. In honor of this achieve ment, players past and present gathered over the weekend of May 20 to pay tribute to their coach. Coach Murdoch stared of the reunion that "it was a tremendous thrill for me and a great opportunity to see some kids whom I haven't seen since they graduared from $\mathrm{Ce}$ darville."

Ranking as the ream's number one player for four years, caprain Gary Coiro provided leadership for the ream as an Academic AllAmerican; he graduated with an ourstanding record in borh singles and doubles. Senior Bruce Richards moved up the ranks to play varsity singles and provided the ream with critical vicrories in both the M.O.C. and district championships.
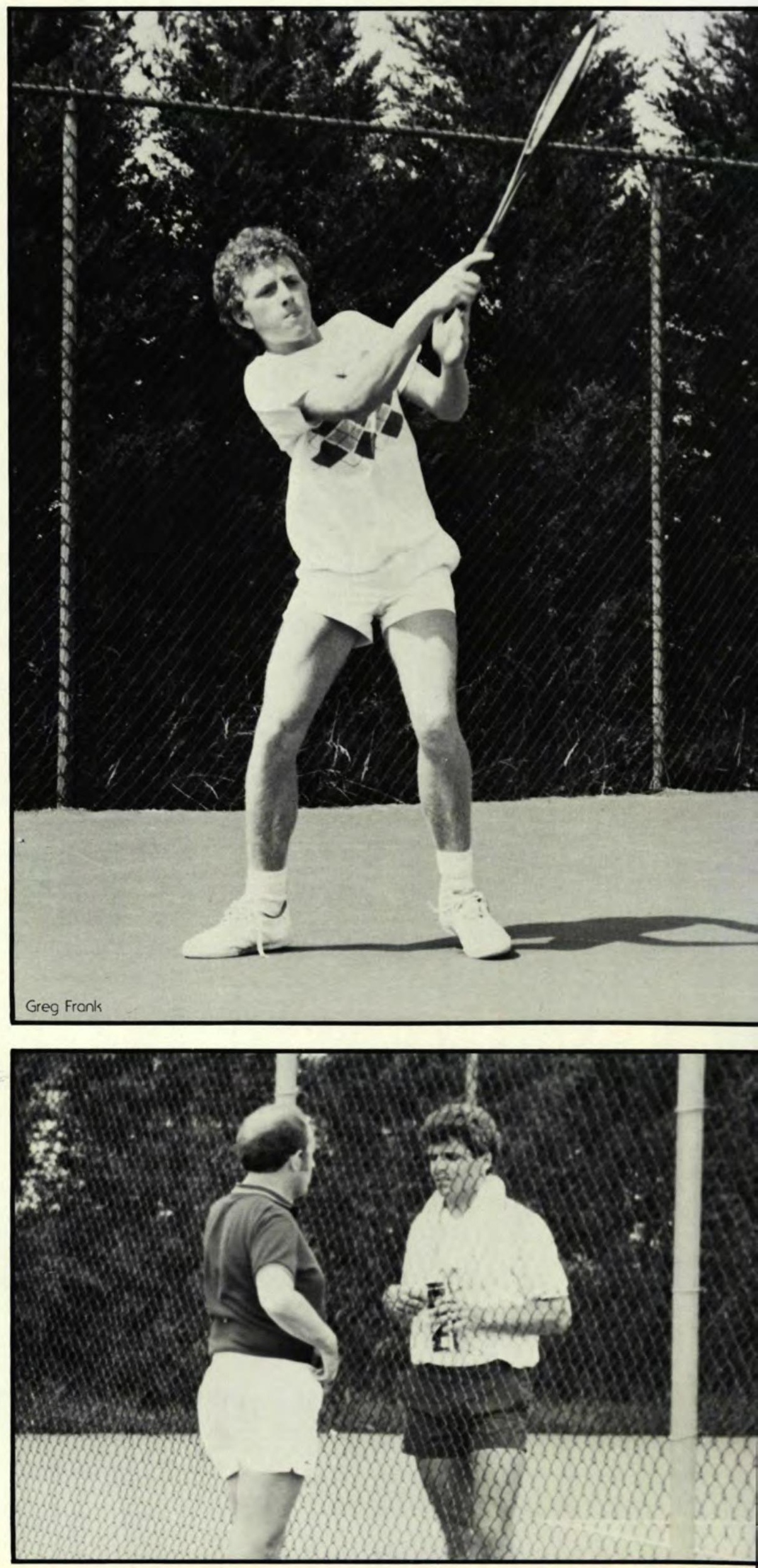


\section{$0^{0} 0^{4}$}

\section{Experienced}

Seniors

\section{Lead Team} To Victories

Next year golf coach Dr. Allen Montoe may nor be blessed with as much success as he has enjoyed in years past. This year marks the graduation of four of Monroe's varsity players, all of who contributed significantly to the 1985 season's success. The departure of seniors Tom Greve, Tom Ewing, Bob Fires, and Dave Kalin will leave next year's team devoid of some allimportant seasoning that only years of experience can provide. This experience led the team to three tournament victories this year: the Xavier and Tiffin Invitationals and the coveted NCCAA District III Championship.

While the experience of the seniors provided opportunity for winning, a freshman, Mark Reed, actually led the ream as its number one player with an average of 77.9. Although next year will be rebuilding one, Coach Monroe can look forward to Reed's return.
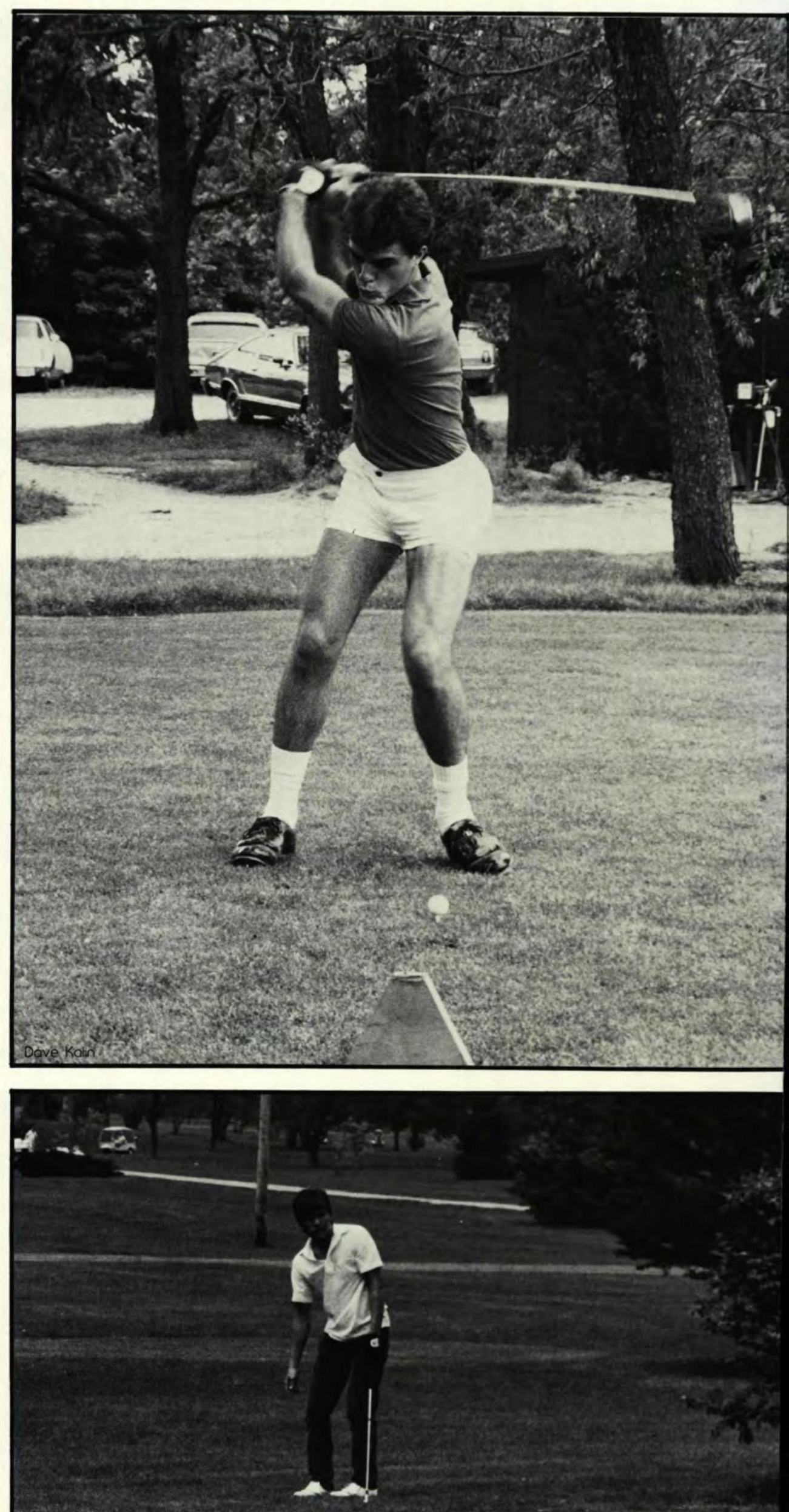

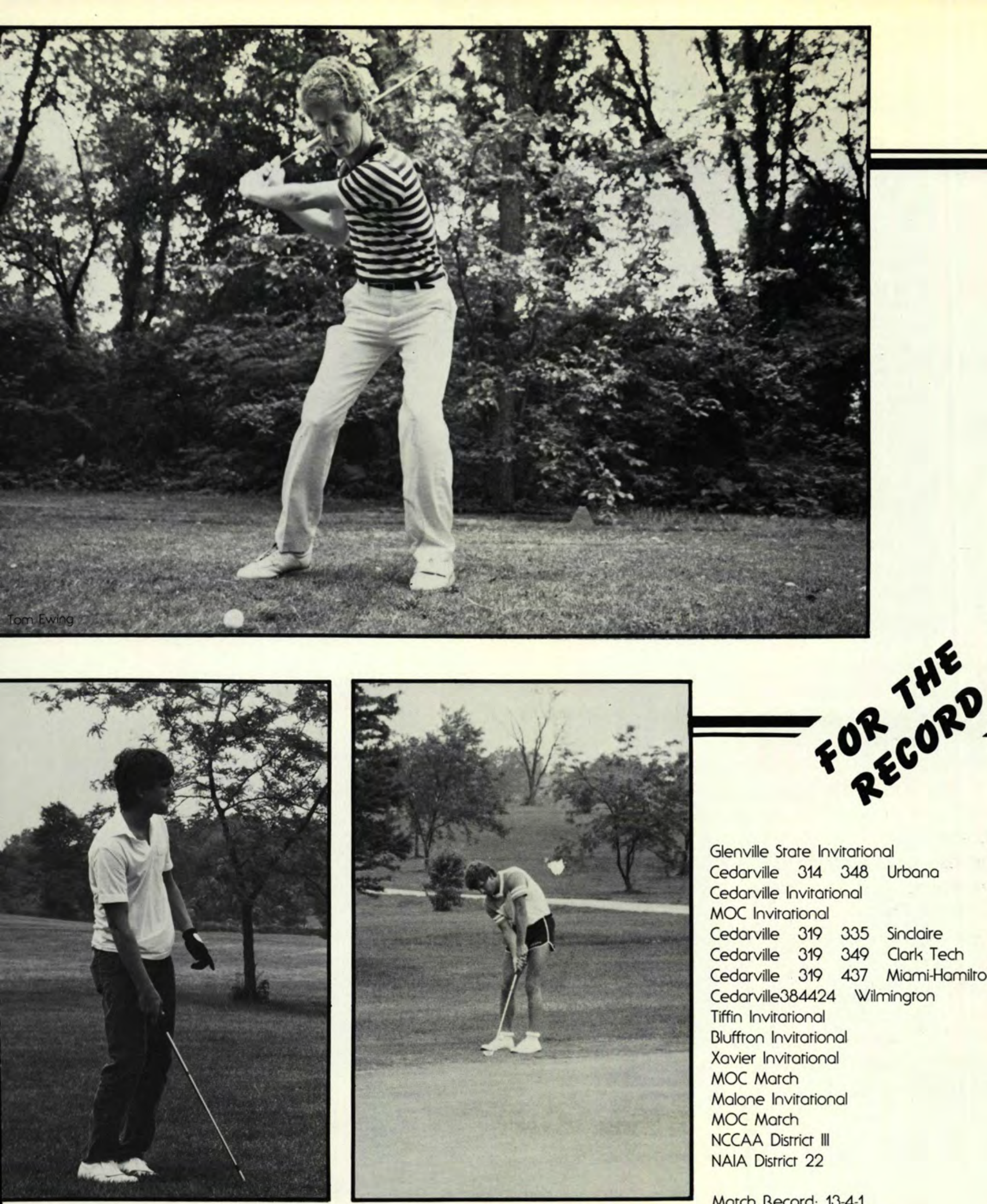

Glenville Srate Invitational

Cedarville 314348 Urbana

Cedarville Invitariona

MOC Invitarional

Cedarville 319335 Sinclaire

Cedarville 319349 Clark Tech

Cedarville 319437 Miami-Hamilton 3rd out of 9

Cedarville384424 Wilmingron

Tiffin Invitarional

Bluffton Invirational

Xavier Invitariono

MOC March

Malone Invitarional

MOC March

NCCAA District III

NAIA District 22

Match Record: 13-4-1

9th out of 12

2nd out of 9

2nd out of 5

1st out of 8

1st out of 11

3rd our of 5

2nd out of 12

2nd out of 5

1st out of 5

3rd out of 8 


\section{Letting $^{p} \mathrm{P}^{\mathrm{T}}$ Loose!}

W inter quarter is highlighted by the excit$W$ ing, exhilararing baskerball games held in the athletic center. Students look forward every week to "lerting loose" and screaming their lungs out to cheer on the Yellow Jackets.

The baskerball games would be much less exciting, however, if not for those special people who cheer, perform, and contribute their musical ability to lead the crowd in cheers. The cheerleaders work extra hard in preparing for the baskerball games. Physical conditioning, learning cheers, and supporting the various teams keeps them busy throughout the year.

The flag team provides enterrainment during pre-game and half-time, doing routines to songs played by the pep-band.

The pep-band plays a major part in school spirit by playing spirited songs that usually make the fans stand to their feet cheering. Mr. Dicuirci, leader of the pep-band, has a special talent for leading the band in songs like "Sloopy" that are perfect at the right moment. The one thing that students will remember once they graduate from Cedarville College is the fun-filled, crazy baskerball games during winter quarter. Without the cheerleaders, flag team and pep-band, the memories would nor be quite so vivid.
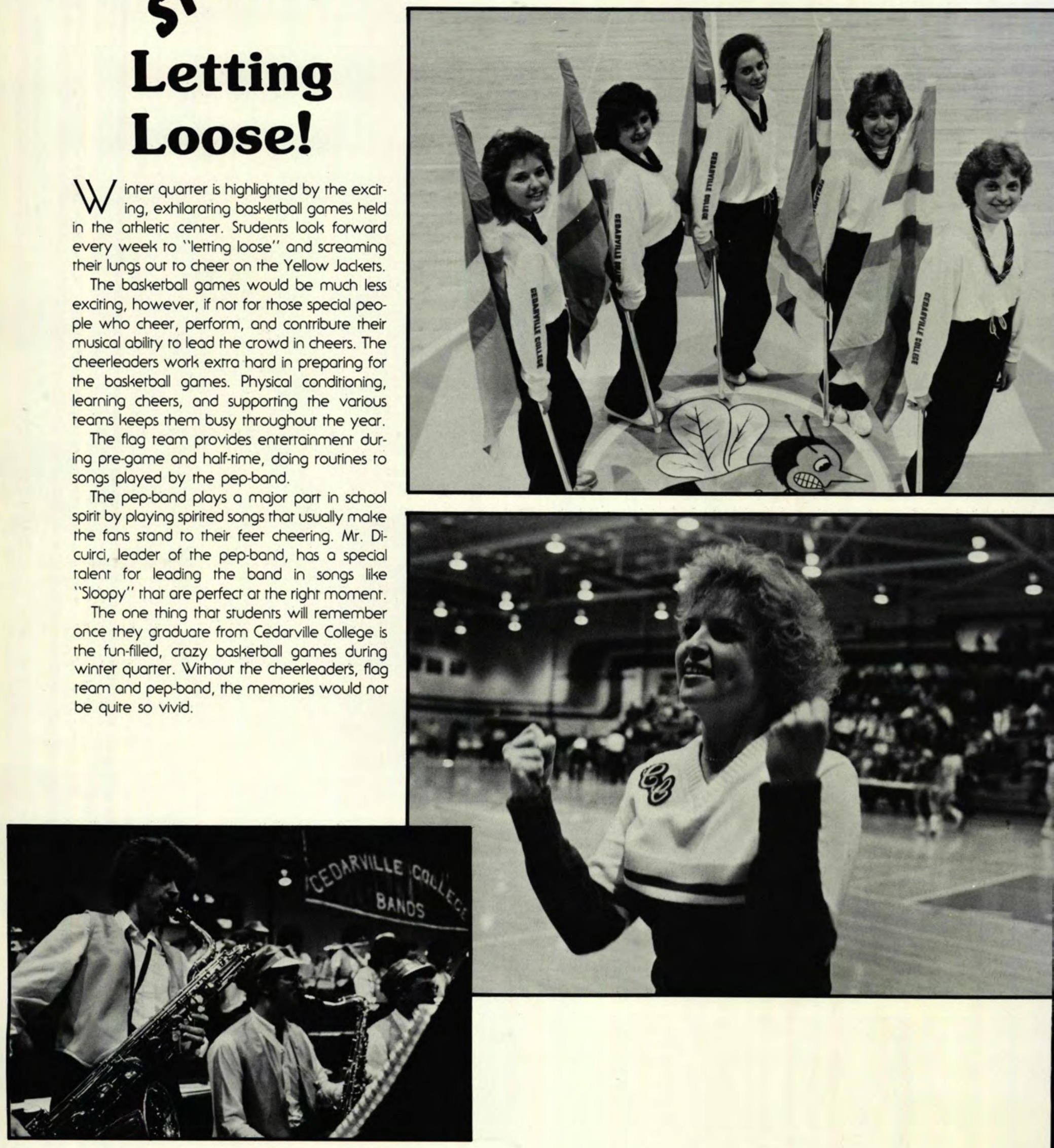


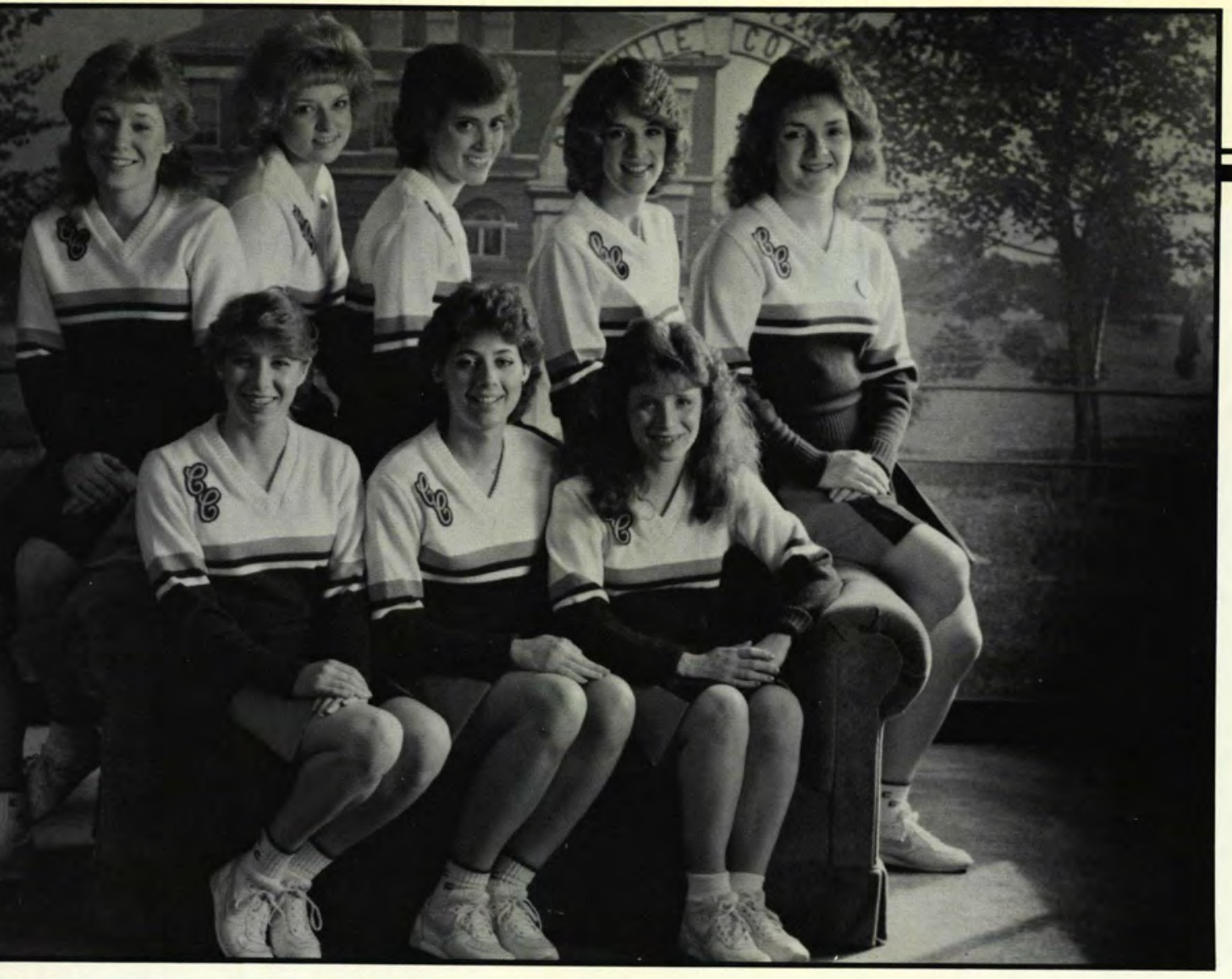

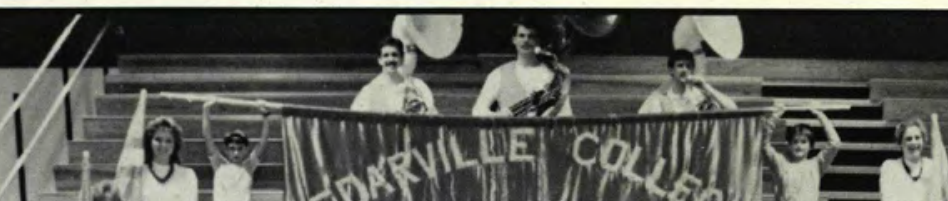

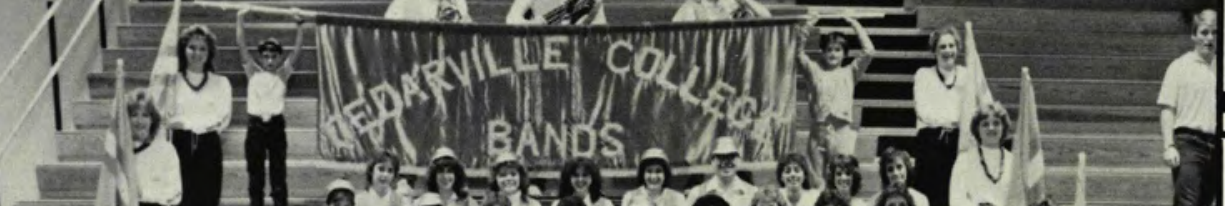
1 - 1 iv?

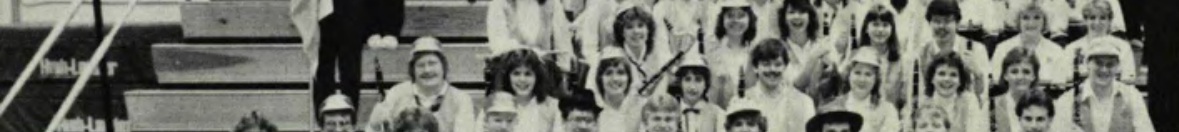

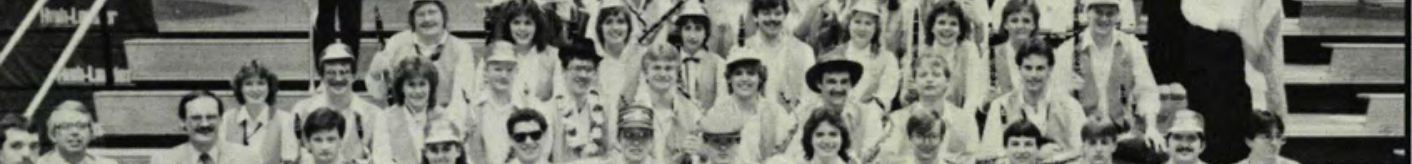

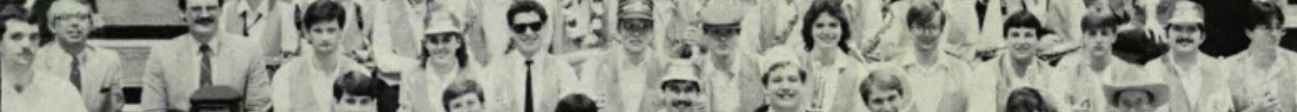

rotala $=8 \cdot 0$

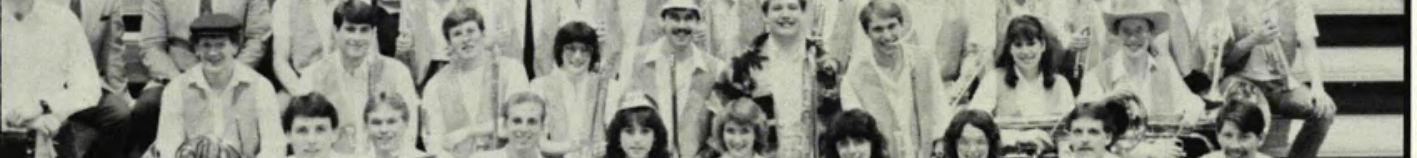

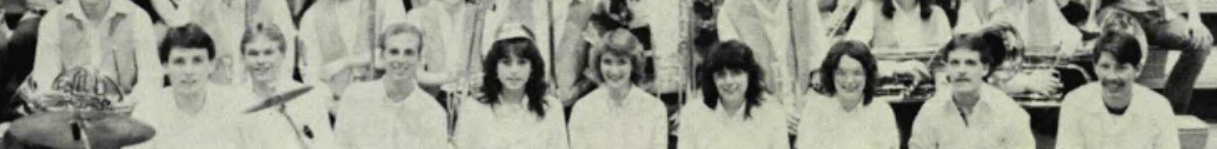

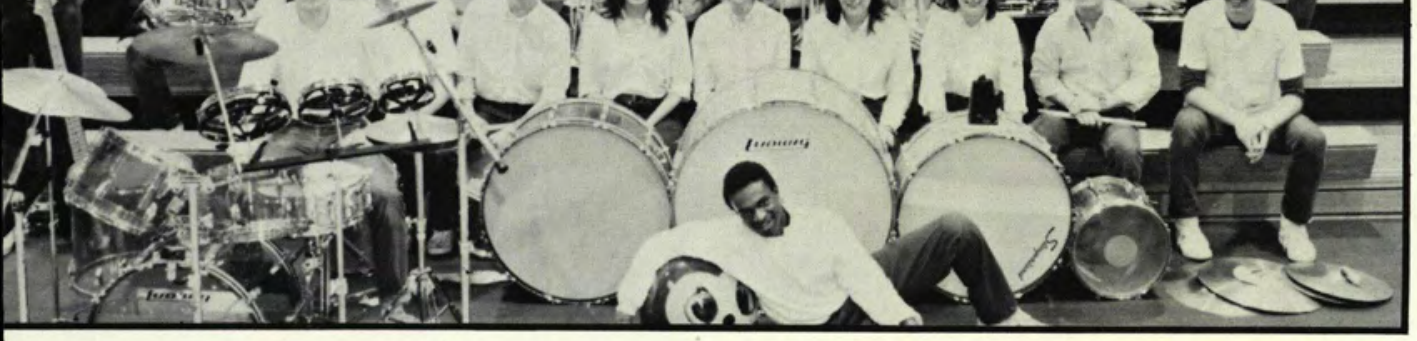
CEDARIILLE Co, $=2$ BANDS T. 
Mission specialist Bruce McCandless takes a walk in space in early 1984. In the photo he is seen using the socalled manned maneuvering unit as he moved away from the Shuttle Challenger during the eight-day space mission.

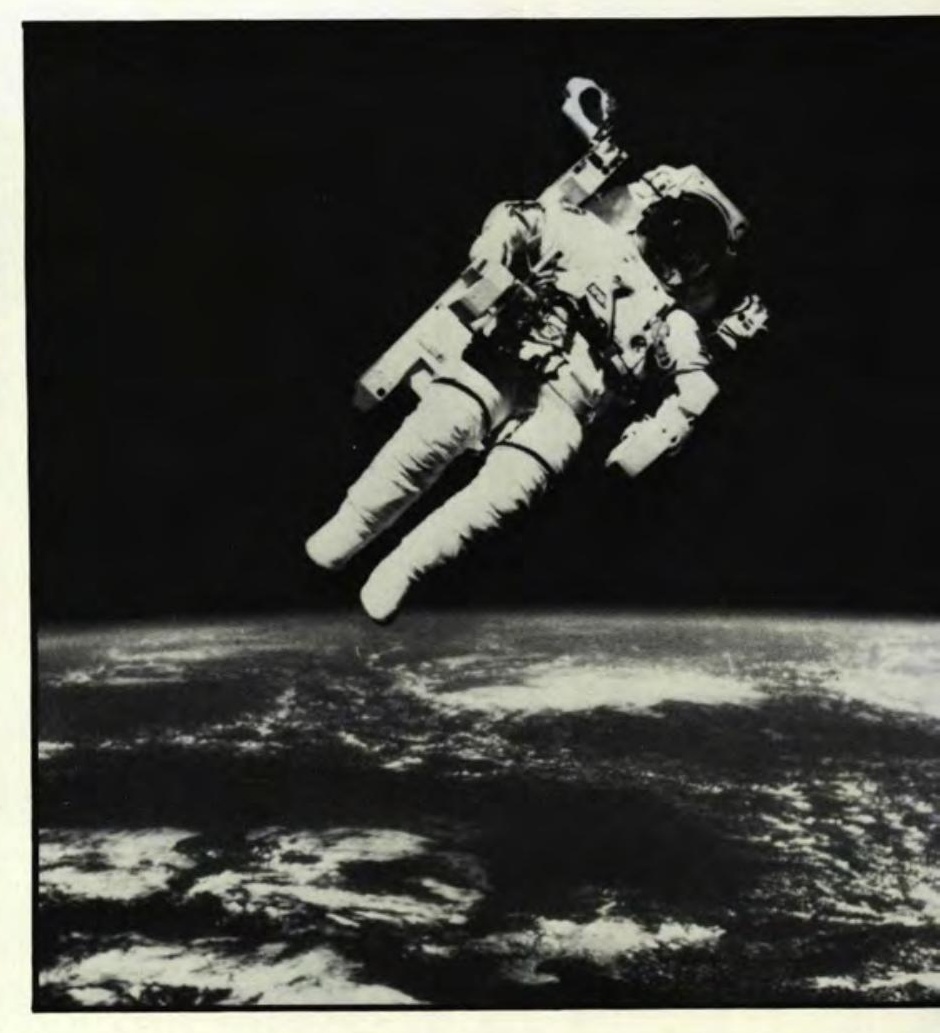

The Statue of Liberty celebrated her 98th birthday in 1984 and she began to show her age. The statue was worn from constant pummeling by wind, salt air and acid rain, and the iron ribbing supporting the copper covering was badly corroded. A two-year restoration began in July 1984. It included a new goldplated torch.

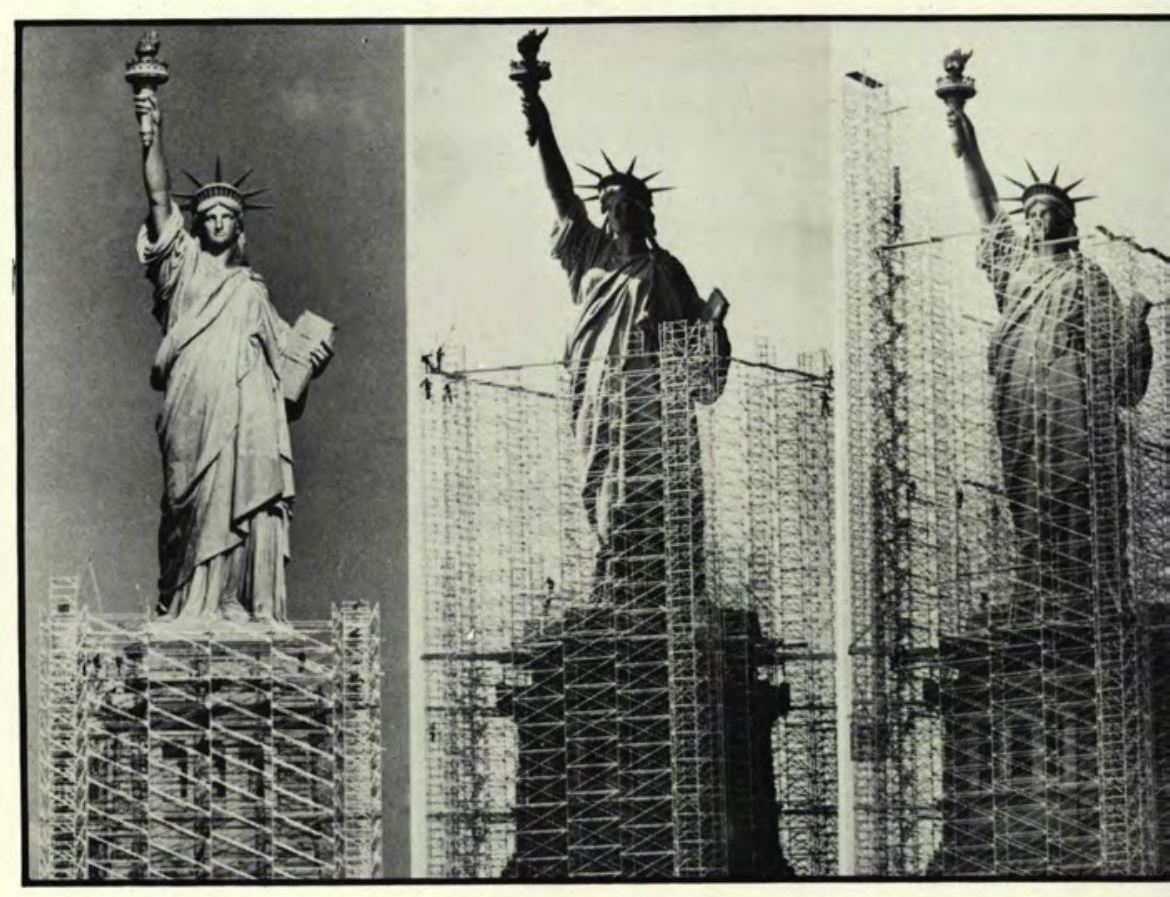

Louisville, Kentucky, March 12. 1985. Murray Haydon, right, was moved out of the intensive care unit at Humana Hospital Audubon, and into a room next door to William Schroeder, left. The two are recipients of permanent artificial heart. Surgeon William DeVries performed the transplants.

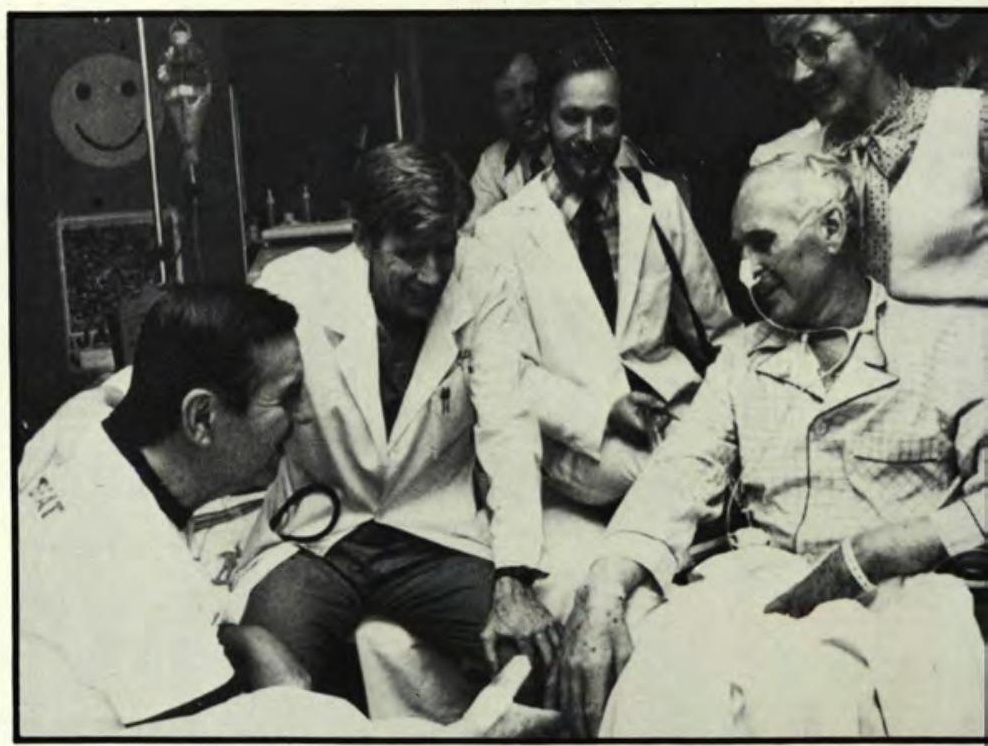


President Ronald Reagan and Vice President George Bush sought re-election in 1984. He vowed not to raise taxes and ran on his record of the previous' four years. His tactic worked. President Reagan won re-election with the biggest electoral vote in the nation's history with 49 percent of the total vote.

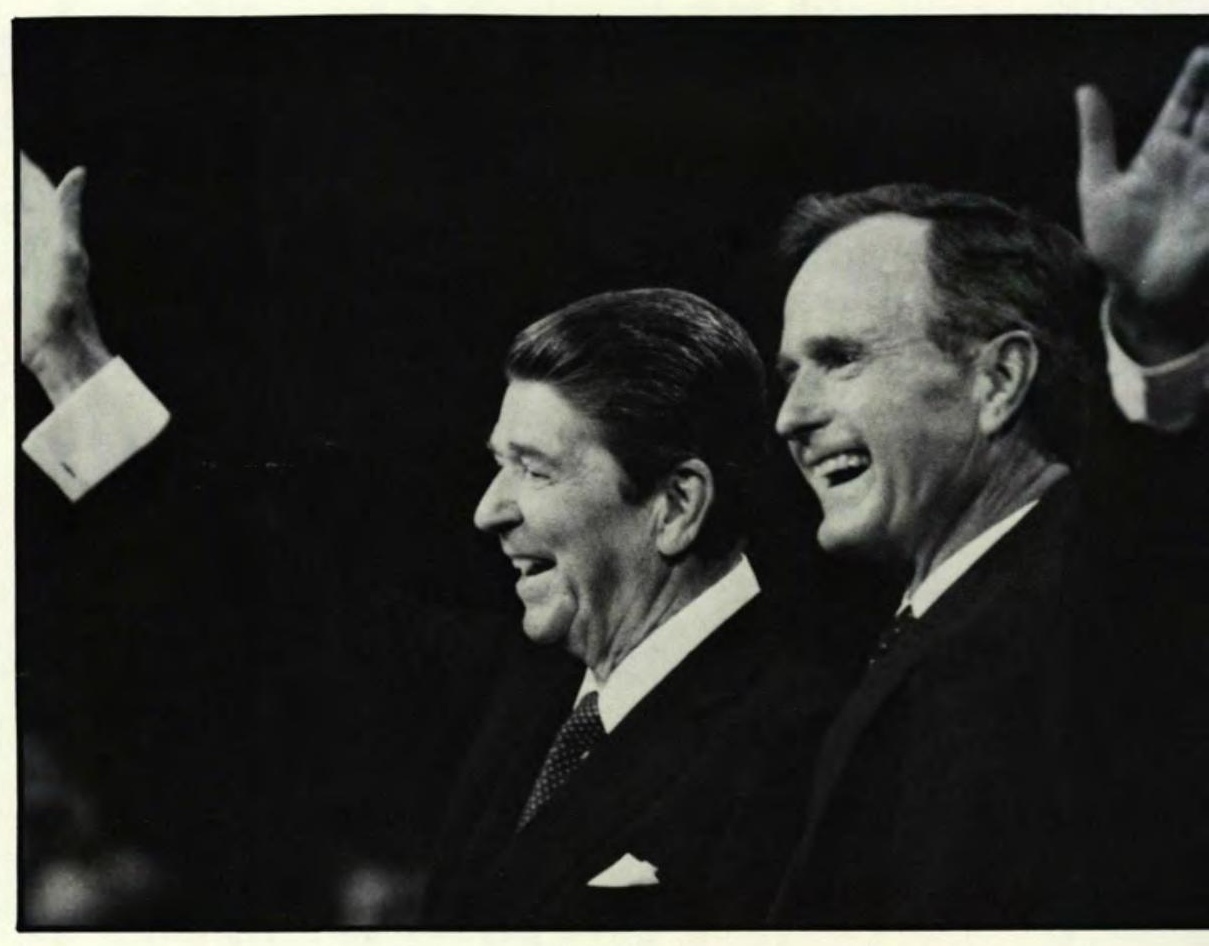

The United States Marines arrived in Beirut in 1982. Lebanon was torn by civil war and foreign invasion. In 1984 when the Marines left, more than 260 Marines were dead, Lebanon was still at war with most of its territory occupied by foreign troups and its government tottering.

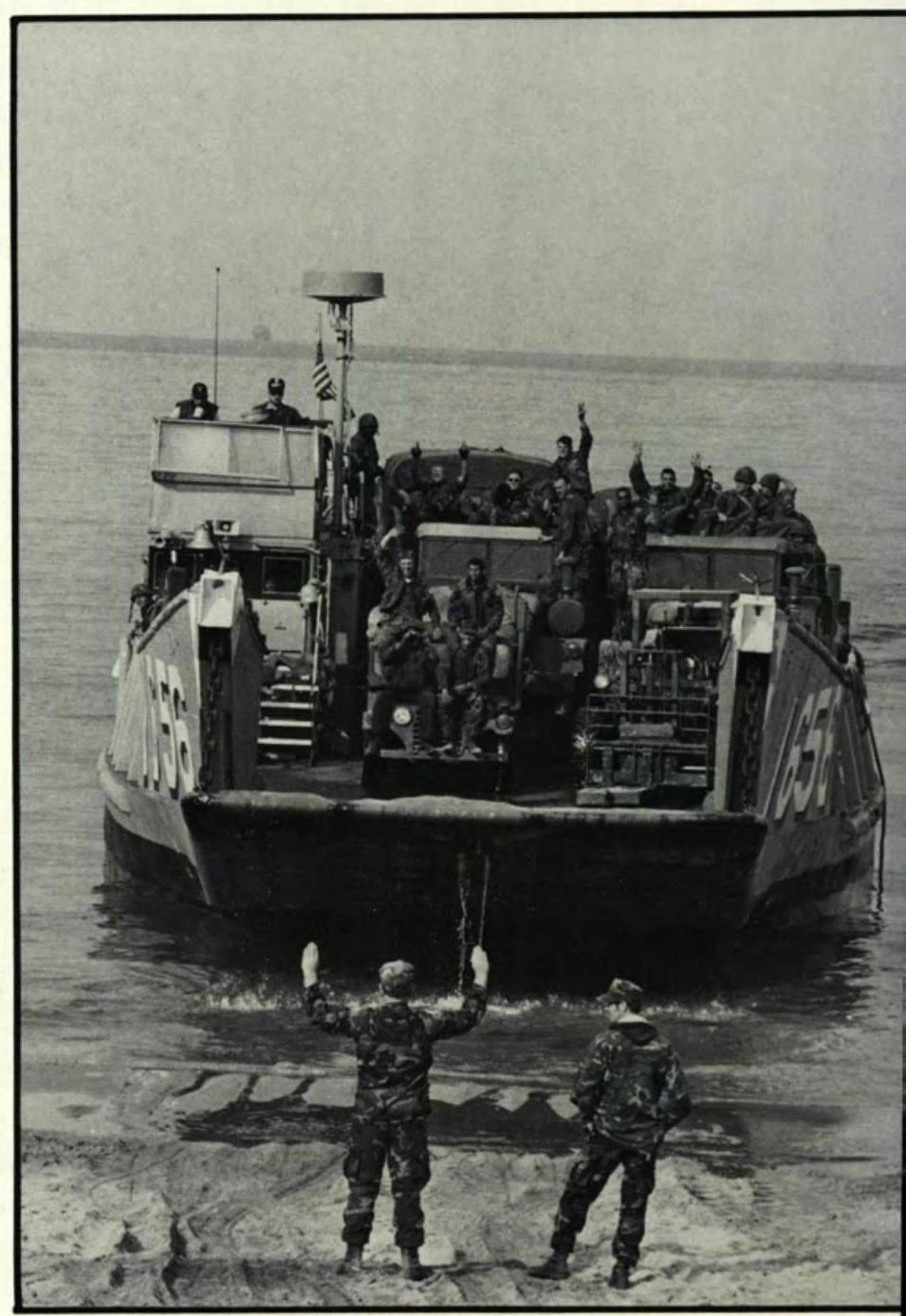




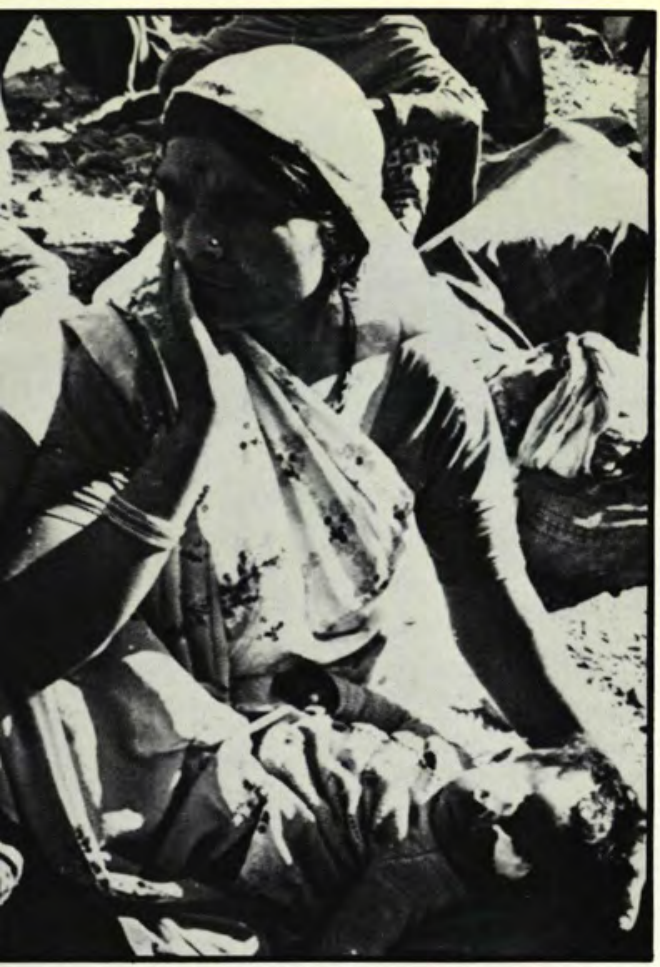

Bhopal, India December 7 , 1984. An Indian woman cradles her baby blinded by poisonous gas which leaked from a Union Carbide pesticide factory in central India. Many people suffered blindness, eye ulcers, and eye irritation. Doctors also reported stillbirths, and said long-term effects could include permanent blindness, partial paralysis, lung, liver and kidney damage.

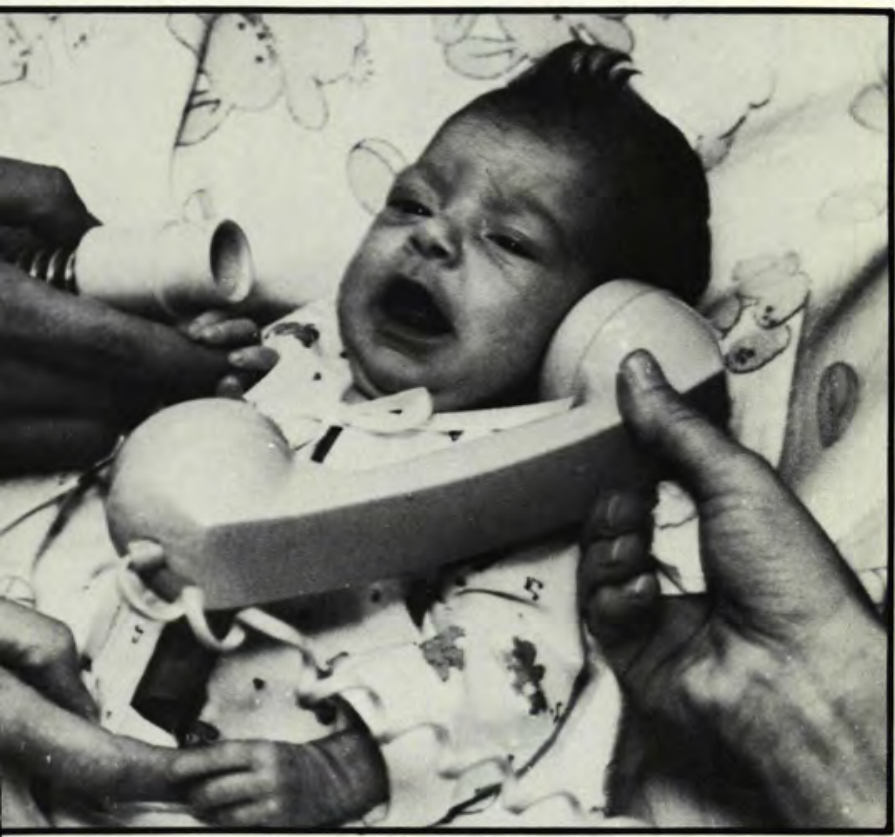

Loma Linda, California, November, 1984. Baby Fae listens to her mother's voice over the telephone just 13 days after the infant's historic heart transplant at Loma Linda University Medical Center. The baby was born with a deformed heart and without a transplant she had a very small chance of surviving. Doctors decided to experimentally replace Baby Fae's deformed heart with that of a baboon.

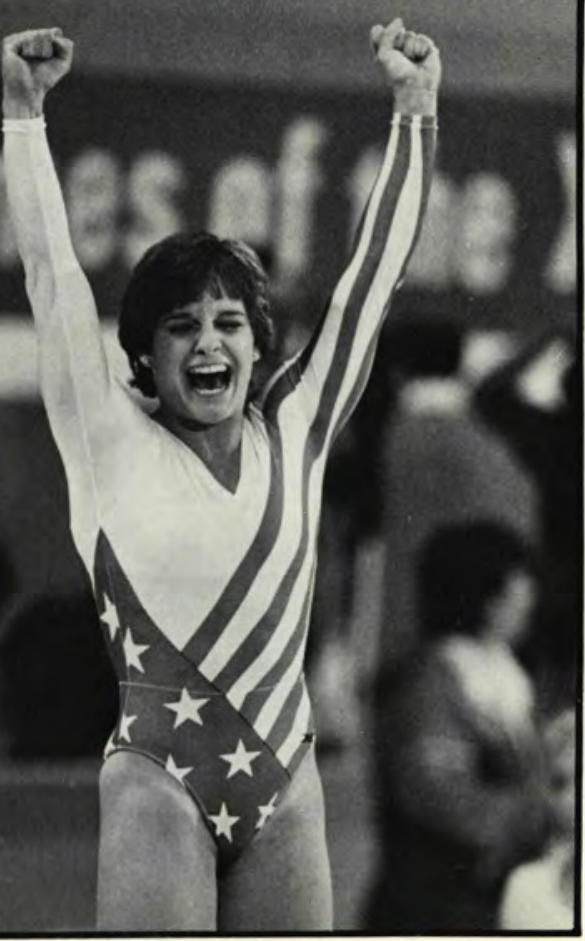

The United States did well in the Summer Olmpics, winning 83 gold medals, 61 silver, and 30 bronze. Mary Lou Retton won the all-around gold medal and led the gymnastics team to a silver medal; she also won bronze medals for the floor exercise and the uneven parallel bars and took a silver medal for the vault. The Soviet Union and other Communist countries boycotted the Summer Olympics. 


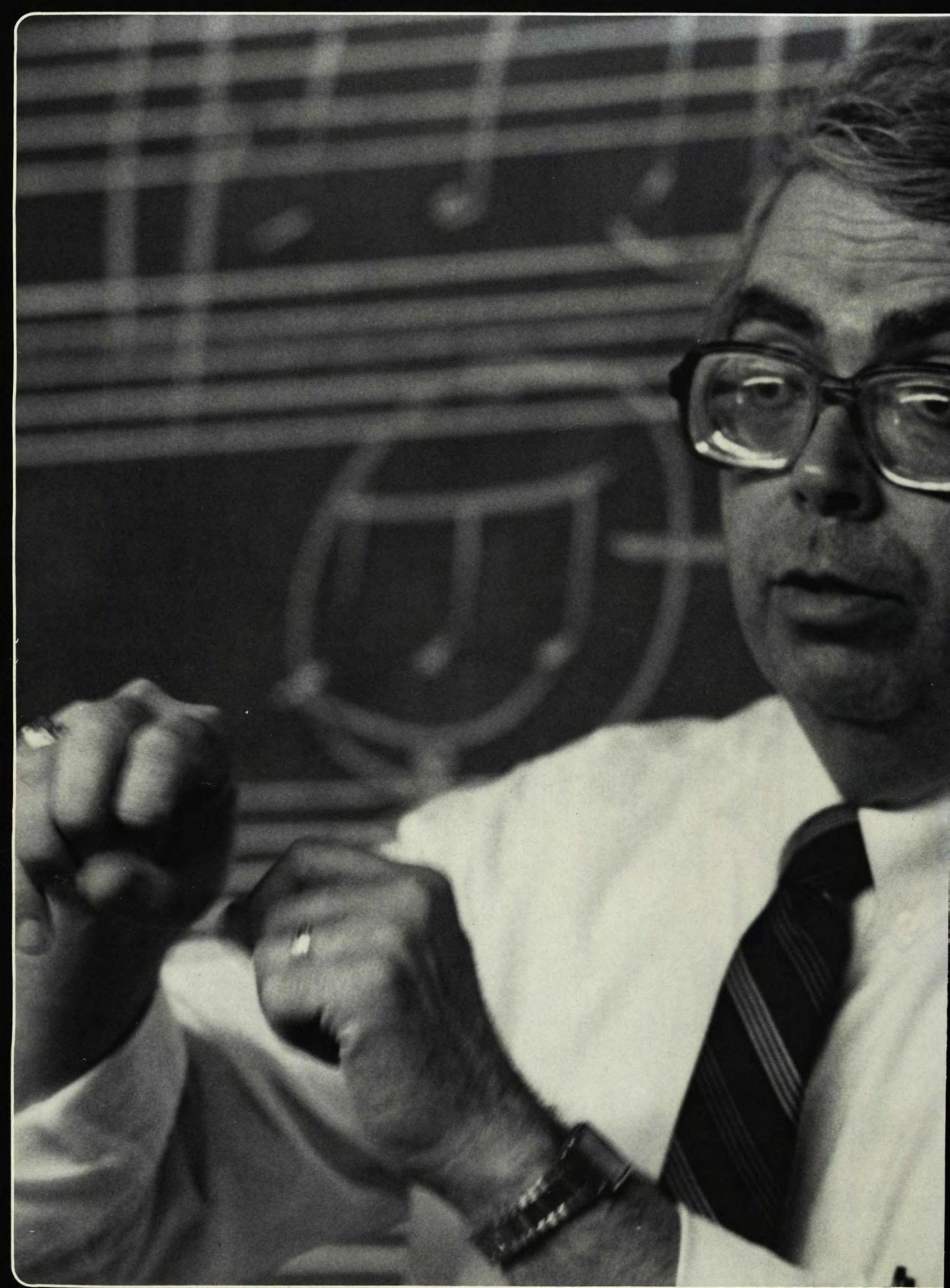




\section{An Extended Family}

A student enters his classroom and sits down pensively, waiting expectantly, trustfully for the mind-guiding words that come from his professor. Down the hall, another student confused by his financial statement, receives sound advice and a trusted explanation that clears up the difficulty.

Far from being an independent experience, attending college requires students to trust God to bring them into contact with faculty and staff members that become part of an extended and trusted family. On the following pages the Miracle staff presents the faces of those whom we as a student body have come to depend on and love so greatly.

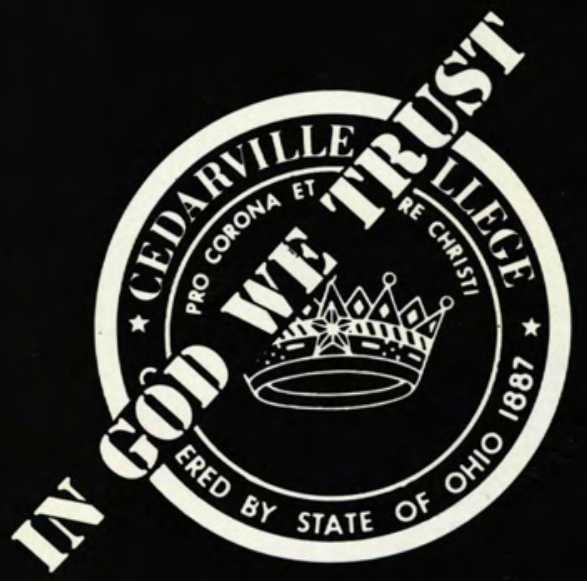




\section{Faculty}

Robert Abbas, Ph. D.

Professor of Psychology

Merlin Ager, Ph. D.

Professor of Education

Irene B. Alyn, R.N., Ph.D.

Professor of Nursing

Lyle Anderson, Ph.D.

Associate Professor of Music

J. Wesley Baker, M.A. Ass't. Professor of Speech

Lois Baker, R.N., M.S.N

Assistant Professor of Nursing Sue Baker, M.Ed.

Associate Professor of Education

Richard Baldwin, M.B.A.

Assistant Professor of Business

Stanley N. Ballard, Ph.D. Professor of Psychology Ray Bartholomew, Ph.D.

Professor of English

Patricia L. Bates, M.S.

Dean of Women

Janet A. Bauer, M.S.

Assistant Professor of Nursing

Donald Baumann, Ph.D. Professor of Biology and Chemistry

Harmon Bergen, M.A.

Associate Professor of Foreign Languages

James Biddle, Ph.D.

Professor of Education Sharon Biddle, Ph.D.

Associate Academic Vice President

Omer Bonenberger, D.Ed. Associate Professor of Education Janice Bosma, M.L.S.

Assistant Dir. of Library Services Tim Bosworth, M.A. Dean of Men

Edwin Braithwaite, Ph.D. Assistant Professor of Mathematics

Lynn Brock, M.L.S Director of Library Services Debra Brown, M.B.A. Assistant Professor of Marketing Elaine Brown, M.Ed.

Assistant Professor of P.E. Stephen Brown, M.L.S Associate Dir. of Library Services
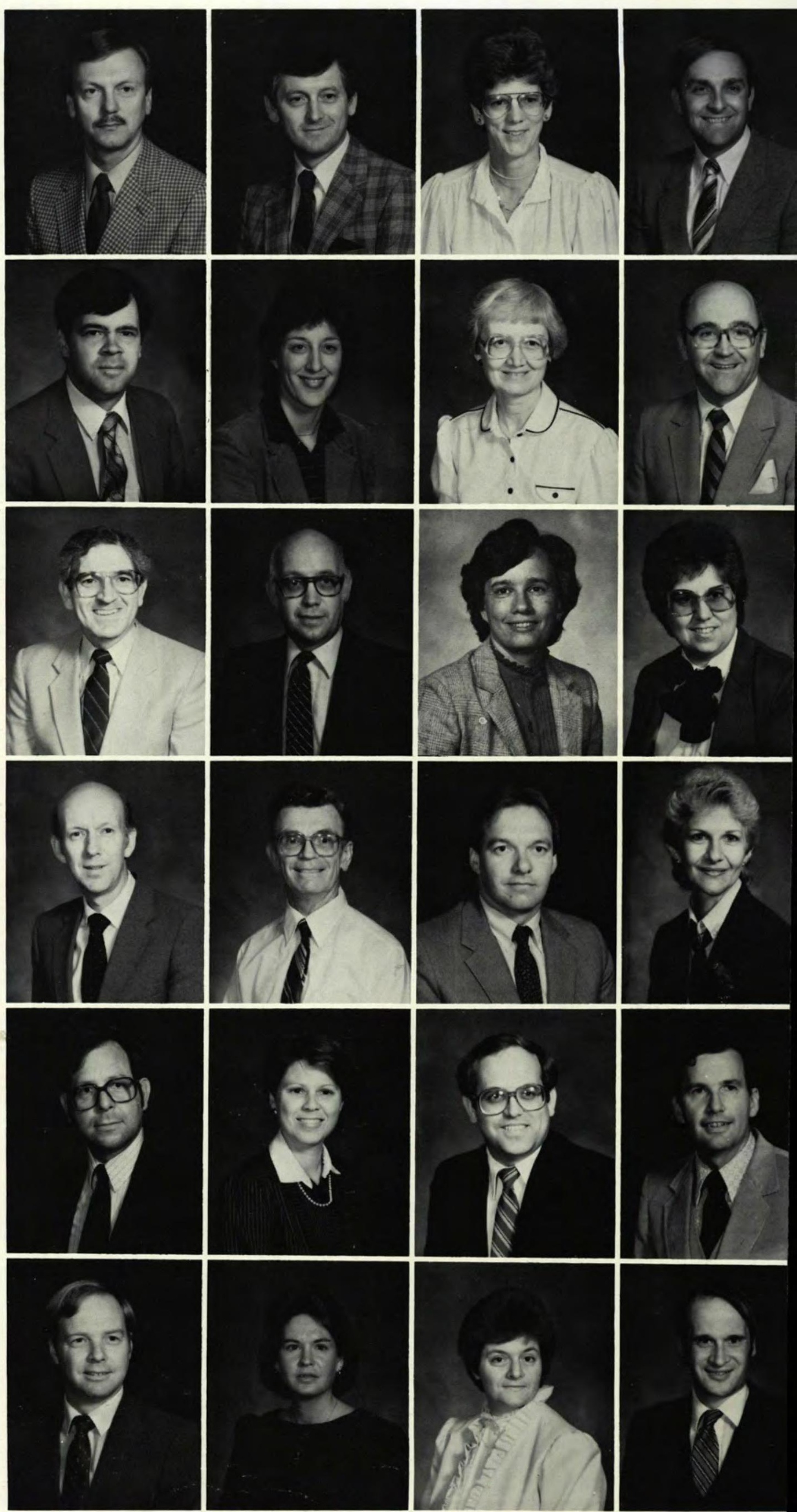
Marinus Hazen, M.B.A., C.P.A. Assistant Professor of Business Larry Helmick, Ph.D Professor of Chemistry Karol Hunt, Ph.D. Assistant Professor of P.E. Martha Johnson, M.A Ass't Professor of Secretarial Sci.

Betsy L. Kempt, B.S. Ass't. Prof of Sec. Science Lawrence Killian, M.A. Associate Professor of Biology Elvin R. King, M.EO

Associate Professor of P.E.

Mark Klimek, M.S.N. Assistant Professor of Nursing

Mark Larson, M.A. Assistant Professor of Spanish James Leightenheimer, B.A. Instructor of Broadcasting Barbara Loach, M.A. Assistant Professor of Spanish Mike Lopez, Ph.D. Assistant Professor of Comm. Arts

Philip McClure, M.M Assistant Professor of Music John McGillivray, M.S. Assistant Professor of P.E. James E. McGoldrick, Ph.D. Professor of History David Matson, Ph.D. Professor of Music

Douglas J. Miller, Ph.D. Assistant Professor of Chemistry Allen Monroe, Ph.D.

Professor of Social Science Beverly Monroe, M.A. Associate Professor of Education Kurt Moreland, M.A. Assistant Professor of Comm. Arts

\section{J. Murray Murdoch, Ph.D.} Professor of History David Ormsbee, B.A. Director of Admissions Charles Pagnard, M.A. Ass't Professor of Music Robert Parr, M.A. Assistant Professor of Sociology
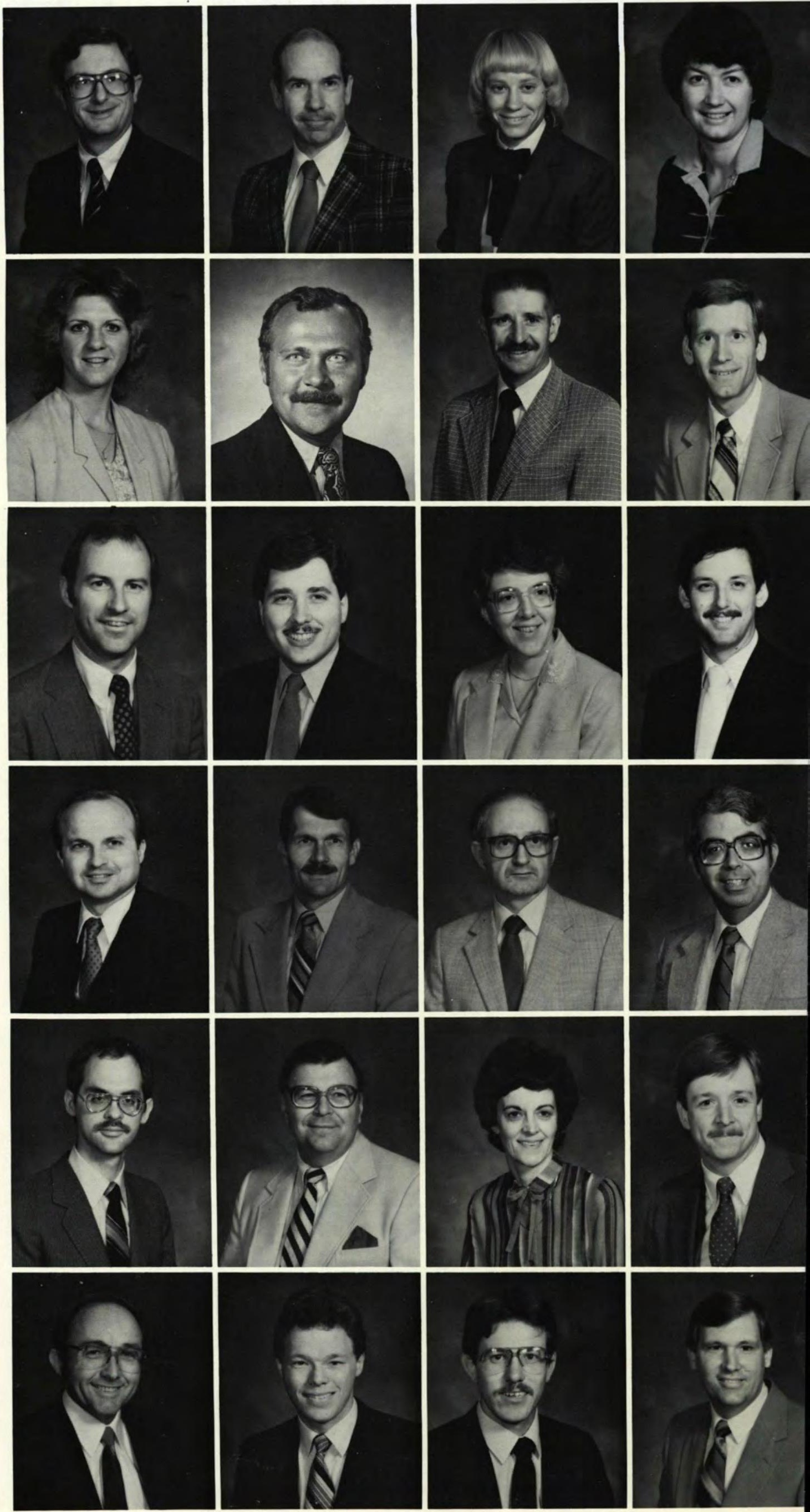

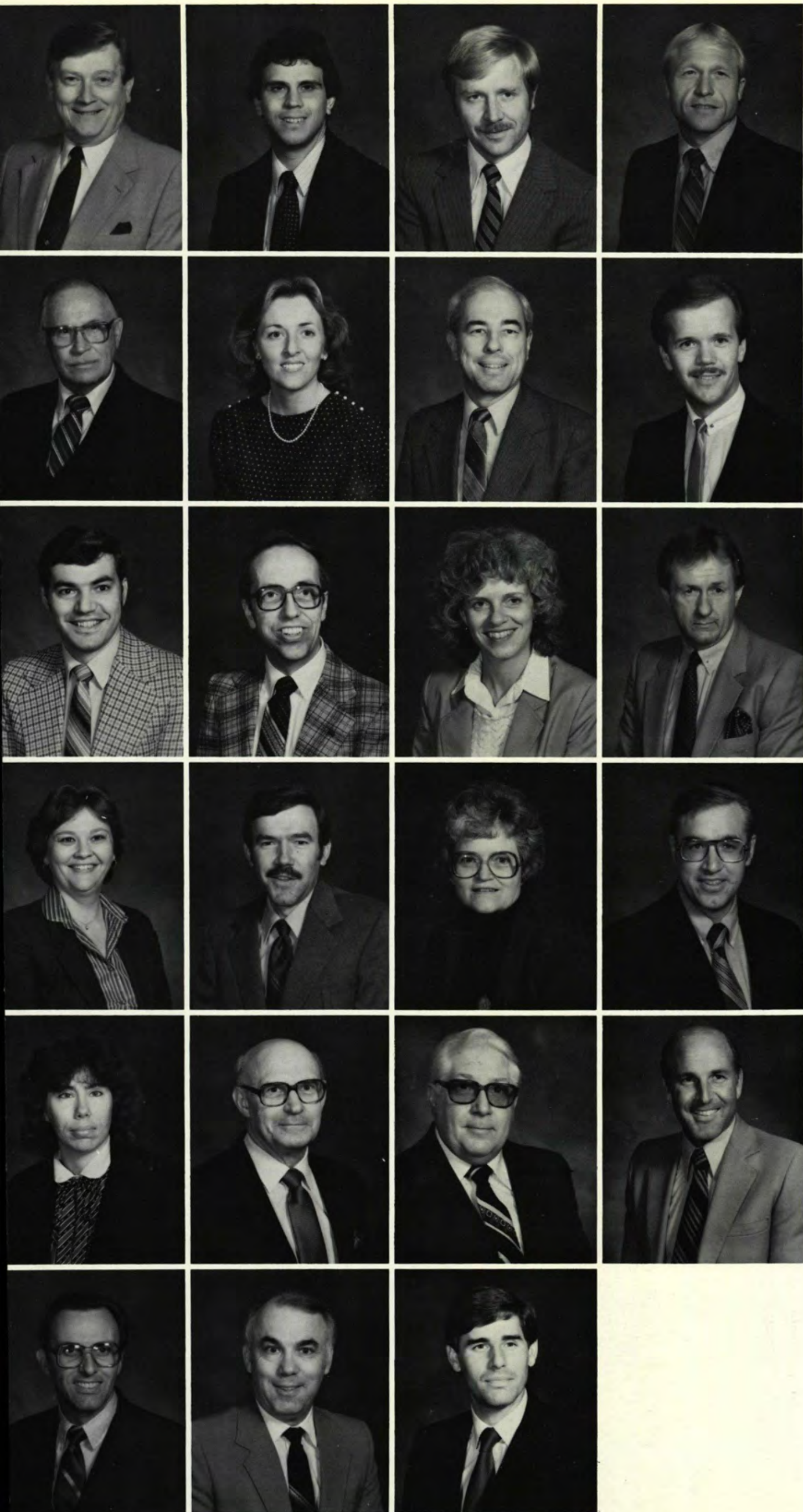
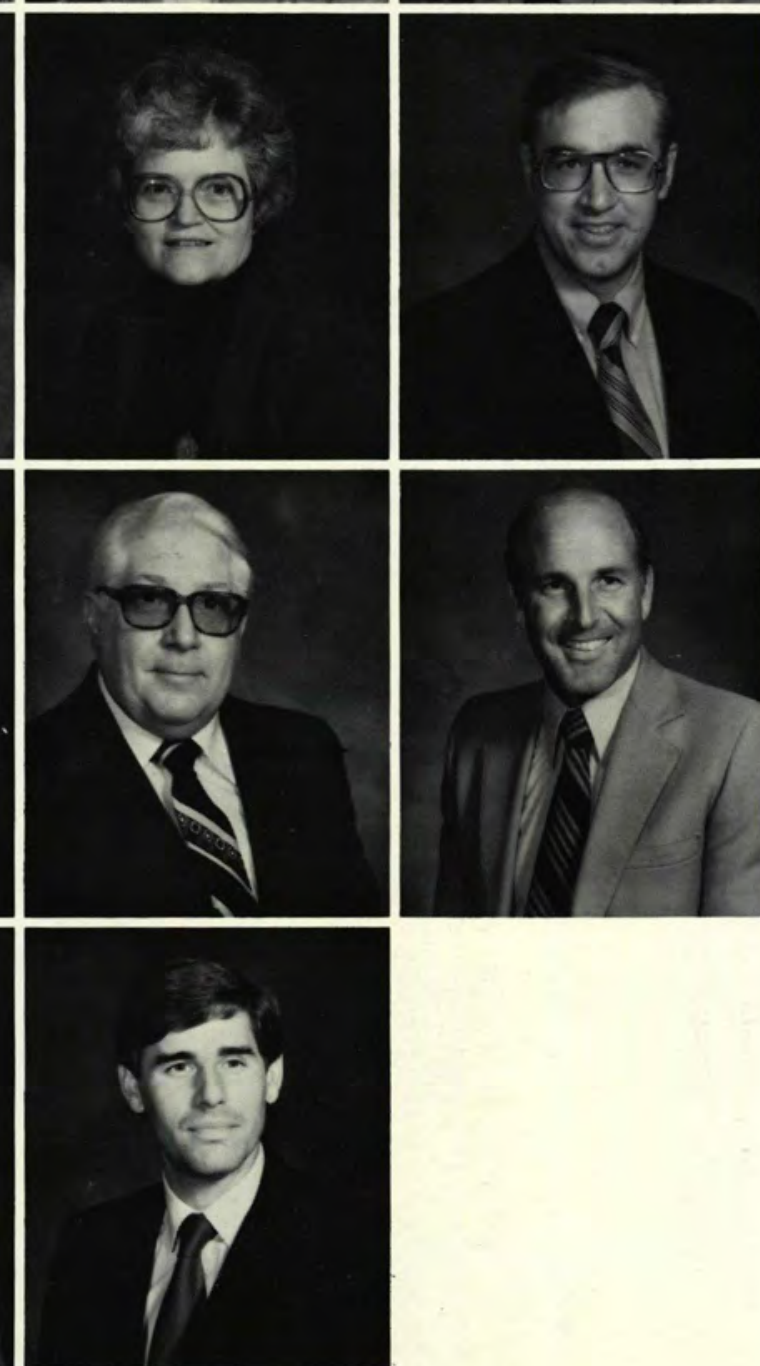

Donald Parvin, M. Div.

Assistant Professor of Bible

Gary Percesepe, M.A.

Assistant Professor of Philosophy James Phipps, Ph.D.

Professor of Communication Arts Terry Phipps, M.S.

Assistant Professor of Biology

Marlin Rayburn, M.A.

Associate Professor of Comm. Arts Anne Rich, M.S., C.P.A.

Assistant Professor of Accounting

Jack Riggs, Th.D.

Professor of Bible

David Robey, M.A.

Ass'† Professor of Comm. Arts

Rex Rogers, Ph.D.

Associate Professor of Political Sci. David L. Rotman, M.A.T., C.D.P.

Assistant Professor of Business

Maureen O. Salladay, R.N., M.P.H. Assistant Professor of Nursing

James Seaman, Ph.D.

Associate Professor of Marketing

Lilla Seaman, Ph.D.

Associate Professor of Education

John Silvius, Ph.D.

Associate Professor of Biology

Ruth Slocum, M.N.

Assistant Professor of Nursing

Galen Smith, M.S.

Assistant Professor of Economics

Sarah Smith, Ph.D.

Assistant Professor of Accounting

Edward E. Spencer, M.A.

Professor of English

Karl Stahl, M.A

Assistant Professor of Music

Ronald J. Walker, M.S

Associate Professor of Business

Dave Warren, Th.M

Associate Professor of Bible

Daniel Wetzel, Ph.D.

Professor of Physics and Math

Stephen Young, B.A.

Instructor of P.E. 


\section{STAFF}

Ruth Ager

Sec. to Assoc. Academic Dean John Anglea

Budget Dir., Bus. Mgr's Office Diane Auckland

Student Employment \& Institutional Loan Co-ordinator, Financial Aid Office Mary Auckland Bookstore, Secretary

Martha Baldwin

P.R., Composer Operator

Donna Beight

Post Office, Clerk

Grace Beikert

Secretary/Clerk, Physical Plant Audrey Bergen

Bookstore, Mgr. Text Book Dept.

Betty J. Bertschinger Patterson Clinic, Director Brenda Boley

Patterson Clinic, Supervisor James Bowersox Security Officer, Physical Plant Richard Bowersox Business Mgr's Office, Controller

Connie Bradds Post Office, Clerk Jeffrey D. Brock Dev. Office, Dir. Annual Giving Mark Brown Dir. of Security, Physical Plant Margaret Burrichter Business Mgr's Office, Cashier

Debbie Cagwin Bus. Mgr's Office Accts. Pay. Clerk Fran Cambell Bookstore, Accts. Pay./Receivable Jack Cambell Dir. Academic Records/Registrar Alberta Carr Bookstore, Sales Clerk/Music Supp.

James Caro WCDR Field Representative Stuart Chaffe Post Office Manager Jim Chambers

Gen. Maint. - Physical Plant Harry Cole Bookstore, Ass'† Manager
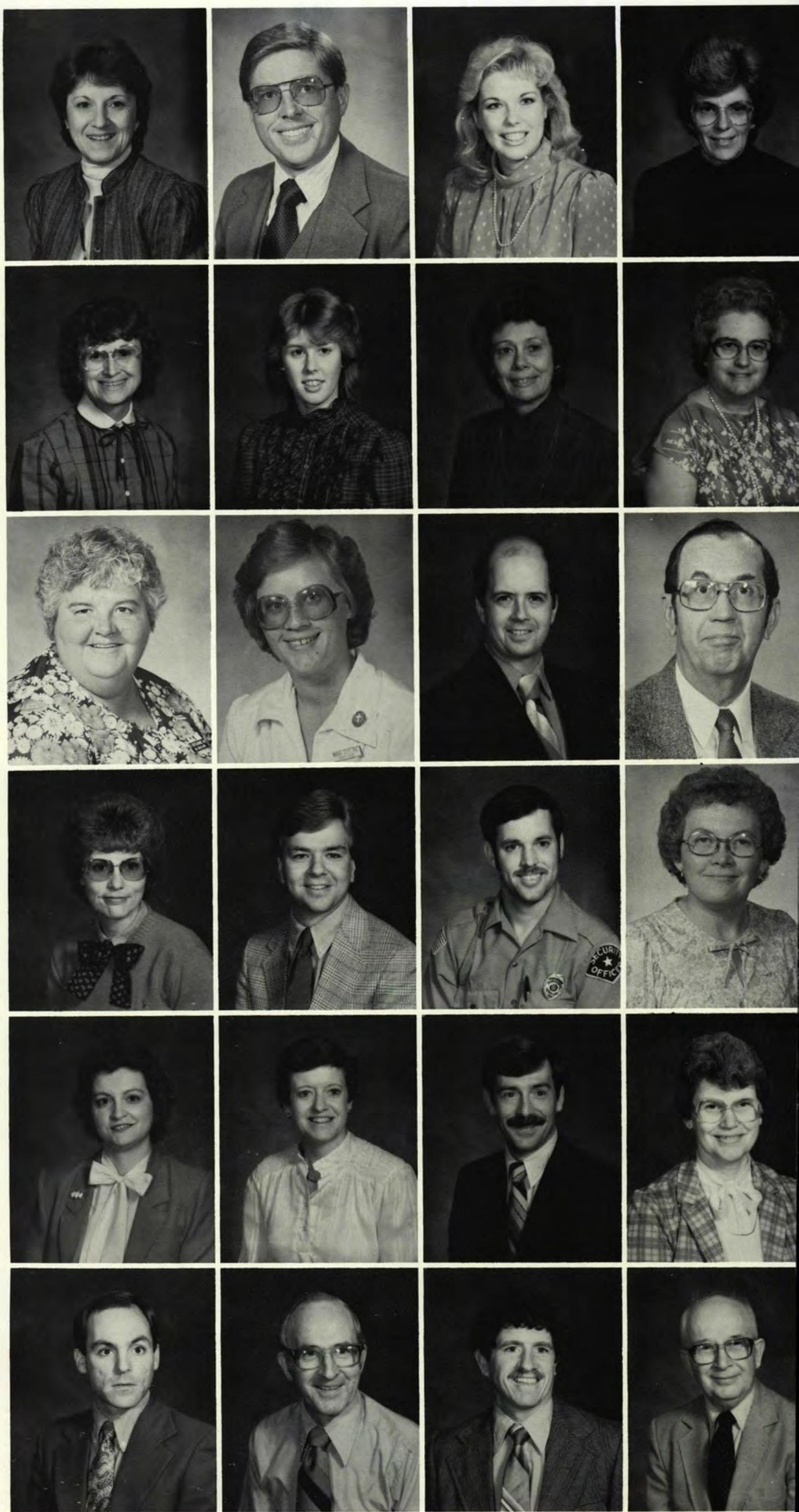
May Greenwood

Sec. Academic Vice President

DeWayne Grooms

WCDR Music Library

Robert Gwinn

HUAC - Physical Plant

Hugh T. Hall

Dev. Off. Dir. of Church Relations

Lorraine Ann Halladay

Secretary, Nursing

Barbara Henderson

Bookstore, Cashier

Carolyn Hollopeter

WCDR Tape Duplicating/Counseling

Sec.

Agnes Howell

Head Resident

Patricla Huber

Social Science Secretary

Helen Hunt

Sec. Physical Plant

Lelgh Hunt

Director of Physical Plant

Robert Hunt

Carpenter - Physical Plant

Judy Johnson

Circulation Supervisor - Library

Timothy Johnson

Storekeeper - Physical Plant

Byron Jones

Plumber - Physical Plant

Emily Kaufman

WCDR Secretary

JoAnne Kendall

Admissions Correspondence Sec.

Helen T. KIng

Education Secretary

Nancy Knauf

Student Services Receptionist

Gary P. Kuhn

Director of Alumn

Matthew E. Kunkel

Head Resident

Susan Larson

P.R. Graphic Artist

Patricia J. Lee

Bus. Mgr's Office - Payroll Mgr.

Diane L/chtenstelger

Business Admin. Sec.
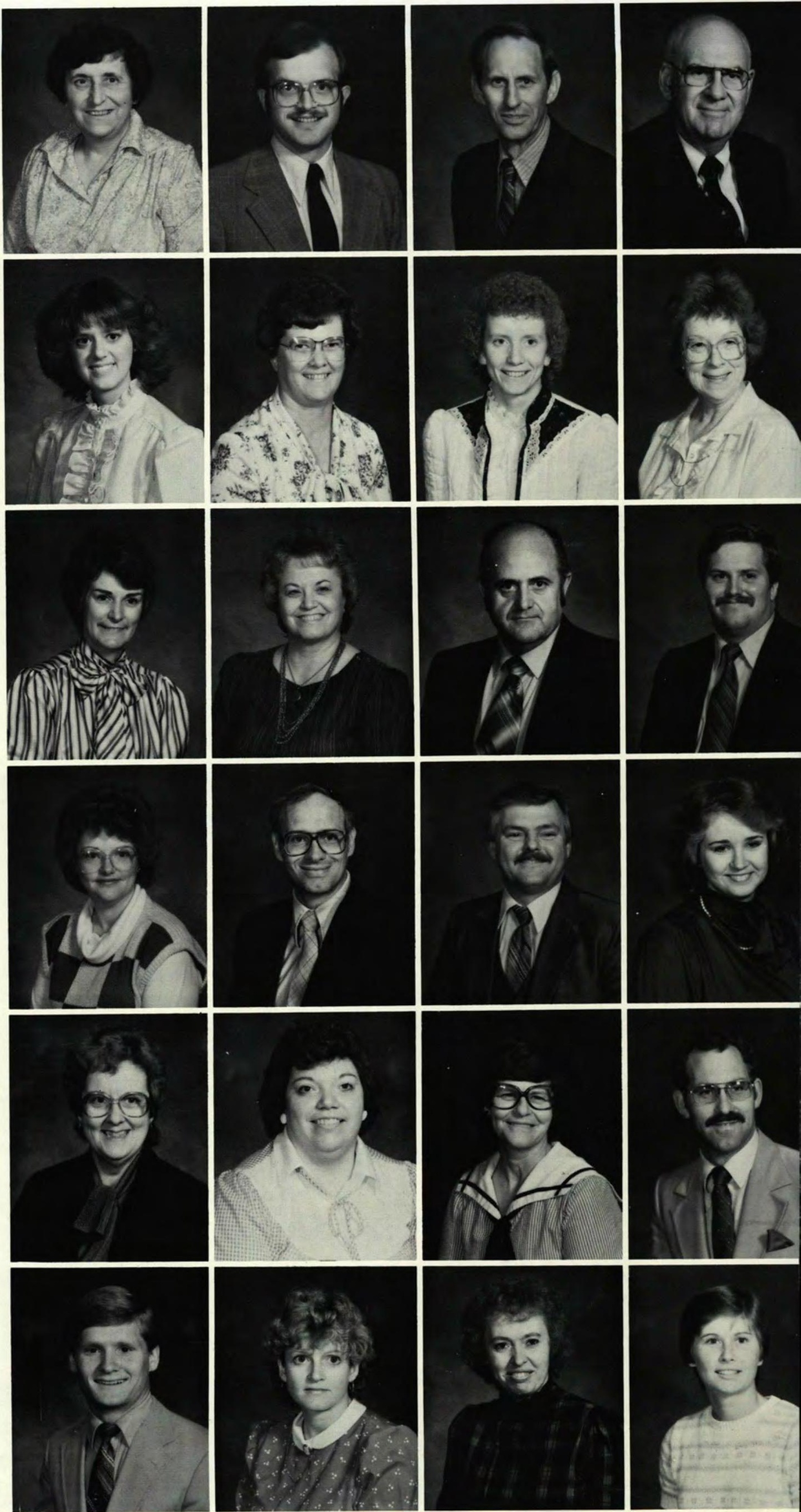

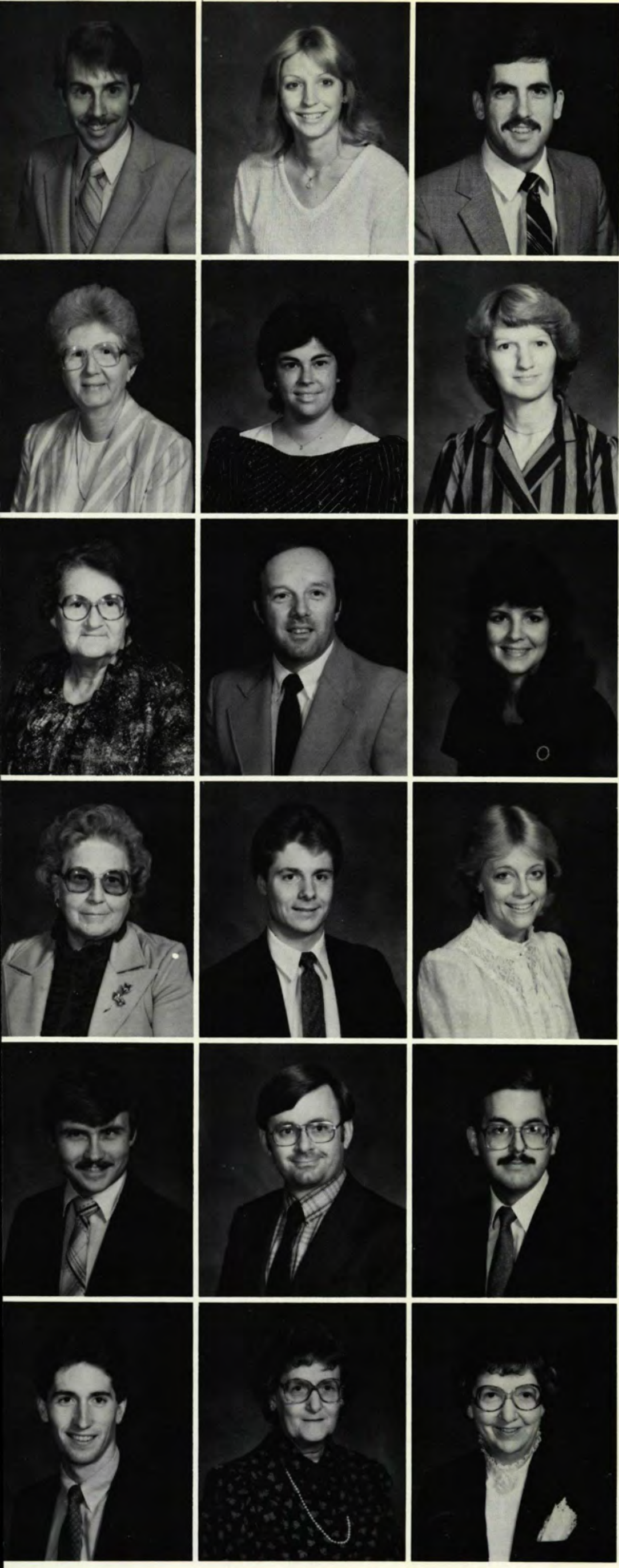

Bruce Maddux

WCDR - Electronic Technician

Dawn Mathews

Admin. Computer Serv. - Computer

Opr.

Mark Mathews

Ass't Dir. Rec. Activities

Stanley Matthews

Gen. Maint./Carpenter - Physical Plant

\section{Bernice Mick}

Bookstore Manager

Cheryl A. Miller

Christian Ministries Secretary

Mary Mitchell

Public Relations Sec.

Paul Paolino

Painter - Physical Plant

\section{Beatrice Printy}

Head Resident

David Purrington

Ass't Dir. of Physical Plant

Jennifer Raught

Library - M.P.C. Supervisor

Sharon Rawson

Admissions Office Manager

\section{Ethel Rayburn}

Library Secretary

Carl Ruby

Admissions Representative

Ruth Sagraves

Financial Aid Secretary

David Samuel

WCDR Audio Engineer

\section{Douglas SJoquist}

Dir. of Admin. Computer Serv.

Jon Skillman

WCDR Program Operations Dir. John Smith

Financial Aid Clerk

Michele Smith

Library - Serials Co-ordinator/

Acquisitions Clerk

\section{Roscoe Smith}

Admissions - Visitor Co-ordinator Dorothy Spencer

Sec., Vice President for Bus.

Ida St. Clair

Bus. Mgr's Off.

Switchboard Opr./Head Recept.

Mary Stahl

Bookstore - Cashier 
Joan Street Head Resident Kathy Sturgis

Campus Min. Ass't Dir. of Music

Rae Taylor

Alumni - Secretary

Virginia Taylo

Development Researcher

Steven Thompson

Ass't. Dir. of Financial Aid

John Tocknell

WCDR - Station Chief Engineer

Bonnie Vickman

Copy Center - Supervisor

Jeff Vickman

Schedule Control - Physical Plant

Allan Vine

Post Office - Clerk Don Wagner

HPE - A.C. Equip., Coordinator

Richard G. Walker

Director of Campus Activities

Paul R. Ware

Head Groundskeeper - Phys. Plant

Phyllis Wetzel

Planned Giving - Sec.

Cynthia Wolfi

Financial Aid - Sec.

Carla Womack

Academic Records - Clerk

Glenda Womack

Health, P.E. - Sec.

Jay Womack

Auto Mechanic - Physical Plant

Mark Womack

HPE - Sports Info. Dir.

Gerri Wyse

Bookstore - Cashier
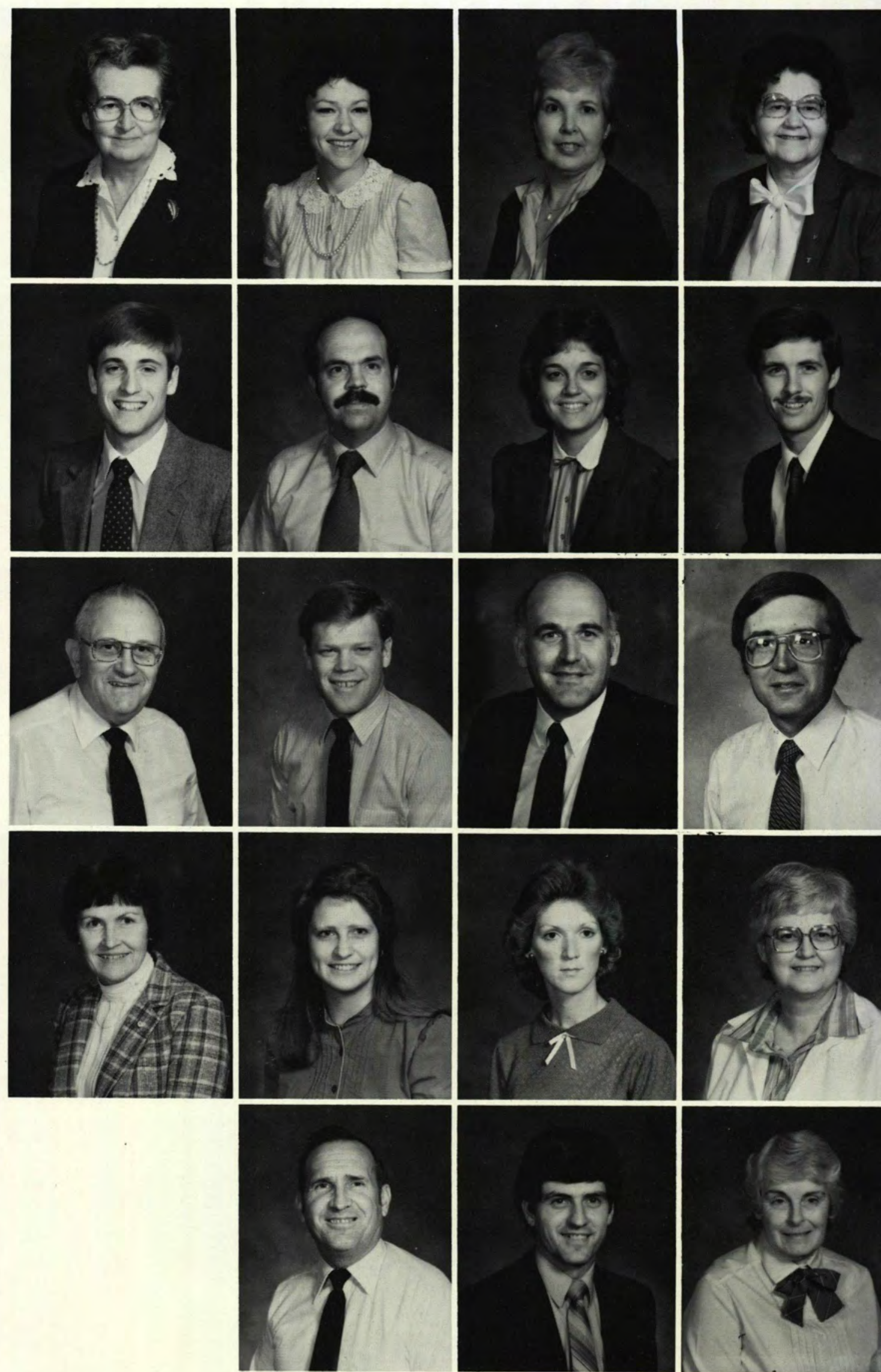


\section{FACULTY AND STAFF OF THE YEAR}

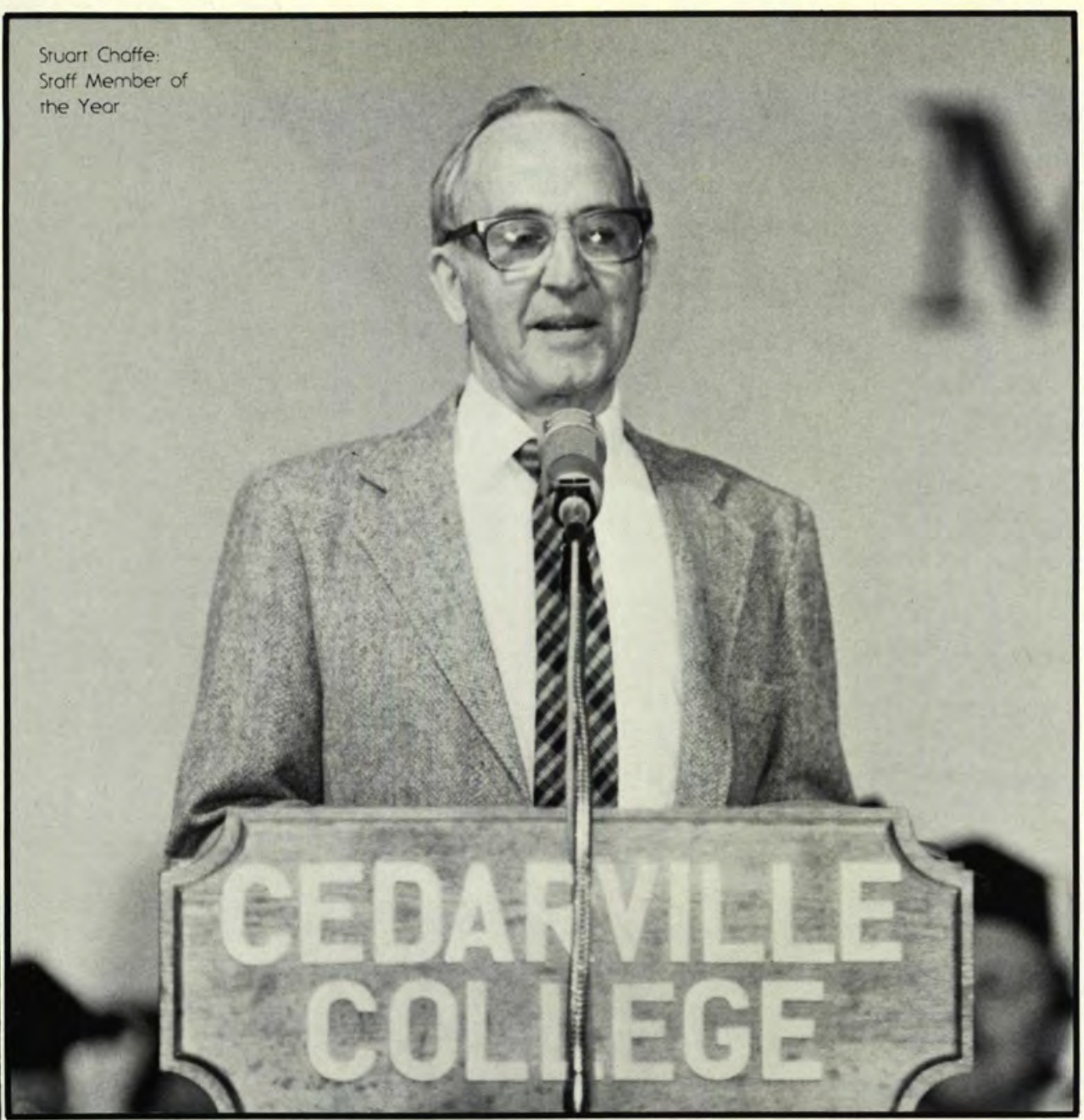

Mr. Stuart Chaffe:

To be associared with Cedarville College means very much to me because it stands "For the Word of God and The Testimony of Jesus Christ." As a student it was a privilege for me to sit under the instruction of Godly professors and also to listen to chapel speakers who contribured to my spiritual growth. Friendships made during those student days have continved through the years and have been a source of rich blessing.

As a staff member, it is a joy for me to have the opportunity to serve the Lord in a Christian environment and to enjoy the fellowship of members of the college family. To have a small part on a ream that is preparing students for their furure ministry is very rewarding. I am grareful to God for giving me a dedicared staff that enjoys their work and does it as unto the Lord.

Although serving the entire college family is a pleasure, it is particularly thrilling to meet second generarion students and M.K.'s whose parents were former classmates.

It has been an exciring experience to warch the Lord bless and enlarge the ministry of $\mathrm{Ce}$ darville College during the 29 years that my wife and I have been associated with it. Along me me, my wife and daughter are proud to have Cedarville College as our Alma Marer. Should the Lord so will, we would be delighred to see our three granddaughters also graduate from Cedarville College.

Stuart Chaffe

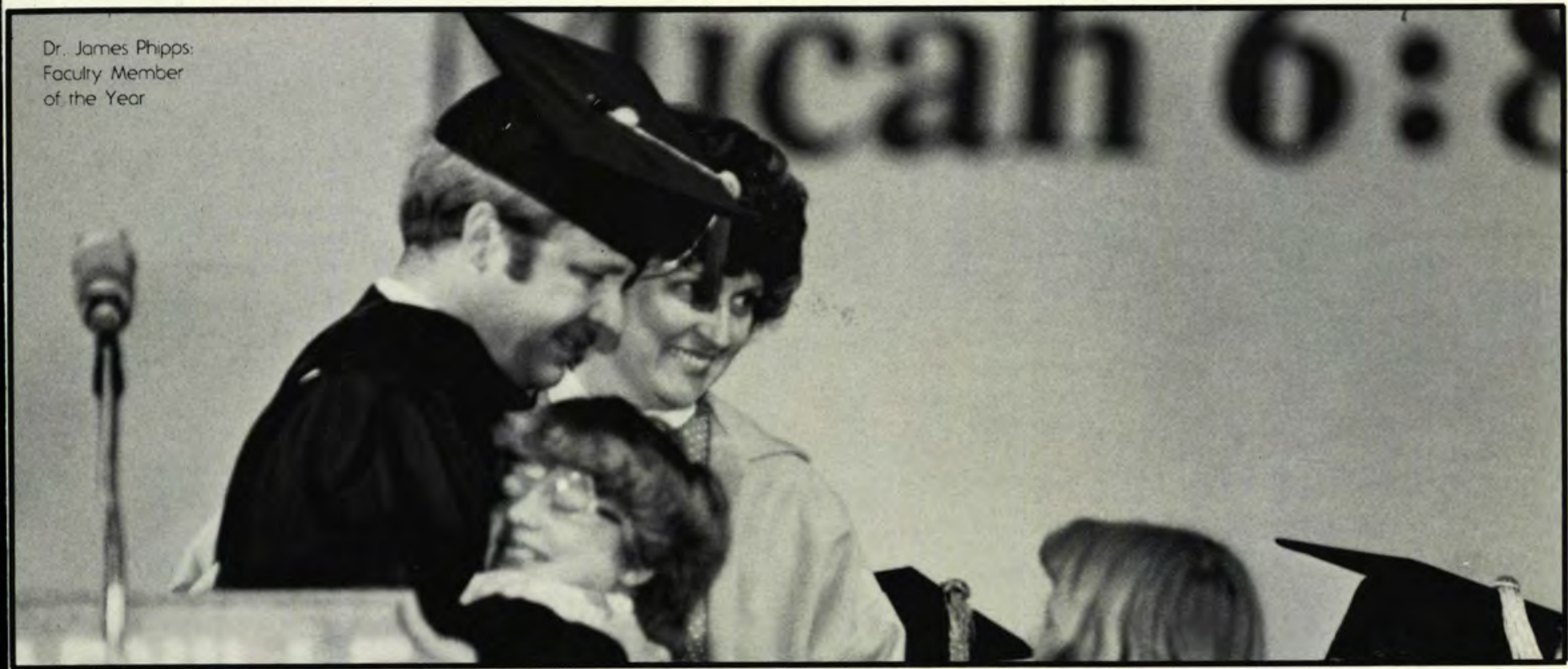

\section{Dr. James Phipps:}

$t$ is hard to express the gratitude that is felt at receiving a student generated award. To be recognized by those that you seek to serve is a great honor

The Lord has given me a grear love for Cedarville College and its students; and, in ret- rospect, I can see His leading in so many of the events of my life here. He has provided for me a family which also loves the college and is very supportive of me in the amount of effort that is necessary to try to do a good job as a teacher.

He has also provided faculty, colleagues, and administrators who continually challenge me to grow professionally and spiritually. These people are more valuable to me than anyone can express. The faculty award could have easily been awarded to many of them.

It is my prayer that we may all be able to work rogether to see God's work continue at Cedarville by challenging each orher to grow in our relationship with Him. 


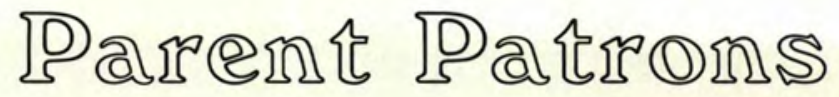

Mr. and Mrs. Lester Morse and family

Wiscasset, ME

Pastor and Judy Moser

Ashland, $\mathrm{OH}$

Walter and Lois Moser

Brook Park, $\mathrm{OH}$

Bob and Marge Mowry

Sherwood, MI

Mr. and Mrs. Ken Muckley

Strasburg, $\mathrm{OH}$

Clifford and Vera Musselman

Noblesville, IN

Carl and Iva Jean Nasse

Canajoharie, NY

Lawrence and Pearl Neal

Sharon Ville, $\mathrm{OH}$

Mr. and Mrs. Raymond A. Nemecek Hollywood, FL

\section{Nervo}

New York, NY

Mr. and Mrs. Gordon Netzley

Shepherd, MI

Bill and Barbara Nickoson

Dayton, $\mathrm{OH}$

Mrs. Vera Oakes

Binghamton, NY

Judge and Mrs. G.L. Oliver

Alexandria, VA

Mrs. Beulah J. Olson

Decorah, IA

Mr. and Mrs. Delwyn I. Orr, Jr. Muncie, IN

Mr. and Mrs. Webster Orton Algona, IA

Phil and Judy Parks

Hancock, $M I$

Mr. and Mrs. Roy Patrick

Kettering, $\mathrm{OH}$

Mr. and Mrs. Garold L. Paxson, Jr. Kokomo, IN

Mr. and Mrs. Silas Pearson

Springfield, MA

Mr. and Mrs. Thomas Perrott Horseheads, NY
Mr. and Mrs. Clarence A. Phillips, Sr. Sebring, FL

Mr. and Mrs. Samuel L. Pierce Dublin, $\mathrm{OH} 43017$

\section{Lori Pitonyak's parents \\ Bellwood, PA}

Mr. and Mrs. Ronald Plooy

Waukesha, WI

Edwin J. and Jean A. Pratt

Ypsilanti, MI

William and Elsie Prevost

Greenlawn, $N Y$

Mr. and Mrs. Phil Parman

Epworth, IA

Mr. and Mrs. Ford M. Patrick

Columbus, $\mathrm{OH}$

Mrs. Margund Pearson

Millburn, NY

Ron and Louise Perkins

Hinckley, $\mathrm{OH}$

Rev. and Mrs. Douglas Peters

Troy, $\mathrm{OH}$

Mr. and Mrs. Thomas J. Phipps III Coates ville, $P A$

Mr. and Mrs. Jack Pomeroy

Troy, MI
Mr. and Mrs. Edward Pugh Louisville, $\mathrm{OH}$

Mr. and Mrs. John Racz Hoffman Estates, IL

Mr. and Mrs. Arnold Ramey Lombard, IL

Mr. and Mrs. Walter Ray Lebanon, $\mathrm{OH}$

Mr. and Mrs. Ralph Reed Mt. Sidney, VA

Mr. and Mrs. George E. Reede Geigertown, PA

Mr. and Mrs. Pete Reese Saugus, $C A$

Mr. and Mrs. Lewis A. Regnier Toledo, $\mathrm{OH}$

Mr. and Mrs. Robert Reichard Gilbertsville, $P A$

Rev. William and Gloria Reid Hong Kong

Warren and Eva Richards Lima, $\mathrm{OH}$

Louis and Virginia Richardson Columbus, NJ

Mr. and Mrs. James Rickard Richland, WA

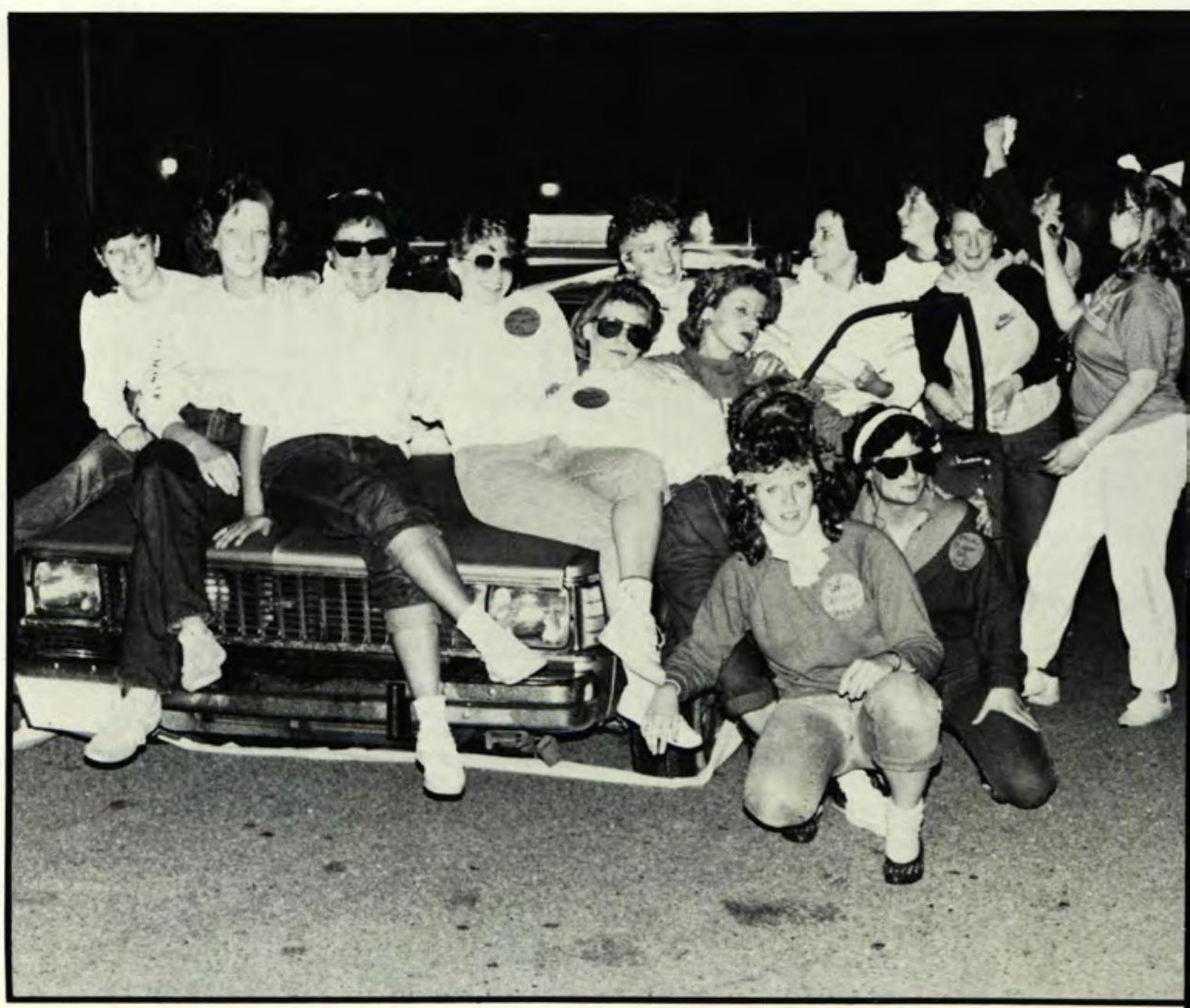



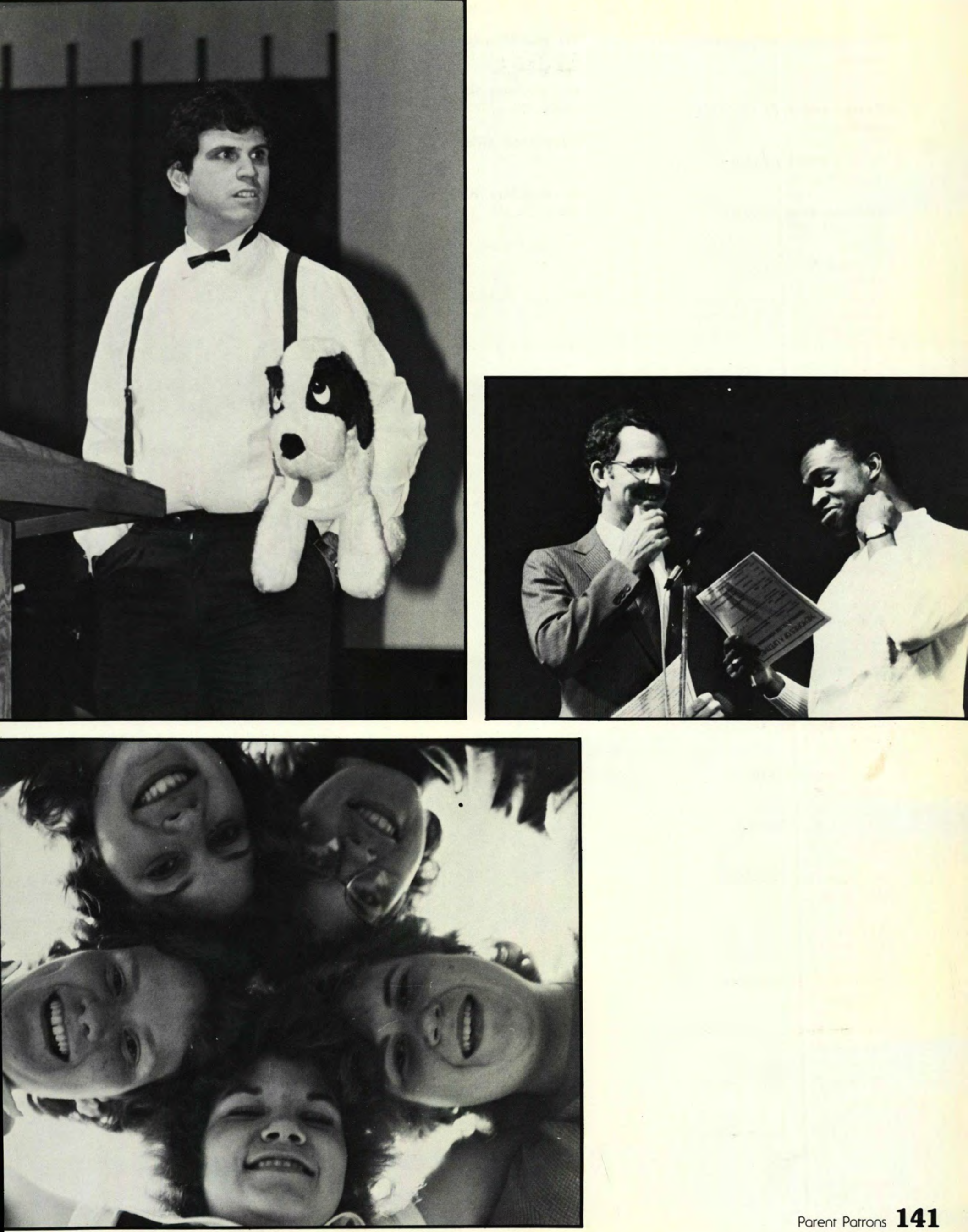

Parent Parrons 141 


\section{Daren Da代OAS}

Loren and Audry Terpstra

Sully, IA

Mr. and Mrs. Arthur E. Tewksbury

Sheffield Village, $\mathrm{OH}$

\section{Art Thompson}

Endicott, $N Y$

Mr. and Mrs. Douglas K. Thompson Berea, $\mathrm{OH}$

Mr. and Mrs. Robert B. Thompson Bridgeville, DE

Mr. and Mrs. Ralph J. Todd

Plainview, $M N$

Mr. and Mrs. Clyde Tome

Detroit, MI

Mr. and Mrs. James R. Triehy

Pepperell, MA

Mr. and Mrs. Glenn Troyer

Kentwood, MI

Ernie and Hazel Truman

Greenville, SC

Mr. and Mrs. Donald L. Tuttle Spring City, PA

Mr. and Mrs. Richard A. Tyler

Portage, MI

Mr. and Mrs. Tom Ulmer

Seymour, IN

Mr. and Mrs. Ellis Vanness

Stickney, IL

Mr. and Mrs. David Van Schoick Bergen, NY

Mr. and Mrs. Allen Ve Strand Westfield, $N Y$

Mr. and Mrs. Albert M. Wagner West Long Branch, NJ

Mr. and Mrs. Frank Walker Cornwall, NY

Mr. and Mrs. James H. Wallace Worthington, $\mathrm{OH}$

\section{Don and Marlene Walter \\ Findlay, $\mathrm{OH}$}

Don and Barbara Ward

Hudson, IA

William and Beth Warfield

Greenwood, IN
Mr. and Mrs. Jack Wassenaar Grand Rapids, MI

Mr. and Mrs. Jack Weber Bigfork, MT

\section{Linden and Judith Welch Huntington, MD}

Mr. and Mrs. Richard Weiss

Centerville, $\mathrm{OH}$

Ted and Jan Weitkamp

Jacobus, $P A$

Bob and Mary Whitaker

West Chester, $\mathrm{OH}$

Mrs. John S. White

Orlando, FL

Rev. Richard D. Whittenburg Houston, TX

Lucille F. Wight

Ravenswood, WV

Mr. and Mrs. John W. Wilson Ravenswood, WV

Rev. and Mrs. C.R. Windnagle Spencer, $N Y$

Dwight and Jan Winkleman

Buffalo Center, IA

Mr. and Mrs. William H. Wolcott

Chardon, $\mathrm{OH}$
Mr. and Mrs. Ralph W. Wyand Hagerstown, MD

Dr. and Mrs. Rod Wyse

Cedarville, $\mathrm{OH}$

Duane and Kathy Young

Columbus Grove, $\mathrm{OH}$

Donna and Thomas Young Orlando, FL

Mr. and Mrs. John Zehrung San Pablo, CA

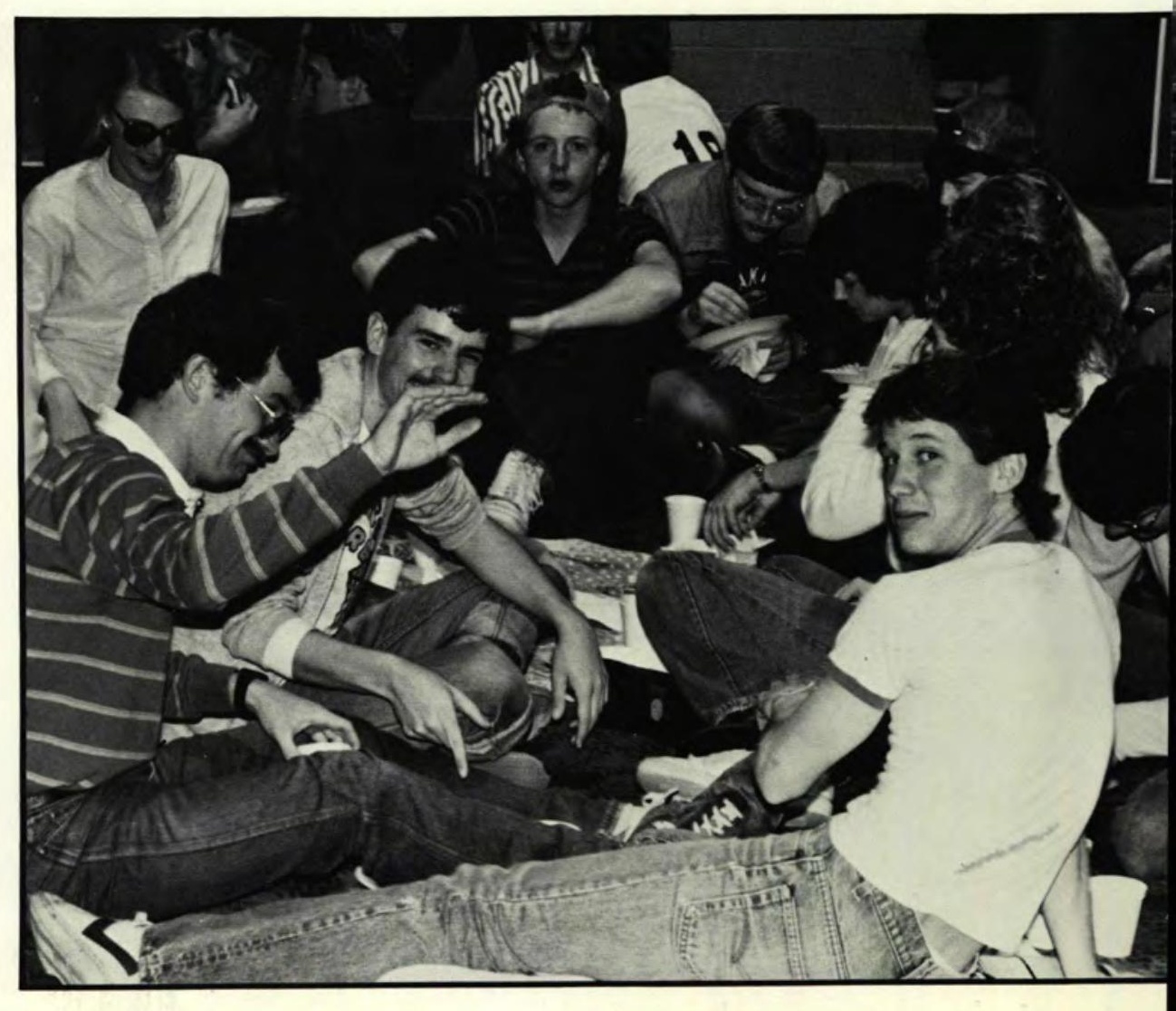



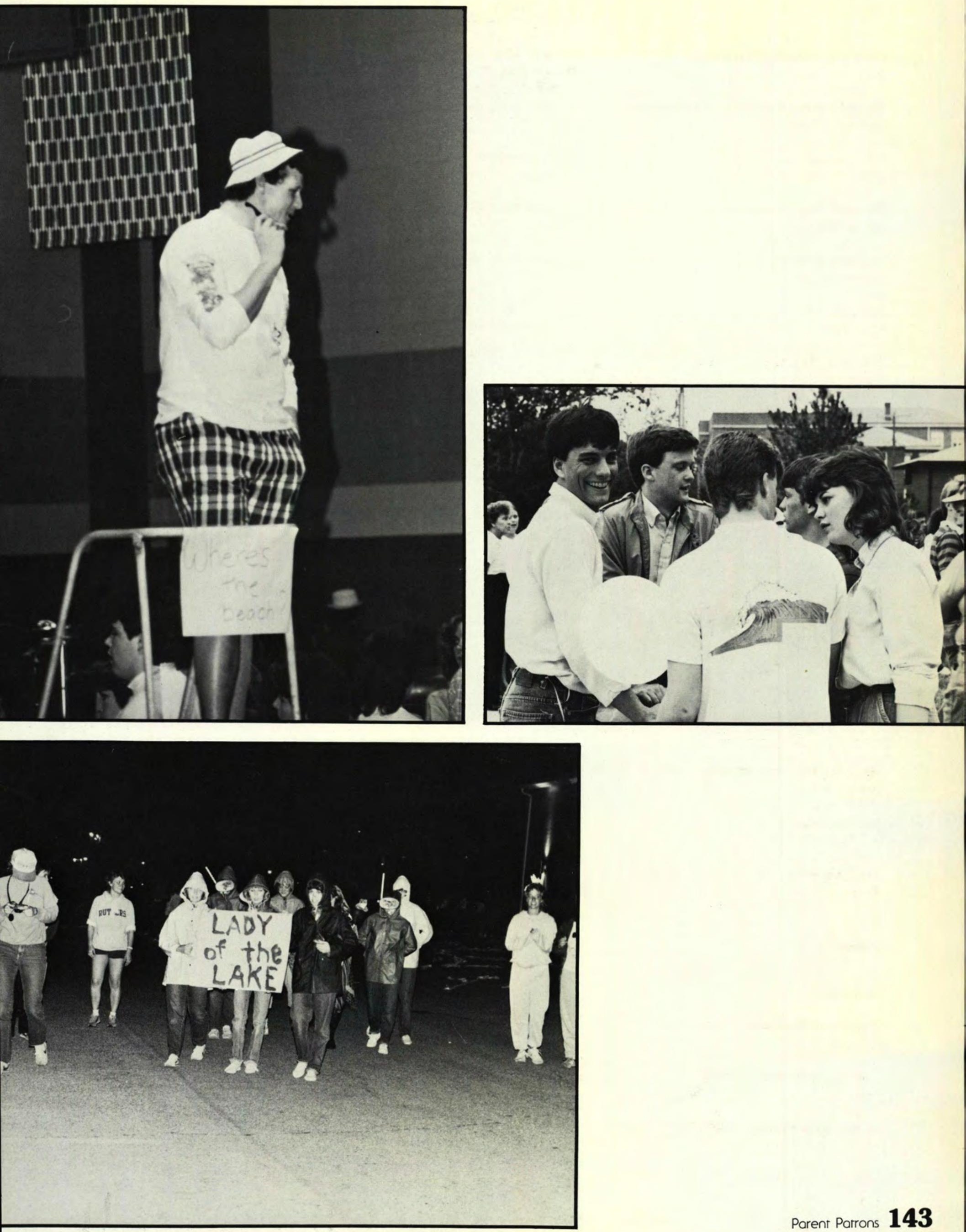


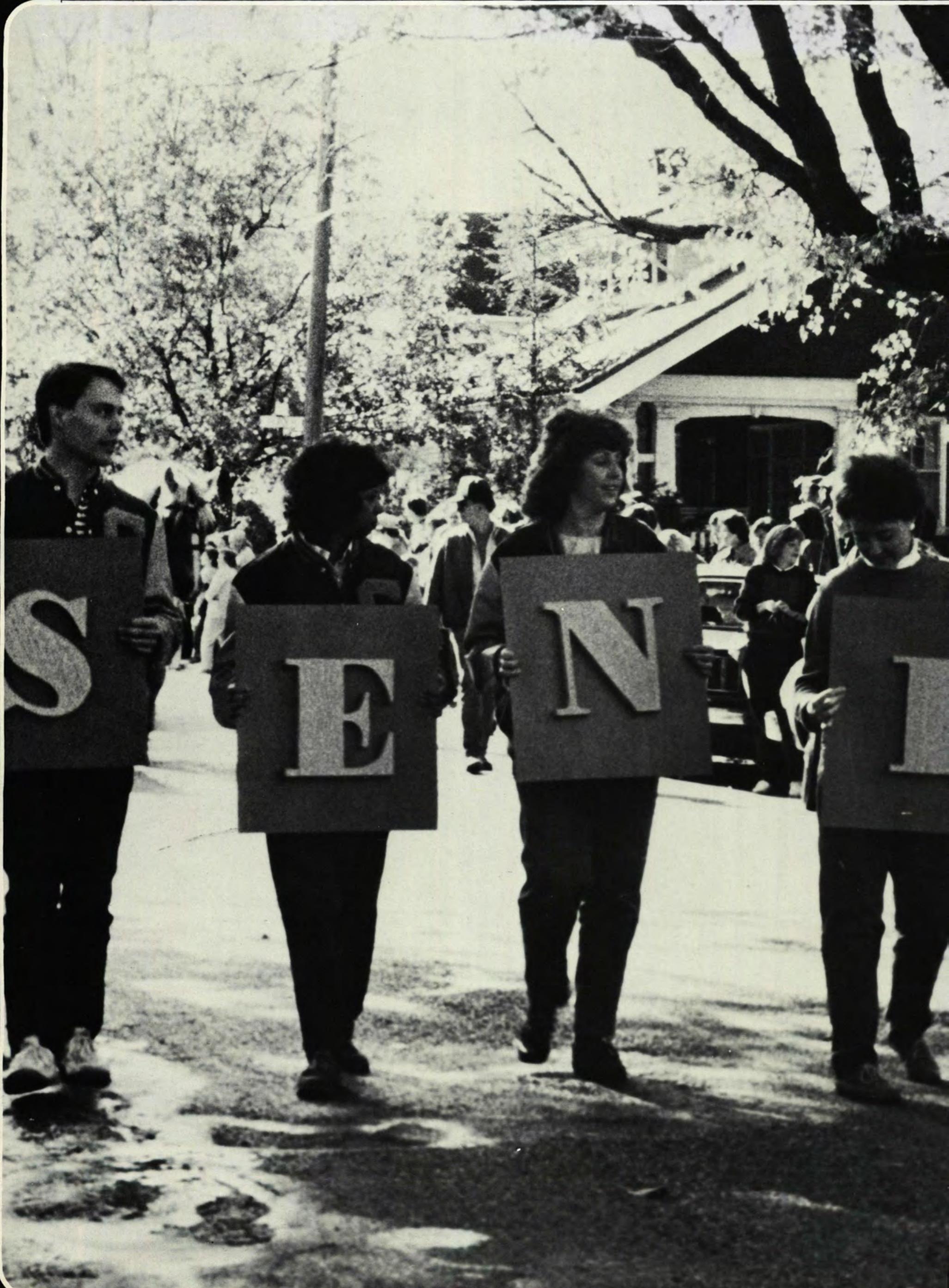




\section{The Day Has Come ...}

The preparation stage is now drawing to a close.

We feel somewhar prepared in

our major,

we've seen ourselves change, marure,

and establish life-time values.

We've often questioned, "Why Lord?

Why can't I be out in the world now?"

Bur that day has come.

We hesitate.

We ponder.

For the goodbyes are sad to say:

those friends to whom we entrusted our lives,

those friends with whom we've spent

hours laughing and crying,

those friends who will always be

in our memories.

But that day has come. As you look

at the next few pages, you will

see our pains, our changes, and

our wisdom. For we shall stand

together on that graduation day,

united as one, soon to be scartered,

soon to be faced with unknown

challenges, and soon to leave

precious friends.

Brenda James

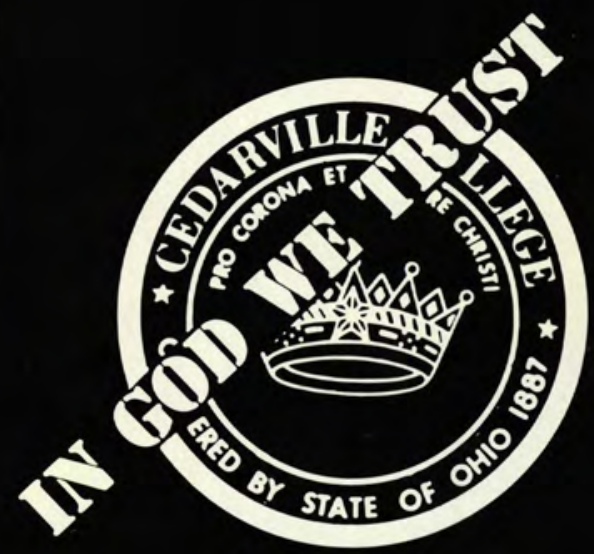




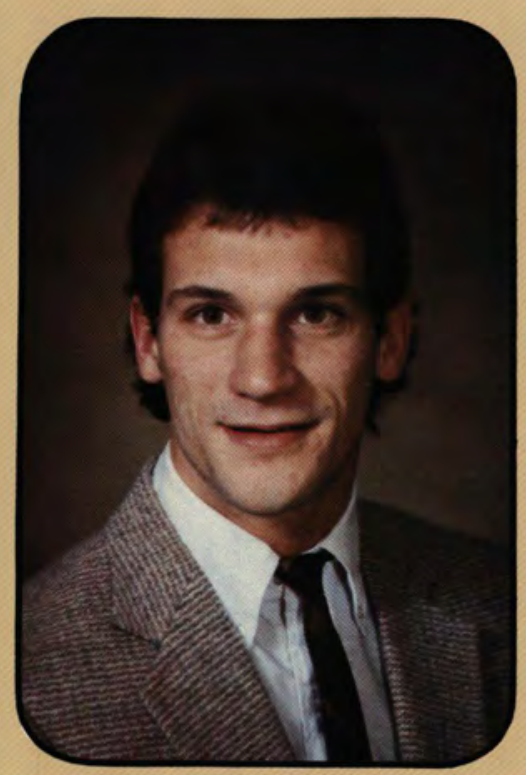

Charles E. Abel Business Administration Covington, Kentucky

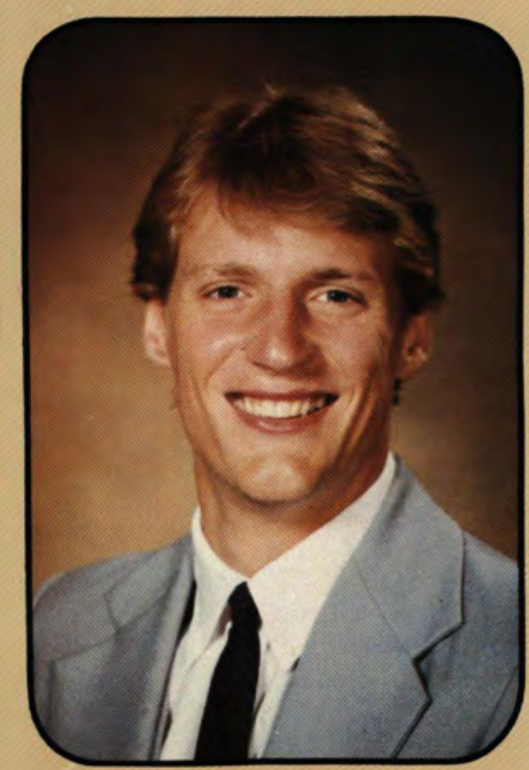

Gary B. Anderson Chemistry Ringwood, New Jersey

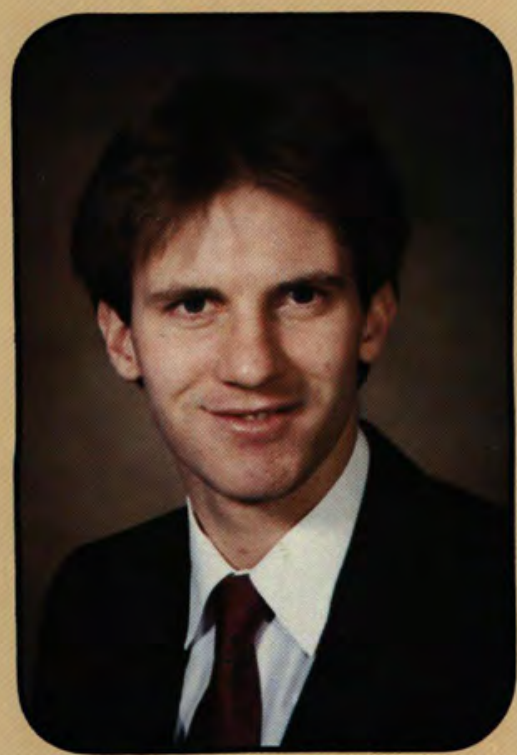

Dave C. Averill Bible/Preseminary New Hampton, lowa

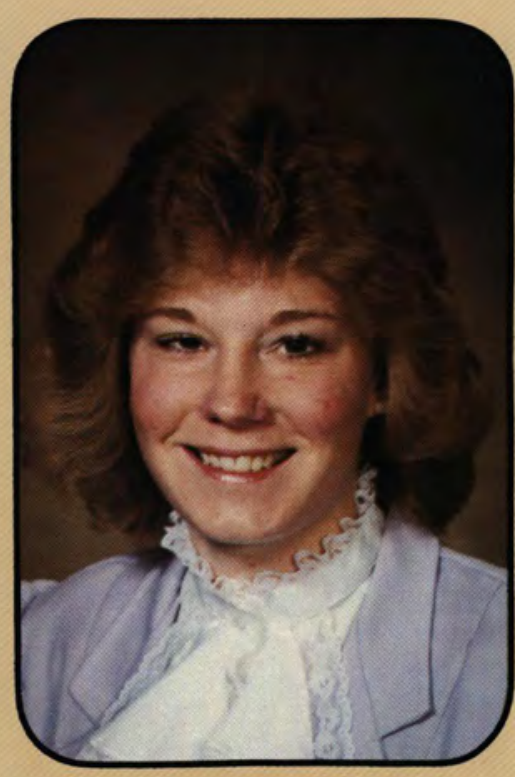

Joyce Ann Abel Accounting

Greenwood, Indiana

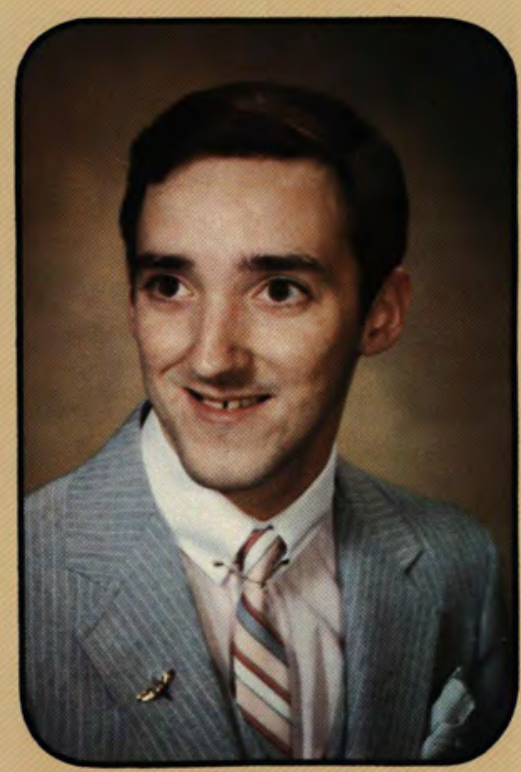

Hugh M. Anderson History

Moundsville, West Virginia

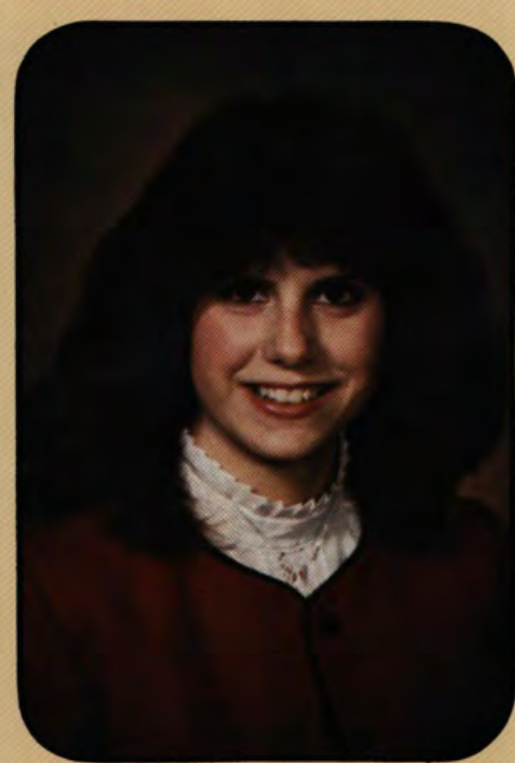

Kimra I. Ayres

Accounting

Cincinnati, Ohio

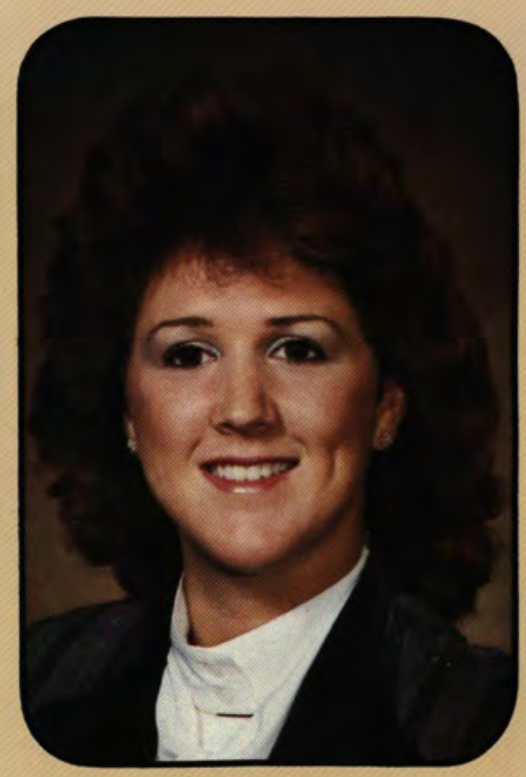

Shari Lynn Altimus

Physical Education

Olmsted Falls, Ohio

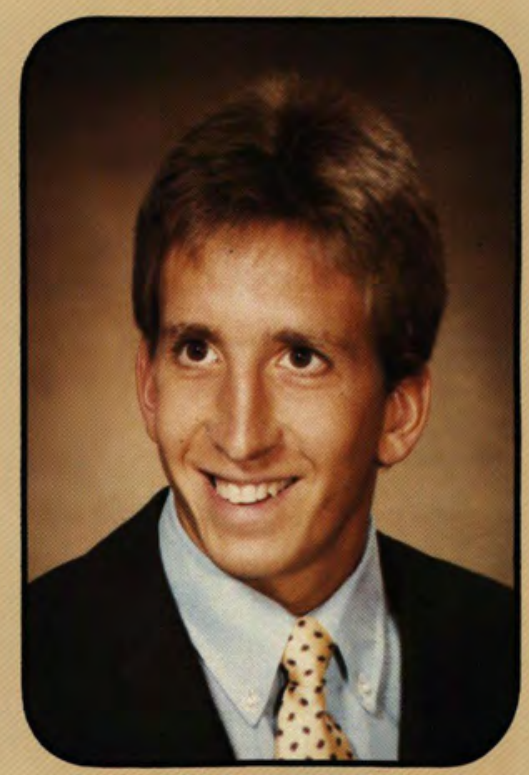

Wayne Paul Anderson

Business Administration

Hamburg, New York

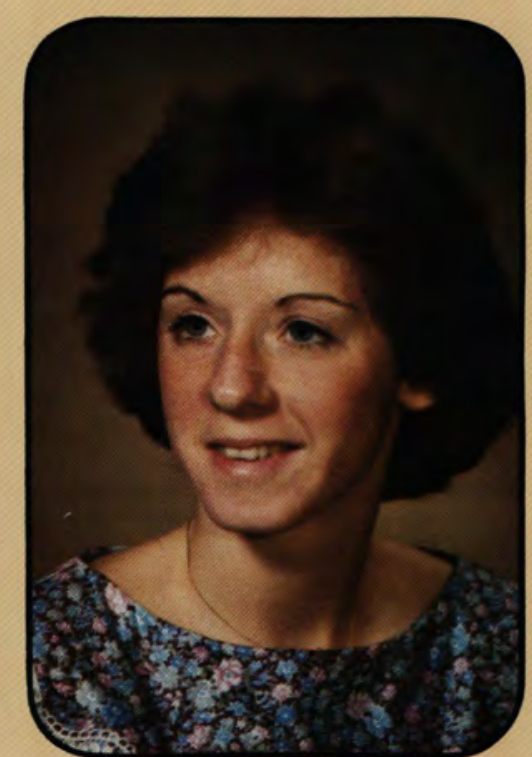

Sharon Lynn Banzhof

Business Administration

Muncy, Pennsylvania

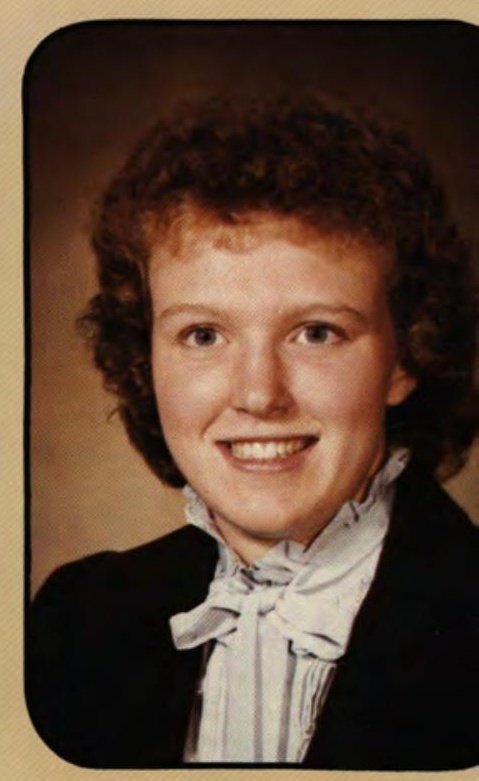

April Lynne Ames English

Florence, New Jersey

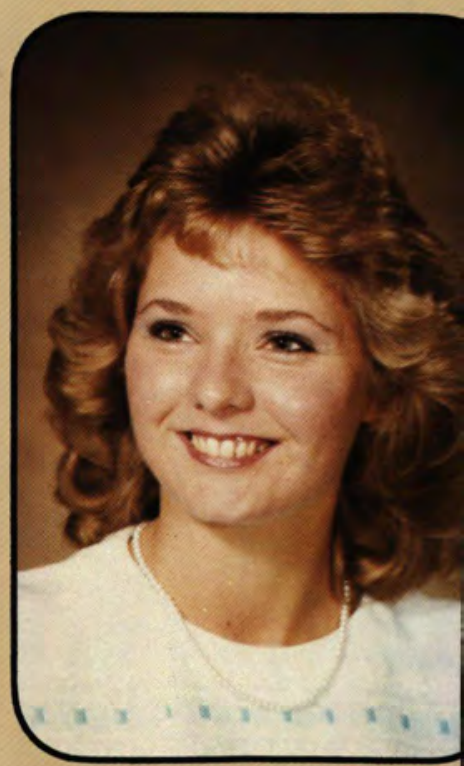

Tina Lynn Ashley

Elementary Education Wellston, Ohio

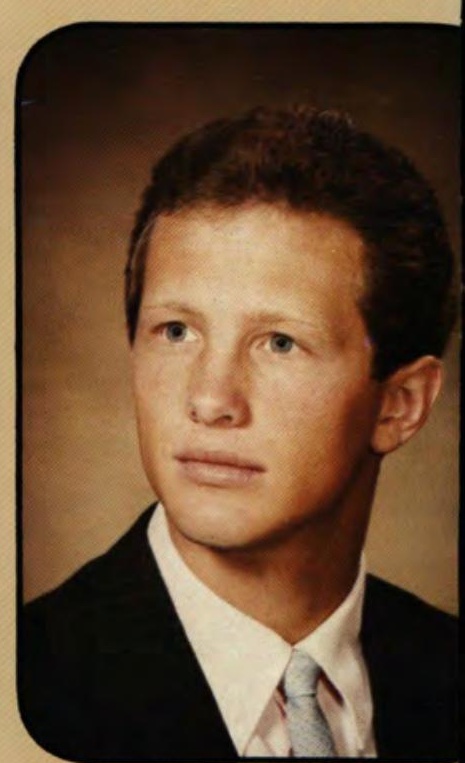

James R. Barber Behavioral Science/Psycholos Seminole, Florida 


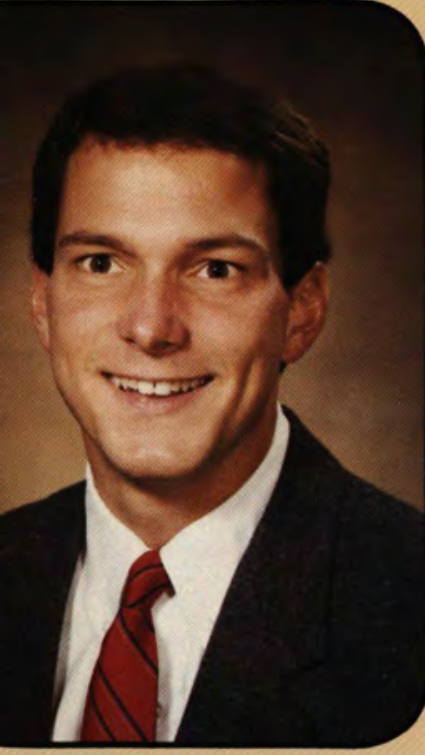

Daniel Dale Barfell

Bible Comprehensive

Elkhart, Indiana

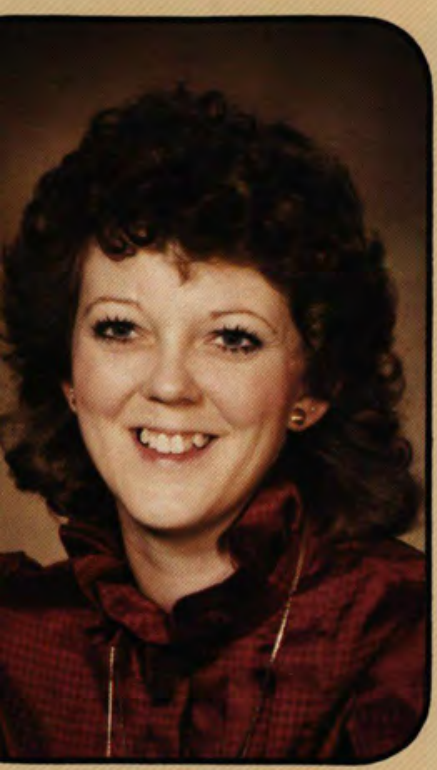

Judy L. Bears

Nursing

Denver, Colorado

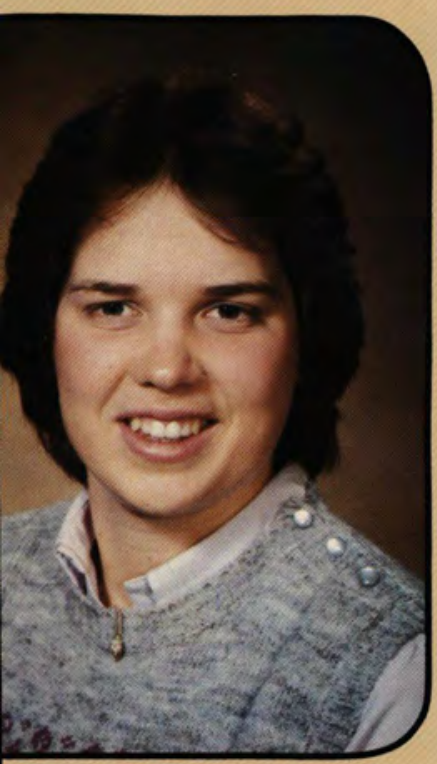

Laurie Ann Benedict

Physical Education

Kalamazoo, Michigan

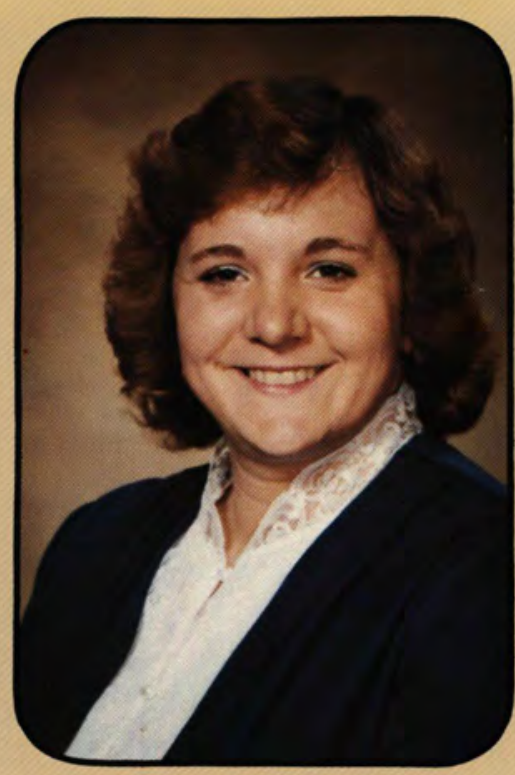

Lorene F. Barram

Elemenaty Education

Medina, Ohio

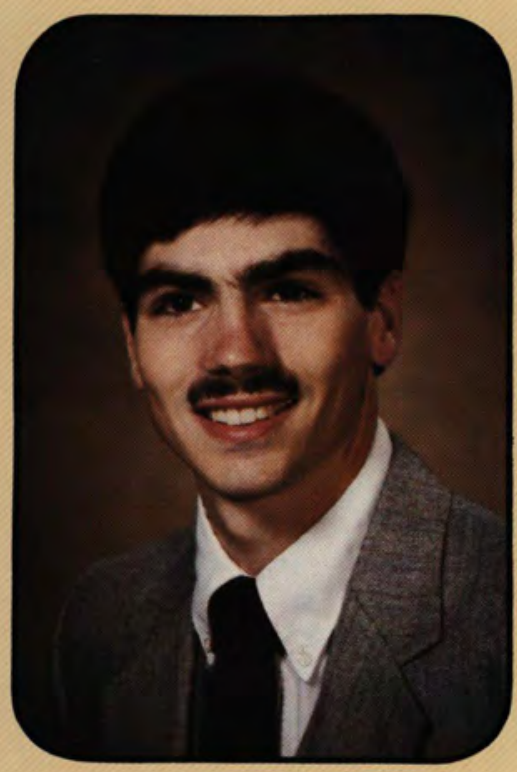

Jon D. Beight

Bible Comprehensive

Brownsburg, Indiana

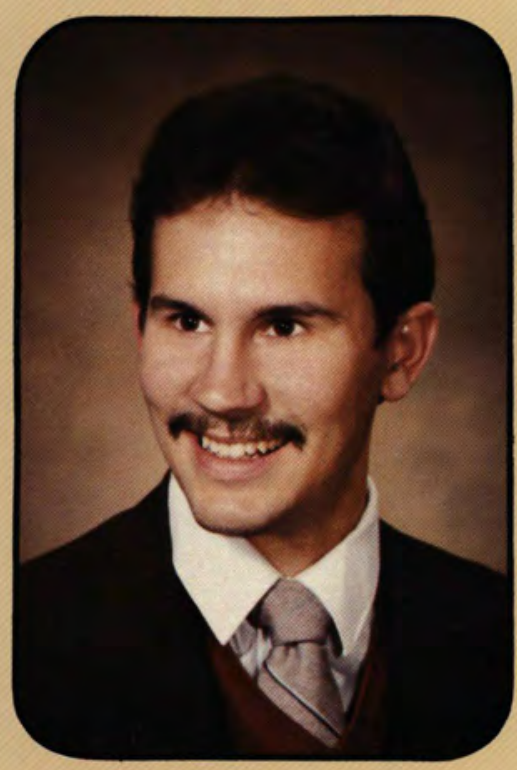

Jim A. Bennett

Bible/Preseminary

Randolph, New York

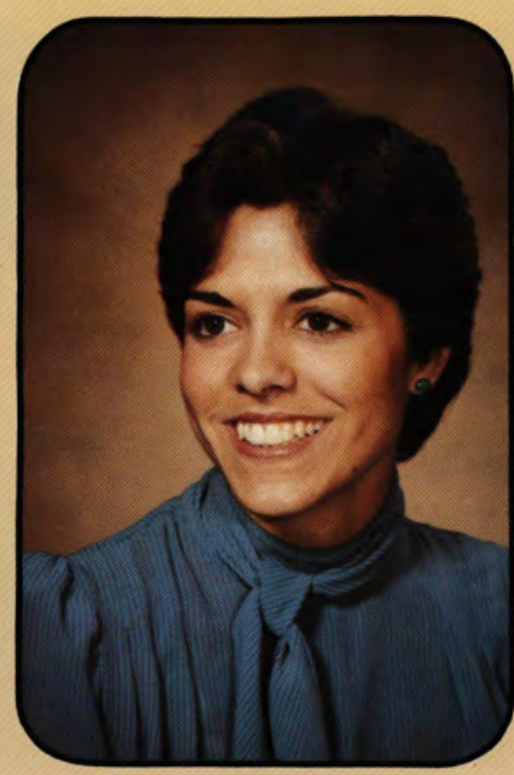

Deborah Ann Battaglia

Accounting

Cedarville, Ohio

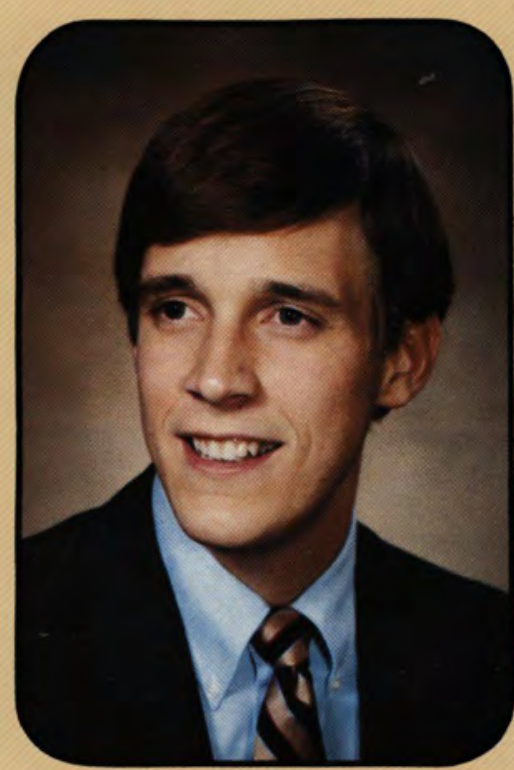

Robert Carl Beikert Jr.

Bible/Preseminary

Cedarville, Ohio

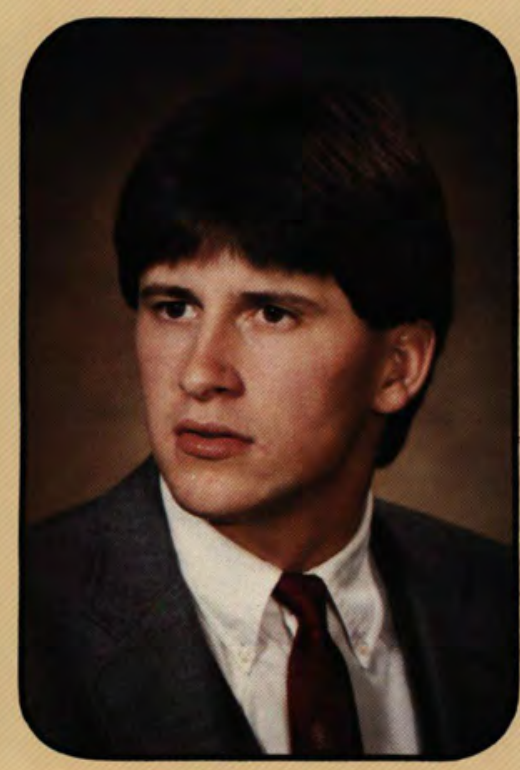

Jay Paul Benson

Broadcasting

Zanesville, Ohio

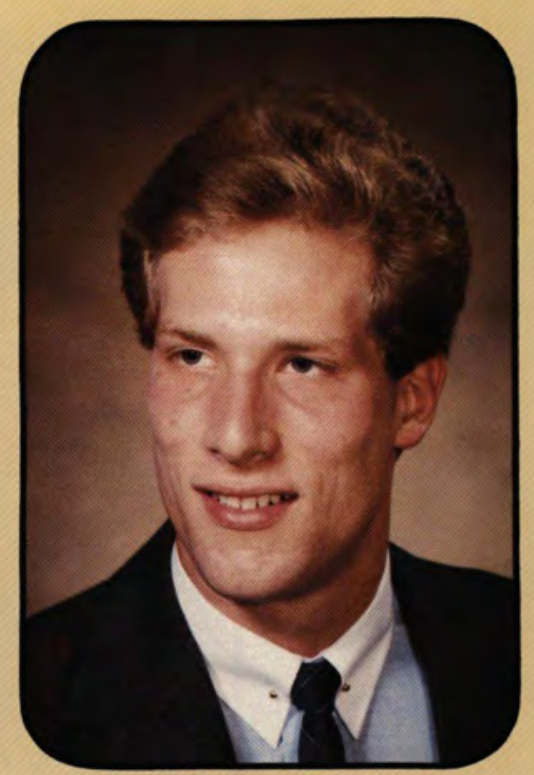

Robert A. Bauer

Business Administration

Beavercreek, Ohio

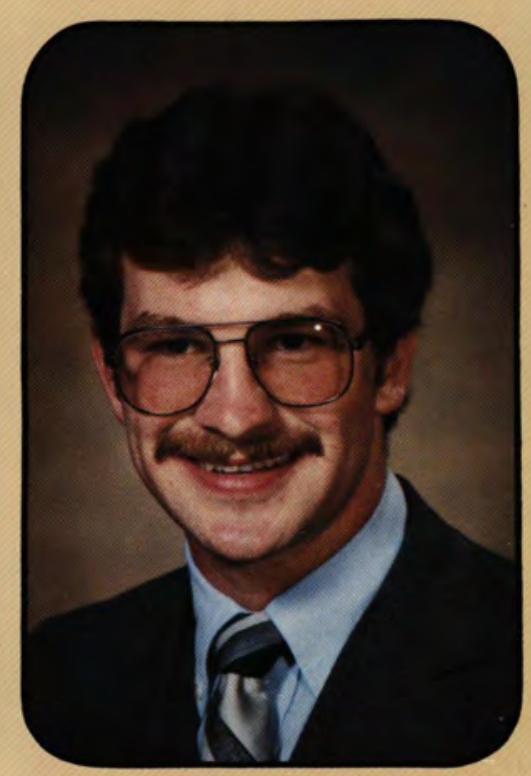

James Robert Benedict

Elementary Education

Port Huron, Michigan

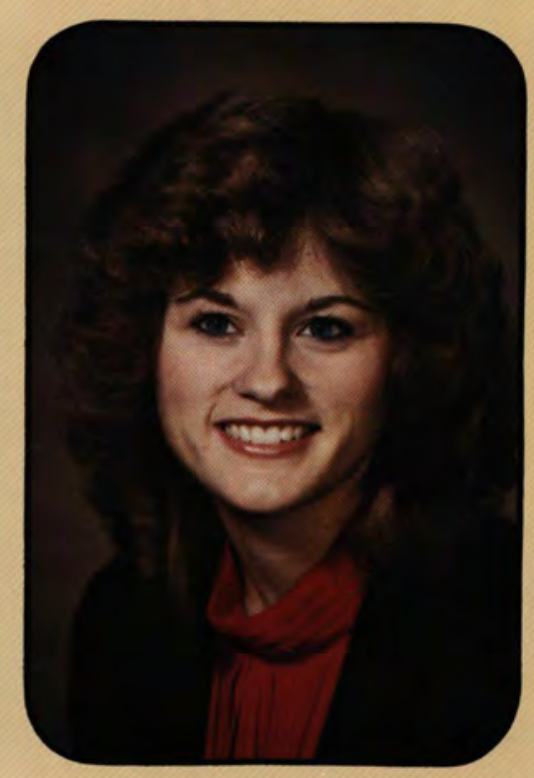

Shellie L. Benson English

Rochester, Illinois 


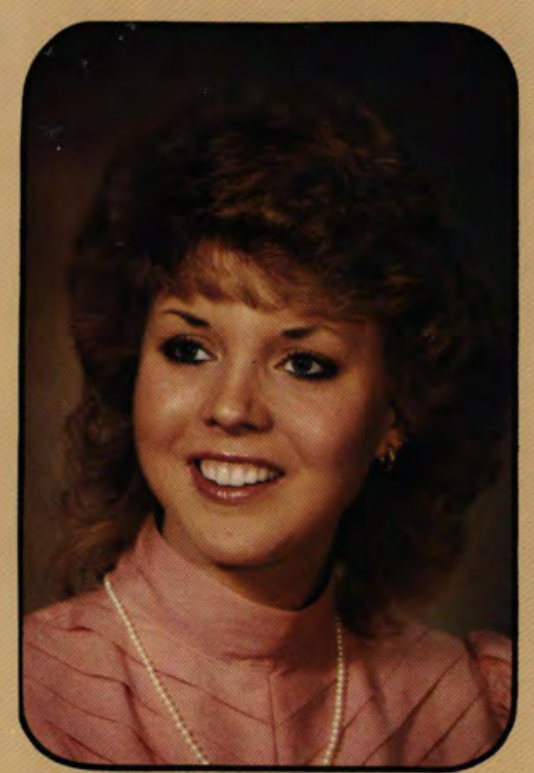

Julie Marie Bergman

Elementary Education

Tacoma, Washington

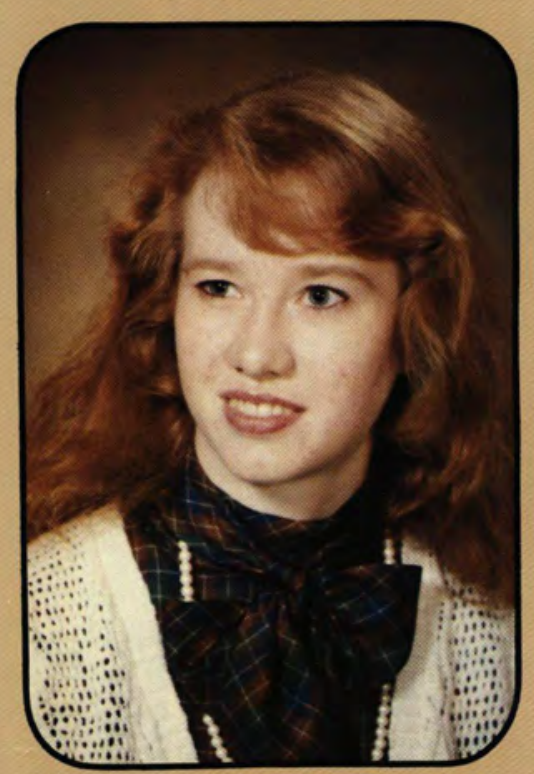

Diane Louise Blasdell

English Education

Eden, New York

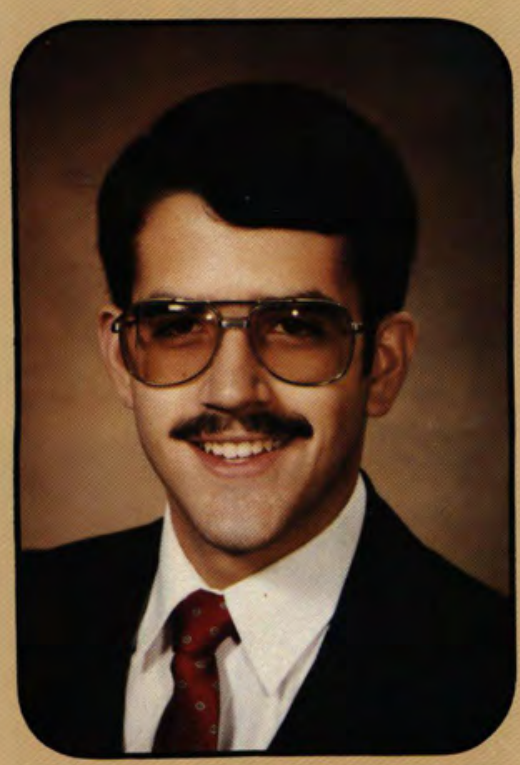

Ricky Clayton Bowers

Accounting

Amherst, Ohio

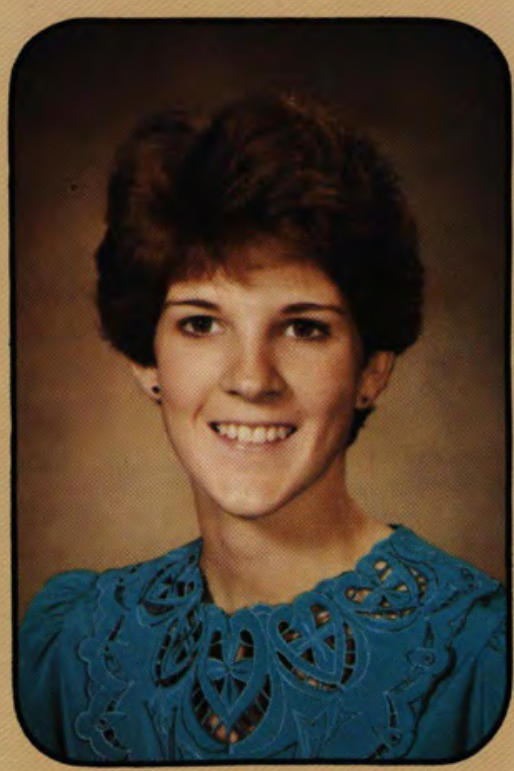

Lori E. Bishop

Accounting

Birmingham, Michigan

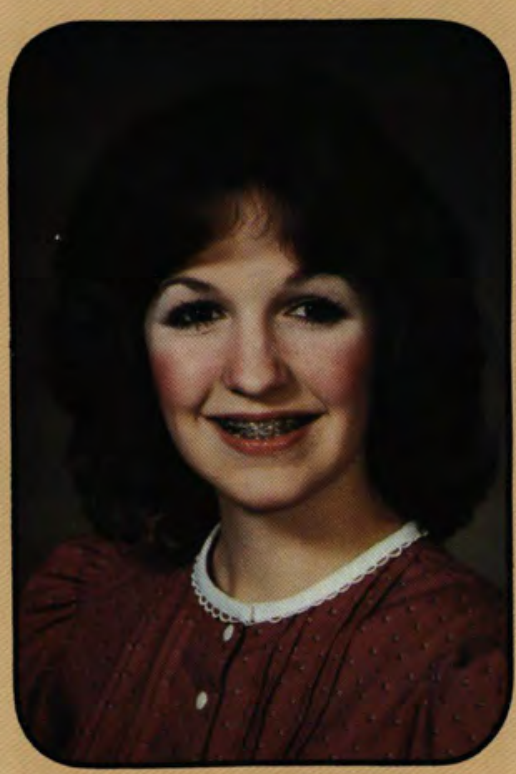

Brenda L. Blass

Nursing

Dayton, Ohio

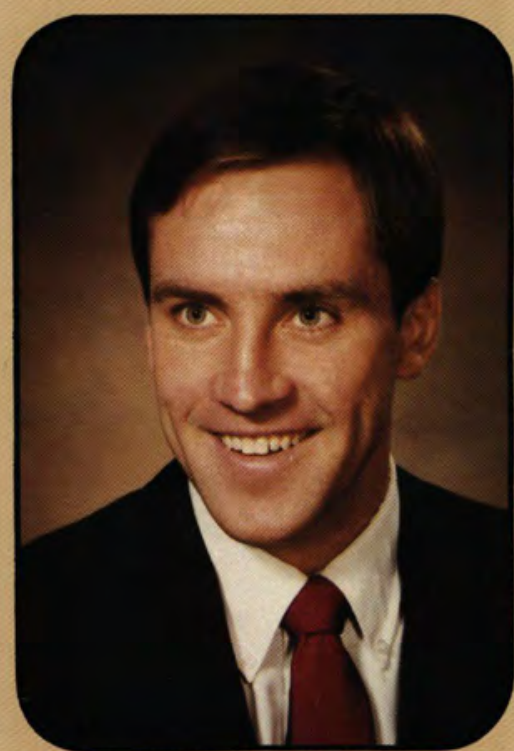

Aaron Timothy Bowes

Bible/Preseminary

Little Current, Ontario

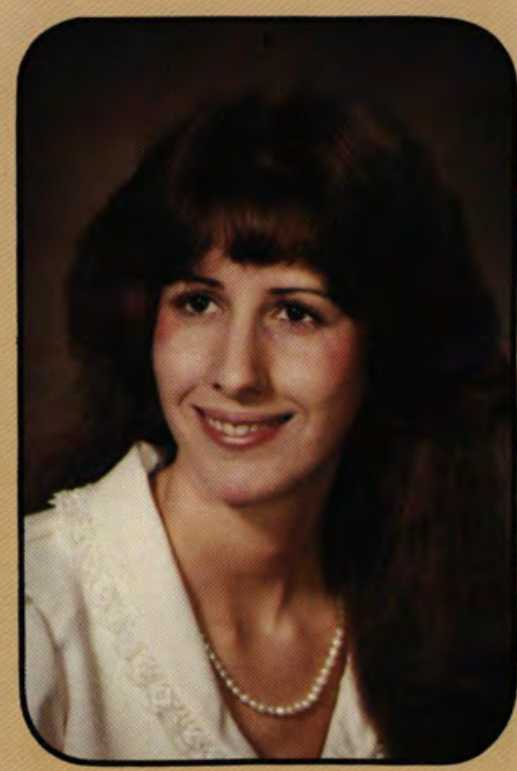

Sara J. Blackburn Nursing

Xenia, Ohio

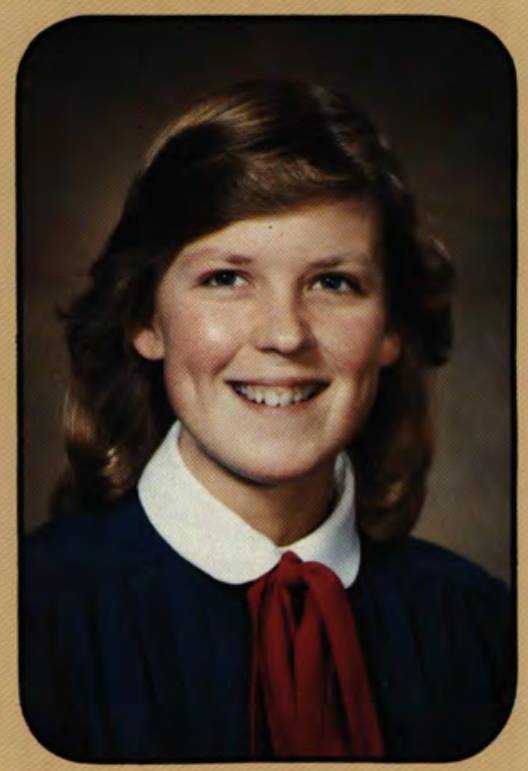

Jenny Anne Boer

Elementary Education

Croydon, Victoria, Australia

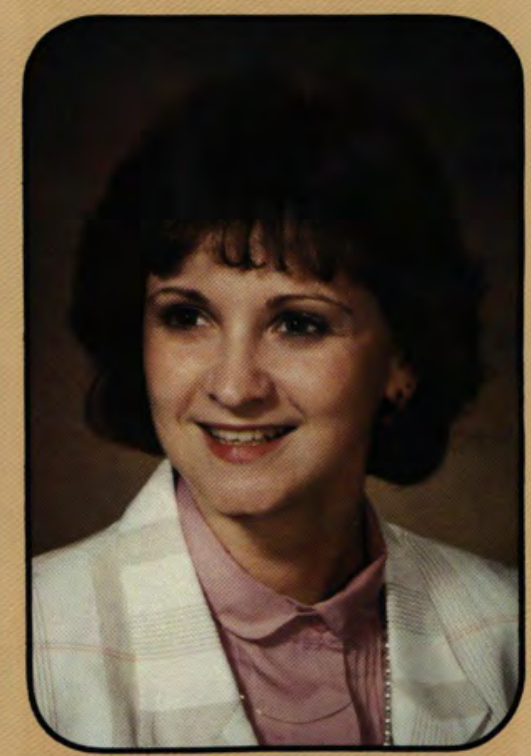

Robin R. Bowling Speech

Columbus, Ohio

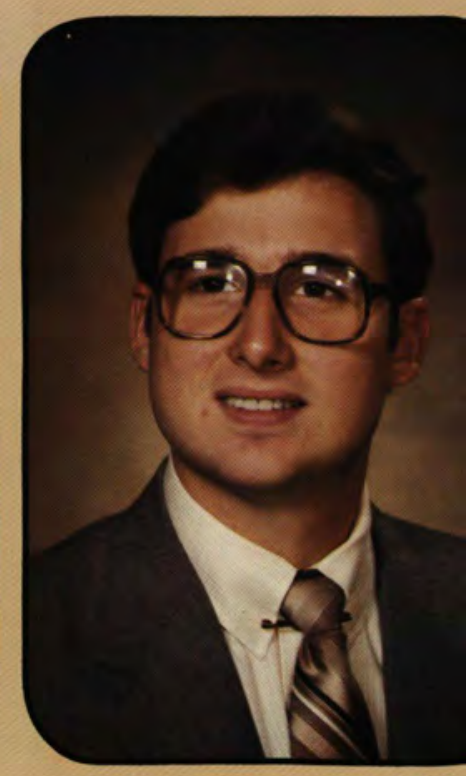

David Joseph Blackston Bible Comprehensive

Cincinnati, Ohio

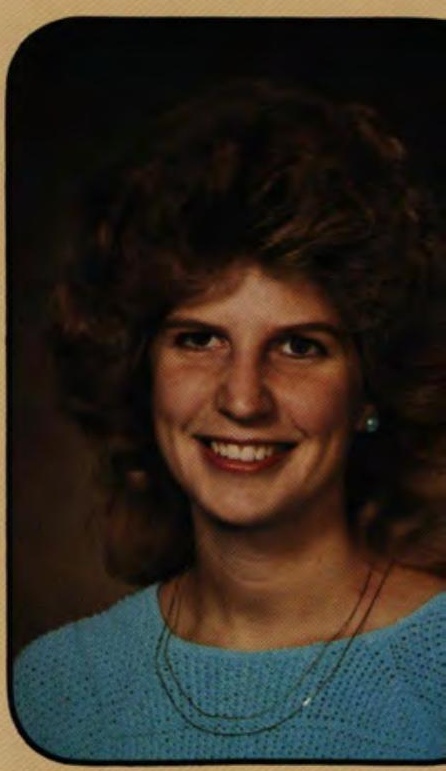

Wendy S. Border

Business Administration Beach City, Ohio

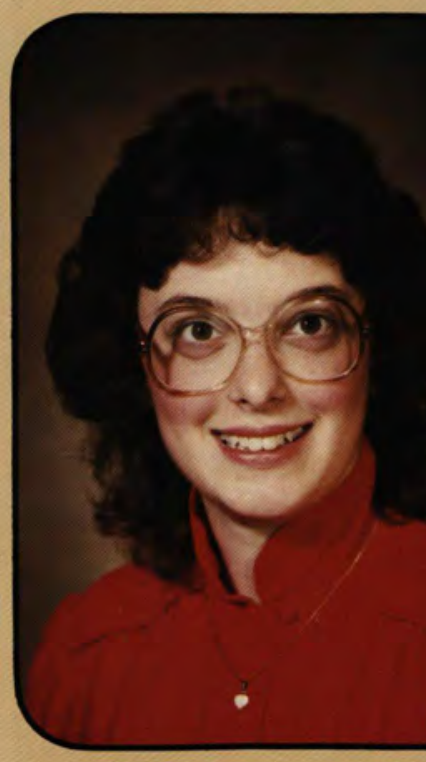

Alice Paulette Boyd Secondary Ed. Spanish Rowley, Massachusetts 


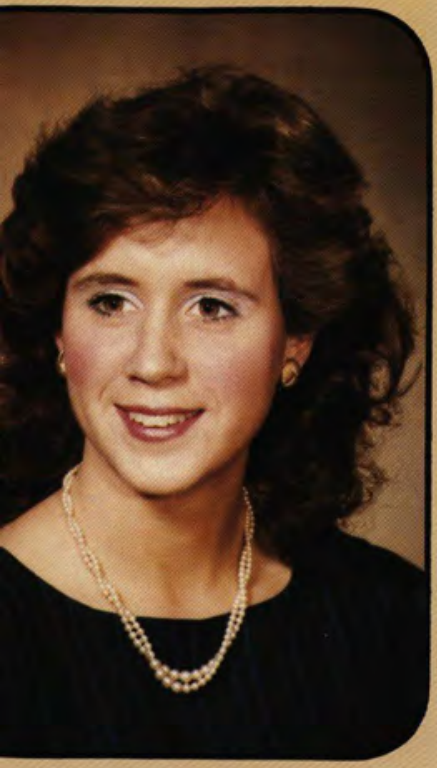

Linda Lee Briggs

Music Education

Jay, New York

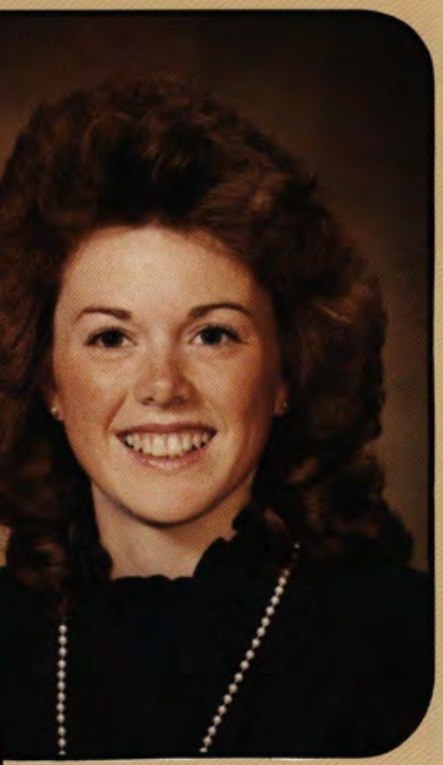

Esther Kae Bucklew

Nursing

Newark, Ohio

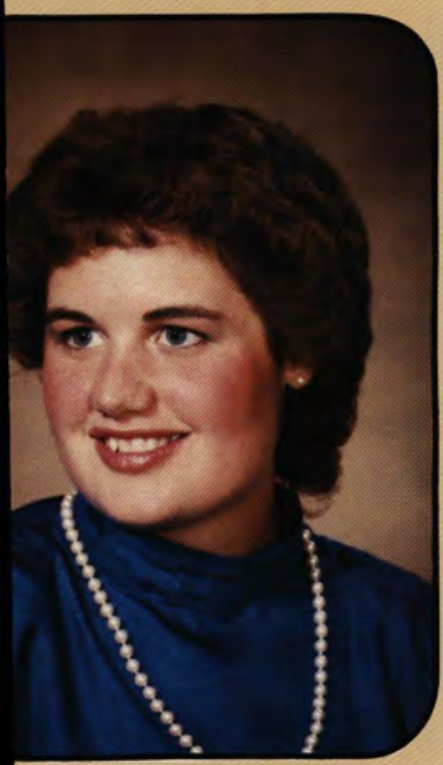

\section{Lynn Butcke \\ Broadcasting}

Dayton, Ohio

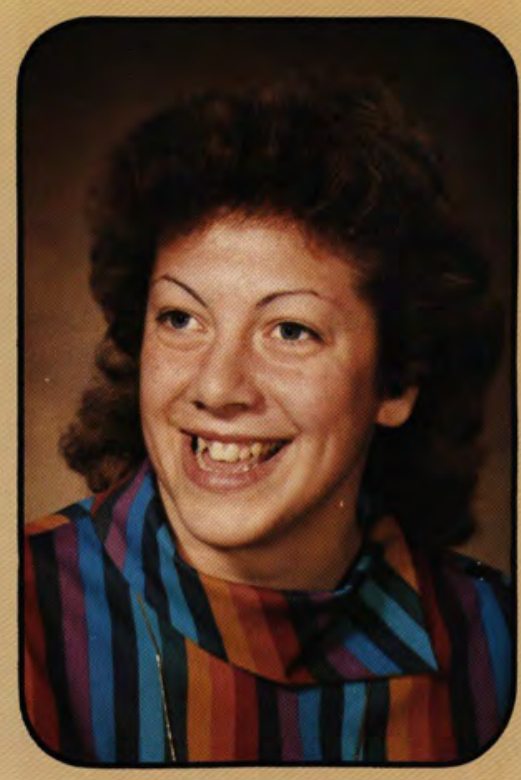

Beth Britton

Biology

Kingston, Michigan

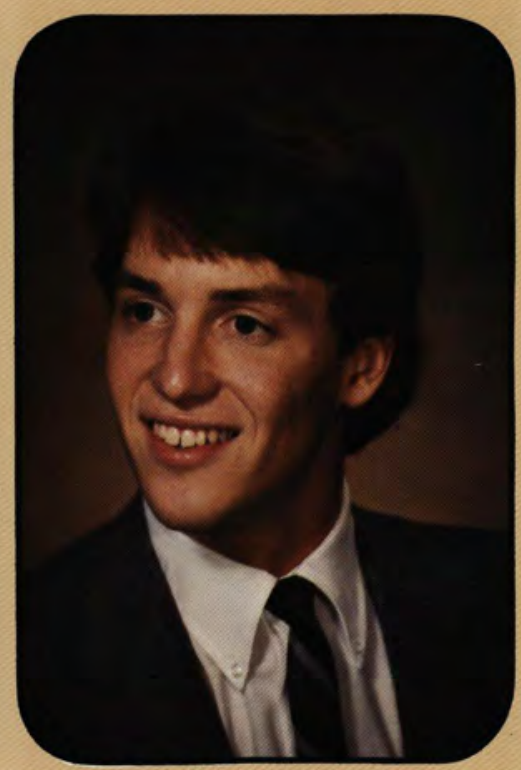

Dale J. Burdick

History Education

Elkhart, Indiana

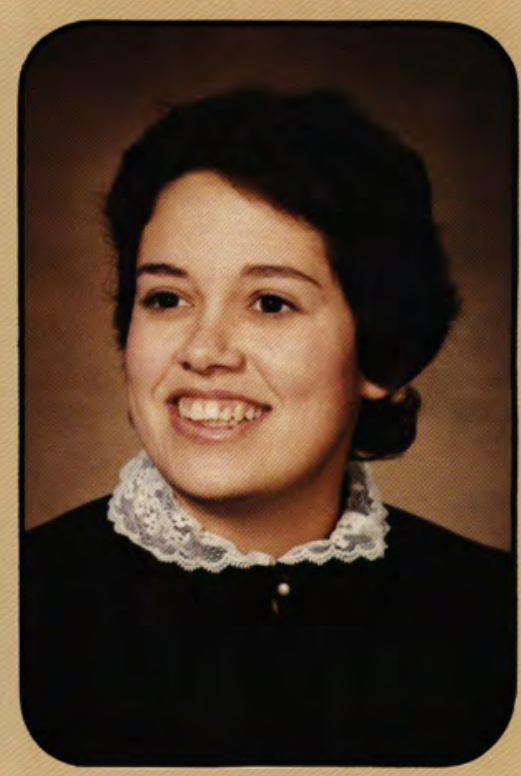

Cynthia L. Butler

Elementary Education Sandusky, Ohio

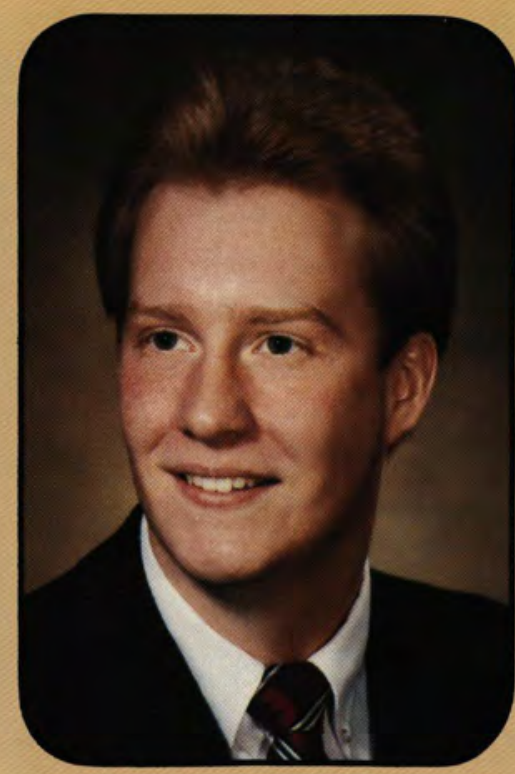

Glen Chalmer Brown

Business Administration Jefferson, Ohio

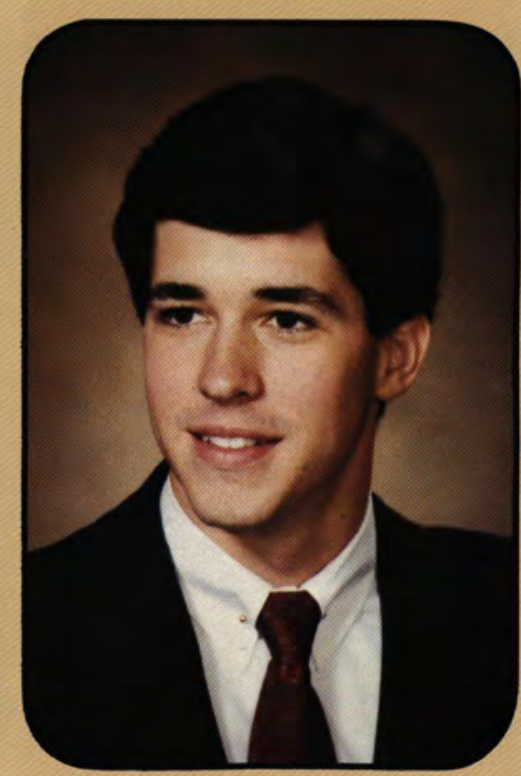

David C. Burghen

Business Administration

Audubon, New Jersey

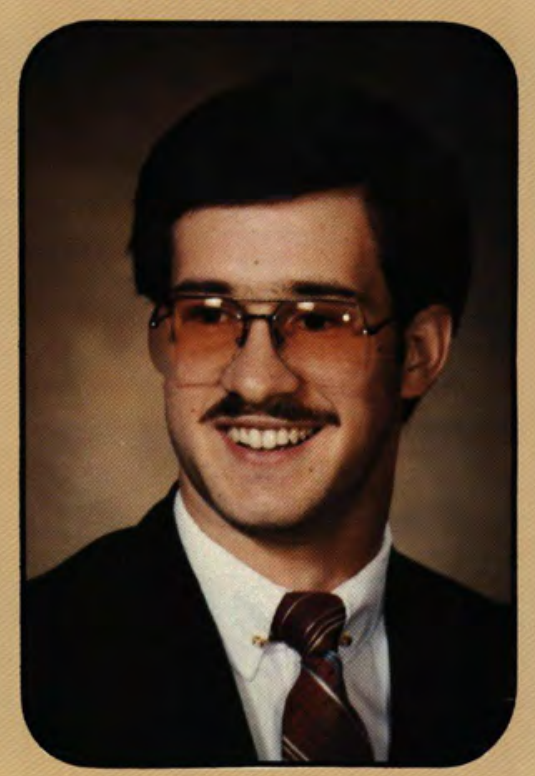

Warren William Byrd Prelaw

Edmeston, New York

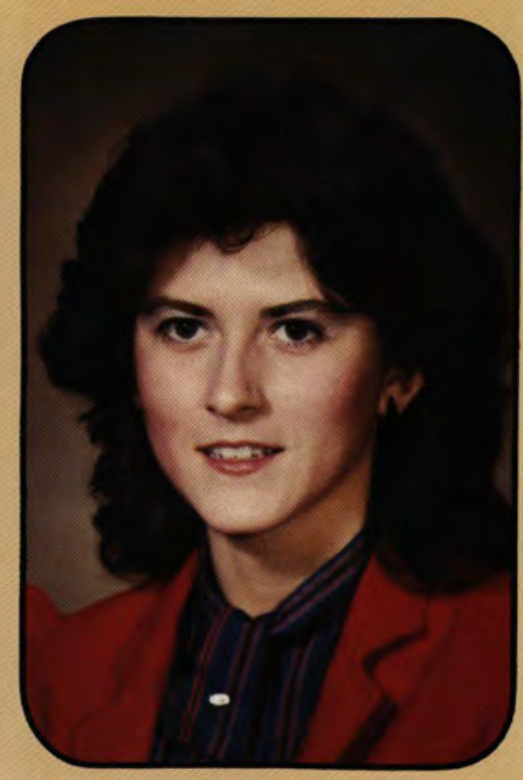

Tracy Lee Brown Speech

Middletown, Ohio

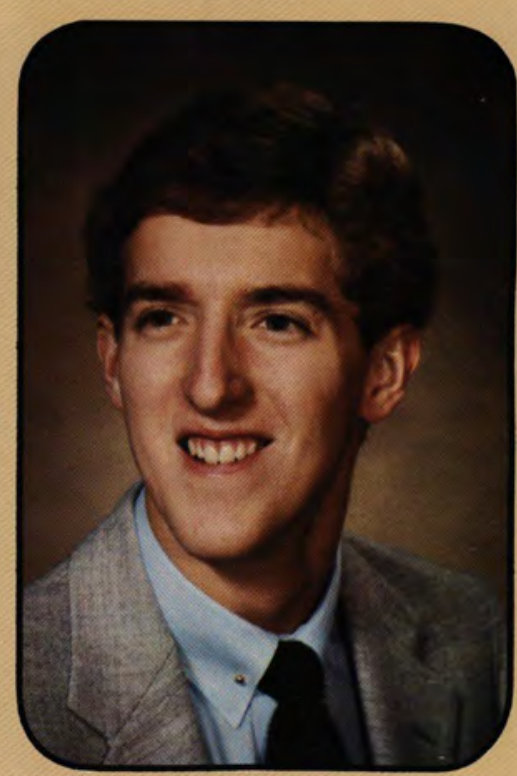

M. Scott Burtis

Bible Comprehensive

Syracuse, New York

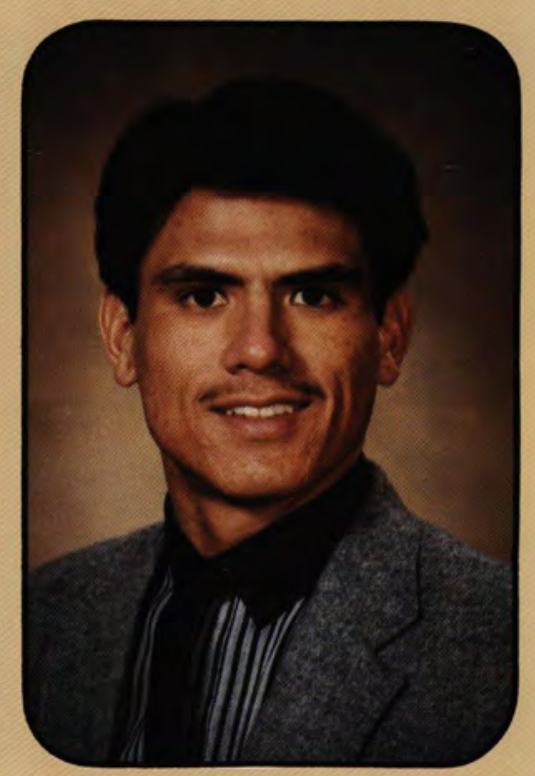

Randy Ivan Caldejon American Studies Patuxent River, Maryland 


\section{SALLY COCHRAN}

palm 96 says to sing to the Lord a new song. That is exactly what I am free to do since I mer Jesus Christ. Five years ago He challenged me to accepr His offer of toral forgiveness from sins and to receive lasting power to lead a new life. By His grace I accepted that gift of forgiveness (what freedom!) and now I can daily learn to let that power change me. Of course I fail and often forget His ways, but $\mathrm{He}$ is faithful and will not forget the work He has begun in me.

Precious also is the knowledge that I am a part of the body of Christ and someday I will know the body and see it function as a whole. It is the Christ I see in others that excites me for eternal things. David says in Psalm 27 that he would have fainted unless he had believed that he would see the goodness of the Lord in the land of the living. This is our hope and it is sure.

Life is a challenge and we have many questions, but we have an understanding that gives purpose and meaning to

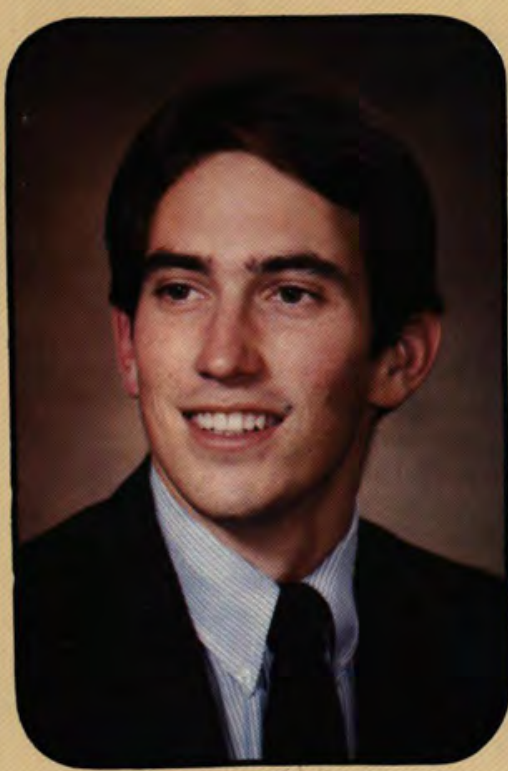

Jon David Callan Elementary Education Cedarville, Ohio

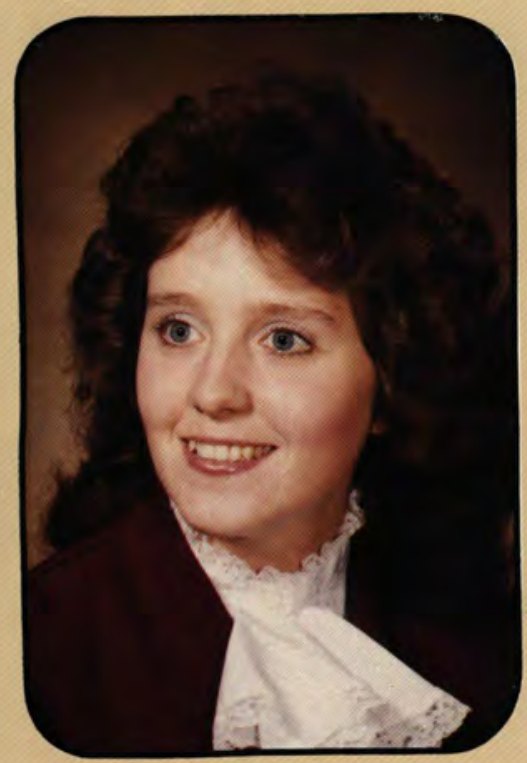

Darleen Louise Carano Nursing

Mio, Michigan

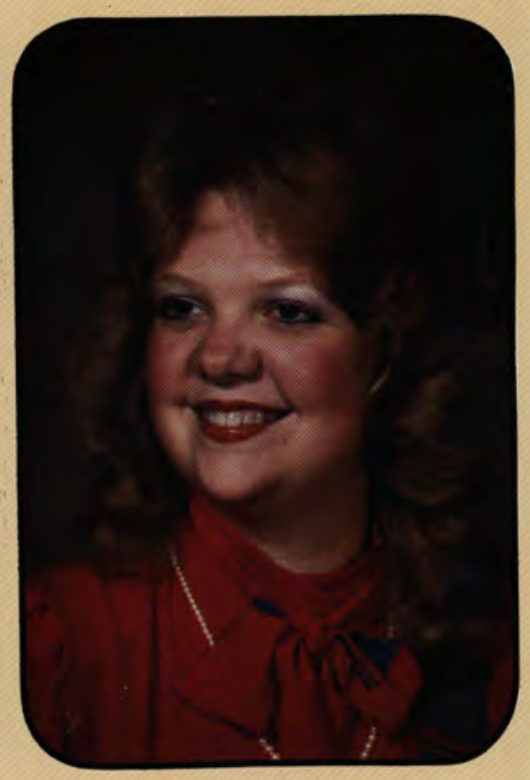

Jill Marie Campbell

Music Education

Plymouth, Indiana

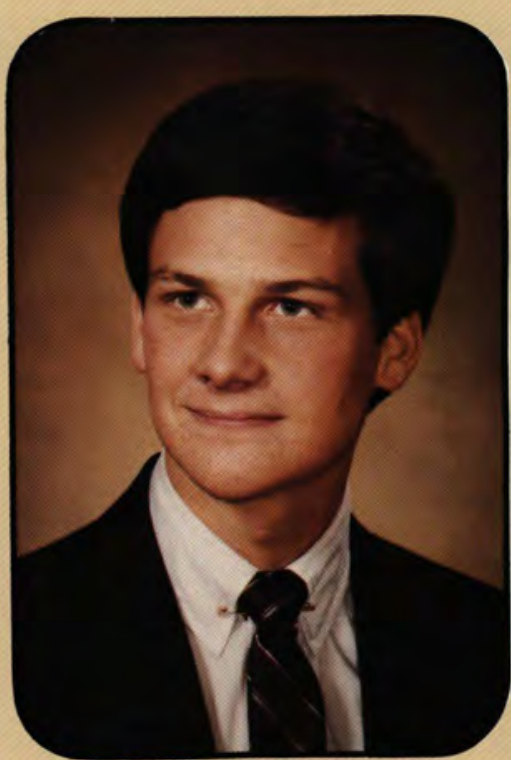

Daniel W. Carey Psychology Uniontown, Ohio all things. In His perfect time we will see the full result of our work because of God's work through Christ. Christ ser His heart on doing the will of the Father and was obedient to the end. Now we can follow Him and be a part of His lifegiving work.

He has changed everything. He gives new strength and an eternal hope; most of all He gives us the love which covers a multitude of sins. People can then become our most precious resource and our highest joy. Since the Lord is not slack concerning His promise to us, we know our work in $\mathrm{Him}$ is profitable.

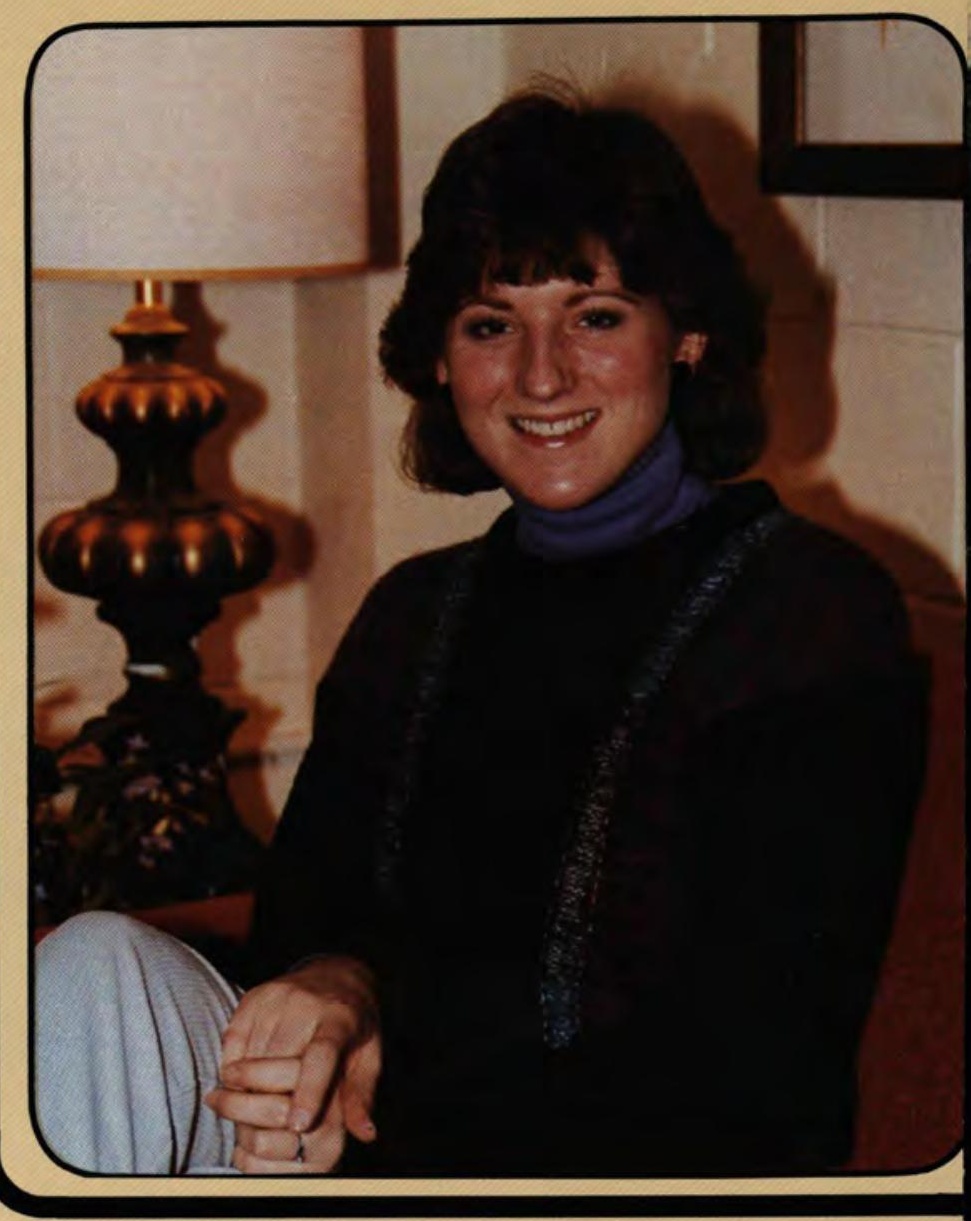




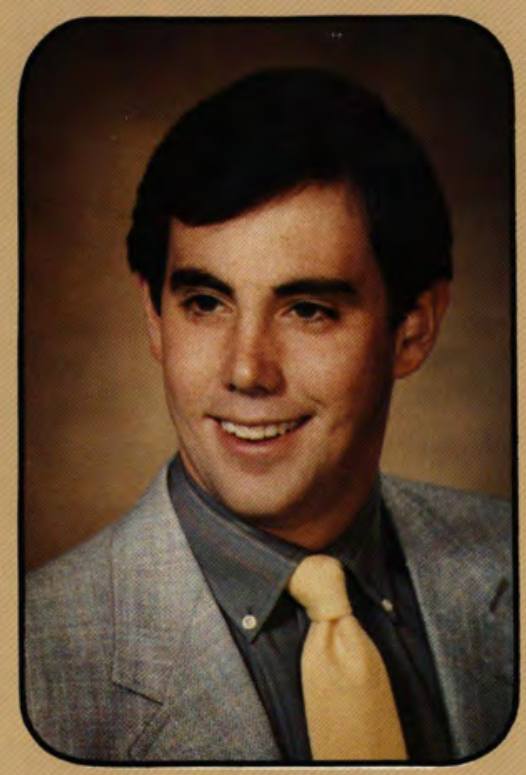

Craig Robert Cotton Computer Info. Sys./Bus. Ad. Cherry Hill, New Jersey

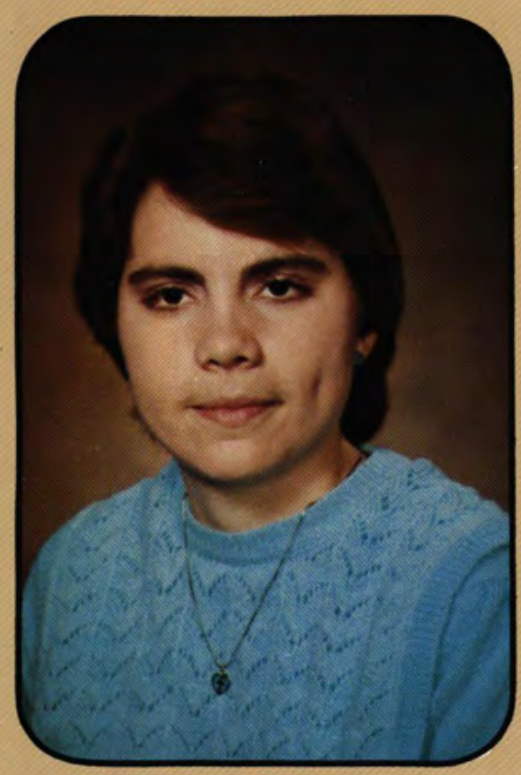

Jennifer D. Cranick

Mathematics

Lake Orion, Michigan

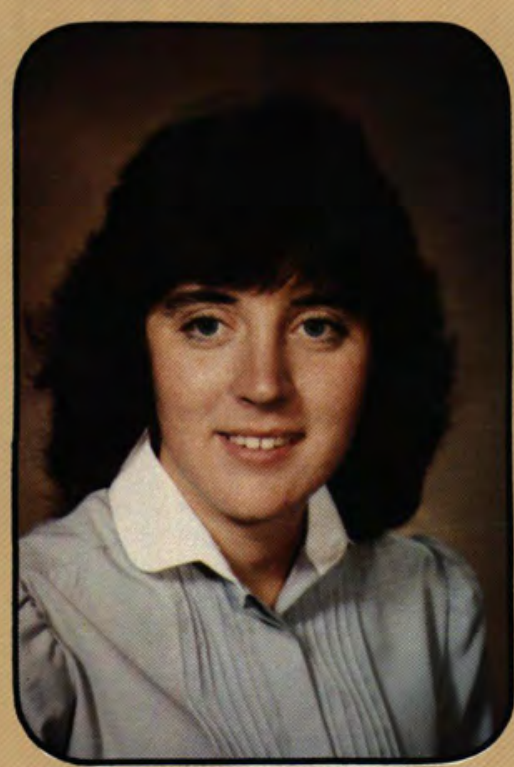

Ruth Ann Darr

Elementary Education Bedford, Ohio

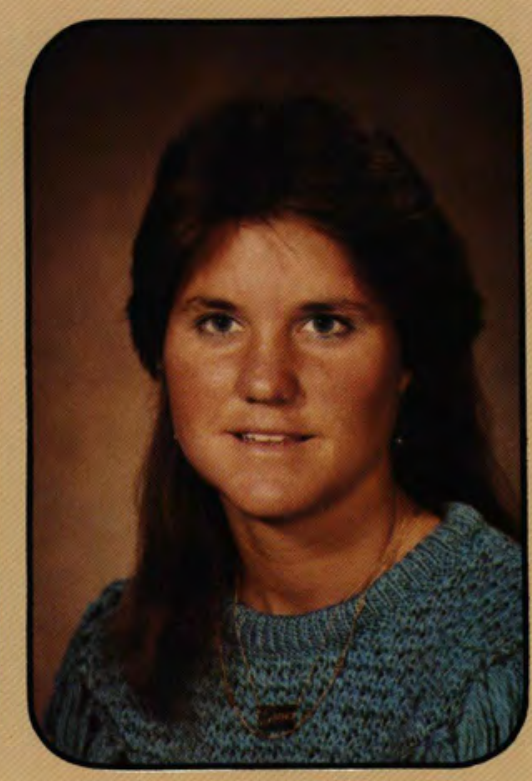

Traci Lynn Cotton

Physical Education

Panama

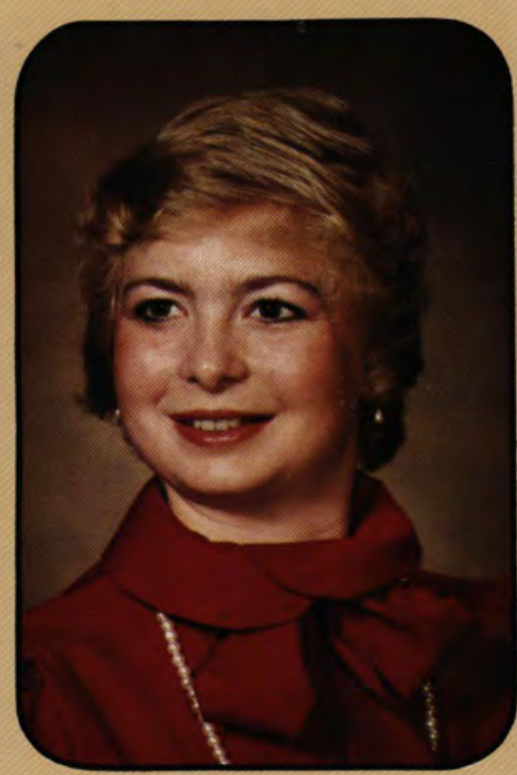

Nancy D. Crick

Spanish

Greenville, Ohio

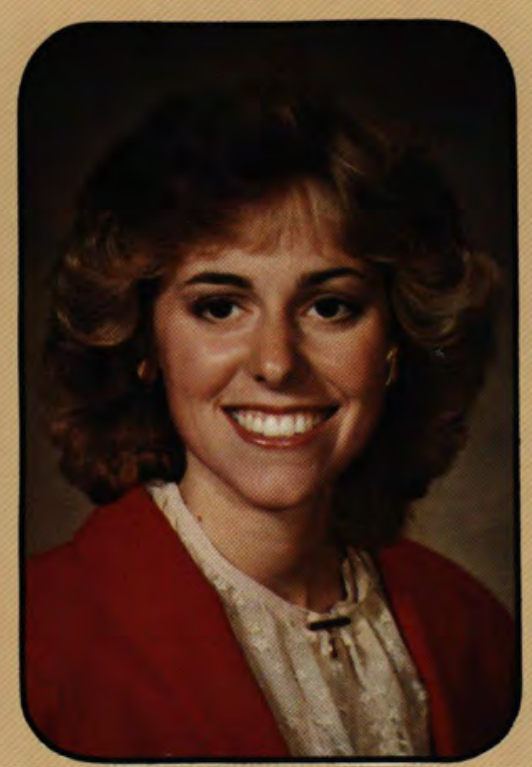

Christine Marie Dell Speech

Watervliet, Michigan

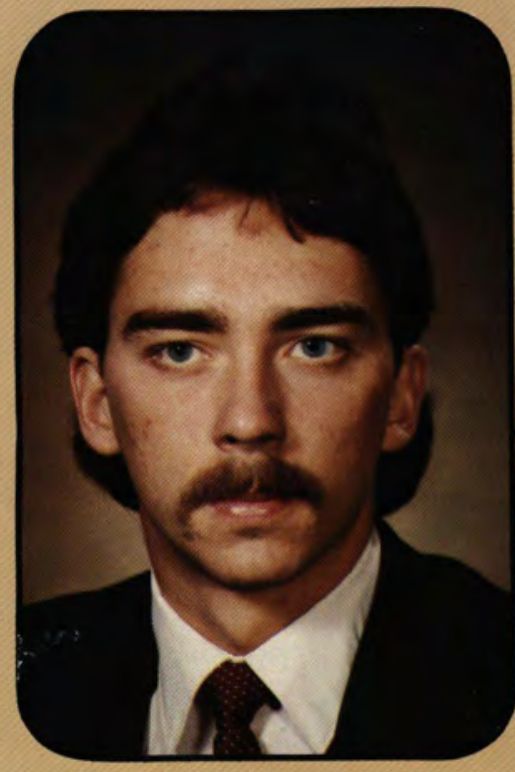

Daniel B. Cowser

Business Administration Griffith, Indiana

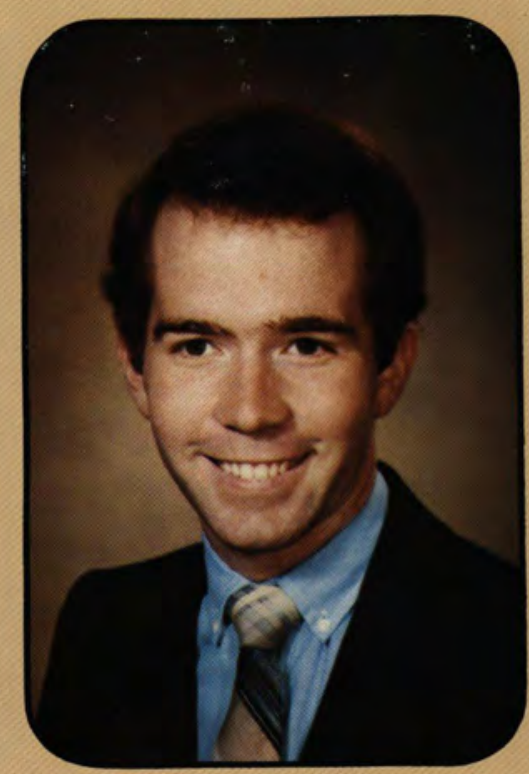

Mark Taylor Dalhouse History

Raleigh, North Carolina

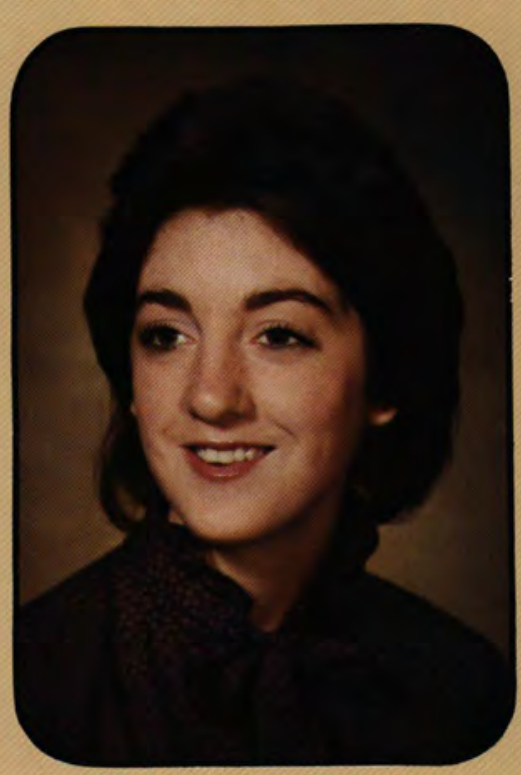

Shawn L. Dexter Physical Education Pine City, New York

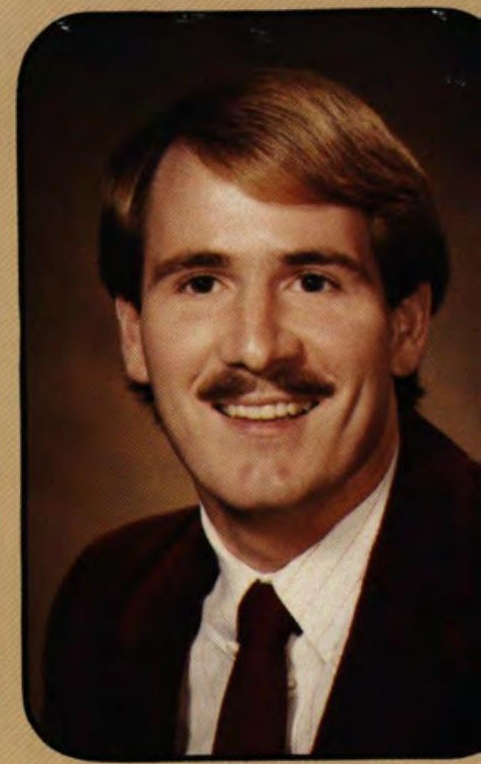

Mark A. Craig Bible Comprehensive Brownsburg, Indiana

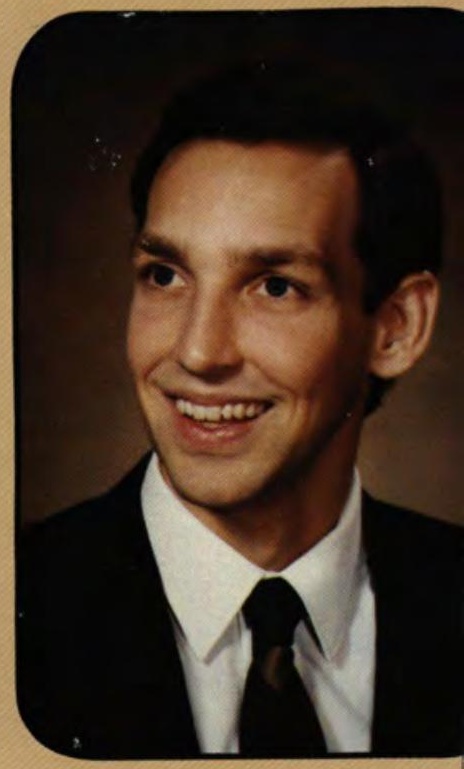

Richard D. Danec

Political Science Columbus, Ohio

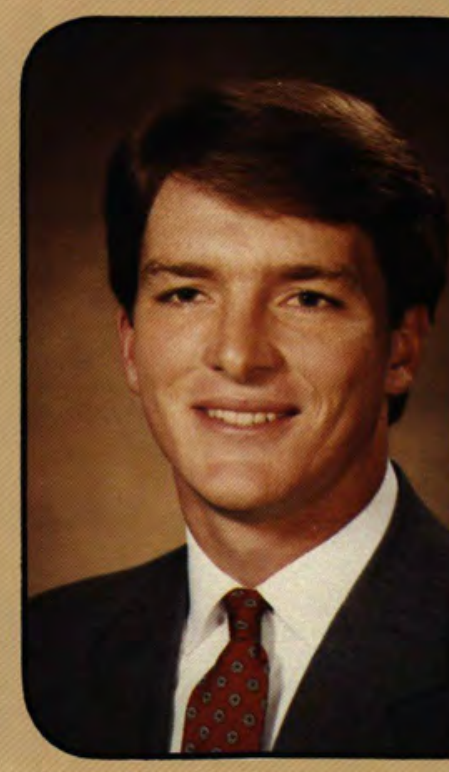

Jeffrey Keith Dilley Accounting

Mishawaka, Indiana

\section{2 seniors}




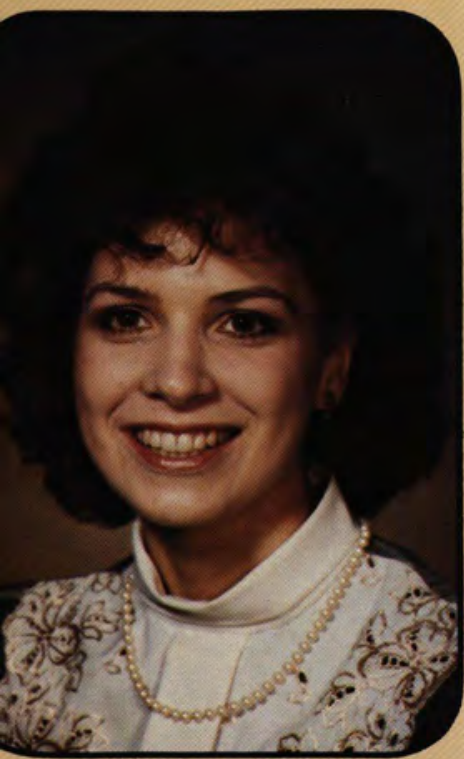

Karel Diane Dobbel

Elementary Education

Schroon Lake, New York

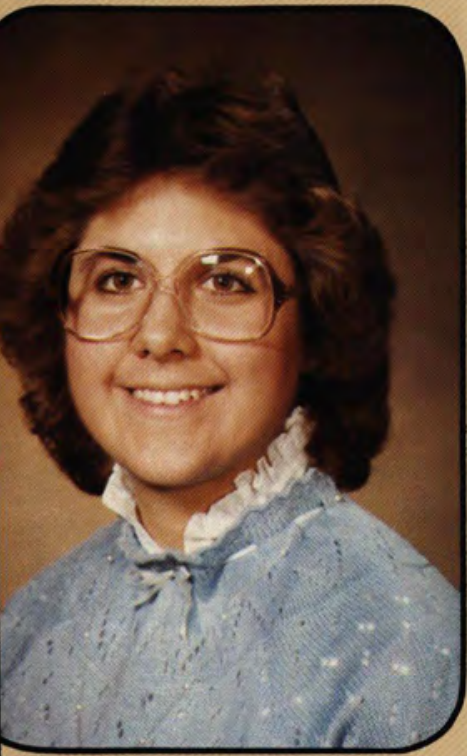

Cynthia J. Dull

Elementary Education

Jackson, Michigan

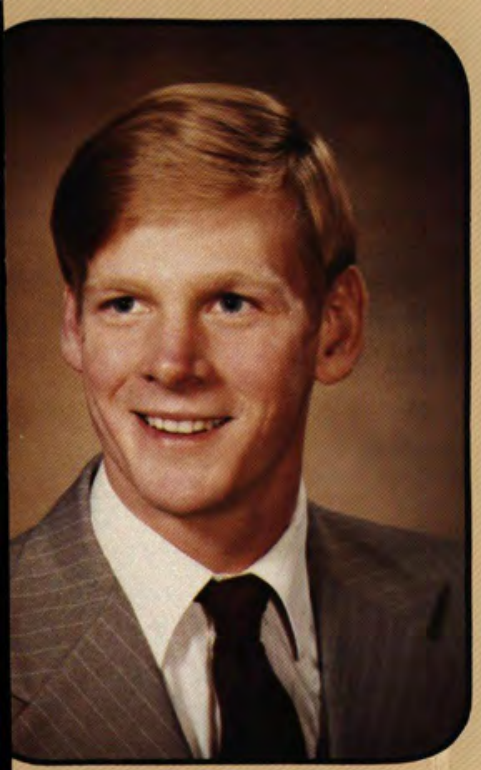

David Paul Eckert

Mathematics

Burlington Flats, New York

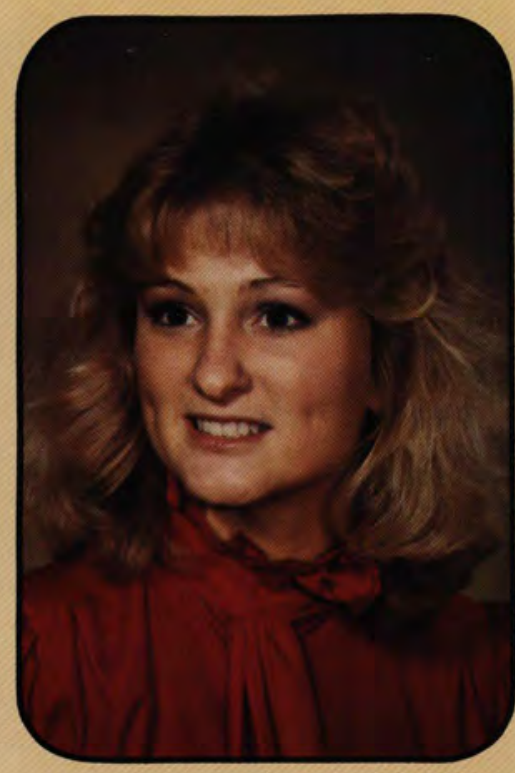

Terri Lynne Driscoll

Business Administration

East Windsor, New Jersey

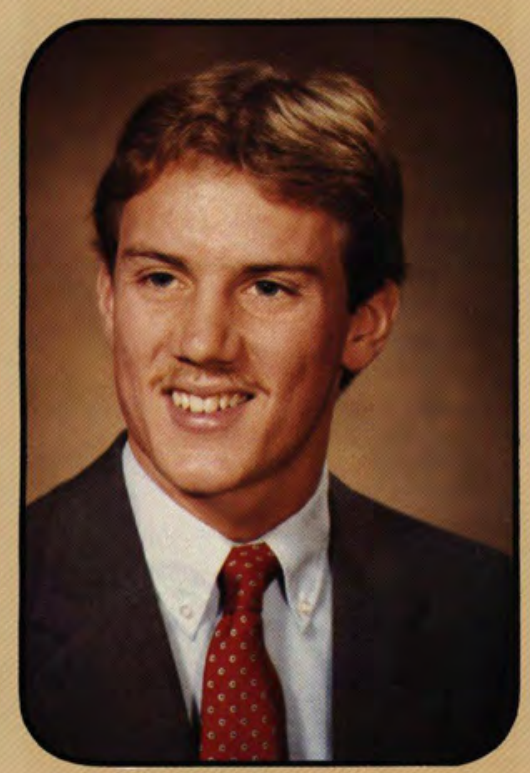

David Craig Dustin

Political Science

Marilla, New York

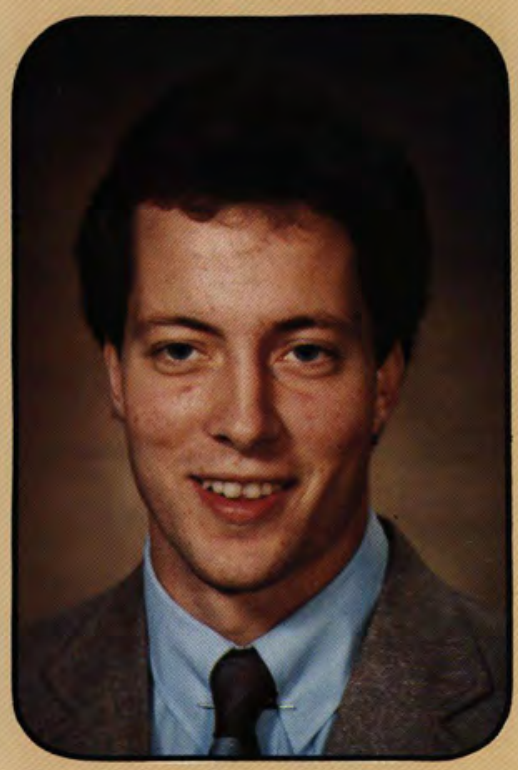

Daniel Earl Edwards Bible Comprehensive Kipton, Ohio

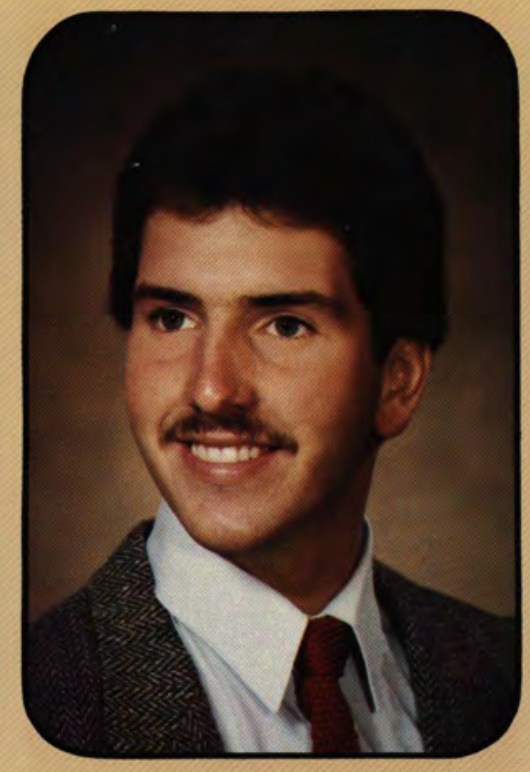

William John Drummer Jr. Biology

Fairview Village, Pennsylvania

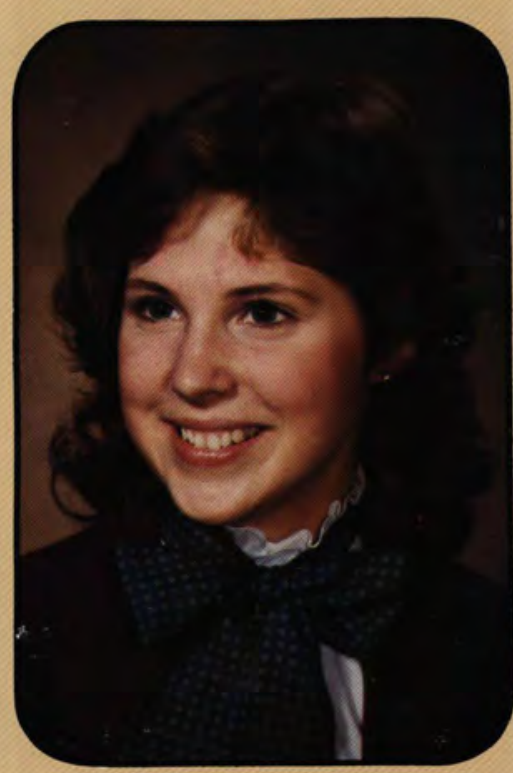

Jennifer Susan Dye Behavioral Sci./Psychology Cable, Ohio

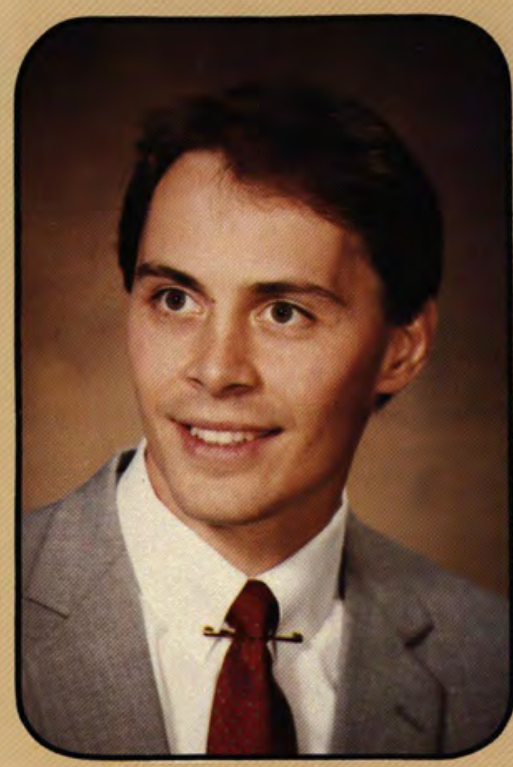

R. Michael Edwards Business Administration Mishawaka, Indiana

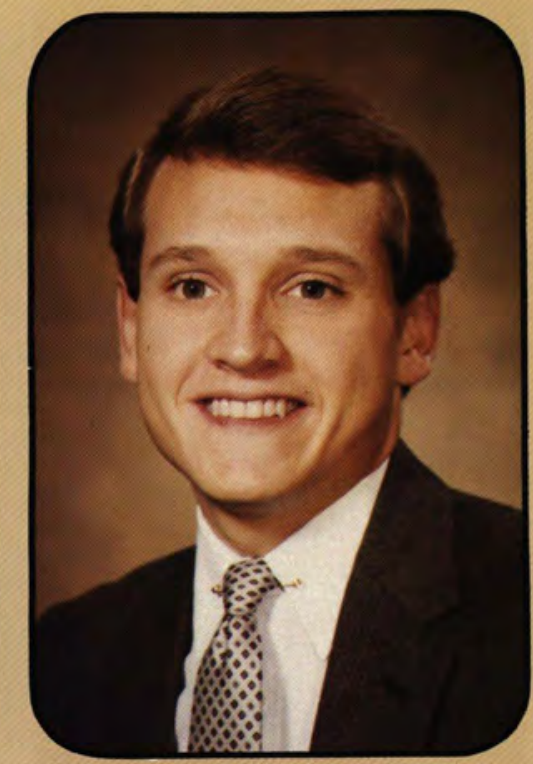

Gregory S. Dudrow

Accounting

Springfield, Ohio

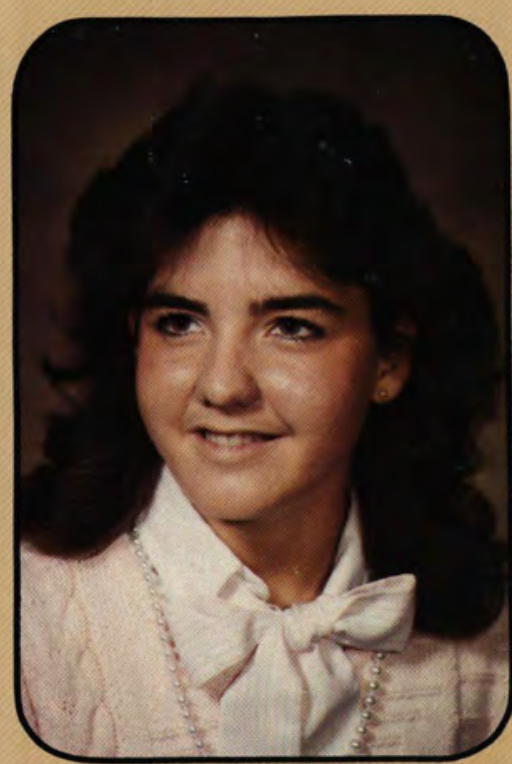

Cathy Carol Eckam

Physical Education

West Seneca, New York

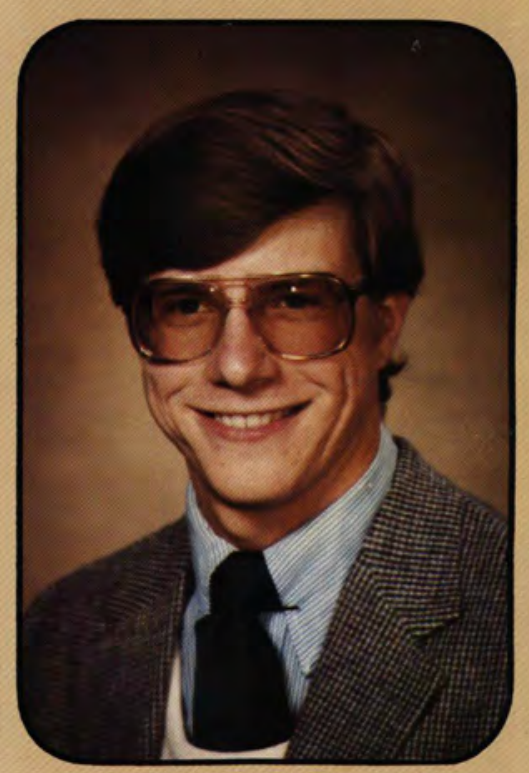

Mitchell D. Ely Bible/Preseminary Troy, Ohio 


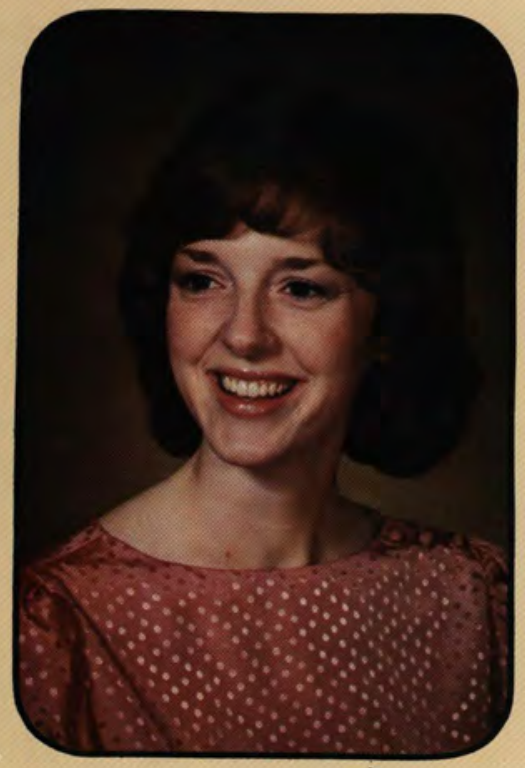

Tricia Maurine Emerson Speech/Broadcasting Oakley, California

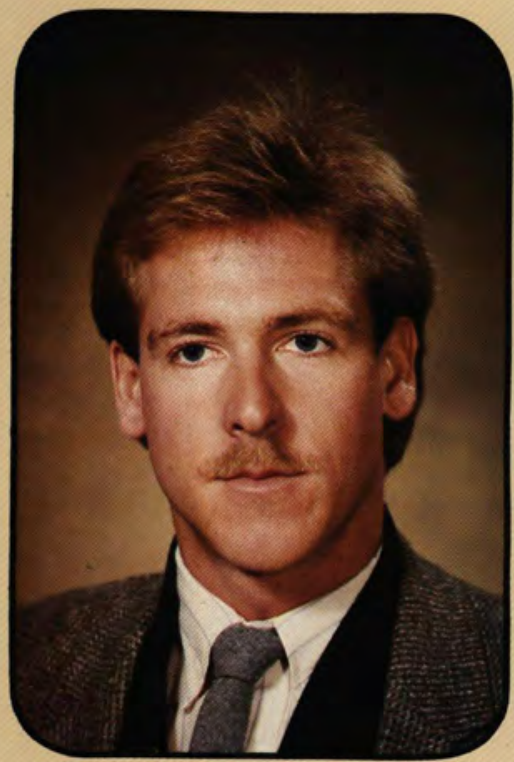

Steven Raymond Erickson

Computer Info. Systems Clearwater, Florida

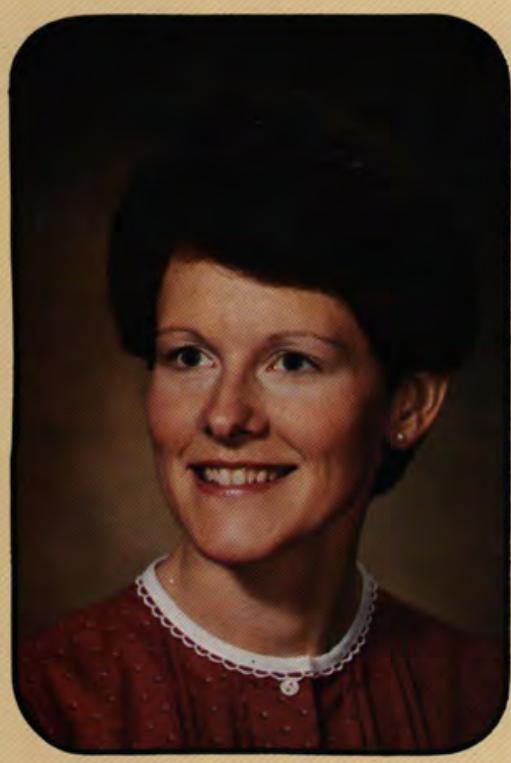

Brandi Lee Fisher Nursing

Elizabethon, PA

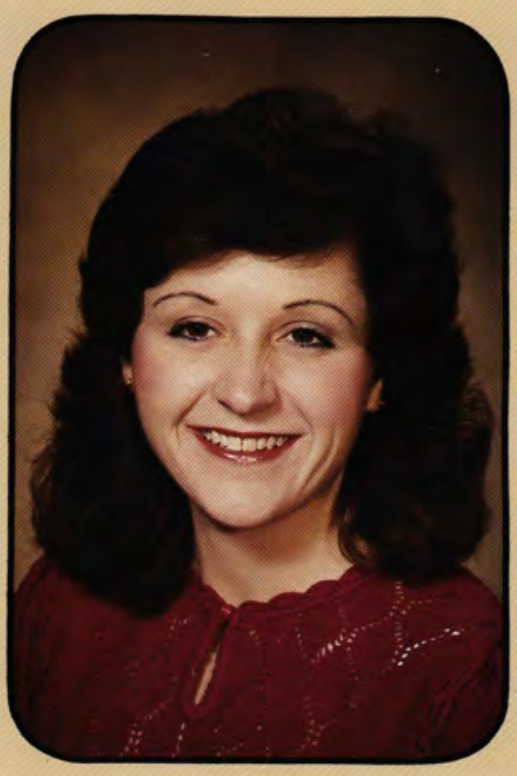

Julia L. English

Music Education

Tipp City, Ohio

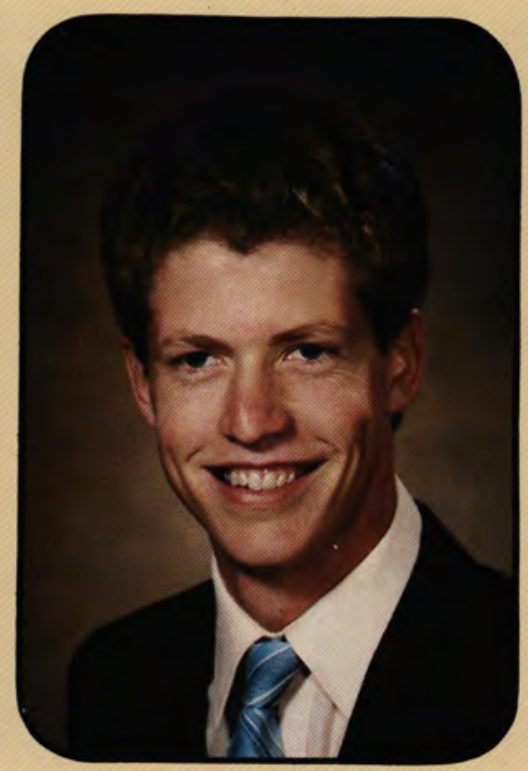

Paul Thomas Ewing, Jr. Bible/Preseminary Greensburg, Indiana

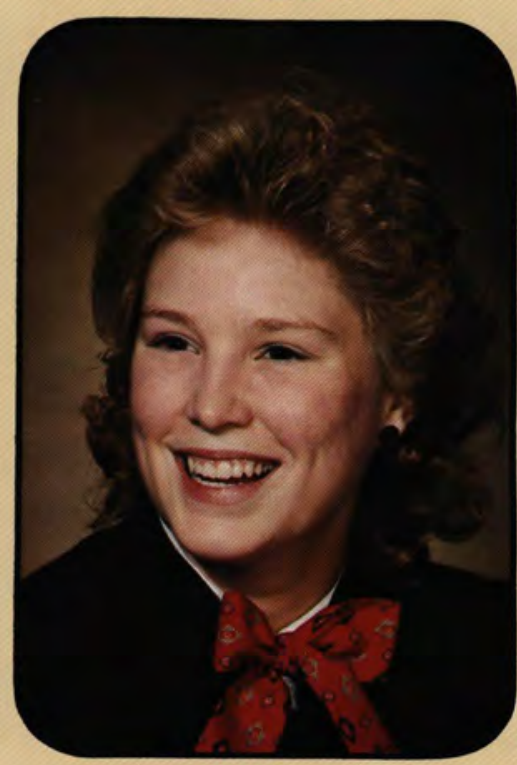

Lorene Leigh Fornell Elementary Education Barron, Wisconsin

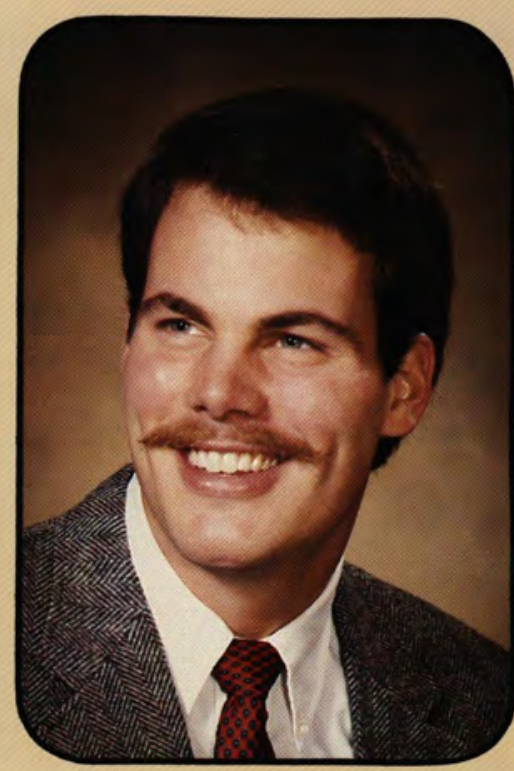

Brian S. Ensminger

Business Administration Edina, Minnesota

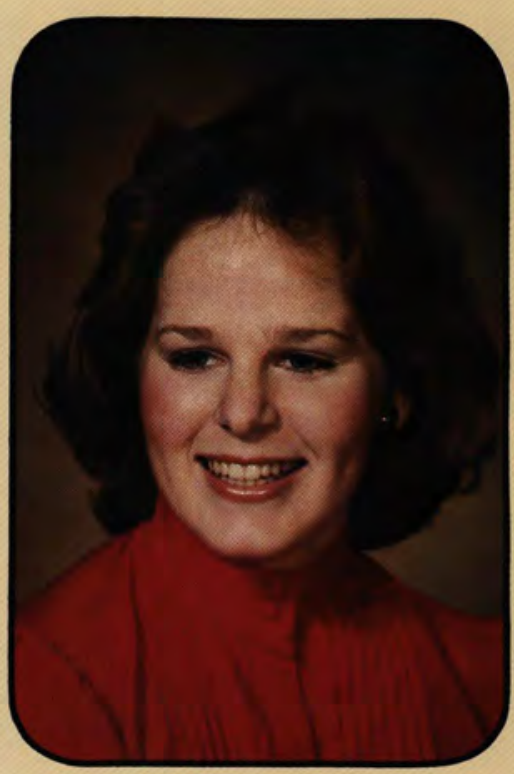

Catherine E. Farley

Elementary Education

Huntington, New York

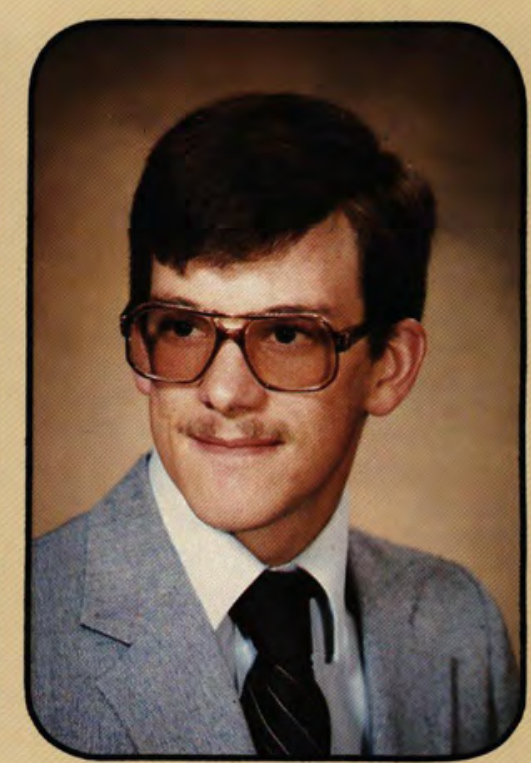

Henry Joseph Forrest Chemistry

Pine Valley, New York

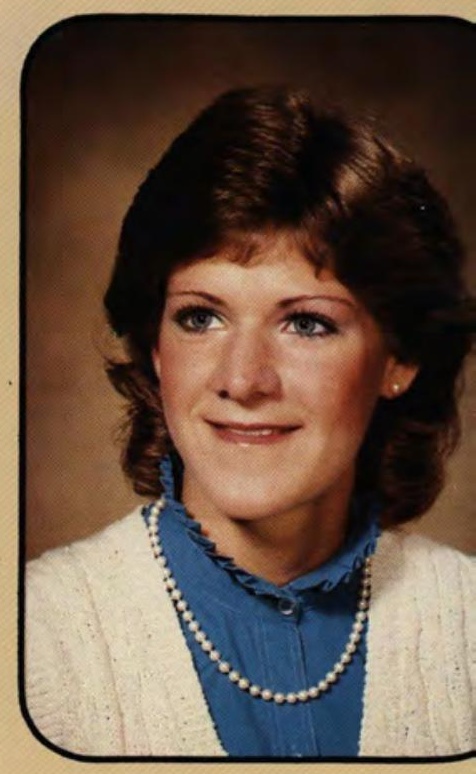

Julie Diane Erdmann Physical Education Southfield, Michigan

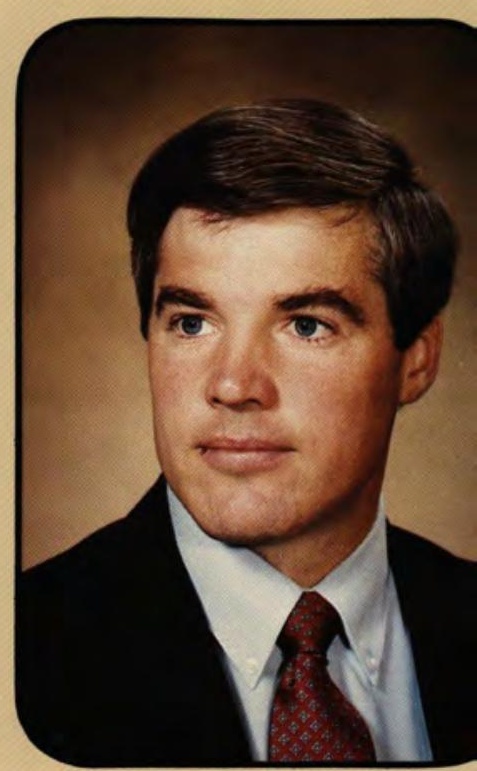

Robert W. Fires Physical Education Cedarville, Ohio

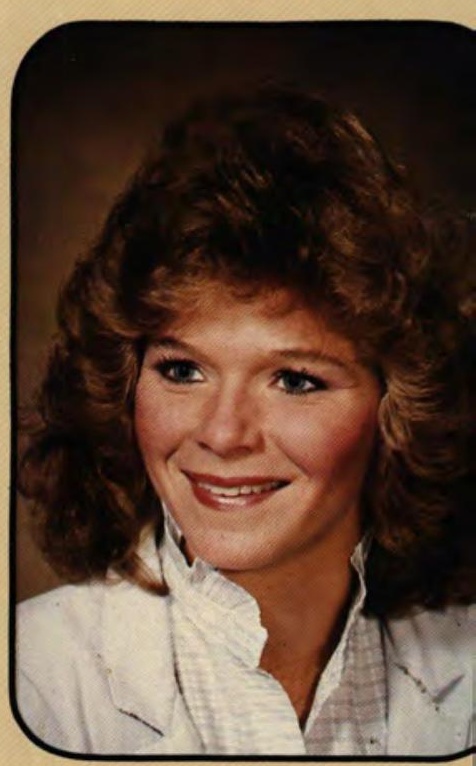

Susan Carol Frazier Nursing

Muncie, Indiana 


\section{MIKE EDWARDS}

" L ey, wait a minute! I'm a carpenter, not a student!"

H This outrageously wild idea of attending college struck my mind while I was feverishly slaving away on the job. Why should I change my career path at this point? I surely couldn't go to college after working four years beyond high school graduation ... or could I? Why not? Life is a continuous learning process, and we are all students regardless of age. I had many lessons to learn, and Cedarville College seemed to be the place to learn them, especially since that happened to be where the Lord was directing me.
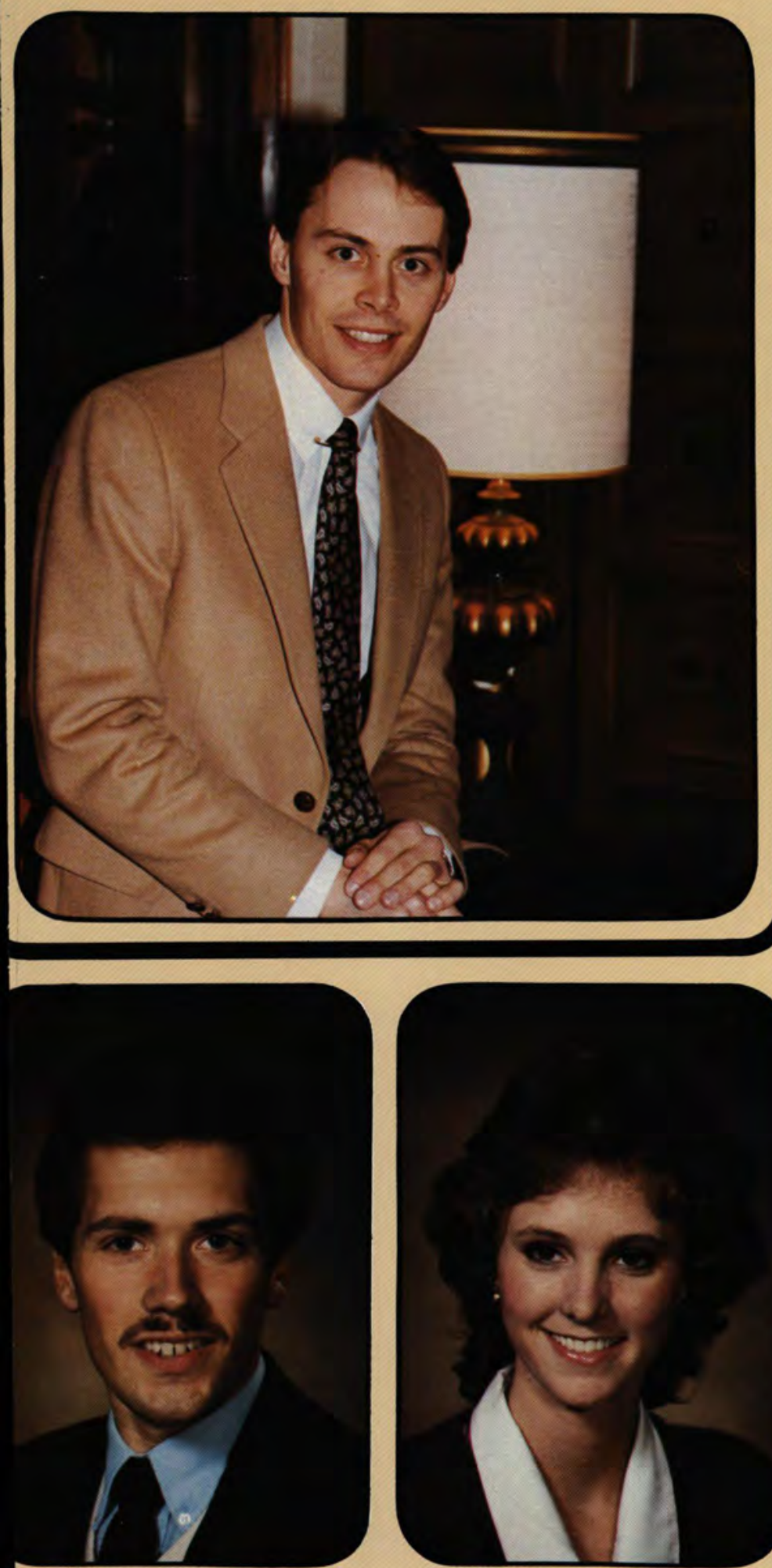

Steven Earl Freeman Bible Comprehensive Flint, Michigan

It didn't take long for me to realize that I had made the right choice. Immediately after setting foot on campus, I began learning and growing in ways which I had not previously anticipared. Now, after broadening my horizons and firming up certain foundational beliefs, I feel better prepared to take on the challenges that will be waiting for me upon graduation. I have truly enjoyed my "excellence experience" and would not trade it for anything, but this is not the end of my education. I plan to continue learning and growing; I challenge you, whoever you are and wherever you go, to do the same.

"But grow in grace, and in the knowledge of our Lord and Savior Jesus Christ. To him be glory both now and forever, Amen" 2 Peter 3:18.

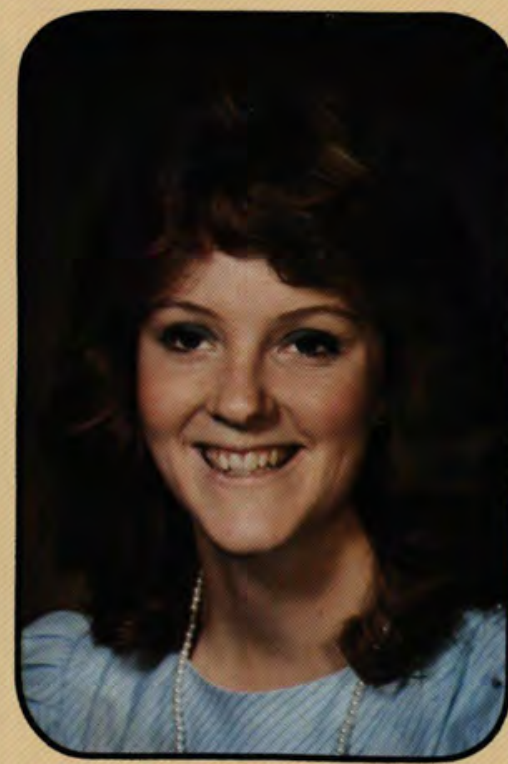

Donna Marie Freeburger Elemetnary Education Southampton, Pennsylvania

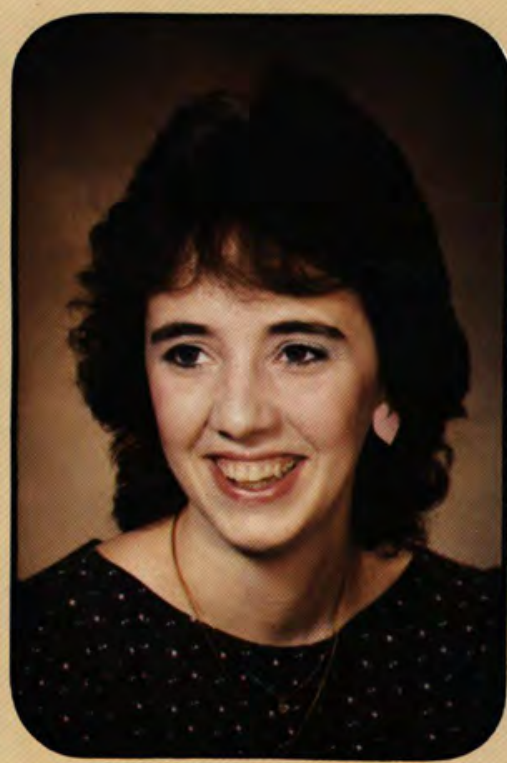

Cynthia A. Galland Business Administration Hartwick, New York

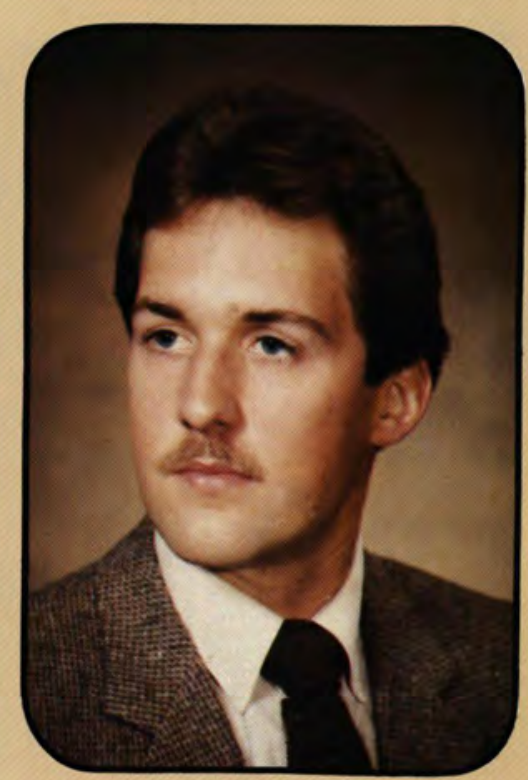

Robert William Freeman English/Secondary Education Flint, Michigan

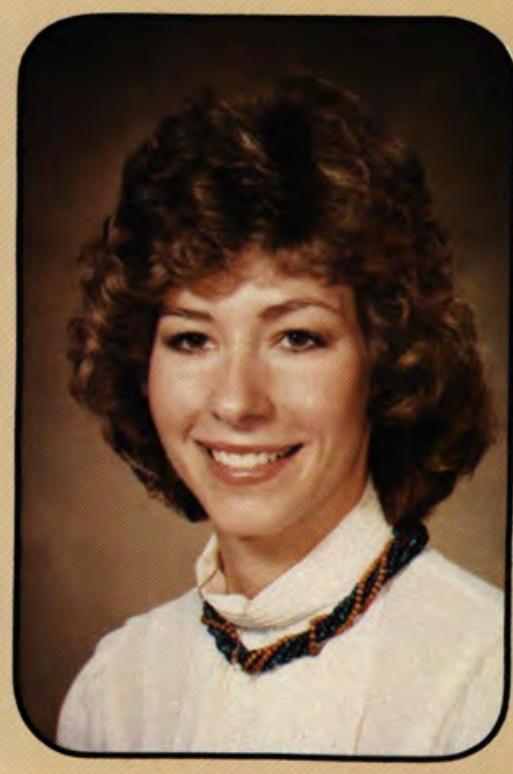

Deborah D. Gardner English Education Pataskala, Ohio 


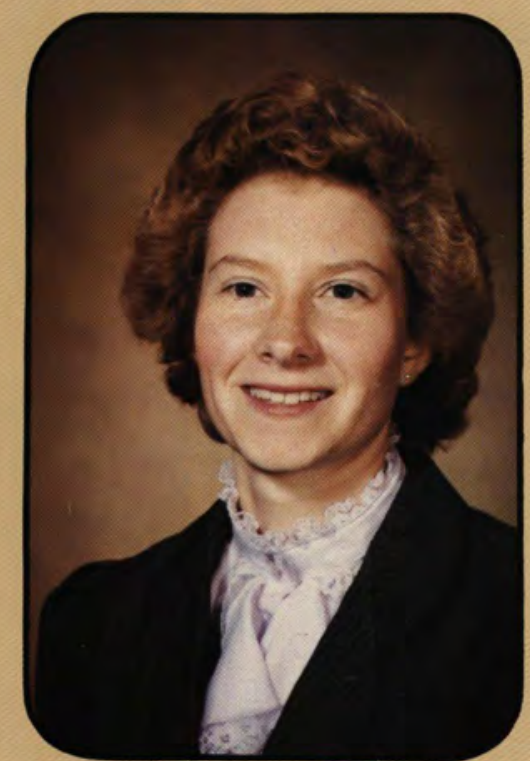

Teresa Annette Geiger

Nursing

Lima, Ohio

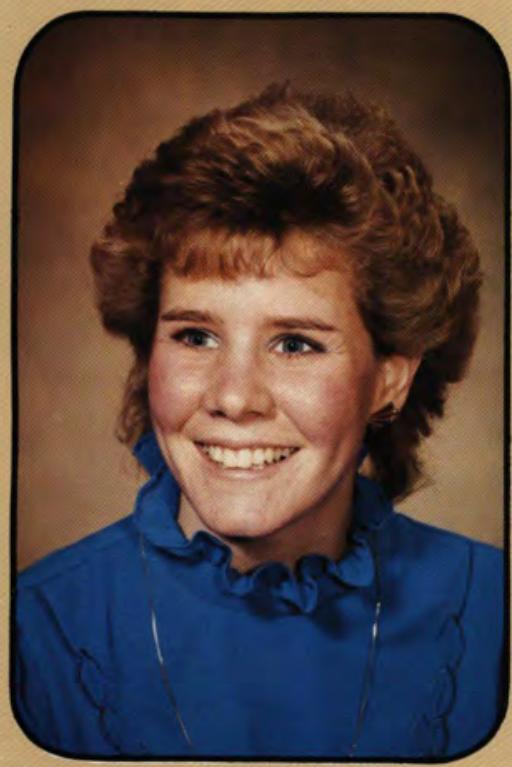

Crissie-Ann M. Gorges

Physical Education

Elyria, Ohio

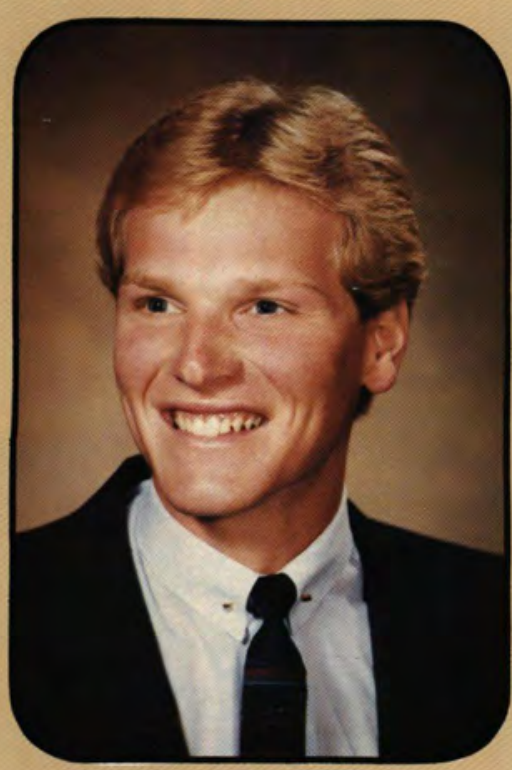

Thomas James Gruet

Bible Comprehensive

Gloversville, New York

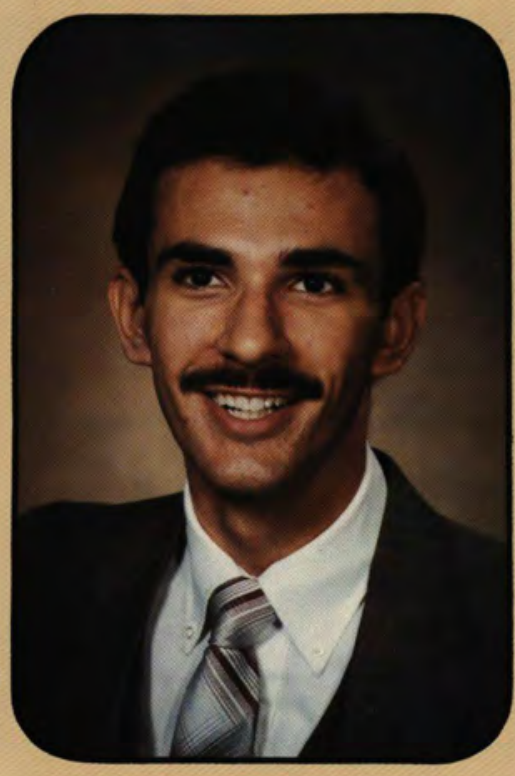

Dan A. George

Business Administration Hillsdale, Michigan

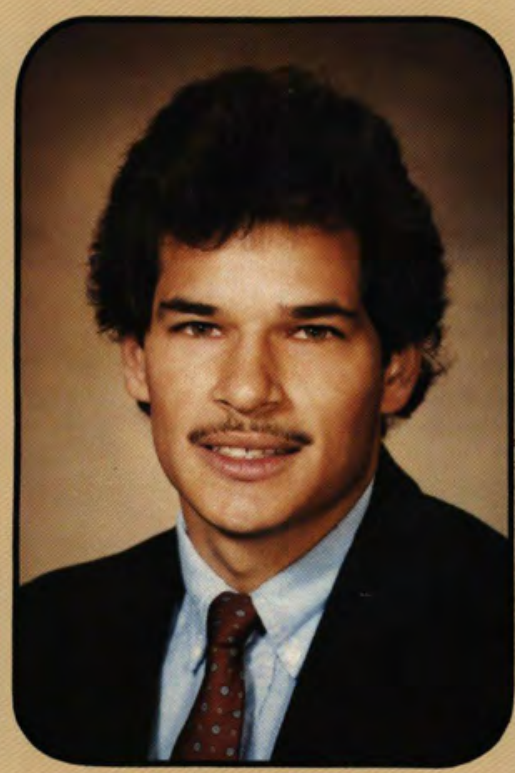

George Charles Gorman

Physical Education

San Juan, Puerto Rico

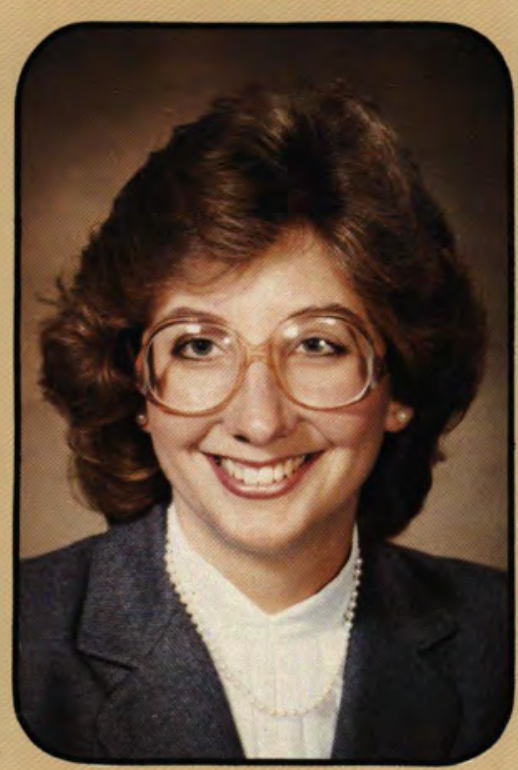

Elizabeth A. Habermehl Business Administration Lennon, Michigan

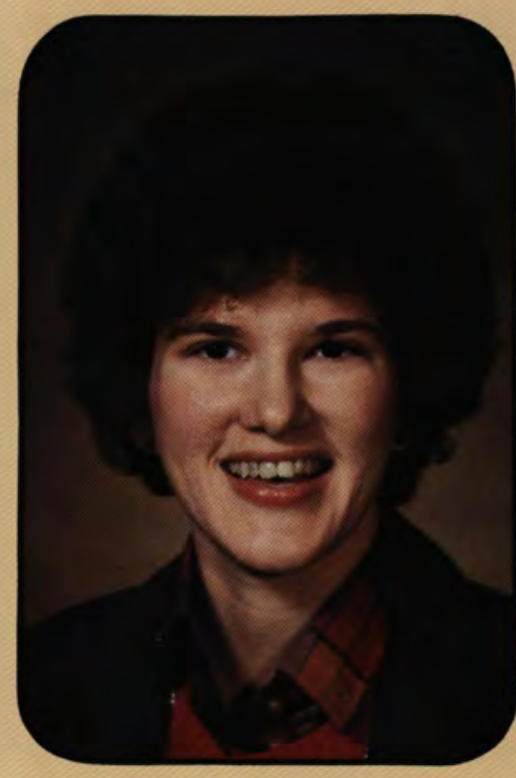

Lynette Marie Gersema

Nursing

Shell Rock, Iowa

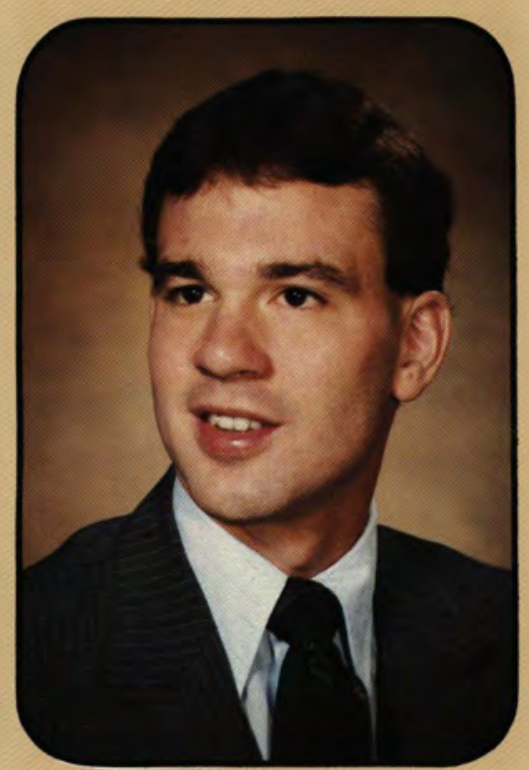

Thomas Alan Greve

Physical Education

Greensburg, Indiana

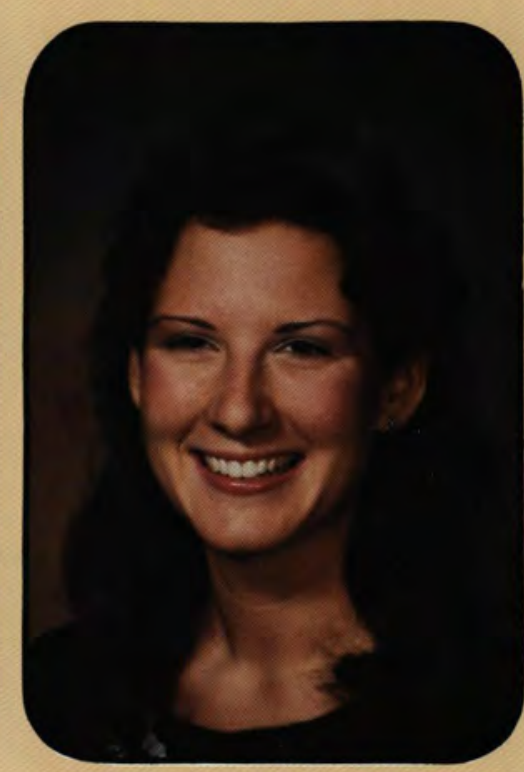

Caryn Beth Hakes

Elementary Education

Lombard, Illinois

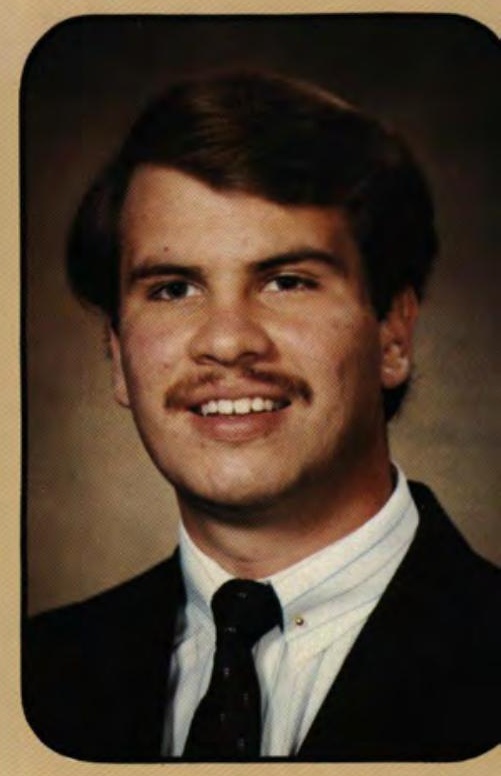

Mal Derrick Gibson Bible/Preseminary

Cambridge City, Indiana

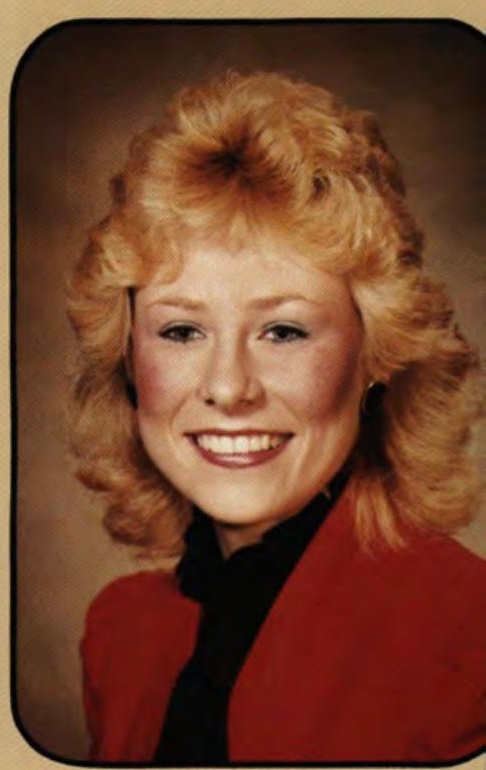

Katrina Renee Gruet

Business Administration Hagerstown, Maryland

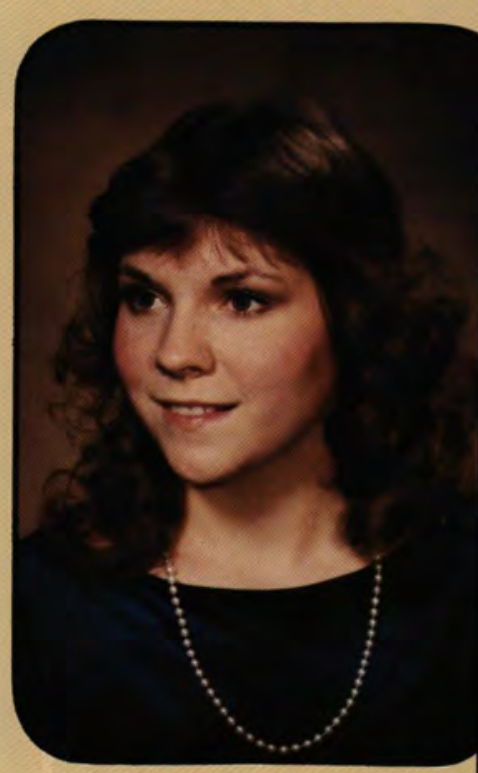

Debra C. Hancock

Elementary Education Cedarville, Ohio 


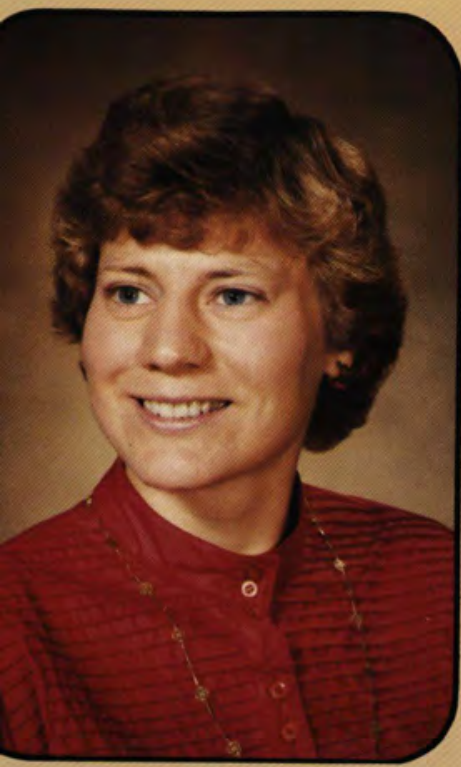

aren Jacqueline Harrington

Physical Education/Biology Akron, Michigan

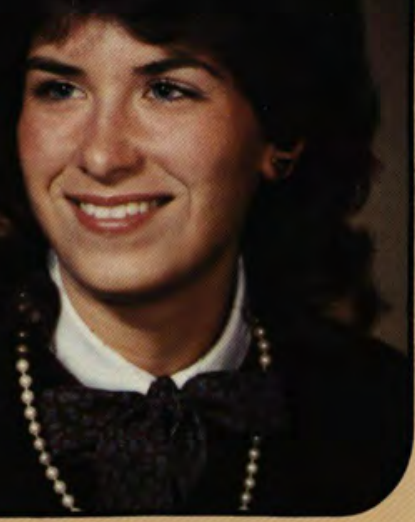

Janet L. Hazen Elementary Education Beavercreek, Ohio

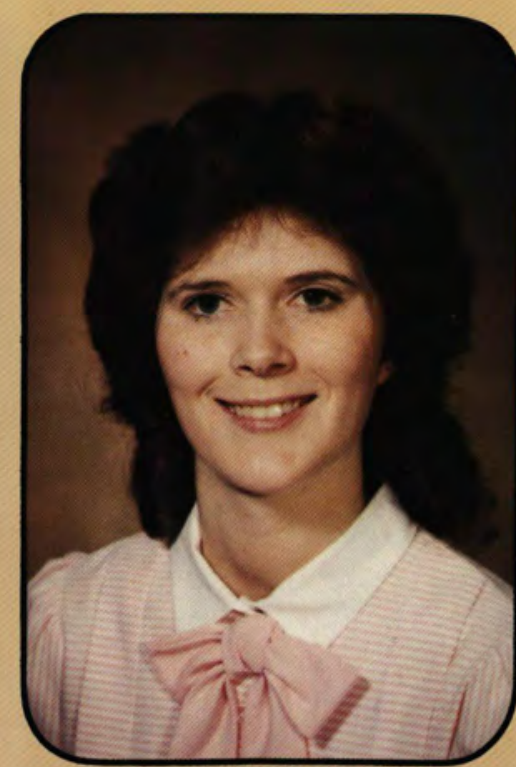

Nadine Sue Harris

Elementary Education Milton, Indiana

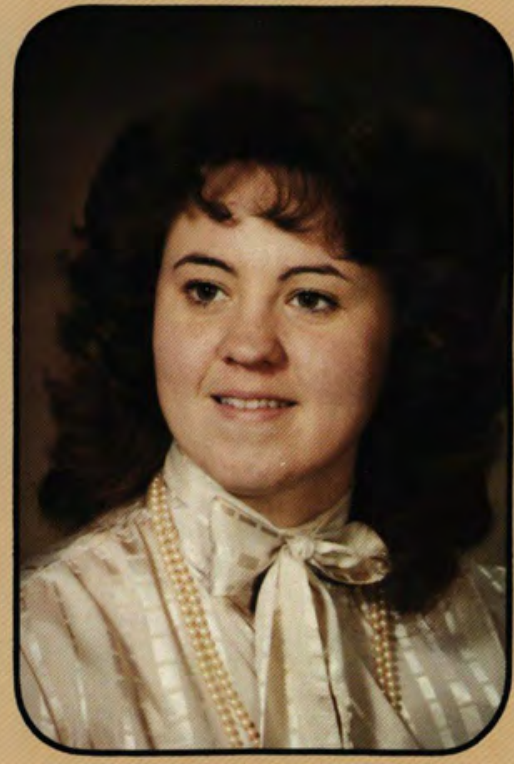

Heather M. Heflick

Social Science

Prospect, Ohio

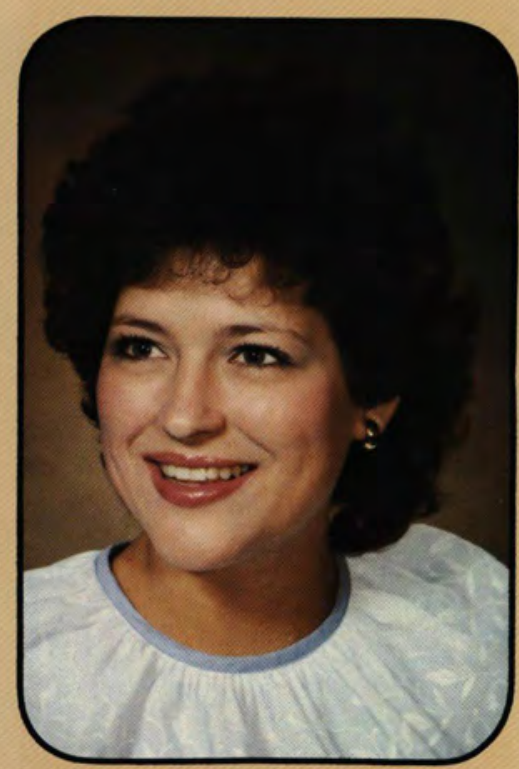

Kelly Jean Herbert

Speech

Waterloo, lowa

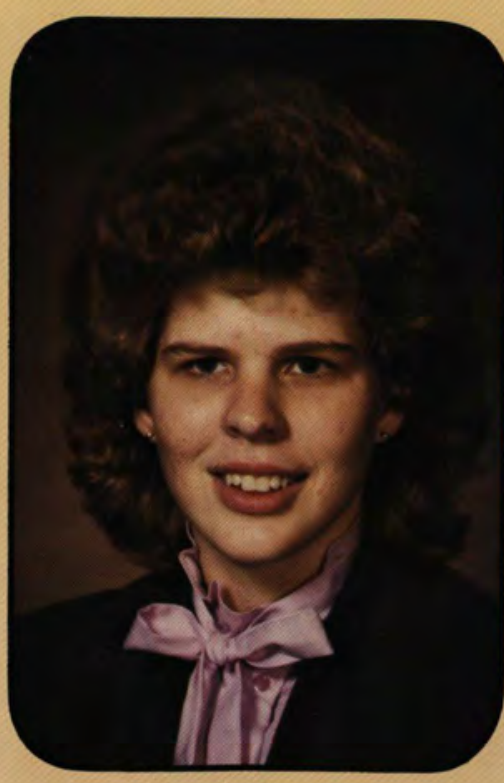

Joy Ann Hart

Mathematics

Greenville, Ohio

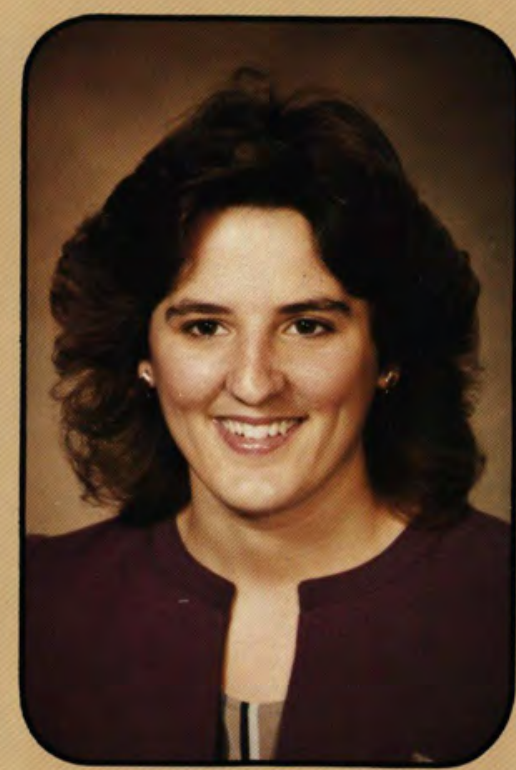

Carol Lee Helmick

Business Administration

West Milton, Ohio

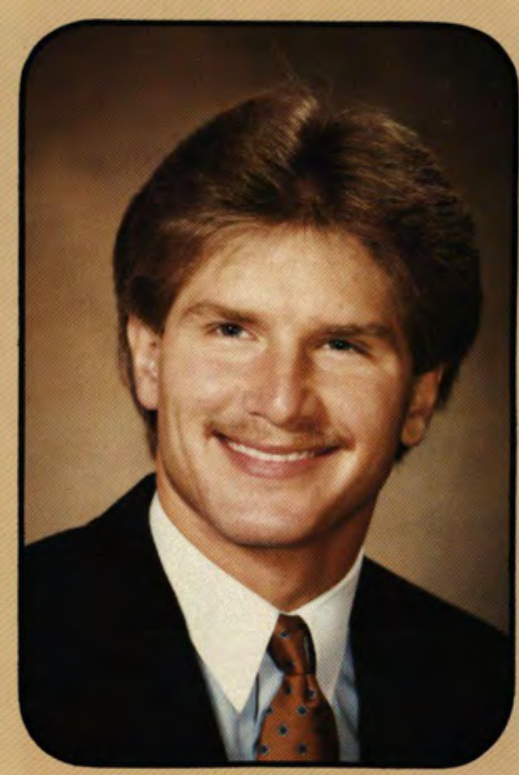

Benjamin James Herr

Behavioral Sci./Psychology Mechanicsburg, Ohio

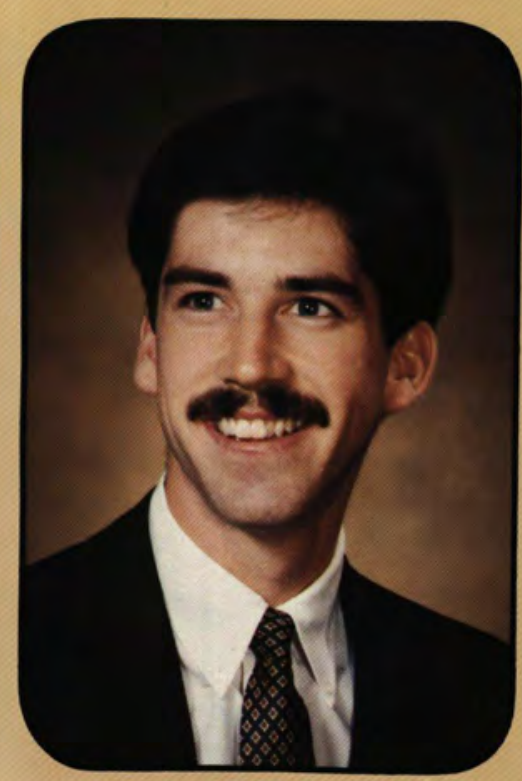

David A. Hartsough

Business Administration

South Bend, Indiana

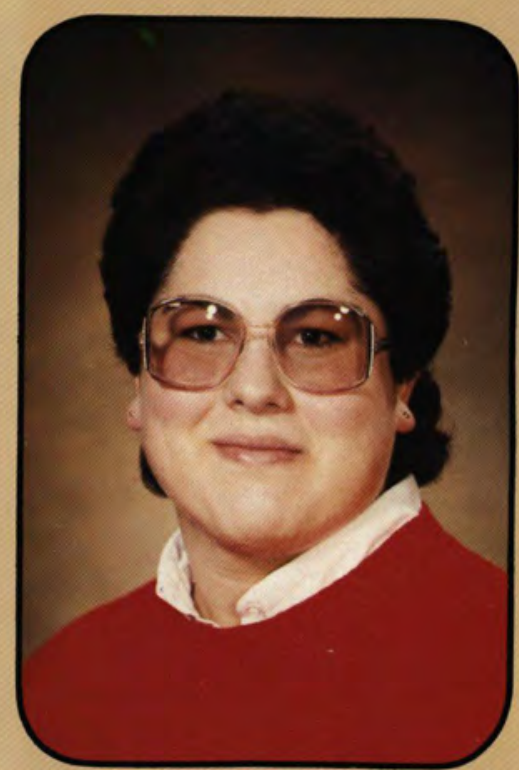

Rebecca K. Henderson Elementary Education

New Bethlehem, PA

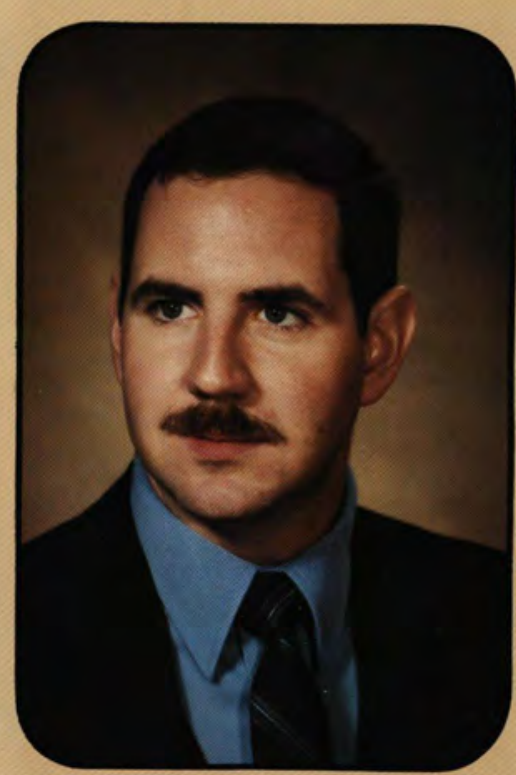

Rick R. Herrington

Business Administration International Falls, MN 


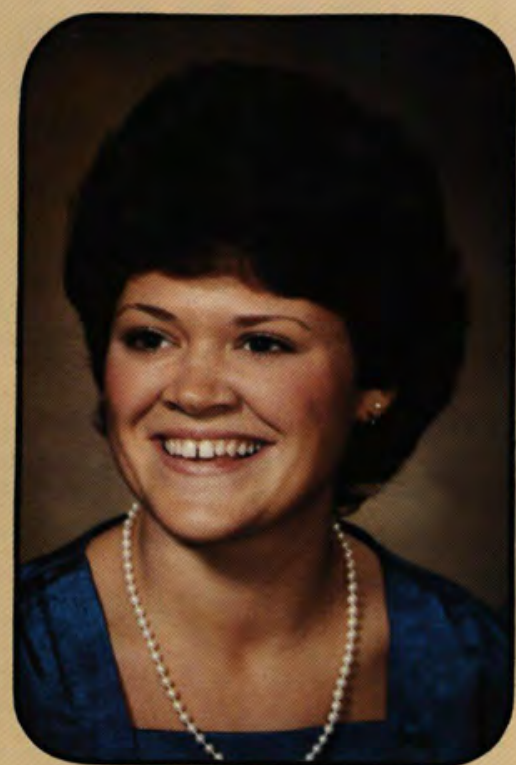

Tamra E. Hershberger

Elementary Education Goshen, Indiana

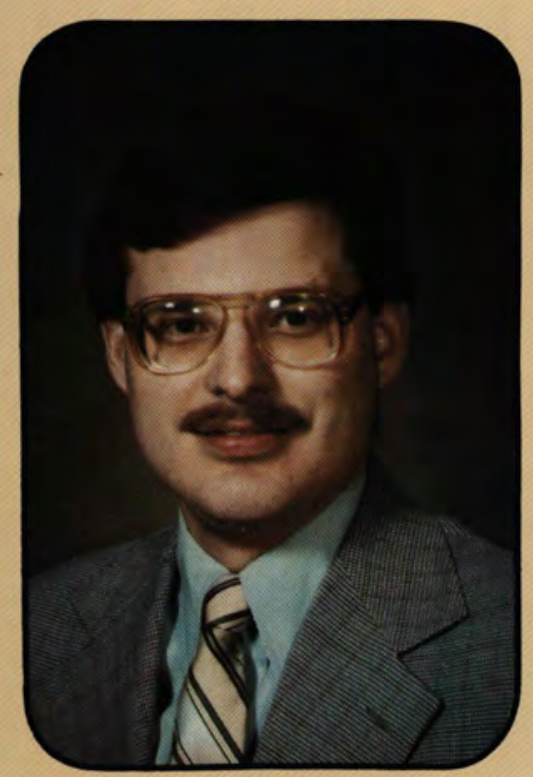

Daniel K. Hicks Chemistry

Fort Wayne, Indiana

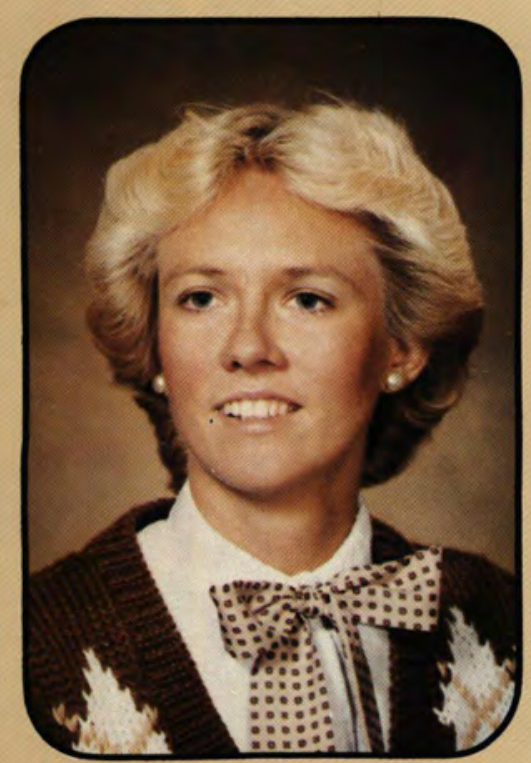

Lori Ann Hippard Business Administration Shelbyville, Ilinois

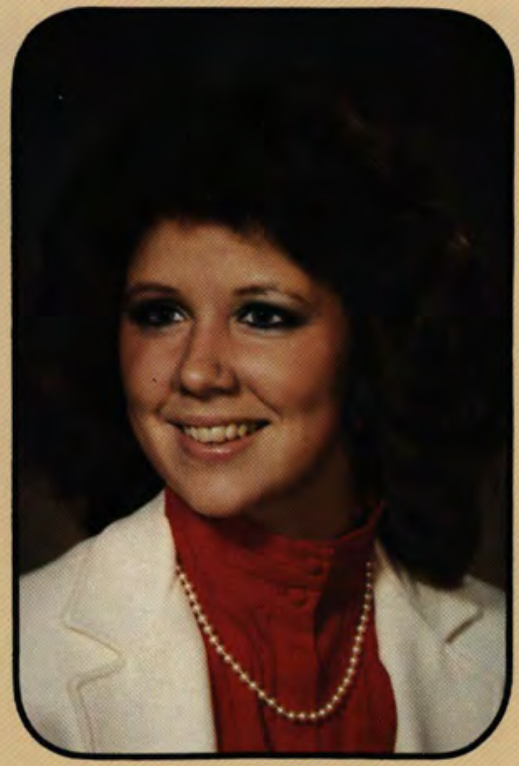

Linda Ann Hess

Elementary Education Akron, Ohio

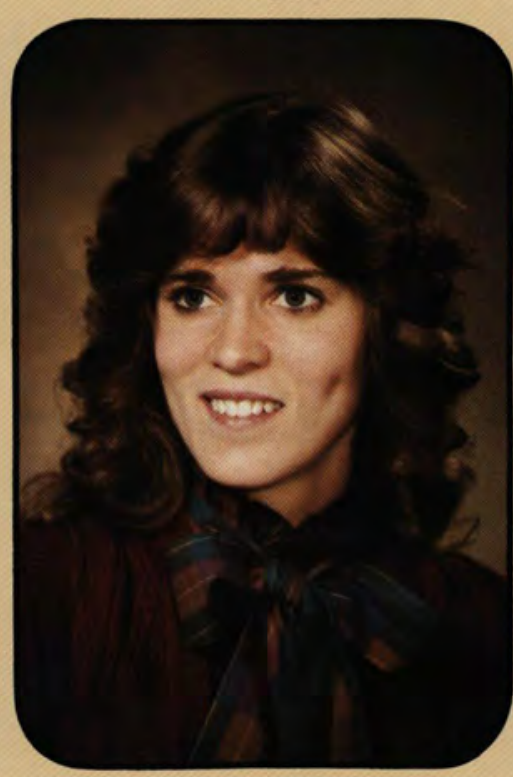

Joeleah Joy Hill English

Davenport, Iowa

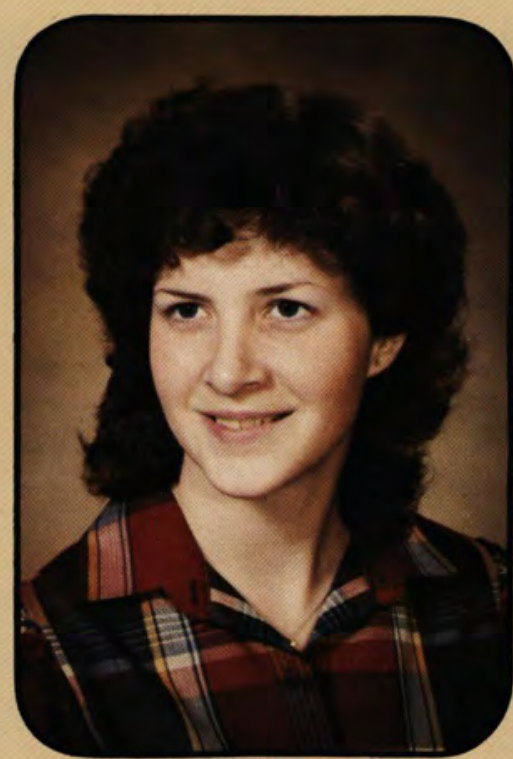

KImberly June Holliday Nursing

Huntsville, Ontario

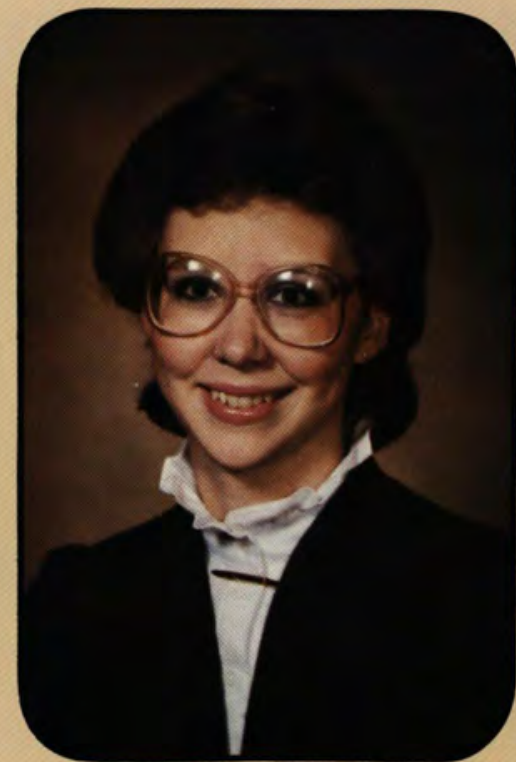

Lori Ann Hess

Elementary Education Akron, Ohio

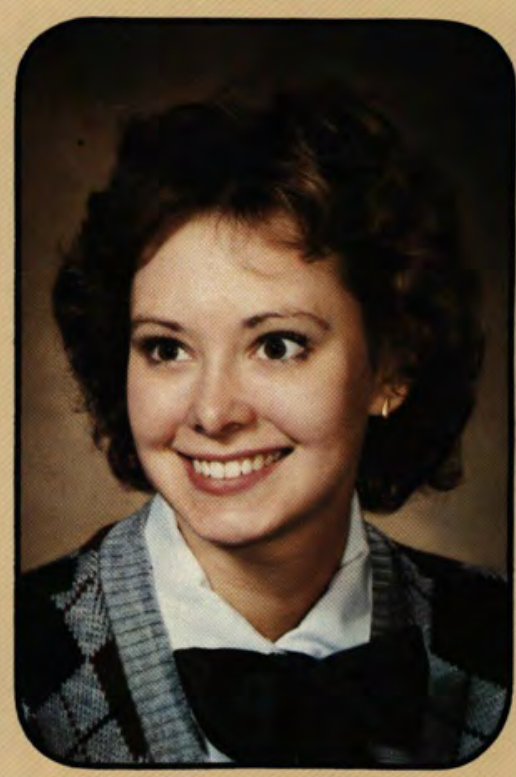

Robin L. Hilsmeier

Elementary Education

North Olmsted, Ohio

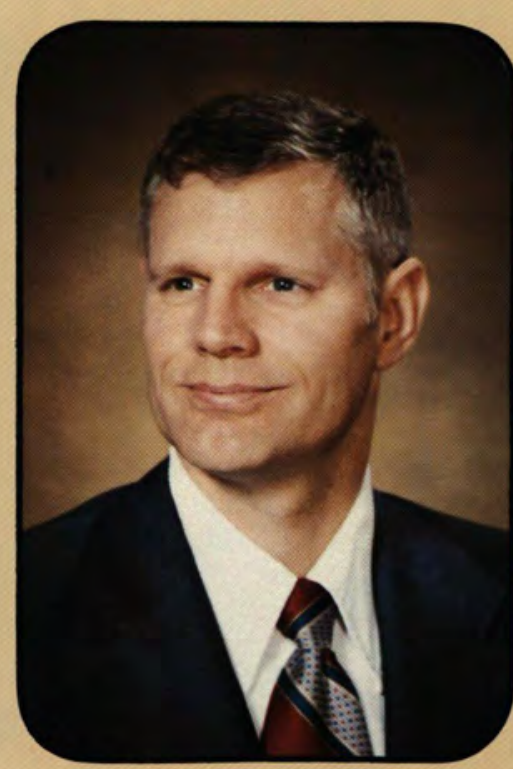

Irvin Raymond Holly

Computer Info. Systems Cedarville, Ohio
Lorrie Ellen Hickey Business Administration Dayton, Ohio

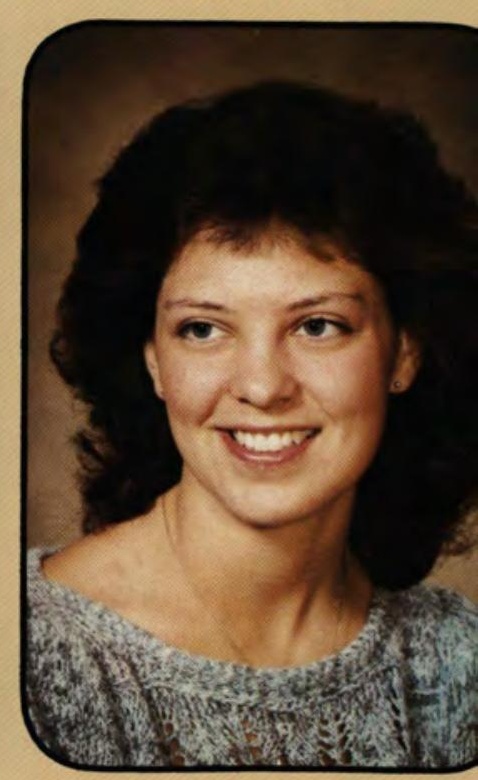

Shawn M. Hinkson Physical Education North Tonawanda, N.Y.

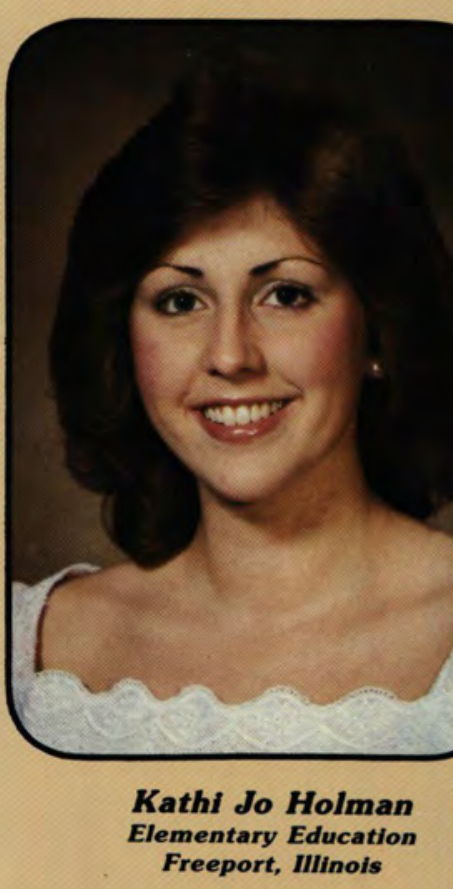




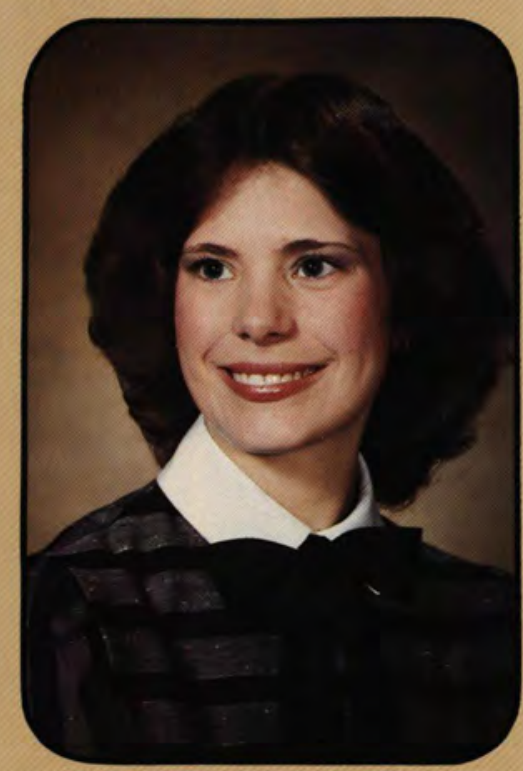

Lori Ann Horner

Nursing

Hauppauge, New York

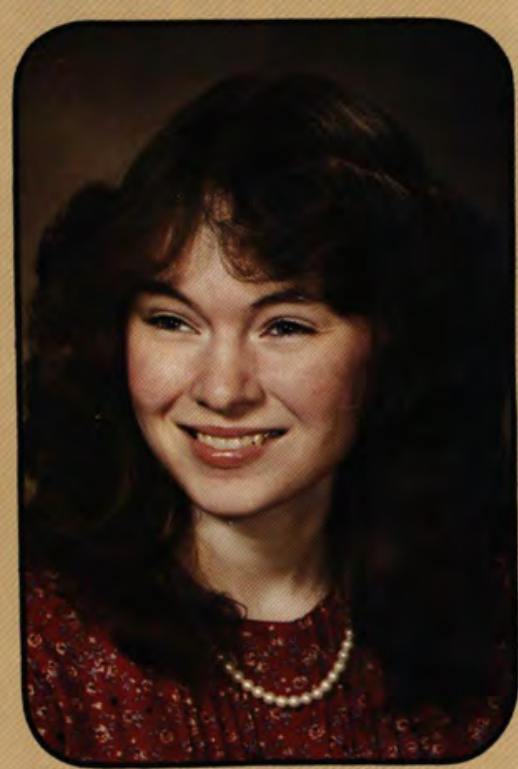

Melanie Neudeck Irving

Ele. Ed./English

Delevan, New York

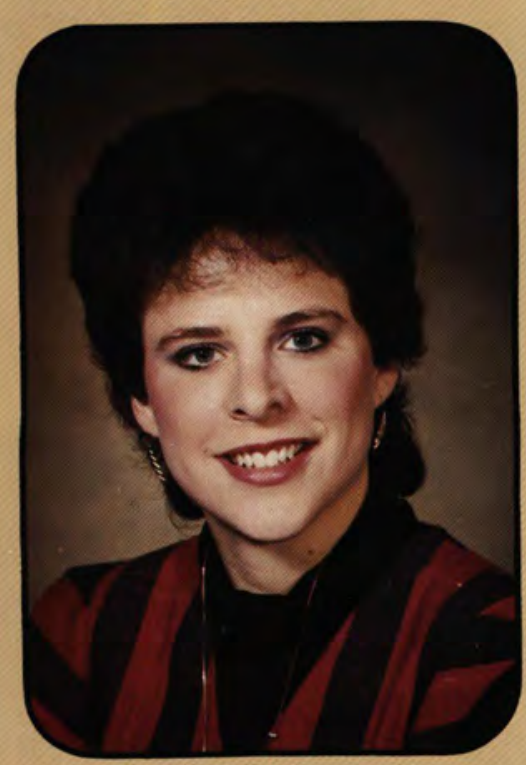

Katherine J. Jillson Mathematics

Hackensack, New Jersey

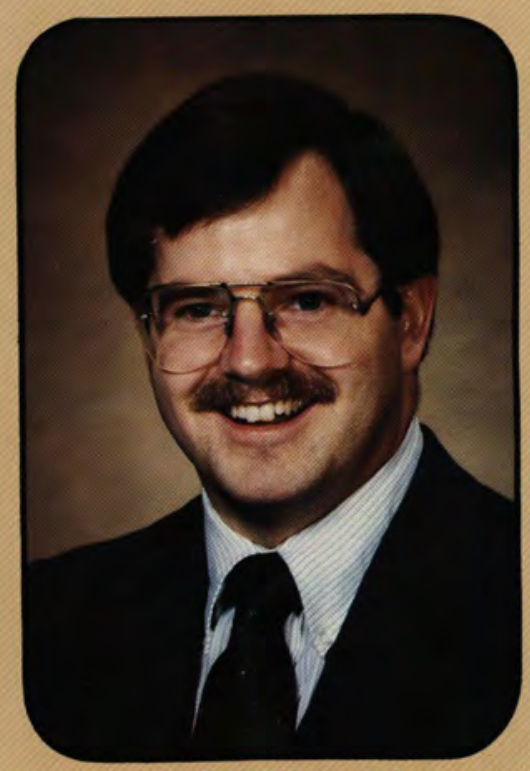

Richard G. Horsfall

Speech

Northfield, Ohio

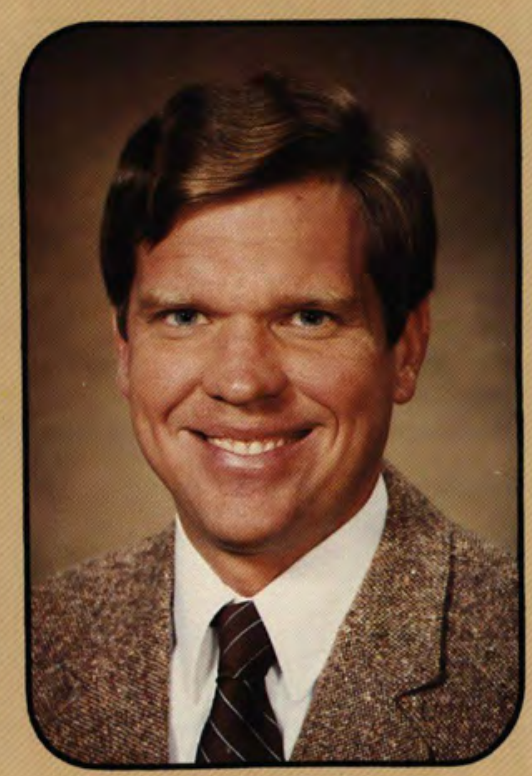

Robert Blair Jacobson

Business Administration Dayton, Ohio

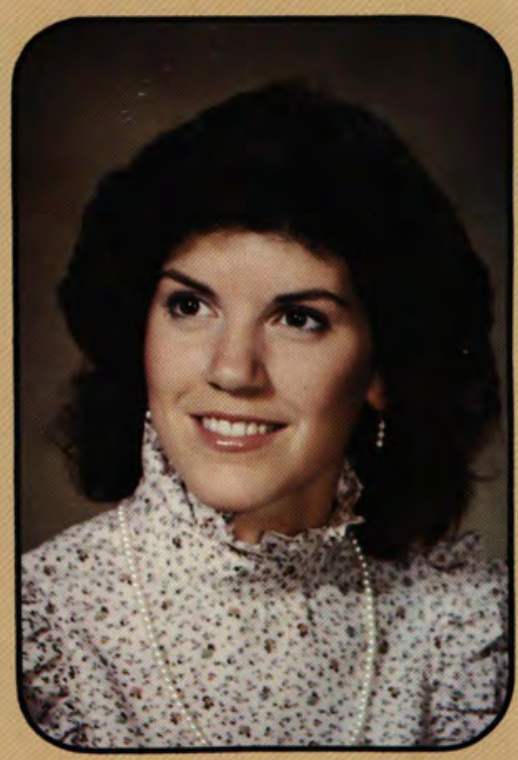

Debra K. Johnson

Elementary Education

North Adams, Massachusettes

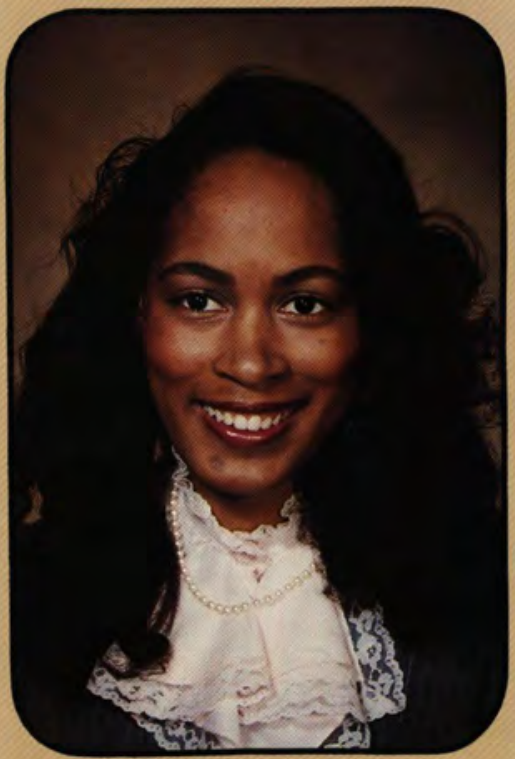

Carolyn Adrian Hunter

Nursing

Amityville, New York

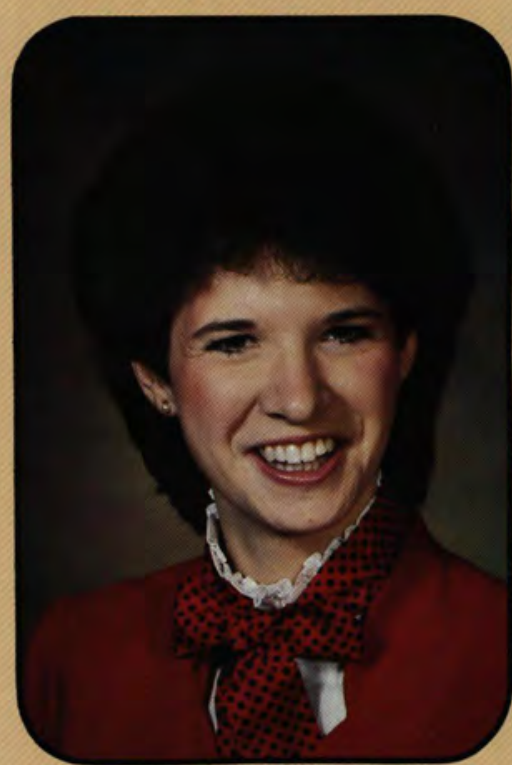

Brenda K. James

Elementary Education

Wheaton, Illinois

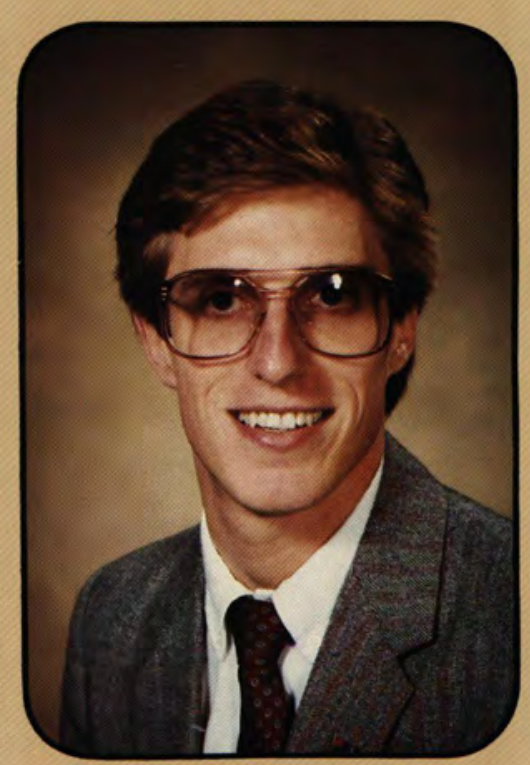

Randall Lee Johnson Nursing

Mellen, Wisconsin

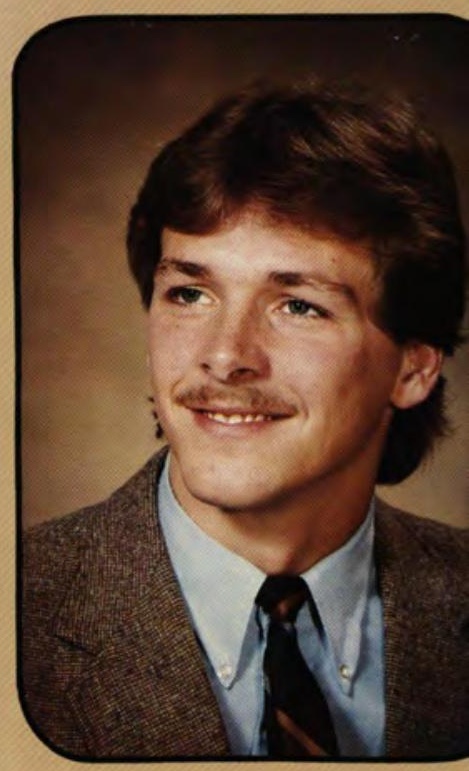

Nate A. Hunter

Physical Education

DuBois, Pennsylvania

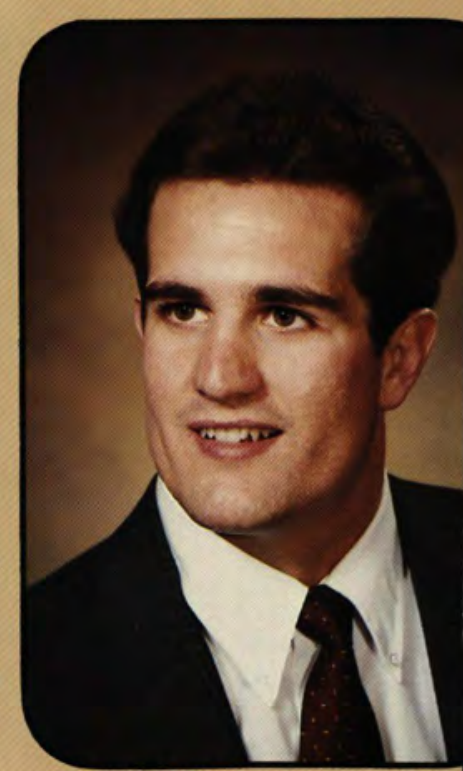

Todd $K$. Jefson

Accounting

Decatur Illinois

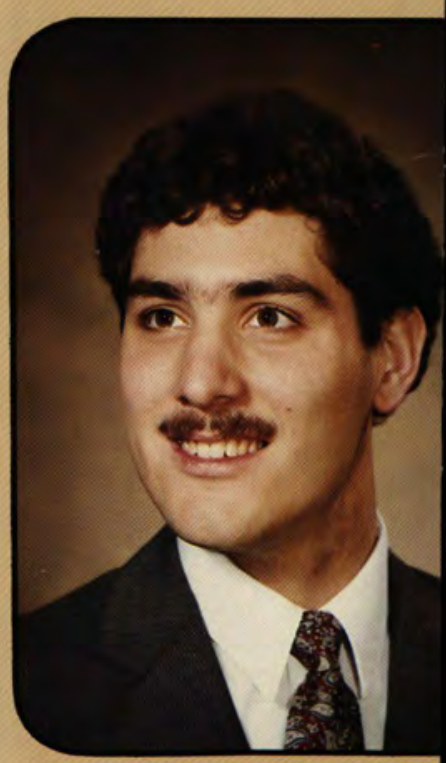

Glen Arthur Jones Accounting/Preseminary Holt, Michigan 


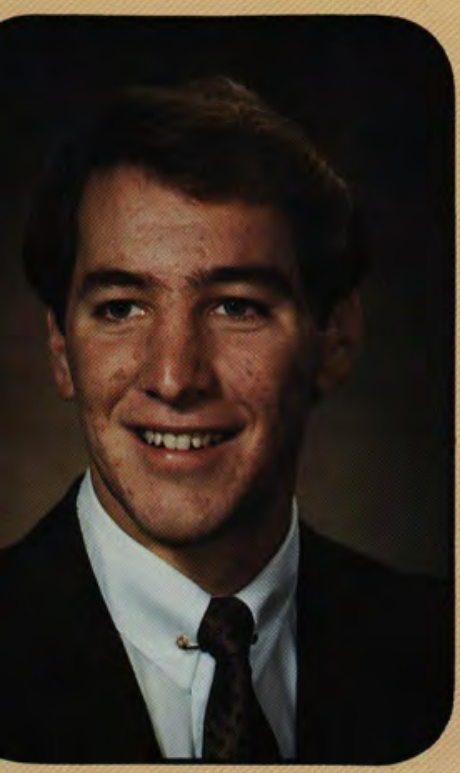

Paul E. Jones

Business Administration Holt, Michigan

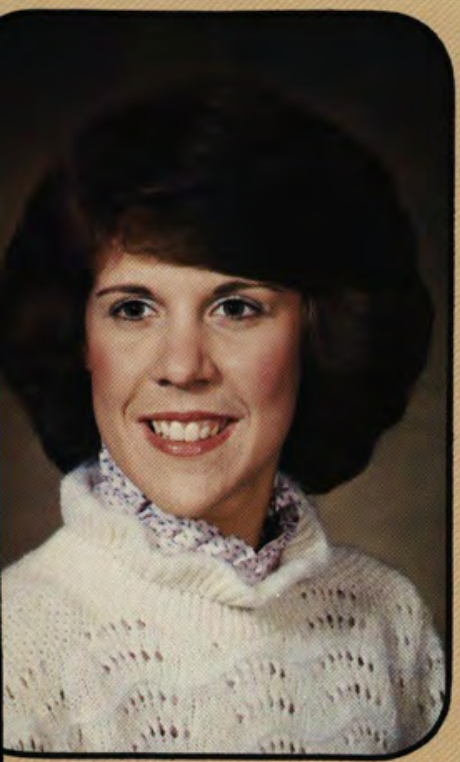

\section{Birgit Elizabeth Kass Nursing}

Centerville, Ohio

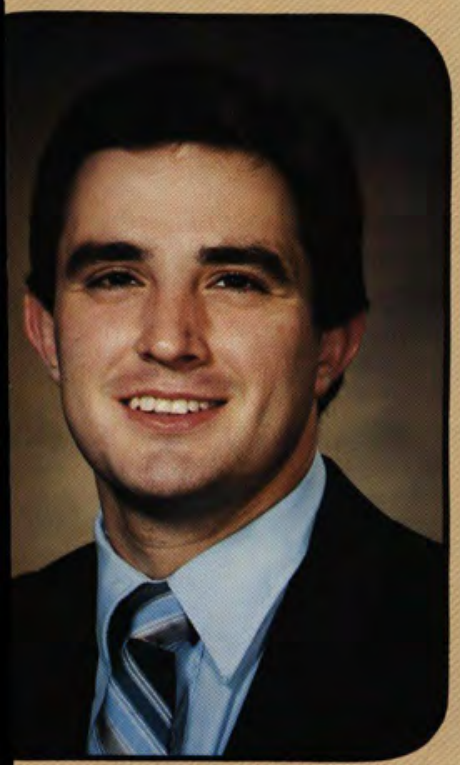

Phillip Alan Kinney

Secondary Ed. English

Wheelersburg, Ohio

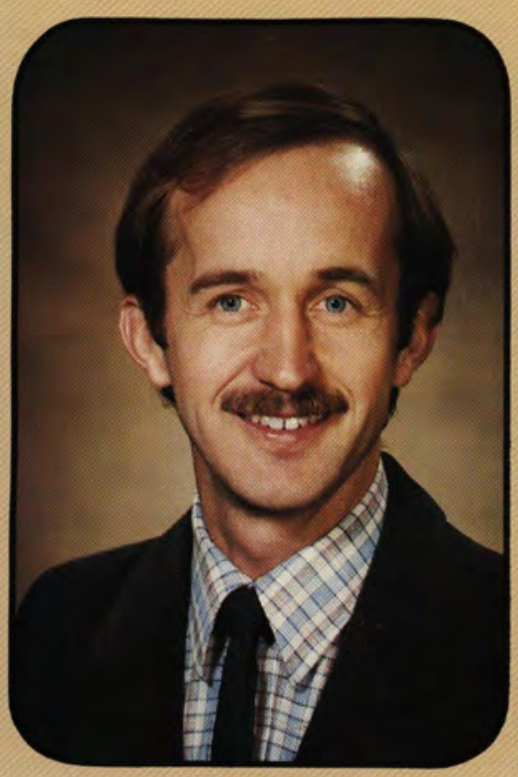

Thomas R. Jude

Bible Comprehensive

Columbus, Ohio

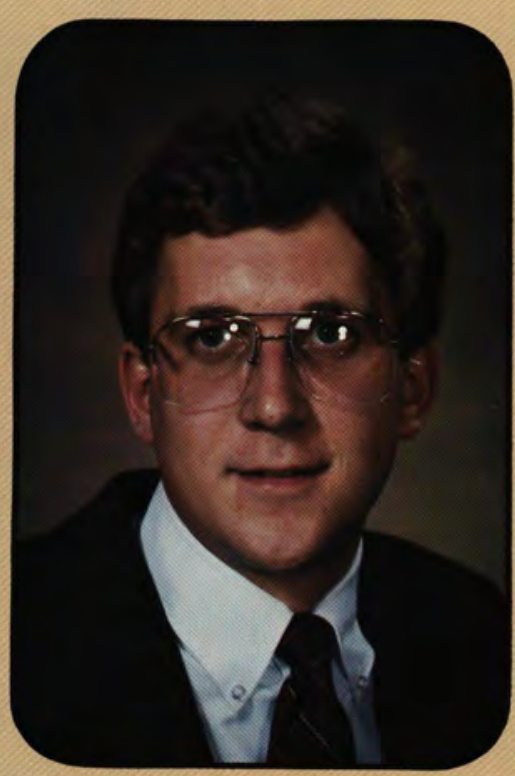

Wayne Warren Keisling Jr. Accounting

Prattsburg, New York

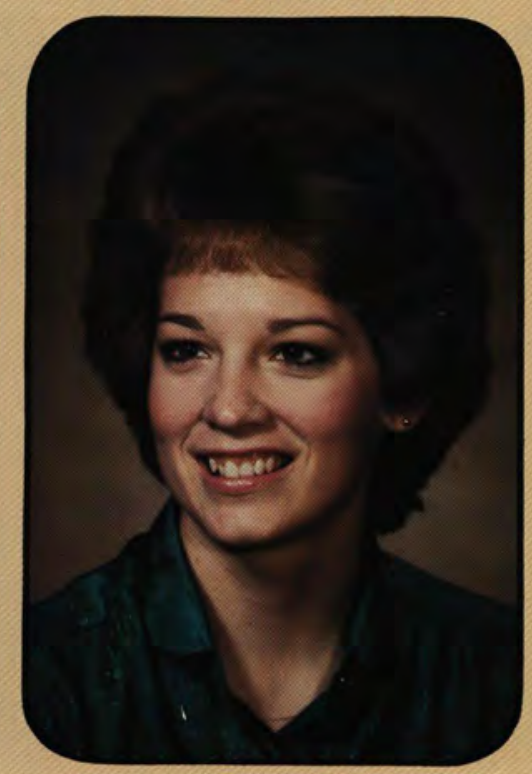

Eileen Faye Kirby

Secondary Ed. English Prospect, Ohio

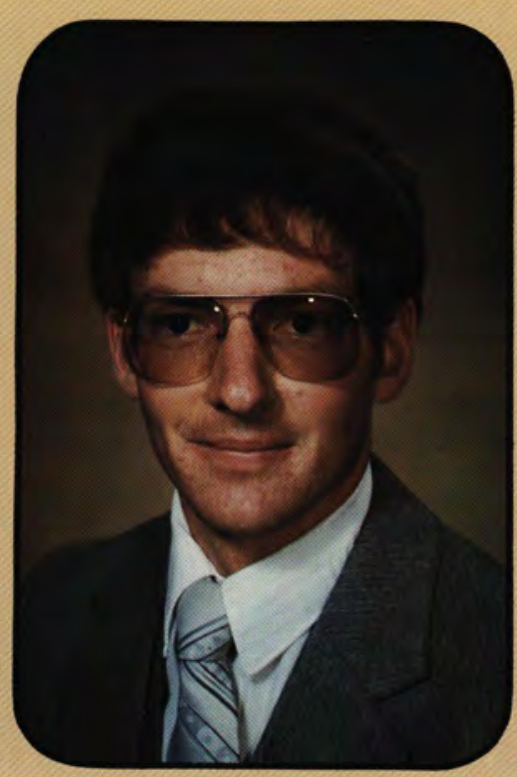

David A. Kammeyer Business Administration Pataskala, Ohio

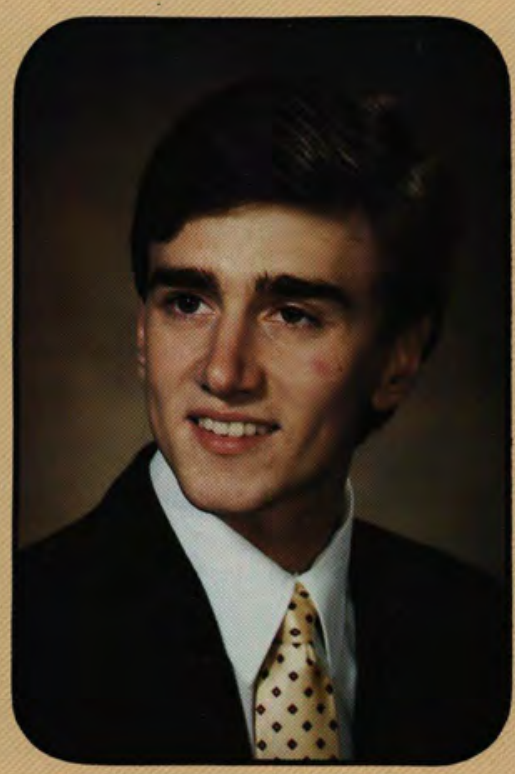

Brian Philip Kennedy Bible/Preseminary Cambridge, Ontario

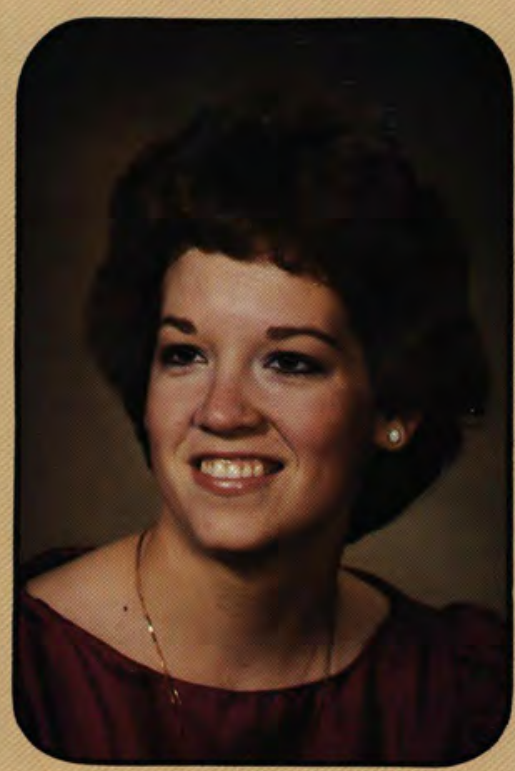

Kathleen Renee Kirby Business Administration Prospect, Ohio

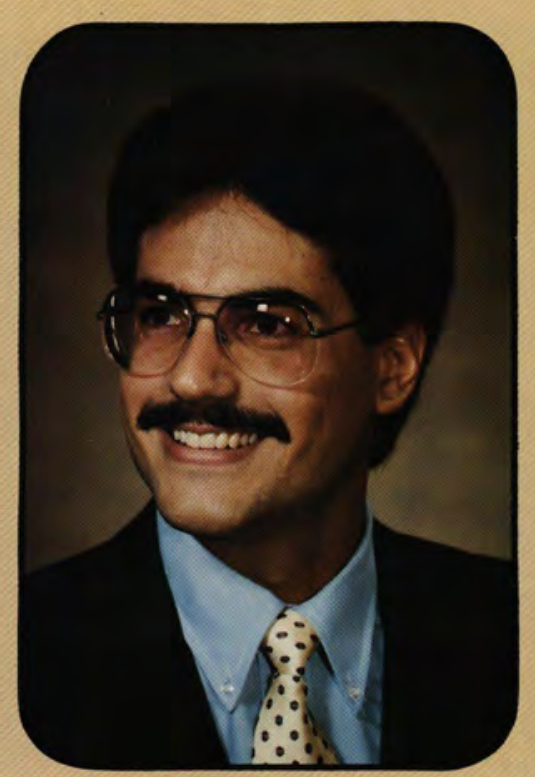

Paul Stephen Kasabian Accounting/Bus. Ad.

Johnson City, New York

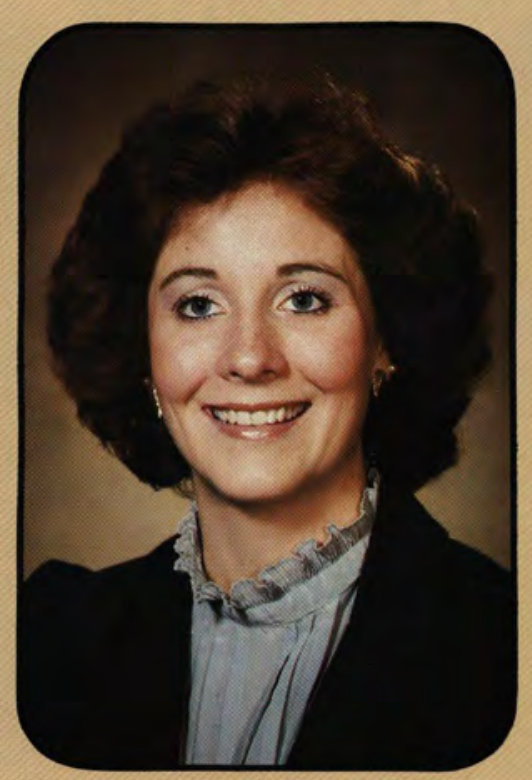

Mary Lou Kincaid Elementary Education Elyria, Ohio

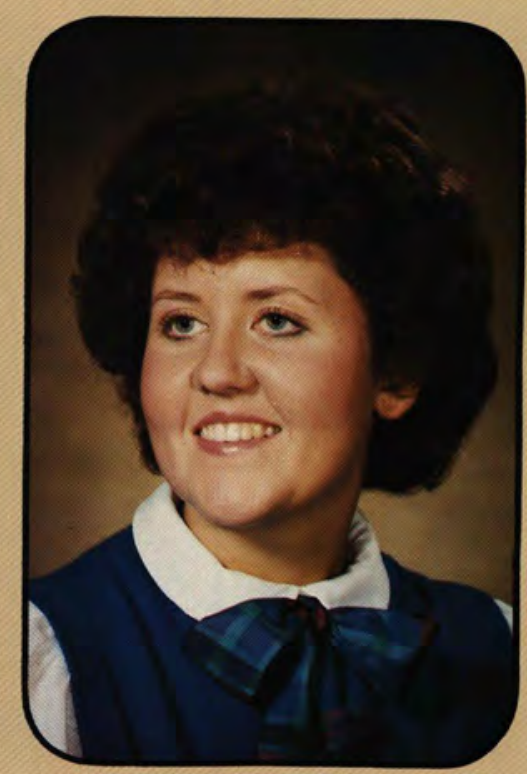

Ruth Elizabeth Kirtland Mathematics

Berkeley Heights, New Jersey 


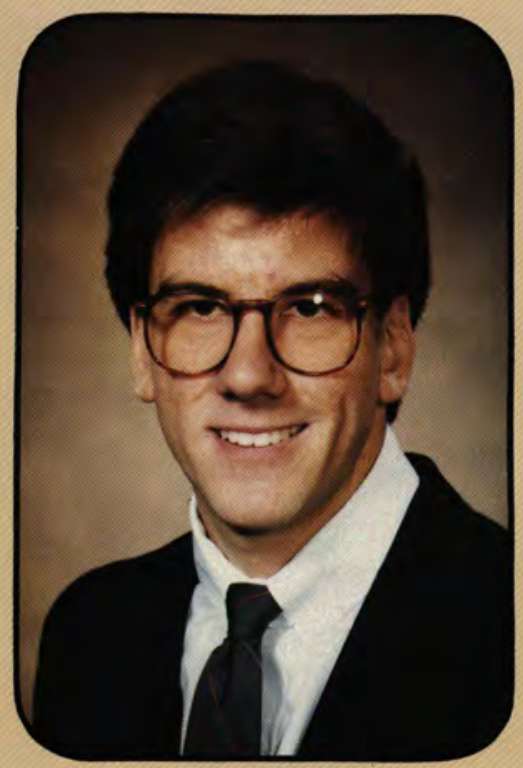

Robert James Kojko English

South River, New Jersey

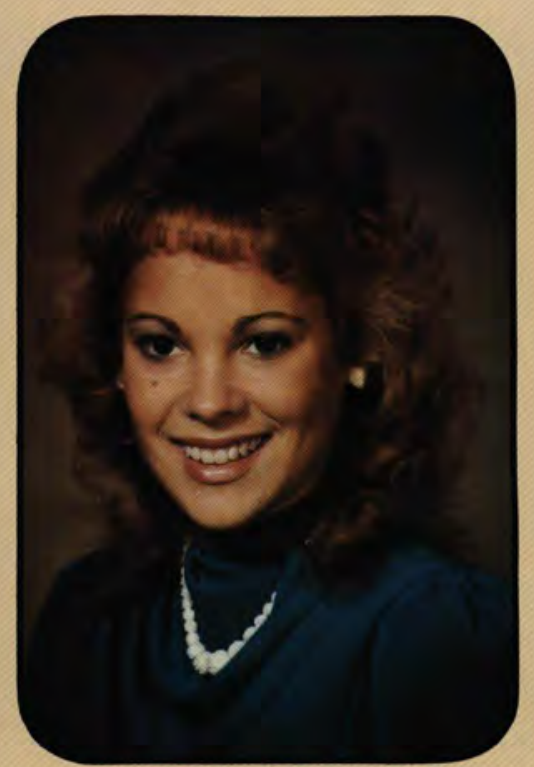

Carol Lynn Koppe

Business Administration

Bergenfield, New Jersey

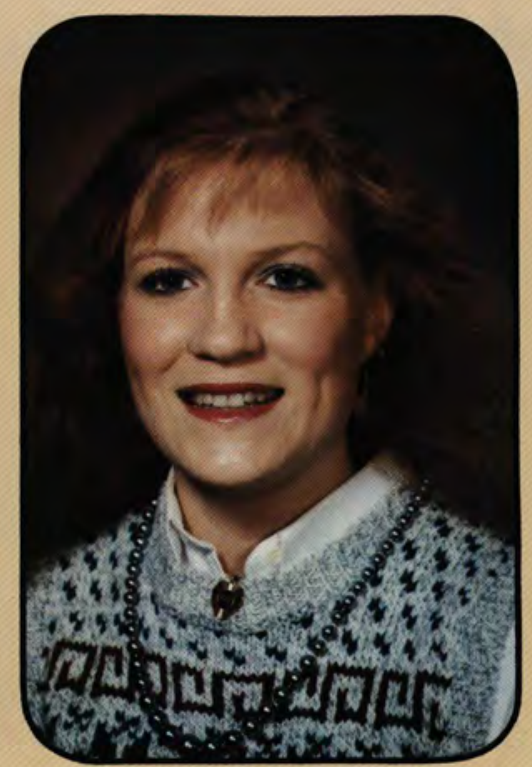

Jill Carver Kramer

Elementary Education

Lexington, Kentucky

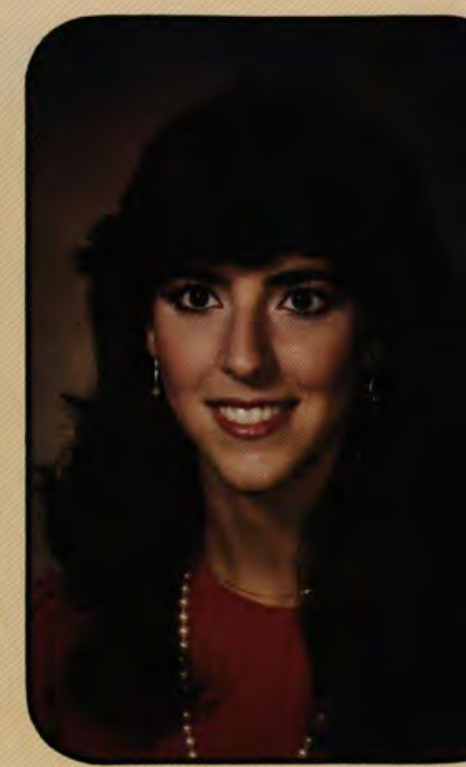

Shari L. Kratche Elementary Education Willoughby Hills, Ohio

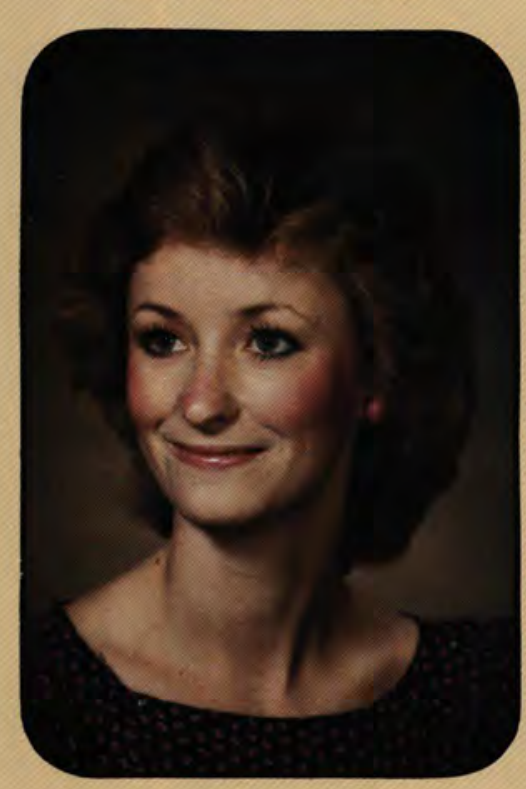

Terry L. Kyle Nursing

Mt. Vernon, Ohio

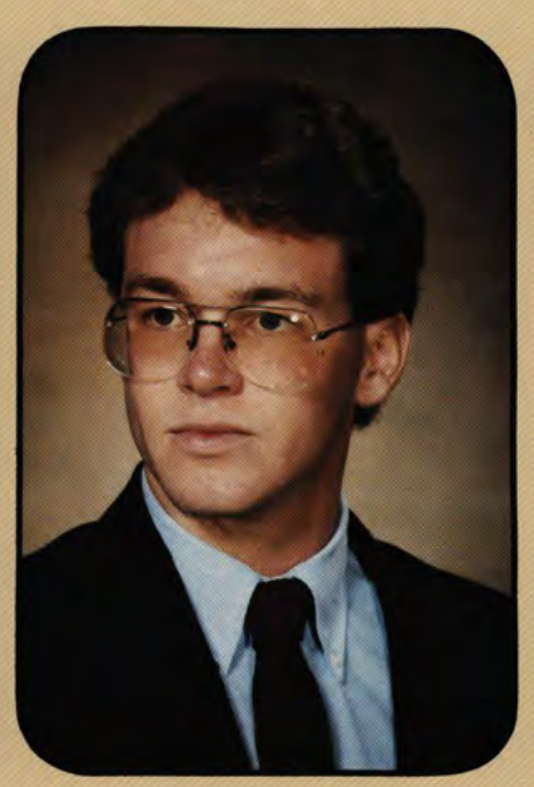

Daniel Reuel La Ponsie Mathematics

Cass City, Michigan

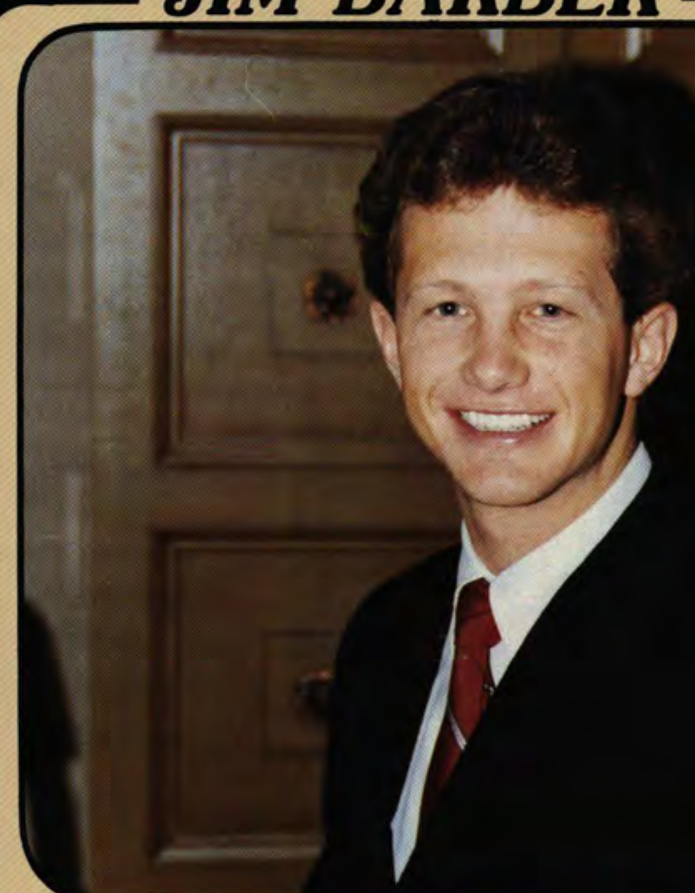

J ovember, 1980: My first visit to Cedarville College. It was my senior year in high school, and I came to visit this school simply to sarisfy a curiosity. For a Floridian, it's hard to imagine oneself in a setting where the sun doesn't shine from Ocrober to May! I had left $80^{\circ}$ weather and had a craving for ice cream; Ohio was experiencing its first snowfall of the year, and I gor strange stares as I ordered my double dip ice cream cone and ate it outside - the first bad sign. Also, I had driven all night to get here, stayed in Williams that first night (it was still a dorm), and a junior who shall remain nameless kept me up till three in the morning relaying his philosophy of life - second bad sign. One more sign and I knew it would be "Goodbye, Cedarville."

I thank the Lord that all that changed the next day. The sun did eventually shine; the campus was simply beautiful. The concept that really gripped me while on campus was that these people were really involved in their college. That
Friday, I knew that the Lord really wanted me at Cedarvill College for the next four years.

In some respects, mine has been the typical colleg experience. I'm convinced that I've received the best ed cation available anywhere: in the classroom, but mo importantly, out of the classroom. We all go throus change. For a majority of the time, due to my involvemer my painful growing up has been before the eyes of $m$ peers. That brings with it an added dimension of pressu that the "rypical" student may not experience; however wouldn't change a thing. Through those peers I've learn the most important lesson of my life; God is not so co cerned with what happens to us as $\mathrm{He}$ is with how $v$ respond to it. Thank you to my friends who have loved $m$ shared with me, and built into my life while at the "Ville You will forever be cherished. Psalm 27:4 


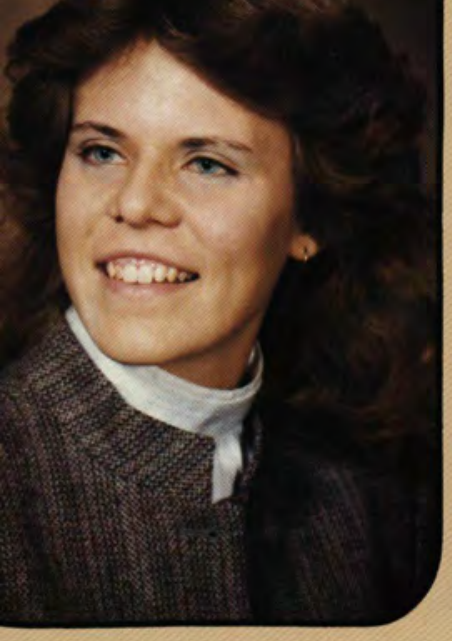

Lori A. Leach Business Administration Kettering, Ohio

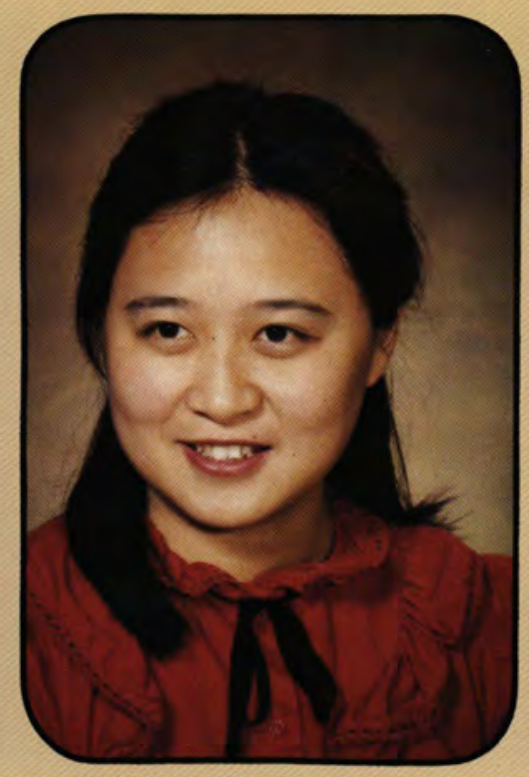

Camila Chao-guang Lin English

Beavercreek, Ohio

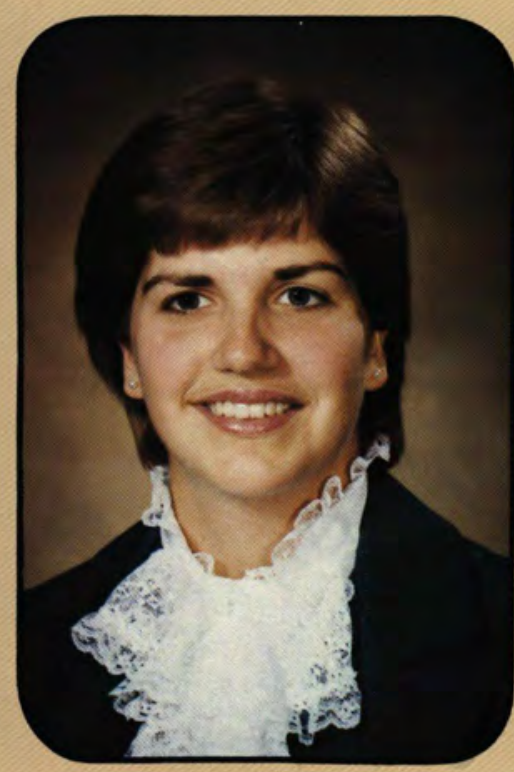

Sharon Ann Longnecker Nursing

Benton, Pennsylvania

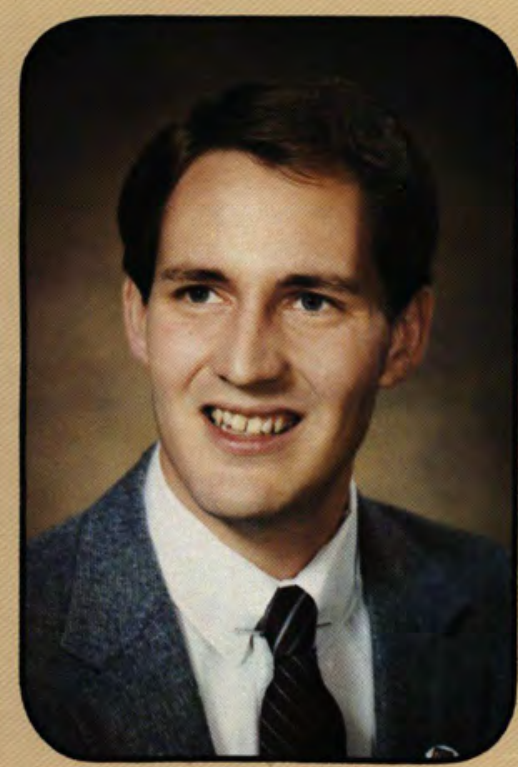

Jeffrey David Lyle Music-Broadcasting Austin, Minnesota

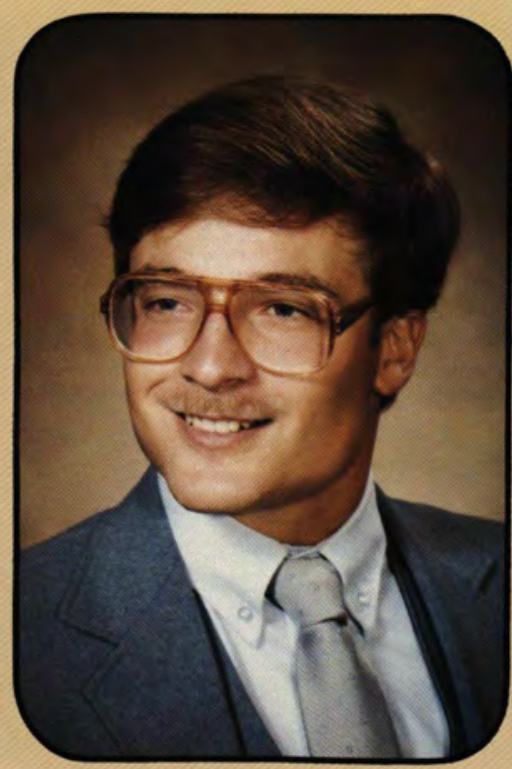

Francis A. Link Jr.

Physical Education

Transfer, Pennsylvania

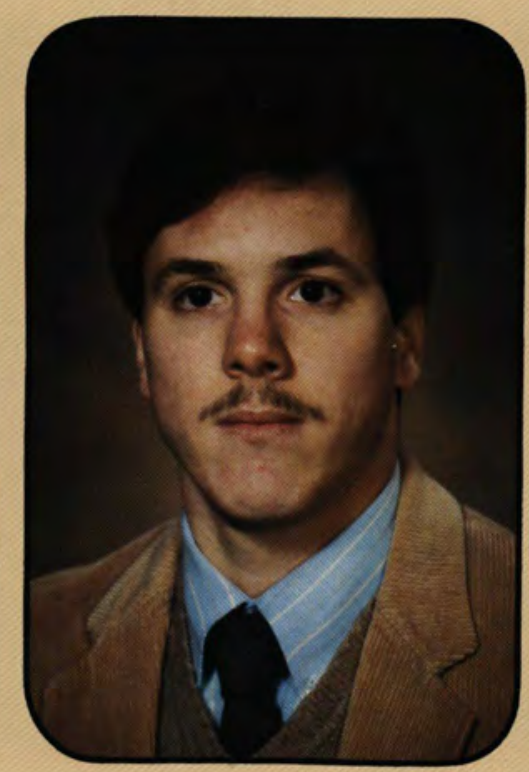

James $M$. Lorch

Bible/Preseminary

Seven Hills, Ohio

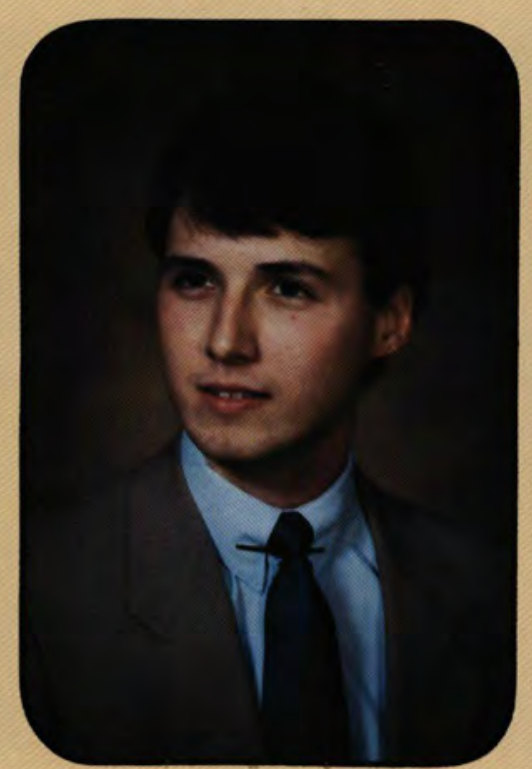

William E. McBrayer

Bible/Presiminary

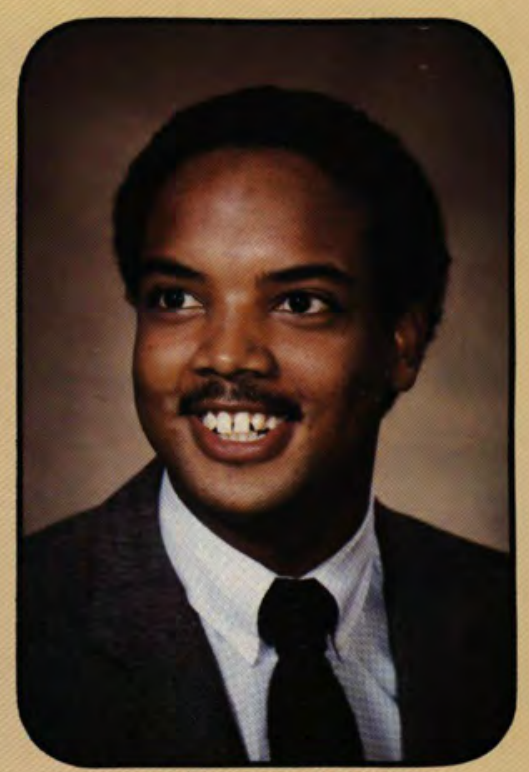

Darryl C. Little

Chemistry

Atlantic City, New Jersey

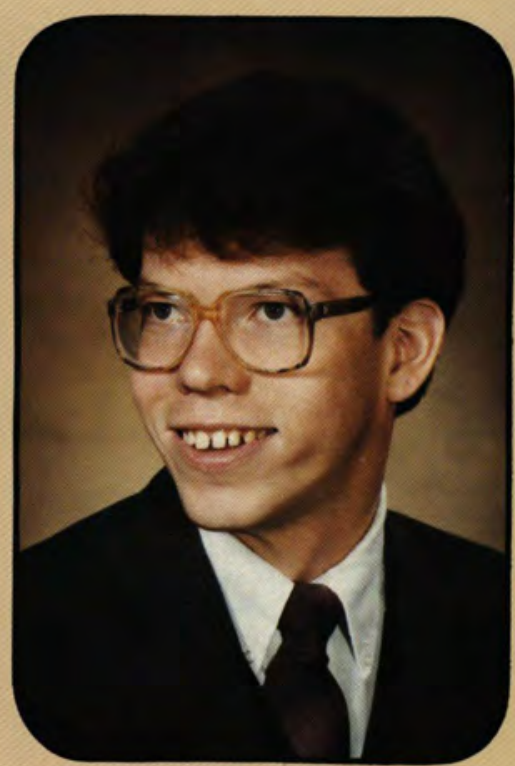

Colin Wendell Lord

Music Education

Perry, Iowa

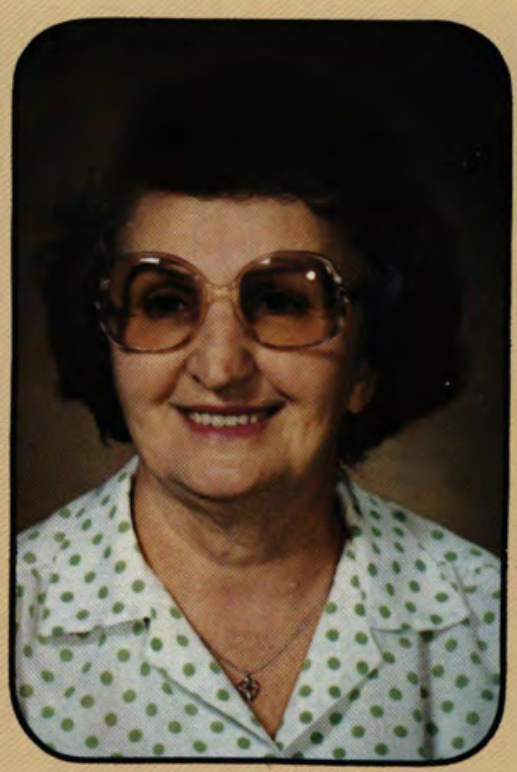

Lois J. McCormick Bible Comprehensive Dayton, Ohio 


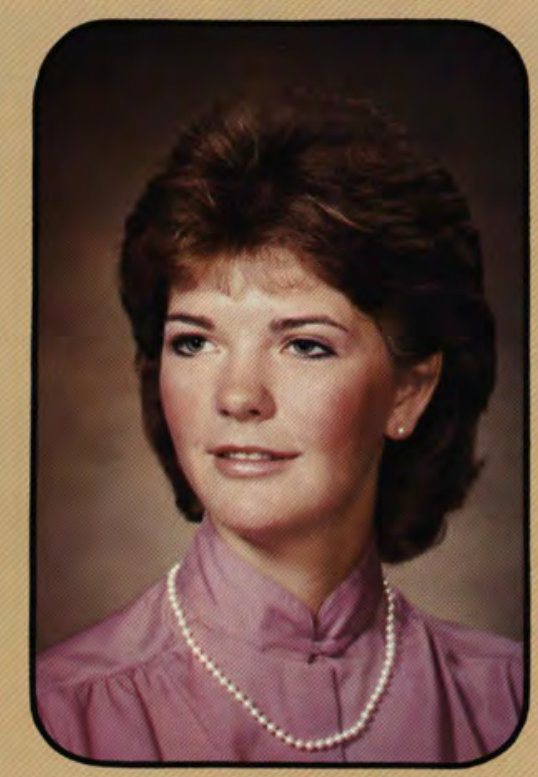

M. Jill McCoy

Nursing

Decorah, lowa

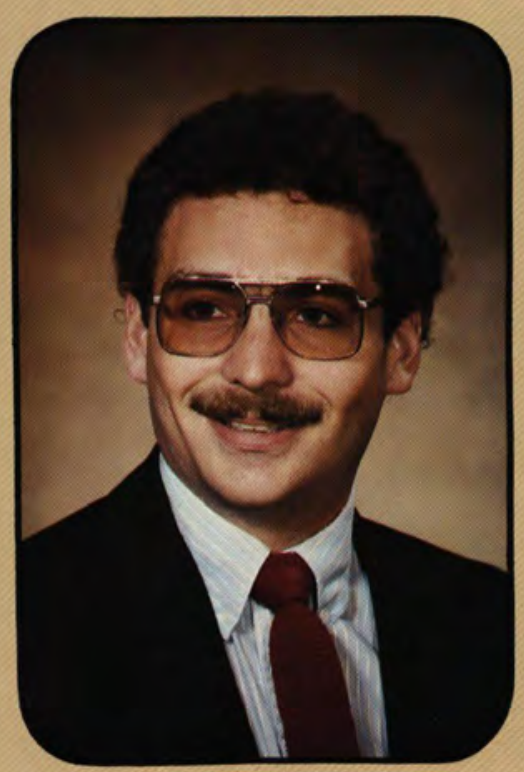

James Phillip Manley, Jr. Mathematics/Chemistry Corning, New York

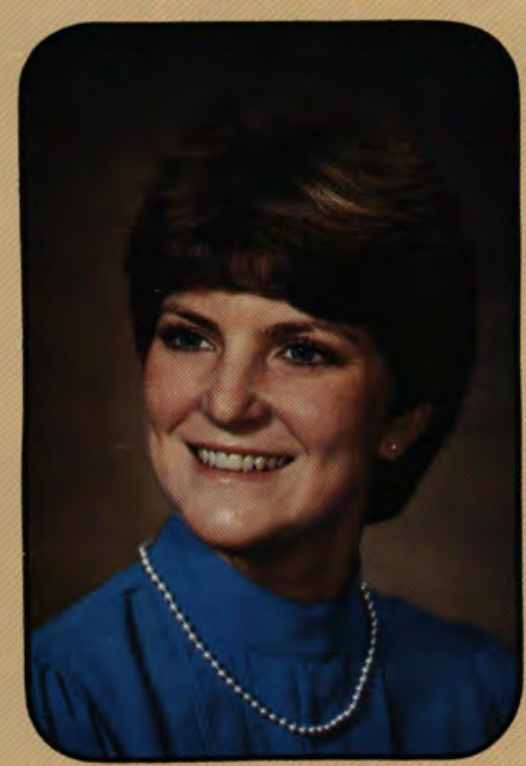

Karen Lynne Mathews Nursing

Grove City, Ohio

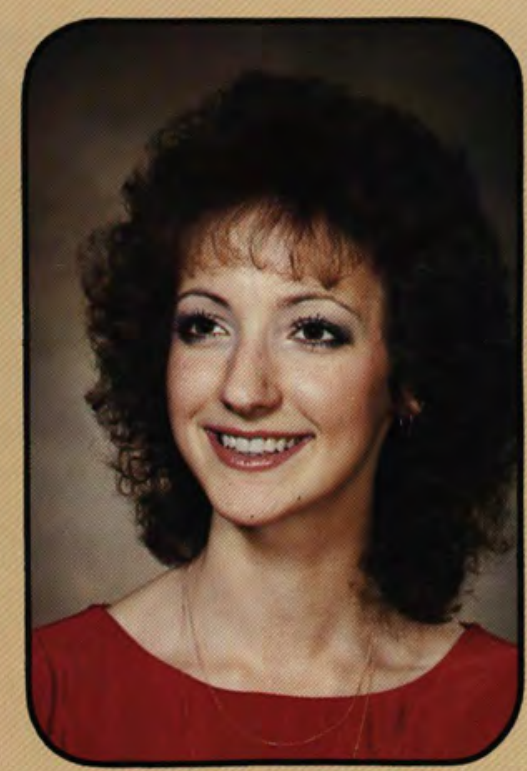

Laura Charlotte McElroy Behavioral Sci./Psychology Worthington, Ohio

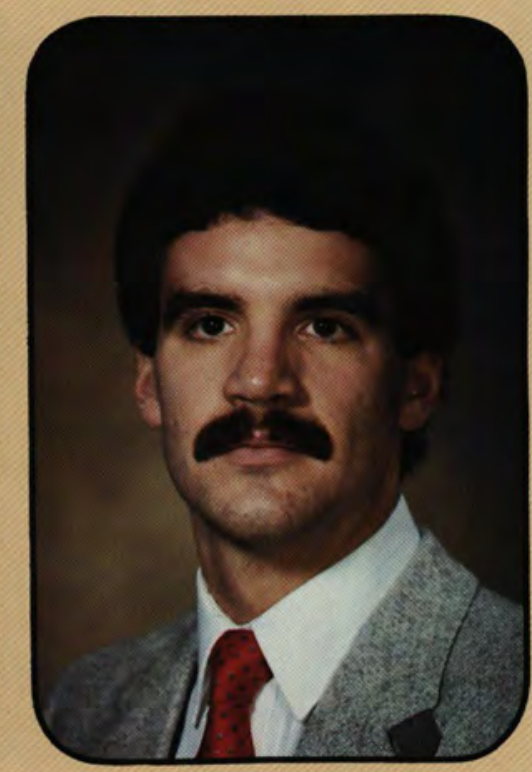

Richard Craig Manuel History

Lebanon, Indiana

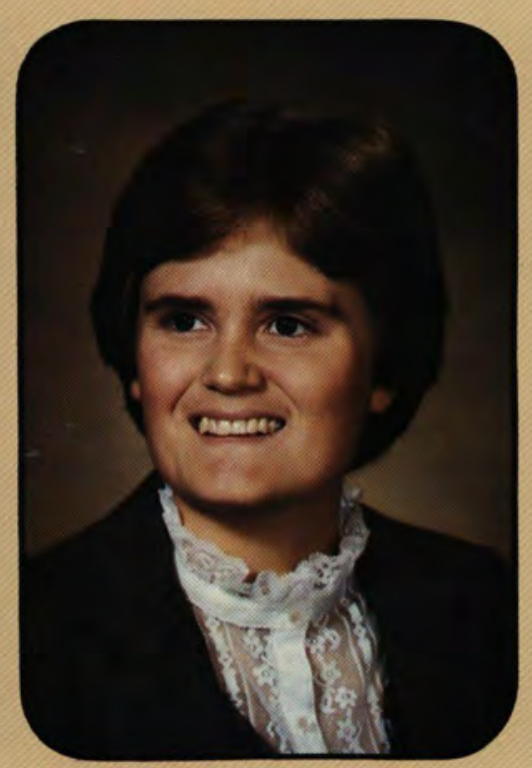

Melanie Ann Mathewson Elementary Education Batavia, New York

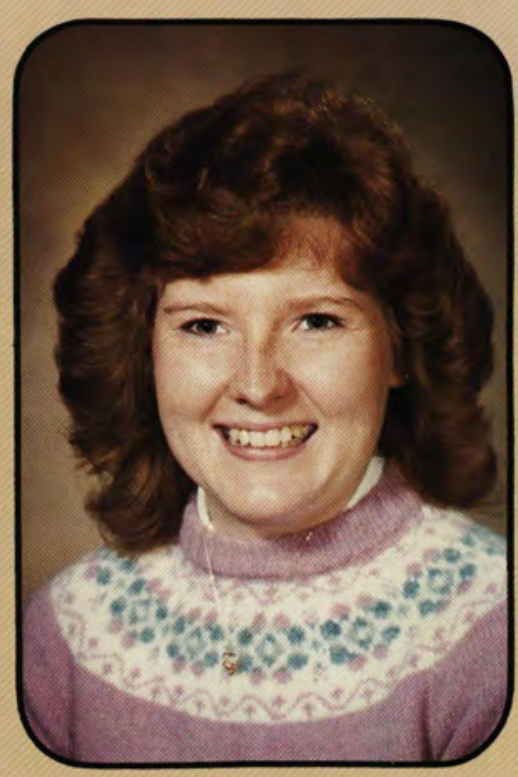

Marilyn Jean McNeish Behavioral Sci./Sociology

Adamsville, Ohio

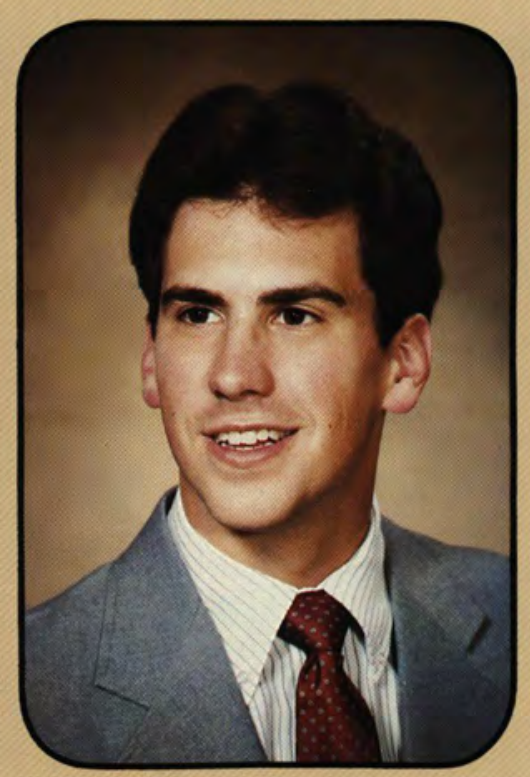

William Randolph Marriott Biology

Cincinnati, Ohio

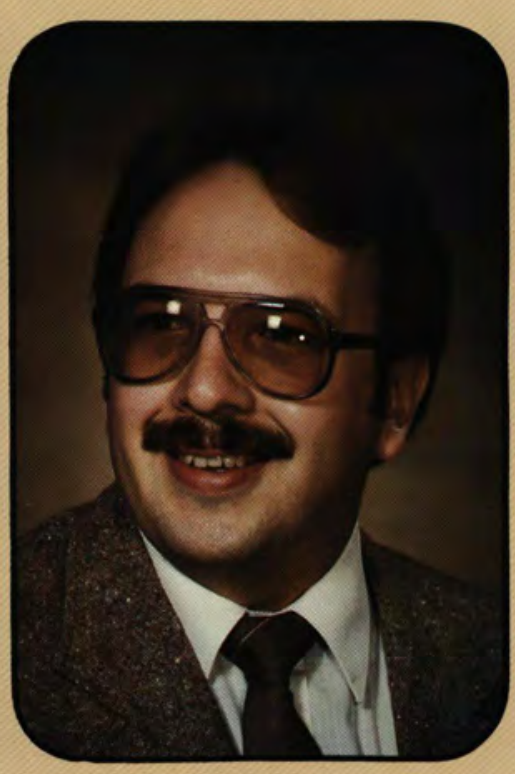

William J. Mazey

Bible/Preseminary

Twinsburg, Ohio

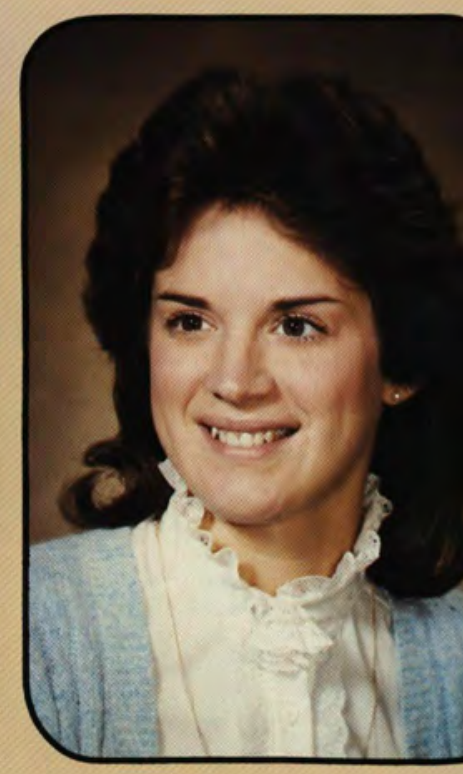

Vicki L. Mangrum Business Administration Rootstown, Ohio

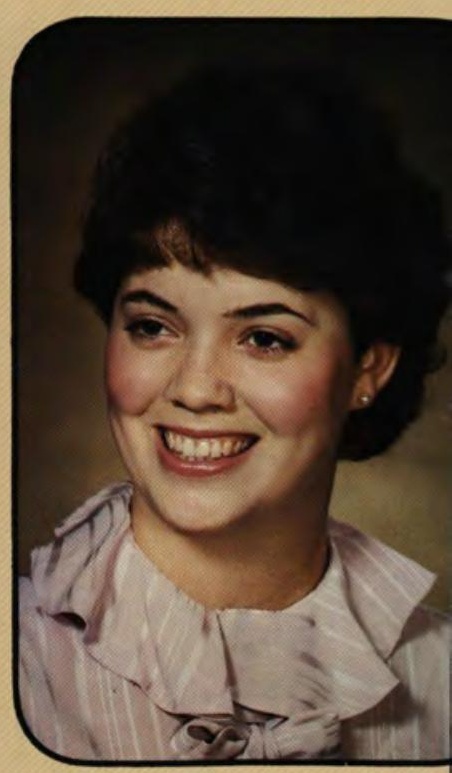

Michele Joyce Martin Elementary Education Springfield, Ohio

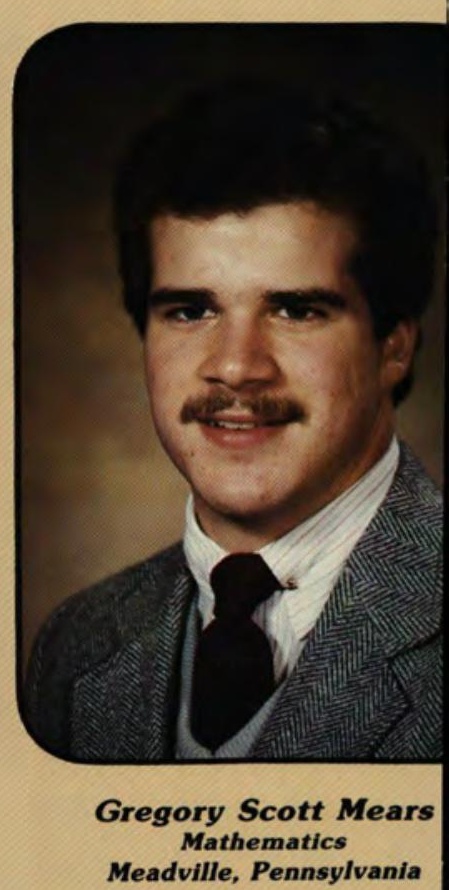




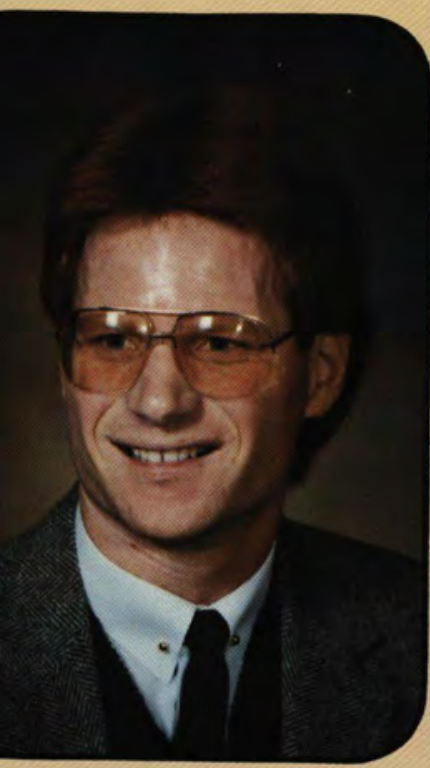

Bradley C. Merchant Bible Comprehensive McKean Pennsylvania

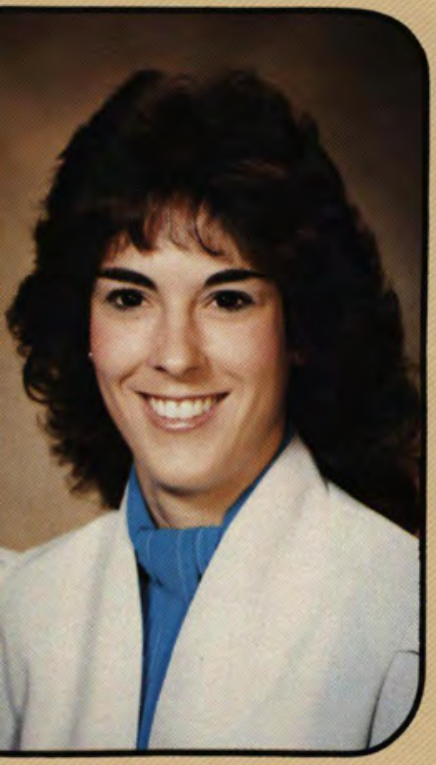

Rebecca Sue Miller

Behavioral Science

Wheelersburg, Ohio

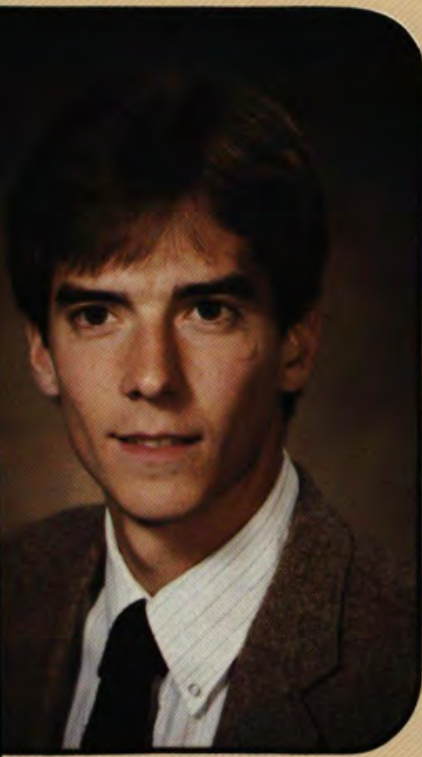

David Lane Moody Business Administration eorgetown, South Carolina

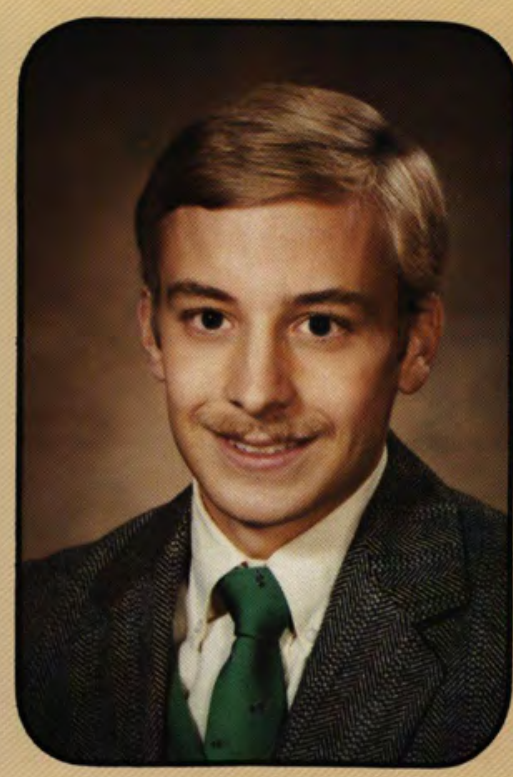

Donald W. Messick

Mathematics

Nortonville, Kentucky

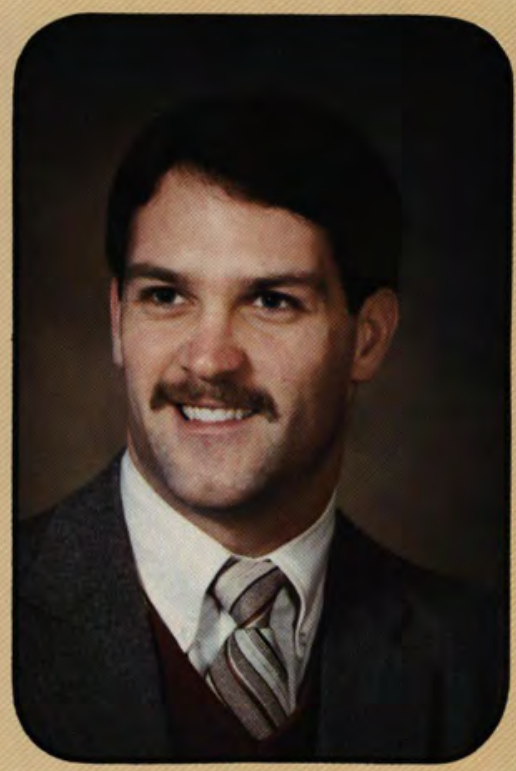

Gary L. Mills

Bible Comprehensive

Vermilion, Ohio

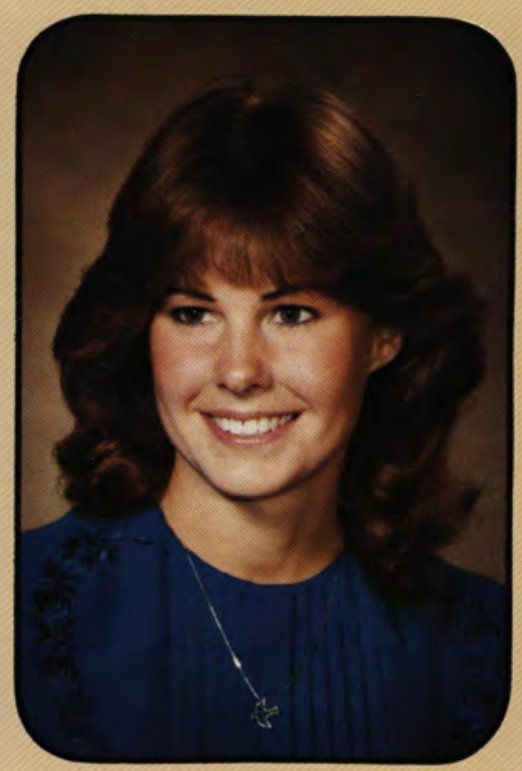

Kimberly Sue Morgan

Business Administration

Howard, Ohio

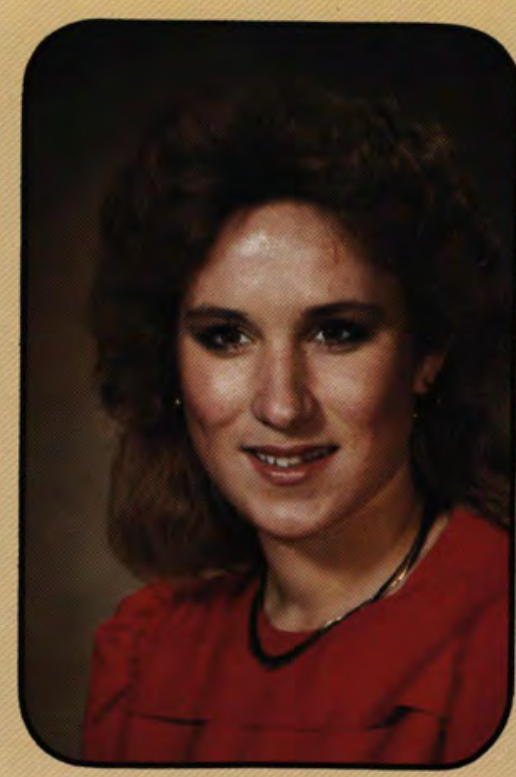

Ruth L. Meyer Biology/Mathematics

Fairfax, Virginia

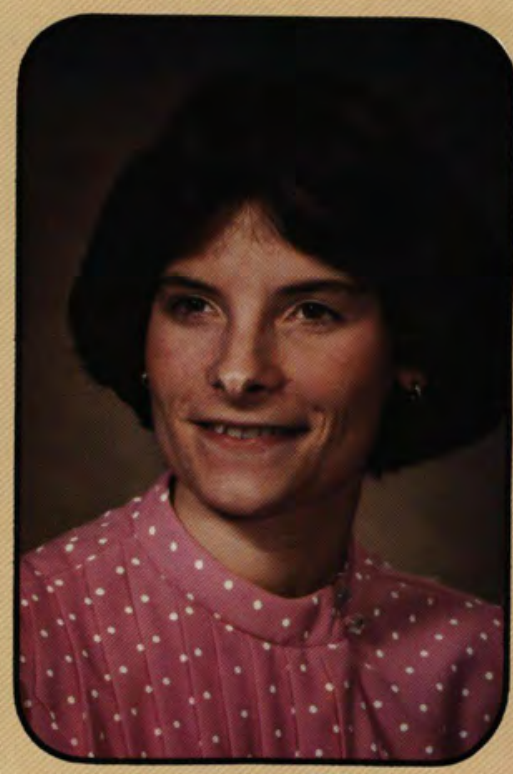

Susan G. Mills

Science Comprehensive

Sandy Creek, New York

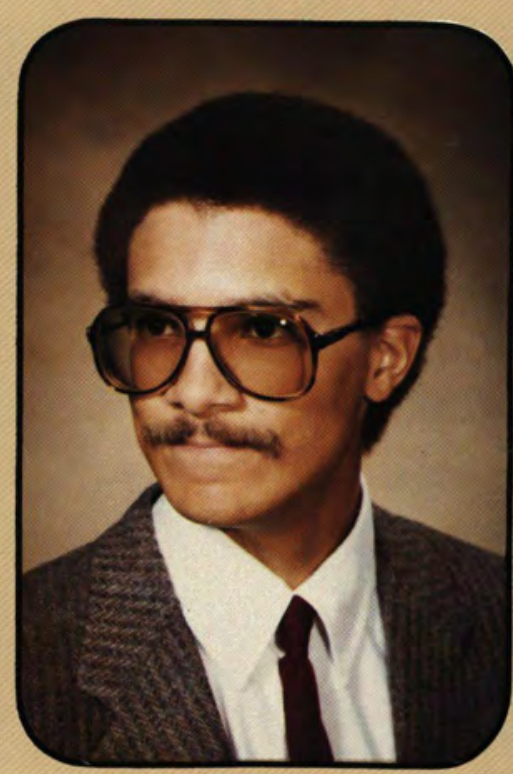

Cicero C. Mukes Jr.

English Education

Indianapolis, Indiana

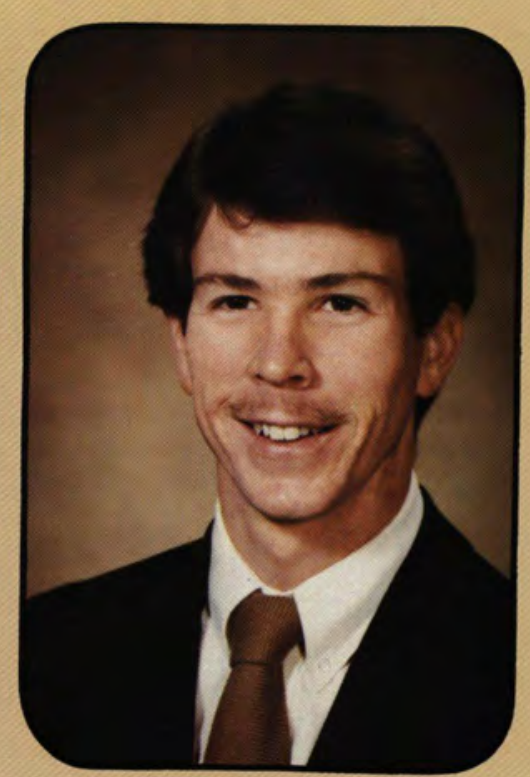

Michael Allan Mikesell

Speech

Xenia, Ohio

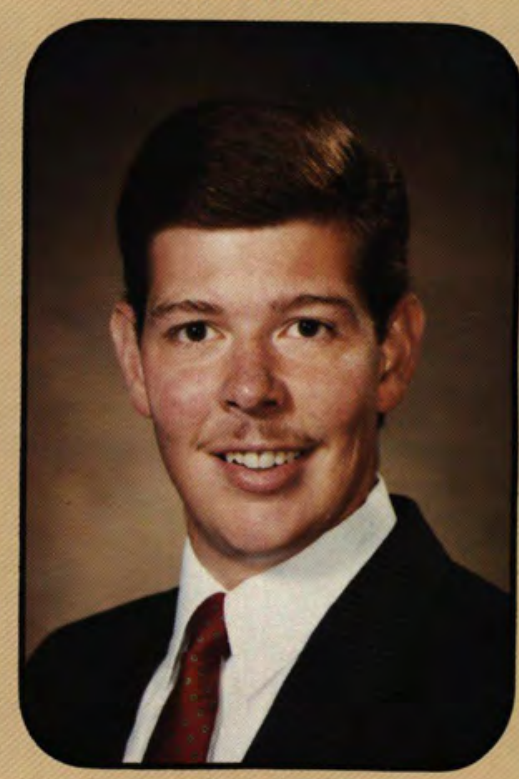

Randall C. Monroe

Behavioral Science

Springfield, Ohio

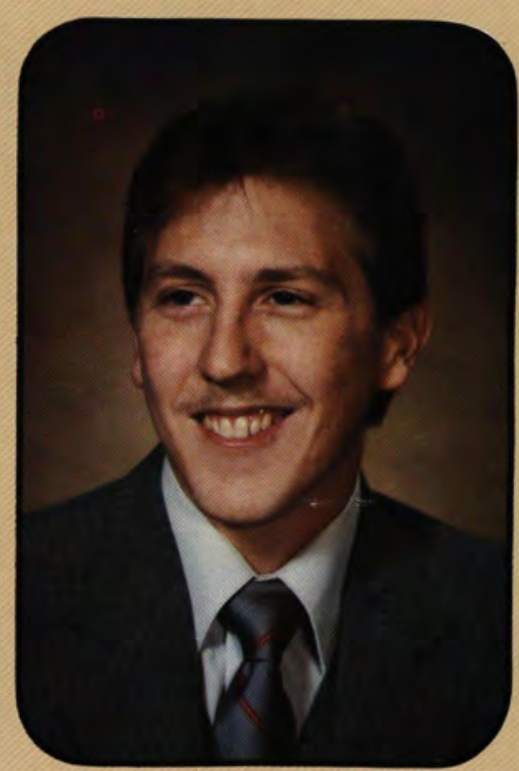

Steve J. Mulligan

Sociology

Big Rock, Illinois 


\section{KRISTINA WHITTAKER}

oing to college involved some new experiences for me

$\exists$ with which most freshman did not have to conrend. Learning to use a Coke machine, for example, or trying to find the appropriate vocabulary to order a hamburger were major adjustments. Thus, to a kid born and raised by missionary parents in Brazil, Cedarville College was a long, fearful step into a vast unknown. It seemed to have at least one million students and fifty-mile long lines to my glazed and tear-blurred freshman eyes. Gradually the homesickness and newness wore off; the panic subsided, and I began to enjoy my college career. It is hard to believe the endless memories of happy, exciring, sad, and challenging times that four years can contain, and that it is now time for another step out to new experiences.

I have learned that next to my relationship with Jesus Christ, the most important investment of my time here at Cedarville has been my friends. I probably won't remember all the "-ologies" of Theology Survey or all of Dr. Monroe's

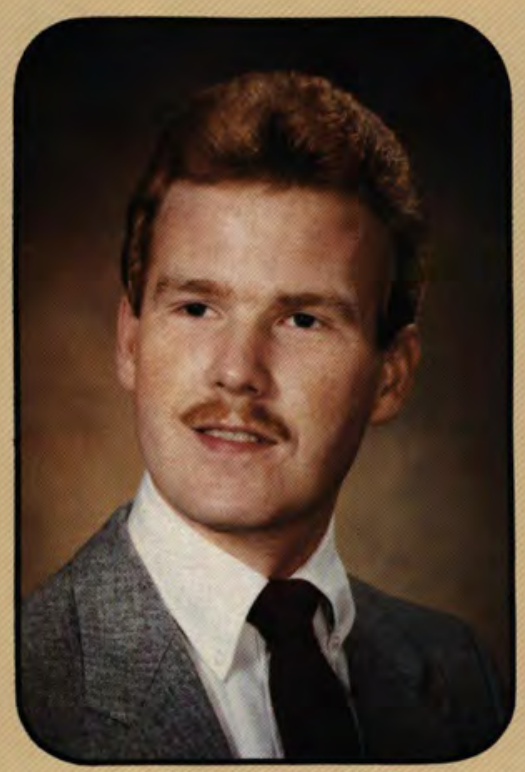

Jeffrey Scott Mullinix Speech Dayton, Ohio

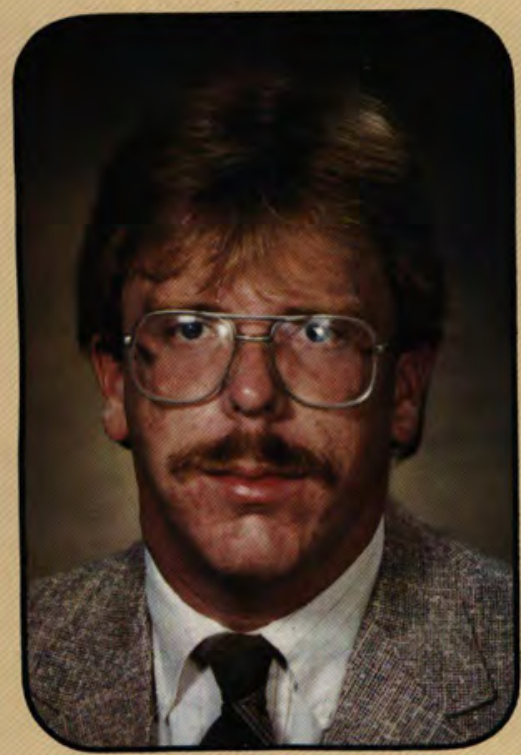

Rex Ala Musselman Computer Info. Systems Noblesville, Indiana

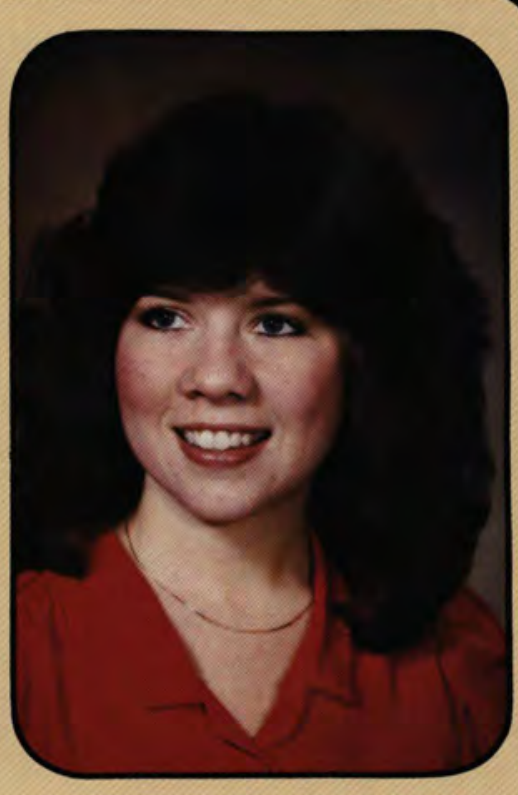

\section{Kimbra Kay Murphy}

Music Education Indianapolis, Indiana

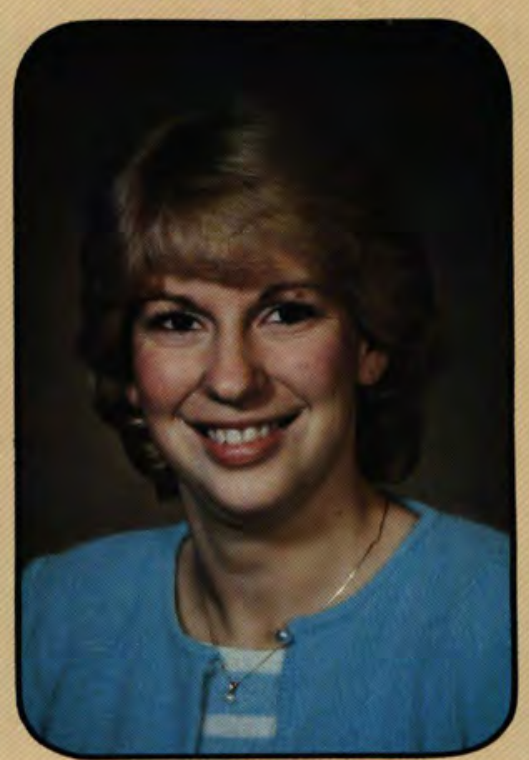

Kimberly A. Myers Business Administration Hilliard, Ohio

contentions in his "Athens vs. Jerusalem" lectures, but I'll always treasure the memories of encouragement, support, correction, and love of my friends. My spiritual challenge to others would be to keep Christ the central focus of their lives and to cultivate relationships that strengthen this purpose; so that as the body of Christ, we really will make a difference and influence the world for Him. With Paul my prayer is "According to my earnest expectation and hope that I shal not be put to shame in anything, but that with all boldness, Christ shall even now, as always, be exalred in my body, whether by life or by death. For to me to live is Christ' Philippians 1:20, 21

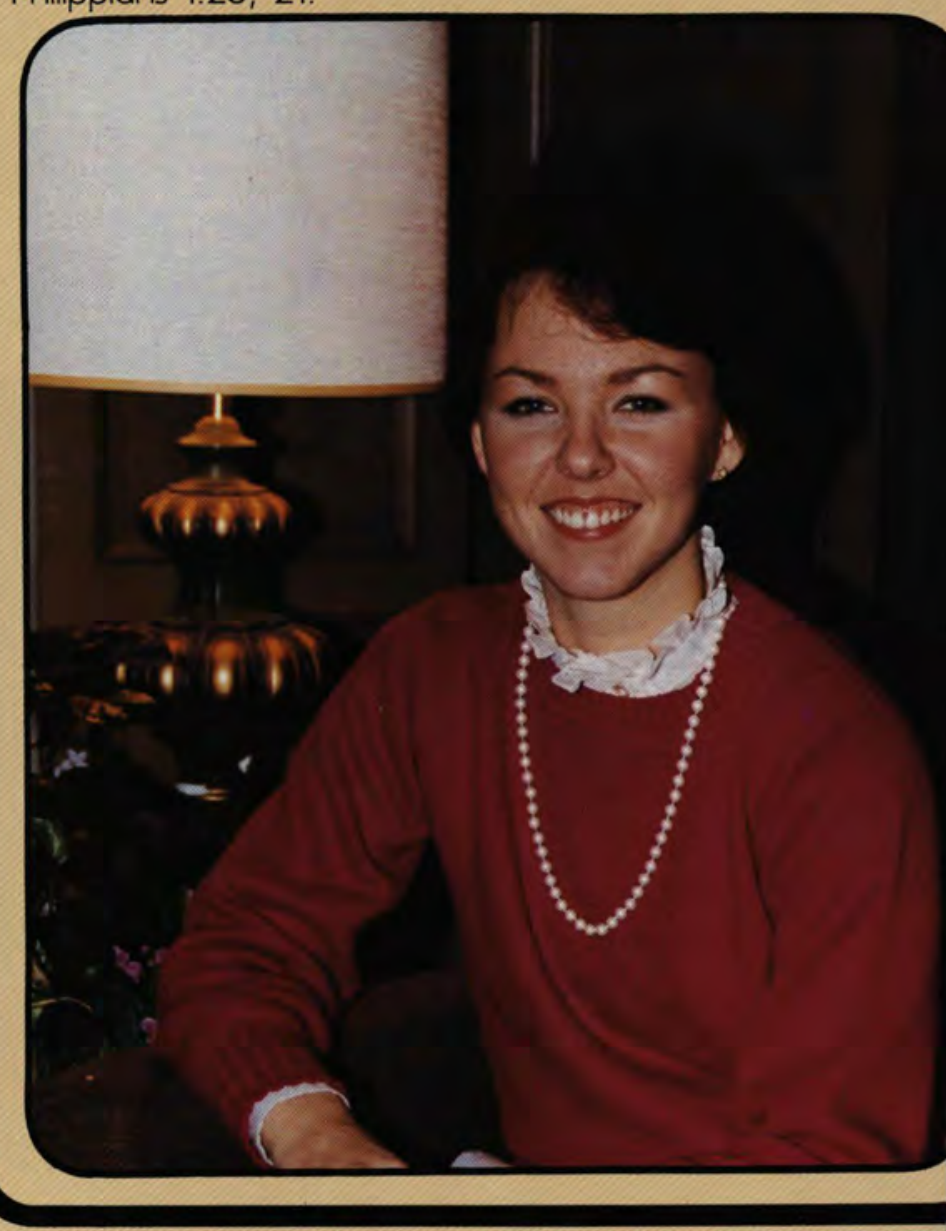

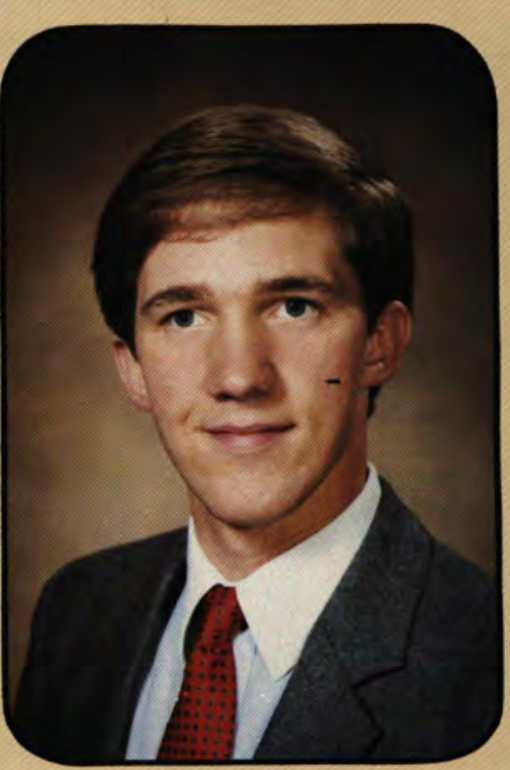

Dwight David Myfelt English

Corning, New York

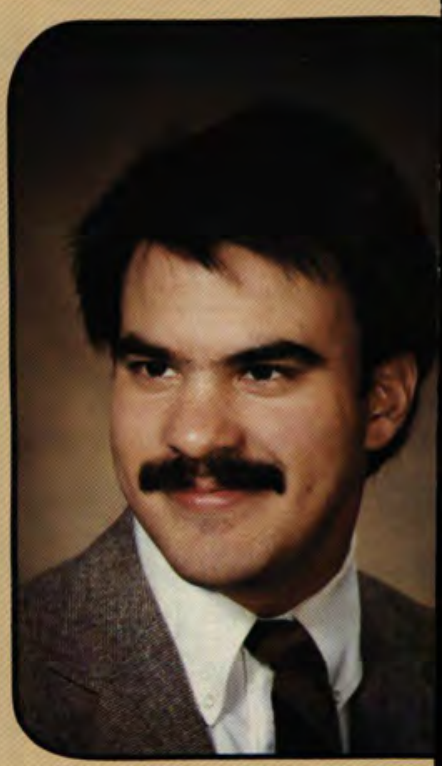

John Alan Nicholas English Godfrey, Ilinois 


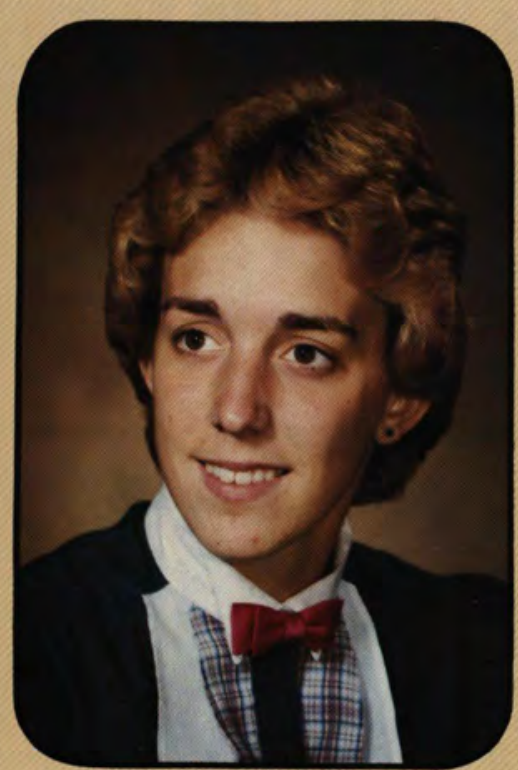

Teri L. Peterson

Physical Education

Fort Dodge, lowa

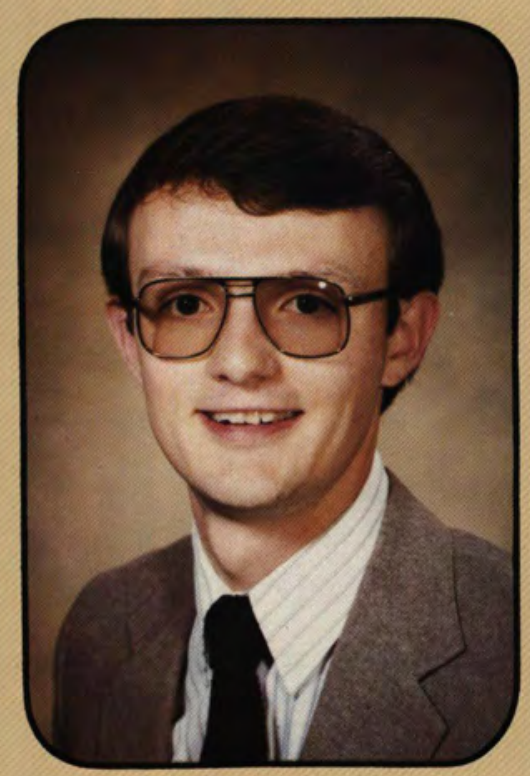

Tod L. Phillips

History/Political Sci.

Ashland, Ohio

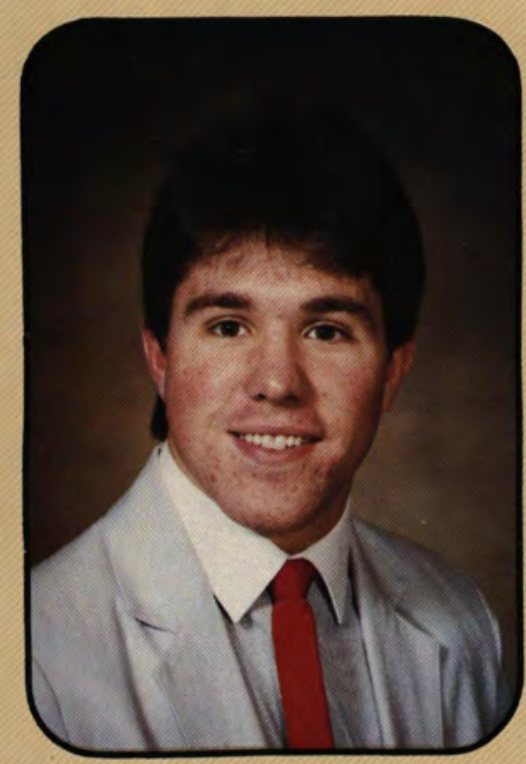

Frank H. Porter

Broadcasting

Dover, Delaware

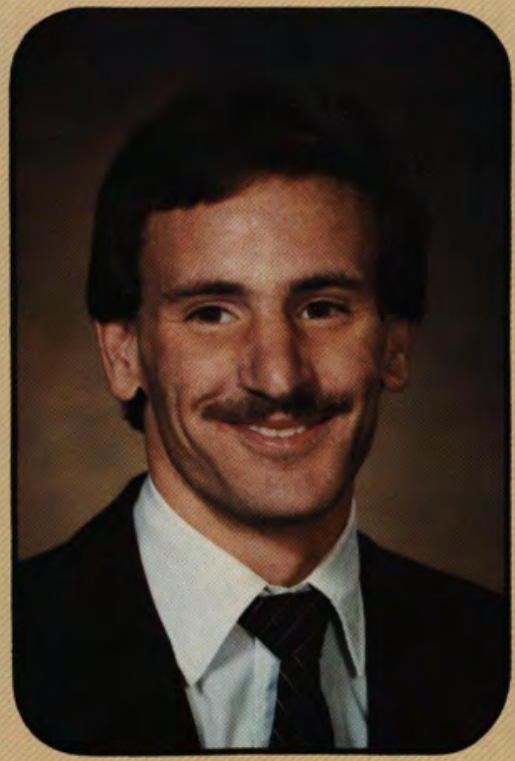

Jim M. Pfuelb

Business Administration

West Seneca, New York

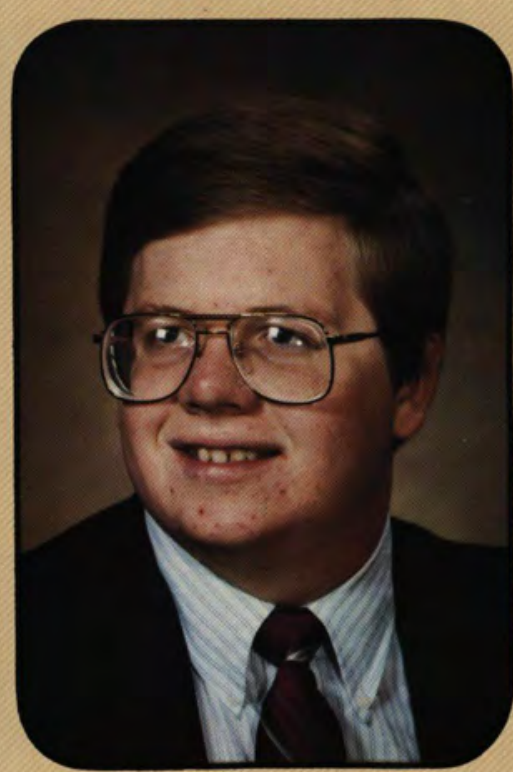

David Paul Piper

Bible/Preseminary

Kenniwick, Washington

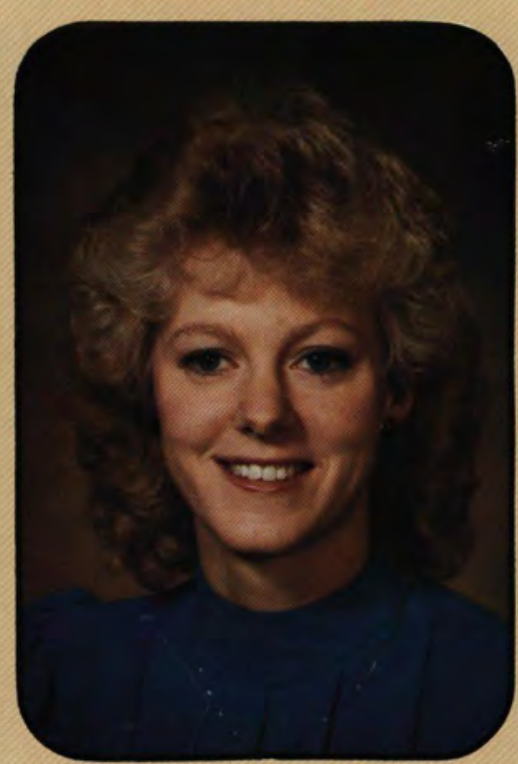

Kathryne Diane Power

Business Administration Quincy, Ilinois

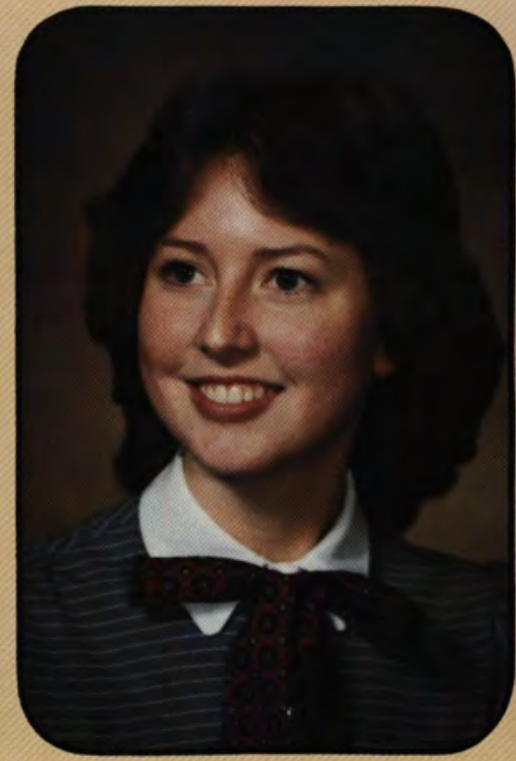

Cheryl A. Phillips

Political Science

Cinnaminson, New Jersey

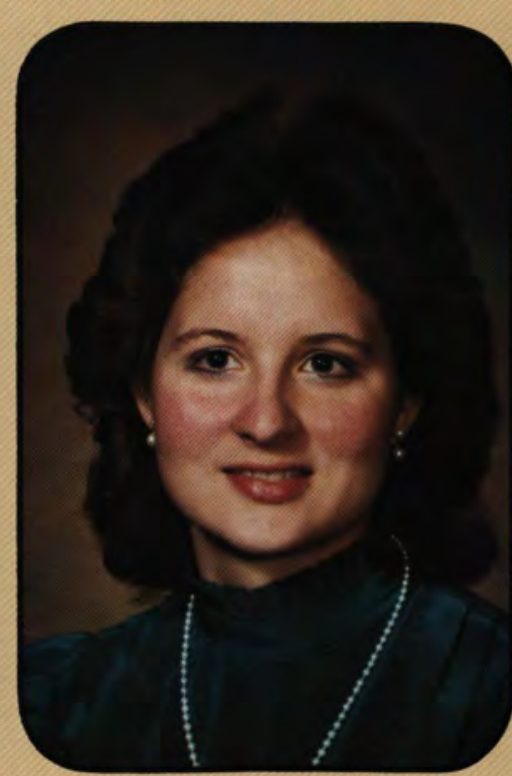

Lori JoAnne Pitonyak

Business Administration

Altoona, Pennsylvania

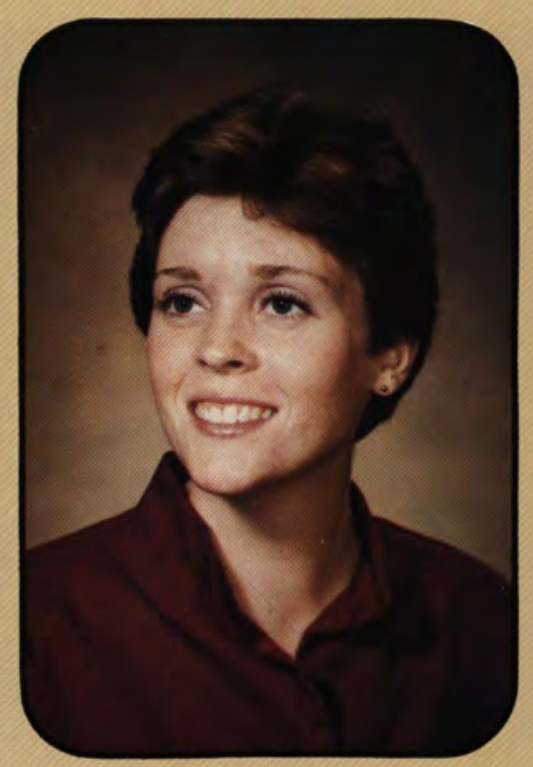

Stefanie L. Pratt

English

Indianapolis, Indiana

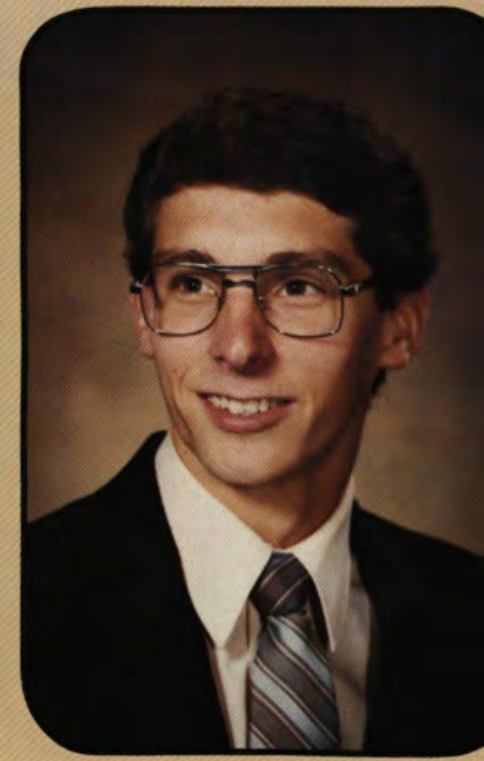

Doug Lee Phillips

Bible Comprehensive

Schaumberg, Illinois

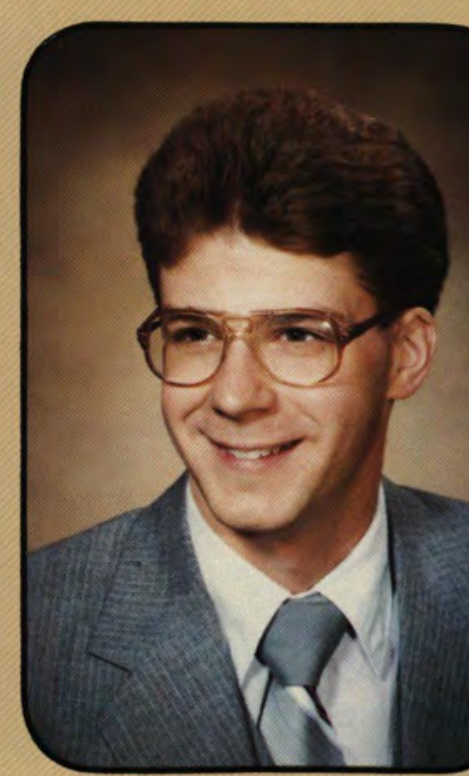

Keith Alan Plunket Bible/Preseminary

Dayton, Ohio

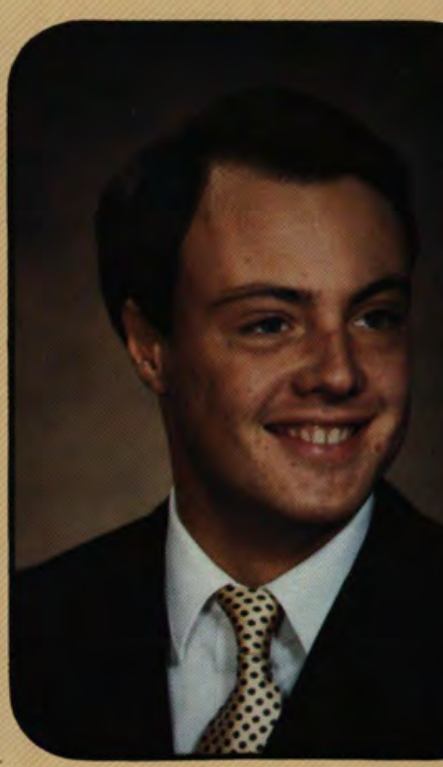

Mark W. Prevost

Business Administration Long Island, New York

\section{8 seniors}




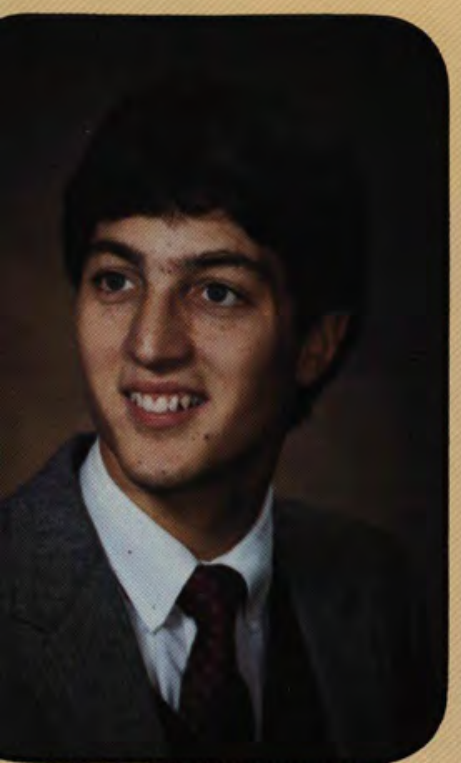

Mark A. Price

Bible/Preseminary

Hilliard, Ohio

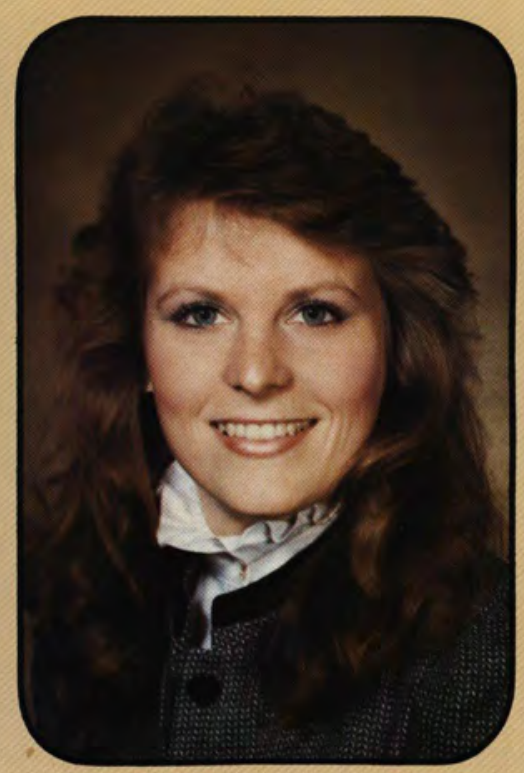

Linda K. Prichard

$$
\text { English }
$$

Chalfont, Pennsylvania

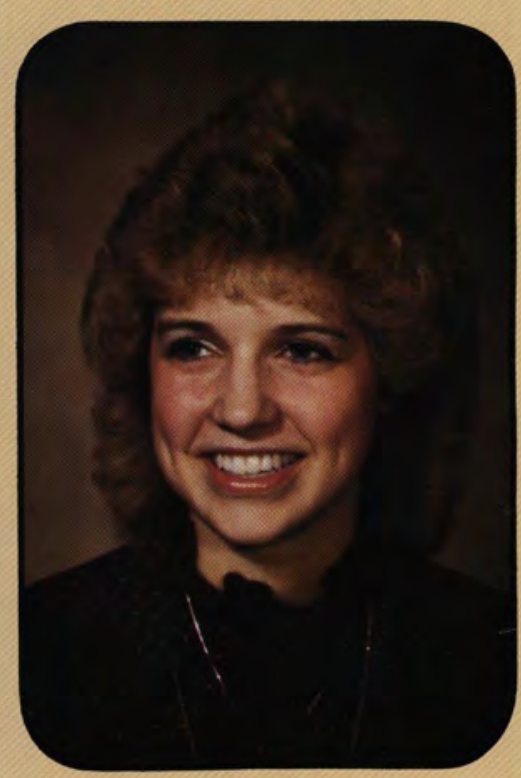

Diane L. Regnier

Elementary Education Toledo, Ohio

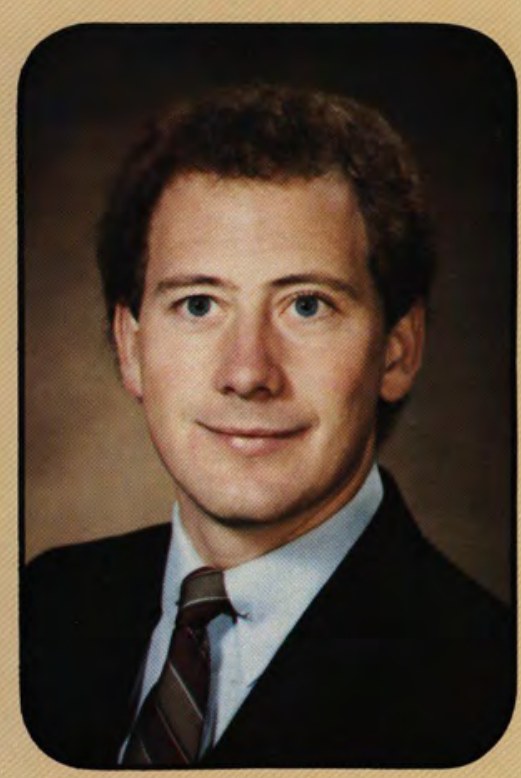

Bruce W. Richards Business Administration Lima, Ohio

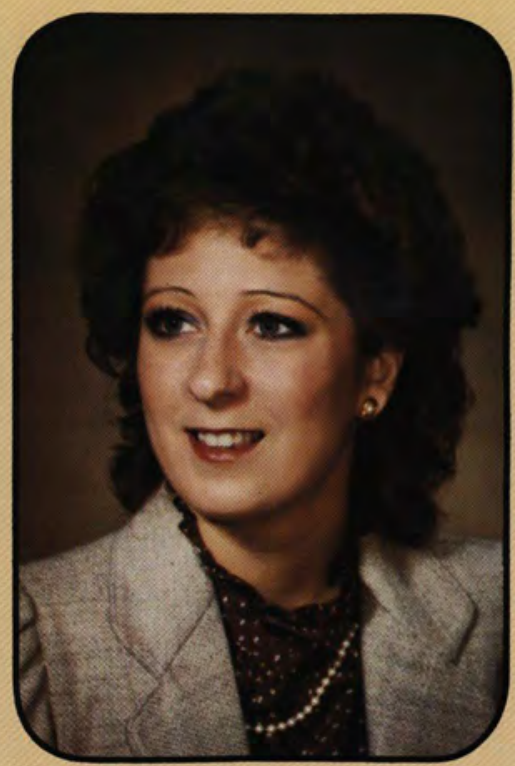

Cheryl L. Provost

Business Administration

Wisconsin Rapids, Wiscosin

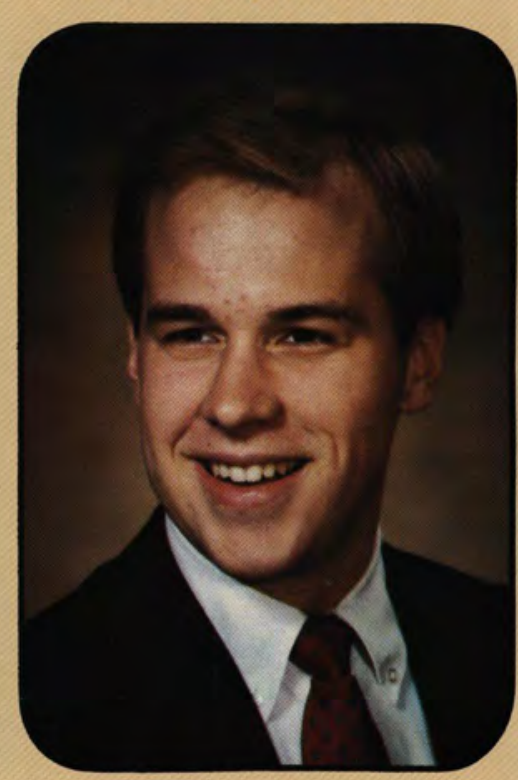

Timothy John Reiter

Accounting

Westerville, Ohio

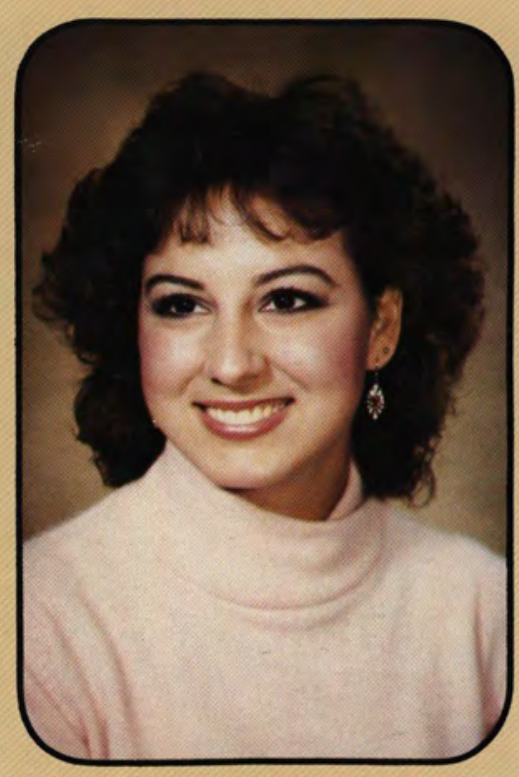

Lisa Ann Richards Speech

Indianapolis, Indiana

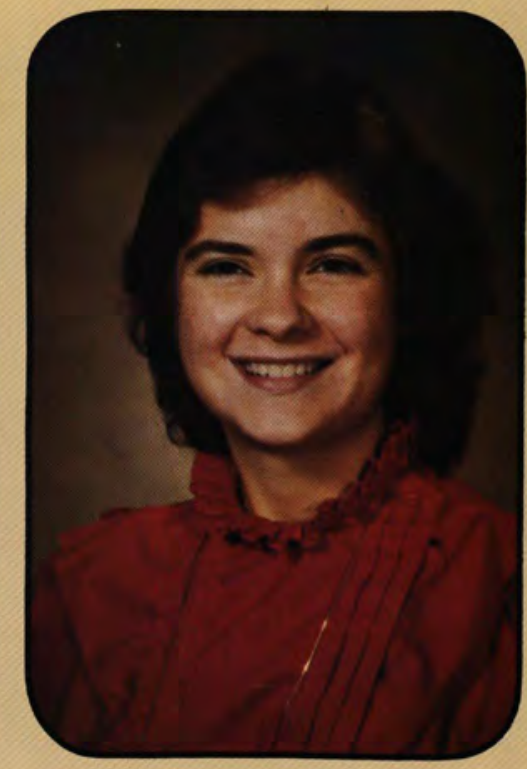

Cynthia Louise Reed

English

Newton, New Jersey

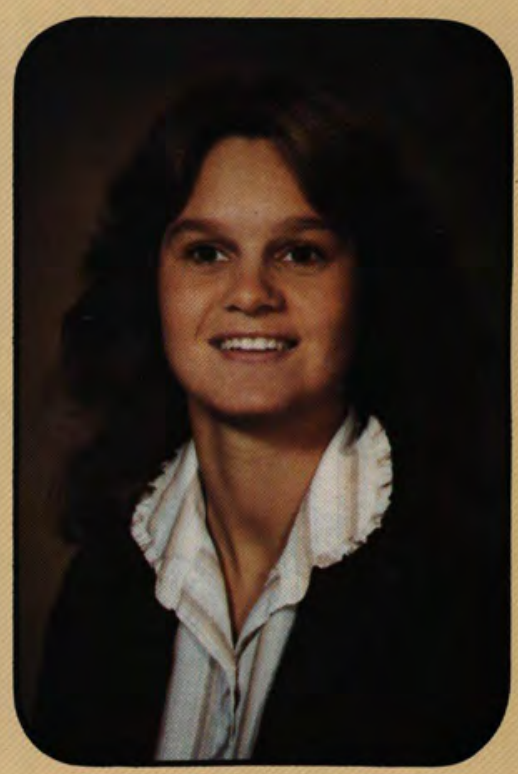

Kelly L. Reminick

Psychology

Euclid, Ohio

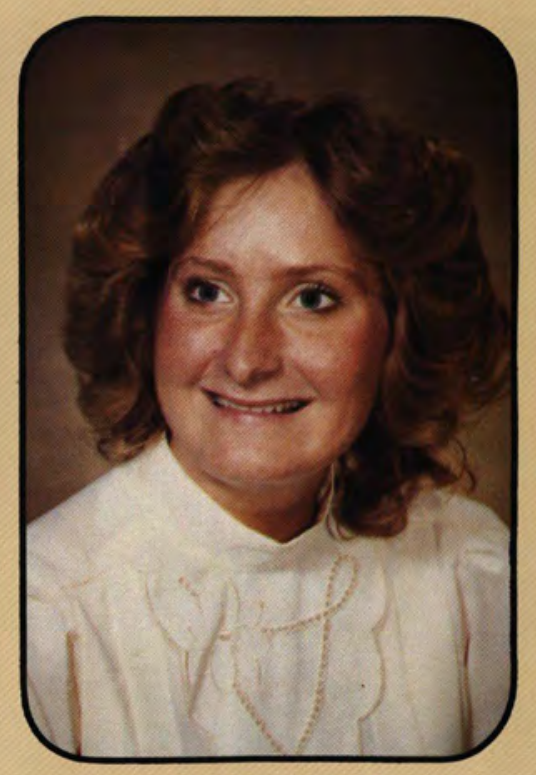

Deborah Lynn Richardson

Elementary Education

Columbus, New Jersey 


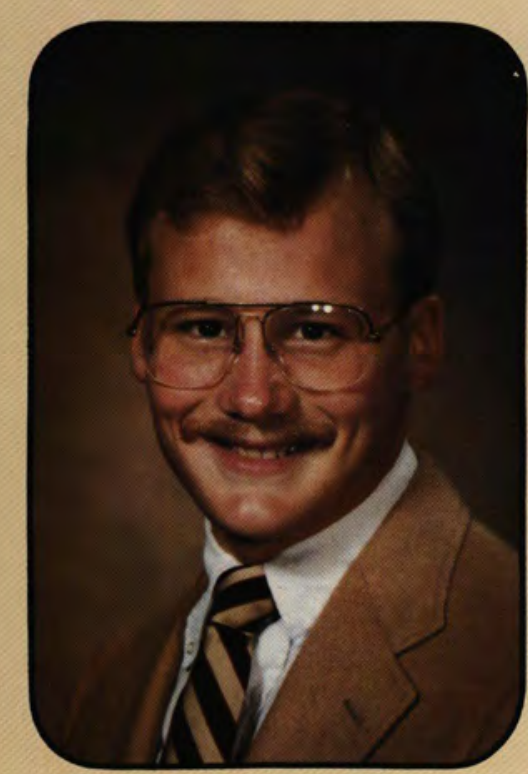

Brad M. Rickard

Bible Comprehensive Xenia, Ohio

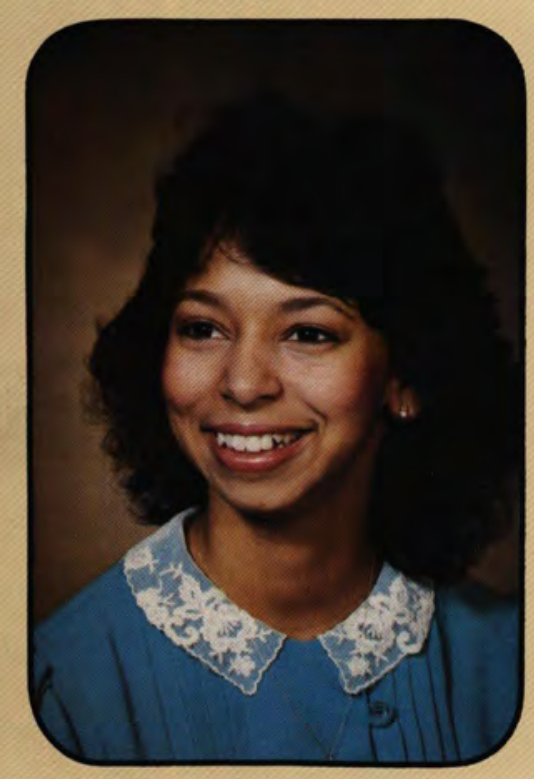

Jenny Rodriguez

Psychology

Guayrabo, Puerto Rico

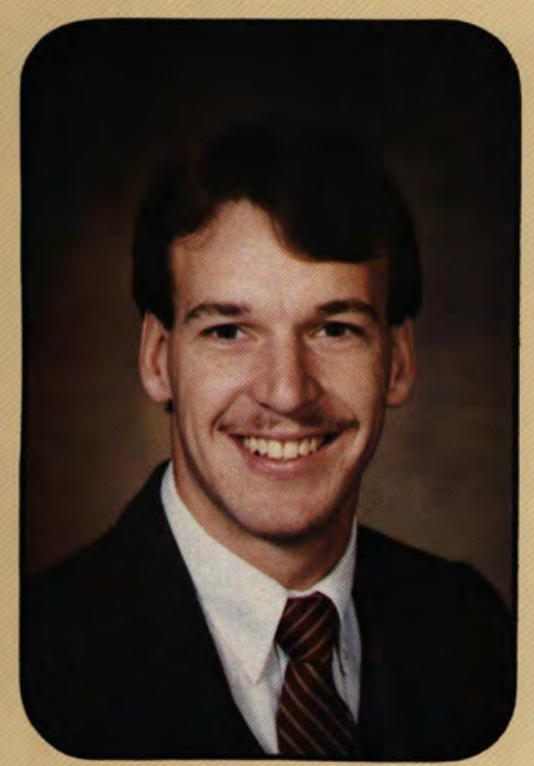

Jan Schaedel

Business Administration

Mattituck, New York

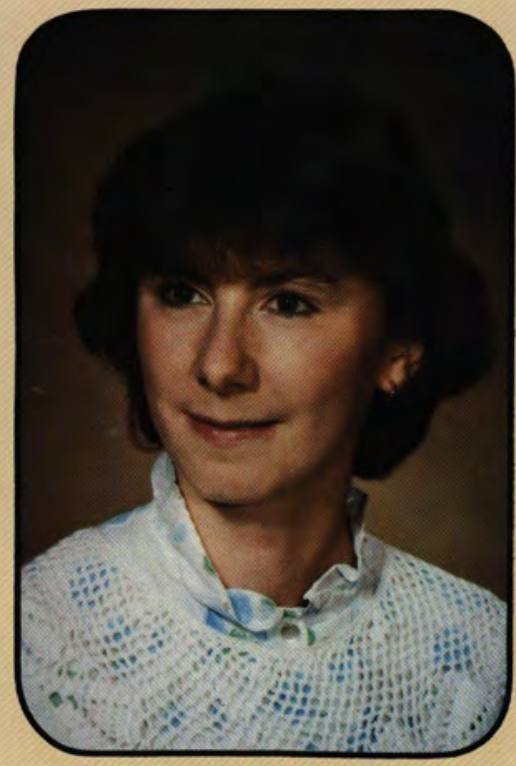

Sylvie Rinderknecht

Chemistry

Limoges, France

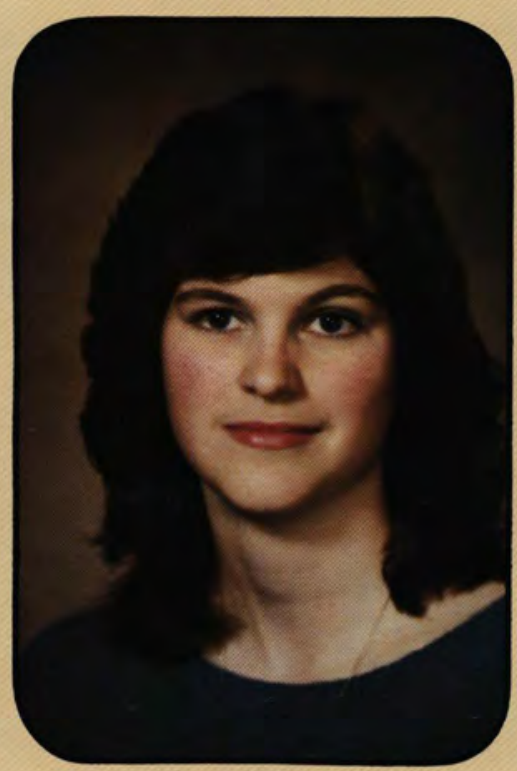

Sandra Ross

Elementary Education

Charleston, Illinois

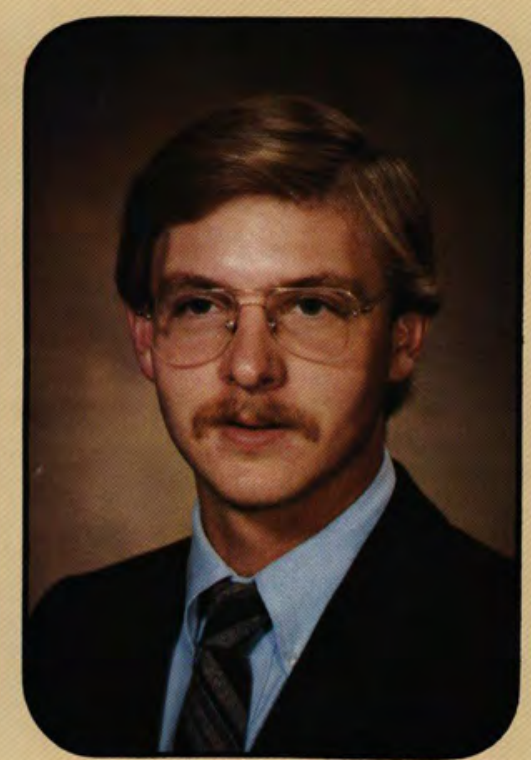

Stan A. Schultz

Business Administration Monticello, Illinois

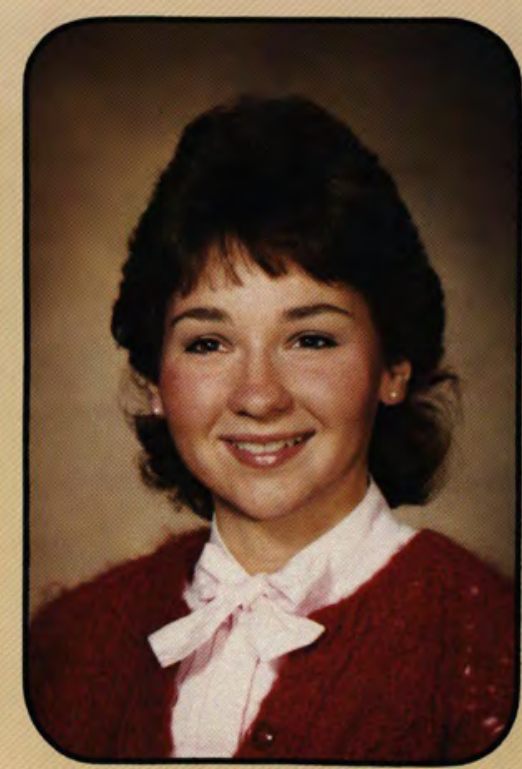

Carla L. Ritchie

Behavioral Science

Vineland, New Jersey

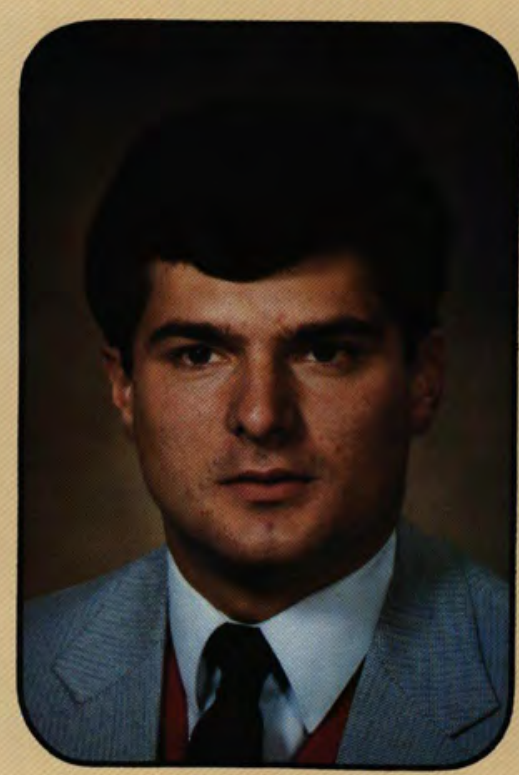

David Michael Sallee

Physical Education

Ferndale, Michigan

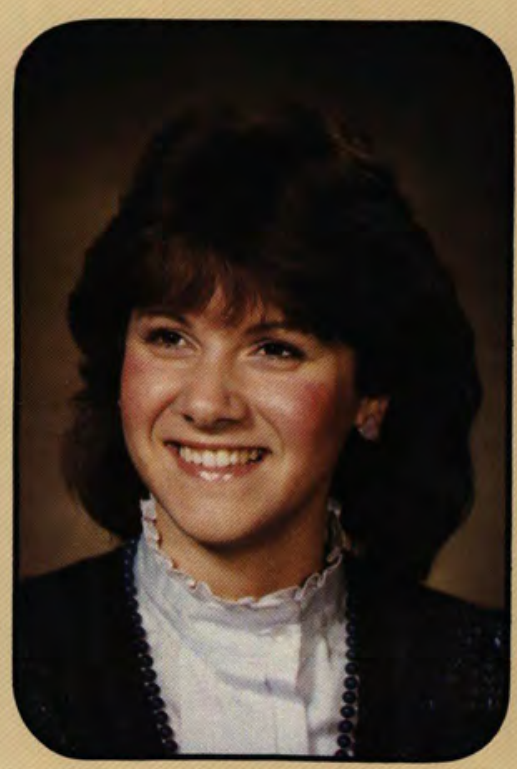

Susan Jean Scott

Church Music

Oneonta, New York

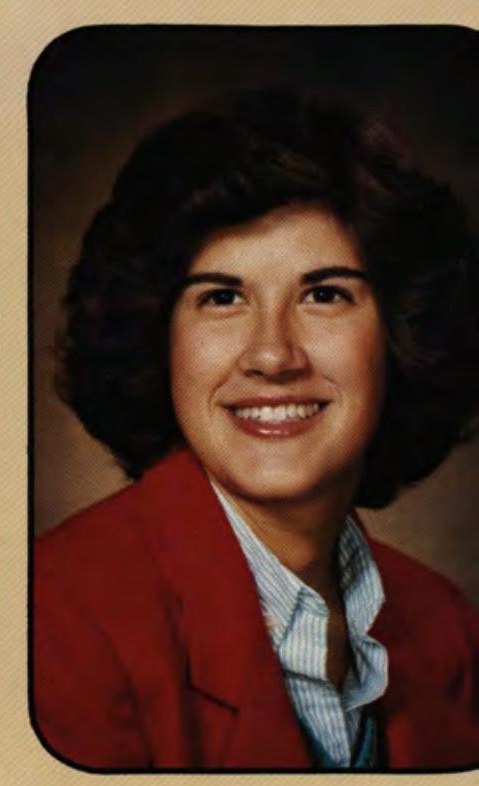

Colleen Susan Rockey Mathematics

Hoagland, Indiana

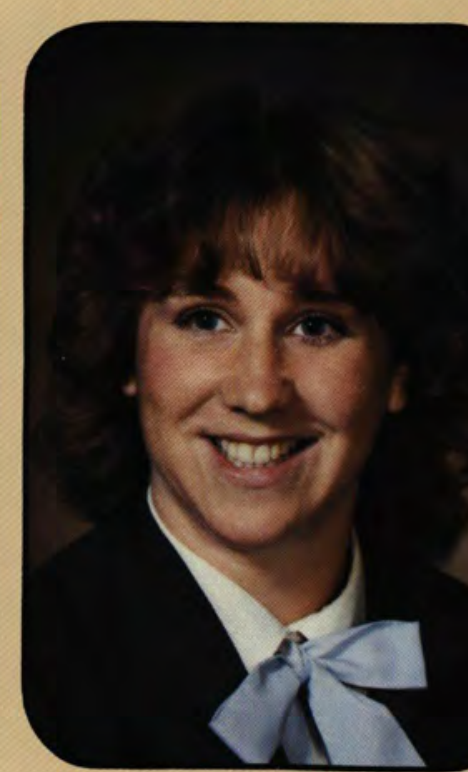

Barbara Arlyn Sanford Nursing

McLean, New York

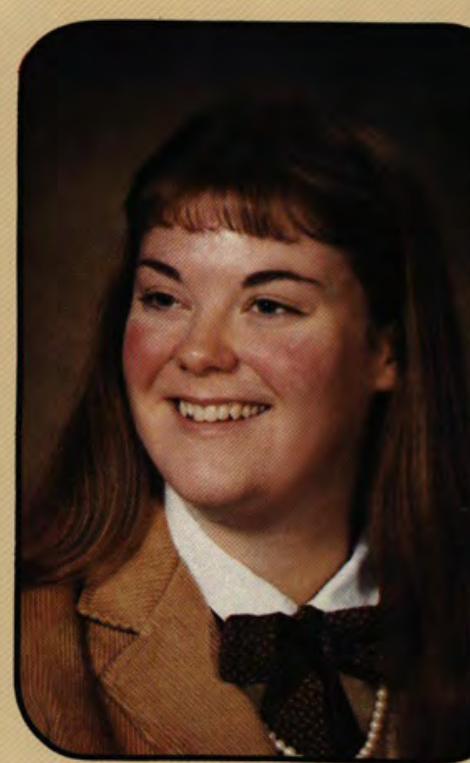

Sharon Rose Scouten Elementary Education Gallipolis, Ohio 


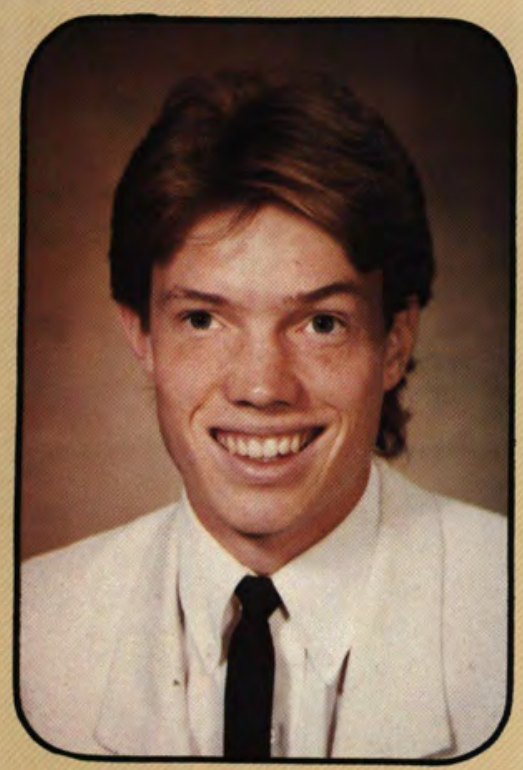

John E. Sidle

Biology/Premedicine

Tell City, Indiana

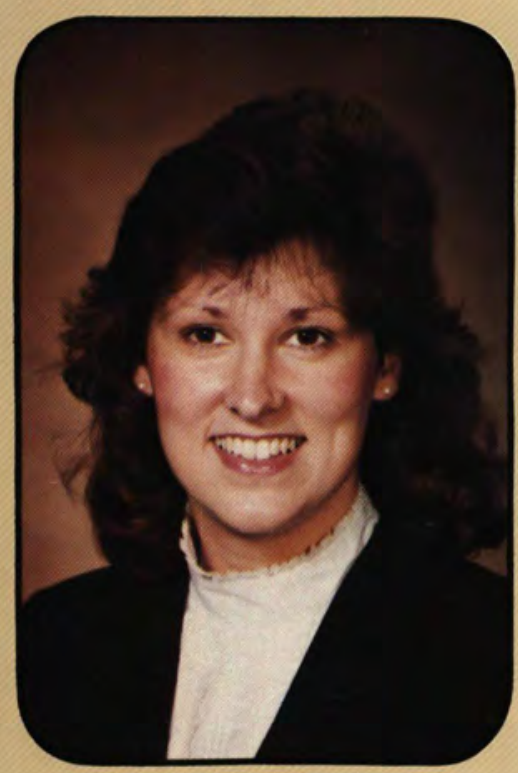

Teresa Ann Smiley Nursing

Dayton, Ohio

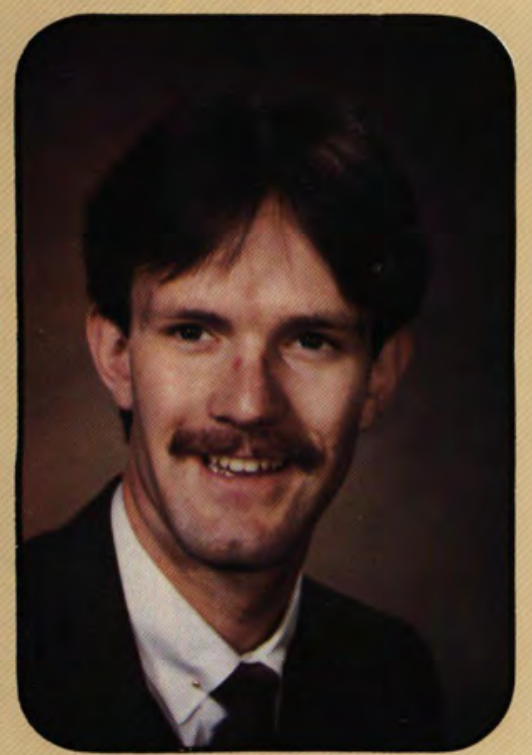

Timothy Glen Smith

Computer Info. Sys./Bus. Ad.

Poughkeepsie, New York

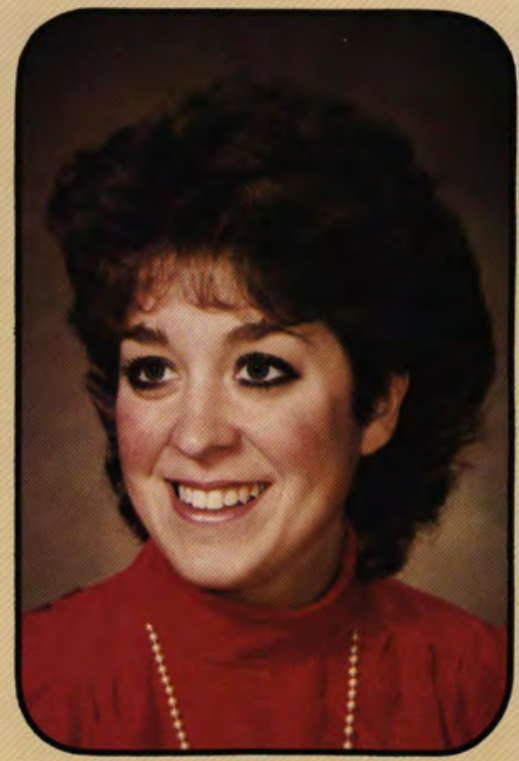

Karen Joy Simpson Business Administration

Flushing, Michigan

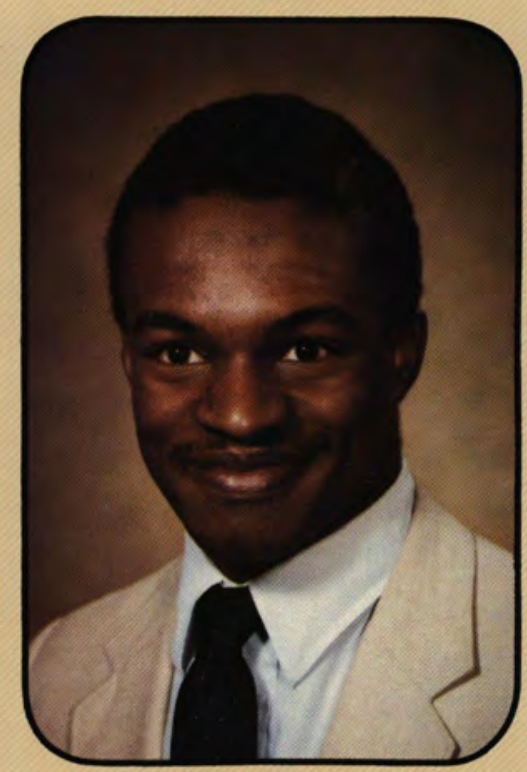

DeMaurice Fitzgerald Smith Political Sci./Philosophy Lanham, Maryland

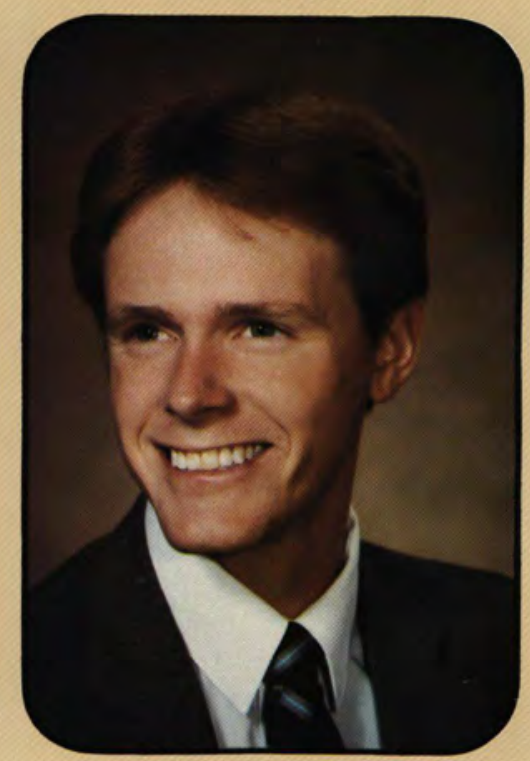

David A. Smyth

Business Administration Pleasanton, California

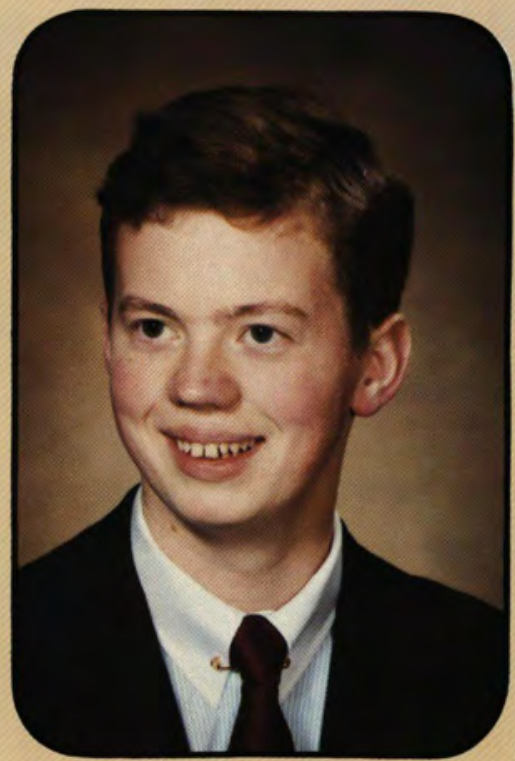

Neil O. Skjoldal

Bible/Preseminary

Catawissa, Pennsylvania

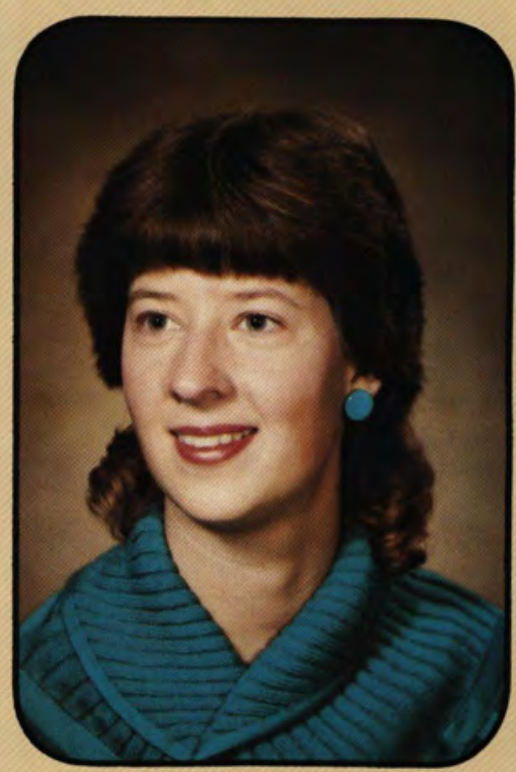

Marcia Sue Smith

Elementary Education

Indianapolis, Indiana

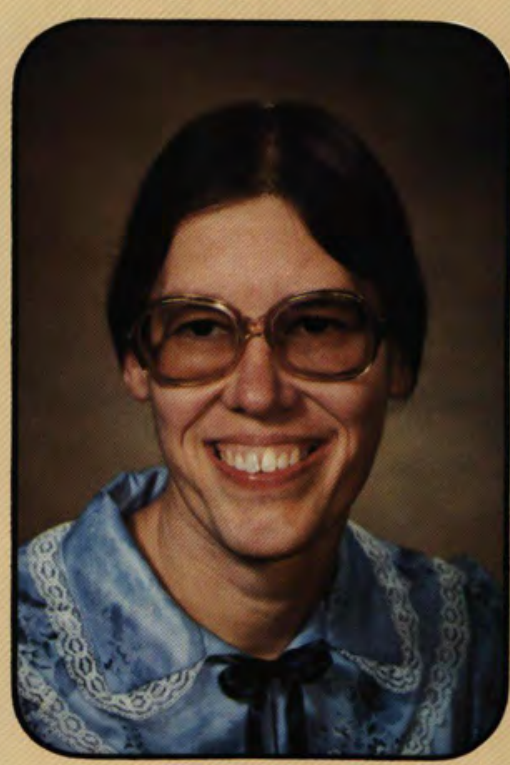

Esther M. Snader

Elementary Education

Reinholds, Pennsylvania

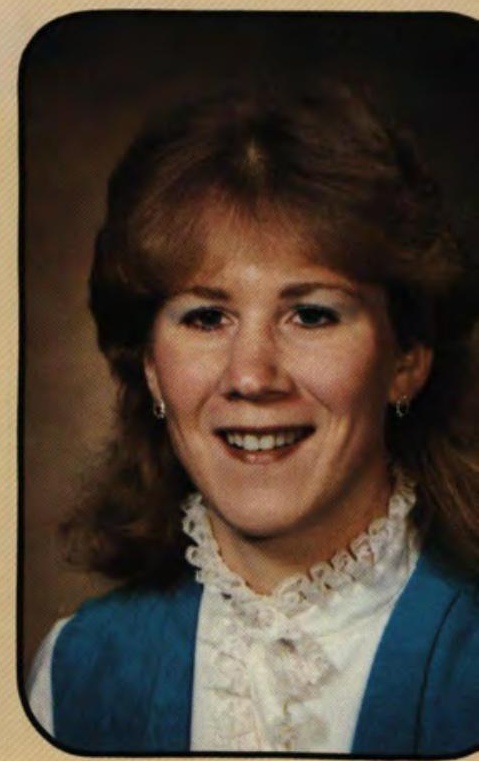

Linda Carol Smart

Physical Education

New Carlisle, Ohio

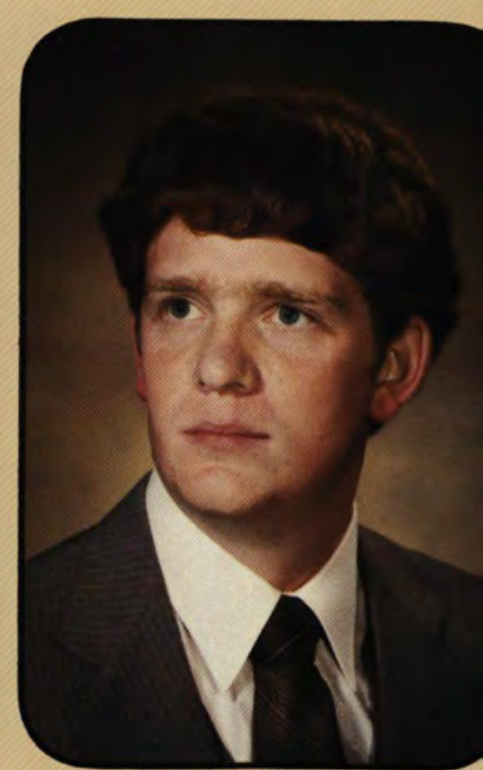

Ronald D. Smith

Business Administration Elyria, Ohia

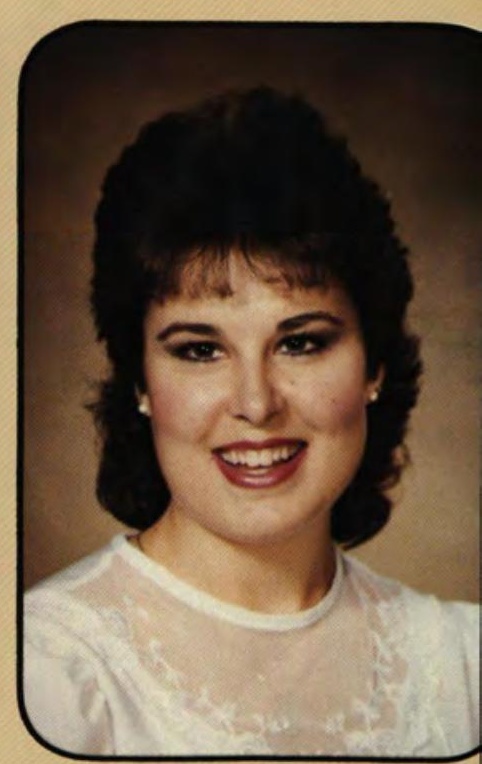

Ruth L. Snook

Business Administration Reynoldsburg, Ohio 


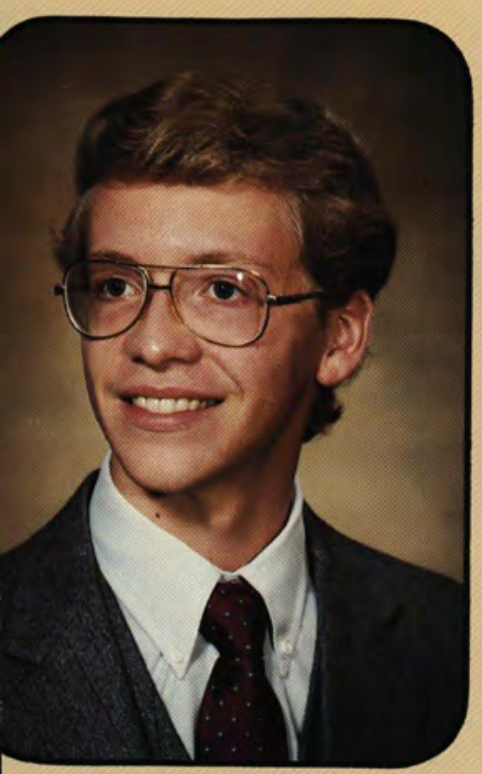

David R. Snyder

Accounting

Union Springs, New York

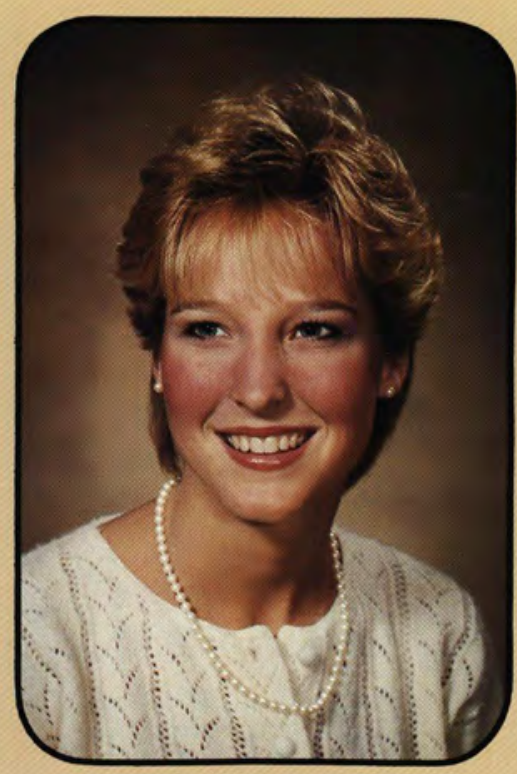

Dianna Kay Snyder

Social Science/History

Elizabethtown, Pennsylvania

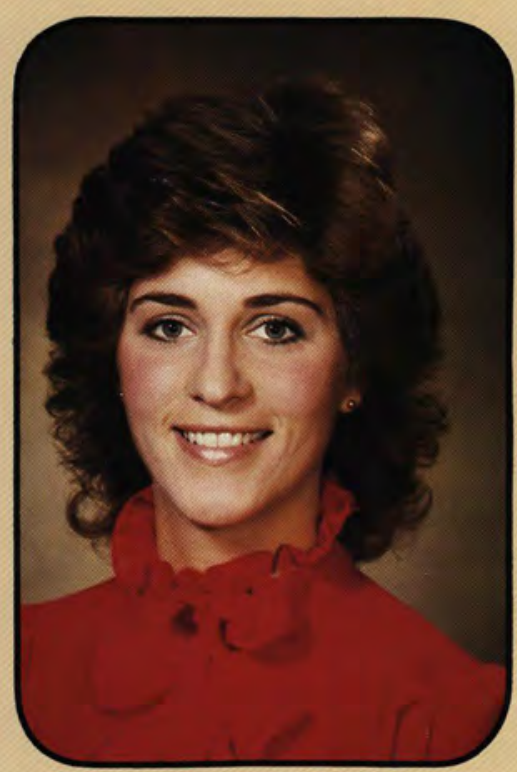

Andrea Spradlin

Secondary Education English

Wheelersburg, Ohio

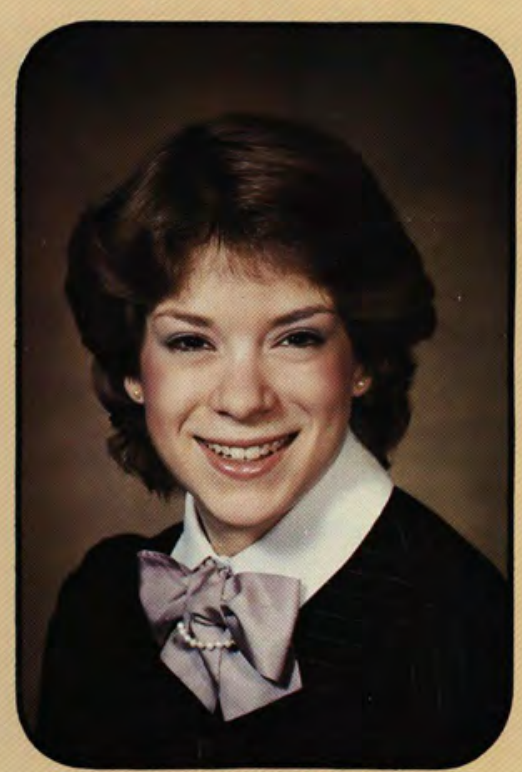

Denice Lynn Stuebe Business Administration

Naperville, Illinois

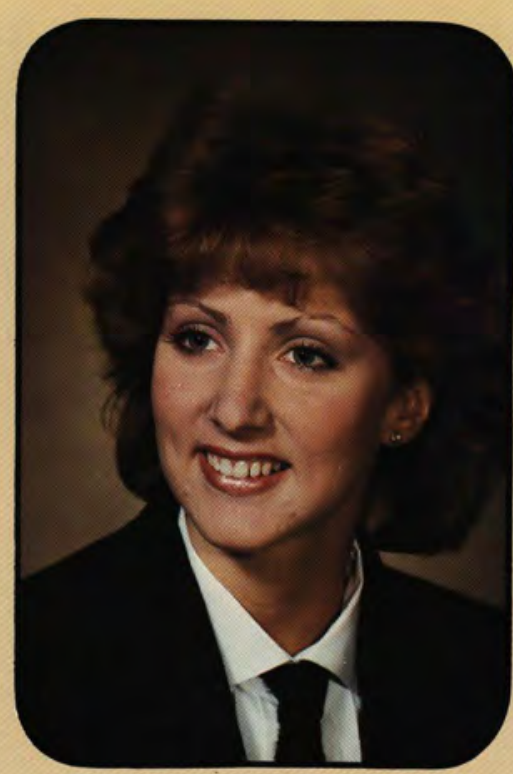

Jayne Marie Snyder

Psychology

Lansdale, Pennsylvania

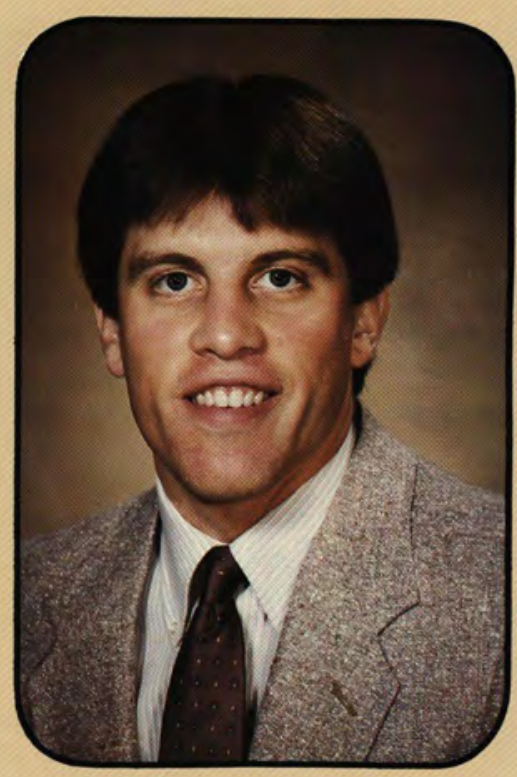

John Paul Srnis

Physical Education Amherst, Ohio

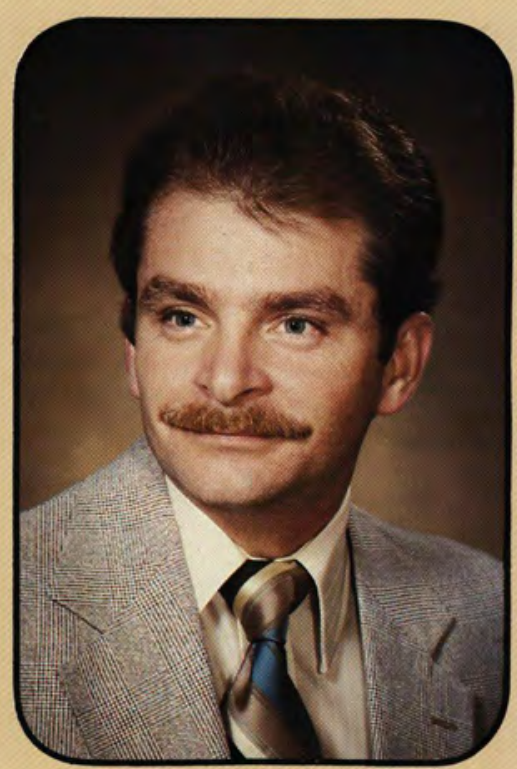

Barry Lyn Sturgis

Elementary Education

Cambridge City, Indiana

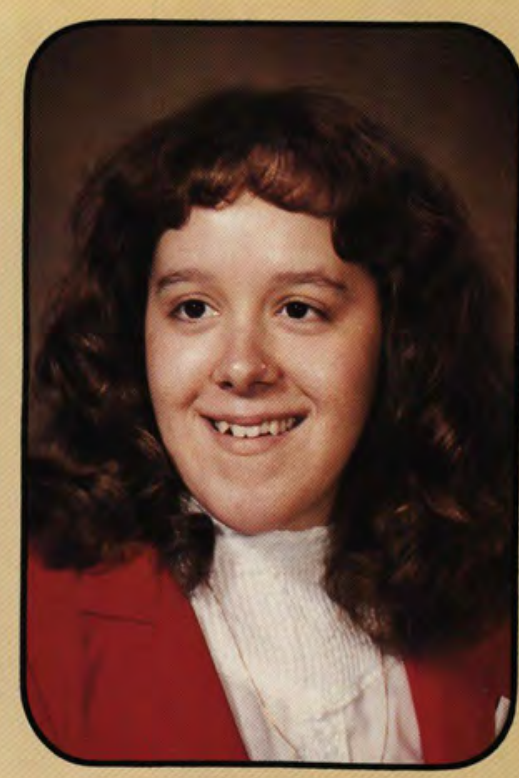

Jane Marie Sparling Bus. Ad./Secondary Ed. Bemus Point, New York

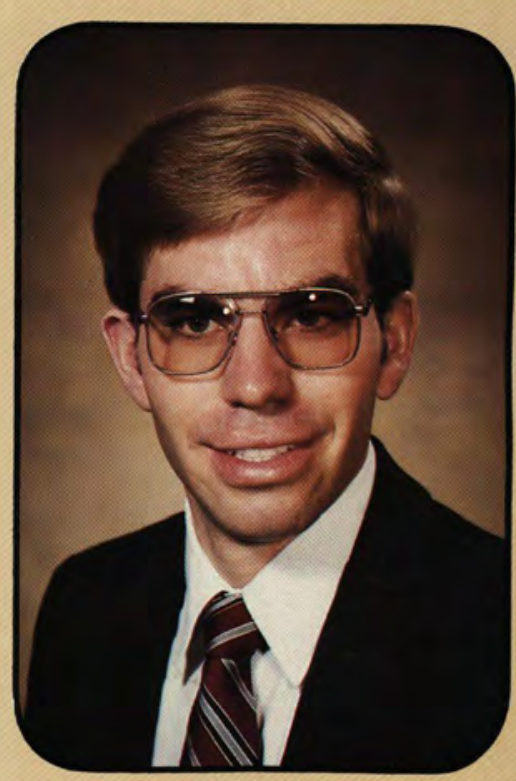

David John Steere History

Pontiac, Illinois

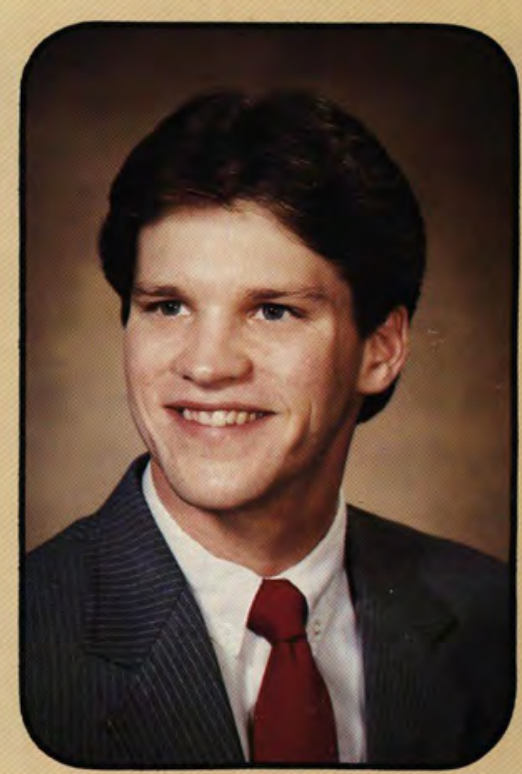

Edward Robert Supplee

Bible/Preseminary

Fremont, Michigan 


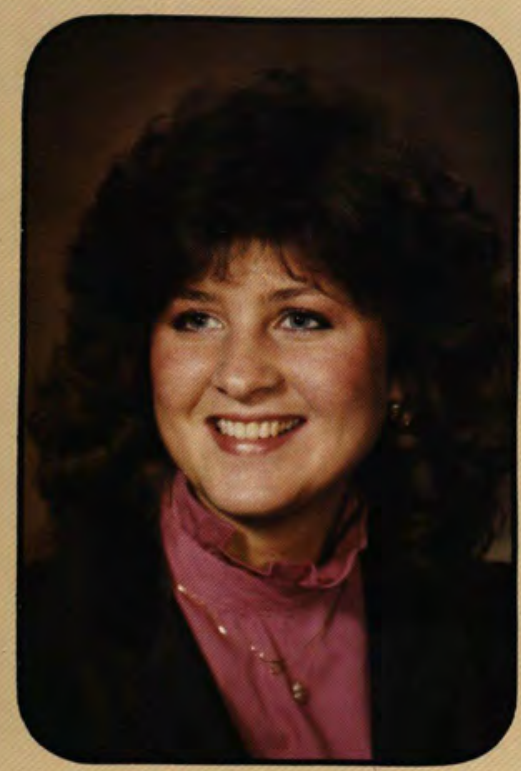

Barbra J. Taylor Speech

Medford, New Jersey

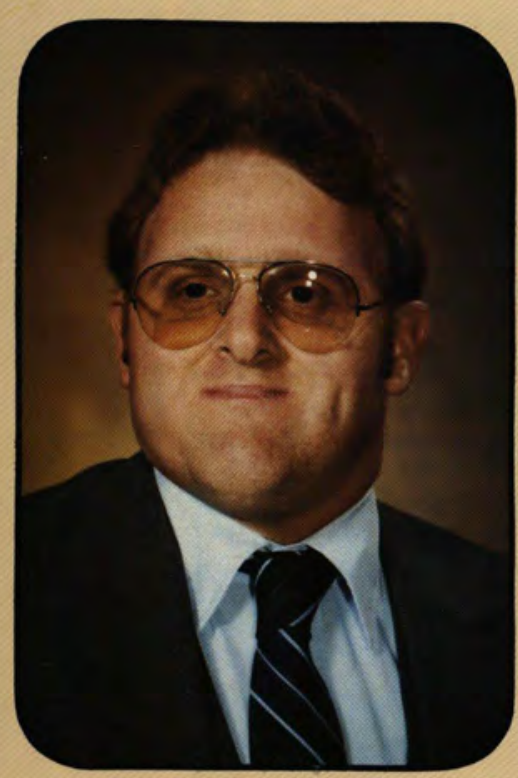

Michael Allen Thane

Business Administration Lapeer, Michigan

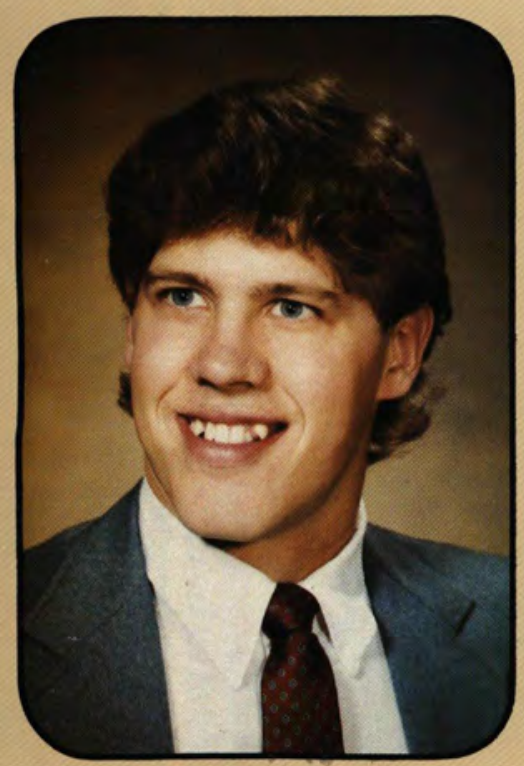

Alvin David Tucker Broadcasting

Friendsville, Pennsyluania

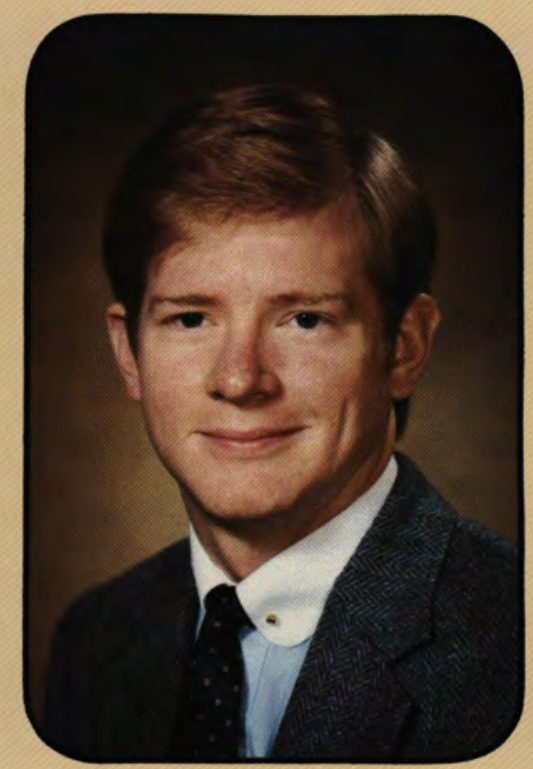

Brian Keith Taylor

Broadcasting

Kokomo, Indiana

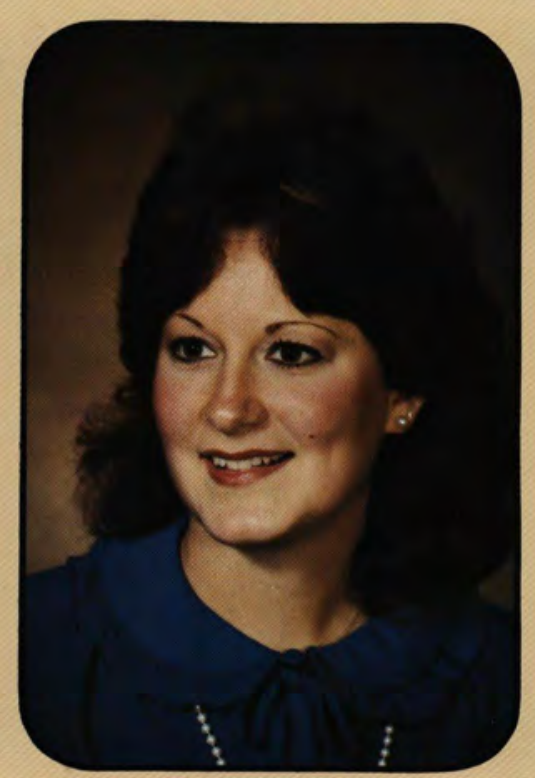

Linda Ruth Theis

Elemetnary Education

Schroon Lake, New York

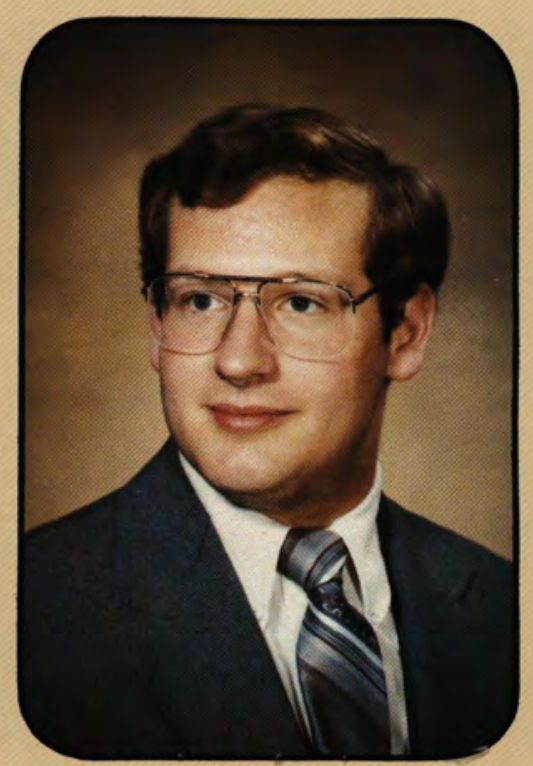

Christopher Shawn Tupps Mathematics Anderson, Indiana

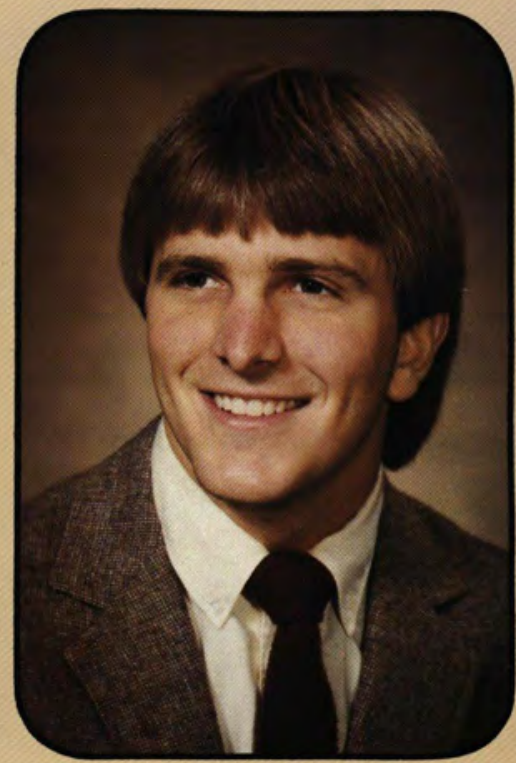

Joel Kenneth Taylor

Business Administration

Williston, North Dakota

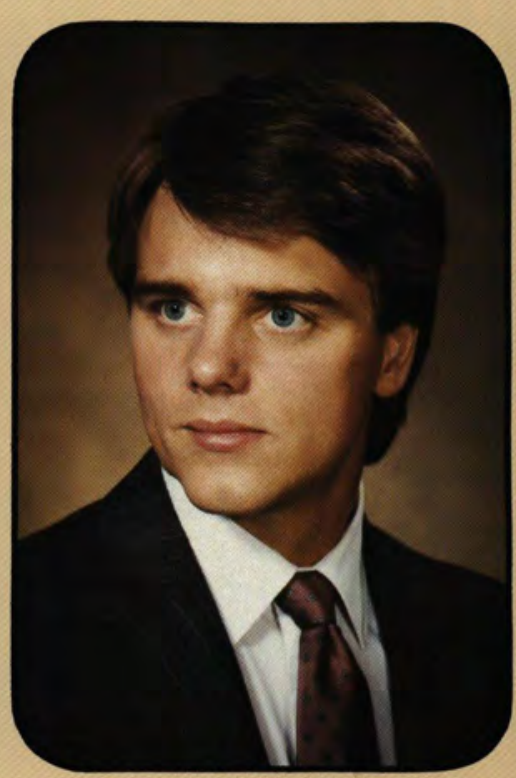

Kevin J. Todd

English

Plainview, Minnesota

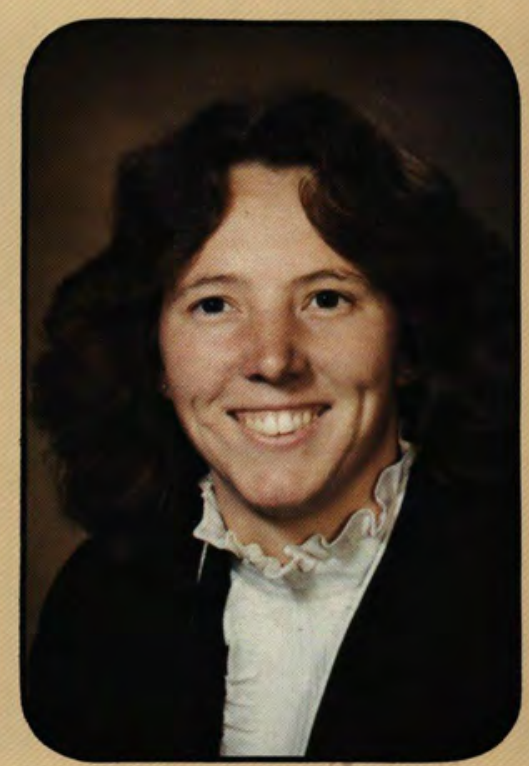

Tracy Lee Turner Physical Education Enfield, Connecticut

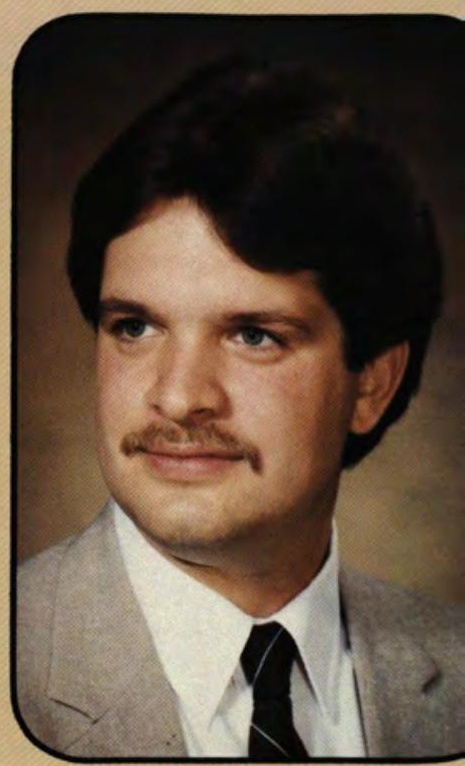

Brent Daniel Thane

Business Administration Cedarville, Ohio

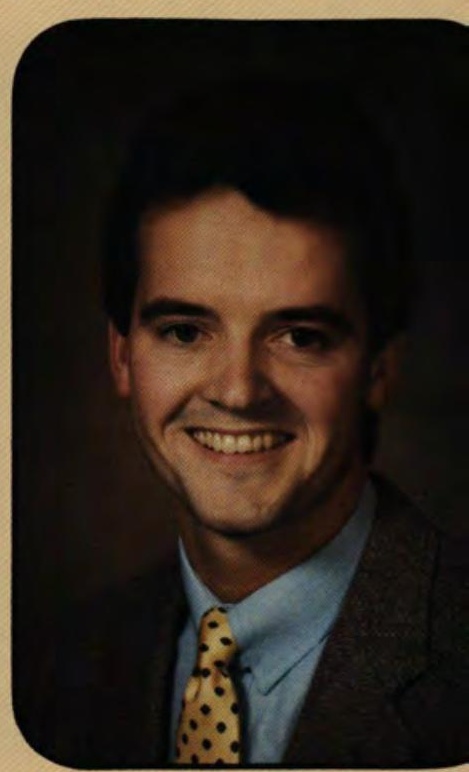

Theodore D. Towne

Business Administration

Northampton, Massachusettes

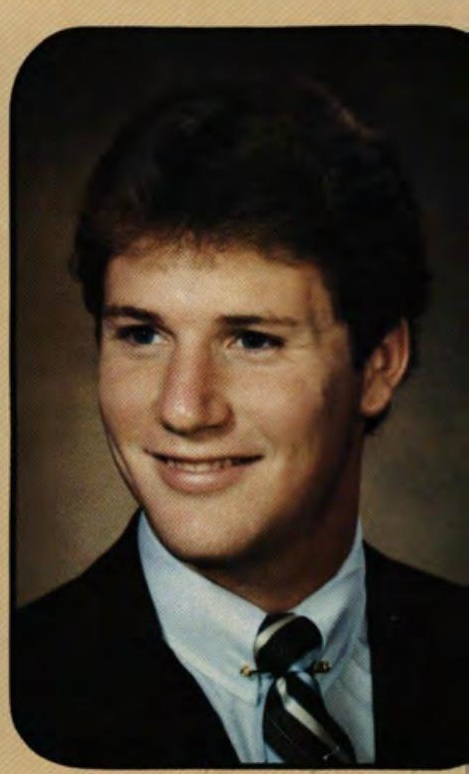

Jeffrey $T$. Ulmer Business Administration Seymour, Indiana 


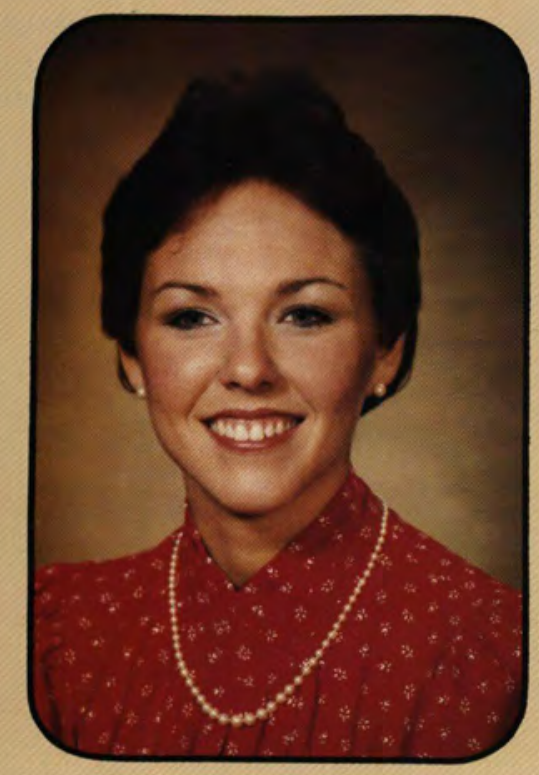

Kristina J. Whittaker English Education Corning, New York

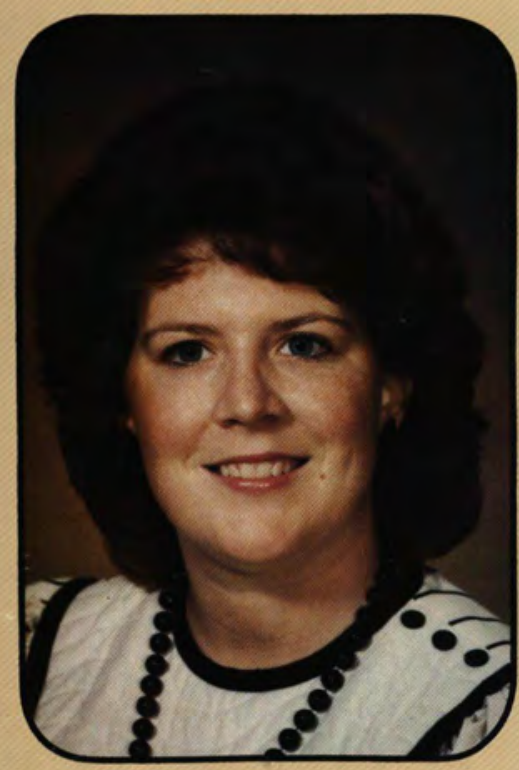

Teresa Kay Williams Elementary Education Charleston, West Virginia

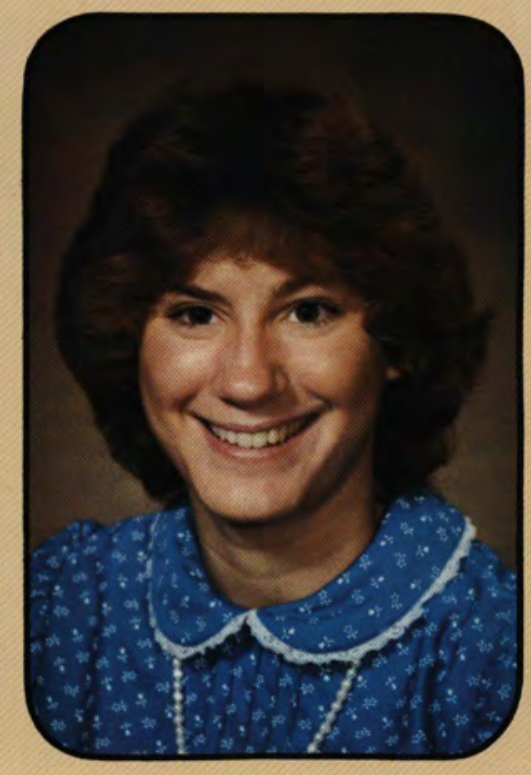

Carin Lynn Wilcox

Bible Comprehensive Elkhart, Indiana

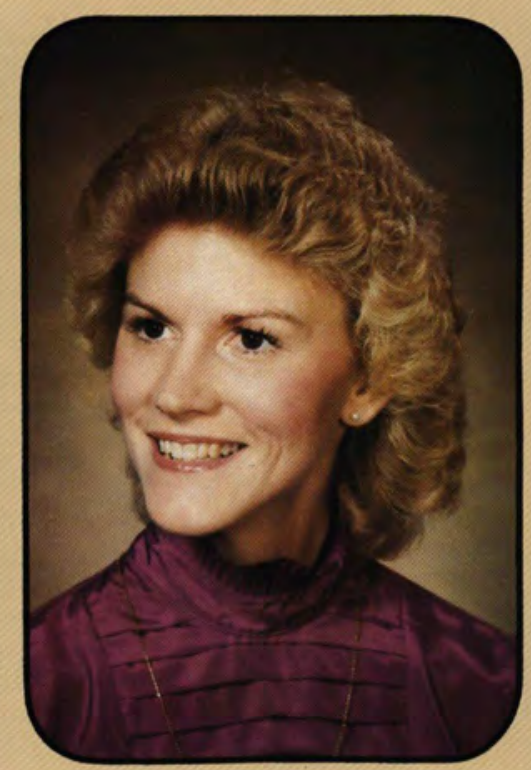

\section{Jill Denise Winkleman \\ Business Administration Buffalo Center, Iowa}

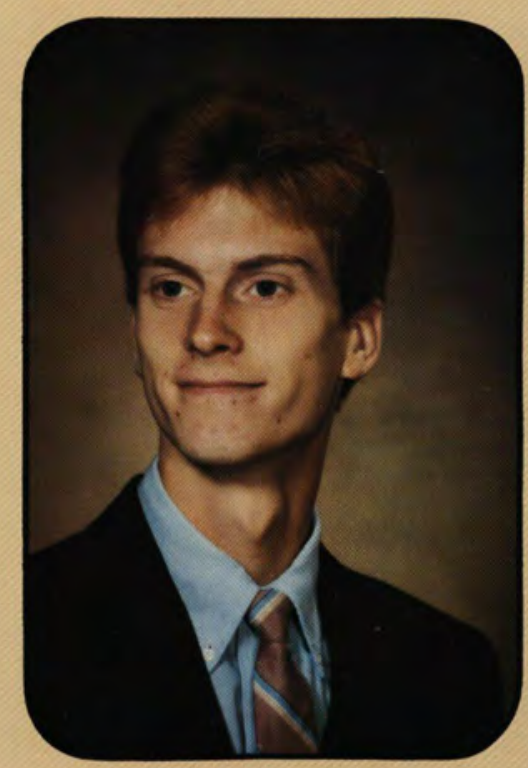

Ralph William Wyand, II Mathematics

Hagerstown, Maryland

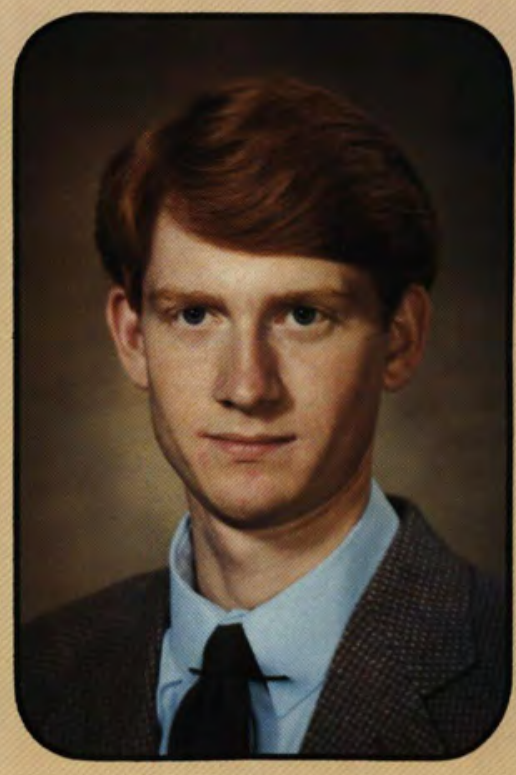

Kris Drew Wilcox

Accounting

Elyria, Ohio

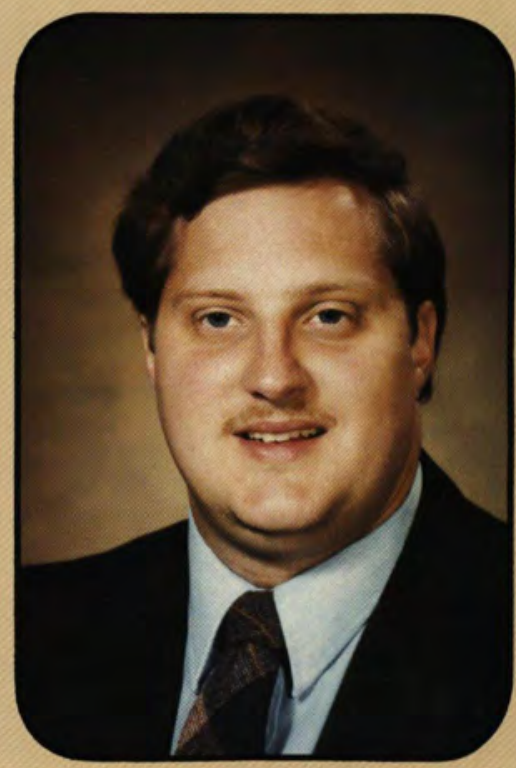

Bryan R. Wolfli

Music/English Education Cedarville, Ohio

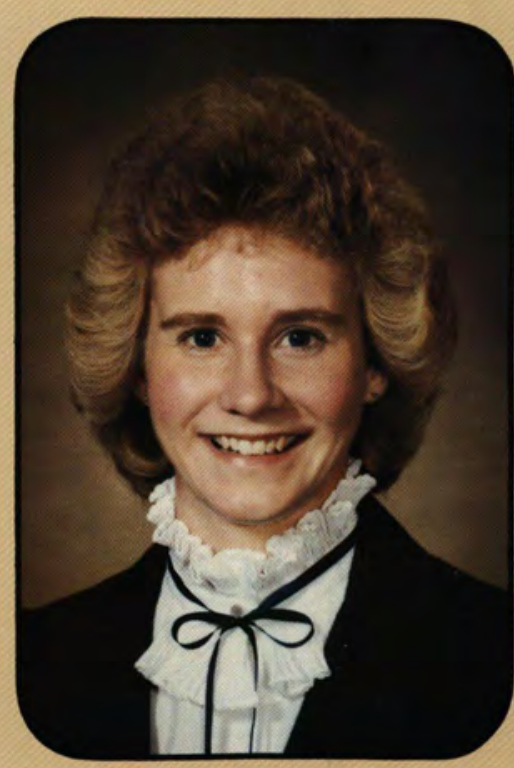

Marcia Kay Yoder Nursing

Louisville, Ohio

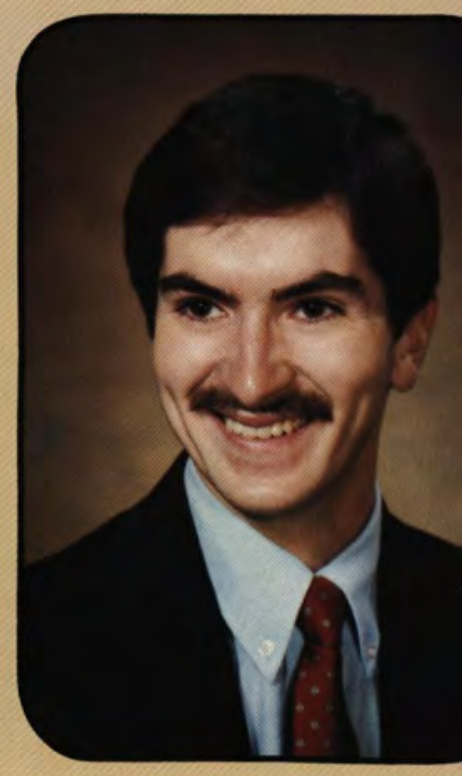

David M. Williams

Business Administration Cleveland Heights, Ohio

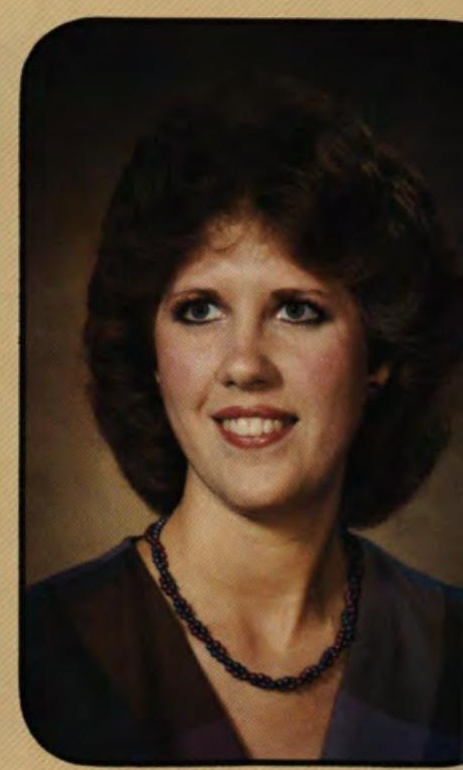

Ruth Ann Wuthnow Nursing Hope, Kansas

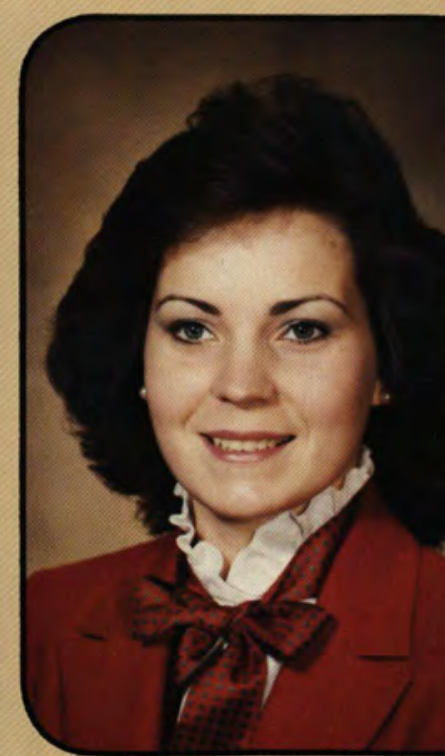

Lynne E. Zielke Business Administration Williamstown, New Jersey 


\section{SENIOR CLASS OFFICERS}

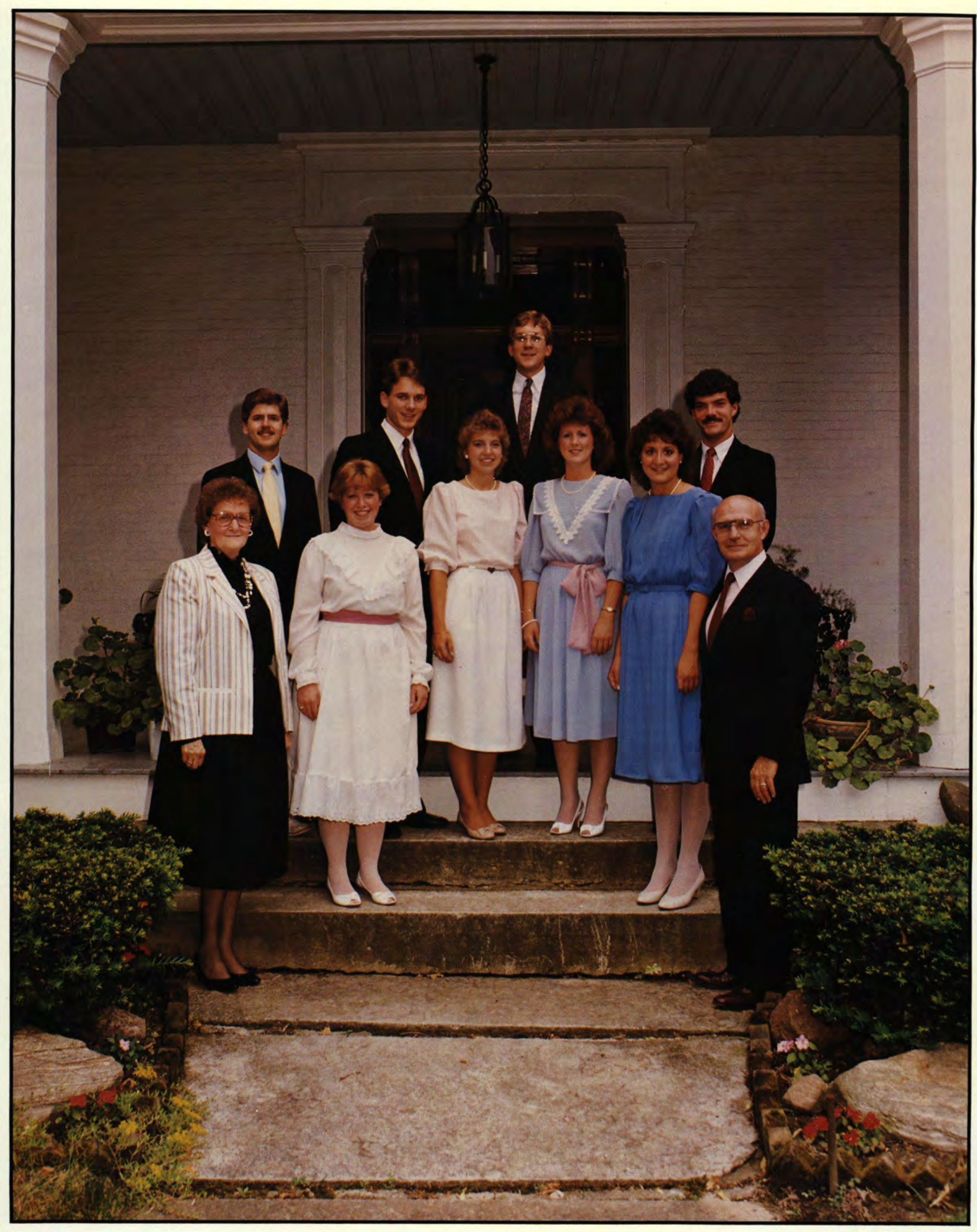

David Shulse

Chaplain
Keirh Holr

President
Woyne Keisling Treosurer
Neil Sergeant

Srudent Senare Rep. 

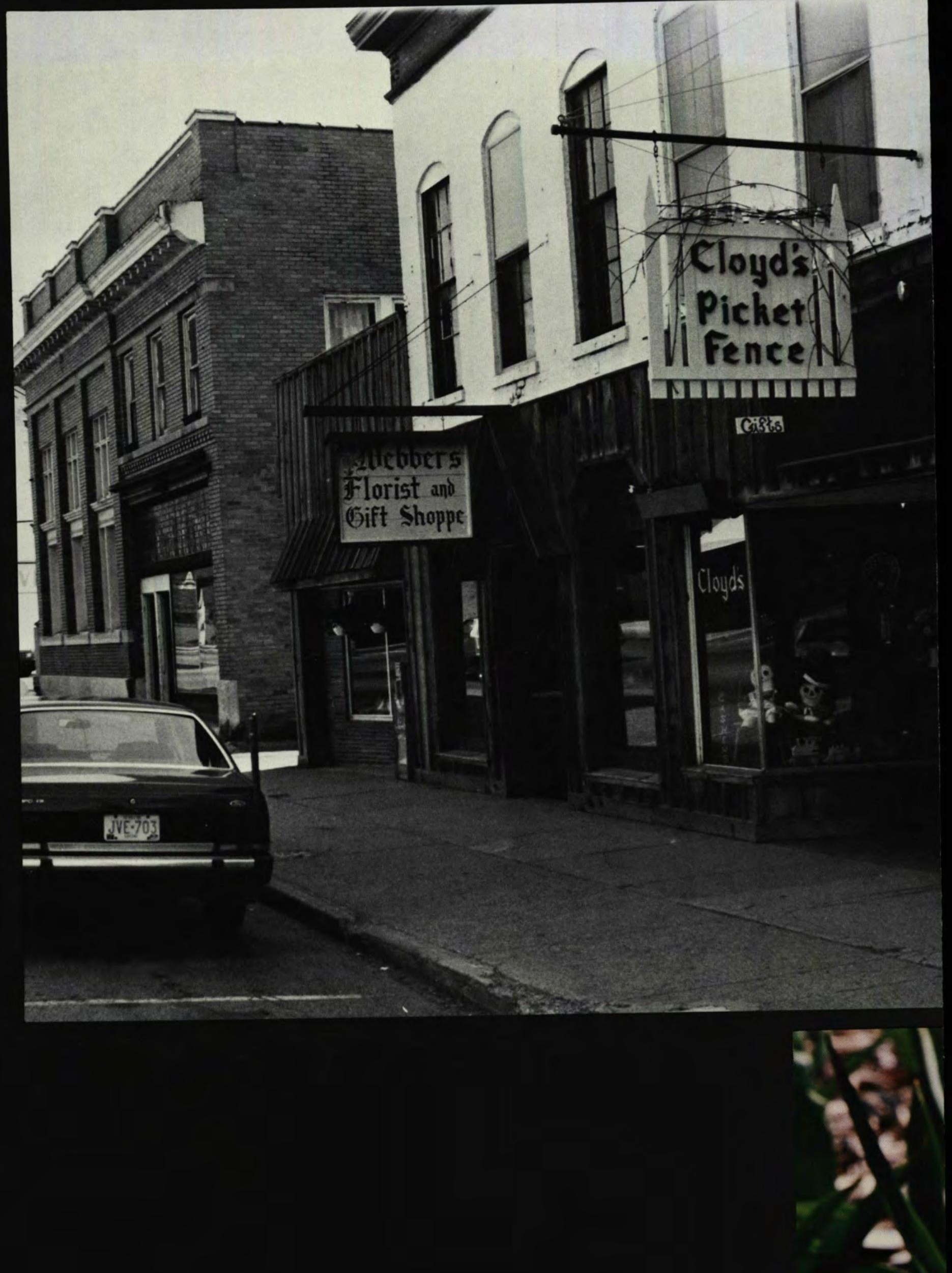


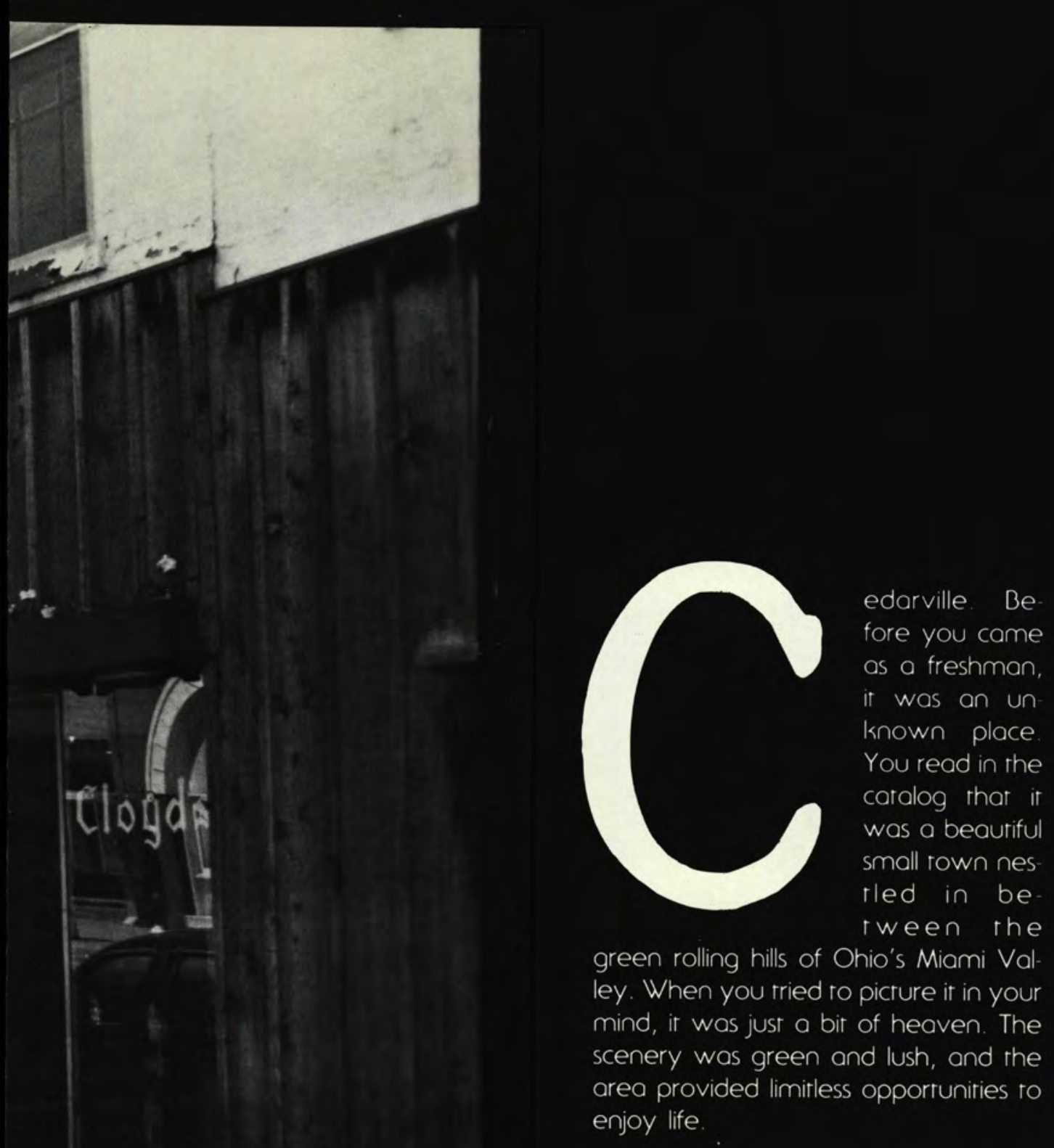




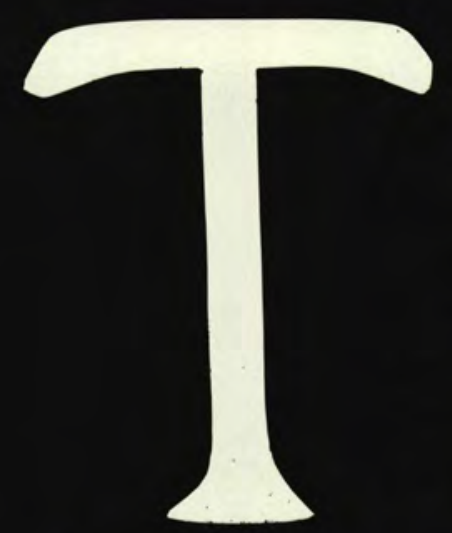

he day you

arrived, however,

was wer

and cold.

The grey

sky was

spitting

drops of

rain on the

windshield

as you

drove past brown cornfields and broken-down barns. This is Cedarville? Where is all the beautiful scenery? You were a little disappointed, a little shocked. It was different than you had imagined. Maybe you had come from the rocky shores of Maine or the majestic mountains of Colorado. You had never seen countryside like this before.
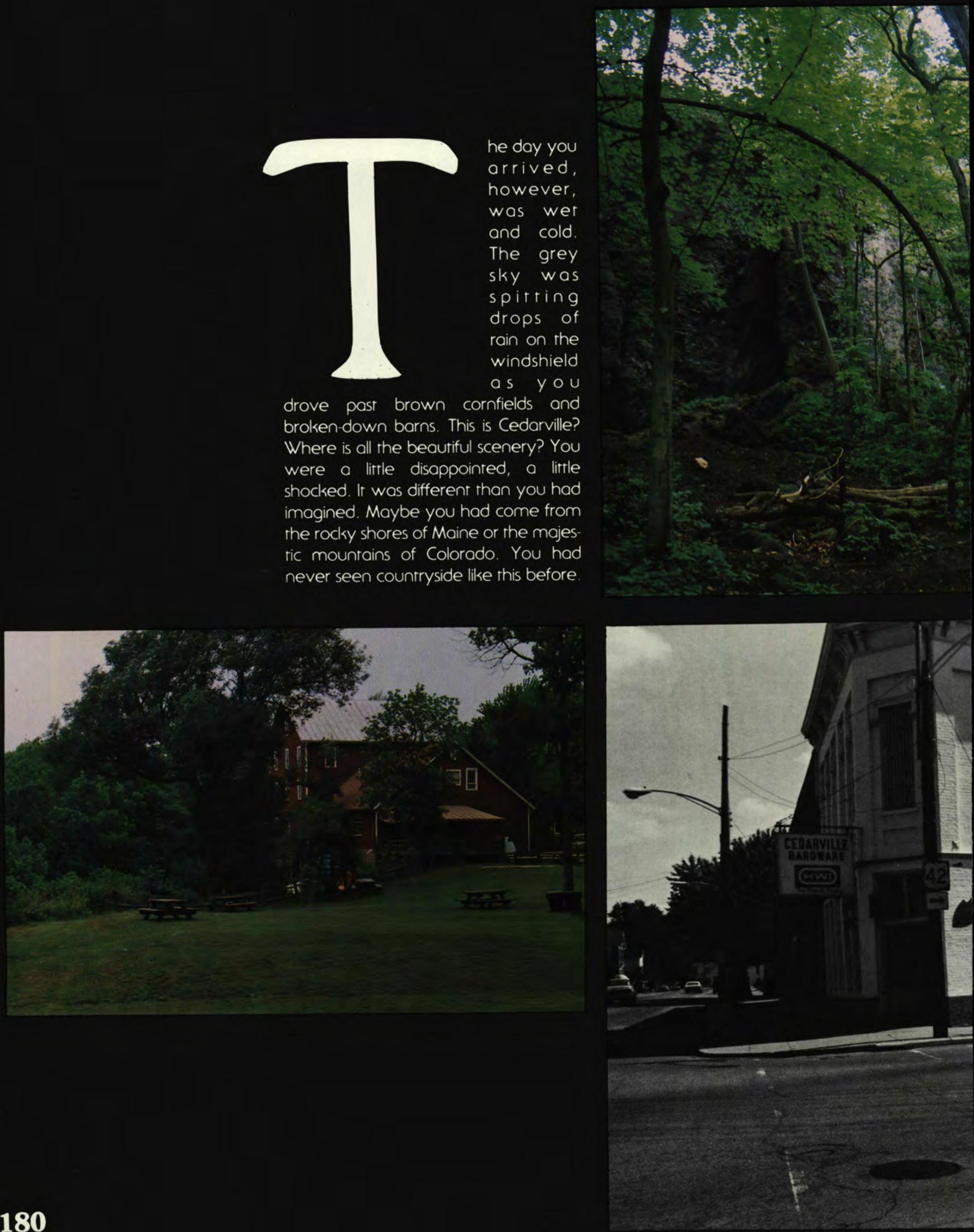


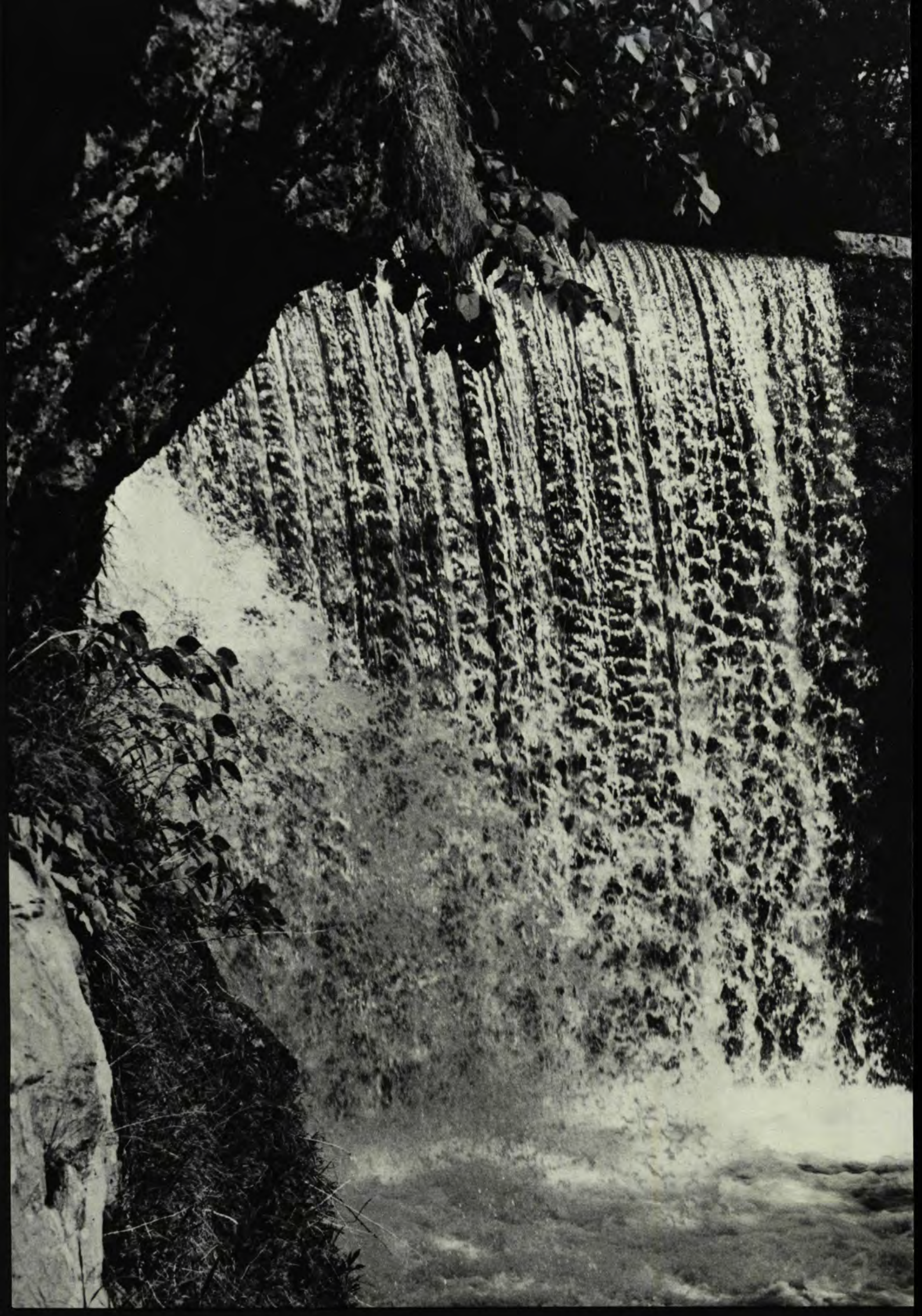




\section{Honoring A Special Class}

$\mathrm{P}$ art of the excitement of Senior
year involves the long-awaited participation in sacred senior activities steeped in tradition. Seniors broke tradition this year, however, at the third annual Senior Night. The seniors chose once again to have a one-evening outing in lieu of a weekend trip in hopes of having greater participation. They also enjoyed another fine meal and drama production of Fiddler on the Roof at La Comedia dinner theater. For the first year, however, the seniors chose not to give awards to a few select individuals. They chose instead to honor and celebrate the uniqueness of the entire class.
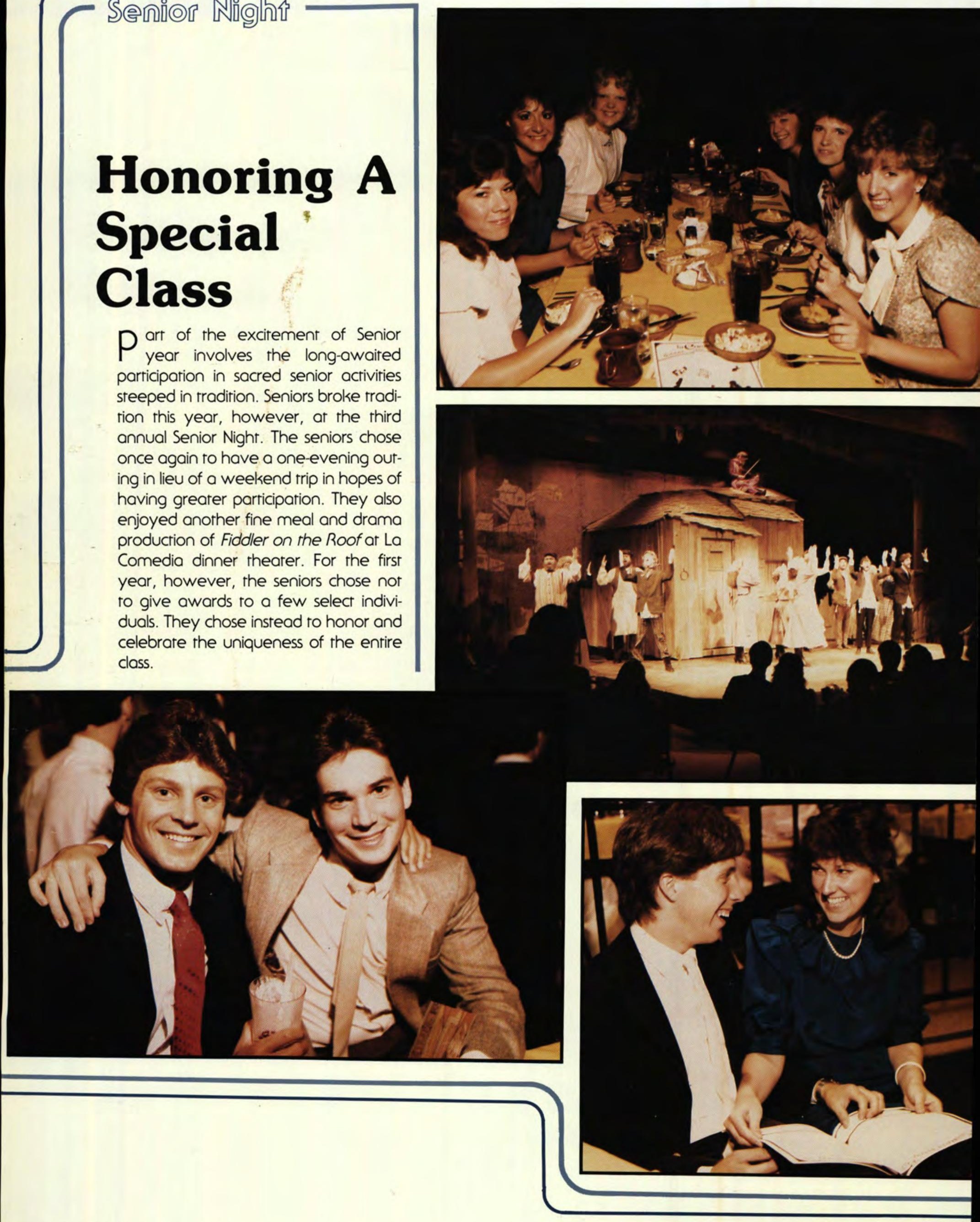


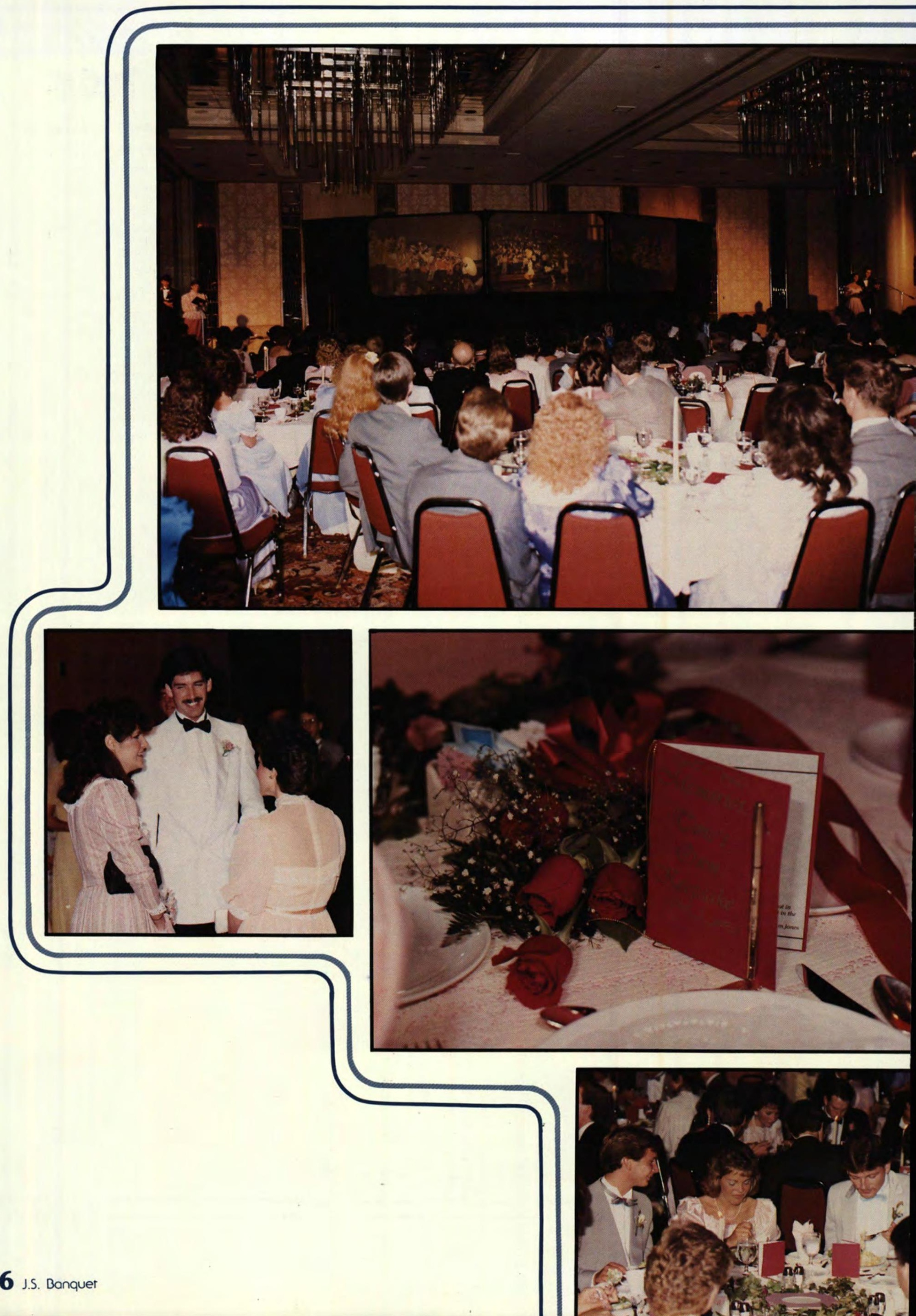




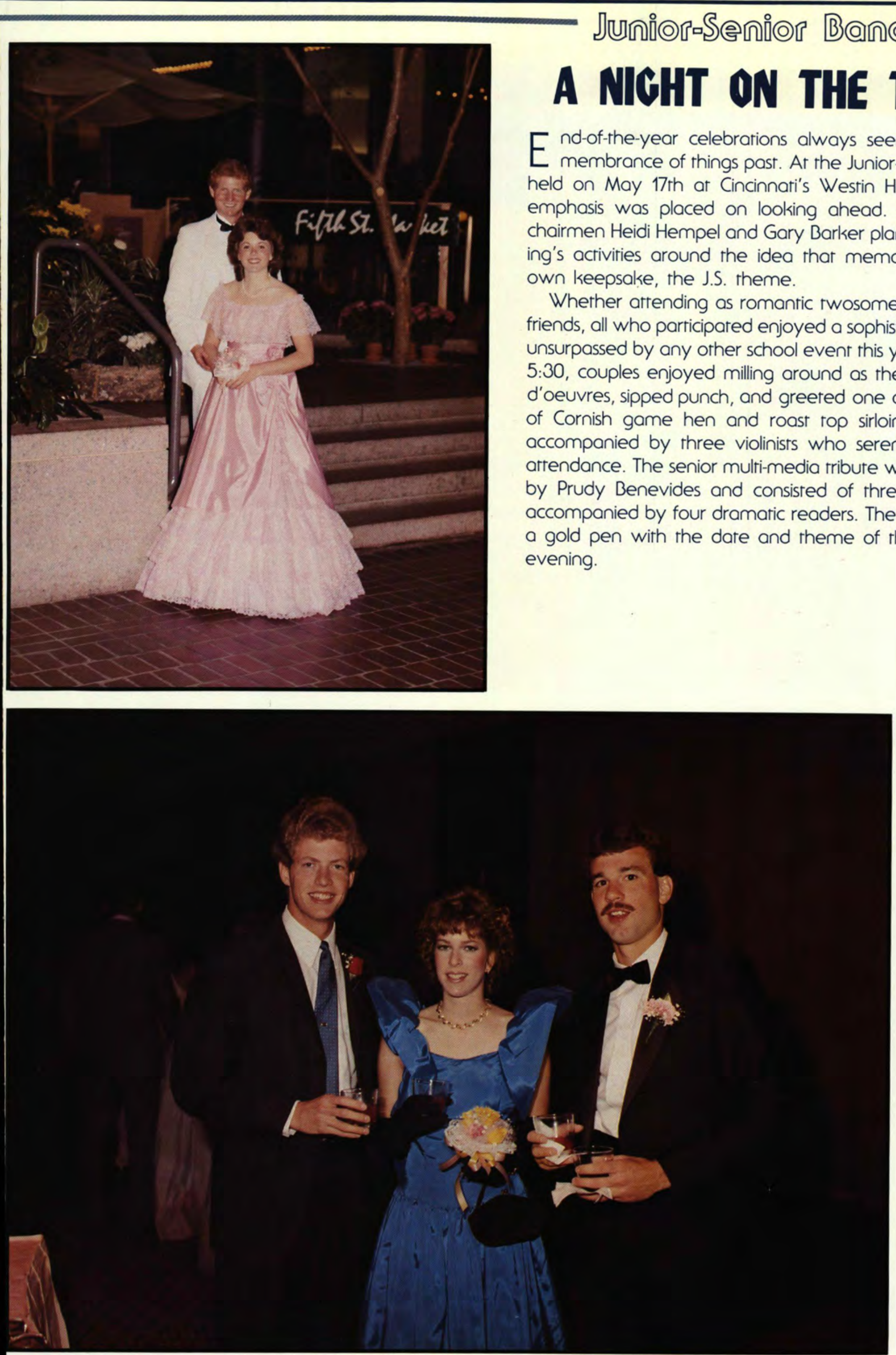




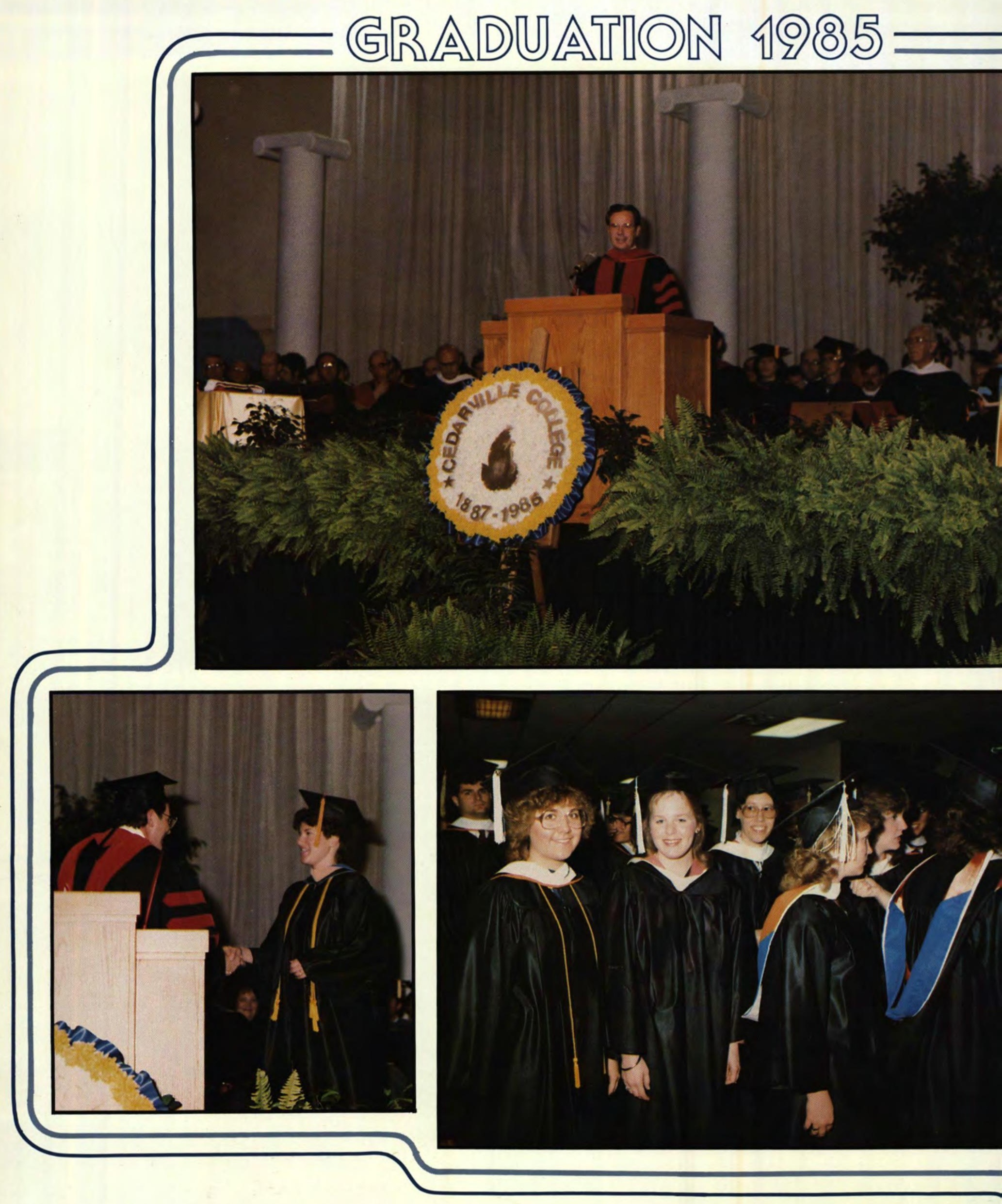




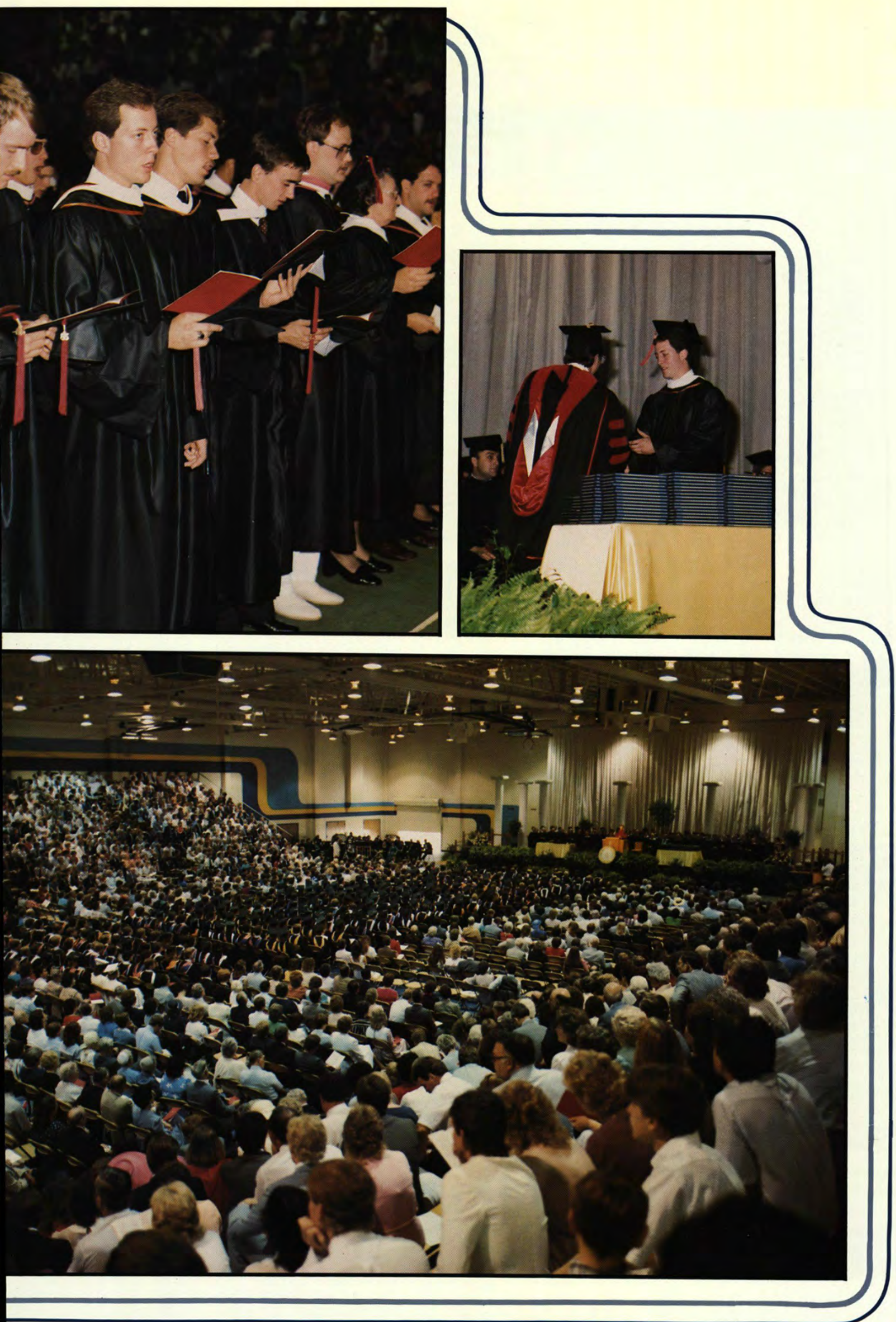



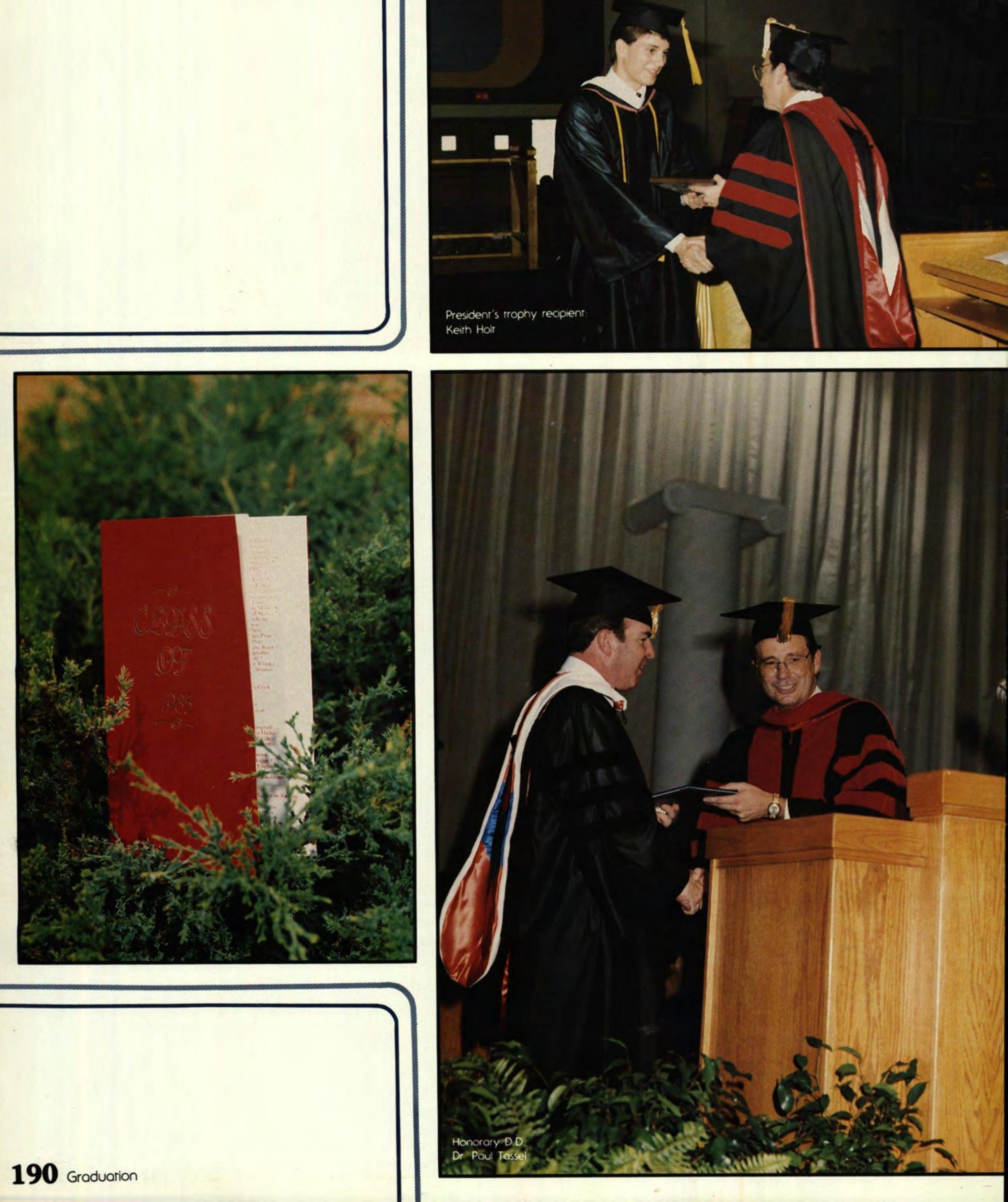

\section{Graduation}




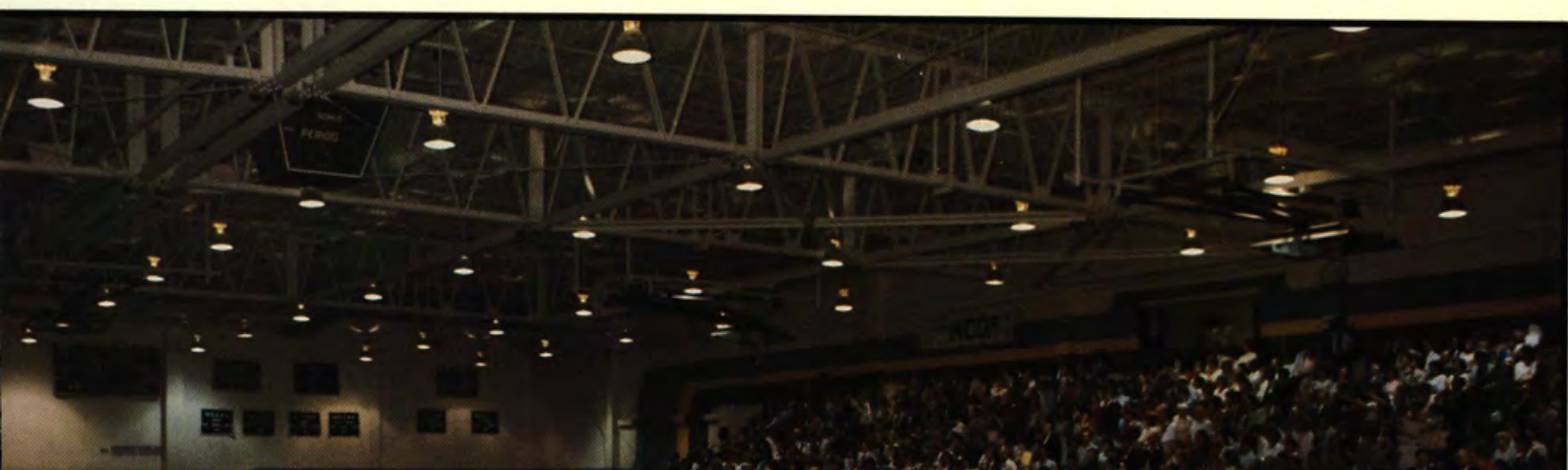




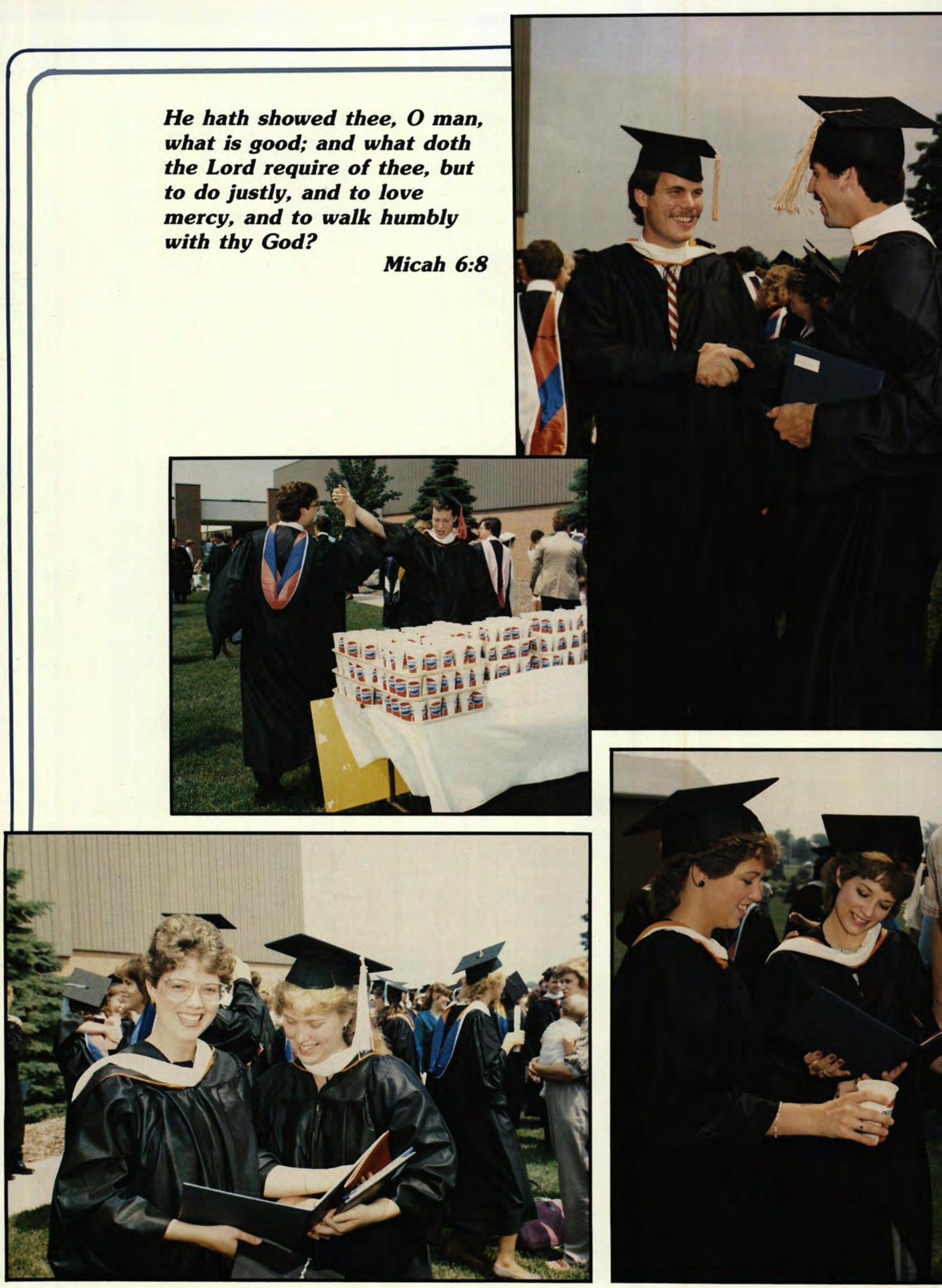




\section{Who's Who}

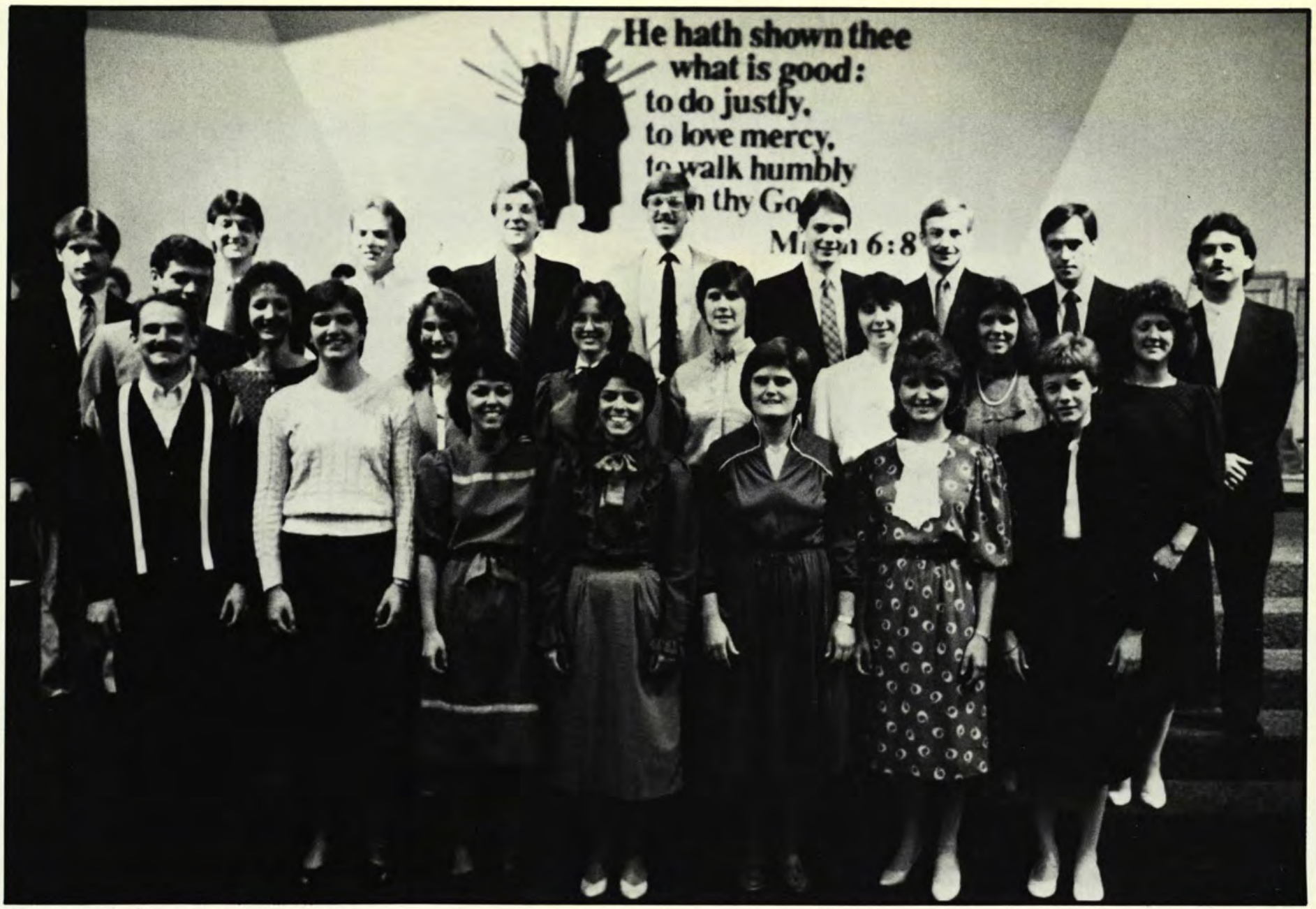

First Row: Gary Barker, Sharon Longnecker, Kristina Wirtacker, Deb Bartaglia, Melanie Marthewson, Susan Olsen, Chris Parman, Second Row: Mark Horne, Laura McElroy, Kendra Docror, Cheryl Phillips, Diane Lichtensteiger, Sylvia Rinder Knechr, Linda Hess, Shari Altimus, Third Row: Ben Herr, Mark Price, Noel Hack, Wayne Keisling, John Vorh, Keirh Holr, Don Messick, Aaron Bowes, Jim Moll.

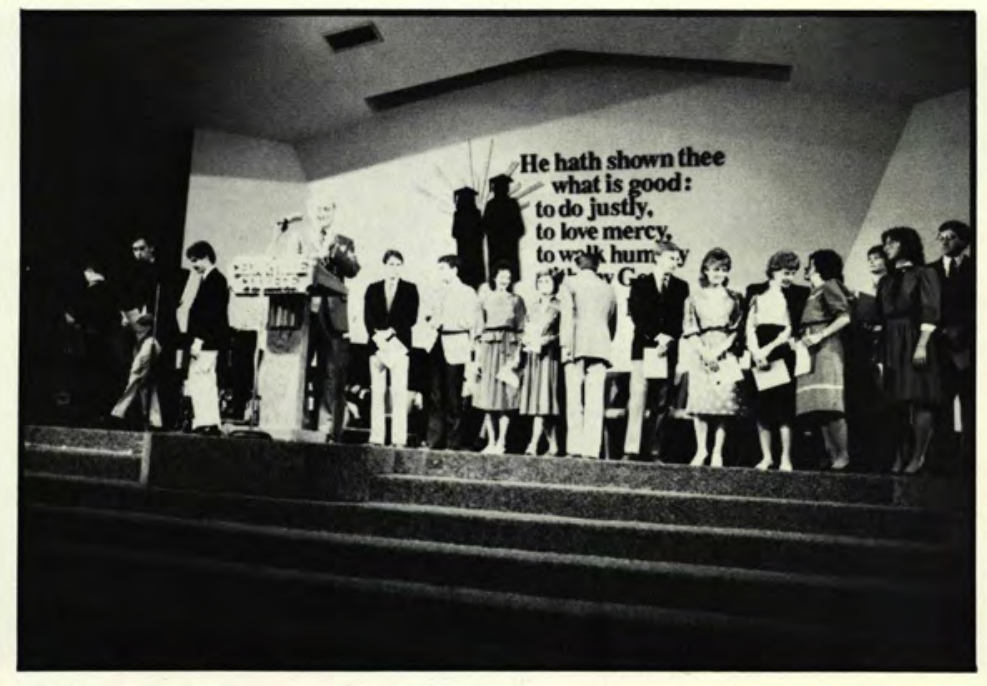

Who's Who recipients receive recognition

Mark Price and Kristina Wirtacker sing a duer during Who's Who Chopel.

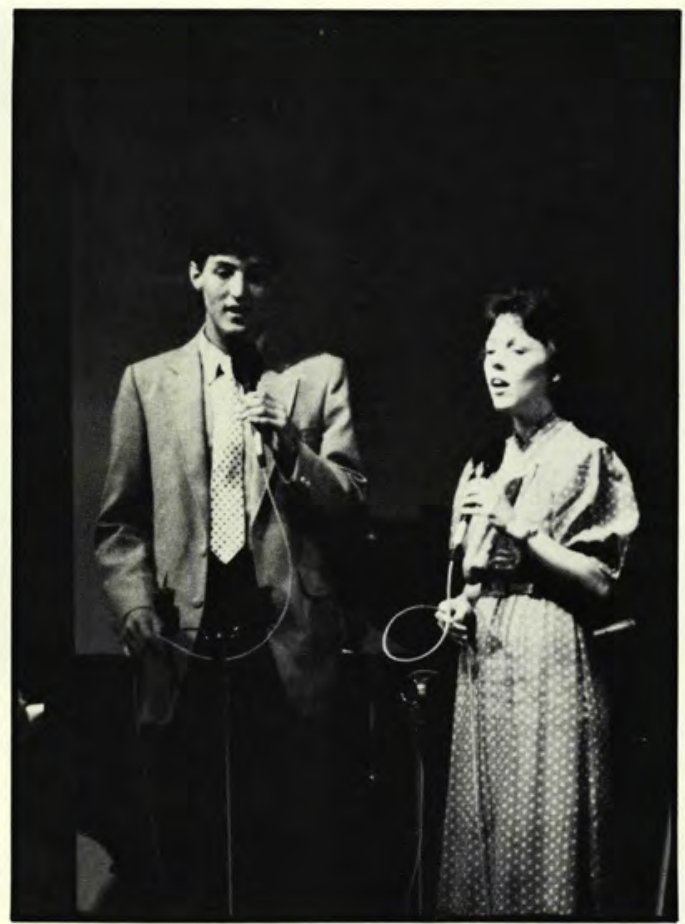




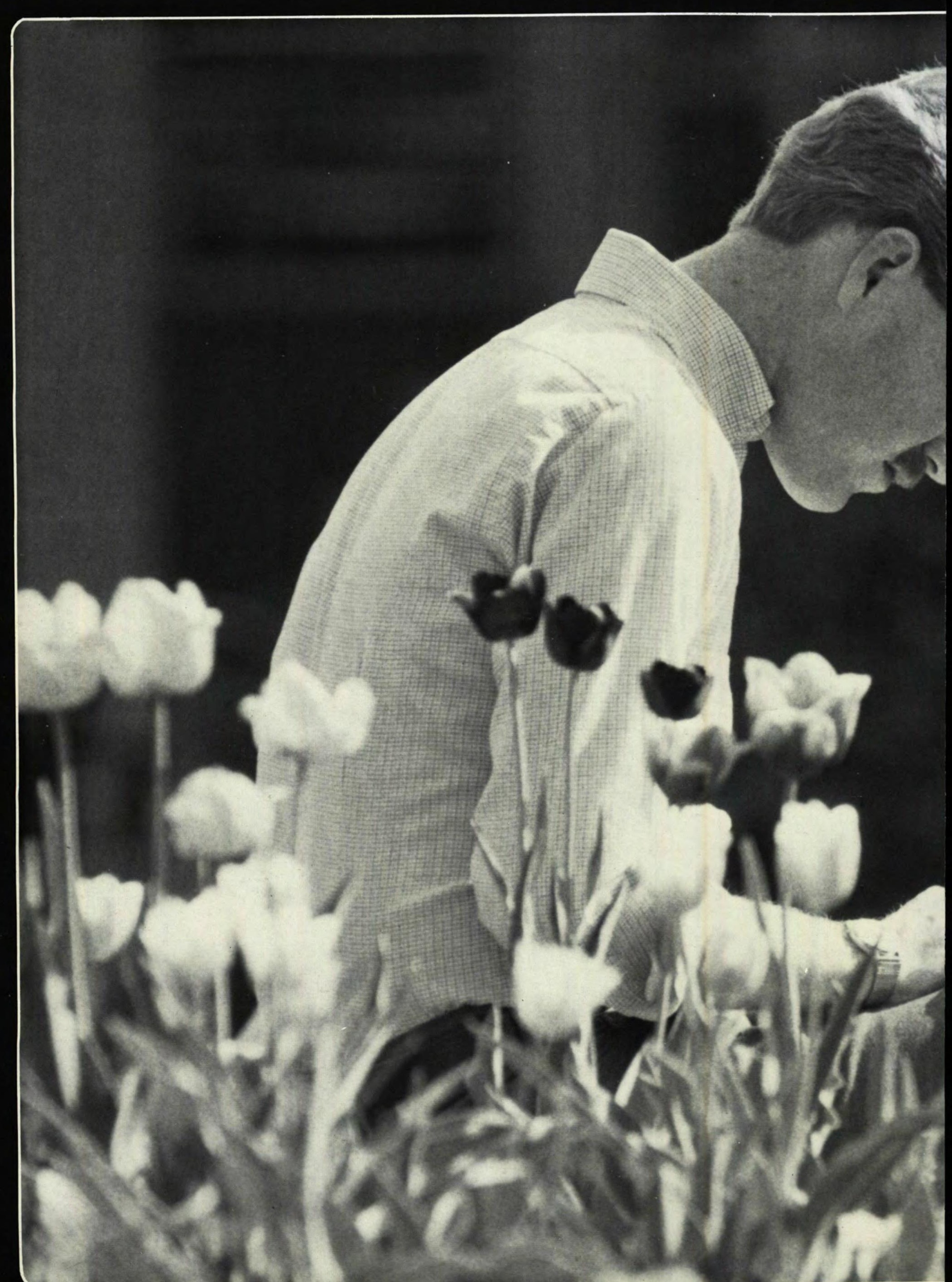




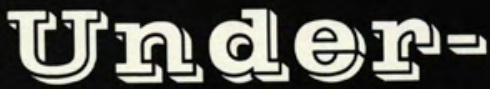

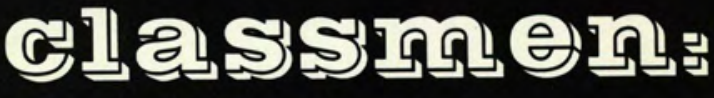 G्Spowing,

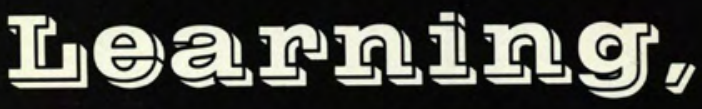

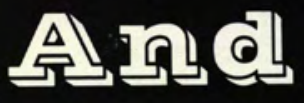

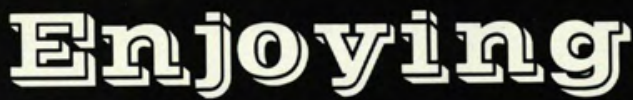

Classes, chapel, making liferime friends, and growing intellectually, spiritually, and emotionally are all involved with being an underclassman. On the following pages are the faces of those underclassmen that experience these events. These faces may somerimes show pain and signs of difficult times which are part of the necessary growth that inevitably takes place. But more often the underclassman's face reflects the happiness and joy that is a result of the good times of college life.

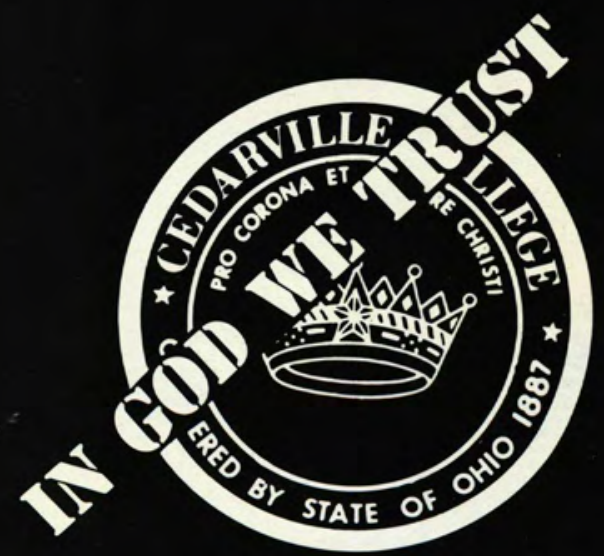




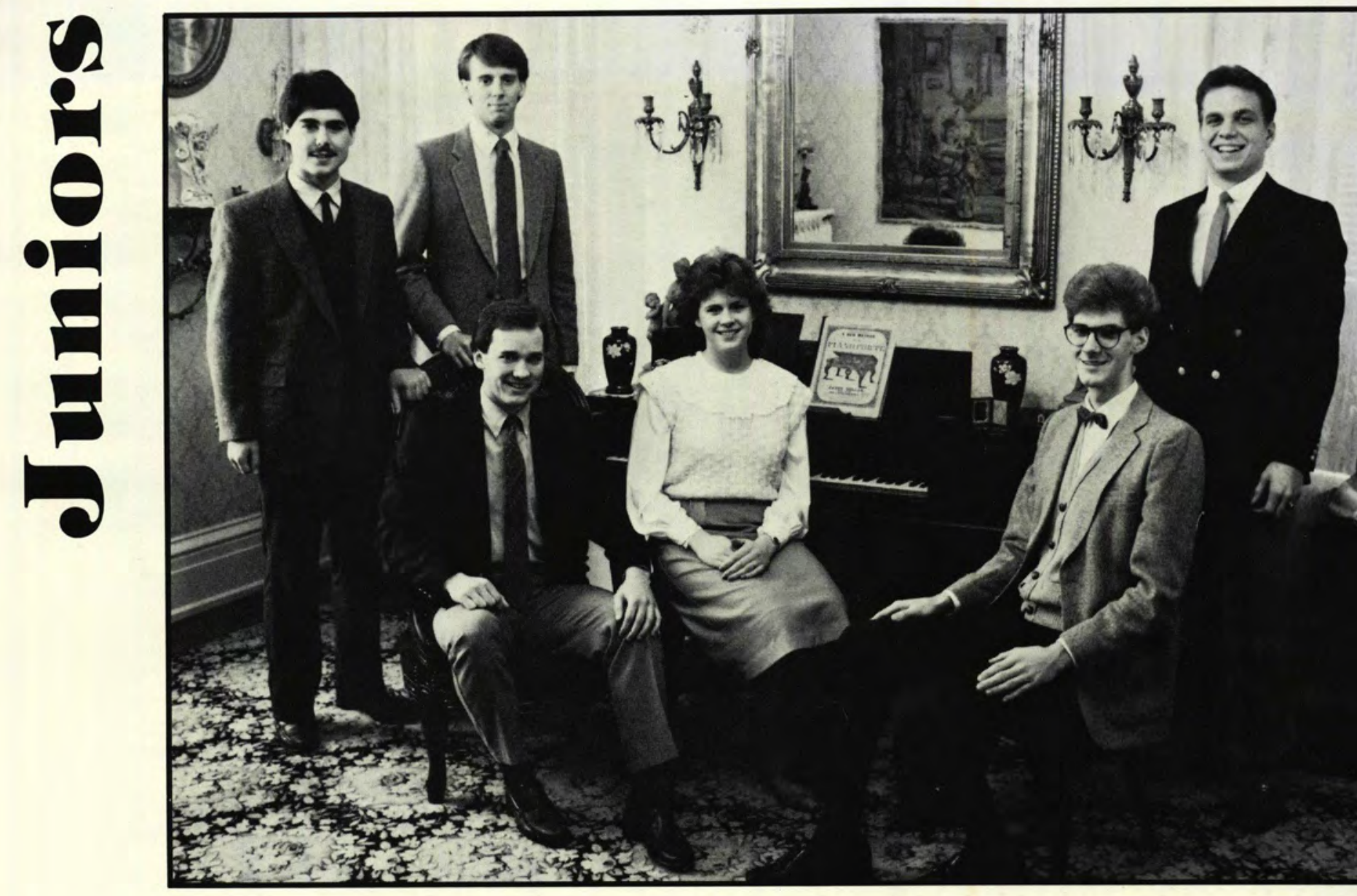

Class Officers: Student Senare Rep. — Jeff Beste, Vice President — Rob Loy, President — Jim Reiter, Secrerary — Bev Hay Treasurer - Bruce Keisling, Chaplain — Dave Eller. Not Pictured: Advisor — Dr. Ellingron, Srudent Senare Rep. — Jim Leibl

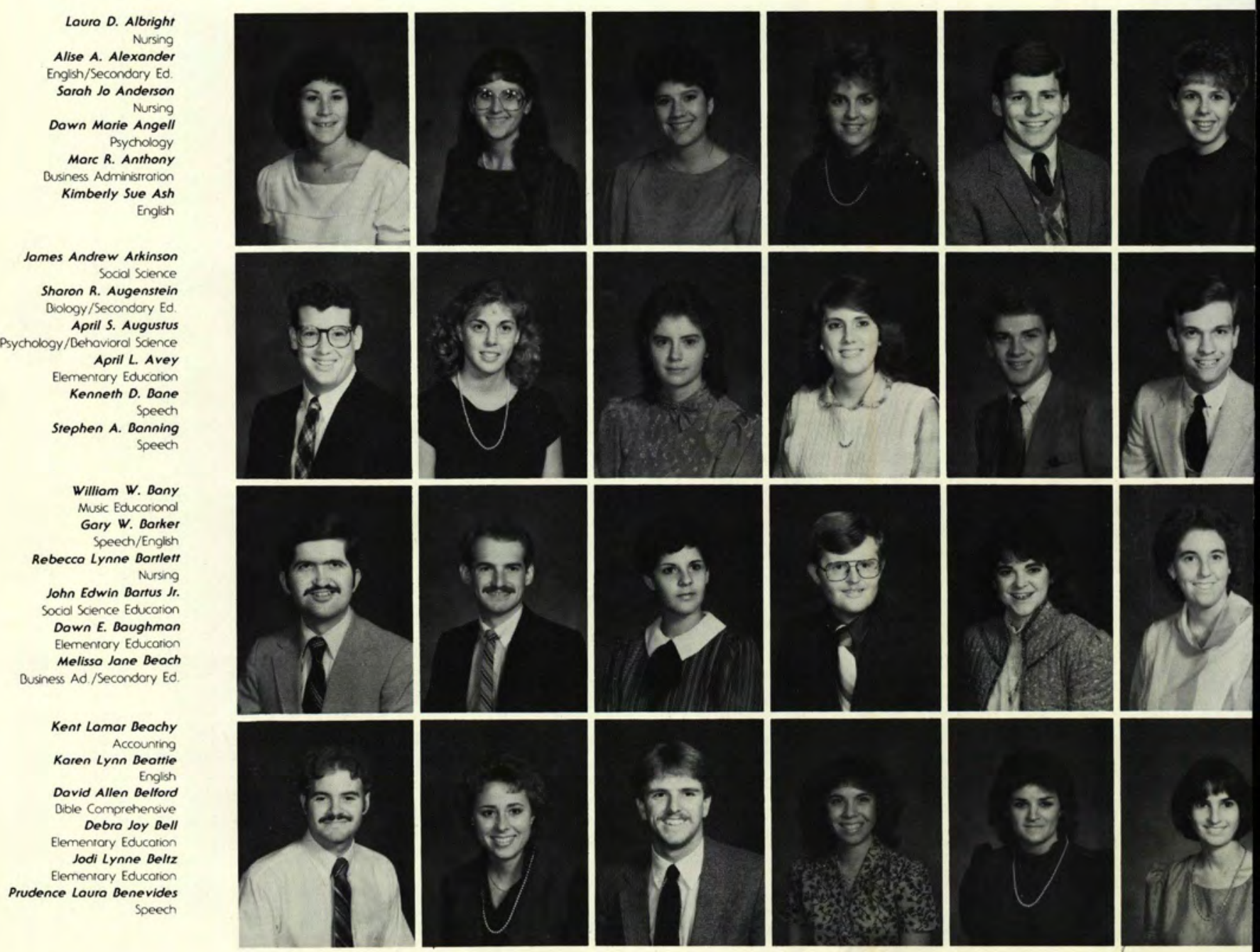




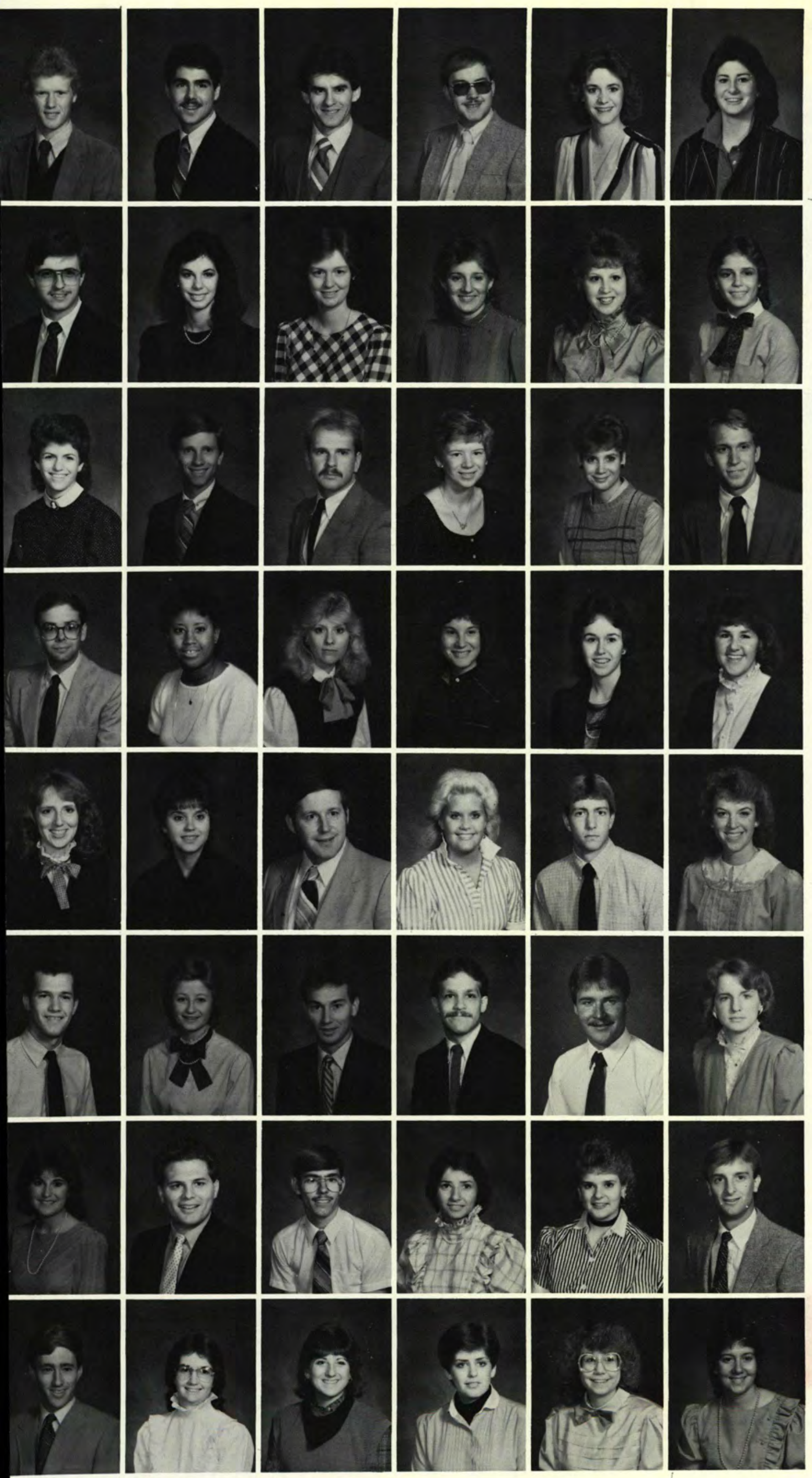

Richord Woyne Bennef

Business Administrotion

Jeffery S. Desio

Motthew B. Biggs

Public Administrotion

Peter Charles Dishop

Corol Sue Bitterman

Business Administration

Susan D. Blake

Prelow

Arthur S. Bloker

science Comprehensive

Ann E. Blessing

Nancy Jean Bliss

Business Administrotion

Rochel Ann Bowman

Uusiness Administronon

Nursing

Saro J. Brand

Ilementory Educorion

Michelle Ann Broun

Elementory Educorion

Chad R. Bresson

Broodcosting

Jomes Poul Brewin

iness Administration

Lourie Ann Briggs

Susan B. Briggs

Scort R. Brooke

Business Administration

Worren Keith Brown

Music Education

Shelley Lynn Browne

Nursing

Jennifer Gay Brugger

Mortho Duck

Chemsiry/Premedical

Elizobeth Ann Buchlew

Dusiness Ad./Secrerorial So

Brendo Dené Burchet

Elementory Eoucorion

Joycelyn Renee Burr

Music Education

Heather Lynn Bymes

Dennis E. Colhoun

Dementary Educotion

Susan Kay Colvert

Mike Alan Campbell

roodcosting

Sandro S. Corpenter

Nursing

\section{Tom A. Corr}

Boble/Preseminary

Tereso Lynn Corter

Accounting

Sydney Stewort Coruthers

Business Administrotion

Jonathan C. Chamberlain

Compurer Information Systems

Stephen M. Chance

Business Administrotion

Liso J. Chandler

Elemenrary Educarion

Christina Anne Chase

Hementary Educorion

Richord D. Chosse

Dible/Preseminary

Marc Douglas Chitwood

Computer Information Systems

Rebecco L. Clarkson

Morhemorics

Kathleen M. Clayton

Elementary Education

Gregory Scott Clemens

Dusiness Administration

Phillip Edward Clifford

Psychology

Spanish Educorion

Sally Jean Cochron

Elementary Education

Meredith R. Collins

Nursing

Jonis Lynne Comfor

Mary Ruth Cook

Music Educorion 


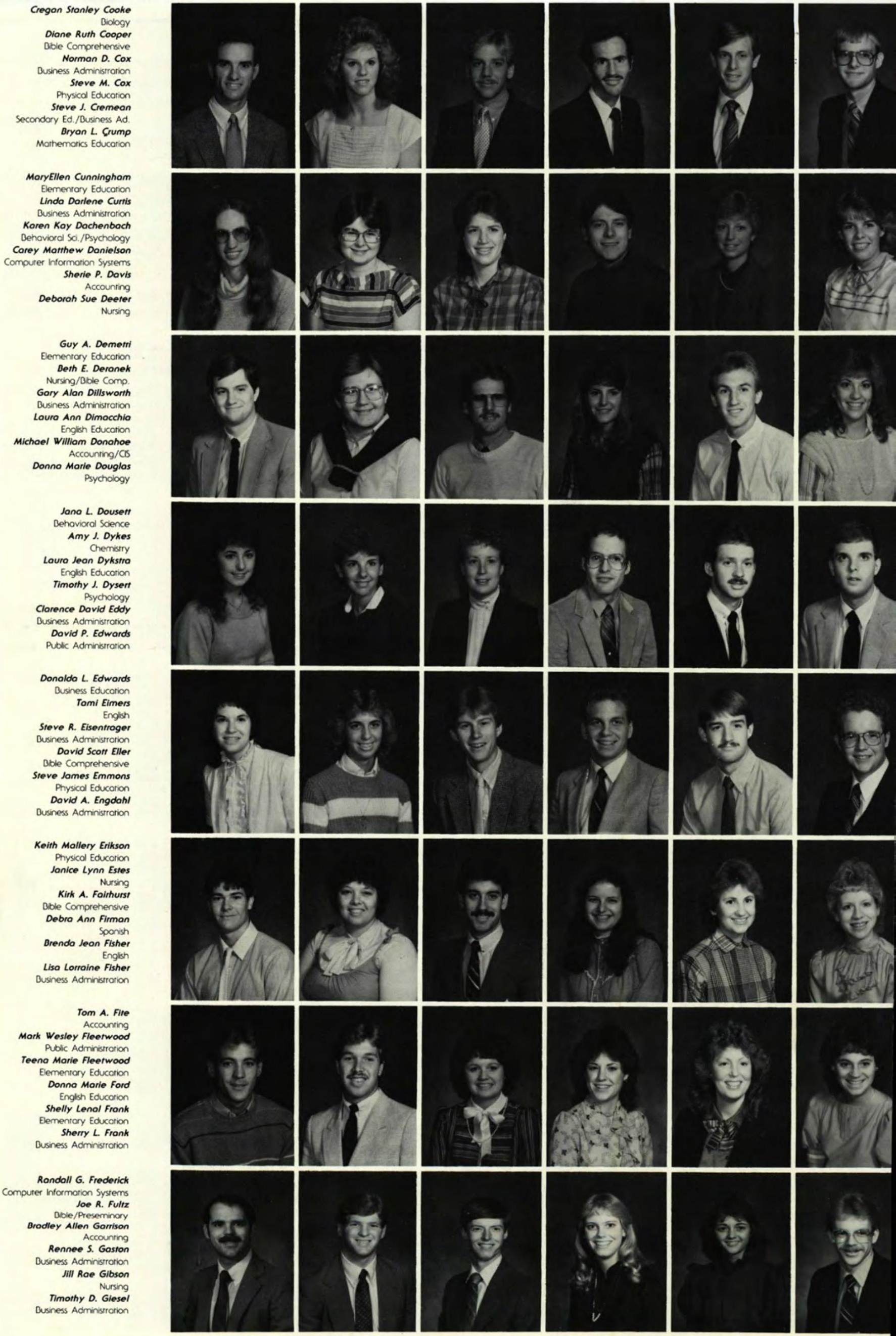


Brian Thomas Hedges Dible Comp./English

Kelley Lee Helmon

Kelly L. Helmick

Science Comprehensive

Heidi Elizobeth Hempel

Business Administrotion

Suzanne M. Herr

English Educarion

Corol Sue Herriman Nursing

Tom C. Hill

Morhemorics

Morionne Jo Hiner

Physical Educarion

Douglos V. Horne

Music Educorion

Mark Horne

Barbaro Anne Hoskins

Socid So. /History

Charles Joseph Hubbord

Bible Comprehensive

Noncy A. Huddleston

Elementary Educanion

Philip R. Hulbert

Physical Educorion

Charlene K. Hunt

Pamela Louise Hysong

Socology

Becky S. Jacobs

Behovioral soence

Accounting

Susan Renee Jockson Susan Renee Jackson Charles D. Jantzi

Psychology

Amy Michele Johnson

Elementary Educorion

Jocelyn Johnson

Business Administration

Rod S. Johnson

S.G. Ross Johnson

s.6. Ross Johnson

Amy M. Johnston

Chorles A. History

Physical Educorion

Kelly Kathleen Jones

Elementary Educarion

Daniel L. Katz

Business Administration

Grant Edwin Koufman

Dusiness Administration/CS

Lori Lynn Koufmonn

Business Administration

Bruce L. Keisling History/Political Soi. Donno Jean Kempf Psychology/Dehovioral Scl.

Jomes A. Kibbey

Bible/Preseminory

Susan Joyce Kiener

Nursing

Kathryn J. Klose

Melanie Lynn Knouff

English

Temple Leigh Knowles

Dusiness Administrotion

Deborah Ann Kocher

Jomes M. Kohlish

Jomes M. Kohlmeyer

Accounting

Elementary Educorion

Stephen A. Kuhn

Accounting

Nursing

Daniel A. Lohaie

CS/Secondary Ed

Joanne S. Laird

Gregory Poul Lomber

Compurer Information Systems

Edword G. Lanning

Mark A. Latin

Dusiness Admin

Suzonne Loub

Physical Educorion
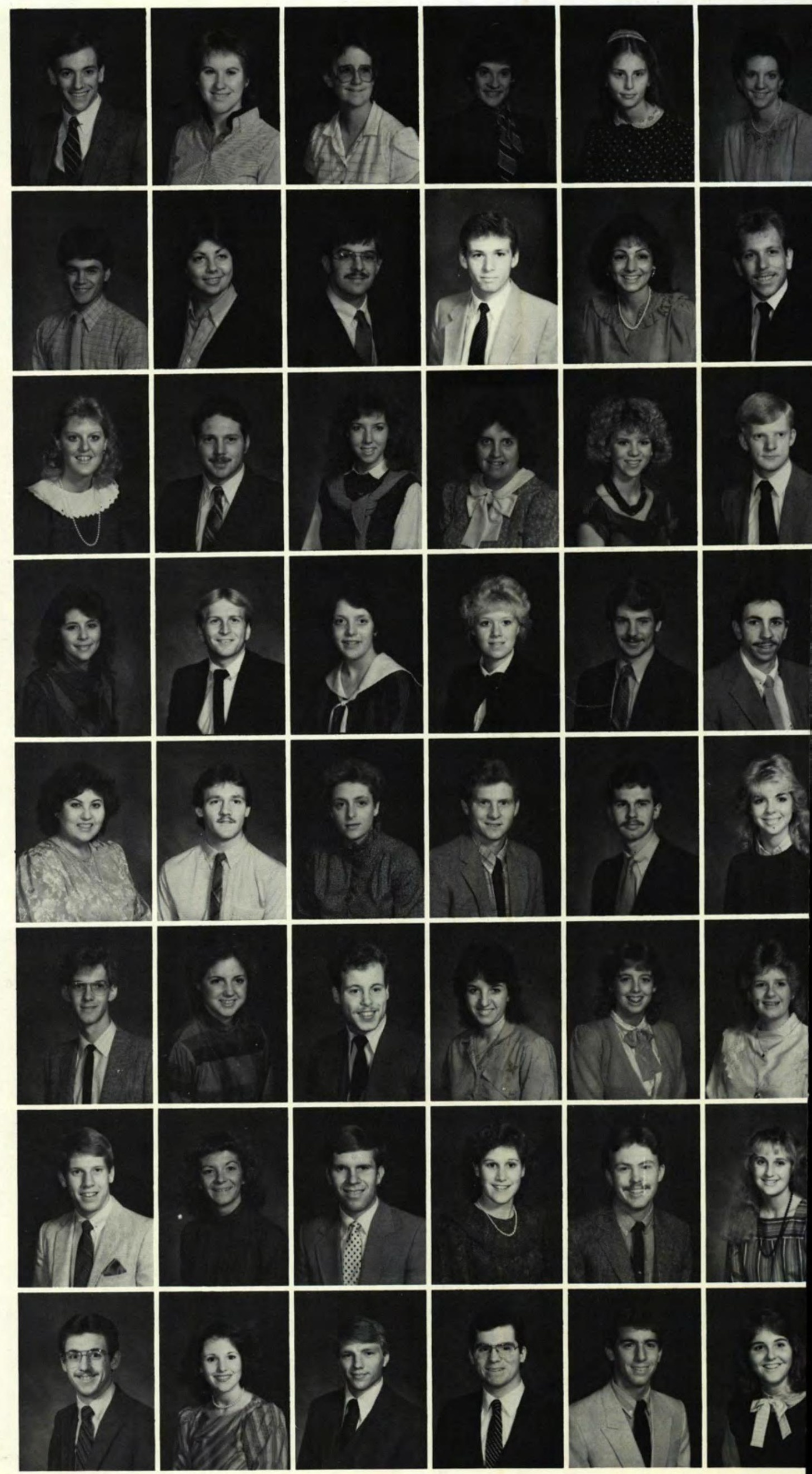

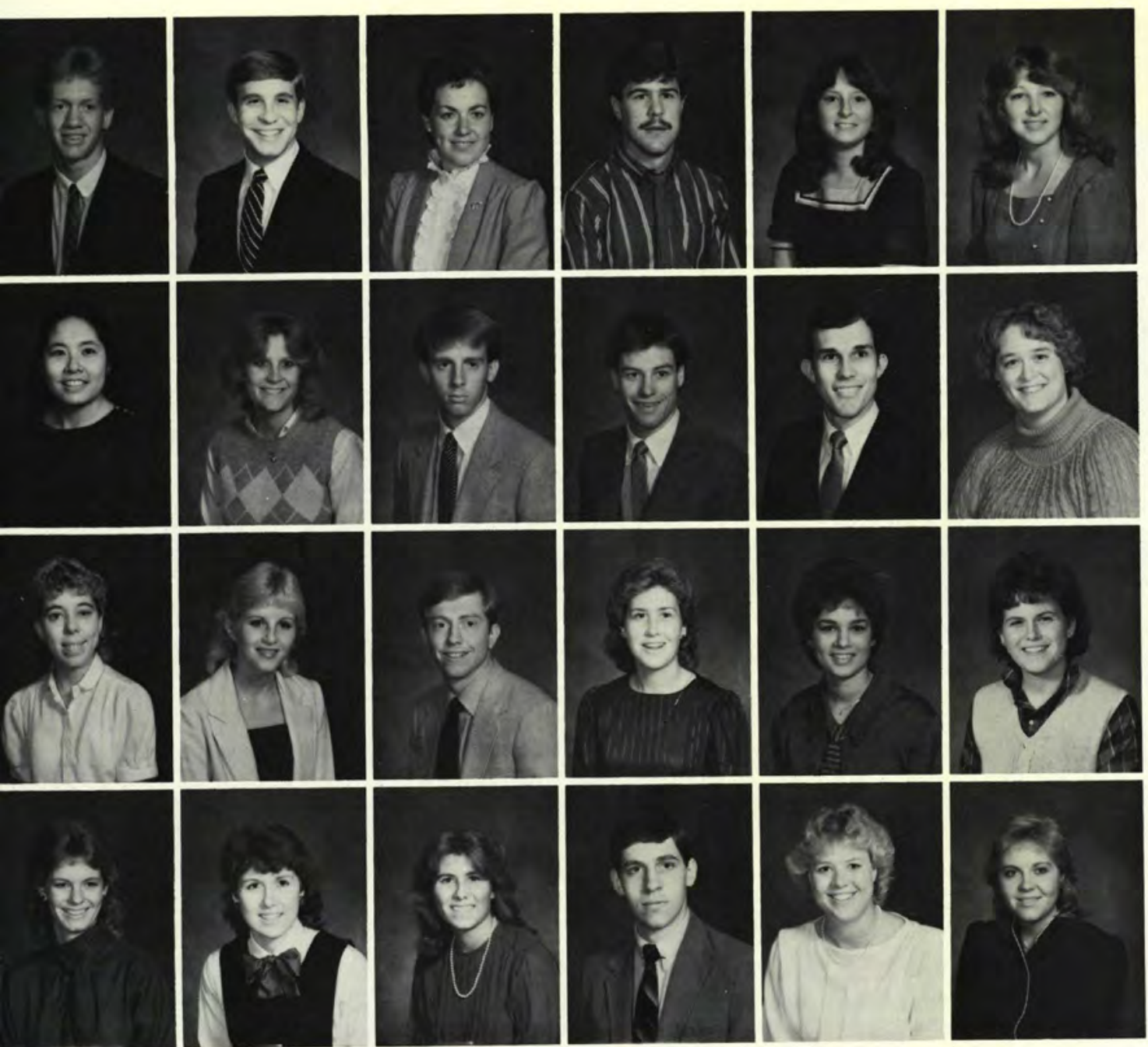

Todd Edwin Lee

Chemistry

James Michoel Liebler

Speech

Lori A. Lindsey

Accounting

John W. Little

Business Administrorion

Cyndia Lynn Long

Cyndia Lynn Long

Tricio Ann Long

Iricia Ann Long

Michelle Morie Longo

Biology

Denise Jayne Lowe

Elementory Educorio

Rob D. Loy

Accounding

Roger D. Luttrell

Speech

Alon McCoin

Compurer Informarion System

Sheryl I. McCrocken

Elementory Educorion

\section{Liso K. McDonald}

Behovioral Solence

Foith A. McGhee

Dehavioral Sci./Psycholog

Rich Doniel McGill

Bible/Preseminary

Comi A. McGrow

Elementary Educotion

Sara Lea MCGuire

Nursing

Cheryl Lynne McHenney

Elementory Education

Beth Ann McKibben

Elementary Educotion

Corol M. McKinley

Elementary Education

Melisso A. MacMichoe

Biology

Bruce Raymond $\mathrm{McNabb}$

Dusiness Administrotion

Joone Koren Majo

Engish

Leslie Rene Molot

Nursing

\section{TCRROLE ROW几AND}

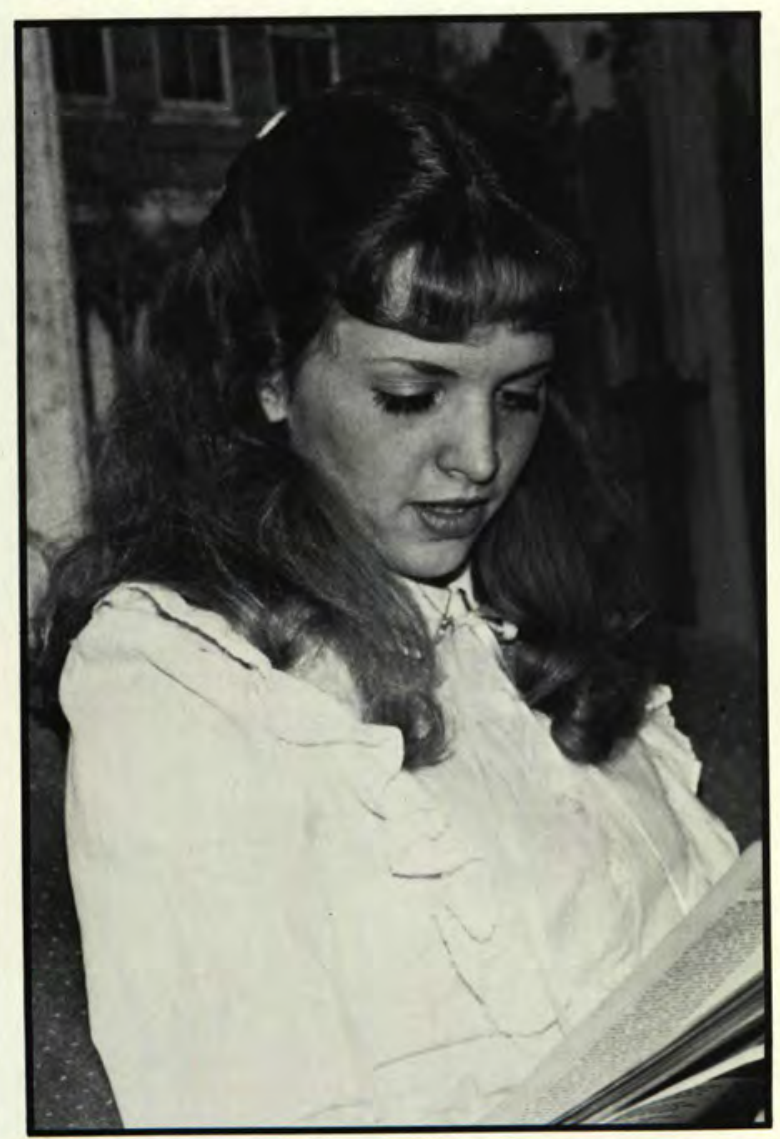

D escribing myself is a hard job! I am basically a happy person, content with life. I enjoy people, both meering them and getting to know them. I could spend loads of time talking with interesting people because everyone is so different and unique from everyone else. That is fun to me, and fun is an important part of my life, too. Practically any activity can be fun or at least pleasant. Why not make the best out of what you've been given? "Variety is the spice of life" is a saying that I agree with heartily!

Another part of me is believing in people for which I am somerimes criticized. Most of the time, I will give other people the benefit of the doubt and never doubr. Some people call this gullibility, but I guess I just think that I shouldn't have any reason to doubr orhers. I do need to balance this area of my life, and I am still growing in this characteristic.

I think I am a simple person. Little things in life please me and make me happy: I like friends, rainbows, balloons, pretzels, ice cream, chocolare, motorcycle rides, playing frisbee, going barefoot in the summer, and good music. I love to sing, but I'm rerrible ar it - just ask my friends! I am strongwilled and, yes, somerimes stubborn. I like to discuss differing ideas, but I'll stand fast to what I believe. I tend to be independent as I realize that God is the ulrimate Provider of the people in my life.

I think the way I live is directly related to my beliefs and mind set. I know that God made me for the purpose of glorifying Himself and serving Himself. I've given myself to $\mathrm{Him}$ to be guided and directed to do whatever He chooses. God comes before anything or anyone else; and if that means giving up other things or people, then that's how it will have to be. Because of His love for me, what He has and continues to do for me, I choose to obey God and show His love to orhers. This is a challenge to me. One of my great desires is to show genuine love to people so that they may see Christ reflected in me. 

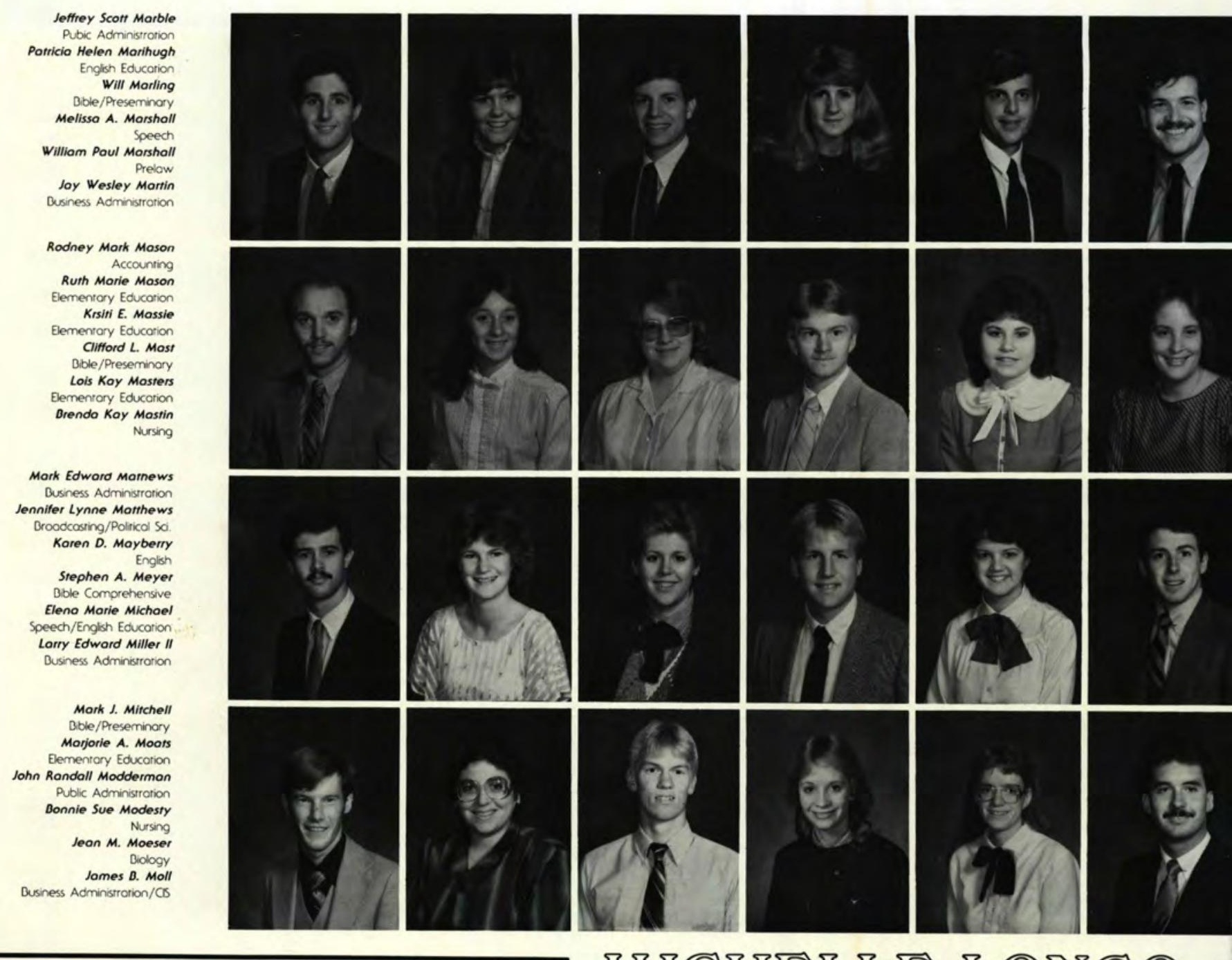
Mistrotion
Broodcosting/Polinical So
Karen D. Mayberry
Stephen A. Meyer
Bible Comprehensive
Eleno
Lorry Edword Miller
Dusiness Administrorton
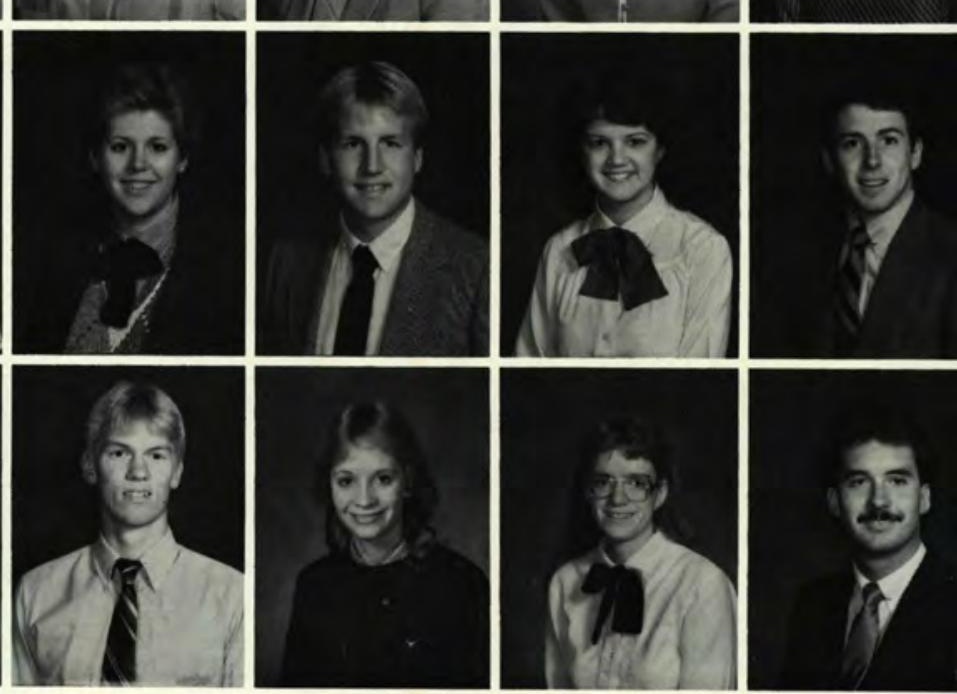

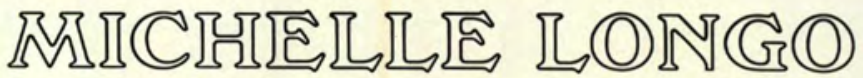

thank the Lord for allowing me to rerurn to the 'Ville this year. After atrending here as a freshman and then spending a year ar a state university, returning to the campus last fall was a homecoming for me. It has been fonrostic to be back.

"Back to what?" you may ask. "Back to this barren land of inverted umbrellas, rainy Sundays, warerlogged shoes, and a "lake' with no whales?" No, that's nor it at all. Ir's nice to be back ar a college that has "live" insturctors and not "video" professors. It has also been refreshing to be back in an environment where people are not constantly looking our for "number one," but rather put Jesus Christ first in their lives.

Mondays are also back to being bearable once again thanks to President Dixon's candid series on "Daring, Marriage, and the Family." Singing "Christ is All I Need" still fills me with a sense of belong- ing an unity with the college family.

It was quite an expereince readjusting to dorm life though; and it wasn't until after my first popcorn popper donut and one of those famous "tallks" that lasted into the early morning hours, that I felt at home away from home. It is true thar you learn more about life in the dorms than you ever could in the classroom. It's in the dorm, too, where the Lord has blessed me with friends whose friendships will last throughout my liferime.

I now have a better appreciation for the college and for what it stands. No, this isn't a 'Ville promo; but too often we rake for granted our time here instead of urilizing it to its fullest.

Looking to the coming year, I pray that God will help me to maintain a "permanent press" in my life as I press on toward maturity in Him.

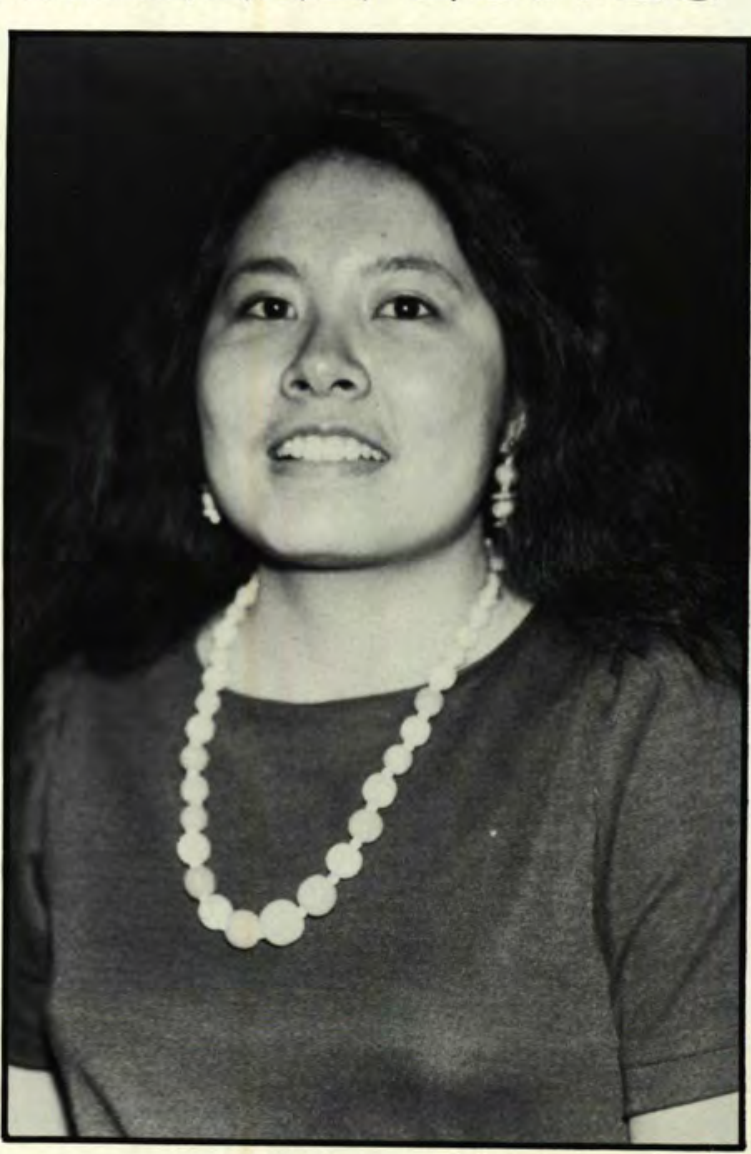




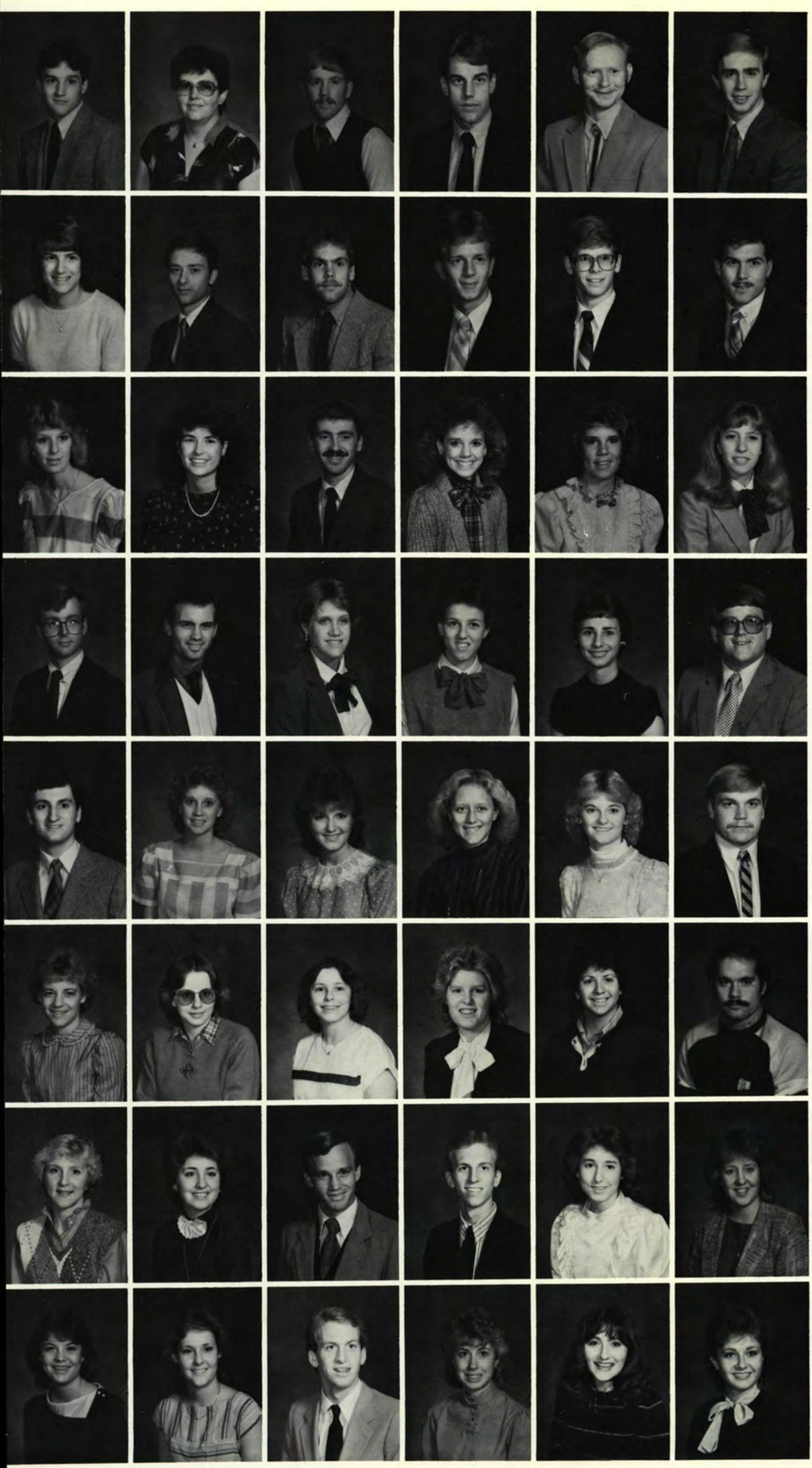

Bryan Edword Montross

Sheillo Dione Moon

Church Music

Dale D. Moore

John Andrew Moore

Science Comprehensive

John Eugene Moore

Motion Systems

James W.R. Morton

Dusiness Administrotion

Susan J. Moser

Elementory Educorion

Mark Allen Moses

Accounting

Business Administronion

Scors Moyer

Compurer Informorion Systems

Dan E. Mulhlland

Greg A. Murroy

Behoviord So. / Psychology

Alicio Moe Murrin

Elementory Educorion

RoseAnn Nemece:

Nursing

Edward Wayne Neudeck

Dusiness Administrarion

Mory Beth Newsome

Englsh Education

Sonyo Renneé Nichols

Elementary Education

Kristo Lynn Nickoson

social Science

Gory S. Nonnemache

Marhemonic

Williom B. Norrell

Biology

Judith E. Oakes

Dusiness Ad./Marhemarics

Rebecco Ellen O'Conno

Elementary Education

Constonce Jone O'Dell

Dusiness Educarion

Potrick Andrew O'Donnell

Diology

Ken Charles Oliver

Droodcossing

Kim Eileen Oljace

Dehovioral science

Susan Lynn Olson

Psychology/Dehoviorol So
Debbie Lynn Osborn

Physical Educorion

Diane Sue Otroway

Business Administrorion

Jerry Alan Porker

Dible Comprehensive

Kristine Kay Parman

Physical Educotion

Helen M. Pearson

Nursing

Marionee Pearson

Elementory Educorion

Ellen M. Pederson

Nursing

Dione M. Peffer

Physicol Educorion

Don Lee Pensworth

Qusiness Administrotion

Kothy Groce Penty

Nursing

Ja-Ellyn Marie Peters

Morhematics Educorion

Douglos Terrell Phillips

Diology/Chemistry

Tim Scott Phillips

social soence

Shelley Morie Polsdorter

Elementary/Speciol Ed

Chrissy J. Ponzani

Dusiness Administrotion

Liso M. Proll

Business Administration

Sondra Gwen Protr

Nursing

Jonothon H. Price

Qusiness Administrotion

Tresso Anne Prioce

Nursing

Deborah Eloine Quick

Engish

Noelle Christine Rodcliffe

Nursing 


\section{இALDU SDRAGUL}

Y es, operaror, a collect call from Ralph Spra gue. I'll hold .... Dad! is Mom awake? Wake her up 'cause I've got some news to tell you borh ... Hi, Mom: yes, I know it's 11:38 pm but I couldn't wair. Yes, I love you too, bur please listen. Are you listening? Well ... un ... I gor saved. What do you mean 'Whar do you mean?' Dad, wake Mom up so she can understand what I'm saying: I gor saved!'

This conversarion occurred during this winter's Missionary Conference. Acrually, I was saved Janvary 6, 1984. After the last Missionary Conference meeting, I went back to my room, read the "Romans Road," knelt beside my desk and asked Jesus to rake personal and permanent control of my heart, head and life

After my experience, I was still living the same "Christian wallk" that I had lived before; only now
I had assurance of God's love for me. This old "walk" was fine for me. I was comforrable with it and wasn't abour to change ourwardly because I didn'r see much wrong wirh it. I guess a continued spiritual growth for me is slow, because it rook almost a full year for me to learn the first lesson Christ would teach me.

God used Mr. Paul Versluis to ger my artention. Every rime he spoke, God was sending me litrle messages. Well, what I gor our of Missionary Conference was that living for Christ is a daily dying to self and a constant renewing of oneself in Christ. This was the missing element to my old "walk." When you're constantly giving yourself to Christ, it makes the relarionship you have with God new. This is why my old "walk" felt stagnant: until I learned to make my old "walls" new, I wouldn't grow.

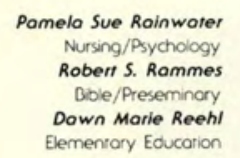

Johnathan Charles Reid Jomes Michoel Reiter Dible/Preseminory Krista Lynn Rhoodes Elementary Educarion Molinda Ann Rhoodes Elementory Educorion Todd A. Rhoodes Droodcosting Miriam Elaine Rhodes Biology

Jerry Ray Robbins Jennifer Sue Robinson Jennifer Sue Robinson Steve Craig Rockwell Steve Craig Rockwell Renee R. Rockwood Richard B. Rogers Marhemonics
Brian Jon Roget Drian Jon Roget

Corole Jean Roland Behovioral Science Catherine Ann Romano Jane Diane Romig Qusiness Administrotion Tracy A. Roy Political So. / History
Judith L. Runge Accounting Virginio Kim Rupe Computer Information Systems

Linda C. Russell Elementory Educotion Marilyn F. Ruth Elementary Educorion Elementary Educorion Glen W. Sollee Business Adminstration Compurer Informert M. Sand Shannon Marie Sounders Business Administrorion
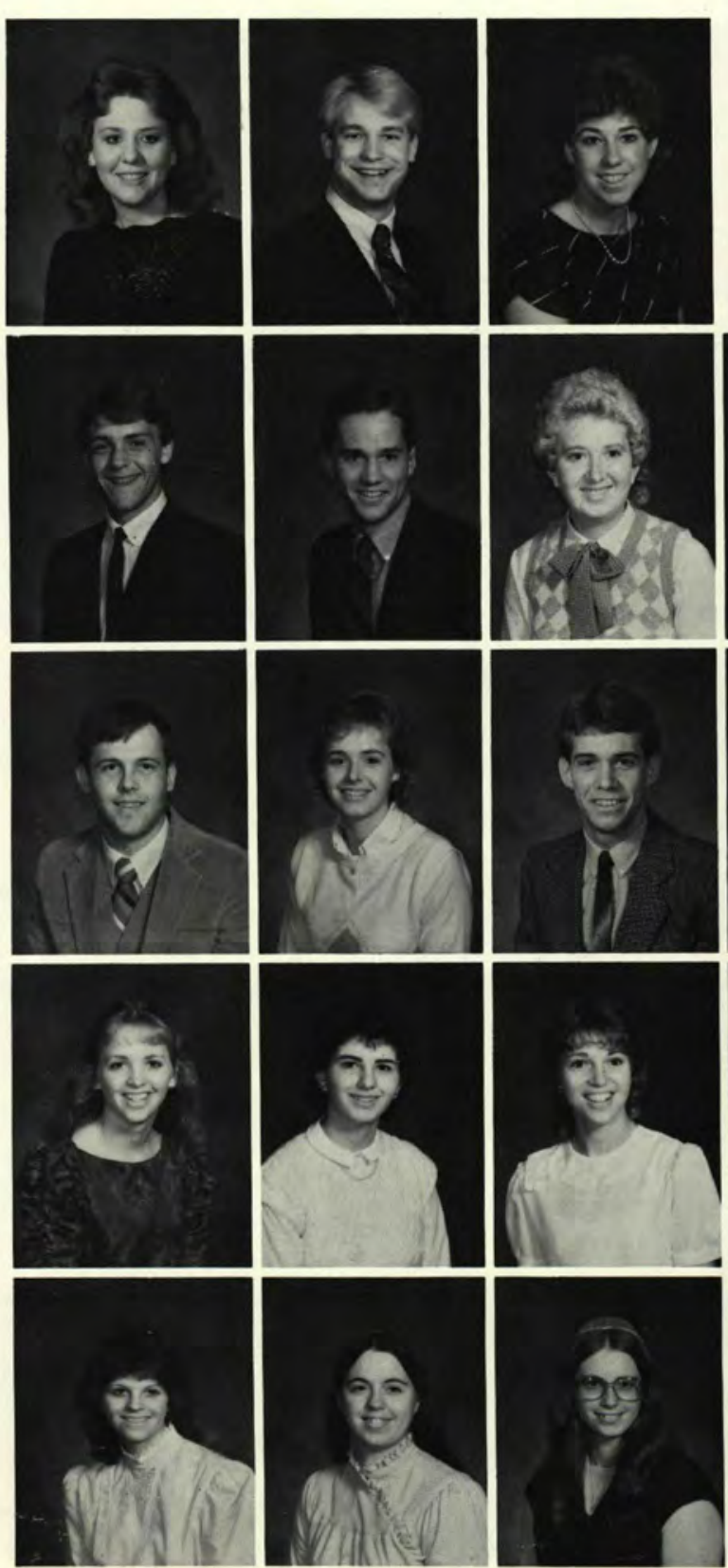
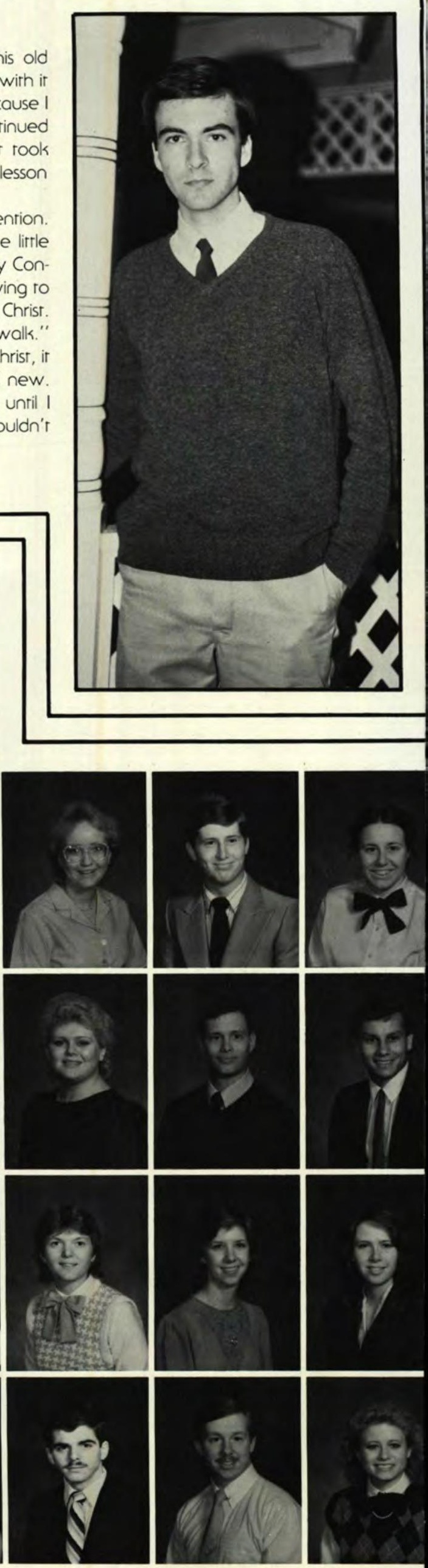


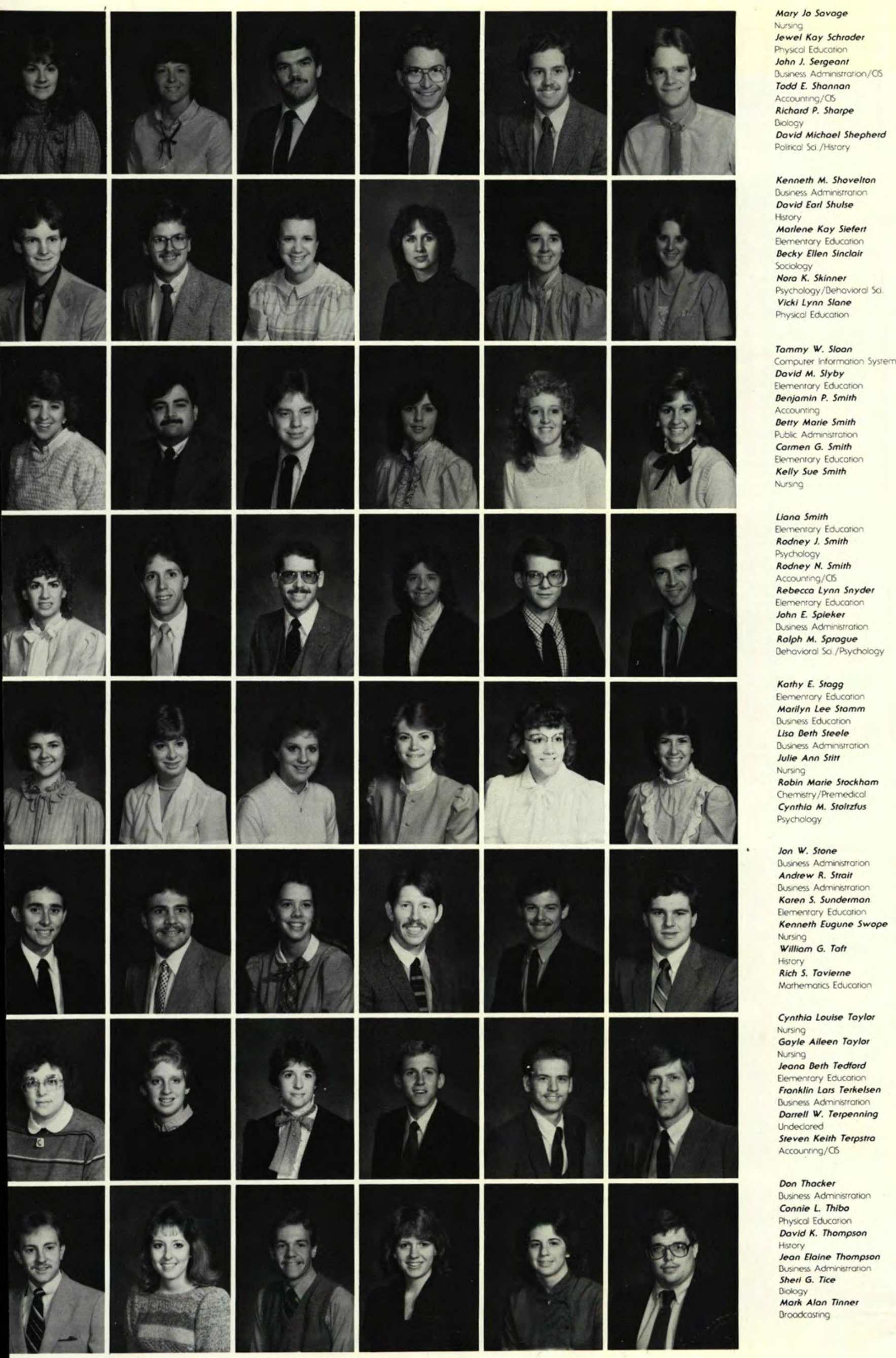




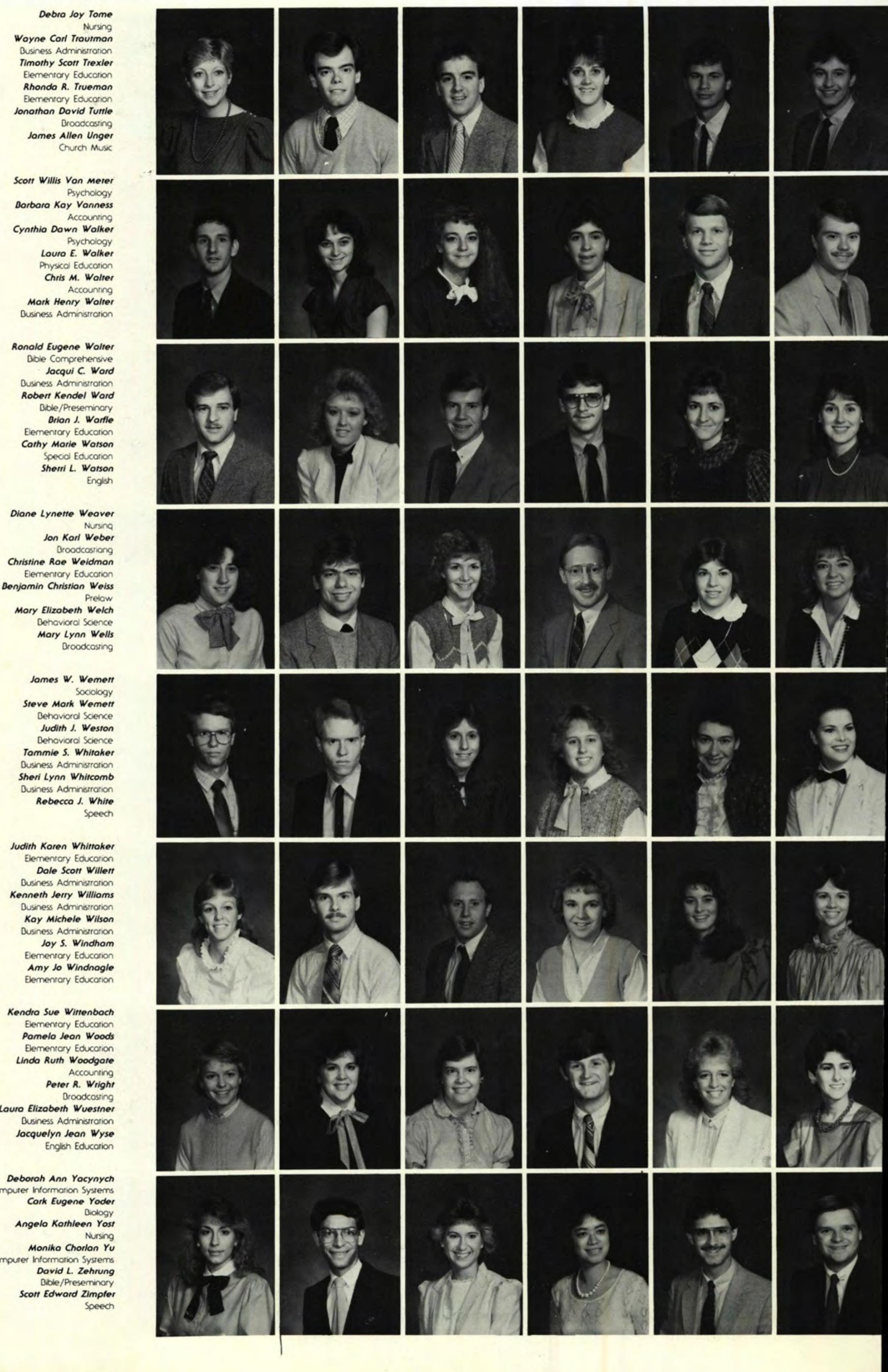




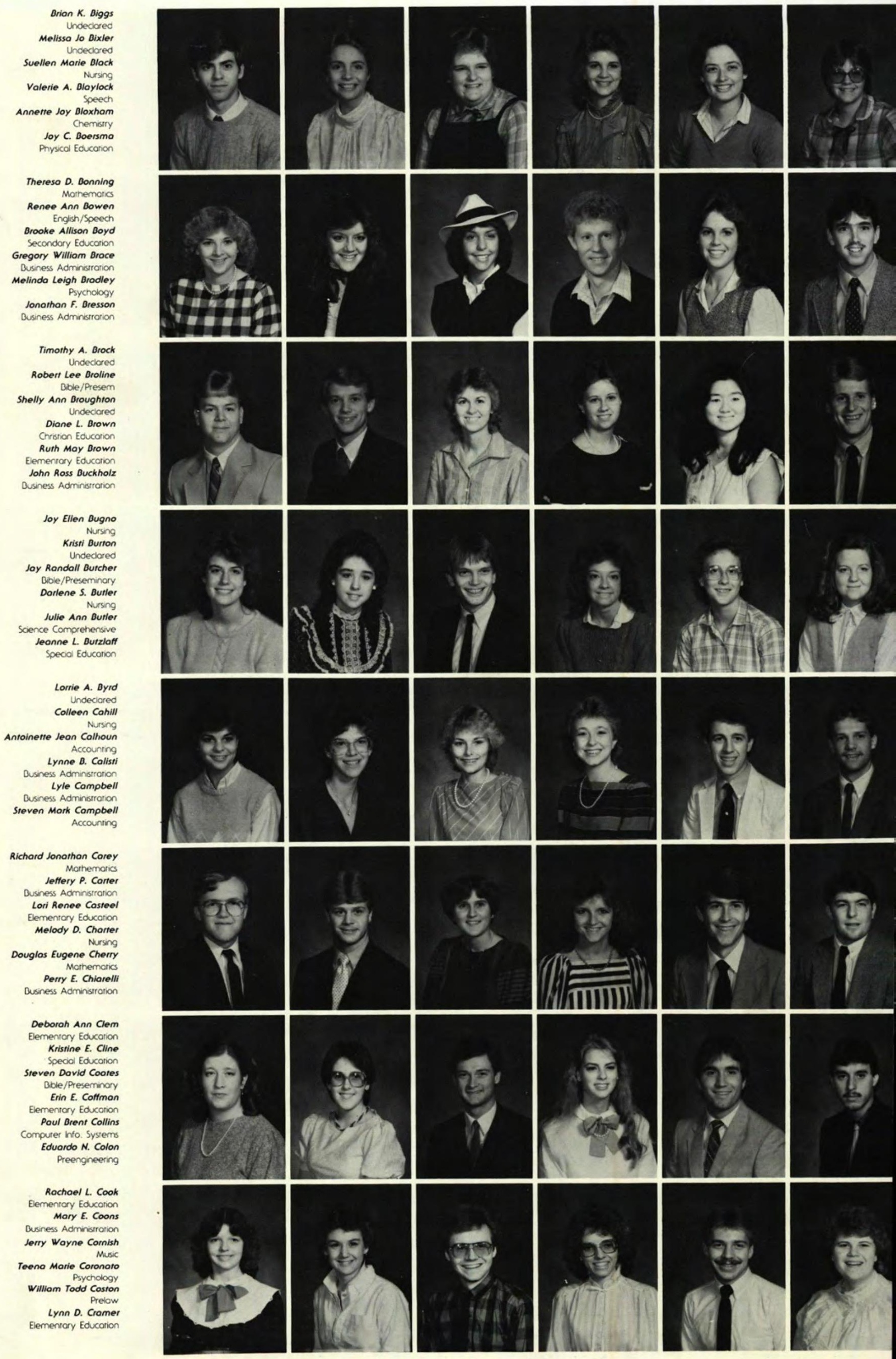




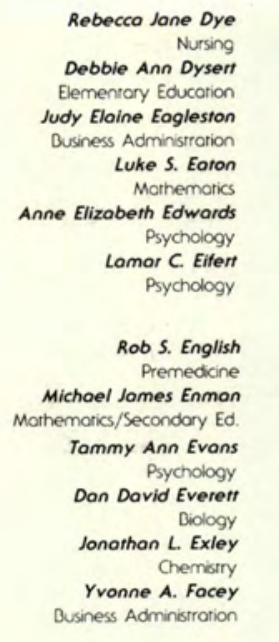

Liso Christine Fowcett

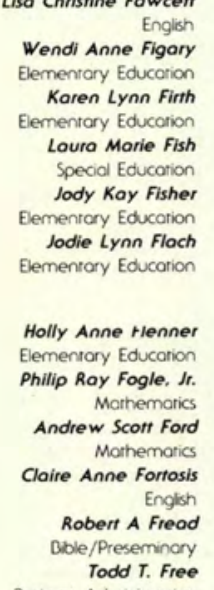
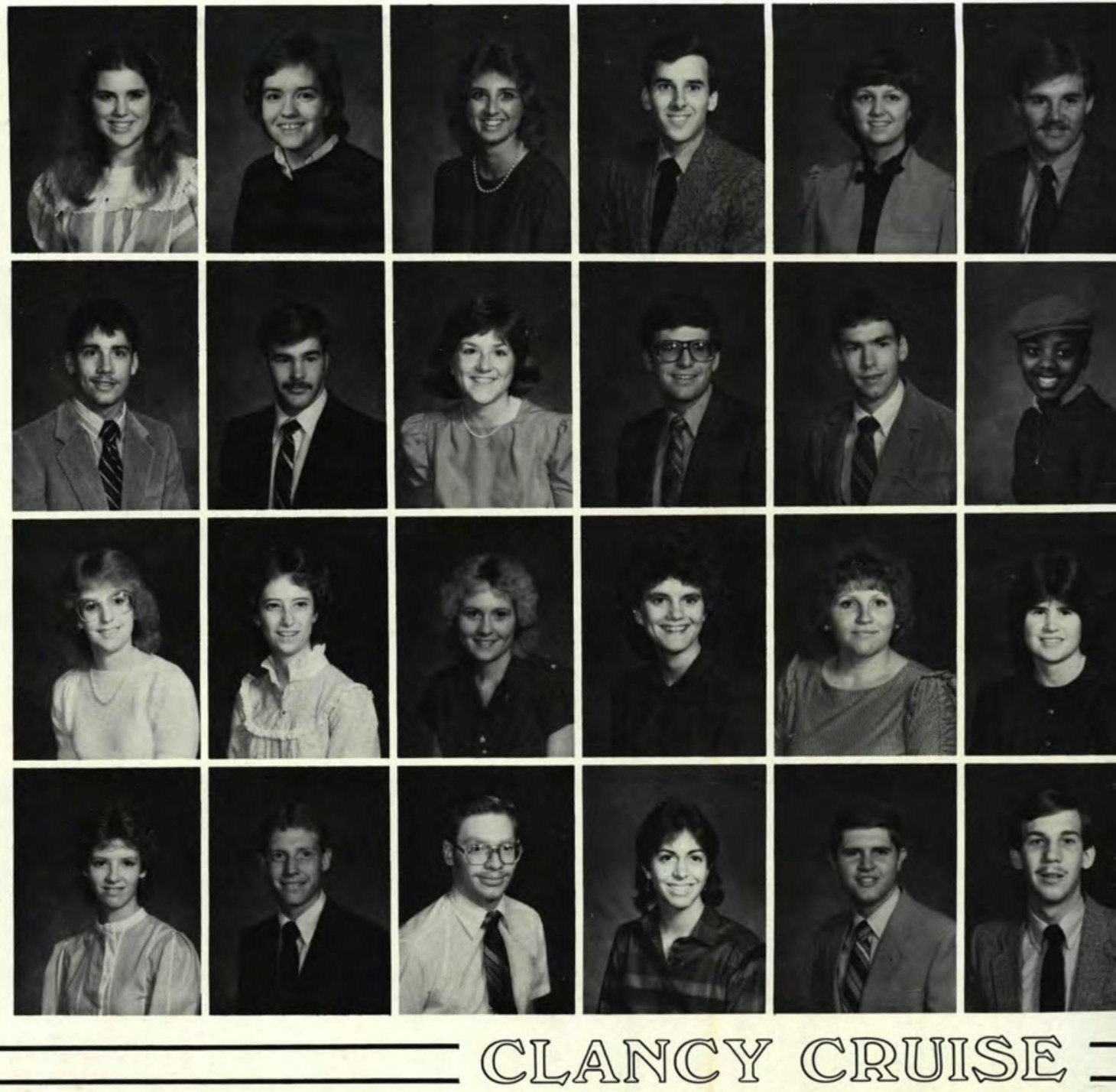

COUISE =

B eing a Bible comprehensive major has given me many opportunities to interact with many different people from different backgrounds. Teaching a Sunday School class at the Campus Fellowship was most definirely the highlight of my sophomore year. The opporrunity to put into practice the reaching and preaching skills that have been developed in me by our fantastic Bible professors has opened up a way to communicare the love for people. I have learned to appreciare more the hurrs and needs of orhers instead of being wrapped up in me all of the rime.

The Lord is also showing me more and more how I need to be disciplined in everyrthing I do, either here ai school or at home. Being a part of the class of 1987 is a privilege, considering that it is the Centennial Class. Having the chance to be a small part of Cedarville's heritage will be an honor I won't soon forger.

Oh, there have been great times run ning track and being on a Christian Service ream, bur the grearest rimes are when one feels the Crearor's prompring by His spirit to draw closer and experience a change or transition in one's life. Yes, there are many things I have learned this school year borh in and our of class; but the one that was the hardest for me to learn and had the most benefits was when I learned to love and respecr people for who they are and where they are. The objective of any kind of minister of God is to push the souls of people Godward. To do so, one must first earn their respect. These two verses are the verses that raught me this lesson and I pray they will do the same for you

Acrs 10:34 "Then Perer opened his mouth, and said, Of a truth I perceive that God is no respector of persons;"

Proverbs 15:1 "A gentle answer rurnerh away wrath, but a harsh word stirs up anger.'

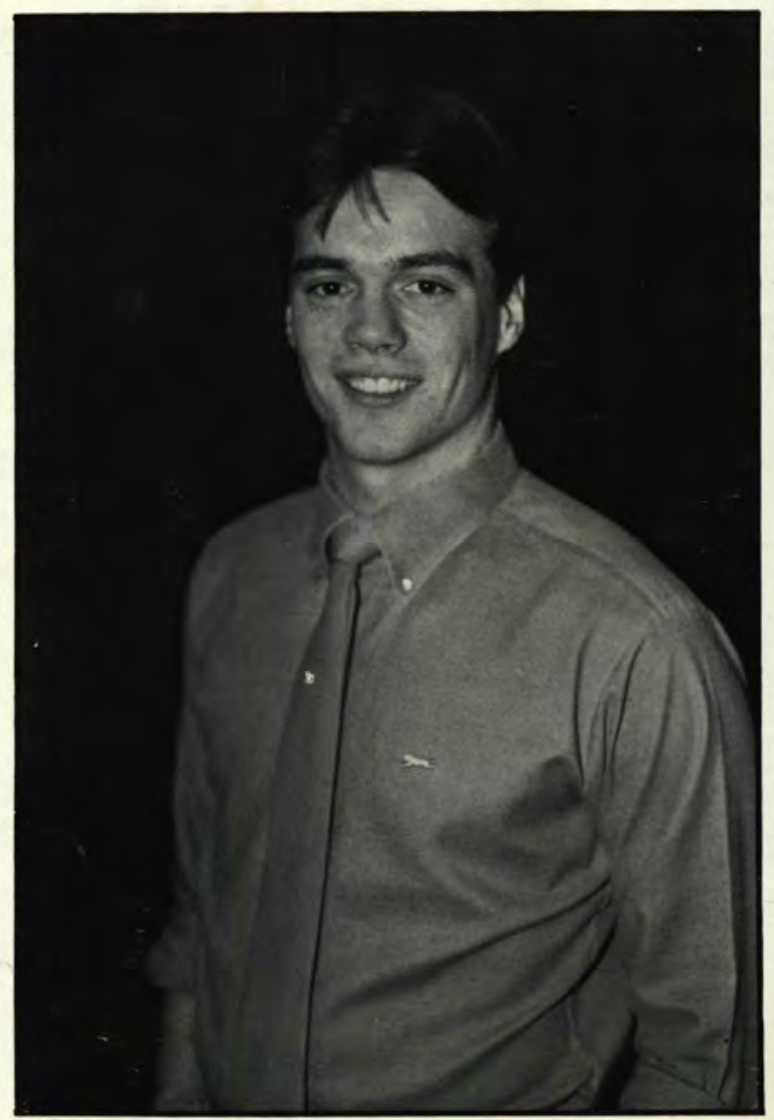



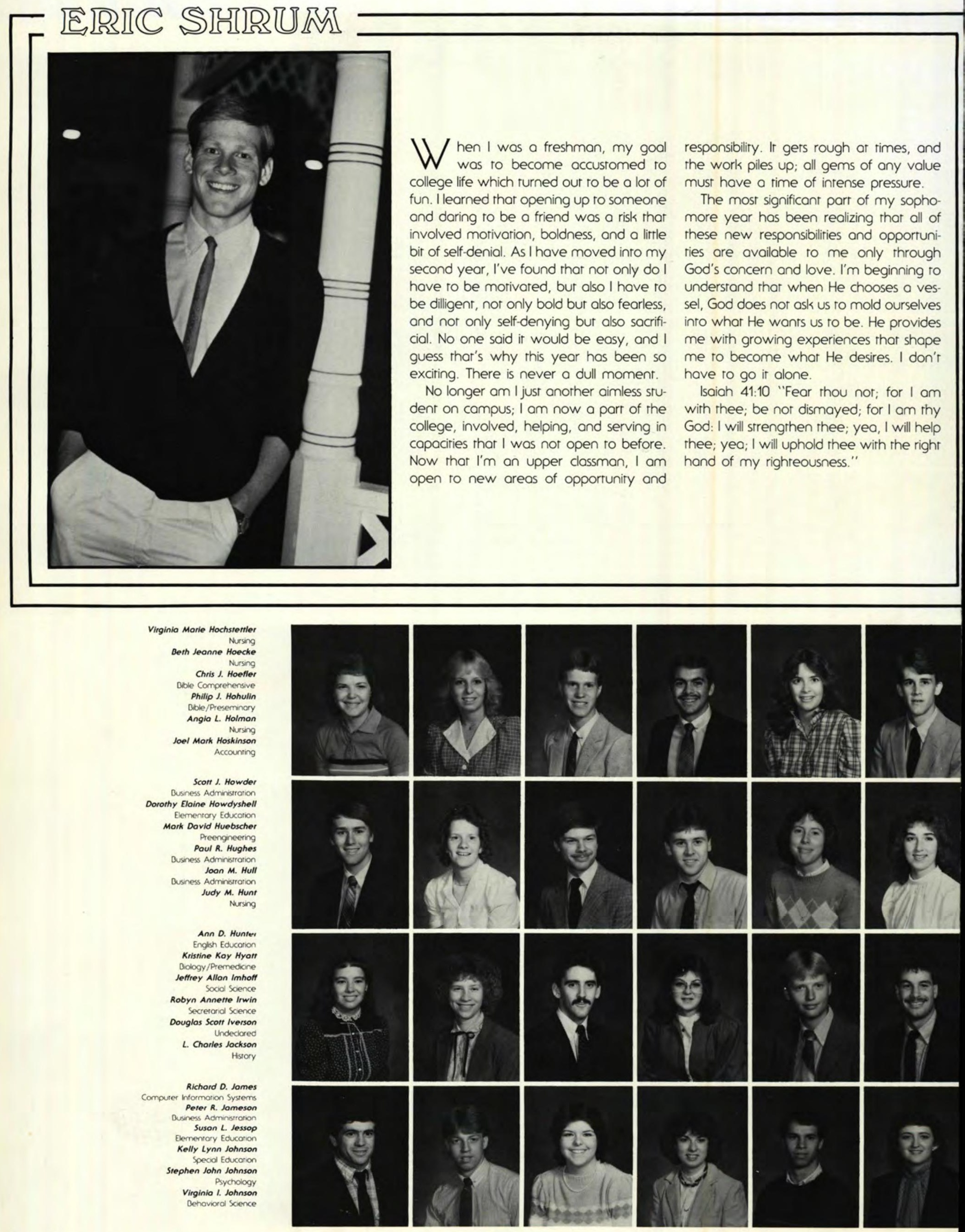


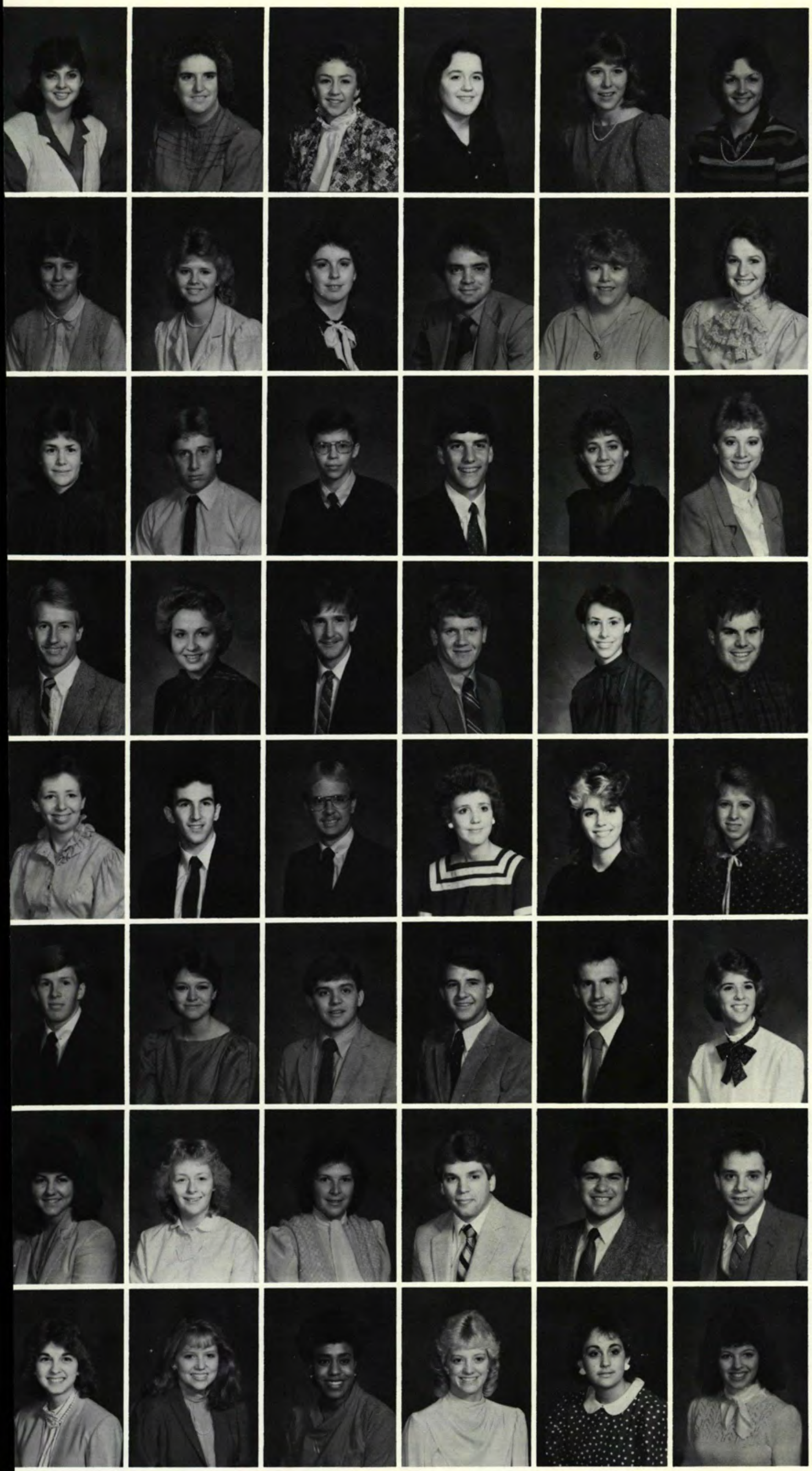

Robin Lynn Johnston

special Educotio

Marsha Jean Jones

Accoun $C$ ines

Mary C. Jones

Rebecco Sue Jones

Nursing

Suzonne Eve Jones

Behovioral Soience

Tommy Lynn Jones

secreranil science

Valerie C. Jones

Behoviord Science

Lynn Marie Kodamus

Business Administrotion

Susannah M. Kamphous

Morh Education

Bible Comprehensive

Joyce Lynn Keim

Jennifer L Kellogg

Morhemorics

Sandra Frances Kennedy

Behovioral Science

Richard Glenn Kensinger

Broodcosting

Richard Thomos Kester

Undedored

Dovid Williom Ketchom

Business Administration

Rebecco Ann Klopp

Pusiness Administrotion

Elementary Educarion

Ron S. Kimbrough

Undectored

Beth Ann King

speech

Russell Allan King

Physical Educarion

Jomes Loddin Kirtland, Jt.

Accounting

Donielle Koy Kizer

Business Administrotion

Jeff $w$. Kline

Behovioral Science/Psychology

Mory Beth Knicely

Accounting

James $R$. Koerber

PJic Administrotion

Preengineering

Kothy Ellene Krull

Dusiness Administration

Rhonda L. Kyser

Nursing

Susan Jone Lofferty

Business Administration

Michael C. Lane

Bible Comprehensive

Sondra M. Lauterboch

Mischoel David Law

Michoel David Low

Jeffrey Alan Leach

Sponish

Doniel E. Leitch

Undeclored

Doris Ann Lindley

Psychology

Michelle Barboro Livingston

Nursing

Cortherine M. Lombord

Nursing

Lindo A. Lons

Accounting

Jeffrey Todd Loomis

Dible one year

Alberto Lopez

Diology/Premedicine

Donald H. Lough, Jt.

Premedicine

Amy L. Lydic

Secrerorial Science

Shoron R. McAllester

Secreroriol Science

Tonyo Renee McBee

Undedored

Dione Roe McClure

Music Educonion

Diona Lynne McConnell

Benovioral solence

Tracy Lynne McCoy

Psychology 


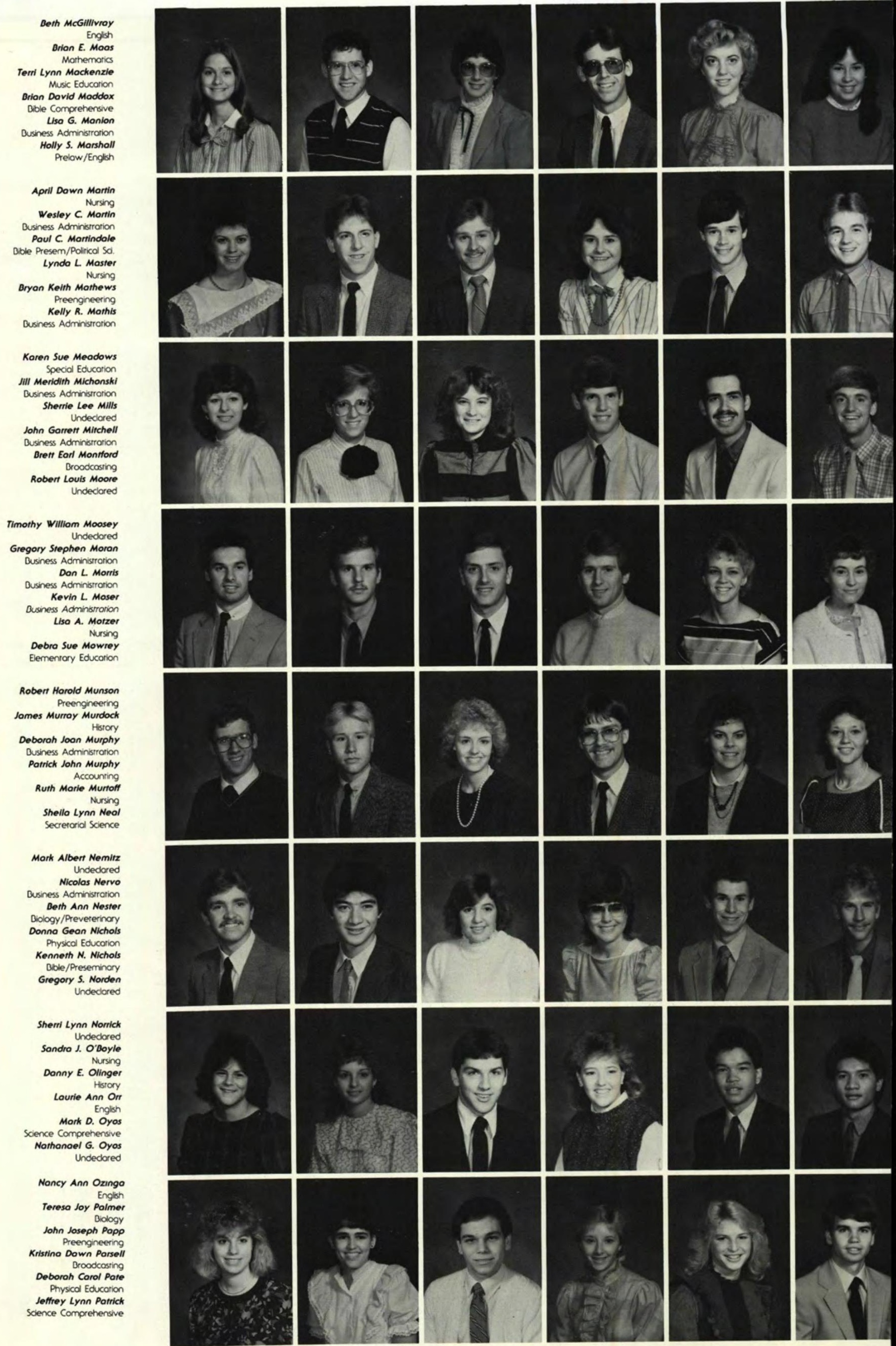




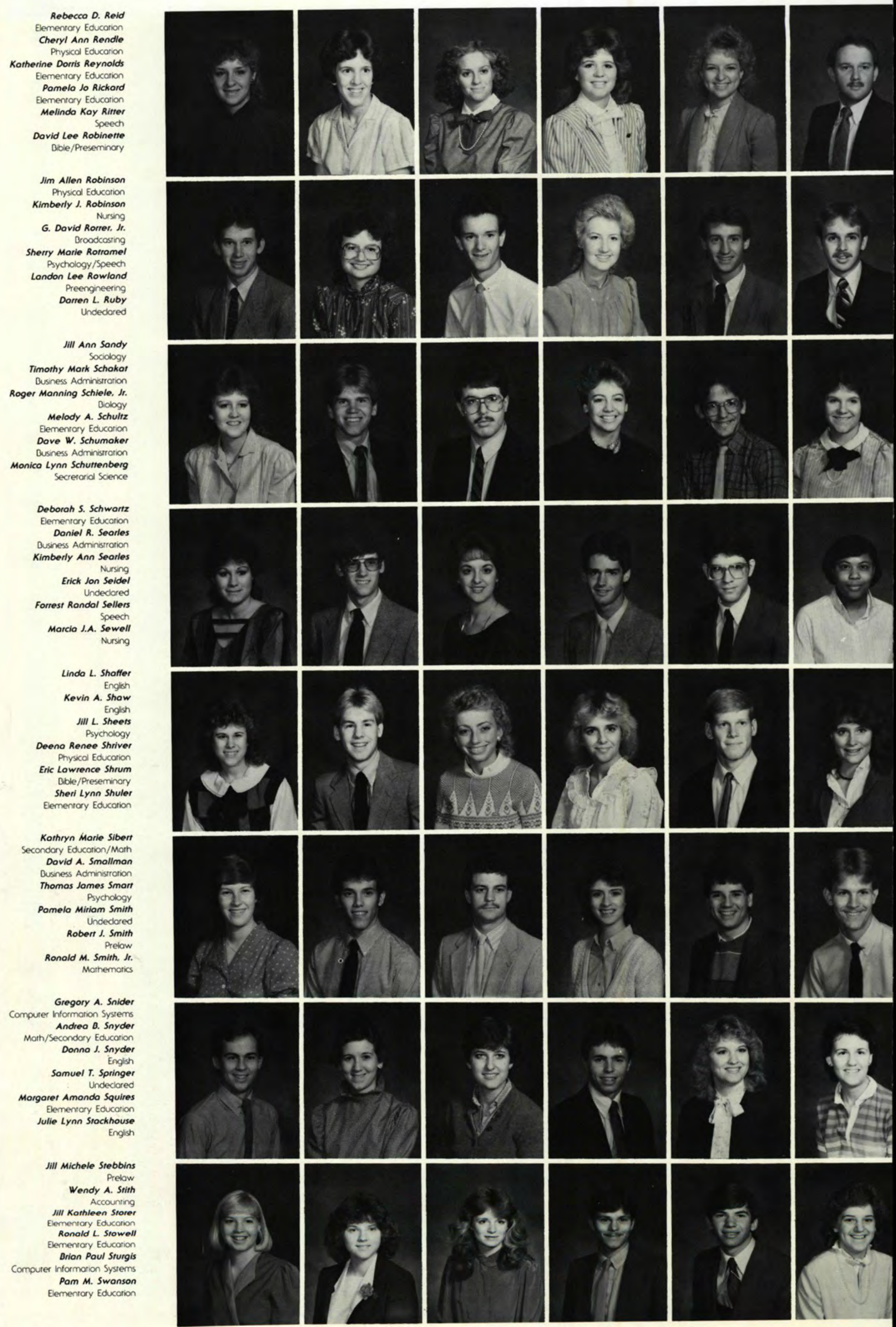




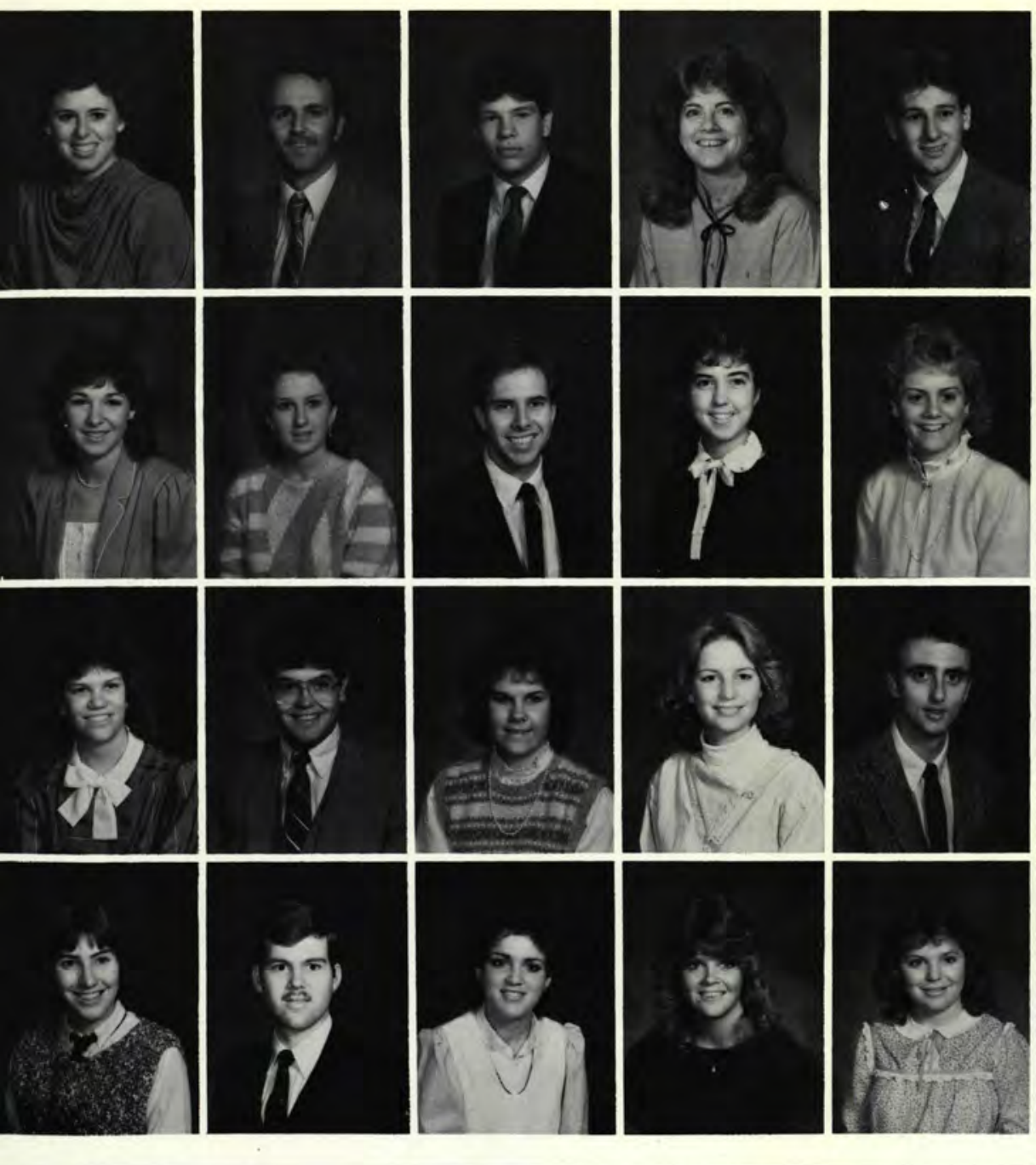

\begin{tabular}{|c}
\hline \\
\end{tabular}


Kimberlee Shermon Venmon Accounting
Jeffrey Allen Vestrond Traci Diane Voorhis Gerald Clayton Wolloce, Jt. Business Adminstration Jonel M. Wolloce Business Administration Physical Educorion

Doniel Lowrence Wolter Dibie Comprehensive Steven Phillip Wolte Elizobeth A. Woltrip Dusiness Adminsto Drons Adoy Wolz Drondon Try wal Jonathon David Woltz

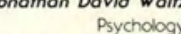
Jonice Lynn Worren

Shari Lynn Woshburn Special Educarion Andy 1 . Wotson Qusiness Administratio Robert Kent Watson Kristin Roberto Weber Elemenrary Educorion Amy L. Welch

- Aaron M. Whitocre undeclored

Douglas Dean Whittenburg Accounting $/ C D$ Dovid A. Wilinamoki Preengineering Angelo G. Wilcox Kothy Ann Wilkinson John Timothy Wilson Business Administrotion

Tanyo Lynne Williamson Tanyo Lynne Williomson Charline Wilson Charline Wilson John Andrew Wilson John Andrew Wilson Tereso Diane Wilso English/secondory Educotion Donne Reho Windish Donna Reha Windish Robyn R. Wiseman Spanish

Jonet Lynn Wittkind Stephen E. Wood Music Educarion Amy Suzanne Wright

Barboro Yando Elementory Educori Dovid Anthony Yeoger Robin Kimberley Young Spanish

Thereso Lynn Youngless Angela Zougg Elementory Education Ric Zehr

Business Administrotion

Brent Dole Ziegler Preogriculure
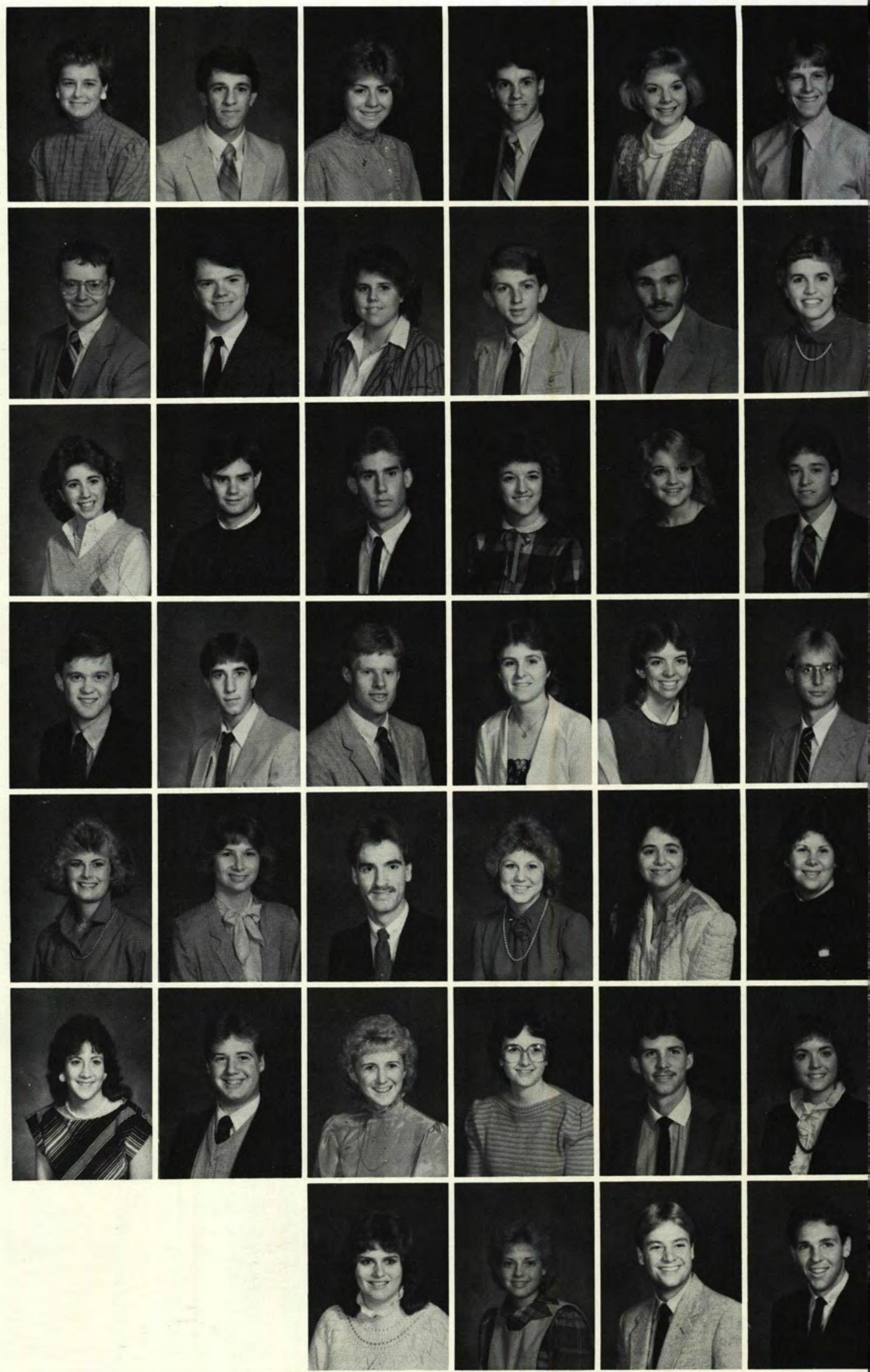

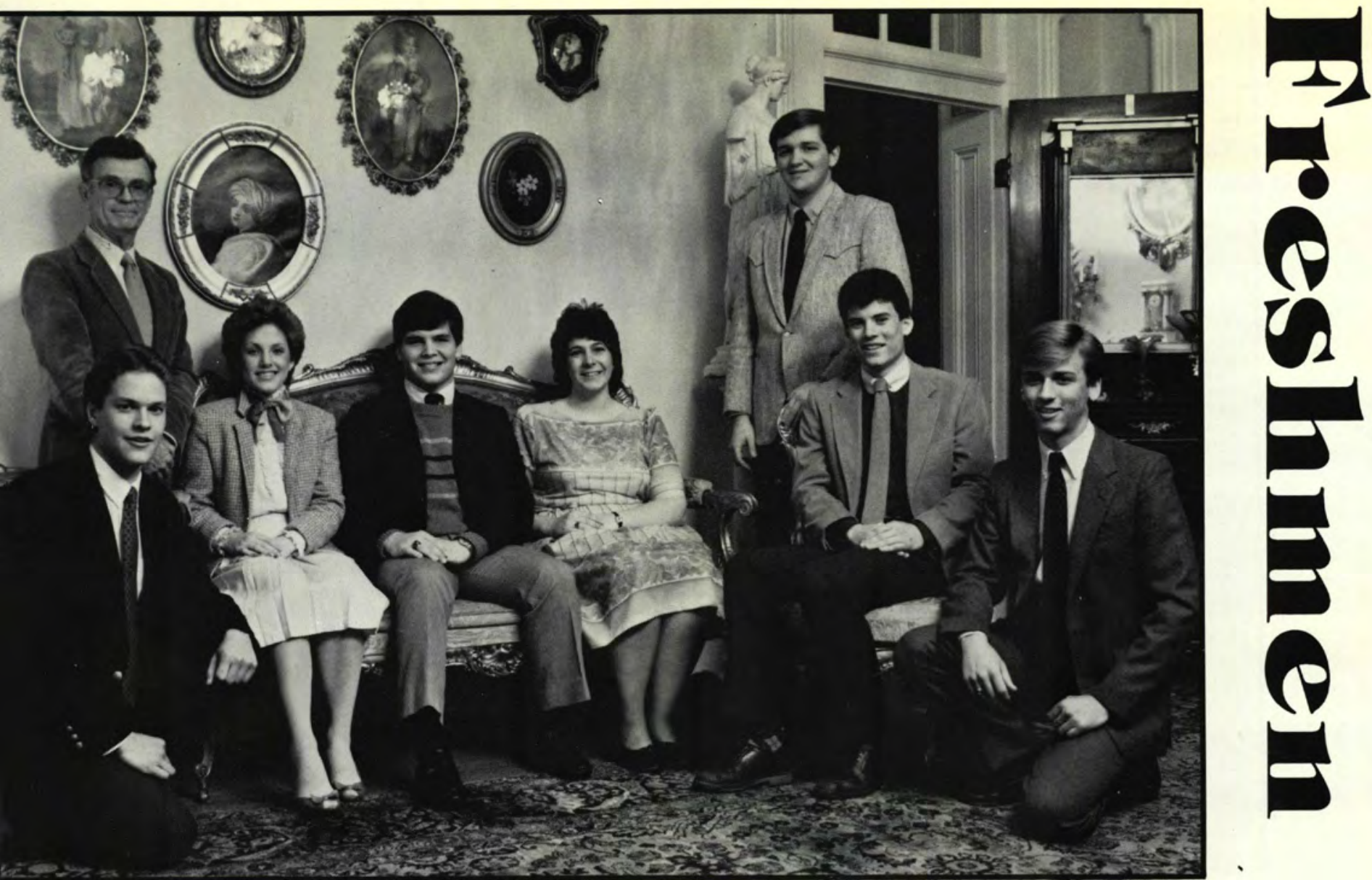

Class Officers: Representarive - Greg Harris, Advisor - Harmon Bergen, Secrerary - Lori Papp, Vice President - Todd fummel, Treasurer - Cindy Guido, Chaplain - Errin Mulberry, President - Bob Gresh, Representarive — Keirh Dewalr.

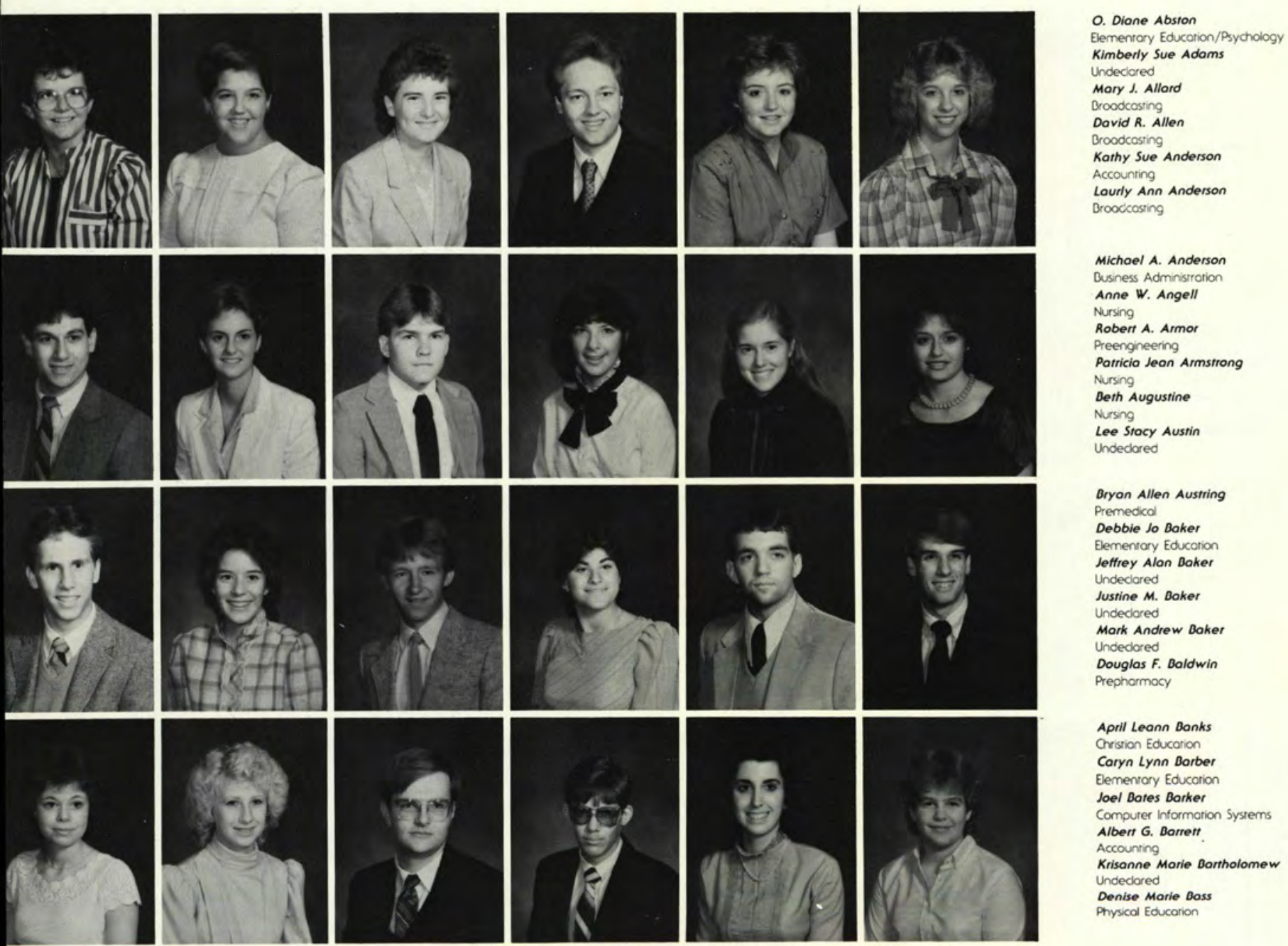




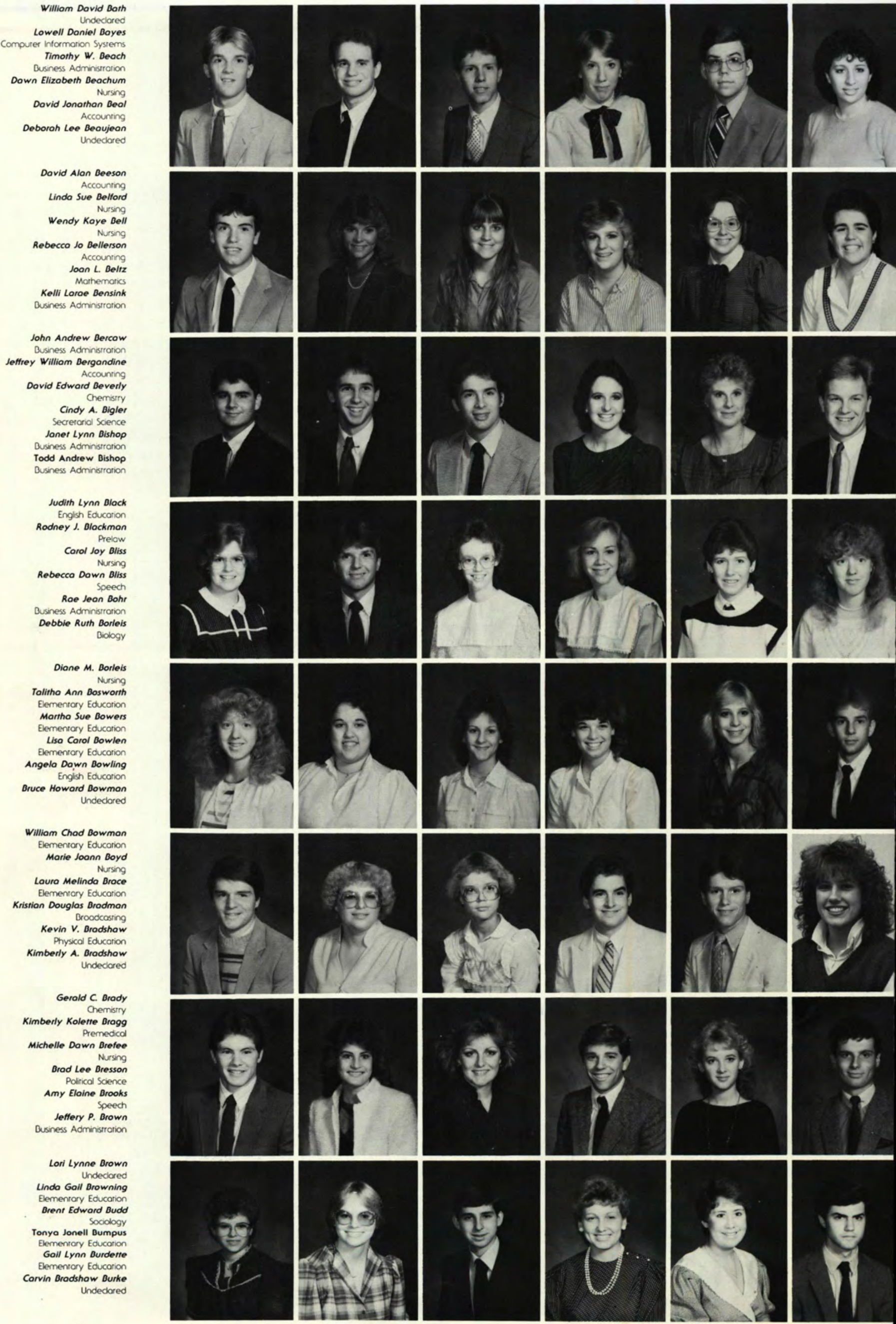








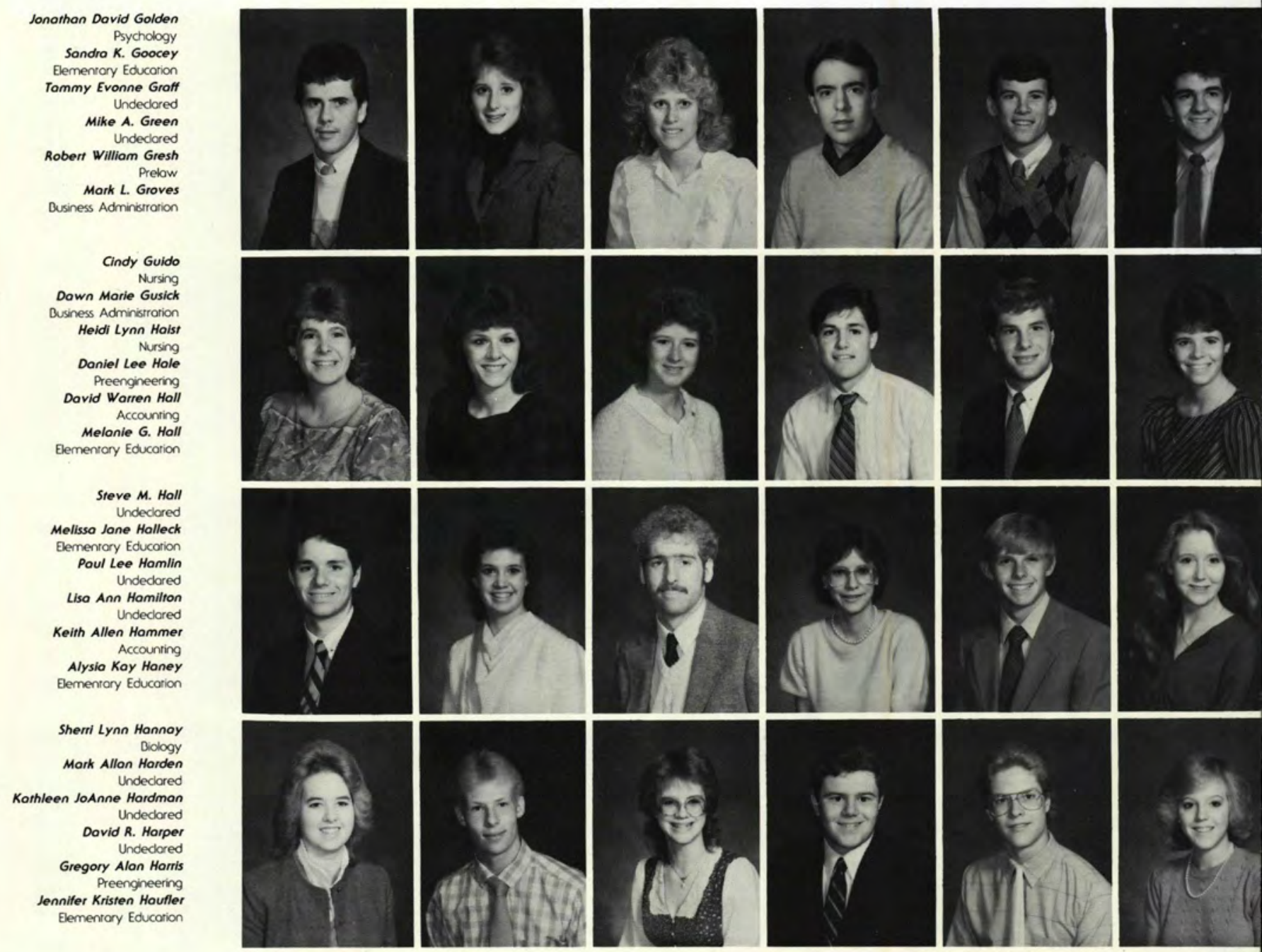

Yes, God had given us a second
chance after high school to be freshman again. We came to college expecting it to be rotally different. We had visions of wild coed parties, all night study sessions and dates with the opposite sex. But reality soon set in; the parties were for from wild (with an exceprion of the "reindeer" at the freshman Christmas party); the study sessions were adjourned, and dares were few and far berween.

We soon had the campus down like the back of our hand along with the layout of downtown Cedarville. Our first shopping spree consisted of the microwave sale at the hardware store, $19 ₫$ tomaro soup at the Village Super Value, and a small garage sale. After the achievement of becoming second quarter freshman came the arrival of our first big day in Dayton. All we can say is that Dayton Mall has never seen such excirement

Our time here ar Cedarville has been very special. We have borh made many close friends that will lost a liferime. The Christian unity we have felt has enriched our lives, making Cedarville close to our hearts.

KIR \& RADOL ROGALEW WIRI =

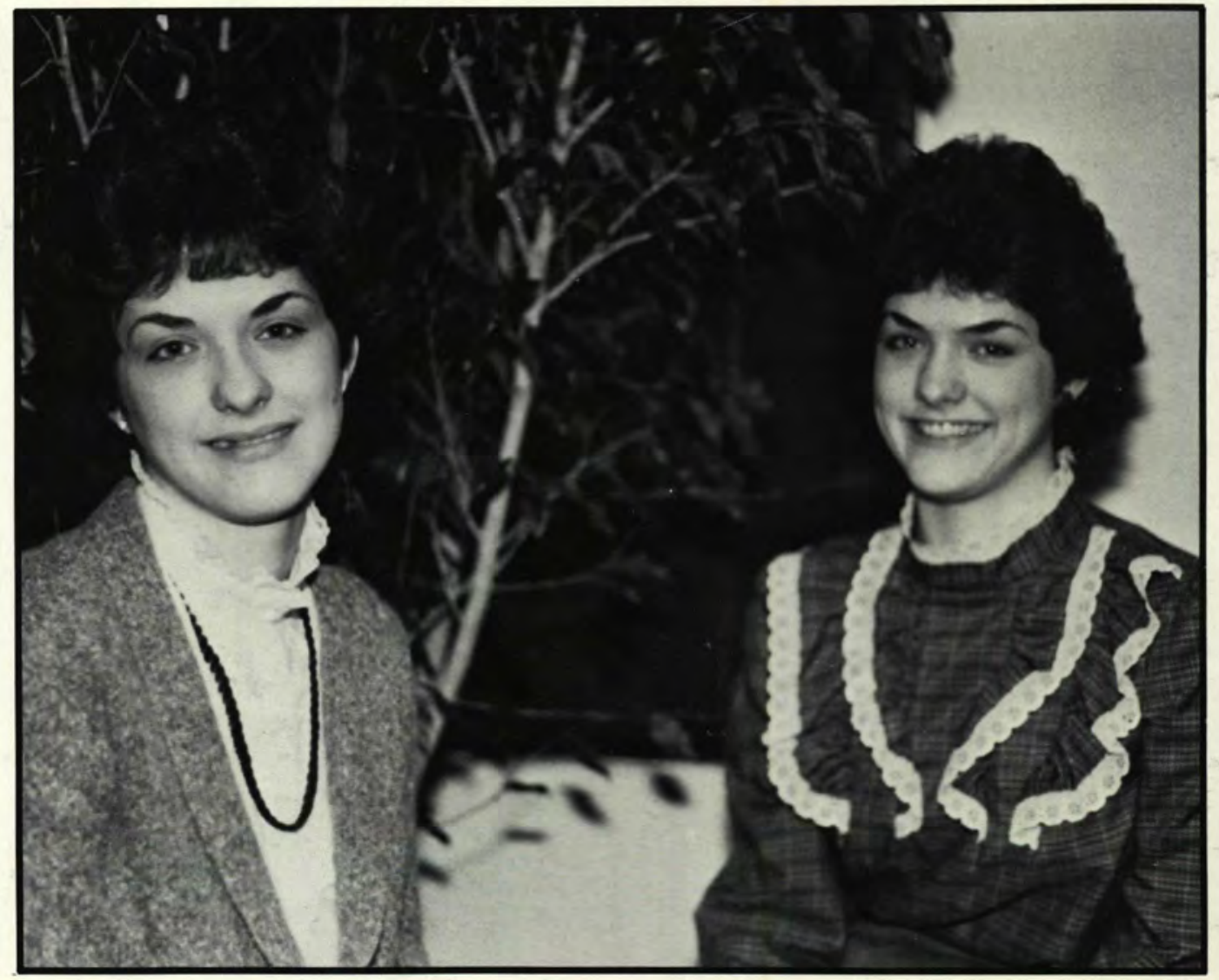


Any rhings come to my mind when M I remember this first year ar Cedarville. I think of the fun of Homecoming, the comic relief of the "Cedar What" campaign, the plays at Alford, concerts in the Chapel, soccer in the gym, Dr. Dixon's handkerchiefs, and "Vance the Viper."

I think, however, what I will remember most about the $1984-85$ academic year is the friendships I have developed. Yes, it does sound trite, but people care at $\mathrm{Ce}$ darville. I would nor delude anyone by saying that the students at this school are one big happy family all of the time: we all have problems relating to each orher
Yet, in spite of this, we can almost always be assured of being greered with a smile from everyone ranging from Mrs. St. Clair at the switchboard to Chuck McKinney in the cafeteria.

The friends I have made in my unit though my involvement in drama, by "ratting" at the gym and while sitting in class are ones that I have surely come to cherish. I know that God has given me these friends through His special love just as He gave me my ultimate friend, Jesus. It is my prayer that we will all be the kinds of friends which God expects us to be

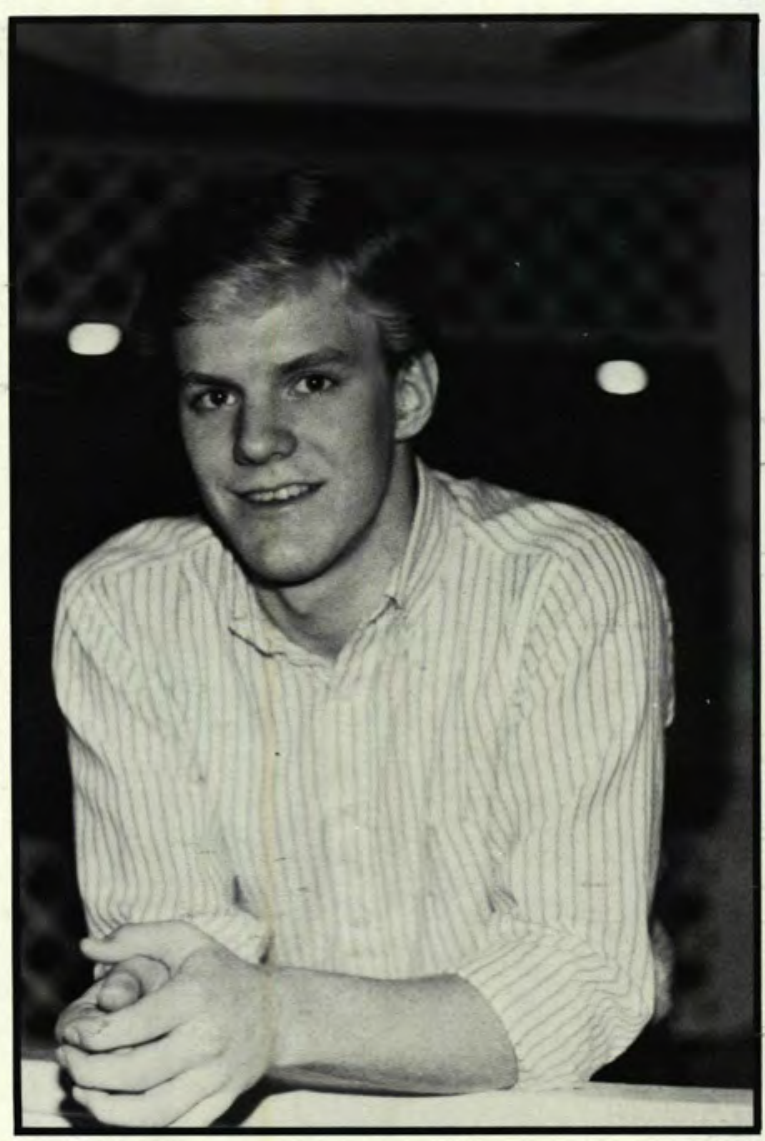

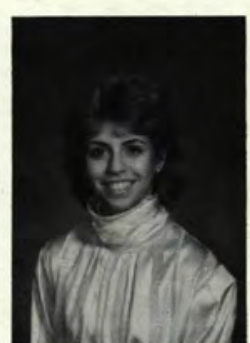
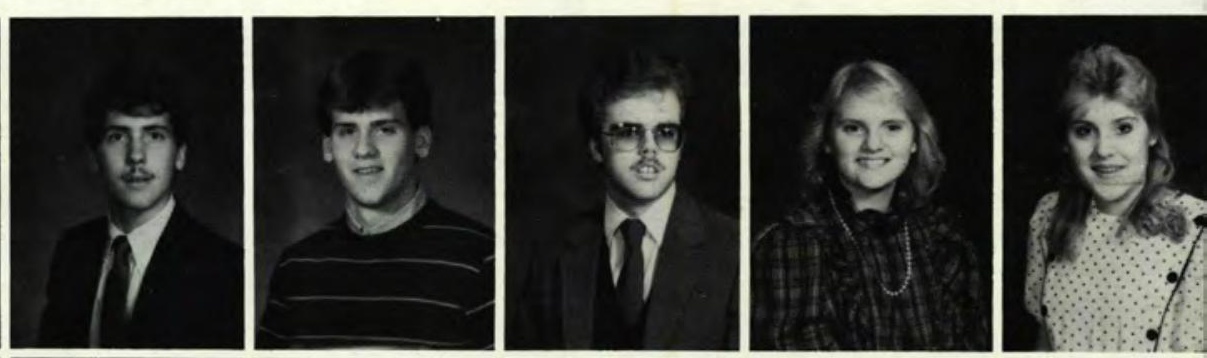

$$
\begin{array}{r}
\text { Jennifer Lynn Kreuscher } \\
\text { Psychology } \\
\text { Michele Denise Loird } \\
\text { Biology } \\
\text { J. Michael Londis } \\
\text { History } \\
\text { Mortin Alric Larsen } \\
\text { Undedored } \\
\text { Rogé Dawn Lash } \\
\text { Undedored } \\
\text { Terry Edword Lossitter }
\end{array}
$$
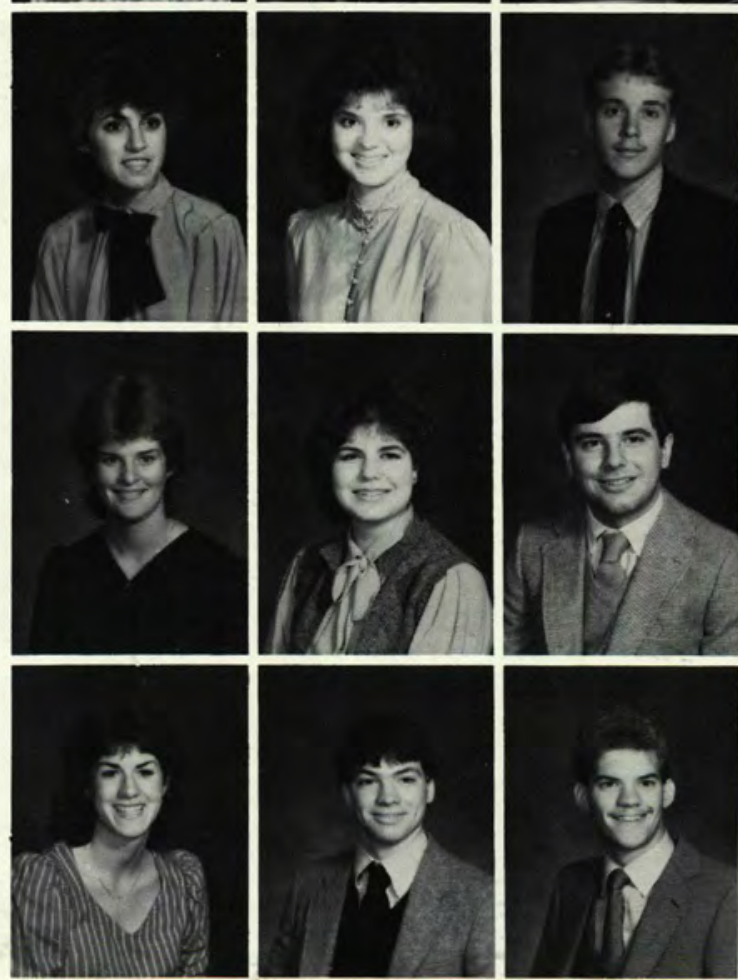
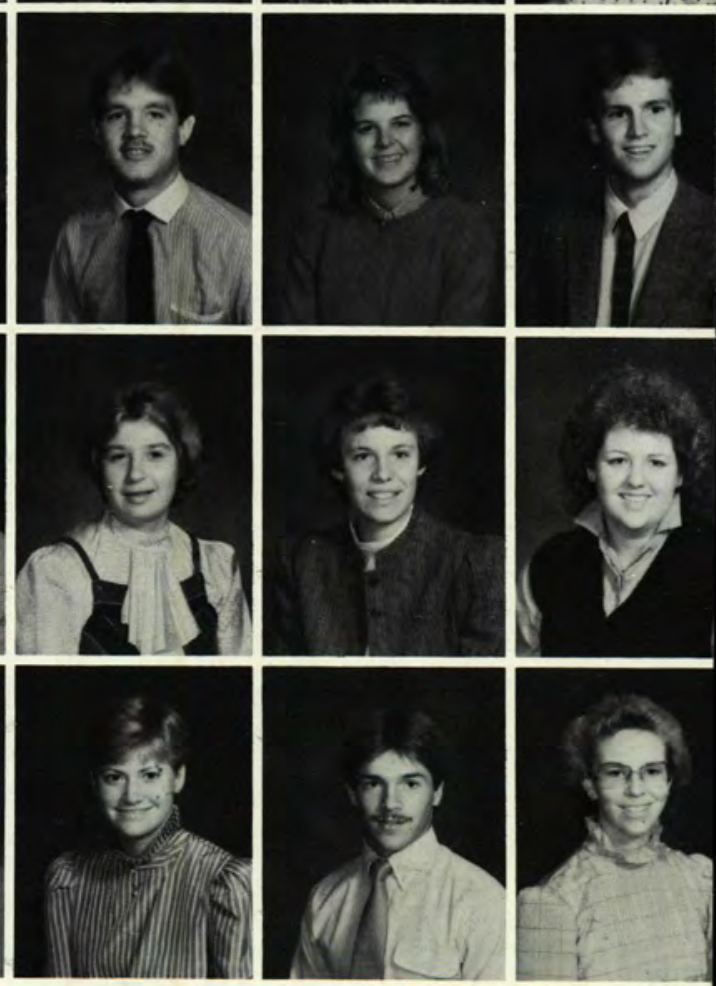


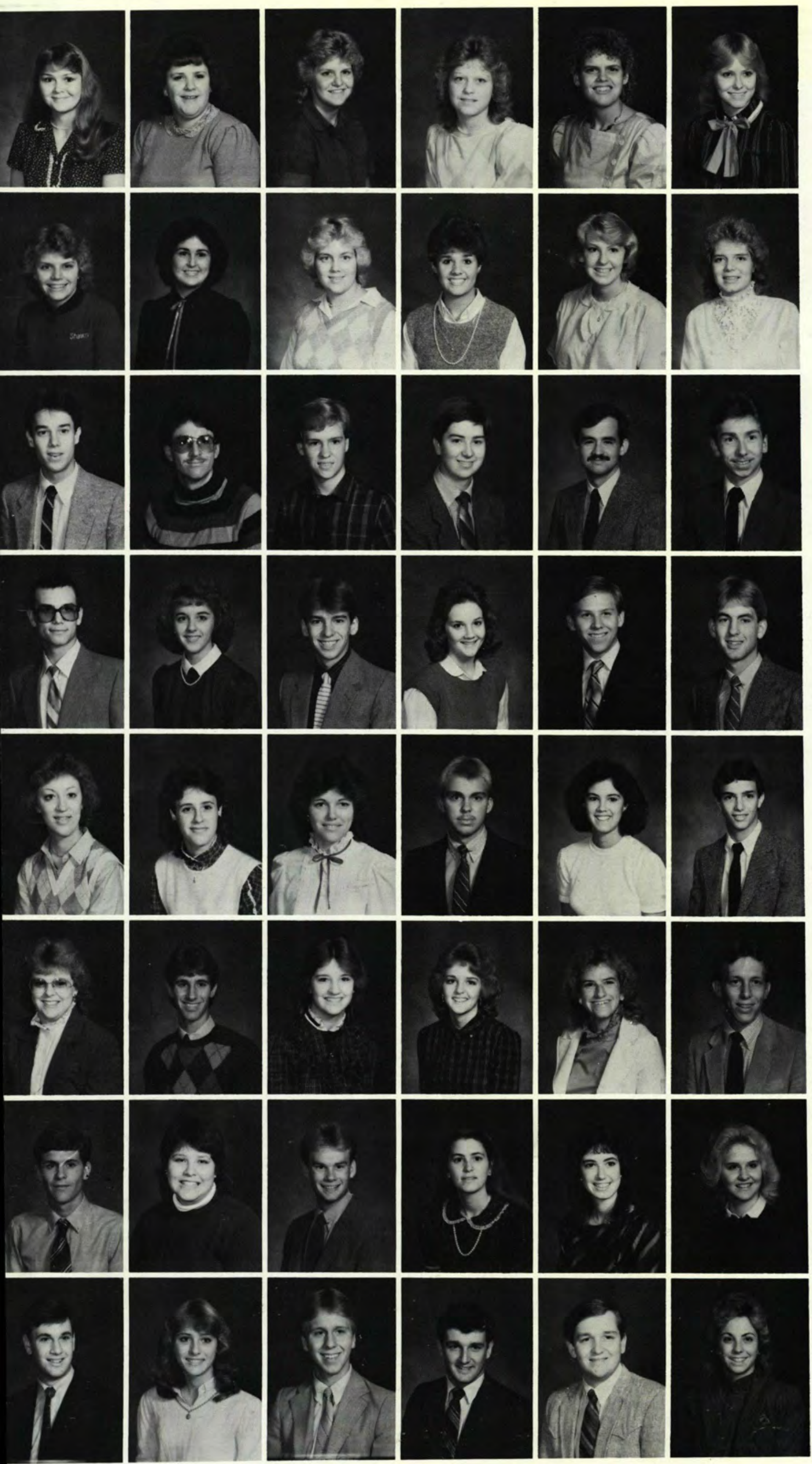

Gina Rae Long

Amy Down Lotrman

Dusiness Education

Syndy 1. McCofferty

sychology

Jody M. McConn

Stocy Morie McCoskill

Stocy Morie McCoskill

Undedared

Theresa Joann McClure

Secreforial Science

Shown Lyndean McConnell

Undedored

Christine Ann McCormick

Elementary Educorion

Michele Lea McGarry

Nursing

Amy Deth McKibben

Behovioral Science

Psychology

Heather Lynna Madorlane

Special Ed./Elementary Ed.

Thomos Stuart Mach

Undeclored

Robbie Allen Mockeen

Morhemotics

Ronold W. Mockey

Undeclared

Mork D. Moglort

Undedored

Jeffrey Donold Main

Music/Comp. Soience

Barry Alan Molek

Business Administrorion

Korl E. Monsfield

Qusiness Administrotion

Kristine Corol Mansfield

Elementary Educanion

Brion Jeffrey Morburger

Ruth Evelyn Margraff

Undedared

David Lowrence Morkison

Accounting

Jeff A. Martin

Prephormocy

Stocy Ann Mellor

Secrerarial Science

Deboroh Lyn Meriwether

Accounring

Jonet Koy Merriman

Qusiness Adminstration

Dusiness Adminstrotion

Sharon Lynn Michoel

Shom Lyn Mlchoel

Emes

Jomes Dovid Mieden
Undedared

Kimberly D. Miller

Undedared

Andrew Lowell Mininger

Undeclared

Pomelo Sue Mitchell

Nursing

Michele Denise Moody

Nursing

Pomelo J. Moon

Nursing

Christopher Dale Moore

Marhemorics

Kelly Micheal Moore

Undedored

Tommy Ann Moreland

Elementary Educorion

Scott Dovid Morgan

Diology/Chemistry

Ruth Down Morris

Undedored

Holly Ann Morse

Special Education

Jeonnetre Lee Mossburg

Secrerorial Science

Dovid Lee Mossman

Comprehensive Bible

Gretchen Lynn Mountz

Accounting

Steven Robert Moyer

Suviness Administrotion

Poul Kennesh Muckley

Mouthematics

Errin Gene Mulberry

Droodcosting

A. Murray

Diology 


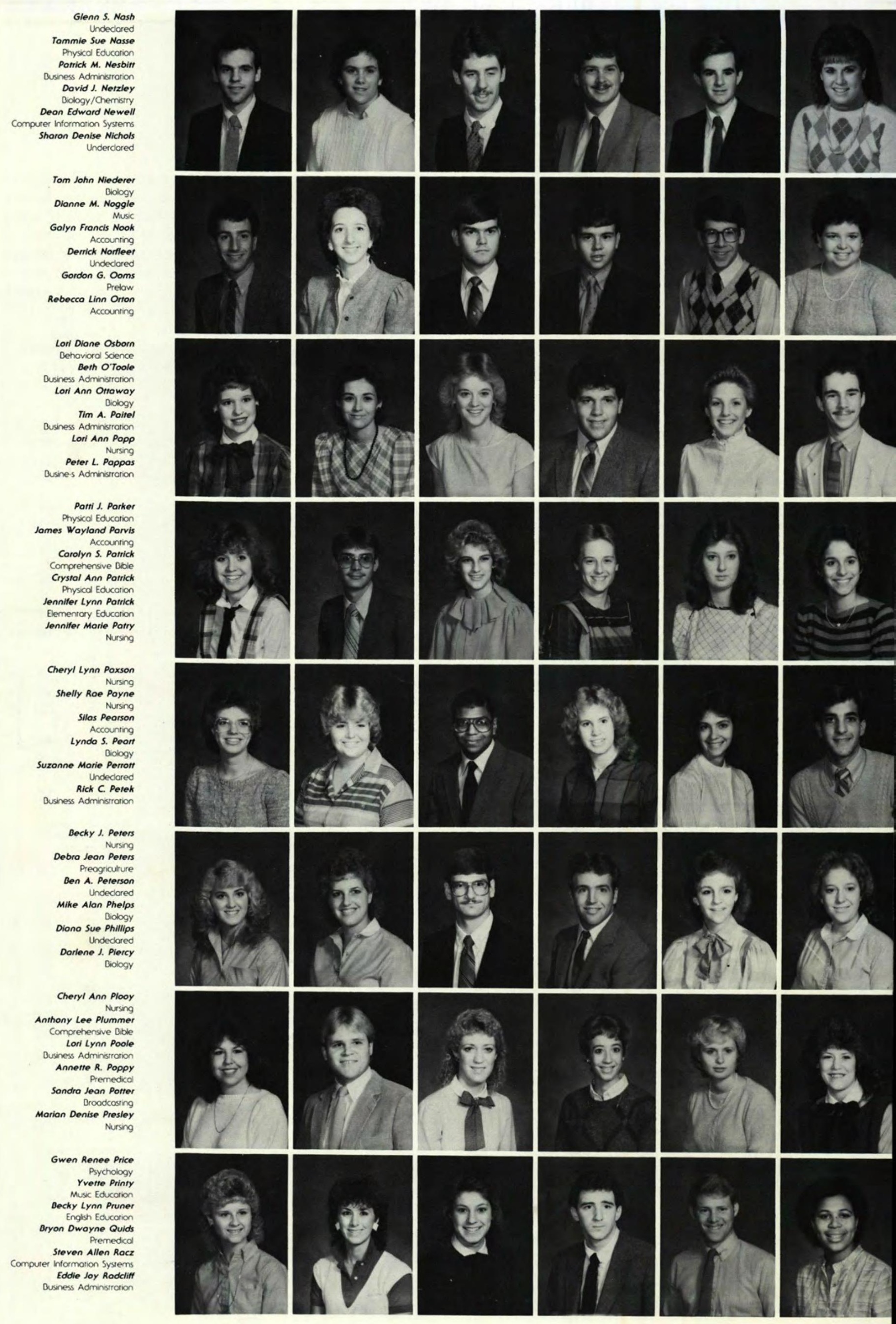




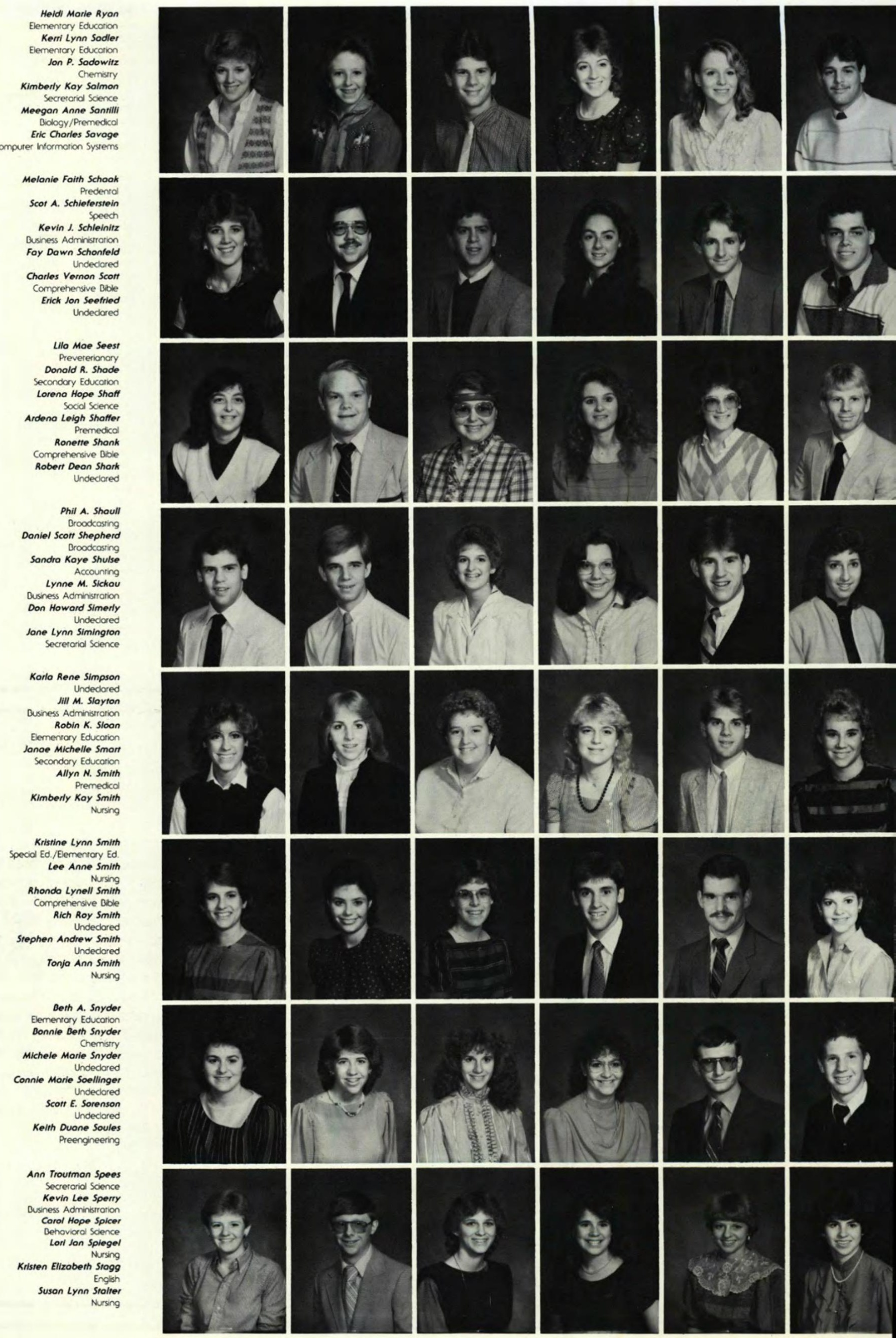



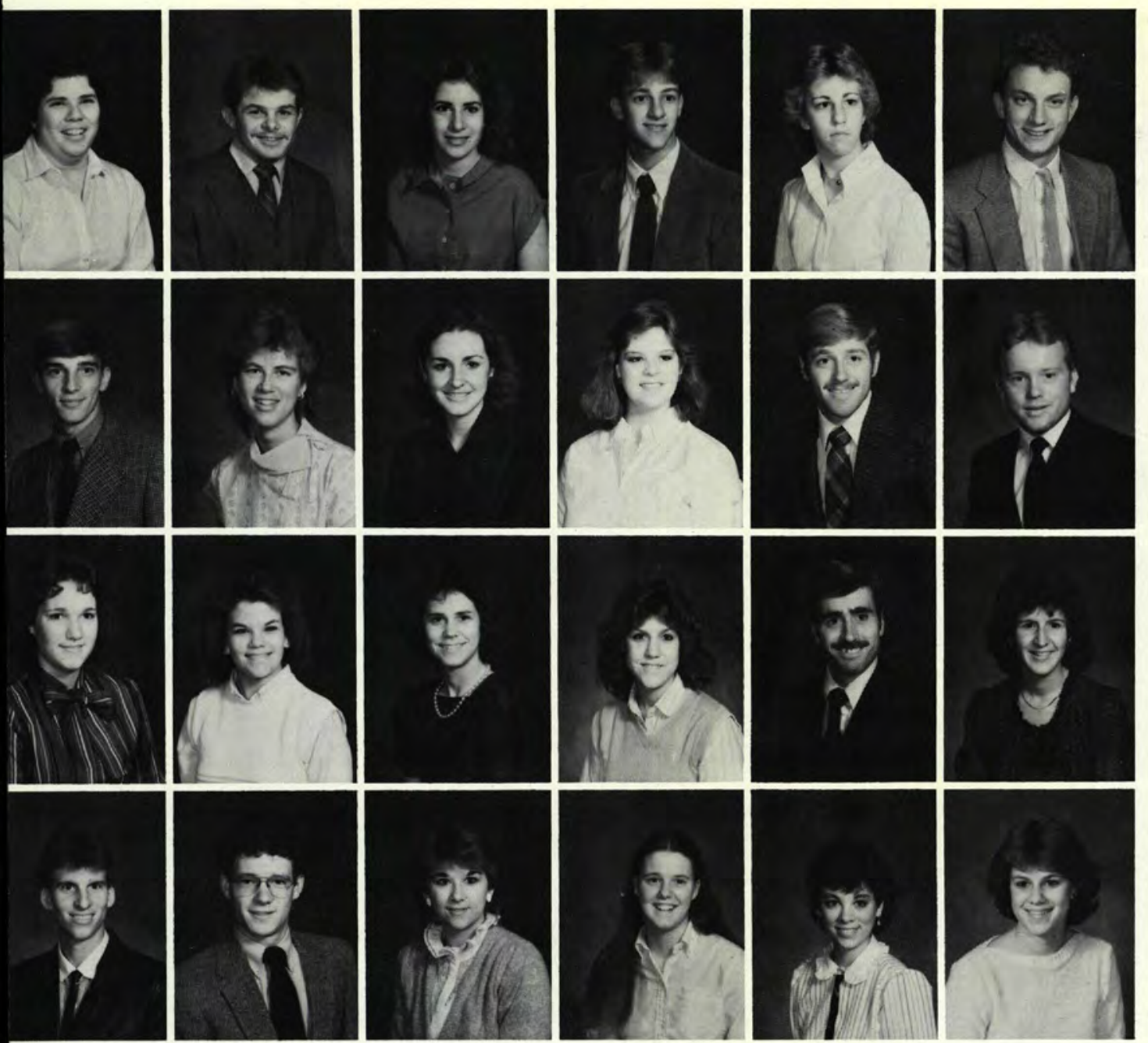

Pomelo S. Stanfill

Business Educorion

Larry Von Starkey

Coredith Ann Sreiner

Meredith Ann Steine

Chemany

John Robert Stephens

Computer hformorion Systems

Betsy Gay Stoltzfus

Undeciored

Kevin Brooks Storms

Psychology
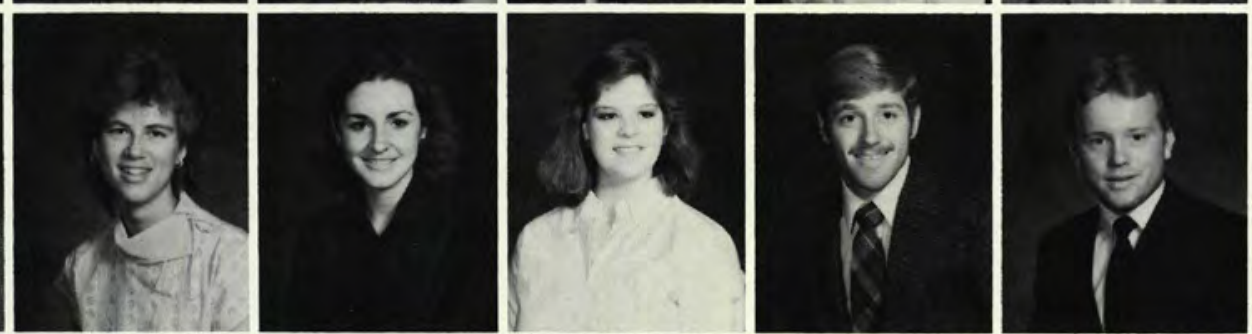

Scott Allan Stover

Accounting

Lilo Louise Strouse

Biology

Heather Renee Stretch

Business Administration

Koren Leslie Stromley

Business Administration

Timothy Paul Schroupe

Business Administrotion

Jock Jomes Stumme

Comprehensive Dible

\section{Brendo J. Sutliff}

Engish
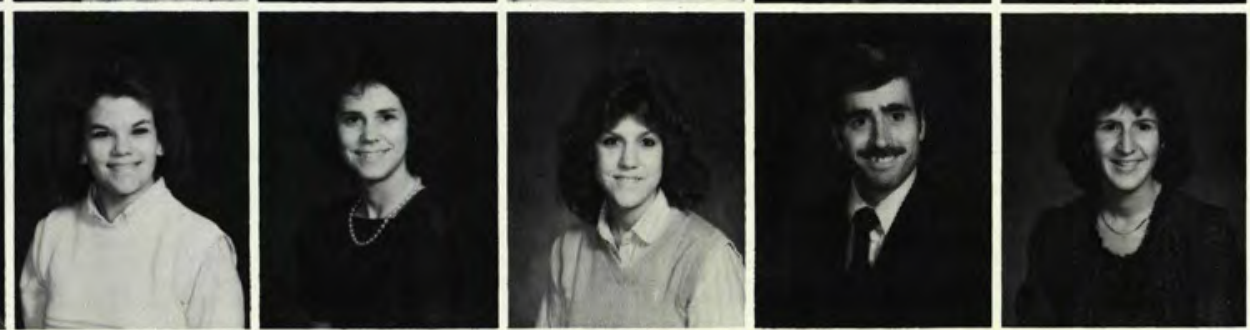

Rebecco Leoh Tocket

Broodcosting

Volerie Jean Teed

Business Administrotion

Linda Kay Tewksbury

Secrerorial Soience

Ronald Dale Thomos

Undedared

Joanne Elizabeth Thompson

Elementary Educarion
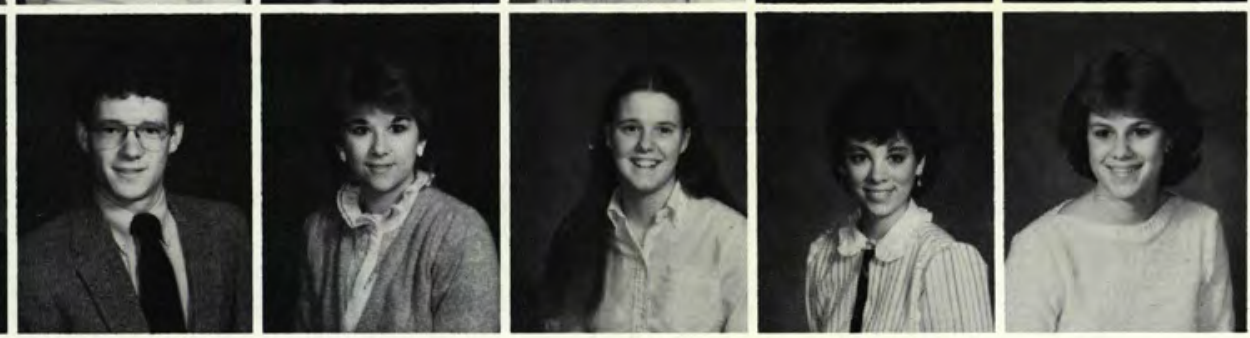

Rob Bruce Thomson

Rob Bruce Thomson

Thomos $R$. Thornton

Undeclared

Debra Sue Timco

Nursing

Penny Lynn Tobert

Undedared

Aubrey A. Tom

Undeclared

Andreo Lee Torok

Undeclared

\section{E Darial Denmis}

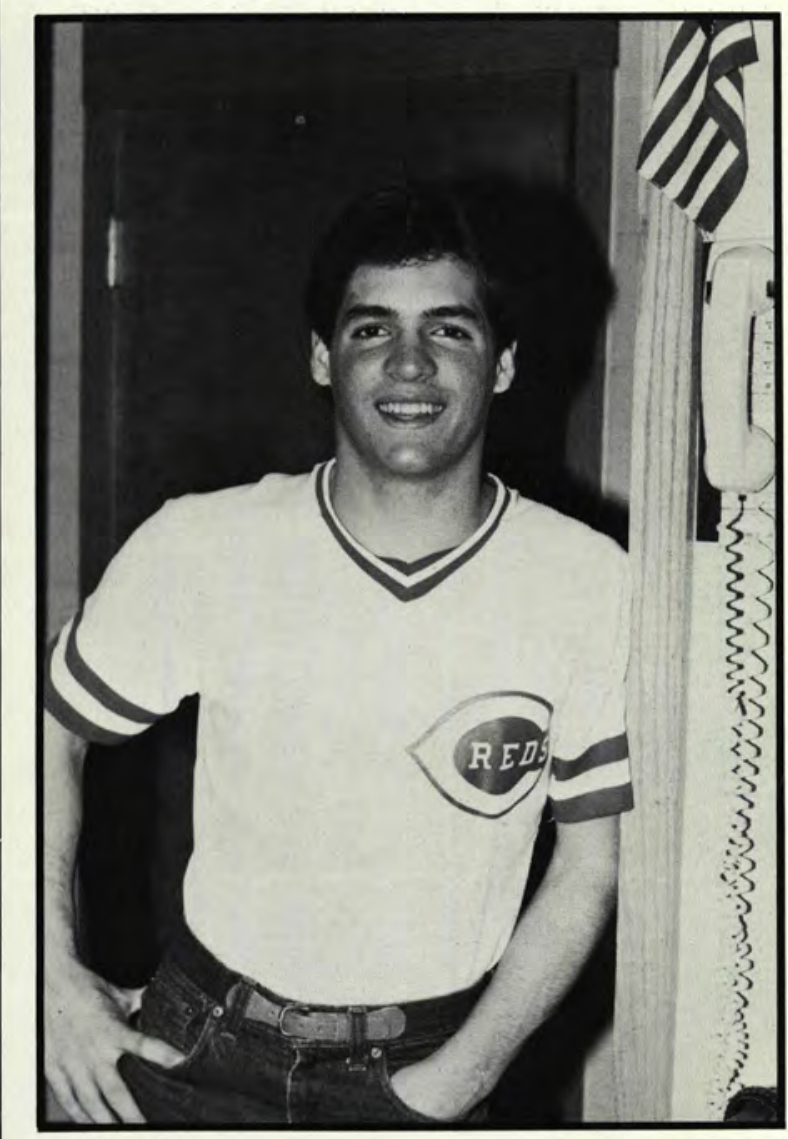

knew the transition from high school and irs lifestyle would be a challenging experience. After being at home in a fairly comforrable and secure environment. all of my life, I knew that all the standards and beliefs I had formed with my parents' guidance would be pur to the test when I was away getring my education. I would be gaining an independency and a responsibility for myself. I realize that this was very important and I needed to go to a college that would build and invest in my life intellectually and most importantly, spiritually.

I realized that the influences on my life as I was on my own could determine my character. I wanted those influences to be Godly - the rype that would make me a better person. I knew from talking with friends and looking at the college that it was the type of college that had these good influences and high standards.

Still it rook some time before I realized that I needed to make a decision to have the artirude that was open to the influences of the sincere Christian people that are here. I think that everyone who comes to Cedarville needs to be open to what it has to offer. We need to reach our and take what God is giving through $\mathrm{Ce}$ darville College. 
Kim Ann Trammel
Dusiness Admin Secreorid Sol

theen Triehy

Volerie Anostosio

Business Administration.

Donald Tung

Englsh
Dovid Christopher Tyler

Undeclared

Kevin Alan Tyree

Undedared

Lori Lynn Tyree

Nursing
Deboroh Sue Uhl

Qusiness Administration

Terri Lynn Vonbeveren

Elementary Educarion

Toni Lynn Vanbeveren

Deborah K. VonDorf

Marhemarics

Mork S. VonKleeck

English

Liso Marie Voughn Business Adminstrotion ompurer Information Systems

James Chase Venman

Undedored

Tamara Lynn Venman

Cynthio Nursing

Cynthio Jayne Wagner

Troy $R$. Woller

Preengineering

Brett J. Woress

Diology/Premedical

Michoel Williom Worfield

Business Administrorion

Melisso Sue Way

Conrad Ray Weaver

Chemisty

Patti Lynn Webb

Carla C. Weitkamp

Undeciared

Deborah Lynne Wemett Secrerorial Science

Loreena G. Westfoll

Elementary Education

Loree S. Wicks

Secrerarial Science

Chris A. Wiedenhoft

Russell Allen Wight

Undeciored

Iim Alan Willms

Undedored

Rebecca Ann Wilson

Elemenrary Educarion

Melissa Modine Windish

Wendy Joy Accounting

indnogle

Down Jylene Winklemon

Undedored

David Alan Wolcort

Jeffrey Owen Wolfe

Preengineering

David Richard Woodard Marhemarics Educarion Morhemarics Educotion
Antony P. Wright

Antony P. Wright
Chemistry

Dave Poul Wuestner

Physical Educarion
Diane Lynn Wuthrich

Diane Lynn Wuthrich

Jill Sharysse Wyse

Undedared

Michelle Morie Yoger

Undeclared

Brian Duane Young Business Administration Christopher Scort Young

Groce Ann Young

Gementory Educorion

Elizobeth Jean Zeck

Business Administrotion
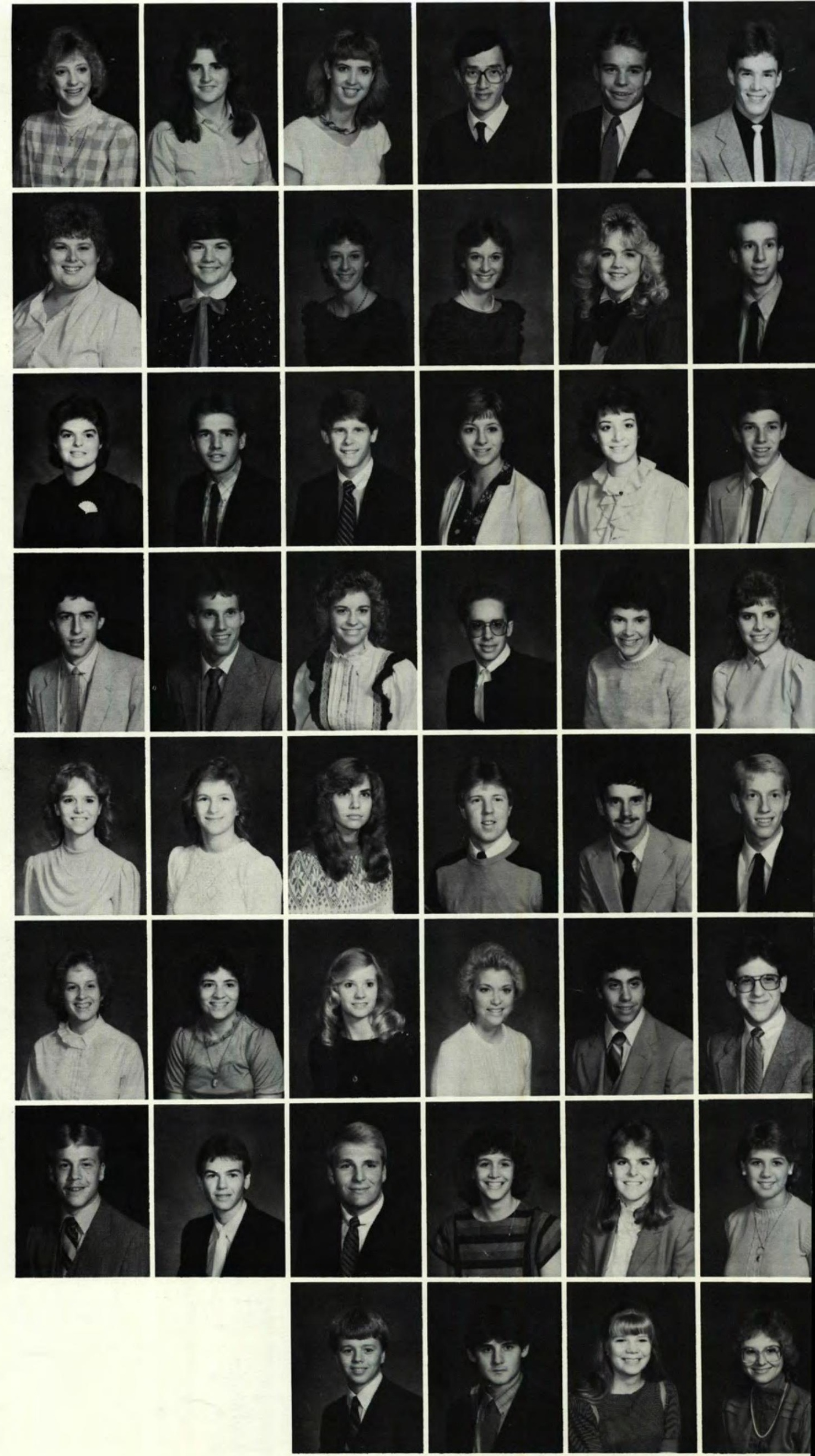


\section{SECRETARIAL GRADUATES}
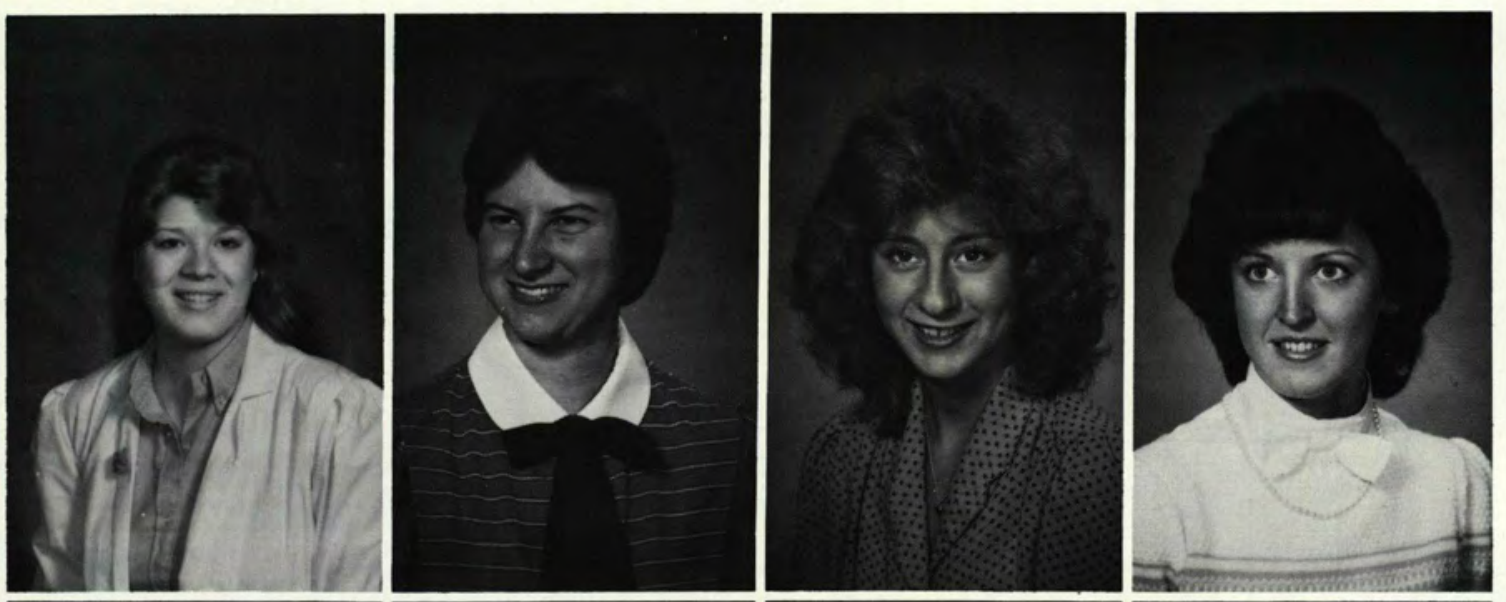

Nancy Ellen Anderson

Donna Lee Birtch

Rebekah J. Bennet

Jan Marie Boulet
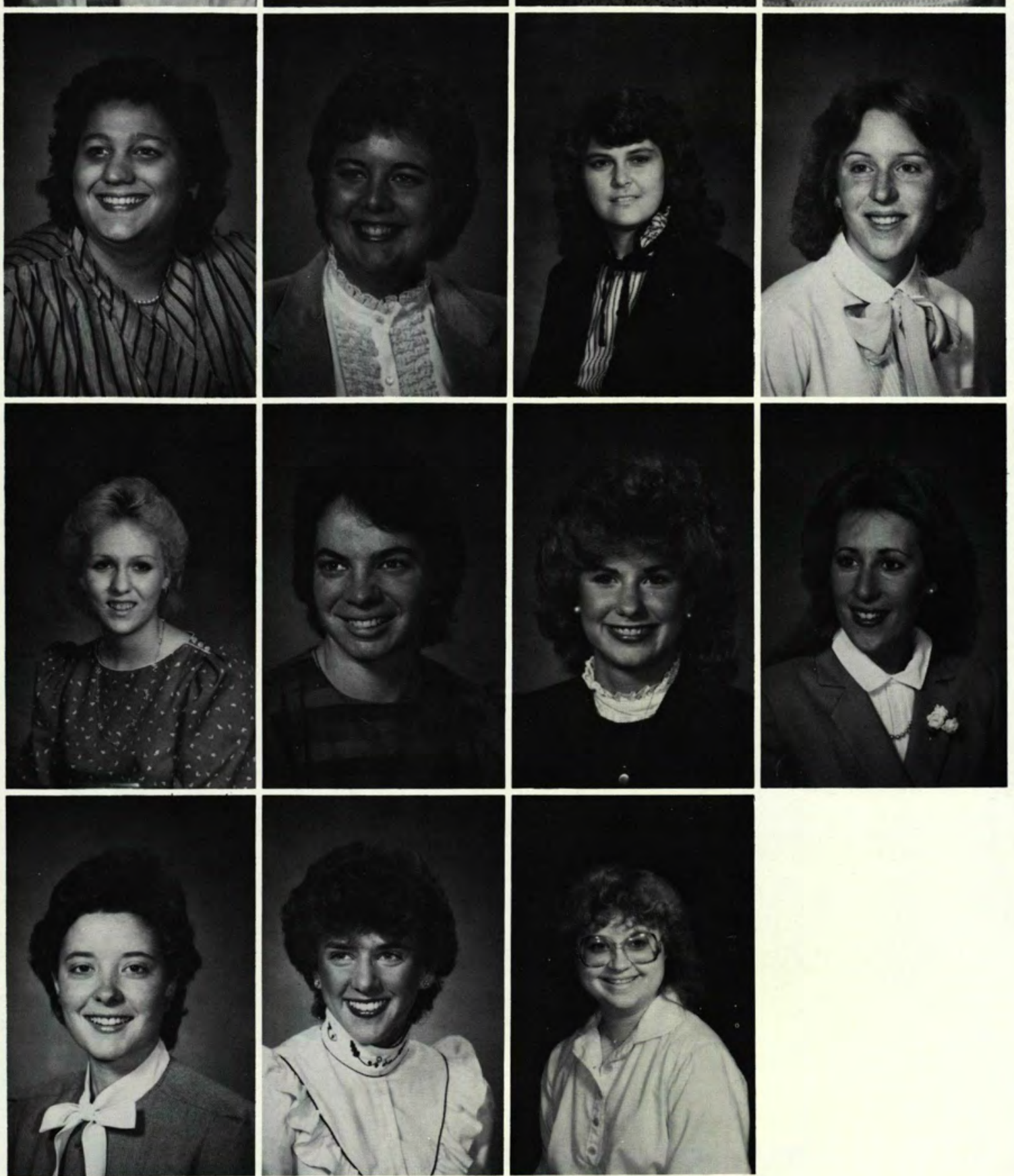

Cynthia Kay Cooley

Janet Fay Derstine

Janice Fugett

Frances Jane Haskowich

Valerie Gay Hite

Lisa Howard

Mary Ann Rose

Deborah Sue Schonfeld

Rhonda Kay Smith

Karen Sue Stag

Diane E. Stamm 


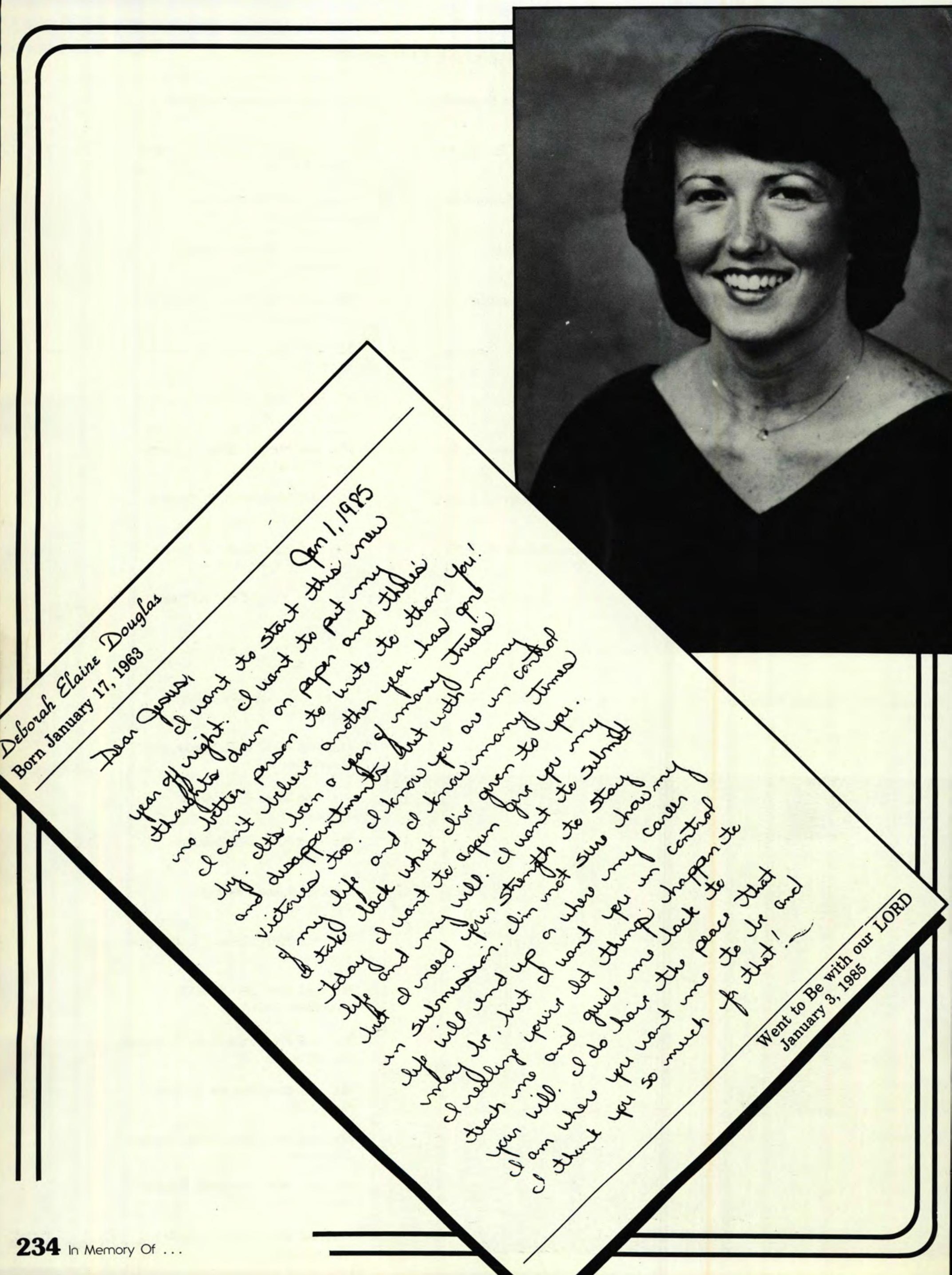




\section{Darent Pa代代S}

Norman L. Romig

Gilbertsville, PA

Steve and Marlene Rose

Manchester, MI

Mr. and Mrs. Charles B. Ross

East Providence, RI

Mr. and Mrs. Jerry K. Rotramel Elkhart, IN

Mr. and Mrs. Melvin L. Ruby

Elizabethtown, $P A$

Mr. and Mrs. Eugene C. Ruggles Michigan City, IN

Mr. and Mrs. Marshall Runge Rochester, NY

Mr. and Mrs. James Rushe

Fulton, $M D$

Mrs. Kathleen Russell

North Olmsted, $\mathrm{OH}$

Lee and Donna Ryan

Almond, NY

Billy and Betty Sadler

Walbridge, $\mathrm{OH}$

Norman and Jane Sand

Franklin Lakes, NJ

Mr. and Mrs. William Saunders

Milford, MI
Mr: and Mrs. George Schaedel

Mattituck, L.I. NY

Mr. and Mrs. Roger M. Shaull

Mansfield, $\mathrm{OH}$

Mr. and Mrs. Stan Schonfeld

Upper Brookville, NY

Richard and Shirley Shaw

Cass City, MI

Mrs. Caroll A. Shovelton

Canajogarie, NY

Herman and Shirley Simerly

Detroit, MI

Clinton and Jean Sinclair

Sheridan, MI

Rev. and Mrs. William H. Smallman Strongsville, $\mathrm{OH}$

Mr. and Mrs. Robert L. Smart

New Carlisle, $\mathrm{OH}$

Mr. and Mrs. Arthur M. Smith

Lanham, $M D$

Mr. and Mrs. Dean Smith

Elyria, $\mathrm{OH}$

\section{The Gail Smiths}

Indianapolis, IN

Dr. and Mrs. James D. Smith

Sioux City, IA
Mr. and Mrs. Lester Smith Akron, $\mathrm{OH}$

Mr. and Mrs. Lowell O. Smith Cedar Falls, IA

Roger and Martha Smith Johnstown, $\mathrm{OH}$

John and Barbara Smyth

Pleasantor, $C A$

Mr. and Mrs. Robert A. Snider South Bend, IN

Mr. and Mrs. Larry G. Snyder Elizabethtown, PA

Mr. and Mrs. Richard Sparling Bemus Point, NY

Mr. and Mrs. James R. Spees Grand Rapids, MI

Mr. and Mrs. Irvin L. Sperry Frostburg, $M D$

Dr. and Mrs. Richard Stagg Malumghat, Bangladesh

Dr. and Mrs. William Stalter Dayton, $\mathrm{OH}$

Mrs. Glenn Starkey, Jr. Albion, MI

Kent and Ann Stockham Carroll, IA

Mr. and Mrs. H.G. Stone Birmingham, $A L$

Mr. and Mrs. Ted Strait

Runnells, IA

Mr. and Mrs. Bill Stroupe

Freedom, PA

Paul and Joan Sturgis

Fairfax, VA

Mr. and Mrs. Robert L. Supplee Fremont, $M I$

Mr. and Mrs. Jay Sutliff,

Huntingdon Valley, PA

Mr. and Mrs. James R. Swanson Cuyahoga Falls, $\mathrm{OH}$

Mr. and Mrs. James A. Tait

Elma, $N Y$

Mr. and Mrs. Earl Dean Taylor Edgewood, $K Y$

Mr. and Mrs. Kenneth Taylor

Williston, $N D$

Mr. and Mrs. Neil C. Taylor

Kempton, $P A$ 


\section{$N \operatorname{NDR}_{\mathrm{qD}}^{\mathrm{FM}}$}

\section{Organizations:}

Together We Trust In God

Trusting in God is usually thought of as a singular, individual effort. Each one of us has made a personal commitment to God; each has a unique relationship with Christ. As we reach out to other believers, however, we have opportunities to share the faith and trust we place in God as a common body of saints. Here on campus we have a variety of organizations with an equal variety of purposes, but at the heart of each group is the bond that we all share because of our trust in our God

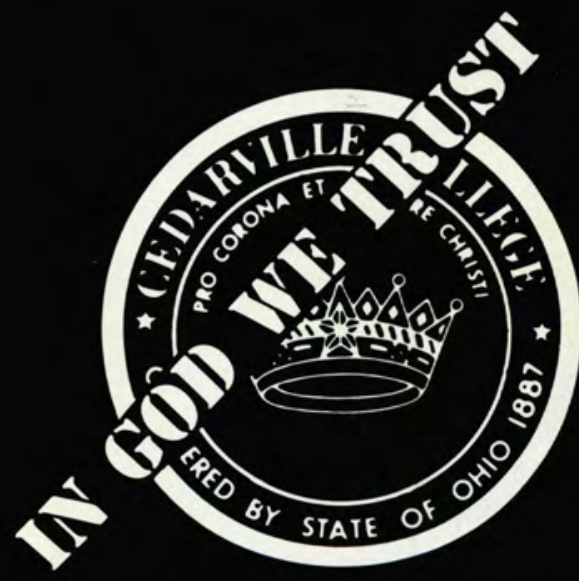




\section{ACADEMIC ADVISORY BOARI}

$\tau$

he Academic Advisory Board

is a group of students selected

to supply sugguestions to the administration.

Lori Hess, Dr. Johnson - Advisor, Dave

Smyth, Rick Rogers, Jill Campbell, Judy Bears, Denise Ross, Mark Dalhouse, Jennifer Marthews, Kevin Todd.

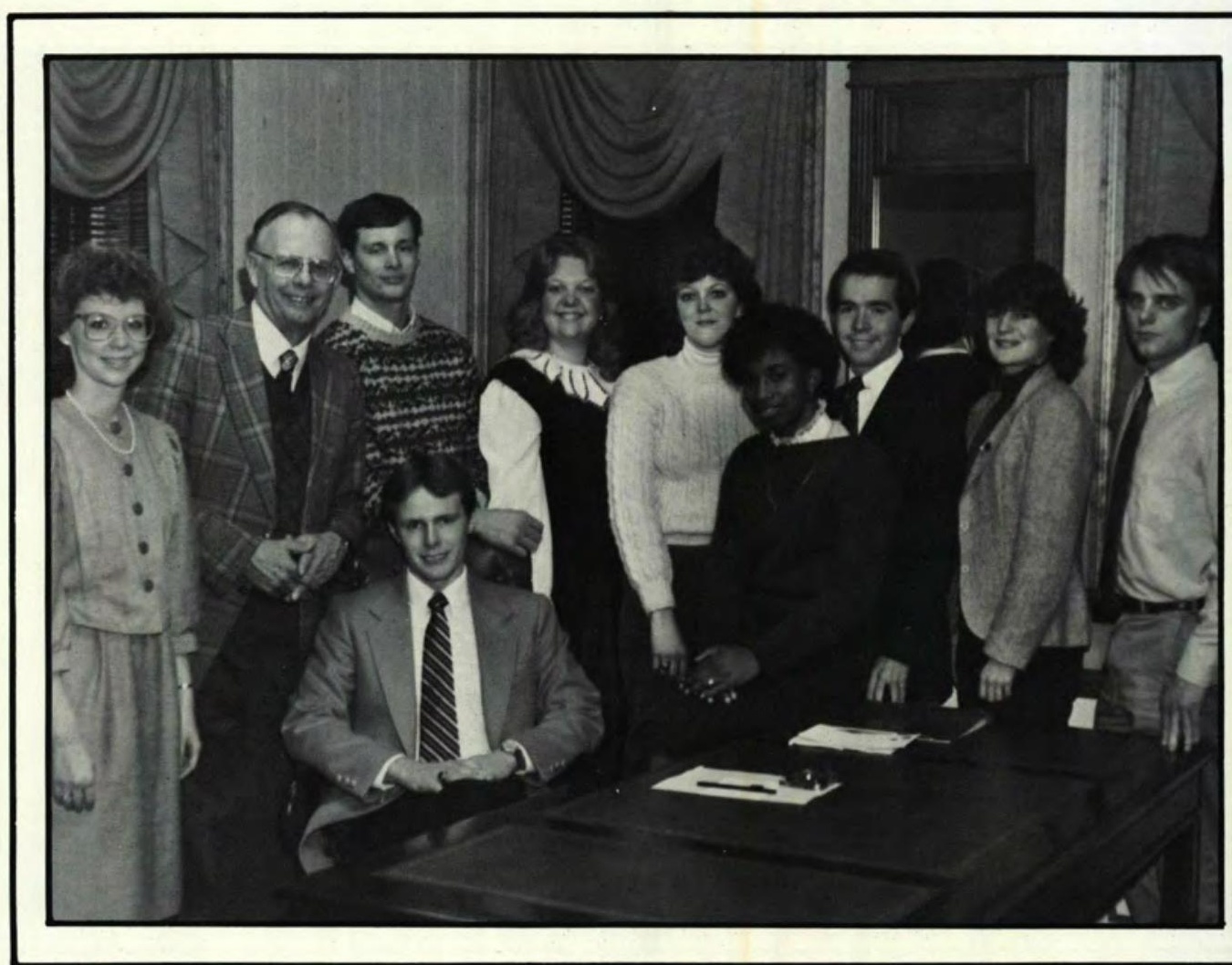

he Advisory Seven is an elect-
ed group of young men who meet the spiritual needs of the student body and serve the Fellowship by coordinating Sunday and Wednesday church services.

Seared: Bob Beikert, Dave Blackstone, Tom Carr,

Standing: Brad Rickard, Chris Tupps, Keirh Holr. Nor Picrured: Kirk Fairhurst.

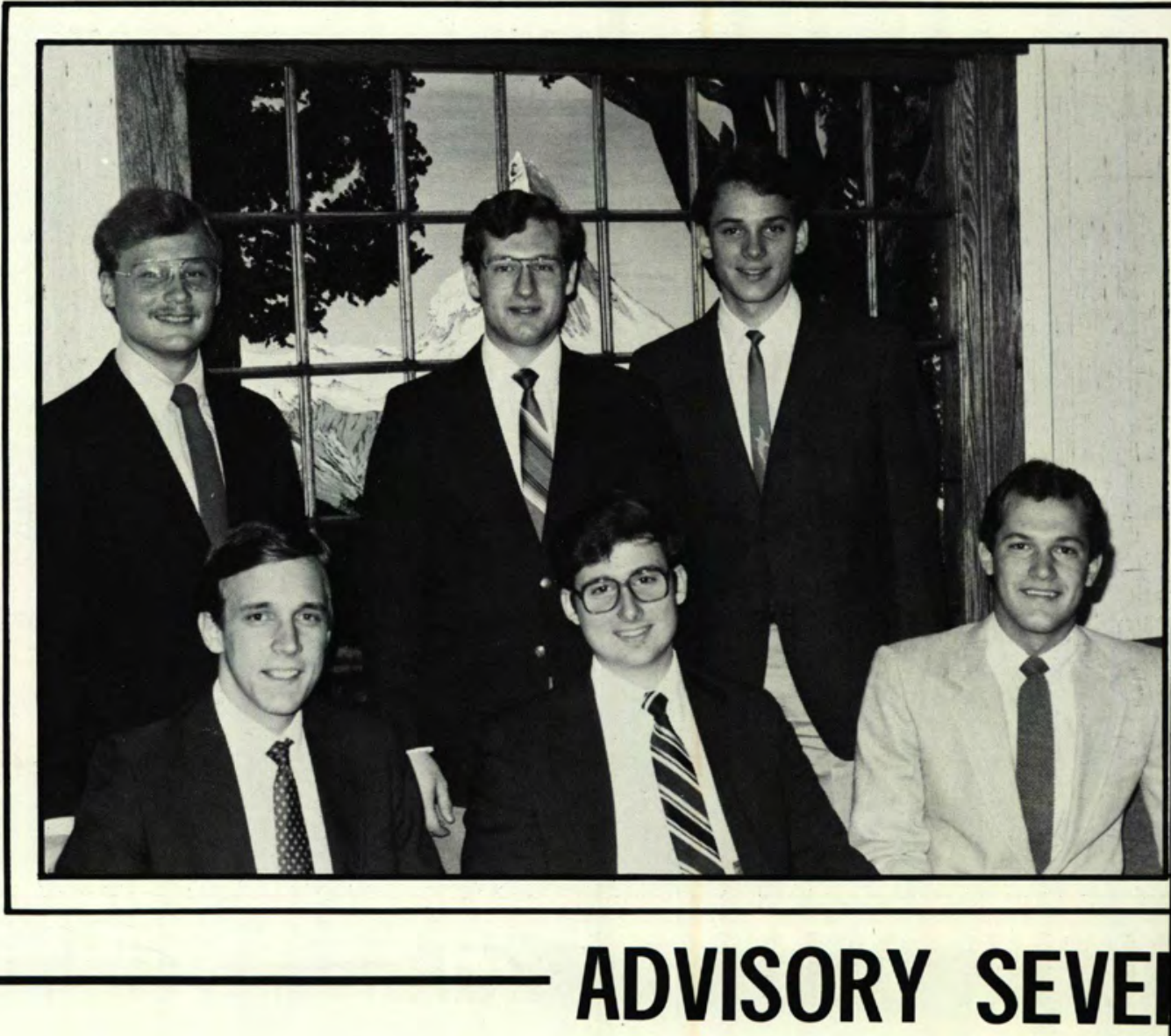




\section{ALPHA MU CHI}

4 Alpha $\mathrm{Mu}$ Chi is a sociery for engaged girls which provides fellowship, instruction in homemaking and ideas for weddings.

Seared: Kim Rupe, Valerie Hire

Seared on Couch: Betry Smirh, Lori Leach, Hearher Heflick, Deb Miller

Standing: Tammy Evans, Charlene Hunt, Advisor - Ma Printy, Renee Bowen, Donna Gean

Nichols, Karen Troyer, Sandy Prart, Marcia Yoder

C edars staff is made up of students who create and publish the campus newspaper semi-monthly.

First Row: Gordon Ooms, Holly Marshall, Kevin Todd

Second Row: Sherri Warson, Karen Troyer, Lyle Compbell, Mark Prevost, Sherri Crewer, Shellie Benson, Nancy Crick, Lisa Fawcert Third Row: Jim Liebler, Jay Benson, Stacy Gunther, Bob Kojko, Rurh Muroff, Brian Maas, Mark Horne


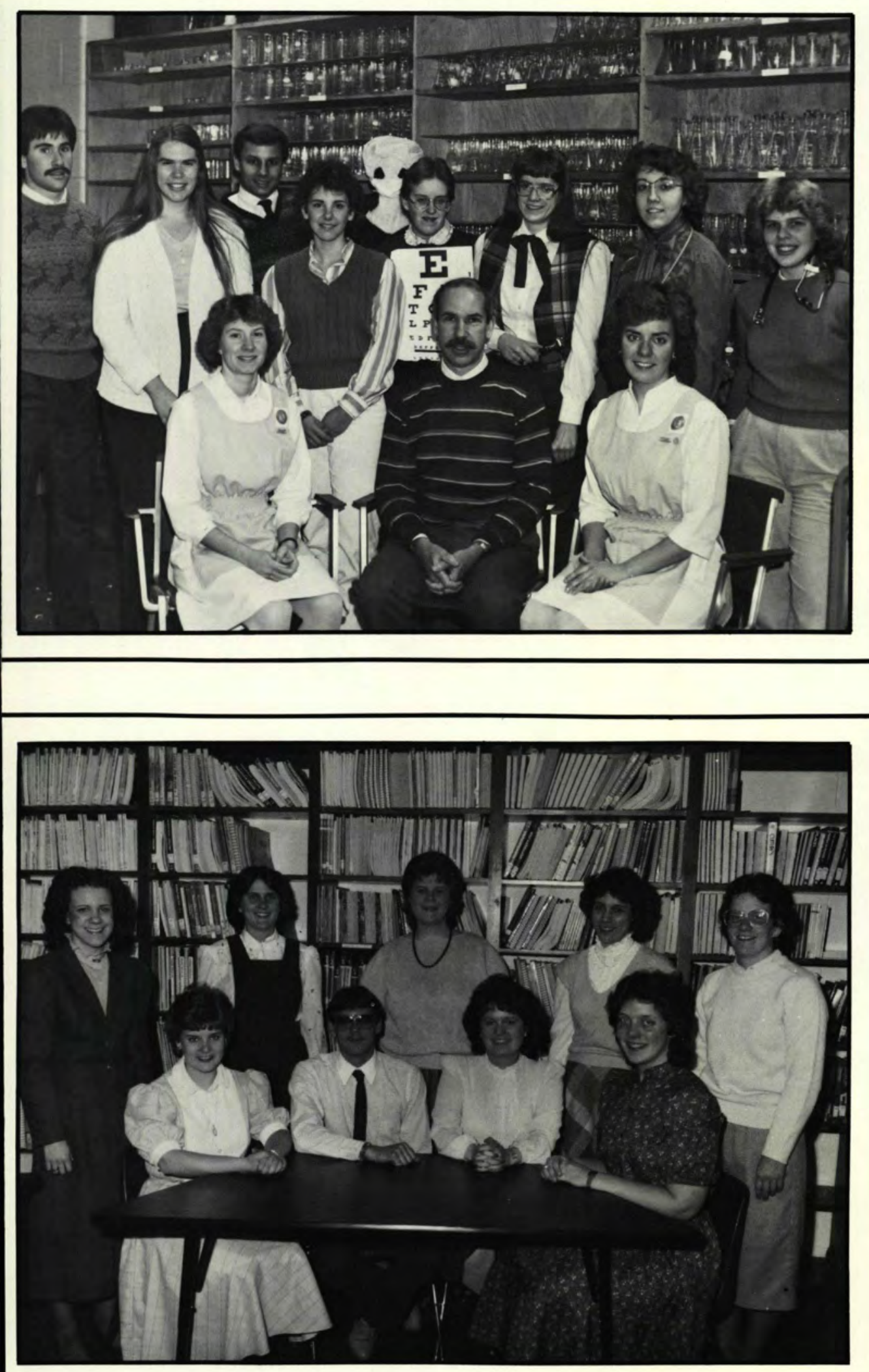

hi Thera $\mathrm{Pi}$ is a group of students who have a common interest in healrh and science professions.

First Row: President - Teresa Geiger, Advisor - Dr. Helmick, Cheryl Clayron

Second Row: John Helmick, Joan Parsons, Brian Roger, Amy Dykes, Sarah Barr, Jean Mozer, Robin Srockham, Joy Hart

\section{$\int_{\square}[E$}




\section{C.C. REPUBLICANS}

edarville College Republicans is a
group of politically aware students who stimulate involvement in political issues.

First Row: Robin Srockham, Lyle Campbell, Karen Troyer, Dave Edwards, Berh Nestor, Thea K. Rivera; Second Row: Brian Biggs, Lori Casreel, Laura Hancock, Dawn Baughman, Cindy Helmick, Scort Zimpfer, Holly Marshall, Sherri Warson, Jim Koerber, Mart Biggs, Amy Jo Guest

e ommunicarions Club provides fellowship for those students interested in careers in the field of communications.

First Row: Pere Wright, Judy Heppe, Jeff Lyle Lynn Burcke, Jennifer Marthews; Second Row: Becki Tackert, Judy Denning; Third Row: Steve Banning, Mark Tinner, Paul Wenz, Bretr Montford, Ken Oliver, Chad Bresson, Jay Benson.


COMMUNICATIONS CLUB 


\section{E.M.S.}
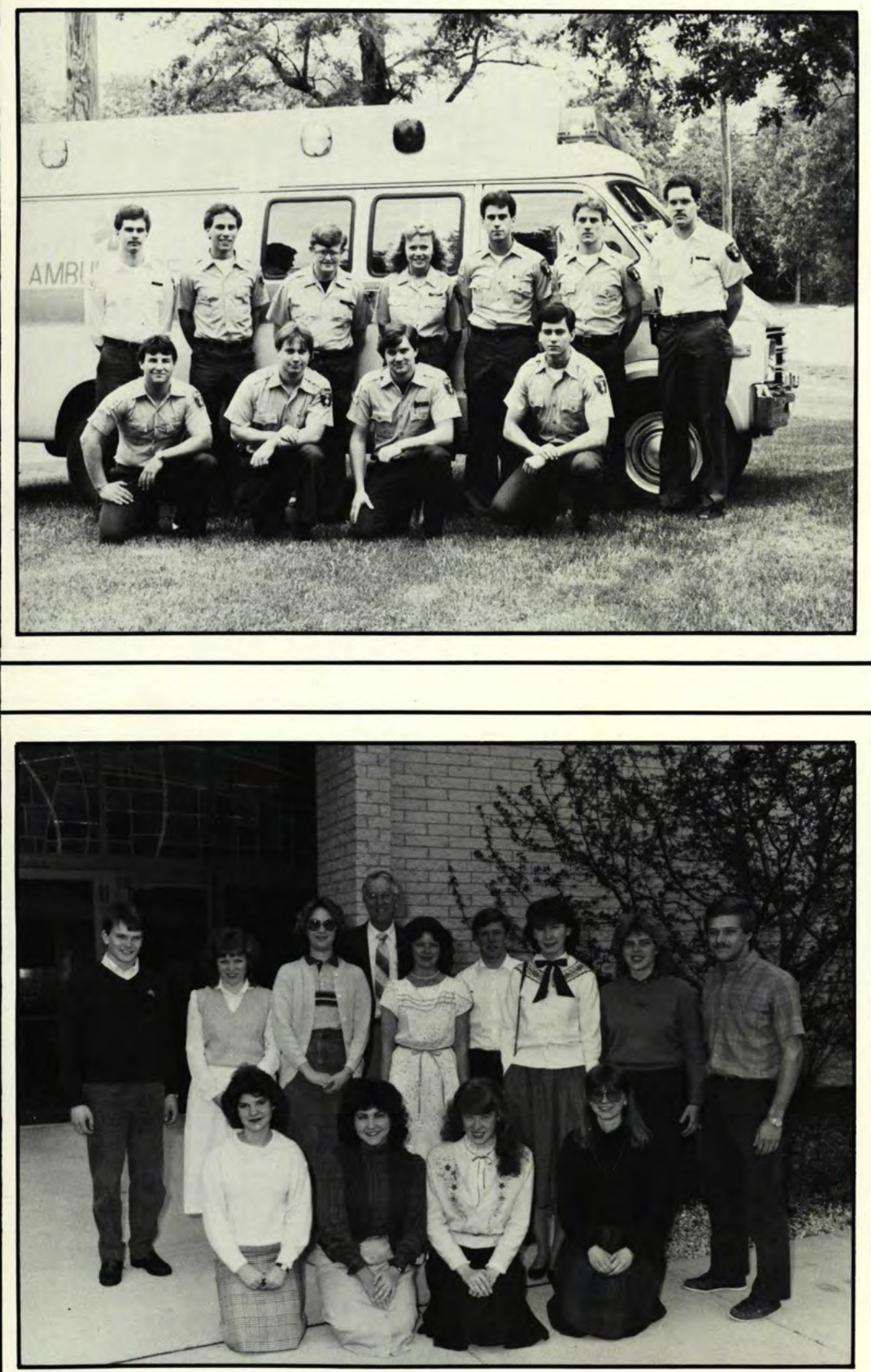

7 ellowship of World Missions meets
weekly to discuss, support, and pray for missions.

First Row: Tonja Smith, Michelle Livingston, Diane Blasdell, Annagret Grosse; Second Row; Jay Burcher, Dina Barchelder, Kendra Docror, Rachel Cook, Richard Durham, Mike Lane, Sylvie Rinderknecht, Joy Hart, Dan Hawk. 


\section{FORENSICS}

- orensics is a speech ream which comperes in areas of dramaric interpretation along

with extemporaneous and persuasive speaking.

Seared: Nadine Terrill, Elana Michael Standing: Tracy Grimes, Sherry Rorramel Sranding Back: Gary Barker, Mark Horne, Advisor - Mr. Robey, Advisor - Mr. Lopez, Jim Liebler

Gamma Chi, a sociery for women, seeks to $\exists$ provide service and social opportunities to develop Christian personality and leadership.
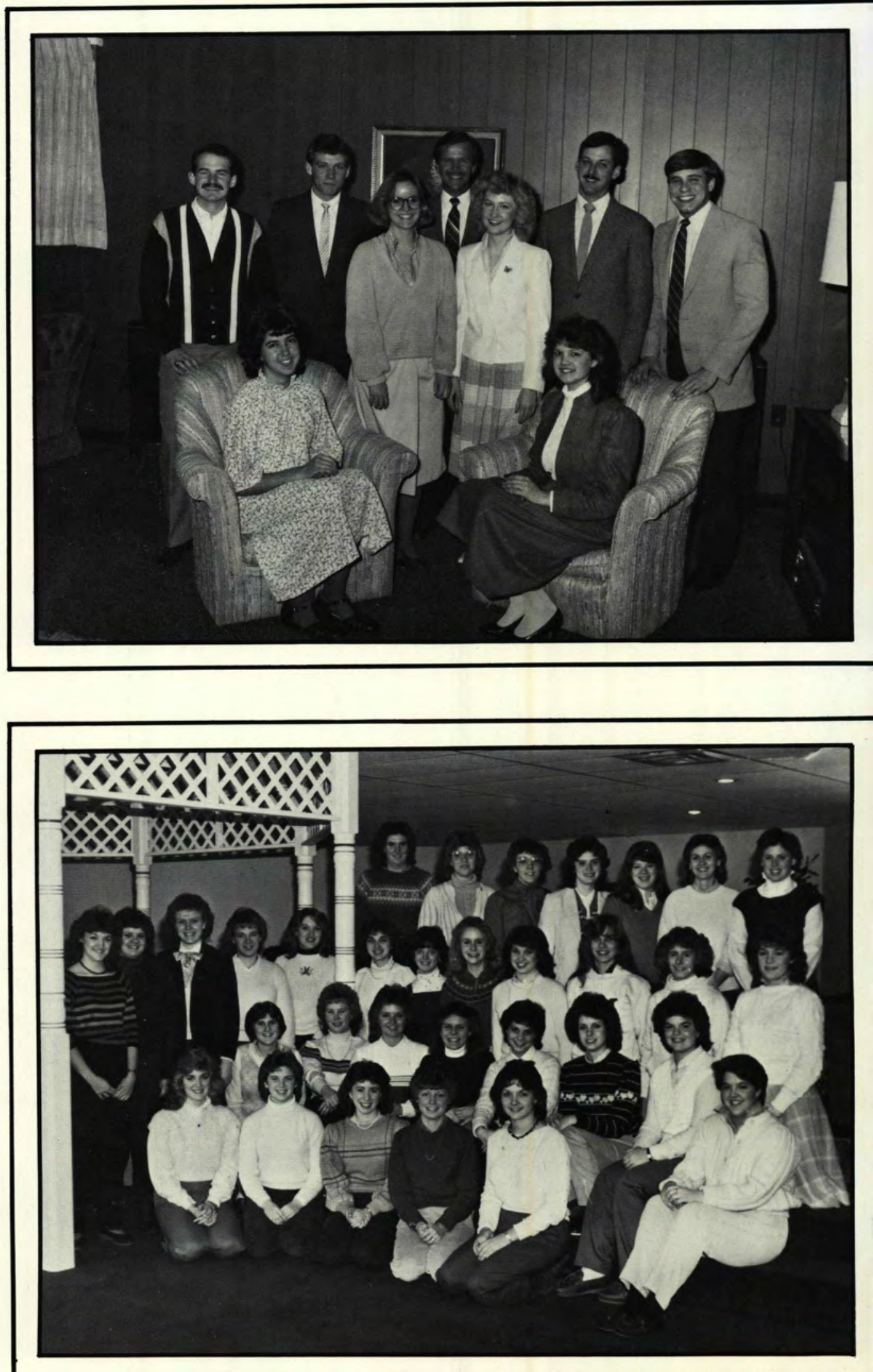


\section{MARRIED STUDENT FELLOWSHIP}

1 arried Student Fellowship is a organized for the purpose of spiritual and social development through family fellowship.

Jack Riggs, Bruce Compron, Bill Mazey, Tom Friedman.

1 EnC is our chapter of Music ence for music majors and others involved in pursuing a music teaching program.

First Row: Diane McClure, Mike Law, Beth Hughes

Second Row: Eileen Friesen, Jill Campbell, Dianne Noggle, Mary Ruth Cook, Steve Wood, Joy Burr, Sandra Holbrook, Terri Mackenzie, Kim Murphy
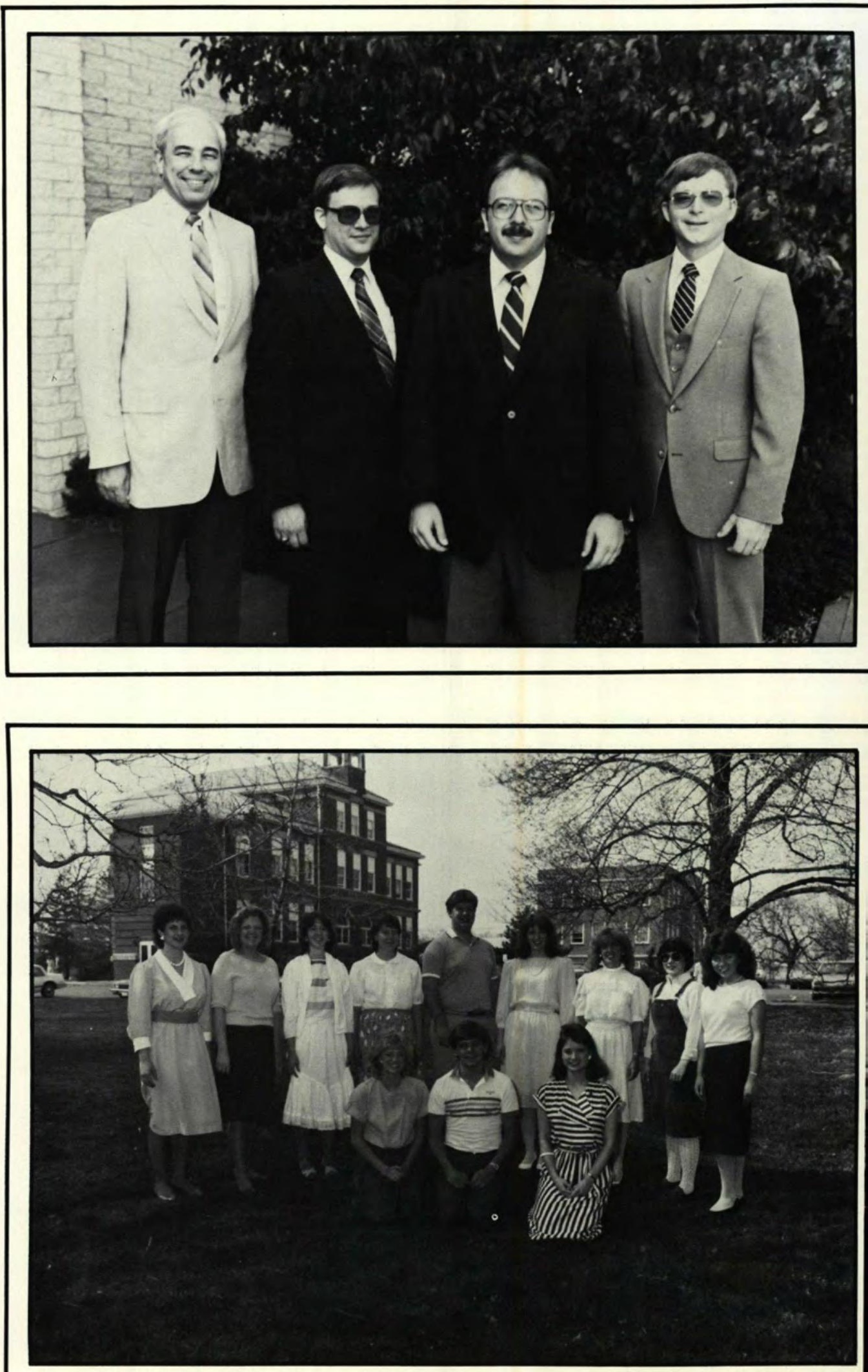


\section{MIRACLE STAFF}
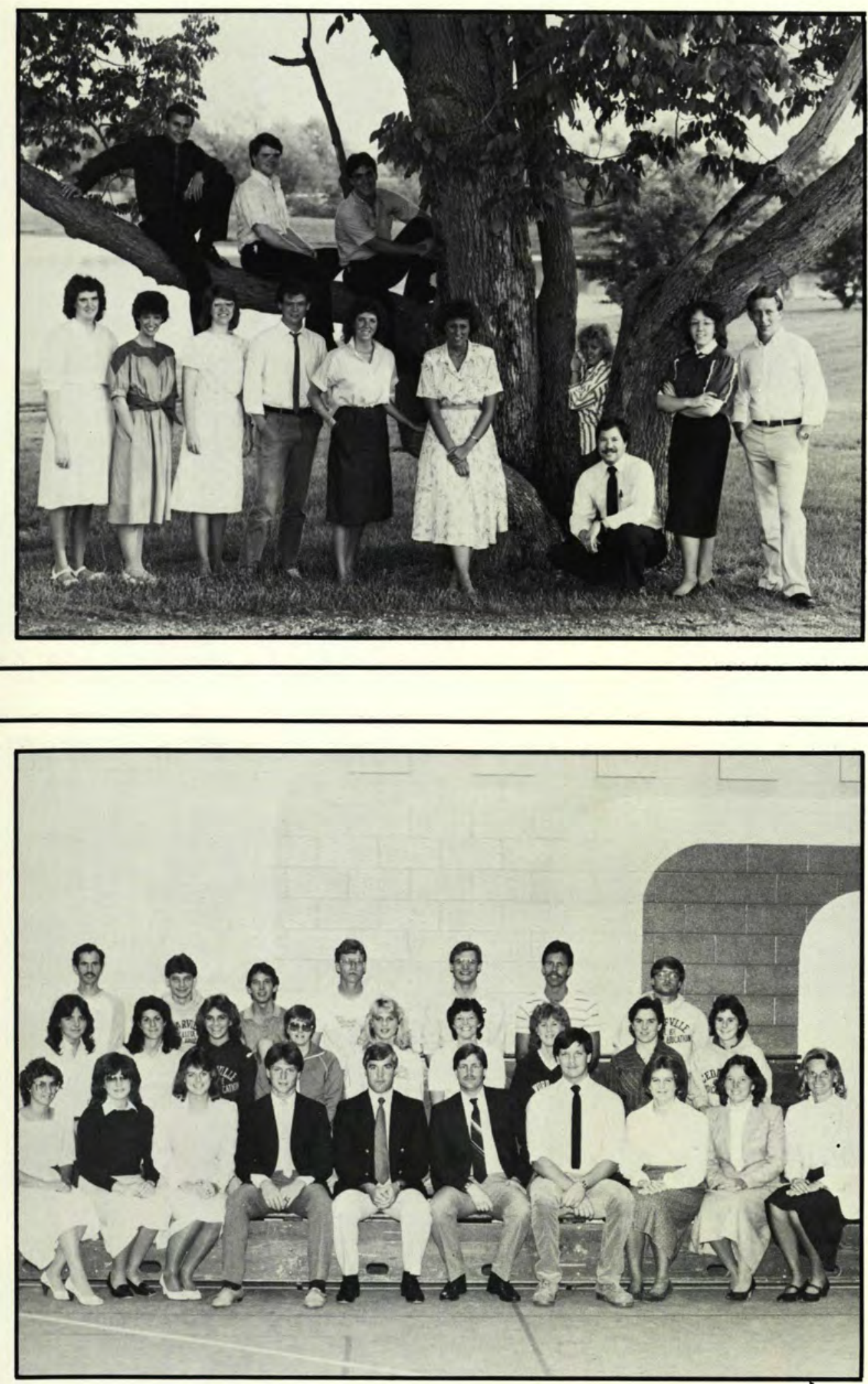

, 


\section{PI DELTA}

1 i Delta is a volunteer, honorary, coeducational student group whose purpose is to host campus visitors.

First Row: Christina Hart, Laura McElroy, Linda Hess, Berh Lundstrum, Janice Warren; Second Row: Melissa Marshall, Amy Jo Windnagle, Macia Yoder, Heidi Hempel, Shannon Saunders, Berh Hornbeck, Debbie Bartaglia; Third Row: Eric Helmurh, David Zehrung, Brian Ensminger, Jim Kohlmeyer, Benjamin Hurr, Gary Barker, Dave Robinetre.

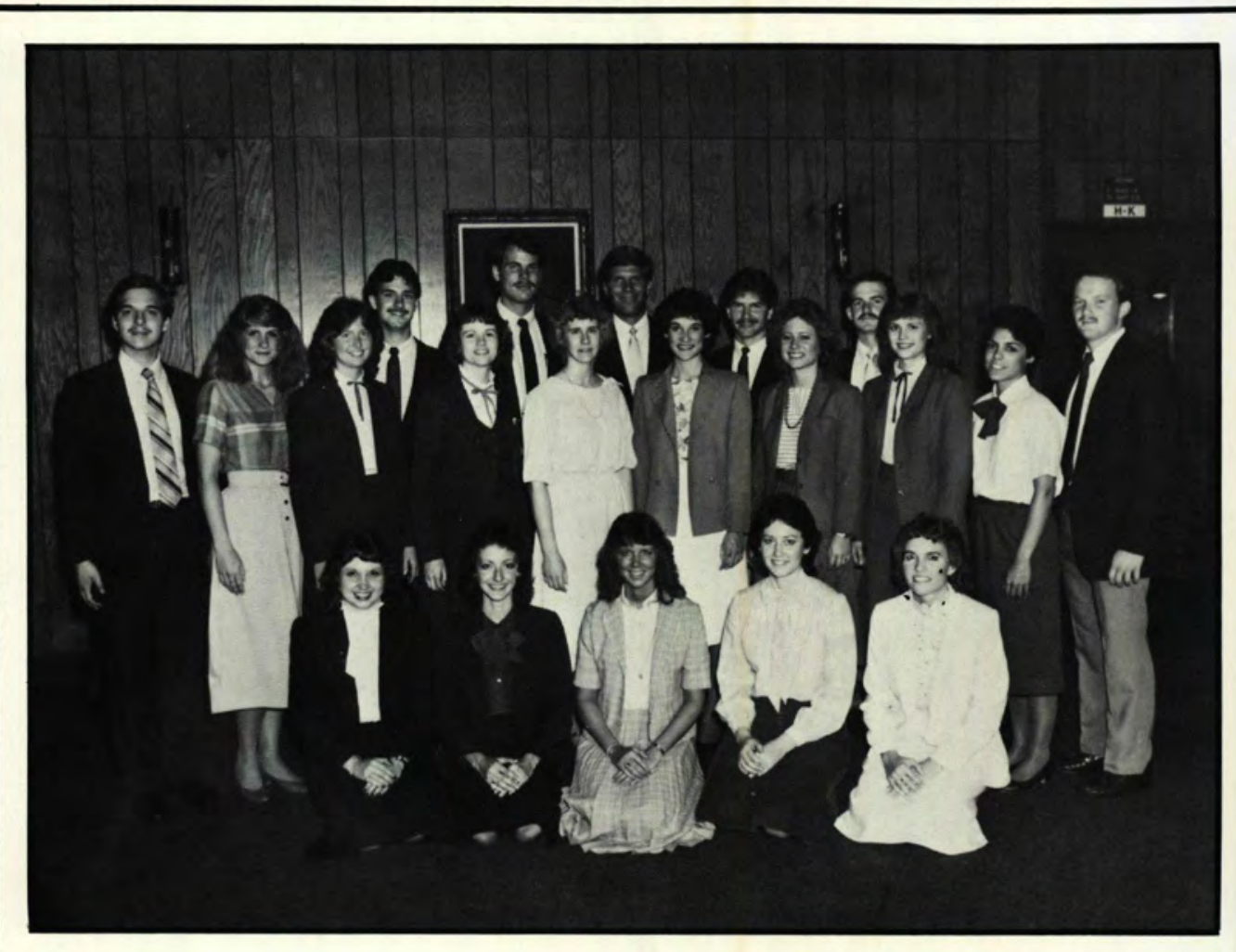

$p$

Sigma Nu is a campus men's group that seeks to aid in the development of the whole man through service projects and social activities.

Front: Rick Manuel, Scort Haynes, Jon Turtle, Jon Reid, Kevin Todd, Brent Long, Jeff Ulmer, Gregg Norden

Back: Tom Fite, Jim Atkinson, Tom Hill, Kevin Shaw, Dave Ormsbee, Kelly Mathis, Jay Martin, Ric Zehr, DeMaurice Smith, Wayne Anderson, Greg Clemens

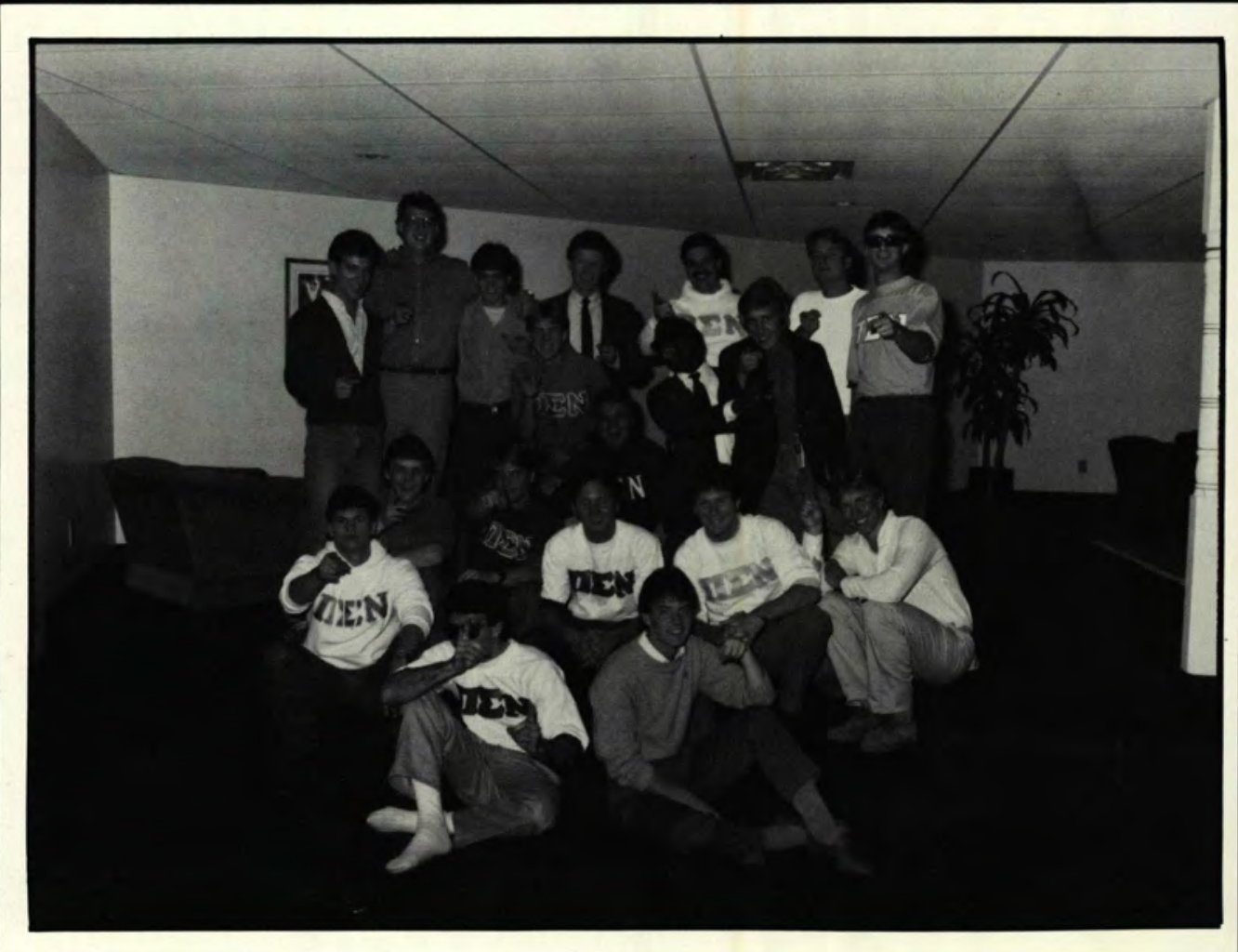


ational Student Nurses is a
group of students with the common interest of pursuing a career in nursing.

First Row: Nancy LaBonte, Angela Yosh, Mary Jo Saboge, Tressa Price

Second Row: Gayle Taylor, Marcio Yoder, Sara McGuire, President - Cheryl Clayton, Teresa Geiger

rudent Senate consists of a
group of students elected to represent the student body. The main purpose of the Student Senate is to assist in providing a well-rounded atmosphere and program of activities on campus.

Kneeling: Greg Harris, Dave Zehrung, Vice President - Scott Haynes, President - DeMaurice Smith, Mark Horne, Keith DeWalt, Jim Liebler, Andy Wilson.

Sranding: Joy Burr, Lisa Steele, Cynthia Cronrarh, Laura McElroy, Cindy Guido, Karhy Horris, Jill Michonski, Gayle Taylor, Holly Marshall, Amy Johnson, Alise Alexander.

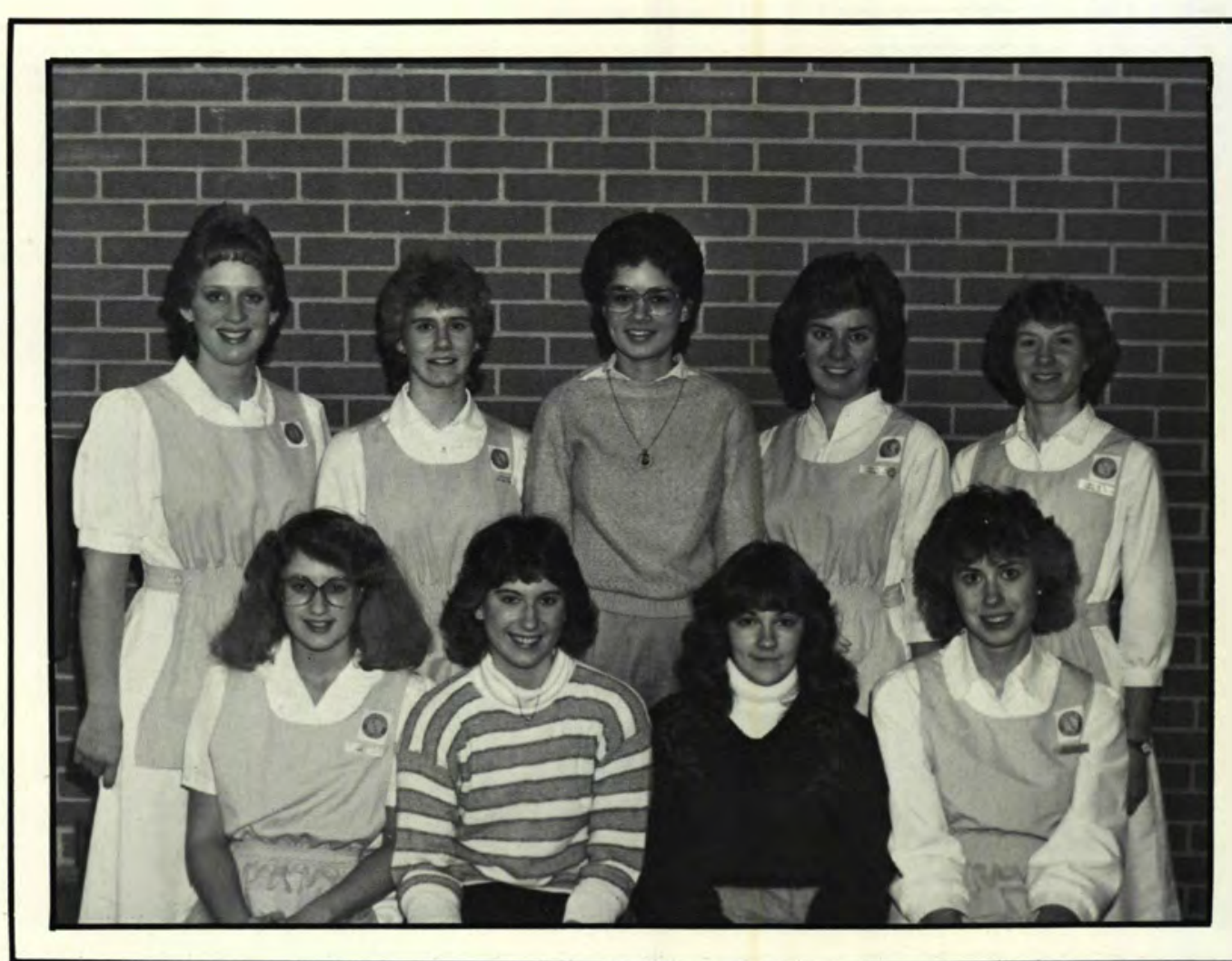

\section{STUDENT NURSES}

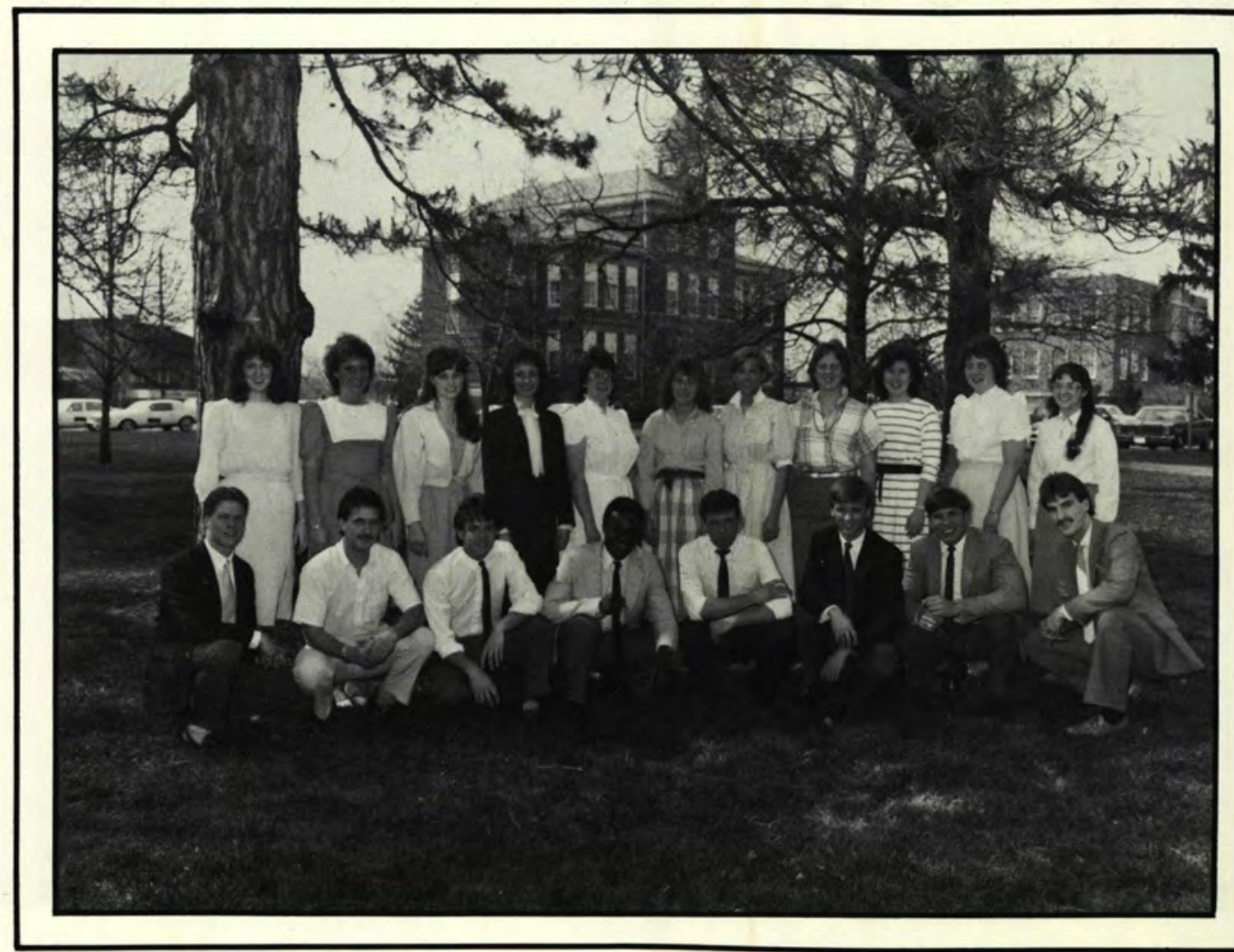




\section{VARSITY "C"}
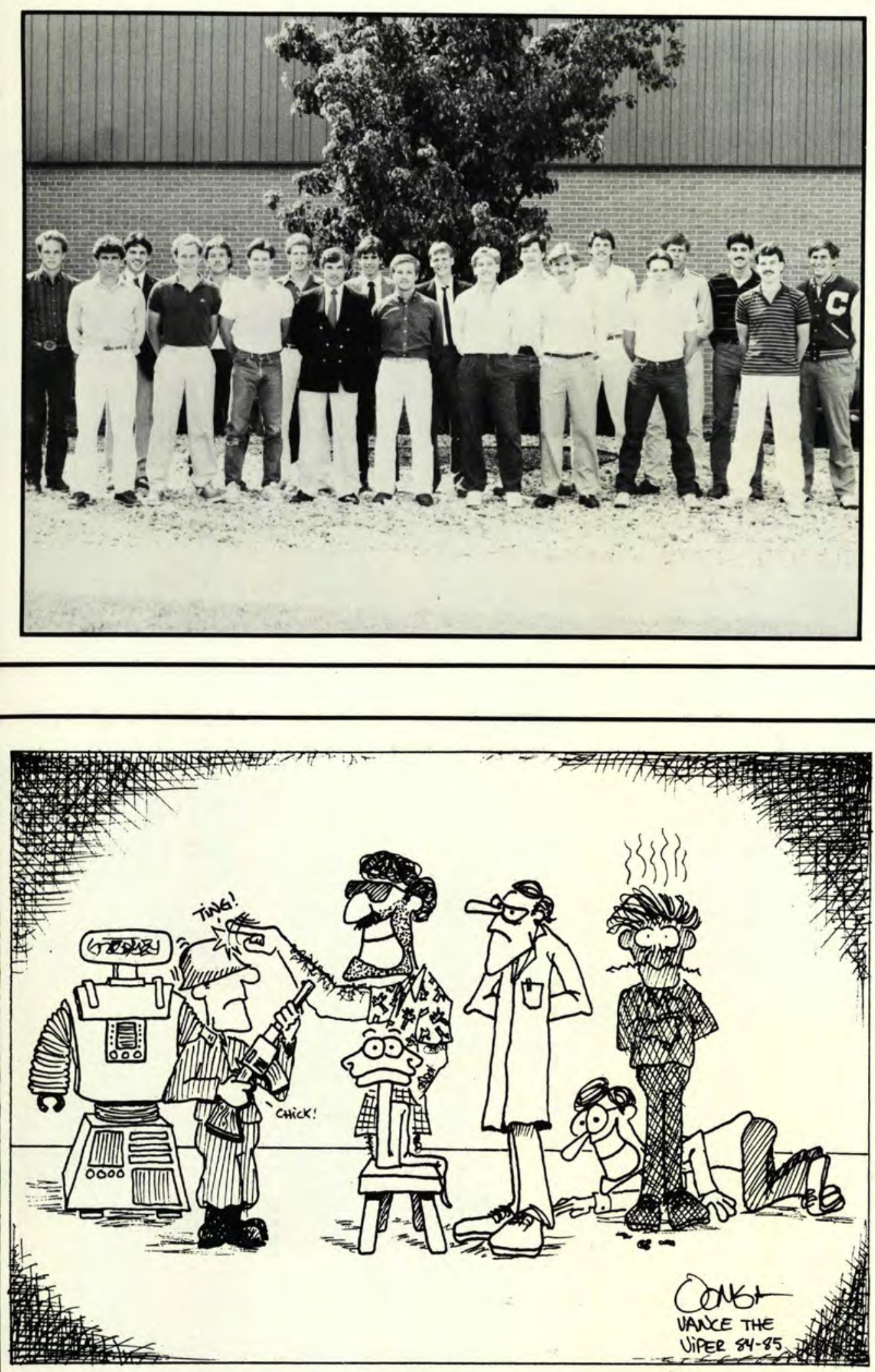
1 arsity " $C$ " consists of indivity letters in intercollegiate sports.

Front Row: Gary Coiro, Bruce Richards, Roger Lurtrell, Bob Fires, Dan Hawk, Norm Cox Lamar Eifert, Clancy Cruise, Tom Greve Back Row: Noel Hack, Dan Olinger, Mark Fleerwood, Tom Ewing - president, Dave Moody, Gary Anderson, Gary Wallace Dove Yeoger. Sreve Terostra, Kirk Fairhurst, Cooch Steve Young

$V$ ance the Viper is a comic strip which appears in the Cedars newspaper to make light of the ups and downs of college life through the adventures of Vance A. Viper $L$ to R: Robbie the Robot, Cedarville Joe Tom Salrlick, Vance A. Viper, Dr. Ivan Von Schlook, Heraldo Rivera, Gordon Ooms (Crearor of Vance the Viper). 


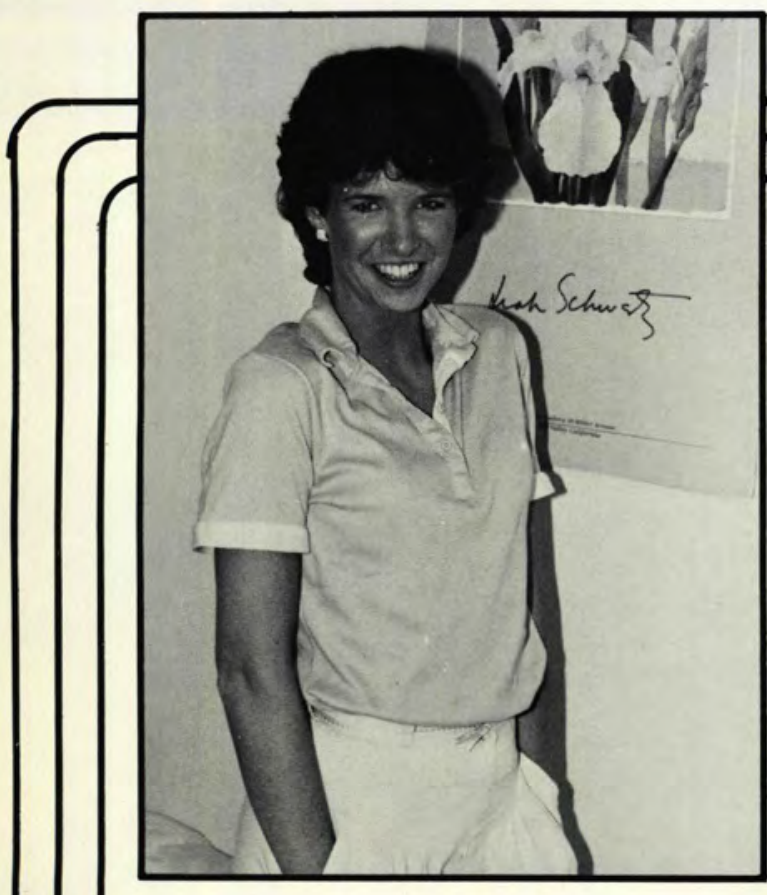

BRENDA JAMES

Student Life/Christian Ministries Editor

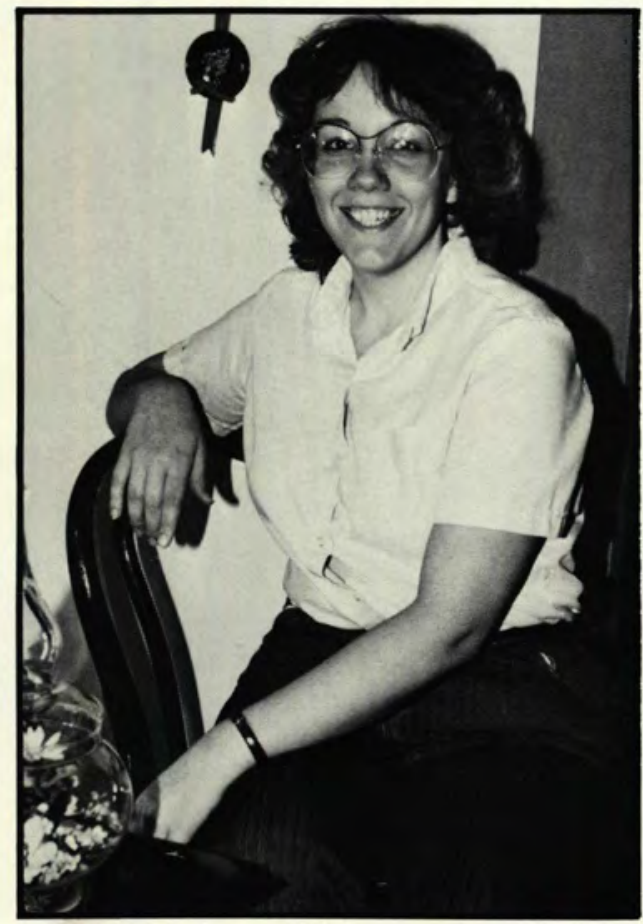

ROBIN STOCKHAM

Class/Organizations Editor

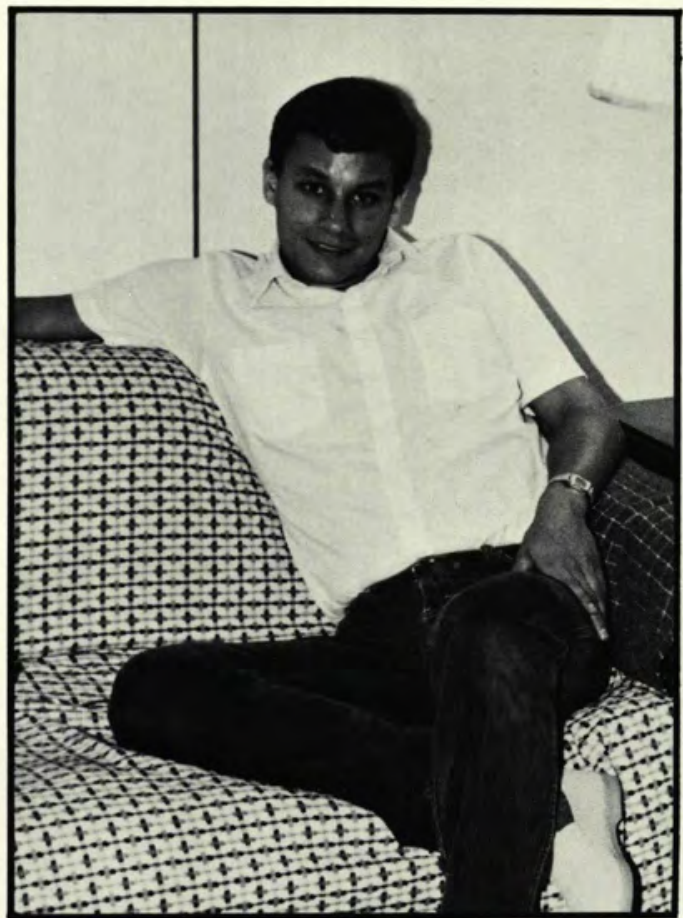

BRIAN ROGET

Darkroom Editor

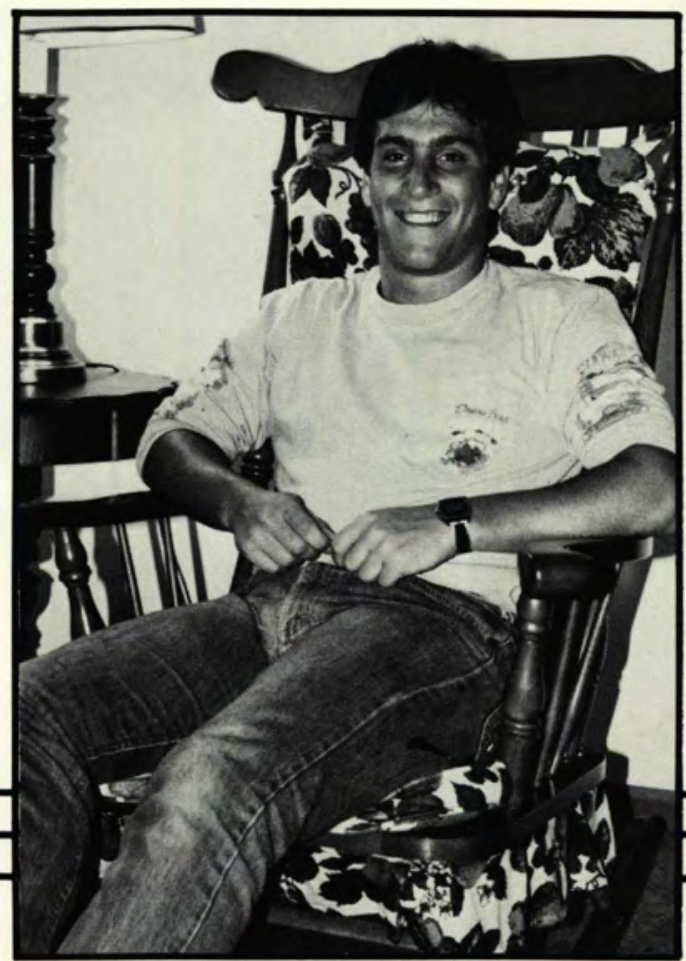

KEITH BERES

Sports/Organizations Editor

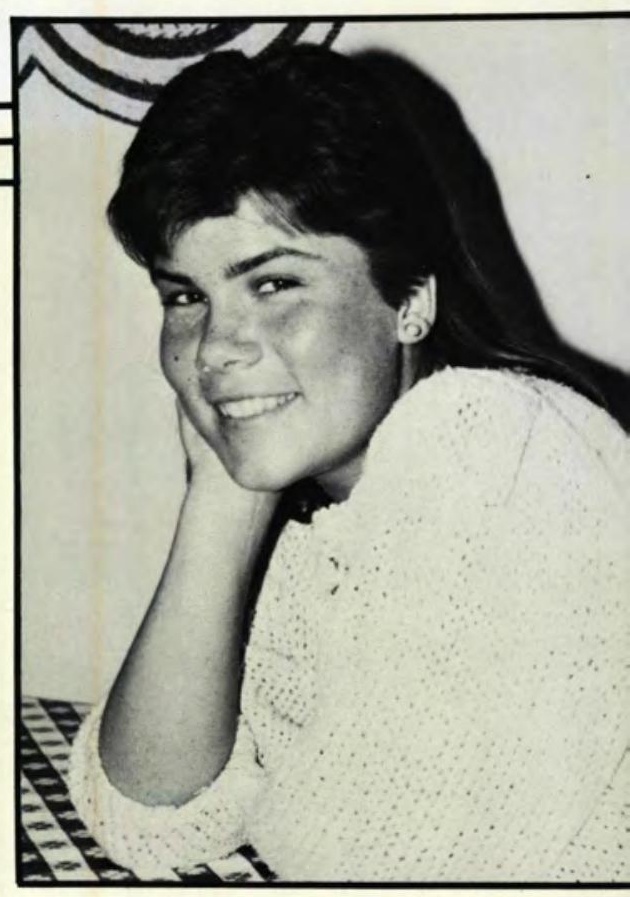

TAMMY PICKTHORN

Copy/Christian Ministries Editor

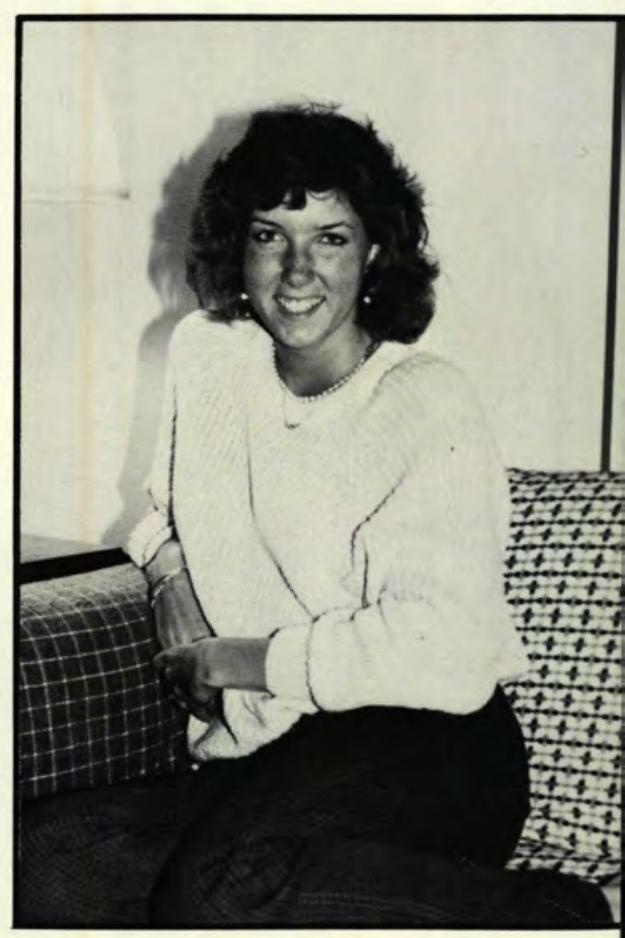

CHARLENE HUNT

Photography Editor 


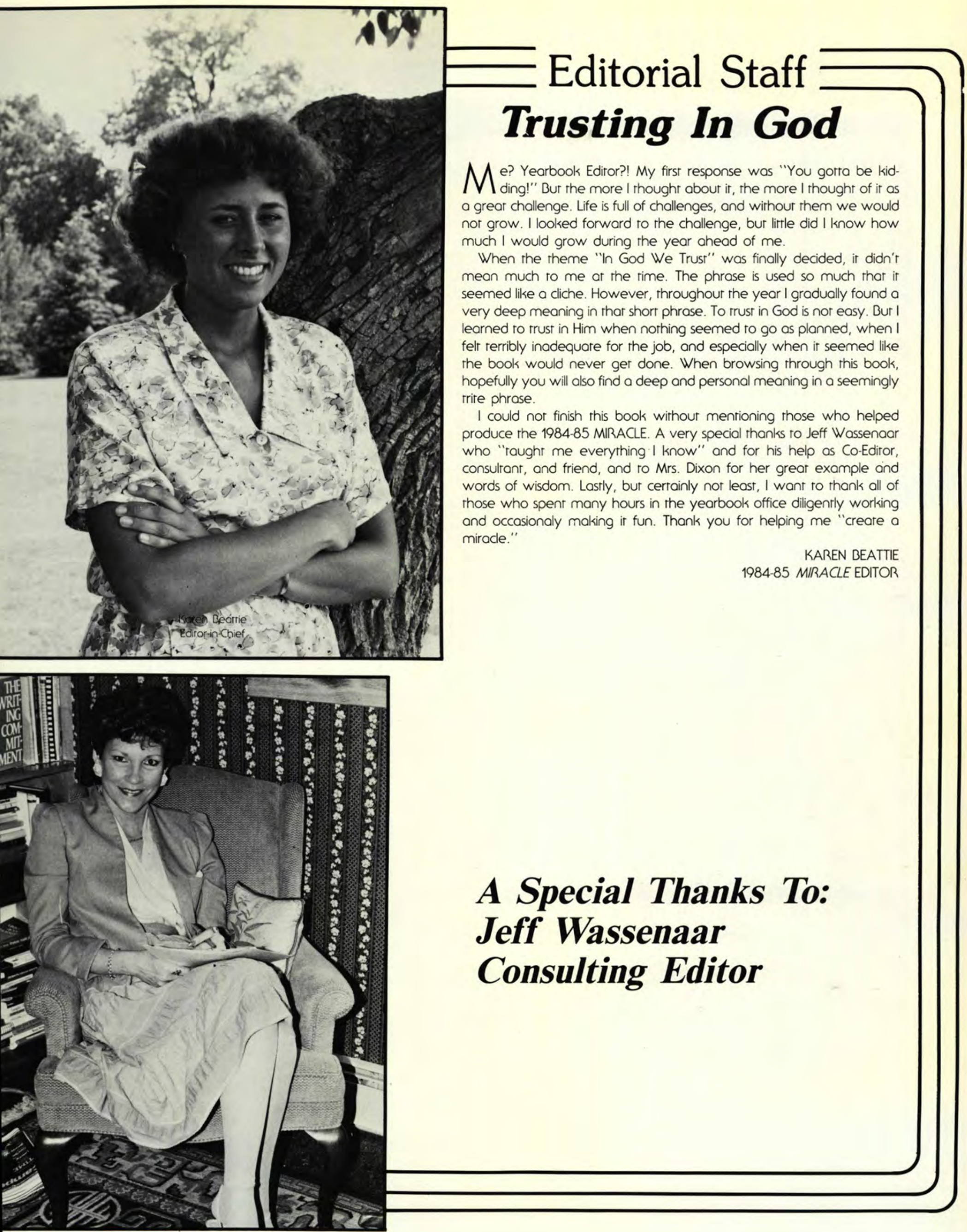

MRS. PAT DIXON

Advisor 


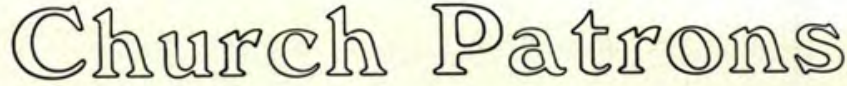

Alaska Baptist Church

7240 68th Street, S.E.

Caledonia, MI 49316

Pastor: None at present time

Anchor Baptist Church

4460 Annistown Road

Lithonia, GA 30058

Pastor: Rev. Sherl P. Walls

\section{Anchor Point Baptist}

Church

P.O. Box 147

Mile 156 1/2 Sterling Hwy.

Anchor Point, AK 99556

Pastor: Kenneth V. Van Loon

Ankeny Baptist Church 2842 S.W. Third St. PI.

Ankeny, IA 50021

Pastor: Norman Hoag

Bailey Road Baptist Church

2121 Bailey Road

North Jackson, $\mathrm{OH} 44451$

Pastor: Rev. Lester R. Webster

Berea Baptist Church

250 West St.

Berea, OH 44017

Pastor: Kenneth J. Spink

Berean Baptist Church

3401 South 6th Street

Springfield, IL 62703

Pastor: Dr. Richard R. Ahlgrim

\section{Bible Baptist Church}

20 Avalon

Bedford, $\mathrm{OH} 44146$

Pastor: William L. Davis

Bible Baptist Church

2635 S. Dixon Rd., P.O. Box

2798

Kokomo, IN 46902

Pastor: Richard T. McIntosh

\section{Bible Baptist Church}

200 Elicken Rd.

Pittsburgh, PA 15239

Pastor: Don R. Stokes
Brown Street Baptist

Church

3125 Brown St.

Alton, IL 62002

Pastor: Rev. Marvin W. DePenning

Calvary Baptist Church

636 North Best St.

Forest City, IA 50436

Pastor: Douglas P. Domokos

Calvary Baptist Church

3575 Shaeffer Ave., P.O. 4025

Kingman, AZ 86401

Pastor: Rev. Gerald L. Booth, Jr.

Calvary Baptist Church

3007 Marietta Road

Lancaster, OH 43130

Pastor: Fred C. Hand

Calvary Baptist Church

Union, IA 50258

Pastor, Bill Miller

Calvary Baptist Church

1399 Falls Ave.

Wabash, IN 46992

Pastor: Stanley Lightfoot, Jr.

Carpenter Baptist

Route \#3 Box 72

Albany, OH 45710

Donald O. Shue

Central Baptist Church

1606 Front St.

Binghamton, NY 13901

Pastor: Gorden P. Hay

Central Baptist Church

Rte. \#2 Cleveland Road

Hobart, IN 46342

Pastor: Dale E. Fisher

Christ Baptist Church

R.D. \#2 Box 2406

Columbia, NJ 07832

Pastor: Mark C. Trautman

Curtis Baptist Church

P.O. Box 67

Curtis, MI 49820

Pastor: None at the present time
Daniels Road Baptist Church

5878 Daniels Road, S.E. R. 25

Fort Myers, FL 33908

Pastor: Willard R. Benedict

Echoes of Joy, Inc.

Sidney, $\mathrm{OH}$

Rev. J. Edward Quick

El-Bethel Baptist Church 12915 West 10th Street Indianapolis, IN 46234

Pastor: Dr. Robert M. Hooten

Emmanuel Baptist Chruch 1120 S. Detroit St.

Xenia, OH 45385

Pastor: R. William Wheeler

Euclid-Nottinham Baptist

Church

18901 Lake Shore Boulevard

Euclid, $\mathrm{OH} 44119$

Pastor: Donald E. McClintick

Evangel Baptist Church,

Inc.

225.17 143 Ave.

Laurelton, NY 11413

Pastor: None at the present time

Evergreen Baptist Church 2005 E. Coolspring Ave.

Michigan City, IN 46360

Pastor: Brooks N. Henry

Faith Baptist

2220 Western Ave.

Mattoon, IL 61938

Pastor: R. Dean Cooper

Fellowship Baptist Church 5046 Broadway Lorain, $\mathrm{OH} 44052$

Pastor: Rev. Frank R. Chittock

First Baptist Church

2809 E. Church St.

Eden, NY 14057

Pastor: Lawrence Walter 
First Baptist Church

R.D. \#3

Edinboro, PA 16412

Pastor: James W. Lynn

First Baptist of Elimsport RR \# 1

Allenwood, PA 17810

Pastor: Rev. Dale E. Moore

First Baptist Church of Enfield

253 Brainard Road

Enfield, CT 06082

Pastor: George H. Heiland

First Baptist Church

Third and Locust

Gallipolis, OH 45631

Pastor: Joseph Godwin

First Baptist Church

Lincoln at Prairie Streets

Creston, IA 50801

Pastor: None at the present time

First Baptist Church

26 E. Church Street

Niles, $\mathrm{OH} 44446$

Pastor: G. Ben Reed

First Baptist Church

P.O. Box 273

Paden City, WV 26159

Pastor: Donald E. Matheny

First Baptist Church

1556 W. Houghton Lake Dr.

Prudenville, MI 48651

Pastor: John E. Pruden

First Baptist Church

302 West Main

Spencer, $\mathrm{OH} 44275$

Pastor: Rev. John T. McCourt

First Baptist Church of

University Place

$2844 \mathrm{Mt}$. View Drive

Tacoma, WA 98466

Pastor: Dr. Phil Williams

First Baptist Church

2336 Buena Vista Ave.

Walnut Creek, CA 94596

Pastor: Tom Younger
First Baptist Church

125 Grand Ave.

Wellington, $\mathrm{OH} 44090$

Pastor: Rev. David L. Birch

The First Baptist Church of Willowick

31433 Vine St.

Willowick, $\mathrm{OH} 44094$

Pastor: Donald Leitch

Foothills Baptist

P.O. Box 431

Hardy, AR 72542

Pastor: Norvin T. Jones

Good News Baptist Church

812 Anderson $R D$.

Churubusco, IN 46723

Pastor: Dr. David B. Hileman

Grace Baptist Church

100 4th Ave. S.E.

Austin, MN 55912

Pastor: Jack Dowden

Grace Baptist Church

109 N. Main

Cedarville, $\mathrm{OH} 45314$

Pastor: W. Paul Jackson

Grandview Park Baptist

Church

1701 East Thirty-Third St.

Des Moines, IA

\section{Haddon Heights Baptist \\ Church \\ Third and Station Avenues \\ Haddon Heights, NJ 08035 \\ Pastor: C. Powers Payton}

Hagerman Baptist Church

1105 Knoll Ave.

Waterloo, IA 50701

Pastor: Robert Humrickhouse

Huntsburg Baptist Church

16419 Mayfield Rd.

Huntsburg, OH 44046

Pastor: Rev. Ben H. Garlick

Northwest Maranatha

Baptist Church

7126 Spring-Cypress Rd.

Spring, TX 77379

Pastor: Floyd Wilcox
Norwood Baptist

2037 Courtland Ave.

Norwood, $\mathrm{OH} 45212$

Pastor: Lee Fullmer

Oak Grove Baptist Church

5500 Woodend

Kansas City, KS 66106

Pastor: James R. Gray

Pleasant Heights Baptist

Church

1817 Montana Ave.

E. Liverpool, OH 43920

Pastor: Rev. J. Edgar Beckley, Jr.

Prairie Baptist Church

R.R. \#3, 206th Street

Noblesville, IN 46060

Pastor: Rev. Gene Parker

Prattsburg Baptist Church

North Main Street

Prattsburg, NY 14873

Pastor: Wayne W. Keisling, Sr.

Riverside Baptist Church

1250 West Mound Road

Decatur, IL 62526

Pastor: Rev. Richard Woodworth

Southgate Baptist Church

2111 S. Center Blvd.

Springfield, $\mathrm{OH} 45506$

Pastor: John R. Greening

Southside Baptist Church

379 South Commerce Ave.

Sebring, FL 33870

Pastor: Russell E. Lethbridge, Jr.

Trinity Baptist Church

$1525 \mathrm{~W}$. Superior

Alma, Michigan 48801

Pastor: None at the present time

Worthington Baptist

Church

Box 130

Worthington, PA 16262

Pastor: Walter E. Pifer 
Abel, Charles E. 91, 146

Abresch, Cheri Ann 207, 243

Abston, O. Diane 219

Acker, Joel D. 207

Adams, Kimberly Sue 219

Allard, Mary J. 219

Albright, Laura D. 196

Alexander, Alise A. 196, 245, 250

Allen, Amy Suzanne 207

Allen, David R. 219

Alliver, Ken 239

Altimus, Shari Lynn 146

Amas, April Lynne 5

Anderson, Gary B. 96, 97, 146, 251

Anderson, Hugh M. 145

Anderson, Kathy Sue 219

Anderson, Kurt Daniel 207

Anderson, Laurly Ann 219

Anderson, Leslie Marie 207

Anderson, Mark D. 207

Anderson, Michael A. 65, 219

Anderson, Sarah Jo 196, 239

Anderson, Sarah Jo 196,

Anderson, Wayne Paul 91, 146, 248

Angell, Anne W. 63, 66, 219

Angell, Anne W. 63, 66,
Angell, Dawn Marie 196

Angell, Dawn Marie 196

Anthony, Marc R. 196

Armstrong, Patricia J. 219

Ash, Kimberlyn Sue 196

Ashley, Tina Lynn 146

Atkinson, James A. 196, 248

Auckland, Denise Ann 207, 239

Augenstein, Sharon R. 196

Augustine, Beth 219

Augustus, April S. 62, 196, 249

Austin, Lee Stacy 62, 219

Austring, Bryan Allen 219, 243

Averill, Dave C. 146

Averill, Rebecca J. 207, 94

Avery. April L. 66, 196

Ayres, Kimra I 146

Baise, Cindy L. 207

Baker, Debbie Jo 219

Baker, Jeffrey Alan 90, 91, 219

Baker, Justine M. 219

Baker, Mark Andrew 64, 219

Baldis, Suan Marie 207

Baldwin, Douglas F. 219

Bane. Kenneth D. 65, 196

Banks, April Leann 219

Banning, Stephen A. 196, 242

Banzhof, Sharon Lynn 146

Bany, William W. 196

Barber, Caryn Lynn 219

Barber, James R. 146, 162

Barfell, Daniel Dale 147

Barker, Gary W. 196, 248, 244

Barker, Joel Bates 219

Barnes, Jeff 239

Barnard, Bret Alan 66, 207

Barr, Sarah Ann 207, 241

Barram, Lorene F. 147

Barrett, Albert G. 219

Bartholomew, Krisanne 219

Bartlett, Rebecca L. 59, 66, 196

Barton, Tammy Jo 207

Bartus, John Edwin Jr. 196, 243

Basler, Michael P. 66, 207

Bass, Denise Marie 219

Batchelder, Dina M. 64, 207, 243

Bath, William David 220

Battaglia, Ann Deborah 147, 239, 245, 248

Bauer, Robert A. 147

Baughman, Dawn E. 196, 242

Baughman, Jane Marie 207

Bayes, Lowell Daniel 64, 220

Bayes, Lowell Daniel 64,

Beach Melissa Jane 196
Beach, Timothy W. 57, 220

Beach, Timothy W. 57, 220
Beachum, Dawn F. 66, 220

Beachum, Dawn F, 66, 220
Beachy, Kent Lamar 196

Beachy, Kent Lamar 196
Beal, David Jonathon 220

Beaman, Rick Anthony 207

Bean, Marilyn Louise 207

Bears, Judy L. 147, 238

Beattie, Karen Lynn 196, 253, 46

Beaujean, Deborah Lee 220

Beeson, David Alan 220

Beight, James D. 66, 20

Beight, Jon D. 147

Beikert, Robert C. Jr. 62, 147, 239, 238

Belford, David Allen 57, 196

Belford, Linda Sue 220

Bell, Debra Joy 64, 196

Bell, Wendy Kaye 220

Bellerson, Rebecca Jo 66, 220

Beltz, Joan L. 220

Beltz, Joan L. 220

Benedict, James Robert 147

Benedict, James Rabert 147

Benevides, Prudence L. 59, 196
Bennett, Becky 245

Bennett, David J. 65, 20

Bennett, Jim A. 147

Bennett, Richard Wayne 197

Bensink, Kelli Larae 220

Benson, Jay Paul 147, 242, 240

Benson, Shellie L. 147, 240

Bercaw, John Andrew 220

Berdy. Debbi Lynn 207

Bergandine, Jeffrey W, 220

Bergandine, Keith Altan 207

Beres, Keith Alan 207

Bergman, Julie Marie 148

Beverly, David Edward 220

Bigelow, John R. Jr. 207

Biggs, Brian K. 208, 242

Biggs. Matthew B. 197, 242

Bigler, Cindy A. 220

Bishop. Janet Lynn 220

Bishop, Lori P. 148

Bishop, Peter Charles 197

Bishop. Todd Andrew 220

Bitterman, Carol Sue 197

Bixler, Melissa Jo 208

Black, Judith Lynn 62, 220

Black, Suellen Marie 61, 208

Blackburn, Sara J. 148

Blackman, Rodney J. 220

Blackstone, David J. 8, 238

Blake, Susan D. 197

Blaker, Arthur S. 197

Blasdell, Diane L. 62, 148, 239, 243

Blass, Brenda 148

Blaylock, Valerie A. 63, 208

Blessing Ann E. 94, 197

Bliss, Carol Joy 220

Bliss, Nancy Jean 197

Bliss, Rebecca Dawn 66, 220

Bloxhan, Annette Joy 65, 208

Boer, Jenny Anne 148

Boersma, Joy C. 208

Bohr, Rae Jean 220

Bonning. Therisa D. 208

Border, Wendy S. 148, 242

Border, Wentie Ruth 220

Borleis, Debbie Ruth

Borleis, Diane M. 220

Bosworth, Talitha Ann 220
Bowen, Renee Ann 208, 240

Bowen, Renee Ann 208, 240
Bowers, Ricky Clayton 148

Bowers, Ricky Clayton 148

Bowers, Martha Sue 220

Bowlen, Lisa Carol 66, 220

Bowling. Angela Dawn 220

Bowling, Robin R. 148

Bowman, Bruce Howard 62, 220

Bowman, Rachel Ann 197

Bowman, William Chad 22

Boyd, Alice Paulette 148

Boyd, Brooke Allison 208

Boyd, Marie Joann 220

Boyer, Colleen Ruth 197

Brace, Gregory W. 208

Brace, Laura Melinda 220

Brace, Lay Melinda Le 220

Bradiey, Melind Leign 208

Bradman, Kristian D. 66, 2

Bradshaw, Kevin U. 220

Bradshaw, Kimberly A.

Brady, Gerald C. 220
Brags, Kimberly K. 61, 220

Brandt, Sara J. 197
Braun, Michelle Ann 197

Braun, Michelle Ann 197
Bresson, Brad Lee 220

Bresson, Chad R. 197, 242

Bresson, Jonathan F. 63, 208

Brezee, Michelle Dawn 220

Brewin, James Paul 197

Briggs, Laurie Ann 197

Briggs, Linda Lee 149

Briggs, Susan B. 197

Britton, Beth 94, 149

Brock, Timothy A. 208

Broline, Robert Lee 63, 208

Brooks, Amy Elaine 220

Brooks, Amy Ele $R$. 220

197

Broughton, Shelly Ann 208

Brown, Diane L. 208

Brown, Glen Chalmer 59, 149

Brown, Jerrery P. 220

Brown, Lori Lynne 220

Brown, Ruth May 58, 60, 208

Brown, Tracy Lee 149

Brown, Warren Keith 197

Browne, Shelley Lynn 197

Browning, Linda Gail 220

Brugger, Jennifer Gray 197

Buck, Martha 197

Buckholz, John Ross 208

Bucklew, Elizabeth Ann 197

Bucklew, Ester Kae 149

Budd, Brent Edward 220249

Bugno, Joy Ellen 208

Bumpus, Tonya Jonell 98, 220

Burchett, Brenda D. 197

Burdette, Gail Lynn 220

Burdick, Dale J. 149

Burghen, David C. 149

Burke, Clavin B. 220

Burt, David A. 221

Burtis, M. Scott 149

Burton, Kristi 98, 208

Burrell, Kimberly Jo 221

Butcher, Jay Randall 208, 243

Butcke, D. Lynn 149, 242

Butler, Cynthia L. 149

Butler, Darlene S. 208

Butler, Jennifer L. 65, 221

Butler, Julie Ann 98, 208

Button, Cheryl Lynne 221

Butzlaff, Jeanne I. 66, 208

Byrd, Lorrie A. 208

Byrd, Warren William 149

Byrned, Heather Lynn 197

Byrum, Daniel Keith 59, 91, 221

Cadle, Patrick Ray 221

Cahill, Colleen 208

Caldejon, Randy Ivan 149

Calhoun, Antoinette J. 208

Calhoun, Dennis E. 197

Calisti, Lynne B. 208, 209

Calkins, Gayl Marie 221

Callan, Jon David 150

Calle, Judy R. 22

Calvert, Susan Kay 197

Campbell, Jill Marie 150, 159, 238

Campbell, Lyle 208, 240, 242

Campbell, Steven Mark 208

Campbell, Mike Alan 101, 197

Carafa, Christine M. 221

Carano, Darleen L. 150

Carey, Daniel W. 150

Carey, Richard J. 208

Carpenter, Sandra S. 197

Carr, Renee L. 221

Carr, Tom A. 197, 238

Carraher, David R.221

Carroll, Kathleen R. 221

Carter, Becky Lynn 22

Carter, Jeffery P. 208

Carter, Teresa Lynn 197, 245

Carter, Teresa Lynn Sydney S. 197

Caruthers, Sydney S. 197

Casteel, Lori Renee 208, 241, 242

Chamberlain, Jonathan 197

Chance, Stephen M. 197

Chandler, Andrew Louis 221

Chandler, Lisa J. 197

Chapin, Allyson Anne 150

Charter, Melody D. 208

Chase, Christina Anne 57, 197

Chasse, Richard D. 197

Cheek, Christine M. 221

Cherry, Douglas E. 97, 208

Chiarelli, Perri E 62, 208

Chilson, Paul Edward 22]

Chitwood, Marc D. 59, 197

Christmas, David Keith 151

Chung. Misun 221

Clark, Kevin L. 151, 245

Clark, Mark A. 66, 221

Clarkson, Rebecca L 197

Clayton, Cheryl Lynn 64, 151, 241, 250

Clayton, Kathleen M. 197, 241

Clayton, Ronald Alan 221

Clem, Doborah Ann 208

Clemens, Gregory Scott 197, 245, 248

Clements, Shelley L. 151, 245

Clifford, Karen E. 221

Clifford, Phillip E. 197

Cline, Kristine E. 66, 208

Coates, Steven David 208

Cobb, Jeannette Dawn 197

Cochran, Sally Jean 62, 150, 197, 239

Cochran, Steven Scott 221

Coffman, Erin E. 65, 208

Coffman, Shelley Kay 221

Colman Shy Justin 151, 251

Coiro, Gary Justin 151, 251

Colas, Laurie D. 151, 239

Coller, Cindy Ann 221

Collier, Peggy Ann 221

Colins, Meredith R. 197 
Eckam, Cathy Carol 153 Eckert, David Paul 15 Eckert, Jody Paula 222 Eddy, Calrence David 198 Edwards, Anne E. 61, 210 Edwards, Daniel Earl 64, 153 Edwards, David P. 66, 198, 242 Edwards, Donalda L. 198 Edwards, R. Michael 153, 155, 239 Edwards, Susan Lori 222 Eifert, Lamar C. 59, 210, 251 Eimers, Tami 198 Eisentrager, Steve R. 198 Eissens, Ruth A. 98, 222 Elissens, Ruth A. 98, Eller, David Scott 57. 62, 196, 198 Elliott, Jeff Brian 65, 222 Elliott, Karen J. 222 Ely. Mitchell D. 153
Emerson, Tricia M. 153 Emerson, Tricia M. 153
Emmons, Steve James 59, 198 Engdahl, David A. 198 England, Mark G. 222 English, Evan W. 222 English, Julia L. 154 English, Rob S. 210 Enman, Michael James 101, 210 Ensminger, Brian S. 62, 154, 248 Erdmann, Julie Diane 154
Erickson, Steven R. 154 Erikson, Jeffrey Scott 64, 222 Erikson, Keith Mallery 198 Erlandson, Daniel B. 222 Estes, Janice Lynn 66, 19 Etclison, Layne E. 222
Evans, Donna Jean 222 Evans, Donna Jean 222
Evans, Tammy Ann 207, 210, 240 Evans, Tonya Lynne 66, 222 Everage, Jennifer Lynn 66, 222 Everett, Dan David 66, 21 Everitt, Susan Renee 222 wing, Antonio Terrill 100, 101, 222 Ewing, Paul Thomas Jr. 154, 251 Exley, Jonathan L. 66, 210

Facey, Yvonne A. 210 Fairhurst, Kirk A. 63, 101, 198, 251, 238 Fairhurst, Mark H. 222 =elt, Melissa $E-222$ Fannin, Brenda J. 222 annin, Brenda J. 222
Farley, Catherine E. 154 Fawcett, Lisa C. 210,240 Eenstermaker, Alice L. 66, 222 Ferguson, Melody Rose 222 Eetzer, Laura Jeanne 222 Field, Keith Eldon 222 Figary. Wendl Anne 210 ires, Robert W. 101, 154, 251 irman, Debra Ann 66, 198 irth, Karen Lynn 210 issh, Gregory David 223 ish, Laura Marie 66, 210 issher, Brandi Lee 154 Fisher, Brenda Jean 198 isher, Jody Kay 211 isher, Leon 223 the Tom A $91,198,248$ ile, Tom A, 91, 198, leetwood, Mark Wesley 91, 198, 251 leetwood, Teena Marie 198, 241 leetwood, Teena Marie 198,
lenner, Bethany Jayne 223 lenner, Bethany Jayne 22
lenner, Holly Anne 210 ogle, Philip Ray Jr. 91, 210 ord, Andrew Scott 210 ord, Donna Marie 198, 239 ord, Lisa A. 223 ordyce, Kimberly Ann 223 ornell, Lorene Leigh 154 orrest, Henry Joseph 15 ortosis, Claire Anne 210 oster, Debbie Lynne 223 rank, Greg L. 223 rank. Judy Lynn 223 rank, Shelly Lenal 19. razier, Susan Carol 154 razier, Susan Carol 15 rederick, Randall G, 198 rederick, Randall $G$. reeburger, Donna M. 155 reeburger, Donna M, 155 reeman, Robert W. 155 reeman, Steven Earl 155 rench, Brooke, Linn 223 rey, David C. 211 rey, Dawn L. 211 riar, David Eugene 223 riedkin, Christine A. 223 ultz, Joe R. 198 abel, Deanna Kay 211
ainey, Daniel F, 211
Galland, Cynthia A. 155

Garbig, Darci Marie 211

Gardner, Deborah D. 155

Gardner, Elainew R. 223

Garmatter, Janet Sue 211

Garrett, David Anthony 223

Garrison, Bradley A. 198

Gaston, Renee S. 198

Gates, Bonnie Faye 223

Gavorski, Mark A. 223

Gayer, Julie Elizabeth 62, 223, 245

Geese, Carol Ann 223

Geiger. Teresa Annette 156, 241, 250

George, Dan 58, 156

Gephart, Diane Lynn 21

Gersema, Julie Ellen 223

Gersema, Lynette Marie 156

Gerzema, Kevin Robert 211

Getz, Sarah M. 66, 211

Gibson, Jill Rae 198

Gibson, Mal Derrick 156

Giesel, Timothy D. 198

Giesman, Kenneth A. 211, 243

Gifford, Jody M. 211

Gilbert, Jeffrey W. 211

Gipson, Alien Dale 64, 223

Glezen, Debbie A. 21

Goehring. Thomas Jay 223

Golden, Jonathan David 224

Goldsmith, Beth Ann 63, 98, 199

Golemba, Brenda L. 199

Goocey, Sandra K. 224

Goocey, Tony Vaughn 199

Good, Timothy Scott 199

Gordon, Anne L. 211, 245

Gorges, Crissie-Ann M. 156

Gorman, George Charles 156

Gorman, Ruth Eudene 211

Gornowich, Theresa L. 211

Grady, Wendy Jo 211

Graef, Stephen Ronald 211

Graff, Tammy Evonne 224

Grant, Kelly Ann 211

Grasley, Michelle Ann 199

Green, Mike A. 224

Green, Sandra Lee 199

Greetham, Susan Lynn 63, 199

Gresh, Robert William 224

Greve, Thomas Alan 101, 156, 251

Grimes, Tracy E 211, 244

Grimes, Tracy E. 211, 244

Groves, Mark L. 62,

Grosse, Annagret 243

Gruet, Katrina Renee 156

Gruet, Thomas James 156

Grumbeck, Holly A. 199

Guido, Cindy 61, 224, 250

Gruneisen, Virginia A. 211

Guest, Amy Jo 64, 211, 217, 242

Gunther, Stacy L. 211, 240

Gusick, Dawn Marie 224

Gust, Brenda Jo 211

Gwinn, Rebecca C. 199

Haberli, Lori R. 211

Habermehl, Elizabeth A. 156

Hack, Noel Martin 59, 91, 199, 251

Hackbarth, John Robert 211

Hackenberry Lyn Marie 211

Haist, Heidi Lynn 224

Hakes, Caryn Beth 156

Hakes, Daniel Lee 224

Hale, Daniel Lee 224

Hale, Gregory Allen 211

Hale, Gregory Allen 211

Hall, David Warren 224

Hall, Melanie G. 224

Hall, Steve M. 224
Halleck, Melissa Jane 224

Hallman, Donna Sue 60, 199

Hamlin, Paul Lee 224

Hamilton, Lisa Ayn 59, 224

Hammer, Keith Allen 58, 224

Hammond, Michael F. 199

Hancock, Crystal Ann 199

Hancock, Debra C 156

Hancock, Laure S. 211, 242

Hancock, Laure S. 211,

Haney, Alysia Kay 224

Hannay, Sherri Lynn 224

Hannay, Sherri Lynn 204

Happe, Judy 199, 242

Harbaugh, Joel 243

Harden, Joy Ann 199

Harden, Mark Allan 224

Hardman, Kathleen I. 22

Harper, David R. 224

Harrington, Karen J. 157

Harris, Gregory Alan 224, 250

Harris, Kathi 59, 207, 250

Harris, Nadine Sue 157

Hart, Christina Joy 199, 248

Hart, Joy Ann 157, 241, 243

Hartsough, David A. 157

Hartsough, Laure Ann 64, 66, 211

Harvey, Doris Eileen 199

Haskins, Kevin Sean 57, 199

Haskowich, Ann K 58, 211

Haufler, Jennifer $K .224$

Haupt, Jennifer Sue 225, 249

Haupt, Jennifer Sue 225, 249
Hawk, T. Daniel 90, 91, 199, 243, 251

Hawkins, Nancy Joann 66, 225

Hawley, Lorivean 199, 245

Hayden, Joel Alan 225

Haywood, Richard G. 211

Hayes, Beverly D. 196, 199

Hazelton, DeAnn Ruth 225

Hazen, Janet L. 15

Heacox, Larry Leon II 211

Headdings, Karen Y. 98, 199

Healey, Heather Ann 211

Hedges, Brian Thomas 65, 200

Heffelfinger, Jeffrey 211

Heflick. Heather M. 157, 240

Hein, Stephanie Jean 225

Heise, Ronda Mae 225

Heitzman, Diana L. 211

Helman, Kelley Lee 200

Helmick, Carol Lee 200

Helmick, Cynthia Joan 211, 242

Helmick, John Scott 225, 241

Helmick, Kelly L. 200

Helmuth, Eric Dale 211, 248, 249

Hempel, Heidi E. 200, 248

Henderson, Matthew $L 211$

Henderson, Nadeen Kay 211

Henderson, Rebecca K. 157

Henry, Debbie Kay 62, 157

Henry, Lisa Beth 211

Henthorn, Rebecca L. 211

Herbert, Kelly Jean 66,157

Herr, Benjamin James 157, 248, 249

Herr, Cheryl Dainne 60, 225

Herr, Suzanne M. 200, 245

Herrick, Kendall Lynn 211

Herriman, Carol Sue 200

Herrington, Rick R. 157

Herrmann, Marc Alan 225

Herron, Lanay Rasue 225

Hershberger, Tamra E. 158

Hershberger, Valorie A. 211

Hess, Linda Ann 62, 158, 248

Hess, Lori Ann 62, 158, 238

Hess, Patricia Judy 225

Hibbard, Hope Ann 211

Hickey, Lorrie Ellen 158

Hicks, Daniel K. 158

Hill, Cheri Annette 225

Hill, Joeleah Joy 158

Hill, Tom C. 96, 97, 200, 248

Hilsmeier, Robin L. 158

Hiner, Marianne Jo 200

Hines, Karla Marie 65, 2

Hinkson, Shawn 63,158

Hippard, Shawn M. 63,

Hite, Valerie 240

Hobby, Richard D. 211

Hochstettler, Virginia 212

Hoddelmann, Kirsten T 225

Hoddelmann, Kristina T 225

Hoecke, Beth Jeanne 61, 212, 239

Hoefler, Chris J. 212

Hofer, Mariso 22

Hoffmeyer, Gretchen A. 225

Hohulin, Philip J. 212

Holbrook, Sandra Lee 225

Holland, Cheryl Lynn 65, 225

Holliday, Kimberly J. 158

Holloway, Van B. 225

Holly, Irvin Raymond 158

Holman, Angia L 212

Hollman, Kathi Jo 158

Holmes, Detorah C. 159

Holmes, Robert Timothy 66, 225

Holt, Keith William 159, 239. 238

Hood, Barbara L. 159

Hood, Robert 159

Hornbeck, Beth Ellen 159, 248

Hornbeck, Joanne R. 225

Horne, Douglas V. 200

Horne, Mark 200, 240, 245, 250, 244

Horner, Jack Alan 159

Horner, Lori Ann 160

Horsfall, Richard G. 160

Horton, Shellie Kim 225

Hoskins, Barbara Anne 200, 239

Hoskinson, Joel Mark 212

Howder, Scott J. 212, 239 
Kirtland, Jon Mark 226 Kirtland, Ruth E. 60, 161 Kitchen, Barry Lee 226 Kizer, Danielle Kay 213 Kline, Jeff $W .213$

Klopp, Rebecca Ann 213 Klopp, Rebecca Ann 213

Knauff, Melanie Lynn 200 Knicely, Mary Beth 213 Knowles, Laurie Anne 226, 245 Knowles, Laurie Anne 226, 245
Knowles, Temple Leigh 61, 200 Knowles, Temple Leigh 61. Koerber, James R. 64, 213, 242, 249 Kohlmeyer, James M. 200, 24 Kojko, Robert James 162, 240 Koppe, Carol Lynn 162, 239 Kozma, Kara Frances 226 Kramer, Jill Carver 162 Kraner, Jane E. 200 Kratche, Shari L. 16 Kreuscher, Jennifer L. 226 Krikke, Lorin Kenneth 213 Krull, Kathy Ellene 213 Kuhn, Stephen A. 200, 239 Kyle, Terry L. 162 Kyser, Rhonda L. 213, 245

Labonte, Nancy Renee 200, 250 Lafferty, Susan Jane 61, 213 Lahate, Daniel A. 200 Laire, Joanne J. 200 Laird, Michele Denise 226 Landis, J. Michael 226 Lane, Michael C. 213, 243 Lanning, Edward C. 200 LaPonsie, Daniel Reuel 162 Larsen, Martin Airie 226 Lash, Roge Dawn 62, 226 Lassitter, Terry E. 226 Latini, Angela Marie 226 Latitini, Mark A. 200 Latini, Mark A. 200 Latorella, Beth Anne 226
Latorella, Robert L. 226
Laud, Suzanne 200 Laud, Suzanne 200 Lauterbach, Sandra M. 213 La Vancher, Barbara L. 226
Law, Michael David 62, 213 Law, Michael David 62,
Leach, Jeffrey Alan 213 Leach, Lori A. 163, 240 Leach, Shari K. 60, 226 Lee, Sheryl Ann 226 Lee, Todd Edwin 201 Leitch, Daniel E. 66, 213 Lelah, Michelle Jan 22 Libby, Craig W. 226 Licklider, Kristin E. 226 Lin, Camila Chao-guang 163 Lin, Camila Chao-guang 163 Lindley, David Andrew 226
Lindley, Doris Ann 213 Lindley, Doris Ann 213 Lindsey, Lori A. 201 Link, Christopher S. 226 Link, Francis A. Jr. 163
Litle, Darryl C. 58, 163 Litle, Darryl C. 58, 163
Little, John W. 63, 201 Little, John W. 63, 201
Livengood, Roxann Lee 226 Livingston, Michelle B. 65, 213, 243 Lombard, Catherine M. 65, 213 Long, Brent A. 163, 248 Long, Cyndia Lynn 201 Long. Gina Rae 65, 227 Long, Tricia Ann 201 Longnecker, Sharon Ann 163 Longo, Michelle Marie 201, 202 Lons, Linda A. 65, 207, 213 Loomis, Jeffrey Todd 213 Loomis, Jeffrey Todd Lopez, Alberto 213 Lord, Colin Wendell 163 Lord, Colin Wendell 163 Lottman, Amy Dawn 227
Lough, Donald H. Jr. 213 Lough, Donald H. Jr. 213
Lowe, Denise Jayne 201, 245 Lowe, Denise Jayne 201, 245
Loy, Rob D. 196, 201, 245 Lunstrum, Elizabeth A. 163, 248 Luttrell, Roger D. 201, 251 Lydic, Amy L. 213 Lyle, Jeffrey David 163, 242

McAllester, Sharon R. 61, 213 McBee, Tanya Renee 58, 61, 213 McBrayer, William E. Jr. 163 McCafferty, Syndy J. 227 McCain, Alan 65, 201 McCain, Alan 65, 201 McCaskill, Stacy Marce 98, 227 McClure, Daine Rae 63, 213 McClure, Daine Rae 63, 213 McConnell, Diana Lynne 213 McConnell, Shawn L. 227 McCormich, Christine A. 227 McCormich, Lois J. 163 McCoy. Tracy Lynne 58, 207, 213
McCoy, M. Jill 164 McCracken, Sheryl J. 201 McDonald, Lisa K. 201 McElroy, Laura C. 164, 248, 250, 249 McGarry, Michele Lea 227 McGhee, Faith A. 201 McGill, Rich Daniel 201 McGillivray, Beth 94, 95, 214 McGraw, Camille A. 201 McGuirre, Sara Lea 201, 250 McHenney. Cheryl Lynne 63, 210 Mckibben, Amy Beth 227 Mckibben, Beth Ann 201 McKinley, Carol M. 201 McLaughlin, Cherry J. 227 McNabb, Bruce Raymond 62, 201 McNeish, Marilyn Jean 164, 249 Mass, Brian F. 214, 240 Macfarlane, Heather L. 227 Mach, Thomas Stuart 227 Mackeen, Robbie Allen 227 Mackenzie, Terri Lynn 214 Mackey, Ronald W. 61, 227 MacMichael, Melissa A. 201 Maddox Brian David 214 Maddox, Brian David 214 Main, Jeffrey Donald 227 Main, Jeffrey Donald 227 Major, Joanne Karen 201 Malek, Barry Alan 227 Malott, Leslie Rene 201 Mangrum, Vicki L. 164 Manion, Lisa G. 214 Manley, James P. Jr. 164 Mansfield, Karl E. 227 Mansfield, Kristine C. 227 Manuel, Richard Craig 164, 248 Marble, Jeffrey Scott 202 Marburger, Brian J. 227 Margraft, Ruth Evelyn 64, 227 Marling, Will 63, 202

Marriott, William R. 164, 243

Marshall, Holly S. 44, 214, 240, 242, 250, 249 Marshall, Melissa A. 202, 248

Marshall, William Paul 202

Martin, April Dawn 214

Martin, Jay Wesley 202, 242, 248 Martin, Jeff A. 227

Martin, Michele Joyce 164

Martin, Wesley C. 214

Martindale, Paul C. 214

Mason, Rodney Mark 202

Mason, Ruth Marie 62, 202

Massie, Kristi E. 62, 202

Mast, Clifford L. 62, 202

Masters, Lois Kay 202

Masters, Lynda L. 214

Mastin, Brenda Kay 202

Mathews, Bryan Keith 214

Mathews, Bryan Keith 214

Mathews, Mark Edward 202, 245

Mathewson, Melanie Ann 164

Mathis, Kelly R. 214, 248

Mathis, Kelly R. 214, 248 242, 238

Matthews, Jennifer L. 202,

Mazey, William J. 164, 2

Meadows, Karen Sue 214

Mears, Gregory Scott 164

Mellott, Stacy Ann 227

Merchant, Bradley C. 165

Meriwether, Deborah L. 22

Merriman, Janet Kay 227

Messick, Don W. 165

Meyer, Phillip R. 227

Meyer, Ruth L. 165

Meyer, Stephen A. 202, 239

Michael, Elena Marie 62, 202,

Michael, Sharon Lynn 227

Michael, Sharon Lynn 227

Michonski, James David 227

Mieden, James David 227

Mikesell, Michae

Miller, Deb 240

Miller, Kimberly D. 227

Miller, Larry Edward II 202

Miller, Rebecca Sue 165

Mills, Gary L. 165

Mills, Sherrie Lee 214

Mills, Susan G. 165

Mininger, Andrew L. 63, 91, 227

Mitchell, John Garrett 214

Mitchell, Mark J. 202

Mitchell, Pamela Sue 227

Mitchell, Pamela Sue 227

Modderman, John R. 101, 202

Modderman, John R. 101,

Modesty, Bonnie Sue 202

Moeser, Jean M. 202

Moll, James B. 202

Monroe, Randall C. 65, 165
Montford, Brett Earl 2, 242

Monttord, Brett Earl 2, 242

Moody, David Lane 91, 165, 251

Moody, Michele Denise 227

Moon Pamela J. 227

Moon, Sheila Diane 203

Moore, Christopher D. 227

Moore, Dale D. 203

Moore, John Andrew 203, 239

Moore, John Eugene 203

Moore, Robert Louls 97, 214

Moore, Robert Louis 97, 214

Moosey, Timothy W. 214

Moran, Gregory Stephen 214

Moreland, Tammy Ann 227

Morgan, Scott David 59, 227

Morris, Dan L. 214

Morris, Ruth Dawn 227

Morse, Holly Ann 227

Morton, James W.R. 203

Moser, Kevin L. 214

Moser, Susan J. 203

Mossburg, Jeannette L. 227

Mossman, David Lee 60, 227

Motzer, Lisa A. 214

Mountz, Gretchen Lynn 227

Mowrey, Debra Sue 214

Mowry, David H. 203

Moyer, Scott 64, 203, 239

Moyer, Steven Robert 227

Muckley, Paul Kenneth 227

Mukes, Cicero C. Jr. 64, 165

Mulberry, Errin Gene 227

Mulholland, Dan E. 203

Mulligan, Steve J. 165

Mullinix, Jeffrey S. 166

Munson, Robert Harold 214

Murdoch, James Murray 64, 2, 239

Murphy, Deborah Joan 214

Murphy, Kimbra Kay 166

Murphy, Patrick John 214

Murray, Greg A. 203

Murrin, Alicia Mac 203

Murtoff, Ruth Marie 65, 214

Murtorf, Ruth Marie 65, 214

Musseiman, Rex Alan 166

Myfelt, Dwight David 166

Nash, Glenn S. 228

Nasse, Tammie Sue 228

Neal, Sheila Lynn 214

Nemecek, Rose Ann 203

Nemitz, Mark A/bert 214

Nervo, Nicolas 214

Nesbitt, Patrick M. 228

Nester, Beth Ann 61, 214, 242

Netzley, David J. 60, 228

Neudeck, Edward Wayne 203

Newell, Dean Edward 228

Newsome, Mary Beth 203

Nicholas, John Alan 166

Nichols, Donna Gean 214, 240

Nichols, Kenneth N. 214

Nichols, Sonya Renee 59, 203

Nickosan, Krista Lynn 203

Niederer, Tom John 228

Noggle, Dianne M. 63, 228

Nonnemacher, Gary S. 203

Nook, Galyn Francis 59, 228

Norden, Gregory S. 91, 2, 248

Norfleet, Derrick, 228

Norrell, William B. 203

Norrick, Sherri Lynn 98, 214

Norton, Lorene 167, 242

Nuss, Randall S. 167

Oakes, Judith E. 58, 64, 203

O'Boyle, Sandra J, 214

O'Connor, Rebecca E. 203

O'Dell, Constance J. 203

O'Donnell, Patrick A. 203

Olinger, Danny E. 101, 214, 251

Oliver, Ken Charles 203, 242

Oliace, Kim Eileen 203

Olson, Brian Edward 16

Olson, Susan Lynn 203

Ooms, Gordon G. 223, 228, 240

Orban, Michael Allan 167

Orr, Laurie Ann 214

Orton, Rebecca Linn 228

Osborn, Debbie Lynn 203

Osborn, Lori Daine 228

O'Toole, Beth 228

Ottaway, Diane Sue 203

Ottaway, Lori Ann 63, 228

Oyos, Mark D. 214 
Reed, Cynthia Louise 169 Red, Krista G. 229 Reed, Mark A. 229 Reed, Michele Beth 229 Reed, Patricia J. 215 Reede, George E. 215 Reeder, Lawrence G. 215 Reehl, Dawn Marie 204 Reese, Chris A. 101, 229 Reeves, Jennifer E. 215 Reeves, Jennifer E. 21. Regnier, Diane L. 169
Reichard, Lawrence A. 169 Reichard, Lawrence A. 169
Reid, Jonathan Charles 91, 204, 248 Reid, Jonathan Charles
Reid, Rebecca D. 216 Reid, Rebecca D. 2 Reid, Lori L. 229
Reiter, James Michael 61, 196, 204 Reiter, Thomas C 229
Reiter, Tomothy John 169 Reiter, Tomothy John 16
Reminick, Kelly L. 169 Reminick, Kelly L. 169 Renole, Cheryl Ann 94, 216 Reverski, Robert S. Jr. 229 Reynolds, Katherine D. 216 Rhoades, Krista Lynn 204 Rhoades, Malinda Ann 204 Rhoades, Todd A. 64, 20 Rhoden, Lori Ann 229 Rhodes, Mirian Elanie 169, 204 Richards, Bruce W. 169,251 Richards, Lisa Ann 63, 169 Richardson. Deborah I 169 Richardson, Deborah 1. 169 Rickard, Brad M. 170, 2 Rickard, Pamela Jo 216 Riggs, Melissa Carol 229
Rinderknecht, Sylvie 58, 170, 243 Rinderknecht, Sylvie
Ritchie, Carla L. 170 Ritchie, Carla L. 170
Ritter, Melinda Kay 216 Ritter, Melinda Kay 216
Rivera, Thea Karina 229, 242 Robbins, Jerry Ray 204 Robinette, David Lee 61, 216, 248 Robinson, David Warren 64, 229 Robinson, Jennifer Sue 204 Robinson, Jim Allen 216 Robinson, Kimberly J. 62, 216 Robinson, Lynn Renee 229 Rockey, Colleen Susan 17 Rockwell, Steve Craig 204 Rockwood, Renee R. 204 Rodriguez, Jenny 170 Rogalewski, Karol A. 224, 229 Roggalewski, Kimberly 224, 229 Rogers, Tamara Karen 229 Rogers, Tamara Karen 229 Rogers, Richard B. 204, 238 Roget, Brian Jon 204, 2. Roland, Carole Jean 204
Romano, Catherine Ann 20 Romano, Catherine Ann 204
Romig, Jane Diane 94, 95, 204 Romig, Jane Diane 94, 95,
Rorrer, G. David Jr. 216 Rorrer, G. David Jr. 216 Rose, Kristine Kay 229 Rose, Mary 223, 239
Rose, Wendy M. 229 Ross, Sandra 170 Rotramel, Sherry Marie 216, 244, 249 Rowland, Jason Dean 229 Rowland, Landon Lee 21 Rowland, Laura Rae 229 Roy, Tracy A. 64, 204, 249 Ruby, Darren L. 216 Ruggles, Gayle Lesley 229 Runge, Judith L. 204, 245 Rupe, Virginia Kim 204, 240 Russell, Linda C. 204 Ruth, Marilyn F. 204 Ruth, Marilyn F. 204 Ryan, Heidi Marie 230 Saboge, Mary Jo 250 Sadler, Kerri Lynn 230 Sadowitz, Jon P. 230 Sallee, David Michael 170 Sallee, Glen W. 204 Salmon, Kimberly Kay $23 \mathrm{C}$ Sand, Robert M. 204 Sanford, Barbara Arlyn 170 Sandy, Jill Ann 59, 216 Santilli, Meegan Anne $23 \mathrm{C}$ Sauage, Eric Charles 230 Saunders, Shannon M. 204, 248 Savage, Mary Jo 20 Schaak, Melanie Faith 230 Schaed, Man 59. 91, 17 Schakat, Timothy Mark 216 Schieferstein, Scot A. 230 Schiele, Roger M. Jr. 2 Schlanitz, Kevin J. 230 Schonfeld, Fay Dawn 230
Schroder, Jewel Kay 98, 99, 20 Schroder, Jewel Kay 98, Schultz, Melody A. 21 Schultz, Stan A. 170 Schomaker, Dave W. 97, 216 Schuttenberg, Monica L. 21 Schwartz, Deborah S, 216
Scott, Charles Vernon 58, 62, 230, 239 Scott, Susan Jean 170
Scouten, Sharon Rose 170 Searles, Daniel R. 216

Searles, Kimberly Ann 216

Seefried, Erick Jon 230

Seest, Lila Mae 230

Seidel, Erick Jon 63, 91, 216

Seller, Forrest Randal 216

Sergeant, John J. 205, 239

Sewell, Marcia J.A. 216

Shade, Donald R. 230

Shaff, Lorena Hope 59, 230

Shaffer, Ardena Leight 230

Shaffer, Linda L. 65

Shamie, Shane Kyle 171

Shank, Ronette 230

Shannon, Todd E. 64, 205, 249

Shark, Robert Dean 230

Sharpe, Richard P. 205, 243

Shaull, Phil A. 230

Shaw, Kevin A. 216, 248

Sheets, Jill L. 216

Shepherd, Charles E. 171

Shepherd, Daniel Scott 230

Shepherd, David Michael 205

Sherman, Michael Howard 171

Shovelton, Kenneth M. 205

Shovelton, Lawrence M. 171

Shriver, Deena Ree 216

Shrum, Eric Lawrence 207, 212, 216

Shuler, Sherri Lynn 216

Shulse, David Earl 205

Shulse, Sandra Kaye 230

Shupert, Teena Y. 65, 171

Sibert, Kathryn Marie 216

Sickau, Lynne M. 230

Sidle, John E. 171

Siefert, Marlene Kay 205, 241

Simerly, Dan Howard 101, 230

Simington, Jane Lynn 230

Simpson, Karen Joy 171, 245

Simpson, Karla Rene 65, 230

Sinclair, Becky Ellen 205

Skinner, Nora K. 205

Skjoldal, Neil O. 171

Slane, Vicki Lynn 205

Slayton, Jill M. 230

Sloan, Robin K. 230

Sloan, Tammy W. 205

Sloan, Tammy W. David M. 205

Smallman, David A. 216

Smart, Janae 230

Smart, Linda Carol 171

Smart, Thomas James 216

Smiley, Teresa Ann 171

Smith, Allyn N. 230

Smith, Benjamin P. 205

Smith, Betty Marie 205, 240, 245

Smith, Carmen G. 205

Smith, Demaurice F. 171, 248, 250

Smith, Kelly Sue 205

Smith, Kimberly Kay 230

Smith, Kristine Lynn 230

Smith, Lee Anne 230

Smith, Liana 205

Smith, Marcia Sue 172

Smith, Pamela Miriam 216

Smith, Rhonda Lynell 230

Smith, Rich Roy 230

Smith, Rich Roy 230

Smith, Rodney J. 205

Smith, Rodney J. 205

Smith, Rodney N. 205

Simi, Ronald $M .172$

Smith, Ronald M. Jr. 216

Smith, Stephen Andrew 230

Smith, Timothy Glen 65, 172

Smith, Tonja Ann 230, 243

Smyth, David A. 172, 238

Snader, Esther M. 172

Snider, Gregory A. 216

Snook, Ruth L. 172

Snyder, Andrea B. 60, 216

Snyderm, Beth A. 59, 230

Snyder, Bonnie Beth 230

Snyder, David R. 173

Snyder, Dianna Kay 173

Snyder, Dianna Kay 173

Snyder, Donna J. 216

Snyder, Jayne Marie 173

Snyder, Michele Marie 230

Snyder, Rebeca Lynn 205

Soellinger, Connie M. 230
Sorenson, Scott E. 230

Sorenson, Scott E. 230
Soules, Keith Duane 58,230

Soules, Keith Duane 58, 230
Sparline, Jane Marie 58, 62, 64, 173

Spees, Ann Troutman 230

Spencer, Ellen R. 62, 173, 245

Sperry, Kevin Lee 230

Spicer, Carol Hope 230

Spiegel, Lori Jan 64, 230

Spieker, John E. 205

Spradlin, Andrea 173

Sprague, Ralph M. 204, 205, 249

Springer, Samuel T. 216

Squires, Margaret A. 216

Srnis, John Paul 101, 173

Stackhouse, Julie Lynn 216

Stagg, Kathy E. 205

Stagg, Kristen Ed. 230

Stalter, Susan Lynn 230

Stamm, Marlyn Lee 205

Stanfill, Parin Lee 205

Stankey, Pamela S. 231

Starkey, Larry Von 231

Steele, Lisa Beth 205, 239, 250

Steere, David John 173

Steiner, Merideth Ann 231

Stephens, John Robert 231

Stith, Wendy A. 64, 216

Stitt, Julie Ann 205

Stockham, Robin Marcie 205, 240, 242

Stoltzfus, Betsy Gay 231, 245

Stoltzfus, Cynthia M. 205

Stone, Elaine Elizabeth 173, 239

Stone, Jon W. 205

Storer, Jill Kathleen 216

Storms, Kevin Brooks, 23.

Stover, Scott Allan 231

Stowell, Ronald L 216

Stratt, Andrew R, 205

Stuebe, Denice Lynn 173

Sturgis, Barry Lym 173

Sturgis, Brin Paul 216

Strause, Lila Louise 231

Stretch, Heater Renee 231

Stromley, Kar Renee 231

Stroupe, Timothy Paul 23

Stumme, Jack James 58, 60, 231

Sutliff, Brenda J. 231

Summerville, Kurt 215

Sunderman, Karen S. 205

Supplee, Edward Robert 173

Swanson, Pam M. 216

Swayze, Jill Aileen 217

Sweitzer, Mark F. 217

Swope, Kenneth Eugene 205

Sykes, John Roger 217

Synnott, Deborah Ann 217

Tacket, Rebecca Leah 231, 242

Taft, William C. 65,205

Tait, Steven P. 217

Tansey, Carrie Marie 217

Tatum, Connie Ann 217

Tavierne, Rich S. 205

Taylor, Allison Kay 217

Taylor, Barbara J. 174, 239

Taylor, Brian Keith 60, 174

Taylor, Cynthia Louise 205

Taylor, Gayle Aileen 205, 250

Taylor, Joel Kenneth 174

Taylor, Walter Lee Jr. 217

Tedford, Jeana Beth 205

Teec, Valerie Jean 231

Terkelsen, Franklin L. 205

Terpenning, Darrell W. 205, 239

Terpstra, Steven Keith 101, 205, 251

Terrill, Nadine Lin 217, 244

Tewksbury, Linda 231

Thacker, Don 205

Thacker, Brent Daniel 174

Thane, Brent Daniel 174

Thank, Michael Allen 174

Thiba, Connie L. 63, 205

Theis, Linda Ruth 174

Thomas, Amy Rebecca 64,
Thomas, Donna J. 217

Thomas, Donna J. 217

Thompson, David K. 205

Thompson, Jean Elaine 205

Thompson, Joanne E. 231

Thomson, Rob Bruce 64, 23

Thornton, Lydia Bae 217

Thornton, Thomas R. 23.

Tice, Sheri G. 205

Timco, Debra Sue 231

Tinner, Mark Alan 205, 242

Titus, Alan 217

Titus, Jenny L 217

Tober, Doris Ilse 21 
Willcott, Dave 239

Willett, Dale Scott 206

Williams, David M. 64, 176

Williams, John Timothy 64, 218

Williams, Kenneth J. 206

Williams, Teresa Kay 176

Williamson, Tanya L. 218

Willms, Tim Alan 232

Wilson, Charline 216

Wilson, John Andrew 218, 250

Wilson, Kay Michele 206

Wilson, Ray Michele 206

Wilson, Rebecca Ann 232

Wilson, Teresa Diane 218

Windham, Joy S. 206, 239

Windish, Melissa N. 232

\section{Faculty:}

Abbas, Robert, PhD 130

Ager, Merlin, $\mathrm{PhD} 130$

Alyn, Irene B., PhD 130

Anderson, Lyle, PhD 130

Baker, J. Wesley, MA 130

Baker, Lois MEd 130

Baker, Sue, MA 140

Baldwin, Richard, MBA 130

Ballard, Stanley N., PhD 130

Bartholomew, Ray, PhD 130

Bates, Patricia L., MA 130

Bauer, Janet A., MS 130

Baumann, Donald, PhD 130

Bergen, Harmon, MA 130

Biddle, James, PhD 130

Biddle, Sharon, PhD 130

Boneberger, Omer, DEd 130

Bosworth, Tim, BA 130

Braithwaite, Edwin, PhD 130

Brock, Lynn, MLS 130

Brown, Debra, MBA 130

Brown, Elaine, MSEd 130

Brown, Stephen, MLS 130

\section{Staff:}

Ager, Ruth 134, 245

Anglea, John 134

Auckland, Diane 134

Auckland, Mary 134

Auckland, Robert C. 134

Baldwin, Martha 134

Beight, Donna 134

Beikert, Grace 134

Bergen, Audrey 134

Boley, Brenda 134

Bosma, Jan 134

Bowersox, James 134

Bowersox, Richard 134

Bradds, Connie 134

Brock, Jeffrey D. 134

Brown, Mark 134

Brown, Stephen 134

Burrichter, Margaret 134

Cagwin, Debbie 134

Campbell, Fran 134

Campbell, Jack 134

Carr, Alberta 134

Cato, James 134

Chaffe, Stuart 134

Chambers, Jim 134

Compton, Deborah 135
Windnagle, Amy Jo 206, 248

Windnagle, Wendy Joy 232

Winkleman, Dawn Jylene 57, 232

Winkleman, Jill Denise 57, 176

Wiseman, Robyn R. 218

Wittenkind, Janet Lynn 65, 218

Wittenbach, Kendra Sue 206

Wolcoll, David Alan 232

Wolcoll, David Alan 232

Wolte, Jeftrey Owen 232

Wood, Braphen E 216

Wood, Shephen 216

Woodard, David Richard 232

Woods, Parnela Jean 206

Woodgate, Linda Ruth 206, 24

Wright, Amy Suzanne 216

Wright, Antony D. 232

Callan, Donald, PhD 131

Clark, Martin, EdD 6

Clevenger, Charles, MA 131

DiCuirci, Michael, MM 131

Diehl, Pamela S., PhD 131

Dixon, Pat, MEd 131

Dolph, Charles D., PhD 131

Durham, Richard, ThD 131, 243

Eimers, Lee, PhD 131

Eimers, Sharon, MSpEd 131

Ellington, Charles, $P h D 131$

Elmore, Austin D., 131

Estes, Daniel, ThM 131

Fawcett, Clifford, DBA 131

Fisher, Jean, MA 131

Flentge, Dennis, PhD 131

Frank, Dwayne, DEd 131

Glanville, Ellen, MSEd 131

Green, Harold, ThB 6

Greenwood, Edward, DA 131

Gromacki, Robert, ThD 131

Grosh, Ronald, PhD 131

Hall, Helen L., MA 131

Halsey, Joseph C., MEd 131

Harner, Sandi, MA 131

Conklin, Wilma 135

Coriell, Ron 135

Couch, Robert 135

Coy, Beth 135

Coy, Sherry 135

Cunningham, Jeff 135

Dailey, Marie 135

Day, Jeannie 135

De Meester, John 135

DePenning, Steve 135

Deranek, Norma 135

Dillon, Charles A. 135

Dillon, Margaret 135

Divan, Linda 135

Draa, Cheryl 135

Entner, Sandra G. 135, 239

Farrow, Patricia 135

Fires, Judy 135

Gaffner, David 135

Gidley, David 135

Gidley, Irene 135

Green, Margaret 136

Greenwood, May 136

Grooms, Dewayne 136

Swinn, Robert 136

Henderson, Barbara 136

Hollopeter, Carolyn E. 136

Howell, Agnus 136
Wright, Peter R. 206, 242

Wues/ner, Dave Paul 59, 232

Wuestner, Laura E. 59, 206

Wuthrich, Diane Lynn 232

Wuthnow, Ruth Ann 176

Wyand, Ralph William II 176

Wyse, Jacquelyn Jean 206

Wyse, Jill Sharysse 232

Yacynych, Deborah Ann 206

Yager, Michelle Marie 232

Yanda, Barbara 216, 245, 248

Yanda, Barbara 216, 245, 248

Yeager, David Anthony 100, 218, 251

Yoder, Carol Eugene 206

Yoder, Marcia Kay 176, 240, 250

Hazen, Marinus 132

Helmick, Larry, PhD 132, 241

Hunt, Karol, PhD 132

Johnson, Clifford, DEd 6

Johnson, Martha, MA 132

Kempf, Betsy, BS 132

Killian, Lawrence, MS 132

King, Elvin R, MEd 132

Klimek, Mark, MSN 132

Larson, Mark, MA 132

Leightenheimer, James, BA 132

Loach, Barbara, MA 132

Lopez, Mike, PhD 132, 244

McClure, Philip, MM 132

McGillivray, John, MS 132

McGoldrick, James, PhD 132

Matson, David, PhD 132

Miller, Douglas J., PhD 132

Monroe, Allen, PhD 132

Monroe, Beverly, MA 132

Moreland, Kurt, MA 132

Murdoch, Murray, PhD 132, 239

Pagnard, Charles, MM 132

Parr, Robert, MA 132

Huber, Trish 136

Hunt, Helen 136

Hunt, Robert 136

Johnson, Judy 136

Johnson, Timothy 136

Jones, Byron 135

Kaufman, Emily135

Knauff, Nancy 135

Kuhn, Gary P. 136

Larson, Susan 136

Lichtensteiger, Diane 136

Maddux, Bruce 137

Mathews, Dawn 137

Mathews, Mark 137

Matthews, Stanley 137

Mick, Bernice 137

Mitchell, Mary 137

Paulino, Paul 137

Printy, Beatrice 137, 240

Purrington, David 137

Raught, Jennifer 137

Rawson, Sharon 137

Rayburn, Ethel 137

Ruby, Carl 137

Sagraves, Ruth 137

Samuel, David 137

Sjoquist, Douglas 137

Skillman, Jon 137
Yosh, Angela 205

Young, Brian Duane 232

Young. Christopher S. 232

Young, Grace Ann 232

Young, Robin Kimberly 64, 218

Youngless, Theresa $L$ 61, 218

Yost, Angela Kathleen 206

Yst, Angela Katheen 206

Zaugg, Angela 218

Zeck, Elizabeth Jean 232

Zehr, Ric 218, 248

Zehurng, David L. 206, 248, 250, 249

Ziegler, Brent Dale 91, 218

Zielke, Lynne E. 176

Zimpfer, Scott Edward 206, 242,

Parvin, Donald, MDiv 133

Percesepe, Gary, MA 133

Phipps, James, PhD 133

Phipps, Terry, MS 133

Rayburn, Marlin, MA 133

Rich, Anne, MAcct, CPA 133

Rickard, Donald, MA 6

Riggs, Jack, ThD 133, 245

Robey, David, MA 133, 244

Rogers, Rex, PhD 133

Rotman, David L., MS 133

Shalladay, Maureen O., 133

Seaman, James PhD 133

Seaman, Lila, PhD 133

Silvius, John, PhD 133

Slocum, Ruth, MS 133

Smith, Galen, MS 133

Smith, Sarah, PhD 133

Spencer, Edward E., MA 133

Stahl, Karl, MA 133

St. Clair, Kenneth, MA 6

Warren, Dave, ThM 133

Wetzel, Daniel, PhD 133

Young, Stephen, BA 133, 251

Smith, John R. 137

Smith, Michele 137

Smith, Roscoe 137

Spencer, Dorothy 137

St. Clair, Ida 137

St. Clair, Kenneth 137

Stahl, Mary E. 137

Street, Joan 138

Sturgis, Kathy 138

Taylor, Rae 138

Taylor, Virgina M. 138

Thompson, Steven 138

Tocknell, John 138

Vickman, Bonnie 138

Vickman, Jeff 138

Vine, Allan 138

Wagner, Don 138

Wallace, Daniel 138

Wetzel, Phyllis 138

Wolfi, Cynthia 138

Womack, Carla 138

Womack, Glenda 138

Womack, Jay 138

Womack, Mark 138

Wyse, Gerri 138 



JOSTENS 


